UNIVERSIDADE DE SÃO PAULO

\author{
INSTITUTO DE FÍSICA \\ INSTITUTO DE QUÍMICA \\ INSTITUTO DE BIOCIÊNCIAS \\ FACULDADE DE EDUCAÇÃO
}

THIAGO MARINHO DEL CORSO

\title{
INDICADORES DE ALFABETIZAÇÃO CIENTÍFICA, ARGUMENTOS E EXPLICAÇÕES - Análise de Relatórios no Contexto de uma Sequência de Ensino Investigativo
}

SÃO PAULO

2015 


\section{THIAGO MARINHO DEL CORSO}

\section{INDICADORES DE ALFABETIZAÇÃO CIENTÍFICA, ARGUMENTOS E EXPLICAÇÕES - Análise de Relatórios no Contexto de uma Sequência de Ensino Investigativo}

Dissertação apresentada ao Instituto de Física, Instituto de Química, Instituto de Biologia e à Faculdade de Educação da Universidade de São Paulo para obtenção do título de Mestre em Ensino de Ciências.

Área de concentração: Ensino de Biologia

Orientadora: Profa. Sílvia L. Frateschi Trivelato 


\begin{abstract}
AUTORIZO A REPRODUÇÃO E DIVULGAÇÃO TOTAL OU PARCIAL DESTE TRABALHO, POR QUALQUER MEIO CONVENCIONAL OU ELETRÔNICO, PARA FINS DE ESTUDO E PESQUISA, DESDE QUE CITADA A FONTE.
\end{abstract}

\title{
FICHA CATALOGRÁFICA \\ Preparada pelo Serviço de Biblioteca e Informação do Instituto de Física da Universidade de São Paulo
}

Del-Corso, Thiago Marinho

Indicadores de Alfabetização Científica, Argumentos e Explicações: análise de relatórios no contexto de uma Sequência Ensino Investigativo . São Paulo, 2014.

Dissertação (Mestrado) - Universidade de São Paulo, Faculdade de Educação, Instituto de Física, Instituto de Química e Instituto de Biociências.

Orientador: Profa. Dra. Sílvia Luzia Frateschi Trivelato

Área de Concentração: Ensino de Biologia.

Unitermos: 1. Biologia - Estudo e ensino; 2. Alfabetização científica; 3.

Argumentação; 4. Ensino por investigação; 5. Sequência de ensino Investigativo.

USP/IF/SBI-093/2014 


\section{RESUMO}

DEL-CORSO, T. M. Indicadores de Alfabetização Científica, Argumentos e Explicações Análise de Relatórios no Contexto de uma Sequência Ensino Investigativo, 2014. 130 f. Dissertação (Mestrado) - Instituto de Física, Instituto de Química, Instituto de Biologia, Faculdade de Educação, Universidade de São Paulo, São Paulo, 2014.

Deveria ser esperado que a população fosse ciente de como a ciência, e principalmente, seus conhecimentos e aplicações, chegam até ela e, para isso, tivesse esclarecimento e discernimento suficientes para perceber, entender e julgar as novidades científicotecnológicas a que tem acesso no que poderíamos chamar de Alfabetização Científica (AC). Sasseron (2008) define a AC como um processo de inserção dos indivíduos dentro da cultura científica. Sasseron e Carvalho (2008), a partir de eixos estruturantes da AC, propõem indicadores que servem como parâmetros que permitam identificar que a AC está em processo. Osborne e Patterson publicam, em 2011, um polêmico trabalho com o intuito de distinguir Argumentos de Explicações, alegando que a falta de distinção entre estes dois conceitos representa uma fraqueza no campo de pesquisa em ensino de Ciências. Tomando a AC como norte para o ensino de ciência, Argumentos e Explicações se valorizam, já que pertencem às práticas da ciência e podem ser um meio de atingir metas cognitivas, epistêmicas e sociais da aprendizagem em Ciências. Os objetivos deste trabalho: a) a partir de apoios da literatura, desenvolver recursos metodológicos para caracterizar e diferenciar argumentos e explicações; b) identificar e analisar argumentos e explicações presentes nas produções escritas de alunos; c) identificar e analisar indicadores de AC presentes nas produções escritas dos alunos. Nossa análise se deu sobre uma das atividades realizadas dentro do contexto de uma sequência de ensino investigativo (SEI), a qual aborda a temática "Dinâmica Populacional", aplicada em duas turmas do $1^{\circ}$ ano do Ensino Médio da Escola de Aplicação da Faculdade de Educação da Universidade de São Paulo (EAFEUSP) em 2012 e 2013. Os alunos realizaram um experimento sobre a capacidade suporte de um ambiente para a população de Lemna sp (uma planta aquática de pequeno porte que apresenta alta taxa de reprodução por brotamento). Após a realização desse experimento, os alunos produziram relatórios coletivamente com conclusões individuais. Analisamos cada trecho (o qual poderia se constituir de um parágrafo, tabela, gráfico ou figura) de um conjunto de 29 relatórios em busca dos indicadores da AC e de Explicações e Argumentos. Foram encontrados 571 indicadores de AC nos relatórios e 367 nas conclusões individuais, e isso nos permite considerar que a AC está em processo. Também podemos considerar que os alunos envolveram-se com as investigações e as discussões propostas. A proposição de uma 
metodologia de desambiguação é tanto metodologia como resultado, e a aplicação desta nos permitiu identificar 35 Explicações e 22 Argumentos nos relatórios e respectivamente 21 e 40 nas 52 conclusões individuais que foram produzidas apenas no ano de 2013. No tocante aos objetivos desta pesquisa, acreditamos tê-los respondido na medida em que desenvolvemos uma metodologia que nos permitiu distinguir Argumentos e Explicações em produções escritas de alunos e identificamos os indicadores de Alfabetização Científica presentes nessas produções. Essa última tarefa culminou na proposição de dois novos indicadores em acréscimo aos que usamos como referência (SASSERON 2008; SASSERON e CARVALHO 2008): um deles é o próprio Argumento, e outro, a Listagem de materiais.

Palavras-chave: Alfabetização Científica, Atividade Experimental, Ensino por Investigação, Argumento, Explicação. 


\section{ABSTRACT}

DEL-CORSO, T. M. Indicators of Scientific Literacy, Arguments and Explanations Analysis of Reports in the Context of an Inquiry-based science teaching, 2014. $130 \mathrm{f}$. Dissertação (Mestrado) - Instituto de Física, Instituto de Química, Instituto de Biologia, Faculdade de Educação, Universidade de São Paulo, São Paulo, 2014.

Should be expected that the population is aware of how science, especially their knowledge and reach, comes to her and, therefore, had sufficient enlightenment and discernment to perceive, understand and judge the scientific and technological innovations that give access to what may be called the Scientific Literacy (SL). Sasseron (2008) defines the SL as a process of integration of individuals within the scientific culture. Sasseron and Carvalho (2008) from the structural axis of SL propose indicators that serve as parameters that identify that the SL is in process. Osborne and Patterson published a controversial study in 2011 in order to distinguish Arguments from Explanations, claiming that the lack of distinction between these concepts is a weakness in the field of research in science teaching. Taking the SL as north to the teaching of science, Arguments and Explanations are valued, since they belong to the practices of science and can be a way to achieve cognitive, epistemic and social goals of learning in science. The aims of this work: a) supported from the literature, develop methodological tools to characterize and differentiate Arguments and Explanations; b) identify and analyze Arguments and Explanations present in the written production of students; c) identify and analyze indicators of SL present in the students' written productions. Our analysis was based on one of the activities carried out within the context of a sequence of investigative teaching (SEI), which deals with the "Population Dynamics" theme, applied to two classes of the 1st year of high school at the Escola de Aplicação from the Faculdade de Educação from University of São Paulo (EAFEUSP) in 2012 e 2013. Students conducted an experiment on the carrying capacity of an environment for the population of Lemna sp (an aquatic plant that features small high rate of reproduction by budding). After performing this experiment, students collectively produced reports with individual conclusions. We analyzed each passage (which could be a paragraph, table, graph or diagram) of a set of 29 reports in search of indicators of the AC, the explanations and arguments. We found 571 indicators of SL in the reports and the 367 in the individual conclusions, and this allows us to consider that the SL is in progress. We can also consider that the students were involved with the investigation and the proposed discussions. The proposition of a methodology for the disambiguation is both method and result. Applying this methodology allowed us to identify 35 Explanations and 22 Arguments in the reports. We found respectively 21 and 40 in 52 
individual conclusions that were produced in 2013 only. Concerning the aims of this study, we believe having them answered, as we developed a methodology that allowed us to distinguish Arguments and Explanations in written production of students, and identify indicators of Scientific Literacy on those productions. This last task culminated in the proposal of two new indicators in addition to those we used as reference (SASSERON 2008; SASSERON e CARVALHO 2008): one is the Argument itself, and another, the Listing of Materials.

Keywords: Scientific Literacy, Experimental Activity, Inquiry-based Science Teaching, Argument, Explanation. 


\section{LISTA DE GRÁFICOS}

Gráfico 1: Quantidade de indicadores de AC presentes em cada relatório, sem considerar as conclusões individuais

Gráfico 2: Quantidades de cada tipo de indicador encontrados nos relatórios somados de 2012 e 2013

Gráfico 3: Porcentagem de ocorrência de cada tipo de indicador em relação aos outros. Em vermelho as frequências relativas nos relatórios e em azul nas conclusões individuais 116

Gráfico 4: Quantidades de indicadores encontradas em cada um dos grupos de indicadores

Gráfico 5: Presença de cada indicador nos diferentes relatórios, independente da frequência 118

\section{LISTA DE TABELAS}

Tabela 1- Quantidade de indicadores de AC encontrados em cada relatório

Tabela 2- Quantidade de indicadores de AC encontrados nas conclusões individuais referentes a cada relatório 


\section{Sumário}

1. A vista do meu ponto

2. Introdução 13

2.1 Alfabetização Científica 13

2.2 Argumentação 16

2.3 Explicações $\quad 19$

2.4 Ensino de Ciências por Investigação 22

3. Objetivos

4. 0 universo da pesquisa e a tomada de dados 26

4.1 A Sequência de Ensino Investigativo (SEI) 28

4.2 A professora, a escola, as classes $\quad 29$

4.3 Padrões éticos na pesquisa em educação 30

4.4 Pressupostos teóricos metodológicos 31

5. Processos para construção e análise dos dados 33

5.1 Procedimentos $\quad 34$

5.1.1 Identificação dos Indicadores de Alfabetização Científica 36

5.1.2 Diferenciando Argumentos de Explicações 40

6. Resultados

6.1 Análise interpretativa $\quad 45$

6.1.1 Relatório $1-2013 \quad 46$

6.1.2 Relatório $2-2013$

6.1.3 Relatório 3-2013 82

6.2 Sistematização dos dados $\quad 110$

7. Resposta às questões de pesquisa $\quad 119$

$\begin{array}{lr}7.1 \text { Explicações e Argumentos } & 119\end{array}$

7.2 Indicadores de Alfabetização Científica (AC) 123

7.3 Todas elas juntas (Respondendo as questões de pesquisa) 126

Referências

APÊNDICES

Relatórios 4 a 10 de $2013 \quad 135$

O Relatório 4 - $2013 \quad 135$

O Relatório 5 - $2013 \quad 149$

O Relatório 6 - $2013 \quad 166$

O Relatório 7 - $2013 \quad 181$

O Relatório 8 - $2013 \quad 210$

O Relatório 9 - $2013 \quad 226$

Relatórios 11 a 18 de $2013 \quad 262$

Relatório 11 - $2013 \quad 262$

$\begin{array}{ll}\text { Relatório 12-2013 } & 270\end{array}$

$\begin{array}{ll}\text { Relatório } 13 \text { - } 2013 & 277\end{array}$

O Relatório 15 - $2013 \quad 294$

O Relatório 16 - $2013 \quad 303$

O Relatório 17 - $2013 \quad 309$

O Relatório 18 - 2013

Relatórios $2012 \quad 334$

O Relatório 1-2012 334

O Relatório 2-2012 338

O Relatório 4 - $2012 \quad 348$

O Relatório 6 - $2012 \quad 360$ 
Thiago Marinho Del Corso

INDICADORES DE ALFABETIZAÇÃO CIENTÍFICA, ARGUMENTOS E EXPLICAÇÕES -

Análise de Relatórios no Contexto de uma Sequência de Ensino Investigativo

O Relatório 7 - 2012

363

O Relatório 8 - 2012

366

O Relatório 9 - 2012

370

O Relatório 10 - 2012

373

O Relatório 11 - 2012

375

ANEXOS

378

ANEXO 1: A SEQUÊNCIA DIDÁTICA ENSINO INVESTIGATIVA (SEI)

378

ANEXO 2: TERMO DE CONSENTIMENTO LIVRE E ESCLARECIDO

390 


\section{A vista do meu ponto}

Ao longo de minha graduação e do trabalho no Museu de História Natural da Unicamp desenvolvi, a partir das participações em congressos e das pesquisas de campo durante a iniciação científica um apreço pela área acadêmica e pela pesquisa, não ainda na área de ensino, mas de ecologia. No final da graduação, durante o estágio supervisionado ou como professor substituto, mas principalmente depois de meu trabalho regular como professor em diferentes escolas da rede de ensino particular, tanto no ensino fundamental II como no ensino médio, é que despertou em mim o interesse pela área de ensino.

Tomado por essas paixões é que decidi voltar à academia, já com o intuito de pesquisar sobre o ensino de Ciências. No mestrado, principalmente no grupo de pesquisa, mas também em disciplinas, tive contato com a ideia de Alfabetização Científica e tomei esta concepção como um norte, como algo que me instigava pesquisar: descobrir como o ensino de Ciências poderia ser concebido para promover a Alfabetização Científica. Sasseron (2008) define a Alfabetização Científica (AC) como um processo de inserção dos indivíduos dentro da cultura científica. Segundo a autora, o termo “Alfabetização Científica” é usado:

"para designar as ideias que temos em mente e que objetivamos ao planejar um ensino que permita aos alunos interagir com uma nova cultura, com uma nova forma de ver o mundo e seus acontecimentos, podendo modificá-lo e a si próprio através da prática consciente propiciada por sua interação cerceada de saberes de noções e conhecimentos científicos, bem como das habilidades associadas ao fazer científico."

Acontece, contudo, que nossos resultados das últimas aplicações dos exames do Programa Internacional de Avaliação de Estudantes (PISA 2003) demonstram que estamos muito longe de atingir parâmetros minimamente satisfatórios.

A intenção deste trabalho é contribuir para o entendimento de um Ensino de Ciências que permita aos estudantes interagir com a cultura científica, que seja fomentador de uma Alfabetização Científica (AC), pois acredito que tive uma construção sócio-histórica que me permitiu participar desta cultura e gostaria que todos pudessem ser alfabetizados cientificamente. 
A investigação proposta por esse estudo se insere em uma perspectiva de pesquisa qualitativa, trabalhando com dados obtidos a partir de produções escritas dos alunos após uma Sequência de Ensino Investigativo, aplicada em aulas de Ciências e Biologia.

A Alfabetização Científica é um conceito amplo, e se isso por um lado é bom por permitir várias diferentes abordagens de pesquisa, por outro lado também não direciona um caminho a ser seguido. No grupo de pesquisa GEPEB (Grupo de Estudos e Pesquisas em Ensino de Biologia) e em contato com a literatura especializada, fui tomando conhecimento da valorização do "discurso argumentativo" para a Alfabetização Científica e do trabalho de Toulmin (2006) para a análise dos argumentos; também neste grupo tive contato com o trabalho que discute que muito do que se considera como argumentos na verdade são explicações, e por final dos trabalhos de Sasseron (2008) e Sasseron e Carvalho (2008) que tratam de indicadores que permitem aferir se a Alfabetização Científica está em processo. Daí surgiram os objetivos deste trabalho: a) a partir de apoios da literatura, desenvolver recursos metodológicos para caracterizar e diferenciar Argumentos e Explicações; b) identificar e analisar Argumentos e Explicações presentes nas produções escritas de alunos; c) identificar e analisar indicadores de Alfabetização Científica presentes nas produções escritas dos alunos.

$\mathrm{Na}$ introdução deste trabalho vamos discorrer um pouco sobre a Alfabetização Científica (AC), os Argumentos, as Explicações e o Ensino por Investigação, trazendo diversos aportes da literatura para embasá-los, de modo a contextualizar este trabalho dentro da área de ensino de Ciências. Logo após, no terceiro capítulo, são apresentados os objetivos e as perguntas de pesquisa e, no quarto capítulo, as informações sobre o universo de pesquisa e a tomada de dados, tratando inclusive de apresentar em linhas gerais a Sequência de Ensino Investigativo (SEI) analisada, da qual derivam os relatórios e conclusões individuais que constituem o corpo de dados deste trabalho. O quinto capítulo apresenta os procedimentos usados para analisar os relatórios produzidos pelos alunos após a SEI; vale ressaltar aqui que, aos indicadores de AC propostos por Sasseron e Carvalho (2008) e Sasseron (2008), foram adicionados dois novos indicadores. A metodologia de desambiguação entre Argumentos e Explicações que aqui propomos não constitui apenas procedimentos de análise, mas é também resultado deste trabalho. O sexto capítulo traz os resultados, apresentando as análises detalhadas de alguns dos relatórios, bem como uma sistematização na forma de tabelas e gráficos. No sétimo capítulo buscamos responder as perguntas de pesquisa, apresentando discussões e conclusões. Incluímos na sequência as referencias bibliográficas e os apêndices, que contêm os relatórios originais escaneados e suas análises e os anexos, que incluem a SEI. 


\section{Introdução}

\subsection{Alfabetização Científica}

Os temas científicos estão presentes em nossa vida cotidiana e despertam cada vez mais interesse. Um amplo estudo feito pelo Ministério da Ciência e Tecnologia (BRASIL, 2011) apresenta resultados de uma pesquisa sobre a percepção pública da Ciência e Tecnologia indicando que $76 \%$ das pessoas se interessam por assuntos relacionados a essas áreas. Esta mesma pesquisa também revelou que $37 \%$ dos entrevistados que disseram não se interessar, ou se interessar pouco, por Ciências e tecnologia, assim se manifestaram porque não entendem do assunto. Some-se a isso que os produtos do conhecimento científico, bem como o próprio conhecimento científico, permeiam a vida das pessoas em todos os momentos de suas vidas -- das atividades mais corriqueiras às mais polêmicas, entendam elas ou não os conceitos e consequências envolvidos em cada situação.

O conhecimento científico apresentado à população pelos meios populares de divulgação científica é entendido pela população como uma verdade incontestável. O termo "científicamente comprovado" usado por esses meios de comunicação denota a infalibilidade associada aos conteúdos e estudos científicos divulgados e também, como apontado por Sasseron (2008), mostra que a forma como a população recebe informações sobre ciência e tecnologia, assim como o conhecimento de como sua vida, pode ser afetada pelos avanços trazidos pelo amplo conhecimento científico que ora possuímos, é muito contestável. O próprio estereótipo do cientista, geralmente apresentado como um "gênio maluco", de óculos e cabelo despenteado e encarcerado num laboratório, à margem da sociedade, realizando um trabalho metódico, mas com insigths e rompantes de genialidade (BRICCIA, 2013) é bastante distorcida. Sasseron (2008) lembra também que, cada vez mais, a população torna-se mais subordinada e propensa aos benefícios e prejuízos que os avanços científicos e tecnológicos são capazes de lhes trazer.

Carvalho (2007) realça que apesar da importância adquirida pela ciência e a tecnologia nos dias de hoje, e do interesse gerado por estas áreas, o conhecimento científico não é tratado nas escolas de modo a representar os aspectos da Ciência como desenvolvimento humano, nem é tratado de forma interessante e que desperte a curiosidade, mas sim de modo memorístico e apresentando os conhecimentos como verdades comprovadas. Isso independentemente de estar se tratando de ensino fundamental, médio ou mesmo na 
Thiago Marinho Del Corso

INDICADORES DE ALFABETIZAÇÃO CIENTÍFICA, ARGUMENTOS E EXPLICAÇÕES -

Análise de Relatórios no Contexto de uma Sequência de Ensino Investigativo

universidade. A autora afirma também que as experiências, quando existem, não envolvem os alunos na reprodução de um problema experimental, com busca por construção de explicações entre outros elementos, mas restringe-se a um método científico. A busca pela construção de explicações seria importante para promover alguns dos aspectos da cultura científica. A diferença sobre como a Ciência é, e como tem sido trabalhada, tem, de acordo com a autora, trazido aos pesquisadores da área a Alfabetização Científica (AC) como condição fundamental para um ensino de Ciências que vise uma participação crítica e consciente dos indivíduos na sociedade contemporânea. Importantes autores da área, como Sutton (1998), Driver et al (2000), Roth (1999), Jimenéz (2005), Carvalho (2005), e Capecchi e Carvalho (2006), concordam com esta posição. Sasseron e Carvalho (2011a) corroboram que as pesquisas atuais têm nos indicado a Alfabetização Científica (AC) como elemento norteador na elaboração dos currículos para dar conta de promover um ensino capaz de levar os alunos a investigar temas das Ciências e a discutir suas inter-relações com a sociedade e o ambiente.

Deveria ser esperado que a população fosse ciente de como a ciência, e principalmente, seus conhecimentos e aplicações, chegam até ela e, para isso, tivessem esclarecimento e discernimento suficientes para perceber, entender e julgar as novidades científicotecnológicas a que tem acesso no que poderíamos chamar de Alfabetização Científica. Sasseron e Carvalho (2011b) comparam a importância desta alfabetização nos dias atuais e para a sociedade atual com a importância que teve o processo de alfabetização no final do século XIX para aquela sociedade.

Concebendo a ciência como uma atividade humana que possui uma linguagem peculiar, há um entendimento da dimensão científica como sendo uma cultura -- e o processo de Alfabetização Científica orienta-se nesta perspectiva sociológica, na qual a dimensão da linguagem, e habilidades como a explicação e argumentação, têm papel fundamental (BORTOLETTO, 2010).

Nós precisamos da semântica da linguagem, pois qualquer conceito ou ideia só faz sentido quando é compartilhado por um grupo (LEMKE, 1990). A comunicação é sempre um fenômeno social. Não nos comunicamos transmitindo apenas sinais, mas criando e manipulando situações sociais. Quando falamos ciência estamos criando, ou recriando, uma comunidade de pessoas que compartilham certa linguagem, crenças e valores (LEMKE, 1990). 
"Falar ciência", "falar científico" ("talking science"), não é simplesmente falar sobre ciência. "Falar ciência" significa observar, descrever, comparar, classificar, analisar, discutir, hipotetizar, teorizar, caracterizar, questionar, argumentar, desenhar experimentos, seguir procedimentos, julgar, avaliar, decidir, concluir, generalizar, reportar, escrever, ler e ensinar em e através da linguagem da ciência (LEMKE, 1990).

A ciência na escola é comumente tratada sob uma "perspectiva positivista" como se existissem respostas claramente corretas e os dados conduzissem diretamente e sem controvérsia a conclusões finais, fechadas. Mas as pesquisas acerca da própria atividade dos cientistas apontam para uma diferente visão acerca de como a ciência se desenvolve (DRIVER et al. 2000). As perspectivas contemporâneas da filosofia da ciência enfatizam que a ciência não é simplesmente a acumulação de fatos acerca de como o mundo funciona. Latour \& Woolgar (1986), em seu livro “A Vida de Laboratório”, desenvolvem a ideia de que a ciência progride mediante disputas, conflitos e argumentação. A ciência envolve a construção de teorias que oferecem explicações sobre como o mundo pode ser.

Práticas tais como a avaliação de alternativas, comparação de evidências, interpretação de textos e avaliação da potencial viabilidade de afirmações científicas são vistas como componentes essenciais na construção de argumentos científicos (DRIVER et al, 2000). Ao fazer afirmações científicas, as teorias são abertas ao desafio e o progresso é feito por meio de disputa, conflito e mudança de paradigma. Assim, argumentos relativos, por exemplo, à adequação de um projeto experimental, ou à interpretação de evidências à luz de teorias alternativas, são vistos como o cerne da ciência e centrais para o discurso dos cientistas Driver et al, (2000). Por isso, os autores acreditam que, se a educação científica têm o propósito de ajudar os jovens com as práticas características da ciência, deve fomentar essas formas de argumentação através da promoção de atividades de sala de aula apropriadas, e suas práticas discursivas associadas.

Assim, um ensino de Ciências que vise uma Alfabetização Científica deve reconsiderar a visão da forma como se dá a própria prática científica. De uma visão basicamente positivista da ciência, na qual as verdades da natureza são obtidas por observação e experimentos, para uma visão de que o conhecimento científico é socialmente construído (LATOUR; WOOLGAR, 1986, HOCHMAN, 1994). 
Reconsiderando a forma como a própria prática científica se desenrola e tomando como norte para o ensino de ciência a capacidade de interagir com esta "cultura científica", a Alfabetização Científica, e particularmente os argumentos e explicações, se valorizam como práticas a serem fomentadas, já que pertencem às práticas da ciência e podem ser um meio de atingir metas epistêmicas, cognitivas e sociais da ciência.

Sasseron (2008, 2013) e Sasseron e Carvalho (2008) apresentam três eixos estruturantes da Alfabetização Científica, que constituiriam bases a serem consideradas no planejamento e construção de propostas de aulas que almejassem o processo de Alfabetização Científico. $\mathrm{O}$ primeiro dos eixos estruturantes refere-se à compreensão básica de termos, conhecimentos $e$ conceitos científicos fundamentais e diz respeito à construção de conhecimentos científicos necessários à estrapolação, de maneira apropriada, para situações diversas do dia a dia. Também é importante para a compreensão de conceitos-chave para as informações e situações do cotidiano. O segundo eixo preocupa-se com a compreensão da natureza da ciência e dos fatores éticos e políticos que circundam sua prática, já que o conhecimento está sempre em produção e transformação e com isso é importante saber como proceder, adquirindo, refletindo, analisando e considerando o contexto. Ou seja: compreender a natureza da ciência e da produção do conhecimento. O terceiro eixo estruturante da AC compreende $o$ entendimento das relações existentes entre ciência, tecnologia, sociedade e meio-ambiente (CTSA): esse eixo envolve o entendimento das relações entre esses elementos, reconhecendo as aplicações dos saberes construídos pela Ciência e as ações resultantes das aplicações desses conhecimentos, mostrando-se fundamental quando temos em mente o desejo de um futuro saudável e sustentável para a sociedade e o planeta.

\subsection{Argumentação}

Colombo et al. (2012) afirmam que a argumentação é uma estratégia que colabora na aquisição da linguagem científica e possibilita desenvolver nos estudantes uma capacidade de raciocinar e discutir sobre problemas científicos e sócio-científicos. Deste modo, é fundamental que professores desenvolvam-na em sala de aula.

Driver et al. (2000) vêem a argumentação e o discurso argumentativo como centrais nas práticas científicas e assim discorrem sobre a importância de incorporar a argumentação no ensino de Ciências. Indicam então que qualquer educação que verse sobre a ciência, ao 
invés de em ciência, deve dar ao argumento uma alta prioridade se quiser considerar as práticas sociais da ciência, e desenvolver conhecimento e compreensão dos critérios utilizados para determinar as teorias científicas. Tal conhecimento é essencial para aumentar a compreensão pública da ciência e melhorar a alfabetização científica.

O objetivo fundamental do ensino argumentativo em Ciência é que os estudantes adquiram competência para defender e justificar as suas ideias e opiniões, e que se tornem capazes de compreender, diferenciar e confrontar as ideias e opiniões próprias com as dos outros (COLOMBO et al. 2012). Assim, argumentos são vistos como produto de uma construção social e coletiva. Segundo Lemke (1998), aprender Ciência significa se apropriar do discurso científico. Aprender Ciência passa por aprender como determinados termos se relacionam entre si e com o contexto em que estão inseridos, produzindo significados específicos. Jiménez-Aleixandre et al. (2000) defendem a argumentação como elemento estrutural da linguagem científica, porém enfatizam que a capacidade de desenvolver argumentos é uma meta normalmente não estabelecida em salas de aula de ciência.

A argumentação é uma estratégia que colabora na aquisição da linguagem científica e possibilita desenvolver nos estudantes uma capacidade de raciocinar e discutir sobre problemas científicos e sócio-científicos. Deste modo, é fundamental que professores desenvolvam-na em sala de aula. Na visão de muitos pesquisadores a argumentação é uma estratégia de raciocínio, em que dados, evidências, crenças e pré-concepções, da mesma forma que no processo de construção do conhecimento científico, "são as bases que conduzem à aprendizagem" (SASSERON; CARVALHO, 2011a; e SASSERON; CARVALHO, 2011b). Atividades em que o professor conduz a discussão, de forma a criar um ambiente argumentativo, podem resultar em argumentos mais complexos, que vão além da apresentação somente de Dados e Conclusões.

Kelly e Takao (2002) entendem a argumentação como uma importante ferramenta para compreender o raciocínio do aluno, para o envolvimento em práticas científicas e para um aprendizado conceitual e epistemológico. Estes autores, numa extensa revisão, trazem que diversos têm sido os trabalhos acerca da construção de Argumentos, tanto no discurso em sala de aula como em produções escritas de alunos. Os autores dizem que as análises derivadas do layout de Toulmin (2006) primeiramente foram aplicadas para o discurso falado em sala de aula, mas que posteriormente começaram a considerar também os argumentos escritos. A produção escrita de argumentos apresenta, ainda de acordo com os autores, uma posição 
central na comunidade científica, considerando que os artigos científicos são em grande parte estruturados para convencer a comunidade. E em ambientes educacionais têm sido identificados como um dos gêneros de produção a serem defendidos e estudados.

Para nossas análises adotaremos o modelo padrão de argumentação TAP (Toulmin's Argument Pattern), proposto por Stephen Toulmin (2006). Nossa escolha do modelo de Toulmin é baseada na observação de que ele tem guiado e influenciou muitos pesquisadores neste campo de pesquisa, tanto no contexto brasileiro (SANTOS et al. 2001; NASCIMENTO; VIEIRA, 2008; SASSERON; CARVALHO 2011 a e b); CAPECCHI; CARVALHO, 2006 e 2007; VIEIRA, 2003) quando no contexto internacional (DRIVER et al. 2000; JIMÉNEZALEIXANDRE et al, 2000; DUSCHL; OSBORNE, 2002; ERDURAN, 2008; JIMÉNEZ; BUSTAMANTE, 2003, entre outros). Acreditamos também que este modelo, mesmo com algumas limitações, traduz muito bem o processo argumentativo em sala de aula (COLOMBO et al 2012).

Originalmente o TAP foi proposto por Toulmin com uma aplicação empírica baseada em argumentos da área jurídica, ou seja, destinada a analisar a racionalidade dos argumentos tipicamente encontrados nos tribunais (TOULMIN, 2006). Não se tinha a percepção de que a proposta de Toulmin poderia ser aplicável a outros campos do saber, por exemplo, da retórica educacional e comunicação. Como ressalta Vieira (2003) os méritos do modelo de Toulmin residem na aplicabilidade a qualquer tipo de raciocínio argumentativo e, como veremos a seguir, na relativa transparência de suas ferramentas.

Toulmin (2006) afirma que nem toda frase se caracteriza como um argumento, e que muito do que ouvimos e lemos não contém qualquer argumento. Se não há intencionalidade em convencer-nos de qualquer coisa, pois apenas se descreve uma situação, reporta-se um evento, conta-se uma história ou se expressa uma atitude pessoal, então é um uso instrumental da língua. Porém, se houver essa intenção, muitas vezes identificável por pequenas palavras, que denotam a intenção de convencer alguém, poderemos estabelecer um confronto argumentativo, desde que a estrutura seja reconhecida e permita iniciar uma discussão. 
Modelo de Toulmin:

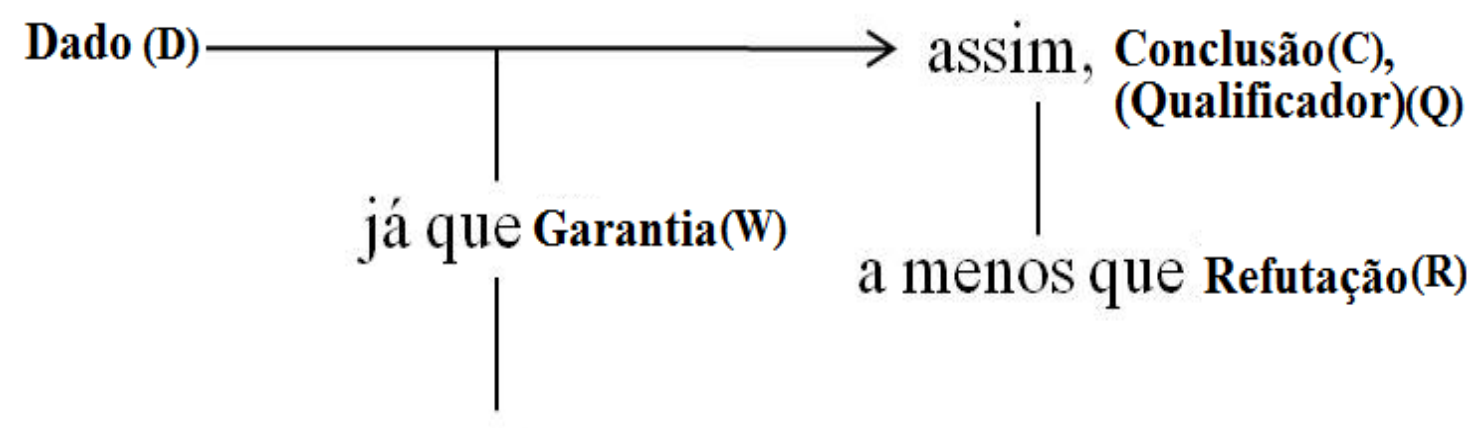

\section{por conta de Apoio(B)}

Segundo Toulmin (2006), todos os argumentos devem apresentar certos elementos em comum, que originam um layout do argumento. Os argumentos, segundo este modelo, devem apresentar Dados (D), ter Garantias (W), sustentadas por Apoios (B) campo-dependentes, que levam a uma Conclusão (C), a menos que um novo dado apresente uma Refutação (R).

Os Dados (D) são os fatos apresentados como base para a Conclusão (C) que se está tentando defender; sem dados não há argumento, seria apenas uma afirmação. No entanto, é necessário algo que legitime essa passagem dos Dados (D) para a Conclusão (C) - a Garantia (W) tem esse papel, sendo a confiabilidade dessa garantia dada pelo Apoio (B). O Qualificador $(\mathbf{Q})$ e a Refutação $(\mathbf{R})$ representam, respectivamente, a força conferida pela garantia para passar do dado para a conclusão e uma exceção à regra dada pela conclusão. Adotamos o modelo de Toulmin para nossas discussões, pois acreditamos que é uma ferramenta poderosa para a compreensão do papel da argumentação no pensamento científico.

\subsection{Explicações}

Martins et al. afirmava em 1999 ser curioso, senão surpreendente, que o tema "explicações" não viesse sendo objeto de estudo ou investigação sistemática na área de Ensino de Ciências. E que da mesma forma, a atividade de 'explicar' não viesse sendo tratada como algo que possa ser entendido, aprendido ou ensinado. Esses fatos acarretariam graves consequências cujos impactos se fariam sentir nas salas de aula. Por exemplo, as implicações para a formação (inicial e em serviço) de professores de Ciências são evidentes. Como não há investigação sistemática nem análise do que está envolvido na tarefa de 'explicar', a 
Thiago Marinho Del Corso

INDICADORES DE ALFABETIZAÇÃO CIENTÍFICA, ARGUMENTOS E EXPLICAÇÕES -

Análise de Relatórios no Contexto de uma Sequência de Ensino Investigativo

experiência pessoal e o exemplo de colegas mais experientes tornam-se os únicos "professores" possíveis para aqueles que se iniciam na profissão.

O que pudemos notar ao revisar, lendo todos os sumários de 21 revistas nacionais e internacionais de ensino de Ciências classificadas pela CAPES com Qualis entre A1 e B2 dos anos de 2011, 2012 e 2013, é que os artigos dedicados às explicações continuam muito pouco recorrentes. Foram encontrados apenas 14 artigos que continham alguma menção ao termo explicação ou algum correlato em seus títulos -- sendo que, destes 14, um é o artigo de Osborne e Patterson (2011) com a desambiguação entre explicação e argumento, outro uma réplica (BERLAND e McNEILL, 2012) a este artigo e outro sua tréplica (OSBORNE e PATTERSON, 2012). Assim, a despeito do papel crucial das explicações na comunicação da ciência a audiências leigas e da importância da explicação para o ensino de Ciências, não se vem tratando o tópico explicação como objeto de investigação sistemática na área de ensino de Ciências. Acreditamos que talvez isso se deva a não desambiguação entre Explicações e Argumentos e que agora, a partir do artigo acima citado, esta prática da Ciência e do ensino de Ciências venha a receber uma maior atenção na pesquisa em ensino de ciências.

Para Martins et al. (1999), embora exista quase um consenso de que explicar é, possivelmente, a tarefa mais fundamental de um professor de Ciências, há dúvidas a respeito do que constitui uma boa explicação. Uma explicação que satisfaz o professor, muitas vezes, contraria as ideias que os estudantes têm a respeito do mundo físico. Uma explicação baseada no senso comum frequentemente não encontra paralelo na visão correntemente aceita pelos cientistas. E o trabalho diário na sala de aula é tentar estabelecer nexos, continuidades, relações entre essas diferentes visões de mundo e aproximar posições que se encontram separadas por abismos conceituais. Parte da dificuldade na explicação de conceitos científicos advém do fato de que aprender Ciências envolve não só alargar os horizontes da percepção e adquirir novos conhecimentos e informações, mas, principalmente, passar a conceber o mundo físico de forma diferente e vislumbrar outras dimensões da relação entre o homem e a natureza no que poderia ser considerada uma Alfabetização Científica. Muitas explicações científicas exigem que o professor tente persuadir o estudante a re-conceber, a ver o mundo a sua volta à luz de determinada teoria -- como passar a pensar a Terra em movimento e não como o chão onde nos movimentamos (MARTINS et al., 1999).

Osborne e Patterson publicam em 2011 um trabalho com o intuito de distinguir argumentos de explicações, alegando que a falta de distinção entre estes conceitos representa 
uma fraqueza no campo de pesquisa do ensino de Ciências, onde, como anteriormente apresentado, o argumento tem papel de destaque. Parte da confusão surge porque os argumentos são usados no processo de validação de qualquer explicação, pois há explicações múltiplas para qualquer fenômeno. Algumas das explicações dadas são completamente falsas, e outras podem falhar no momento de esclarecer o problema. Explicações são julgadas por argumentos na medida em que vão se tornando coerentes, plausíveis e abrangentes. Os dois não são, contudo, uma mesma coisa. Pelo contrário, há duas entidades discursivas: a explicação, que tenta explicar o fenômeno dado, e um argumento que examina a questão para saber se a explicação é válida -- isto é, se ela foi bem sucedida, gerando o entendimento, e se ela é melhor comparando-se a outras.

Ainda de acordo com Osborne e Patterson (2011), a chave para a distinção entre explicação e argumento é que uma explicação deve dar sentido a um fenômeno com base em outros fatos científicos. As explicações consistiriam, então, num subconjunto de descrições coerentes com os conhecimentos e teorias atuais. Numa explicação o fenômeno em questão não está em dúvida, não está colocado à prova; Explicações, portanto, são essencialmente respostas a perguntas: "explicar, descrevendo como o explanandum veio a ser".

Também de acordo com Osborne e Patterson (2011), explicações são uma tentativa de "tornar claro ou inteligível, tirar da obscuridade ou dificuldade" e não são construídas a partir de dados e garantias, mas a partir de modelos e representações da realidade. Especificamente, explicar algo é fazer com que essa coisa se torne compreensível para alguém. Assim, se não existir a intenção de fazer algo compreensível para alguém, então não se constitui uma explicação. Isso deixa a Explicação dependente do contexto, uma vez que o que deve ser feito para tornar algo compreensível para alguém pode depender dos interesses e conhecimentos da pessoa em busca de entendimento. Explicar envolve, de acordo com Martins et al. (1999), além de uma análise cuidadosa dos conteúdos a serem tratados, considerar diferentes estratégias de comunicação, diferentes interesses e habilidades cognitivas dos interlocutores, a motivação, os objetivos e papéis sociais dos participantes, as restrições impostas pelo contexto, etc.

Em seu artigo resposta a Osborne e Patterson (2011), Berland e Mcneill (2012) dizem entender as explicações e argumentações como práticas científicas complementares, através das quais a comunidade científica constrói conhecimento. A construção de conhecimento perpassaria, de acordo com estas autoras, pela produção de sentido focada no entendimento do 
fenômeno investigado quando os cientistas estão tentando entender como ou porque um fenômeno ocorre, o que estaria alinhado com a prática científica da explicação. As autoras também apontam que a construção de conhecimento também perpassa pelo convencimento dos pares da qualidade da explicação construída, o que está relacionado à produção de argumentos. Assim estas práticas ocorreriam concomitantemente na construção de conhecimento.

A derivação óbvia, para a área de ensino de Ciências, da distinção apresentada pelas autoras (BERLAND; MCNEILL, 2012), seria a distinção dessas duas práticas para professores e alunos, como anteriormente dito por Osborne e Patterson (2011). Ocorre que estas autoras acham que a distinção, neste nível, não seria benéfica para a aprendizagem, já que para os professores poderia gerar uma algoritmização do ensino destas duas práticas, quando estes sempre pediriam uma explicação primeiro para depois pedir um argumento, em vez de pedir o engajamento das duas práticas que são mutuamente suportadas. Berland e McNeill salientam também a sinergia entre os dois termos e que por isso trabalhá-los separadamente seria pior que tratar apenas da construção de conhecimento, sem diferenciar se está se construindo argumentos ou explicações. As autoras (BERLAND; MCNEILL, 2012) afirmam também que instruções explícitas acerca da diferença entre argumentos e explicações atrapalham o engajamento dos estudantes em práticas investigativas e fomentariam assim pseudo-argumentações.

O que Berland e McNeill não discordam é que argumentar e explicar são duas práticas científicas diferentes que vieram sendo tratadas como uma só, e que deveriam ser mais claramente distinguidas pela comunidade de pesquisa.

\subsection{Ensino de Ciências por Investigação}

É importante perceber que o uso de modalidades didáticas diversificadas é essencial em qualquer currículo. A maior variedade de metodologias fornece uma maior variedade de caminhos para se trabalhar os conteúdos previstos, sendo que cada aluno reage de uma forma diferente a cada modalidade; alunos diferentes podem se sentir mais atraídos ou mais confortáveis com diferentes modalidades didáticas, estimulando assim sua participação (KRASILCHIK, 2008). Dessa forma, a inclusão de atividades diferenciadas, como atividades em grupo, no laboratório ou fora da sala de aula, podem contribuir com os cursos de Ciências por promover motivação e o uso de habilidades diferenciadas entre os alunos. 
Neste capítulo trataremos do ensino de Ciências que considera a investigação uma das características centrais da produção do conhecimento científico e desta forma considera que utilizá-las no ensino de Ciências seja de grande valia, já que seria uma maneira de ensinar não só o conteúdo científico, mas as características que compõem a construção deste conhecimento, suas práticas comuns, sua linguagem, inclusive contemplando os três eixos estruturantes da Alfabetização Científica (SCARPA; SILVA, 2013). Esta metodologia trabalha, mesmo que implicitamente, características da Natureza da Ciência (BRICCIA, 2013). E entendemos que o ensino de Ciências não deveria se restringir ao ensino de conceitos e ideias científicas, mas introduzir os alunos no universo das Ciências e desenvolver a cultura e a linguagem das Ciências. Com esse objetivo, a escola deve oferecer condições para que esse universo, essa cultura e essa linguagem sejam trabalhados. O ensino por investigação seria um caminho deveras interessante para abarcar não só conceitos e ideias científicas, mas esses outros aspectos da natureza da Ciência. Ensinar os alunos a construir conhecimento fazendo com que eles, ao perceber os fenômenos da natureza, sejam capazes de construir suas próprias hipóteses, elaborar suas próprias ideias, organizando-as e buscando explicações para os fenômenos e assim proporcionando habilidades para atuar consciente e racionalmente também fora do contexto escolar (CARVALHO 2011).

Scarpa e Silva (2013) acreditam que o ensino por investigação trata os conteúdos de Biologia de forma mais integrada, relevante e contextualizada, desenvolvendo habilidades envolvidas no fazer científico, o que contribuiria para a Alfabetização Científica. Mas existem características básicas para uma Sequência de Ensino Investigativo (SEI)? Em uma revisão do que seria esperado em uma SEI são apresentados diferentes autores, os quais apesar de diferenças quanto à terminologia e outros aspectos, têm um mesmo esquema geral de elementos ou etapas: 1) valorização de um problema autêntico; 2) uma estratégia para resolução do mesmo, que comumente contém atividades práticas, experimentais, que perspassam pela observação, coleta e tratamento de dados (vale ressaltar que não é condição sine qua non a existência de experimentação); 3) comunicação, com elaboração de explicações e argumentos.

Ao perpassar por esses elementos que caracterizam o ensino de Ciências por investigação não significa que se almeja construir conhecimentos científicos em sala de aula, ou desenvolver novas teorias científicas, mas, sim, inserir aspectos da natureza da Ciência, mesmo que de forma implícita, no ensino de Ciências (BRICCIA, 2013). 
Aprender a realizar investigações sobre problemas naturais para os quais seja necessário criar hipóteses, testar as ideias planejadas e construir conclusões sobre os resultados alcançados e seus vínculos com a sociedade e o meio-ambiente são algumas das habilidades que pensamos que devam ser trabalhadas no ensino de Ciências em qualquer nível escolar. E a proposição de atividades abertas pode permitir que os alunos trabalhem ativamente em sala de aula e se envolvam com os conteúdos tratados. Ao mesmo tempo, estas atividades devem ser planejadas para atingir os interesses desses alunos e, assim, permitir-lhes progressos intelectuais. E segundo Carvalho (2011) esse tipo de atividade envolve, além da manipulação do objeto de estudo, a reflexão, relatos, discussões (que podem levar a construção de argumentos), ponderações e explicações.

Quanto a isto, Lemke (2006) lembra que a maioria dos adultos escolarizados não possui estas habilidades, ou seja, ao terminar seus estudos os jovens não estão alfabetizados cientificamente. Sua ideia para começar a reverter este quadro é a elaboração de um currículo que privilegie os objetivos da alfabetização científica e que, deste modo, possibilite aulas e atividades nas quais os alunos trabalhem ativamente resolvendo e/ou discutindo problemas referentes às Ciências e às suas tecnologias. Tendo este objetivo, o autor propõe o ensino por investigação como "uma forma excelente de favorecer a Alfabetização Científica" defendendo um currículo baseado em propostas de situações problemáticas nas quais os alunos se envolvam na busca por uma resposta -- daí a importância do desenvolvimento de atividades que, em sala de aula, estimulem a Alfabetização Científica e permitam a argumentação entre alunos e professor em diferentes momentos da investigação e do trabalho envolvido e permitam a construção compartilhada de explicações para os fenômenos científicos. Assim, as discussões devem propiciar que os alunos levantem hipóteses, construam argumentos para dar credibilidade a tais hipóteses, justifiquem suas afirmações e busquem reunir argumentos capazes de conferir consistência a uma explicação para o tema sobre o qual se investiga.

A inclinação desse trabalho pela valorização do ensino por investigação como um meio pelo qual a Alfabetização Científica pode ser propiciada encontrou grandes apoios na literatura especializada, anteriormente apresentada, mas estas diretrizes são assumidas também por documentos que têm a pretensão de dar parâmetros nacionais para o ensino. 
Os PCN de Ciências Naturais (BRASIL, 1998) trazem ainda como objetivos do ensino de Ciências:

- A comparação entre as ideias e previsões preliminares e aquelas concluídas após a realização de investigação sobre tema determinado é importante ocasião para a valorização da aprendizagem realizada.

- $\quad$ elaborar perguntas e hipóteses, selecionando e organizando dados e ideias para resolver problemas;

- confrontar as diferentes explicações individuais e coletivas, reconhecendo a existência de diferentes modelos explicativos na Ciência, inclusive de caráter histórico, respeitando as opiniões, para reelaborar suas ideias e interpretações;

- elaborar individualmente e em grupo relatos orais, escritos, perguntas e suposições acerca do tema em estudo, estabelecendo relações entre as informações obtidas por meio de trabalhos práticos e de textos, registrando suas próprias sínteses mediante tabelas, gráficos, esquemas, textos ou maquetes;

Das "Orientações Curriculares para o Ensino Médio" do Ministério da Educação (BRASIL, 2006) temos ainda que os temas estruturadores devem ser utilizados para criar situações de aprendizagem que permitam o desenvolvimento de competências tais como:

"saber comunicar-se, saber trabalhar em grupo, buscar e organizar informações, propor soluções, relacionar os fenômenos biológicos com fenômenos de outras Ciências, construindo, assim, um pensamento orgânico. Não se trata simplesmente de mudar o planejamento para que a ação pedagógica se enquadre nos temas estruturadores, e sim de utilizar esses temas biológicos como instrumentos para que a aprendizagem tenha significado, de forma que o aluno seja capaz de relacionar o que é apresentado na escola com a sua vida, a sua realidade e o seu cotidiano."

\section{Objetivos}

A literatura atual aponta como condição fundamental que os indivíduos participem de forma crítica e consciente na sociedade contemporânea (SUTTON, 1998; DRIVER et al 2000; ROTH, 1999; JIMENÉZ-ALEIXANDRE; AGRASO, 2006; CARVALHO， 2005; CAPECCHI \& CARVALHO, 2006; CARVALHO, 2007) e para isso a Alfabetização 
Científica é considerada por muitos autores como um norte para o ensino de Ciências (SASSERON e CARVALHO 2011a e b) alcançar esses propósitos. Sasseron (2008) e Sasseron e Carvalho (2008) propõem indicadores que poderiam servir de evidências que a Alfabetização Científica está em processo.

Tomando como norte para o ensino de Ciência a Alfabetização Científica, os Argumentos e Explicações se valorizam como práticas a serem fomentadas, já que pertencem às práticas da Ciência e podem ser um meio de atingir metas epistêmicas, cognitivas e sociais da Ciência. Acontece que em 2011 dois pesquisadores, Osborne e Patterson, publicam um polêmico trabalho alegando que a falta de distinção entre estes conceitos representa uma fraqueza no campo de pesquisa em ensino de Ciências.

Os objetivos deste trabalho são: a) a partir de apoios da literatura, desenvolver recursos metodológicos para caracterizar e diferenciar argumentos e explicações; b) identificar e analisar argumentos e explicações presentes nas produções escritas de alunos do $1^{\circ}$ ano do ensino médio de uma escola publica brasileira durante uma Sequência de Ensino Investigativo (SEI) que tem como temática central a dinâmica populacional do crescimento de Lemnas (planta aquática de rápida reprodução); c) identificar e analisar indicadores de Alfabetização Científica presentes nas produções escritas dos alunos após a supracitada SEI. Destes objetivos derivaram as seguintes questões de pesquisa:

“Como diferenciar Argumentos de Explicações nas produções escritas dos alunos após uma Sequência Didática de Ensino Investigativo (SEI)?”

"Quais indicadores de Alfabetização Científica podemos encontrar como evidências desse processo nas produções escritas dos alunos após uma Sequência Didática de Ensino Investigativo (SEI)?”

\section{0 universo da pesquisa e a tomada de dados}

O corpo de dados utilizado para esta análise constitui-se dos relatórios elaborados pelos alunos como parte de uma Sequência de Ensino Investigativo (SEI) sobre dinâmica populacional (ANEXO 1), desenvolvida com turmas de $1^{\circ}$ ano do Ensino Médio da Escola de Aplicação da Faculdade de Educação da Universidade de São Paulo (EAFEUSP), nos anos de 2012 e 2013. Esta SEI foi desenvolvida por uma colega de programa, orientação e grupo de 
pesquisa, como parte de seu doutoramento e em 2012 aplicada como piloto de sua pesquisa. Desta aplicação piloto derivam 11 relatórios apresentados na íntegra e analisados nesta dissertação. Da aplicação da SEI em 2013 derivam 18 relatórios. As SEIs de 2012 e 2013 guardam poucas alterações, como o formato dos recipientes do experimento de crescimento das Lemnas, redondos em 2012 e retangulares ou quadrados em 2013 e a confecção dos relatórios que em 2012 foi feita como tarefa de casa e em 2013 na escola. Além disso, em 2013, foi pedido aos alunos que escrevessem individualmente conclusões para estes relatórios, o que não foi pedido em 2012.

A aplicação da SEI em 2013 foi acompanhada e gravada em vídeo por pesquisadores colegas de programa, orientação e grupo de pesquisa, incluindo o autor desta dissertação. Dessa aplicação derivam 18 relatórios também apresentados na íntegra e analisados neste trabalho. A comanda para a confecção dos relatórios, seja a versão 2012 ou 2013 da SEI, consistiu da seguinte pergunta: "O que acontece com uma população biológica após a colonização por alguns indivíduos de um ambiente com as condições ideais para desenvolvimento da espécie?"

Além dos relatórios confeccionados em grupo, no ano de 2013 foi pedido que os alunos escrevessem individualmente uma conclusão, que também foi analisada. Para escrever essa conclusão os alunos receberam uma cópia dos seus respectivos relatórios (confeccionados em grupo) e a comanda fornecida pela professora e escrita na lousa foi: "Sabendo que a conclusão do relatório científico consiste na resposta à pergunta inicial, justificada com evidências (dados produzidos durante a investigação), conclua seu relatório."

Tanto em 2012 como em 2013, o $1^{\circ}$ ano do Ensino Médio era constituído de duas salas $\left(1^{\circ} \mathrm{I} \mathrm{e} 1^{\circ} \mathrm{II}\right)$ com aproximadamente 30 alunos cada. O relatório utilizado é escrito em grupos, com entre 3 e 5 alunos, e têm como mote gerador a investigação sobre a capacidade suporte de um ambiente para a população de Lemna sp. Os relatórios utilizados neste trabalho consistem na etapa final da Sequência de Ensino Investigativo (SEI) e, resguardados seus anos de produção, foram aleatoriamente misturados para evitar julgamentos de valor sobre diferenças entre as salas. Esses relatórios foram também, dentro de seus anos de produção, aleatoriamente numerados. Os conceitos atribuídos pela professora aos relatórios (PS = Plenamente Satisfatório, $S$ = Satisfatório, NS = Não Satisfatório) foram ignorados. Os relatórios foram escaneados, sendo assim apresentados neste trabalho. 


\subsection{A Sequência de Ensino Investigativo (SEI)}

Se a função da escola é desenvolver nos alunos as qualidades necessárias para uma vida adulta responsável e fomentar uma Alfabetização Científica, as aulas experimentais Investigativos ganham importância no repertório de estratégias disponíveis aos professores. Tendo em mente tais considerações, preocupamo-nos em analisar uma sequência didática de ensino Investigativo, que contém um experimento, sobre temas de Ciências Naturais que proporcionam momentos nos quais os alunos trabalham e discutem temas científicos, utilizando, para isso, ferramentas culturais próprias desta comunidade e dessas práticas.

A sequência que é analisada nesta pesquisa (ANEXO 1) baseia-se no ensino por investigação e apresenta os seguintes estágios essenciais: o engajamento em perguntas de orientação científica; a utilização de evidências para responder às questões; a formulação de explicações a partir das evidências; a avaliação dessas explicações à luz de alternativas, especialmente as científicas, e a justificação e a comunicação das explicações propostas.

Esta sequência tem como temática o crescimento populacional de Lemnas sp (planta aquática de rápida reprodução). As atividades da sequência de ensino envolvem leitura e interpretação de texto e gráficos, exercícios sobre amostragem populacional, elaboração de metodologia para resolver problema investigativo, coleta de dados, produção de relatório científico para comunicar resultados e avaliação individual com consulta. Durante o desenvolvimento das atividades os alunos trabalham em pequenos grupos de forma autônoma, individualmente e também de forma coletiva, sempre mediados pela professora. São abordados procedimentos almejados na alfabetização científica: interpretação de texto científico, interpretação e construção de inscrições literárias, argumentação com base em evidências (empíricas ou não), elaboração de metodologia de investigação, comunicação de resultados e de conclusões, criação de hipóteses explicativas para os fenômenos.

A atividade experimental se deu da seguinte forma: cada grupo de estudantes recebeu um recipiente com água, terra e indivíduos de Lemna sp. para formação de uma população inicial. Lemna sp. é uma planta aquática popularmente conhecida como lentilha d'água e que apresenta alta taxa de reprodução por brotamento. A atividade se relaciona ao desenvolvimento do tópico da ecologia, dinâmica populacional, onde os alunos investigam a capacidade suporte de um ambiente para essa população de Lemnas sp.. Os alunos acompanharam o desenvolvimento da população, fazendo observações e registros, mediados 
pelo professor. Após a conclusão das atividades práticas os alunos sistematizaram os trabalhos em um relatório que deveria conter os seguintes elementos:

Pergunta: $O$ que acontece com uma população biológica após a colonização por alguns indivíduos de um ambiente com as condições ideais para desenvolvimento da espécie?

Metodologia: descrição detalhada dos materiais e dos procedimentos realizados para coleta e produção de dados.

Resultados: descrição dos resultados encontrados na forma que o grupo achasse mais representativo daquilo que foi observado empiricamente (desenhos, fotos, tabelas, gráficos, símbolos, etc.)

Interpretação: explicação, baseada em conhecimento empírico ou teórico, de todos os resultados encontrados.

Cada grupo produziu um relatório e os alunos de 2013, além do relatório em grupo, como anteriormente apresentado, escreveram uma conclusão individual a partir da seguinte comanda: "Sabendo que a conclusão do relatório científico consiste na resposta à pergunta inicial, justificada com evidências (dados produzidos durante a investigação), conclua seu relatório". Para esta conclusão foi fornecida uma cópia do relatório para cada aluno do grupo.

Nessa sequência didática os alunos se envolvem na resolução de um problema de natureza científica, realizam procedimentos investigativos à procura de dados, argumentam e comunicam suas conclusões (JORDE, 2009). Para Jiménez-Aleixandre e Fernandéz-Lopes (2010), o envolvimento dos alunos em práticas associadas à produção, validação e comunicação do conhecimento científico pode favorecer a utilização de evidências empíricas para justificar conclusões, a argumentação com seus pares sobre quais explicações adotar e, por fim, a comunicação dos resultados da investigação.

\subsection{A professora, a escola, as classes}

A professora que desenvolveu e aplicou a sequência é educadora de Biologia/Ciências na Escola de Aplicação da Faculdade de Educação da Universidade de São Paulo (EAFEUSP) desde 2005, com mestrado na área de ecologia e, atualmente, aluna de doutorado do programa de Pós-Graduação em Educação da Faculdade de Educação da Universidade de São Paulo. Sua prática didática é fortemente influenciada pela literatura especializada, 
particularmente no que tange aos interesses desta pesquisa em Alfabetização Científica, Argumentação e Explicação. Também podemos considerar esta professora experiente em sua prática de sala de aula e bastante integrada à escola.

A Escola de Aplicação da Faculdade de Educação da Universidade de São Paulo (FEUSP) localiza-se dentro da própria Cidade Universitária e é uma instituição de ensino que, além de oferecer escolaridade em nível fundamental e médio a cerca de setecentos alunos, destina-se à realização de pesquisas no campo da educação, visando o aperfeiçoamento de seu projeto educativo, a produção de conhecimento no campo da educação, e a contribuição ao ensino público em geral, por meio da divulgação de suas experiências e reflexões. O próprio regimento da escola tem como diretrizes a necessidade de conciliar atividades de pesquisa científica e prática pedagógica, de dar conta da grande quantidade de solicitações normalmente dirigidas à escola e de oferecer subsídios para a avaliação das pesquisas realizadas nesta instituição.

A sequência didática é destinada ao $1^{\circ}$ ano do Ensino Médio $\left(10^{\circ}\right.$ ao $12^{\circ}$ ano de escolarização) e foi aplicada em duas salas com aproximadamente 30 alunos cada. A duração de cada aula, independentemente da disciplina, é de 50 minutos; e cada sala tem duas aulas semanais de Biologia em sala ambiente. Esta sala é composta por um espaço com arranjo semelhante a uma sala convencional (com as carteiras enfileiradas de frente para uma lousa) e outro com duas grandes bancadas de laboratório, o que permite maior integração entre os ambientes, pois a professora pode mesclar as aulas em ambos os locais sem precisar deslocar os alunos de uma sala para outra. No ensino médio os alunos são responsáveis por se deslocar até as salas de aula específicas de cada matéria.

\subsection{Padrões éticos na pesquisa em educação}

O projeto seguiu todos os requisitos delimitados nos PADRÕES ÉTICOS NA PESQUISA EM EDUCAÇÃO formulado pela FEUSP:

Foram recolhidas todas as autorizações necessárias dos responsáveis pelos menores envolvidos, assim como da instituição escolar mantendo o caráter voluntário do assentimento. O modelo do termo de consentimento livre esclarecido com autorização dos pais para a gravação está no ANEXO 2. 
Foi garantida a confidencialidade das informações e a privacidade dos sujeitos, assegurando que os dados da pesquisa não serão utilizados em prejuízo ou para a estigmatização das pessoas ou comunidades, e que nas publicações será mantido o anonimato dos participantes e instituições envolvidas.

Nos comprometemos em providenciar o retorno dos resultados às instituições envolvidas.

\subsection{Pressupostos teóricos metodológicos}

A investigação proposta por esse estudo se insere em uma perspectiva de pesquisa qualitativa, trabalhando com dados obtidos a partir de produções escritas dos alunos, anteriormente apresentadas, após uma Sequência de Ensino Investigativo (ANEXO 1), aplicada em aulas de Biologia da escola também já comentada.

Lüdke e André (1986) apontam que por muito tempo, nas pesquisas em educação, tentaram-se seguir os modelos que serviram tão bem ao desenvolvimento das Ciências físicas e naturais, e que assim, tal como nessas Ciências, o fenômeno educacional foi estudado como se pudesse ser isolado, da mesma forma que se faz com um fenômeno físico onde as variáveis que o compõem podem ser isoladas, a fim de constatar a influência que cada uma delas exerceria sobre o fenômeno em questão. Essa perspectiva considerava possível decompor os fenômenos naturais de tal forma que seu estudo analítico, em suas variáveis básicas, e se possível de modo quantitativo, permitiria o conhecimento total dos fenômenos, no que é entendido pelas autoras como uma perspectiva positivista de pesquisa. Do desenvolvimento dos estudos na área percebeu-se que poucos são os fenômenos que podem ser submetidos a esse tipo de abordagem analítica, pois em educação as coisas acontecem de maneira tão integrada que é quase impossível isolar variáveis e mais difícil ainda apontar responsáveis diretos por determinado efeito.

A impossibilidade de desconsiderar as muitas variáveis e a extrema dificuldade de estabelecer relações causais diretas faz da pesquisa qualitativa a forma preponderante de pesquisa na área em que se insere esse trabalho. Como dito por Lüdke e André (1986), “... em vez da ação de uma variável independente, produzindo um efeito sobre uma variável 
dependente, o que ocorre em educação é, em geral, a múltipla ação de inúmeras variáveis agindo e interagindo ao mesmo tempo.".

O estudo qualitativo é o que se desenvolve numa situação natural, sendo rico em dados descritivos, com um plano aberto e flexível e que focaliza a realidade de forma complexa e contextualizada. Na abordagem qualitativa de pesquisa a observação ocupa um lugar privilegiado (LÜDKE E ANDRÉ, 1986), e em nossos estudos, presenciamos a aplicação da SEI que culminou na confecção dos relatórios e conclusões individuais analisados. Outro método de coleta de dados apontado como importante pelos autores supracitados é a análise documental, sendo considerado por esses documentos: "quaisquer materiais escritos que possam ser usados como fonte de informação sobre o comportamento humano". A análise documental busca identificar informações factuais nos documentos a partir de questões ou hipóteses de interesse.

Os mesmos autores (LÜDKE E ANDRÉ, 1986) afirmam que a construção de categorias de análise para documentos não é tarefa fácil, e que estas brotam, num primeiro momento, do arcabouço teórico em que se apoia a pesquisa, mas que este conjunto inicial de categorias vai ser modificado ao longo do estudo, num processo de confronto constante entre teoria e empiria. Exatamente destes confrontos e por conta do ir e vir dos relatórios e conclusões individuais para a teoria é que nasceram em nosso estudo dois novos indicadores de Alfabetização Científica (AC) e os critérios de desambiguação entre Argumentos e Explicações que serão apresentados nos próximos capítulos.

Segundo Lüdke e André (1986), a análise de dados qualitativos é um processo criativo que exige grande rigor intelectual e muita dedicação. Não existe uma forma melhor ou mais correta. O que se exige é sistematização e coerência do esquema escolhido com o que se pretendo no estudo. Poderão ser feitas anotações à margem do próprio material analisado, como fizemos para demarcar as unidades de análise (marcas), outros utilizarão esquemas, diagramas e outras formas de síntese da comunicação, como os quadros preenchidos para cada relatório analisado. Essas anotações, como um primeiro momento de classificação dos dados, incluíram: o tipo de fonte de informação (transcrição de trecho escrito, desenho, foto, gráfico ou tabela produzido pelos alunos); os tópicos ou temas tratados; a natureza do material coletado e a interpretação do autor segundo as categorias de análise. Por fim, a construção de novas inscrições literárias (tabelas e gráficos, seção 6.2) foi desenvolvida pelos autor para sistematizar e evidenciar aspectos dos dados obtidos. 


\section{Processos para construção e análise dos dados}

Dois foram os procedimentos de análise dos dados. Os indicadores de Alfabetização Científica derivam do trabalho de Sasseron (2008) e Sasseron e Carvalho (2008) com o acréscimo de dois novos indicadores: Argumento e Listagem de materiais. Os critérios de desambiguação entre Explicações e Argumentos foram construídos a partir do referencial teórico anteriormente apresentado e são tanto procedimentos de análise como resultados deste trabalho.

O acréscimo do Argumento como um indicador se justifica com os apontamentos feitos pelo trabalho de Osborne e Patterson (2011 e 2012) que pressupõe ser importante a desambiguação entre Argumentos e Explicações, o que para estes autores, quando não diferenciados, consistiria uma fragilidade nos trabalhos na área de ensino de Ciências de até então. Assim, da concordância, e com a intenção proposta pelos autores supracitados, propusemos o acréscimo do indicador de alfabetização científica, Argumento, à lista de indicadores propostos por Sasseron (2008) e Sasseron e Carvalho (2008) e também uma procedimento de desambiguação entre Argumentos e Explicações.

O indicador Listagem de materiais surgiu durante as análises dos relatórios quando se verificou que em grande parte dos relatórios (24 de 29 relatórios) os materiais utilizados para a montagem do experimento de crescimento da população de Lemnas sp eram listados. Inicialmente as marcas que apresentaram esta lista de materiais foram classificadas como Seriação de informações, mas este indicador, de acordo com Sasseron (2008) e Sasseron e Carvalho (2008), “...está ligado ao estabelecimento de bases para a ação investigativa... uma lista ou uma relação dos dados trabalhados ou com os quais se vá trabalhar..." - e como essas listas de materiais tinham uma função diferente, não eram usadas como bases para a ação investigativa, nem eram dados retomados nas interpretações dos resultados, não poderiam ser classificadas como Seriação de informações. Desta forma a apresentação dos materiais, que é prática comum nos trabalhos científicos, e que se fez presente em 24 de 29 relatórios, não apresentava nenhum indicador correspondente e assim, para não ignorar uma prática presente no fazer Ciência e que se fez presente no fazer escola, criamos um indicador, a Listagem de materiais.

Para facilitar a leitura e interpretação das análises, os indicadores de Alfabetização Científica, incluindo aqueles adicionados por nós, Argumento e Listagem de materiais, 
foram escritos em negrito e com a primeira letra maiúscula. Os elementos do Argumento do layout simplificado de Toulmin (2006), apresentado em nosso referencial teórico, estarão sempre grafados também em letra maiúscula, com negrito e com a sigla referente a este elemento em letra maiúscula, negrito e entre parênteses após o elemento - exemplo: Dado (D), Conclusão (C). Isso para diferenciar estes elementos do Argumento de seu uso comum na linguagem escrita. $O$ fenômeno a ser explicado em uma Explicação será chamado de explanandum, definido como a característica do fenômeno a ser explicado e muitas vezes é formulado como uma pergunta (OSBORNE; PATTERSON, 2011 e 2012), que por se tratar de palavra de língua estrangeira e constituir-se em elemento da Explicação será grafado em itálico e negrito, assim como os elementos causais, modelos e representações da realidade que se relacionam ao fenômeno (explanandum) da Explicação, chamados de explanans. Posteriormente, para análise, trechos manuscritos pelos alunos foram digitados, usando-se fonte; Mamãe(bue hos faz. Os erros originais de ortografia e gramática foram mantidos.

\subsection{Procedimentos}

O primeiro procedimento de análise consistiu na leitura na íntegra do relatório a ser analisado. Esta leitura visava o entendimento do relatório como um todo e durante ela não se buscou a identificação dos indicadores de Alfabetização Científica ou a identificação de Argumentos ou Explicações: a intenção aqui era familiarizar-se com o relatório. Os relatórios começam sempre com um pequeno cabeçalho, que pode apresentar diferentes ítens, mas não necessariamente todos eles (nome da escola, disciplina a qual se refere, nome e número dos integrantes dos grupos e data). Nesta primeira leitura das unidades de análise as marcas eram assinaladas. Definimos nossa unidade de análise como marca(s), que pode se referir a um parágrafo, quando se tratava de um texto corrido, a um gráfico, a uma tabela, a um conjunto de fotos e suas legendas, a um desenho, ou a um quadro construído pelos alunos. Como os relatórios se constituem de inscrições literárias variadas, os parágrafos, que de início supúnhamos ser as unidades, não se demonstraram as únicas possibilidades. Foi uma decisão pragmática assumir que cada parágrafo, assim como cada gráfico, tabela, desenho ou conjunto de fotos constitui uma marca. Estas marcas foram identificadas nos relatórios. 
Num segundo momento, para a identificação dos indicadores de Alfabetização Científica, os relatórios eram lidos parágrafo a parágrafo e o seguinte quadro era preenchido, conforme apresentado na marca 1 e com exemplos nas marcas 2 e 3 :

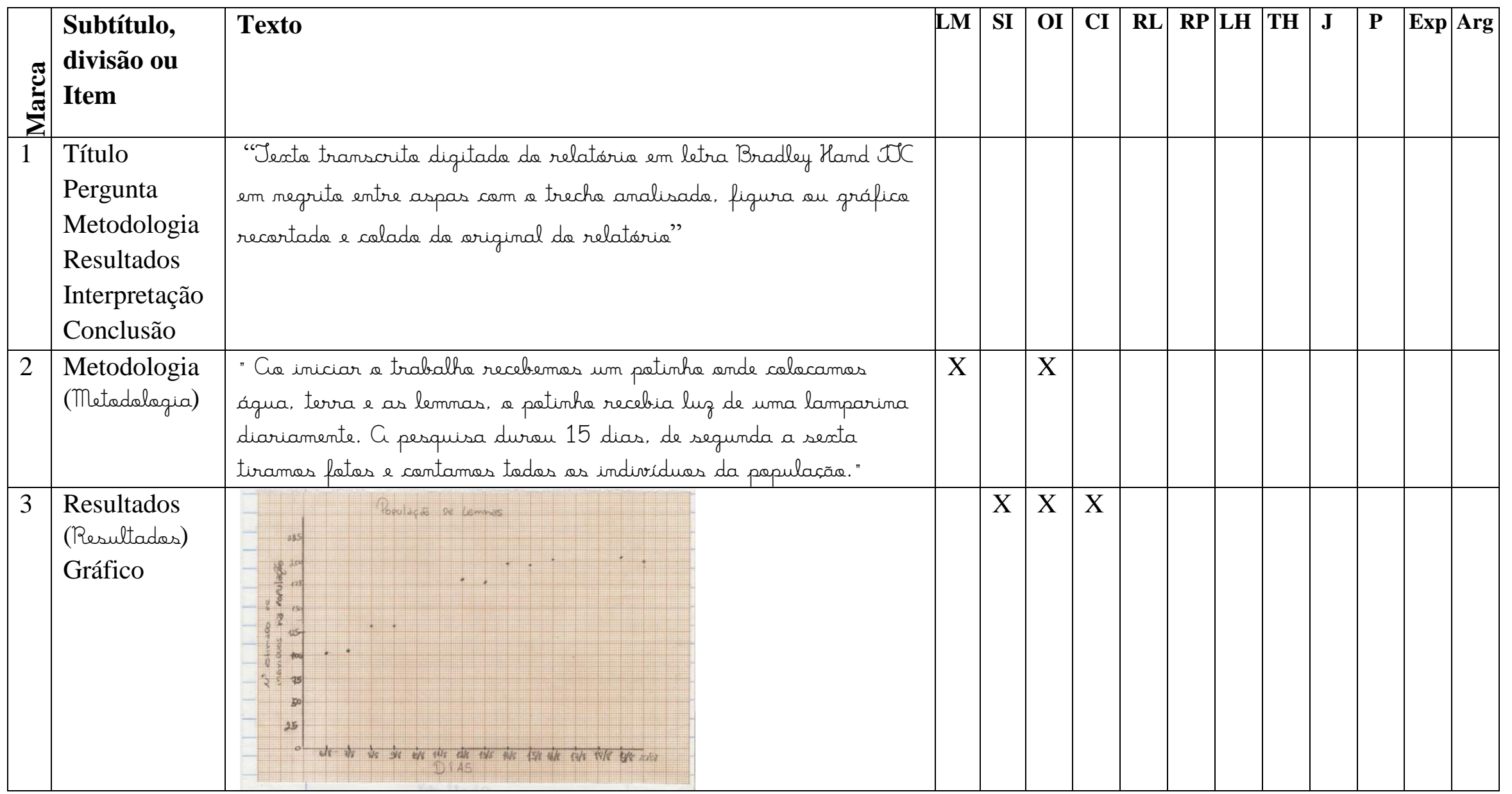


Thiago Marinho Del Corso

INDICADORES DE ALFABETIZAÇÃO CIENTÍFICA, ARGUMENTOS E EXPLICAÇÕES -

Análise de Relatórios no Contexto de uma Sequência de Ensino Investigativo

A coluna com Subtítulo, Divisão ou Item foi preenchida segundo a seguinte metodologia. Os itens Título, Pergunta, Metodologia, Resultados, Interpretação e Conclusão eram identificados nos relatórios, mesmo que não discriminados pelos alunos. Quando discriminados, seja exatamente com esses nomes ou nomes similares, eram apresentados entre parênteses e com a letra Mamae(hue hos Faz. Por exemplo: em 7 relatórios, trechos que nos outros relatórios eram nomeados como Interpretação foram nomeados como análise pelos alunos e desta forma na primeira coluna ficam da seguinte forma: Interpretação (análise). Houve a preocupação de usar o termo mais recorrentemente utilizado; no caso, Interpretação foi utilizado em 12 relatórios.

A presença dos indicadores naquela marca é indicada por um $\mathrm{X}$ onde se cruzam as marcas com as colunas dos indicadores de Alfabetização Científica. A identificação dos indicadores obedeceu os critérios e a descrição propostos por Sasseron (2008) e aplicados em seu artigo Sasseron e Carvalho (2008). O próximo ítem apresenta os indicadores de $\mathrm{AC}$ propostos pelas autoras citadas, acrescidos dos indicadores por nós propostos.

Havendo a identificação de um trecho, chamado de assertiva, que fosse potencialmente um Argumento ou Explicação, este passava por uma desambiguação para ser classificado como Argumento ou Explicação. A metodologia para diferenciar Argumentos de Explicações é apresentada após a descrição dos indicadores de Alfabetização Científica e é proposta e construída neste trabalho segundo os referenciais teóricos anteriormente apresentados. Para a análise discursiva, os indicadores de alfabetização científica foram escritos em negrito e com letra inicial maiúscula.

\subsubsection{Identificação dos Indicadores de Alfabetização Científica}

Sasseron, em sua tese de 2008, faz uma extensa revisão dos termos Alfabetização Científica, Letramento Científico e Enculturação Científica e seus marcos, e encontra, ademais as particularidades, muitas semelhanças que são tratadas como eixos estruturantes da Alfabetização Científica. Destes eixos, se estabeleceram os Indicadores de Alfabetização Científica propostos em sua tese, que consideraram as 
Thiago Marinho Del Corso

INDICADORES DE ALFABETIZAÇÃO CIENTÍFICA, ARGUMENTOS E EXPLICAÇÕES -

Análise de Relatórios no Contexto de uma Sequência de Ensino Investigativo

habilidades utilizadas pelos cientistas durante seu trabalho de investigação. Os

indicadores propostos mostram o encaminhamento de ações que levam à resolução de um problema de tema científico, e que servem como parâmetros que permitem identificar que a Alfabetização Científica está em processo.

"Estes indicadores são algumas competências próprias das Ciências e do fazer científico: competências comuns desenvolvidas e utilizadas para a resolução, discussão e divulgação de problemas em quaisquer das Ciências quando se dá a busca por relações entre o que se vê do problema investigado e as construções mentais que levem ao entendimento dele."

Abaixo, o quadro com os Indicadores de Alfabetização Científica propostos por Sasseron (2008) e Sasseron e Carvalho (2008), e sua descrição:

\begin{tabular}{|c|c|c|}
\hline Indicador & Descrição (SASSERON, 2008) & $\begin{array}{l}\text { Descrição } \quad \text { (SASSERON; } \\
\text { CARVALHO, 2008) }\end{array}$ \\
\hline $\begin{array}{l}\text { Seriação de } \\
\text { Informações }\end{array}$ & $\begin{array}{l}\text { Está ligada ao estabelecimento de } \\
\text { bases para a ação Investigativo. } \\
\text { Não prevê, necessariamente, uma } \\
\text { ordem que deva ser estabelecida } \\
\text { para as informações: pode ser } \\
\text { uma lista ou uma relacão dos } \\
\text { dados trabalhados ou com os } \\
\text { quais se vá trabalhar. }\end{array}$ & $\begin{array}{l}\text { É um indicador que não } \\
\text { necessariamente prevê uma } \\
\text { ordem a ser estabelecida, mas } \\
\text { pode ser um rol de dados, uma } \\
\text { lista de dados trabalhados. Deve } \\
\text { surgir quando se almeja o } \\
\text { estabelecimento de bases para a } \\
\text { ação. }\end{array}$ \\
\hline $\begin{array}{l}\text { Organização } \\
\text { de } \\
\text { Informações }\end{array}$ & $\begin{array}{l}\text { Surge quando se } \begin{array}{r}\text { procura } \\
\text { preparar os dados existentes }\end{array} \\
\text { sobre o problema investigado. } \\
\text { Este indicador pode ser } \\
\text { encontrado durante o arranjo das } \\
\text { informações novas ou já } \\
\text { elencadas anteriormente e ocorre } \\
\text { tanto no início da proposição de } \\
\text { um tema quanto na retomada de } \\
\text { uma questão, quando ideias são } \\
\text { relembradas. }\end{array}$ & $\begin{array}{l}\text { Ocorre nos momentos em que se } \\
\text { discute sobre o modo como um } \\
\text { trabalho foi realizado. Este } \\
\text { indicador pode ser vislumbrado } \\
\text { quando se busca mostrar um } \\
\text { arranjo para informações novas } \\
\text { ou já elencadas anteriormente. } \\
\text { Por isso, este indicador pode } \\
\text { surgir tanto no início da } \\
\text { proposição de um tema quanto } \\
\text { na retomada de uma questão. }\end{array}$ \\
\hline $\begin{array}{l}\text { Classificação } \\
\text { de } \\
\text { Informações }\end{array}$ & $\begin{array}{l}\text { Aparece quando se buscam } \\
\text { estabelecer características para } \\
\text { os dados obtidos. Por vezes, ao se } \\
\text { classificar as informações, elas } \\
\text { podem ser apresentadas conforme } \\
\text { uma hierarquia, mas o }\end{array}$ & $\begin{array}{l}\text { Ocorre quando se busca conferir } \\
\text { hierarquia às informações } \\
\text { obtidas. Constitui-se em um } \\
\text { momento de ordenação dos } \\
\text { elementos com os quais se está } \\
\text { trabalhando procurando uma }\end{array}$ \\
\hline
\end{tabular}


Thiago Marinho Del Corso

INDICADORES DE ALFABETIZAÇÃO CIENTÍFICA, ARGUMENTOS E EXPLICAÇÕES -

Análise de Relatórios no Contexto de uma Sequência de Ensino Investigativo

\begin{tabular}{|c|c|c|}
\hline & $\begin{array}{l}\text { aparecimento desta hierarquia não } \\
\text { é condição sine qua non para a } \\
\text { classificação de informações. } \\
\text { Caracteriza-se por ser um } \\
\text { indicador voltado para a } \\
\text { ordenacão dos elementos com os } \\
\text { quais se trabalha. }\end{array}$ & relação entre eles. \\
\hline $\begin{array}{l}\text { Raciocínio } \\
\text { Lógico }\end{array}$ & $\begin{array}{l}\text { Compreende o modo como as } \\
\text { ideias são desenvolvidas e } \\
\text { apresentadas. Relaciona-se, pois, } \\
\text { diretamente com a forma como o } \\
\text { pensamento é exposto. }\end{array}$ & $\begin{array}{l}\text { Compreende o modo como as } \\
\text { idéias são desenvolvidas e } \\
\text { apresentadas e está diretamente } \\
\text { relacionada à forma como o } \\
\text { pensamento é exposto. }\end{array}$ \\
\hline $\begin{array}{l}\text { Raciocínio } \\
\text { Proporcional }\end{array}$ & $\begin{array}{l}\text { Assim como o raciocínio lógico, } \\
\text { é o que dá conta de mostrar o } \\
\text { modo que se estrutura o } \\
\text { pensamento, além de se referir } \\
\text { também à maneira como as } \\
\text { variáveis têm relacões entre si, } \\
\text { ilustrando a interdependência } \\
\text { que pode existir entre elas. }\end{array}$ & $\begin{array}{l}\text { Como o raciocínio lógico, dá } \\
\text { conta de mostrar como se } \\
\text { estrutura o pensamento, e refere- } \\
\text { se também à maneira como } \\
\text { variáveis têm relações entre si, } \\
\text { ilustrando a interdependência } \\
\text { que pode existir entre elas. }\end{array}$ \\
\hline $\begin{array}{l}\text { Levantamento } \\
\text { de Hipóteses }\end{array}$ & $\begin{array}{l}\text { Aponta instantes em que são } \\
\text { alcadas suposiç̃es acerca de } \\
\text { certo tema. Esse levantamento de } \\
\text { hipóteses pode surgir tanto como } \\
\text { uma afirmação quanto sob a } \\
\text { forma de uma pergunta (atitude } \\
\text { muito usada entre os cientistas } \\
\text { quando se defrontam com um } \\
\text { problema). }\end{array}$ & $\begin{array}{l}\text { Aponta instantes em que são } \\
\text { alçadas suposições acerca de } \\
\text { certo tema. Este levantamento de } \\
\text { hipóteses pode surgir tanto da } \\
\text { forma de uma afirmação como } \\
\text { sendo uma pergunta (atitude } \\
\text { muito usada entre os cientistas } \\
\text { quando se defrontam com um } \\
\text { problema). }\end{array}$ \\
\hline $\begin{array}{l}\text { Teste de } \\
\text { Hipóteses }\end{array}$ & $\begin{array}{l}\begin{array}{l}\text { Trata-se das etapas em que as } \\
\text { suposiç̃es }\end{array} \\
\begin{array}{l}\text { anteriormente } \\
\text { levantadas são colocadas à }\end{array} \\
\text { prova. Pode ocorrer tanto diante } \\
\text { da manipulação direta de objetos } \\
\text { quanto no nível das ideias, quando } \\
\text { o teste é feito por meio de } \\
\text { atividades de pensamento } \\
\text { baseadas em conhecimentos } \\
\text { anteriores }\end{array}$ & $\begin{array}{l}\text { Concerne nas etapas em que se } \\
\text { coloca à prova as suposições } \\
\text { anteriormente levantadas. Pode } \\
\text { ocorrer tanto diante da } \\
\text { manipulação direta de objetos } \\
\text { quanto no nível das idéias, } \\
\text { quando o teste é feito por meio } \\
\text { de atividades de pensamento } \\
\text { baseadas em conhecimentos } \\
\text { anteriores. }\end{array}$ \\
\hline
\end{tabular}


Thiago Marinho Del Corso

INDICADORES DE ALFABETIZAÇÃO CIENTÍFICA, ARGUMENTOS E EXPLICAÇÕES -

Análise de Relatórios no Contexto de uma Sequência de Ensino Investigativo

\begin{tabular}{|c|c|c|}
\hline Justificativa & $\begin{array}{l}\text { Aparece quando, em uma } \\
\text { afirmação qualquer proferida, } \\
\text { lança-se mão de uma garantia } \\
\text { para o que é proposto. Isso faz } \\
\text { com que a afirmação ganhe aval, } \\
\text { tornando-a mais segura. }\end{array}$ & $\begin{array}{l}\text { Aparece quando em uma } \\
\text { afirmação qualquer proferida } \\
\text { lança mão de uma garantia para } \\
\text { o que é proposto; isso faz com } \\
\text { que a afirmação ganhe aval, } \\
\text { tornando mais segura. }\end{array}$ \\
\hline Previsão & $\begin{array}{l}\text { Este indicador é explicitado } \\
\text { quando se afirma uma ação e/ou } \\
\text { fenômeno que sucede associado } \\
\underline{\text { a certos acontecimentos. }}\end{array}$ & $\begin{array}{l}\text { É explicitado quando se afirma } \\
\text { uma ação e/ou fenômeno que } \\
\text { sucede associado a certos } \\
\text { acontecimentos. }\end{array}$ \\
\hline Explicação & 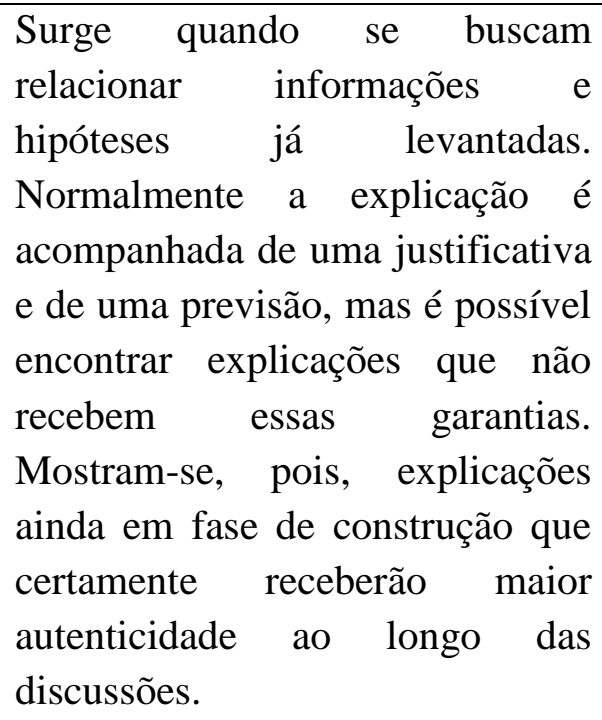 & 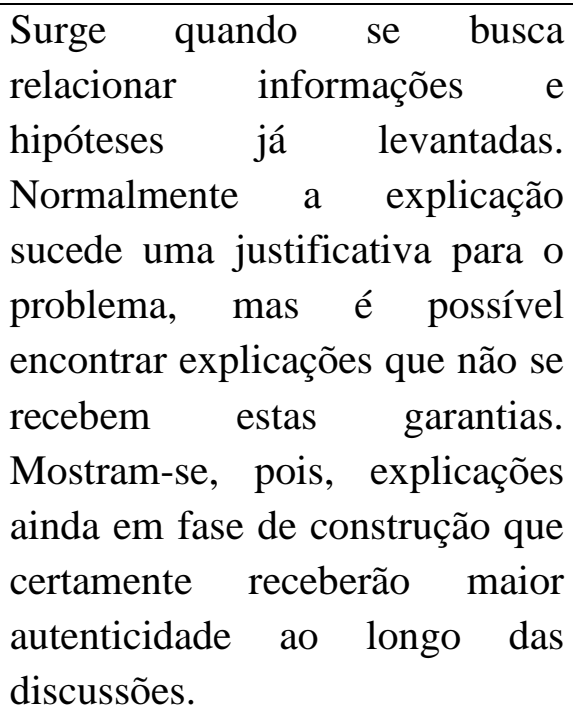 \\
\hline
\end{tabular}

Quadro 1: Indicadores de Alfabetização Científica propostos por Sasseron (2008) e Sasseron e Carvalho (2008) e sua descrição.

Agora segue um quadro com a descrição dos dois indicadores propostos neste trabalho:

\begin{tabular}{|l|l|}
\hline Indicador & Descrição \\
\hline $\begin{array}{l}\text { Listagem de } \\
\text { materiais }\end{array}$ & $\begin{array}{l}\text { Aparece quando os materiais utilizados na atividade são } \\
\text { apresentados. Pode aparecer como uma lista ou na descrição da } \\
\text { montagem das atividades. }\end{array}$ \\
\hline Argumento & $\begin{array}{l}\text { São encontrados quando uma afirmação é feita baseada em dados, } \\
\text { que podem ser empíricos ou não, estes levam a uma conclusão. } \\
\text { Comumente são encontradas justificativas que avalizam a relação } \\
\text { entre a conclusão e os dados que levam a ela, mas esta justificativa não } \\
\text { é condição sine qua non. Aparecem para defender e justificar } \\
\text { opiniões. }\end{array}$ \\
\hline
\end{tabular}

Quadro 2: Indicadores de Alfabetização Científica propostos neste trabalho e sua descrição. 
Thiago Marinho Del Corso

INDICADORES DE ALFABETIZAÇÃO CIENTÍFICA, ARGUMENTOS E EXPLICAÇÕES -

Análise de Relatórios no Contexto de uma Sequência de Ensino Investigativo

Sasseron (2008) e Sasseron e Carvalho (2008) dividem os indicadores em

três grupos, onde o primeiro grupo, constituído por Seriação, Organização e

Classificação de Informações, compreende os indicadores relacionados ao trabalho direto com os dados empíricos ou com as bases por meio das quais se compreende um assunto ou situação. Ao nosso ponto de vista o indicador proposto de Listagem de materiais se encaixa neste primeiro grupo. O segundo grupo, composto por Raciocínio Lógico ou Proporcional, se relaciona à estruturação do pensamento e à construção de uma ideia lógica e objetiva para as relações que regulam o comportamento dos fenômenos naturais. Acreditamos que o indicador proposto de Argumento pertença ao último grupo de indicadores que compreende também o Teste de Hipóteses, Justificativa, Previsão e Explicação. Estes estão vinculados à procura do entendimento da situação analisada -- sendo que, de acordo com Sasseron (2008), os três últimos se relacionam fortemente e podem explicitar um padrão de acontecimentos passível de expansão a outras situações. Sasseron diz ainda, acerca destes três últimos indicadores, que:

“...se bem estruturada, esta idéia (afirmações que mostram relações entre eles) deve permitir a percepção de relações entre os fenômenos do mundo natural e as ações humanas sobre ele. Caso isso ocorra, estaremos defronte a uma outra habilidade importante para o desenvolvimento da AC: a construção de modelo explicativo capaz de tornar claro a compreensão que se tem de um problema qualquer e as relações que se pode construir entre este conhecimento e outras esferas da ação humana."

\subsubsection{Diferenciando Argumentos de Explicações}

Os indicadores de Alfabetização Científica foram propostos por Sasseron (2008), como já apresentado, anteriormente ao trabalho de Osborne e Patterson (2011) que levanta a importância da diferenciação entre Argumentos e Explicações. Esse trabalho levantou grande polêmica na comunidade acadêmica do ensino de Ciências, tendo inclusive publicada entre outros diversos trabalhos tratando do assunto réplica por Berland e McNeill (2011) e tréplica por Osborne e Patterson em 2012. Diante da polêmica entre diferenciar-se ou não Argumentos e Explicações tomamos o 
Thiago Marinho Del Corso

INDICADORES DE ALFABETIZAÇÃO CIENTÍFICA, ARGUMENTOS E EXPLICAÇÕES -

Análise de Relatórios no Contexto de uma Sequência de Ensino Investigativo

posicionamento de acreditar ser importante esta distinção e disto derivou, para manter a

coerência deste posicionamento, já que um dos indicadores de Alfabetização Científica propostos consistia na Explicação, a proposta de adicionar como indicador de Alfabetização Científica o Argumento.

Tratando separadamente Argumentos e Explicações:

Argumentos constituem-se quando Dados (D) levam a Conclusões (C), desde que intermediados por Justificativas ( $\mathbf{J})$, com mais fundamento se apoiado em conhecimento básico, Garantia (W), modulado por Qualificadores (Q) e Refutadores (R) (TOULMIN 2006). Como se constroem Explicações? Quando se busca maior compreensão, quando se estabelece relação causal, quando se aplicam modelos, quando se estabelecem representações, quando se usam analogias, metáforas (OSBORNE e PATTERSON 2011)?

A diferenciação entre Argumentos e Explicações se baseia em sua função epistêmica: nos Argumentos a conclusão é que está em cheque, é para tentar convencer que se está argumentando. Os elementos que levam a Conclusão (C) do Argumento são mais plausíveis que a própria Conclusão (C). Já nas Explicações o fenômeno ou fato a ser explicado não está sob dúvida, são os elementos que levaram a esse fenômeno que podem ser contestados: o fenômeno é mais plausível que os elementos apontados como responsáveis por este fenômeno (MURCHO, 2003). Inclusive, Explicações podem pedir Argumentos que as defendam. Assim, quando houver conclusões concorrentes, mesmo que muitas vezes implícitas, espera-se encontrar Argumentos e não Explicações. Também quando a intenção da assertiva for convencer, esta estará relacionada a um Argumento; já para uma Explicação a intenção seria tornar aquele fenômeno mais claro.

Em um Argumento tentamos, a partir dos Dados (D), chegar a uma Conclusão (C) usando Garantias (W) apropriadas. Tomados em conjunto, os Dados (D), e as Garantias (W) reforçam as evidências para a validade da nossa alegação. Assim, um Argumento é uma declaração onde as premissas são declaradas para provar ou justificar uma Conclusão (C). O objetivo da argumentação é providenciar garantias que dêem suporte à Conclusão (C) e mostrem que a Justificativa (J) foi verdadeira (OSBORNE e PATTERSON, 2011). 
Thiago Marinho Del Corso

INDICADORES DE ALFABETIZAÇÃO CIENTÍFICA, ARGUMENTOS E EXPLICAÇÕES -

Análise de Relatórios no Contexto de uma Sequência de Ensino Investigativo

As Explicações tentam elucidar o porquê de algum fenômeno se proceder,

sem que este fenômeno esteja em discussão, podendo ser assim identificadas. O que deve ser explicado, a priori, já está estabelecido, isto é, não está em dúvida ou discussão; o que se demanda é uma Explicação para o fenômeno. Colocando simplificadamente, Explicações não são motivadas pela necessidade de persuadir a favor de uma conclusão, mas pelo desejo de responder à pergunta "Por quê?" (OSBORNE e PATTERSON 2011). Explicações se apresentam como tentativas de formulação de relações causais ou de atribuição de coerência a uma alegação, em comparações, ou no uso metafórico de um modelo explicativo já estabelecido para uma situação análoga.

Baseado no que foi acima citado e no referencial teórico, desenvolveu-se uma metodologia de desambiguação de Argumentos e Explicações. Esta metodologia é apresentada ordenada conforme os procedimentos que foram adotados no processo de identificação e diferenciação de Argumentos e Explicações.

\begin{tabular}{|l|l|}
\hline $\begin{array}{l}\text { 1. Identificação } \\
\text { de assertivas a } \\
\text { serem } \\
\text { desambiguadas. }\end{array}$ & $\begin{array}{l}\text { Leitura integral do relatório e identificação das assertivas que } \\
\text { possam se configurar como Argumentos (Toulmin, 2006) ou } \\
\text { Explicações (Osborne e Patterson, 2011). Estas são identificadas } \\
\text { quando a assertiva apresenta uma afirmação e a tentativa de explicar } \\
\text { ou justificar esta afirmação. Quando houver apenas enumeração de } \\
\text { fatos, sem relação de causa e efeito explicitada, estes não serão } \\
\text { considerados Argumentos ou Explicações. }\end{array}$ \\
\hline $\begin{array}{l}\text { 2. Identificação } \\
\text { da conclusão da } \\
\text { assertiva: }\end{array}$ & $\begin{array}{l}\text { Identificação daquilo que se está tentando explicar ou justificar. Se } \\
\text { for decidido que esta assertiva é uma explicação este elemento será } \\
\text { chamado de explanandum; se a assertiva for considerada um } \\
\text { argumento, este será a Conclusão (C). }\end{array}$ \\
\hline $\begin{array}{l}\text { 3. Análise da } \\
\text { assertiva: }\end{array}$ & $\begin{array}{l}\text { Quando a intenção da assertiva for convencer, esta está relacionada } \\
\text { a um Argumento. } \\
\text { Quando a intenção for deixar um fenômeno mais claro, apresentar } \\
\text { as causas que levaram ao desenrolar deste fenômeno, trata-se de } \\
\text { uma Explicação. }\end{array}$ \\
\hline $\begin{array}{l}\text { 4. Presença de } \\
\text { diferentes } \\
\text { motivadores: }\end{array}$ & $\begin{array}{l}\text { Quando houver hipóteses explicativas concorrentes, uma em relação } \\
\text { à outra, explicita ou implícita, a assertiva está relacionada a um } \\
\text { Argumento. } \\
\text { Quando houver motivos que se somem para explicar o o } \\
\text { explanandum e não concorram como diferentes hipóteses } \\
\text { explicativas, esta se relacionaria a uma Explicação. }\end{array}$ \\
\hline
\end{tabular}


Thiago Marinho Del Corso

INDICADORES DE ALFABETIZAÇÃO CIENTÍFICA, ARGUMENTOS E EXPLICAÇÕES -

Análise de Relatórios no Contexto de uma Sequência de Ensino Investigativo

5. Análise da Se o elemento [explanandum ou Conclusão (C)] estiver sobre Conclusão (C) contestação, (sub-júdici), se houver conclusões concorrentes, trataou $\quad$ se da Conclusão (C) de um Argumento.

explanandum: $\quad$ Se o elemento [explanandum ou Conclusão (C)] não estiver sobre contestação, se não houver dúvida, se não estiver sendo colocado a prova, se não houver conclusão concorrente, trata-se do explanandum de uma Explicação.

6. Análise da Consoante se as premissas são ou não mais plausíveis do que a relação de conclusão:

plausibilidade entre os

elementos:

Nos Argumentos: a Conclusão (C) é menos plausível que os elementos que levem a ela. Logo, se as premissas forem mais plausíveis, mais certas que a conclusão (Conclusão C), trata-se de um Argumento.

Nas Explicações: O explanandum (conclusão) é mais plausível que os elementos que levam a ele. Logo, se as premissas forem menos plausíveis, mais incertas que a conclusão (explanandum), trata-se de uma Explicação.

7. Tentativa de Para as assertivas identificadas como Argumentos haverá a correspondência ao modelo modificado de Toulmin (2006):

tentativa de reestruturação no layout adaptado de Toulmin (2006) como proposto por (OROFINO, 2011; DRIVER et al., 2000).

Dado (D)

Justificativa assim, Conclusão(C), (Qualificador)(Q)

Proposta de modelo simplificado do proposto por Toulmin (2006).

A correspondência permite revisitar a origem e natureza dos Dados (D), das Conclusões (C) e Justificativas (J).

Quadro 3: Metodologia de diferenciação de Argumentos e Explicações

Como apresentado em nosso referencial teórico, esta reestruturação se inicia sempre a partir da identificação da Conclusão (C) do argumento (OROFINO 2011, ERDURAN, et al., 2004). Os Dados (D) são geralmente precedidos, no Argumento, por palavras como 'por que', 'uma vez que', 'como', 'pois'. As Justificativas (J) (junção de garantias e apoios) são frases ou sentenças que conduzem os Dados (D) até as Conclusões (D). Quando houver apenas enumeração de fatos, sem relação de causa e efeito explicitada, estes não serão considerados Argumentos e não haverá reestruturação. 
Thiago Marinho Del Corso

INDICADORES DE ALFABETIZAÇÃO CIENTÍFICA, ARGUMENTOS E EXPLICAÇÕES -

Análise de Relatórios no Contexto de uma Sequência de Ensino Investigativo

Acerca dos Argumentos, muitos pesquisadores (JIMENEZ e DIÁZ, 2003;

SIMON et al, 2006) relataram dificuldade em diferenciar, no layout de Toulmin, garantias de apoios, e é por isso que adotamos esta simplificação do modelo de Argumento utilizado para análise, unindo Garantia (W) e Apoio (B) em um só elemento, chamado de Justificativa (J).

\section{Resultados}

No capítulo anterior apresentamos como foram desenvolvidos nossos procedimentos de análise dos relatórios, tanto no que tange aos indicadores de Alfabetização Científica e a criação de uma metodologia de desambiguação entre Argumentos e Explicações.

Este capítulo, referente aos resultados, apresenta dois conjuntos e dois formatos de apresentação: um deles mais extensivo, referente ao trabalho interpretativo (6.1) e que, por ter essa característica mais verbal e mais próxima do exercício de interpretação conterá, como exemplo, apenas a análise de três relatórios e suas respectivas conclusões individuais; o outro tópico (6.2) apresenta uma sistematização dos indicadores de AC e a desambiguação entre Argumentos e Explicações, encontrados em todos os 29 relatórios e conclusões individuais e é constituído por tabela e gráficos, servindo de base para responder as questões de pesquisa.

Nosso conjunto de dados para esse exercício de interpretação nessa análise mais descritiva da aplicação de procedimentos é constituído de 11 relatórios confeccionados em 2012 e 18 relatórios referentes a 2013, sendo que estes últimos contém conclusões que foram escritas individualmente e somam 52 conclusões individuais.

Para o tópico (6.1) foram escolhidos três exemplos com o intuito de ilustrar a aplicação dos procedimentos de análise apresentados no capítulo cinco. Nos apêndices são apresentados todos os demais relatórios e respectivas conclusões individuais, quando houver.

O segundo tópico (6.2) traz uma síntese dessa interpretação, e compõe um quadro que permite visualizar os indicadores de alfabetização científica identificados nos relatórios e conclusões individuais analisados, bem como os Argumentos e Explicações que foram diferenciados. Os dados produzidos da aplicação dos 
Thiago Marinho Del Corso

INDICADORES DE ALFABETIZAÇÃO CIENTÍFICA, ARGUMENTOS E EXPLICAÇÕES -

Análise de Relatórios no Contexto de uma Sequência de Ensino Investigativo

procedimentos de análise são arranjados em tabelas e gráficos para facilitar uma visão

global de quais os indicadores mais presentes, como estes se distribuem nos relatórios e conclusões individuais, ou outros padrões que serão discutidos no capítulo sete. São esses dados sistematizados que são usados para responder as questões de pesquisa.

\subsection{Análise interpretativa}

Este capítulo apresenta três exemplos de nossa análise interpretativa, pois acreditamos que apresentar as análises de todos os relatórios e respectivas conclusões individuais correria o risco de deixar a leitura cansativa e desinteressante e comprometeria a fluidez da leitura; as demais análises interpretativas são apresentadas nos apêndices.

Em cada análise: primeiramente é apresentado o relatório a ser analisado escaneado e com as marcas apontadas; em seguida é preenchido um quadro, como o do exemplo apresentando no tópico 5.1 dos procedimentos, em que são assinalados quais indicadores estão presentes em cada marca atribuída ao relatório; por último são apontados e discutidos os motivos pelos quais cada marca foi entendida como um dos indicadores de AC; quando houver, são apresentadas as considerações que nos ajudaram a entender se tratar de Explicações ou Argumentos e, se entendido ser um Argumento, este é reestruturado segundo o layout de Toulmin (2006) modificado. Estes quadros contém também as tabelas, gráficos, figuras ou trechos transcritos que compõem a marca, assim como a parte do relatório em que a marca está contida ou se ela corresponde a uma conclusão redigida individualmente. 
Thiago Marinho Del Corso

INDICADORES DE ALFABETIZAÇÃO CIENTÍFICA, ARGUMENTOS E EXPLICAÇÕES -

Análise de Relatórios no Contexto de uma Sequência de Ensino Investigativo

6.1.1 Relatório $1-2013$

O Relatório 1 - 2013

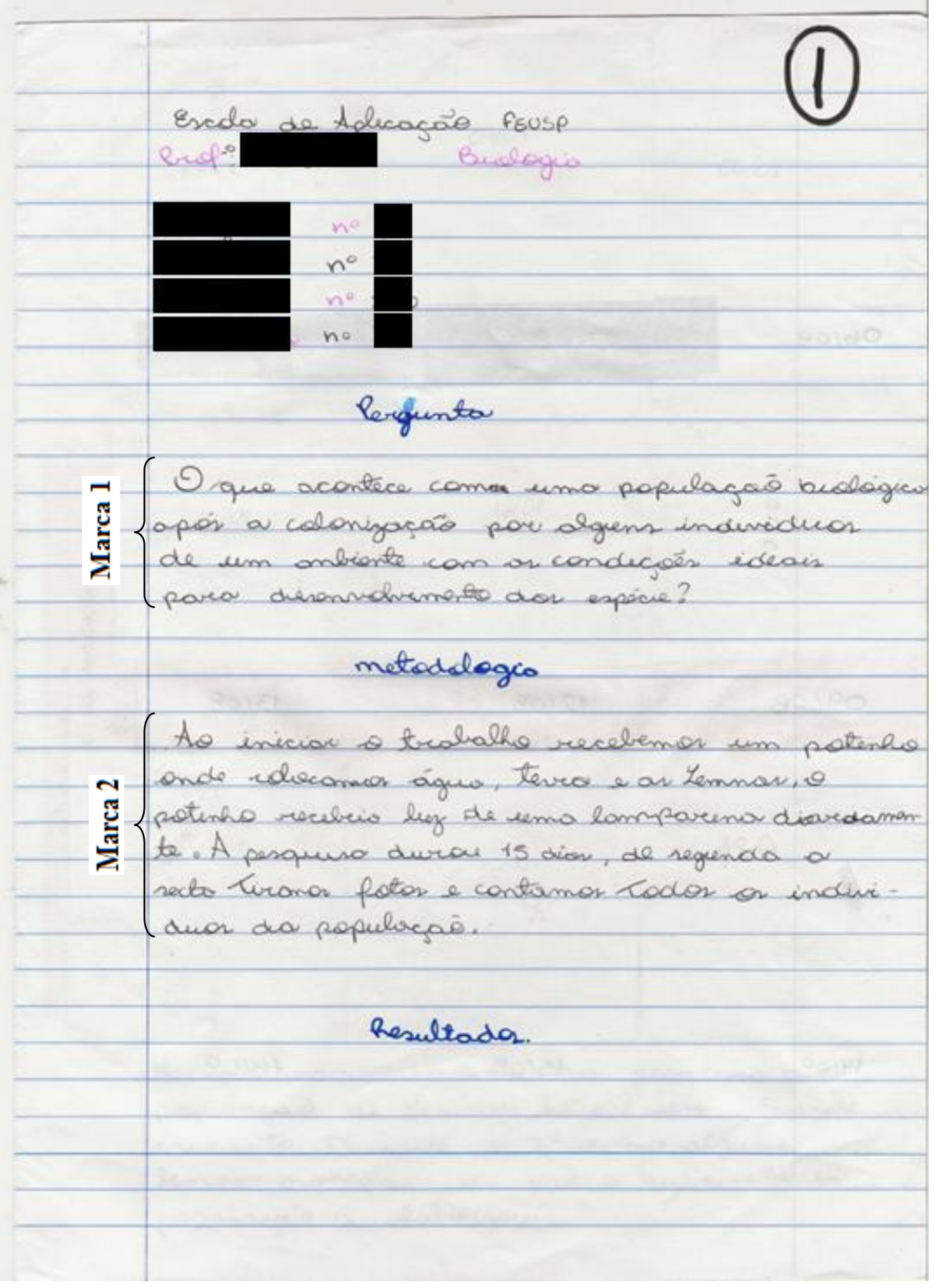


Thiago Marinho Del Corso

INDICADORES DE ALFABETIZAÇÃO CIENTÍFICA, ARGUMENTOS E EXPLICAÇÕES -

Análise de Relatórios no Contexto de uma Sequência de Ensino Investigativo

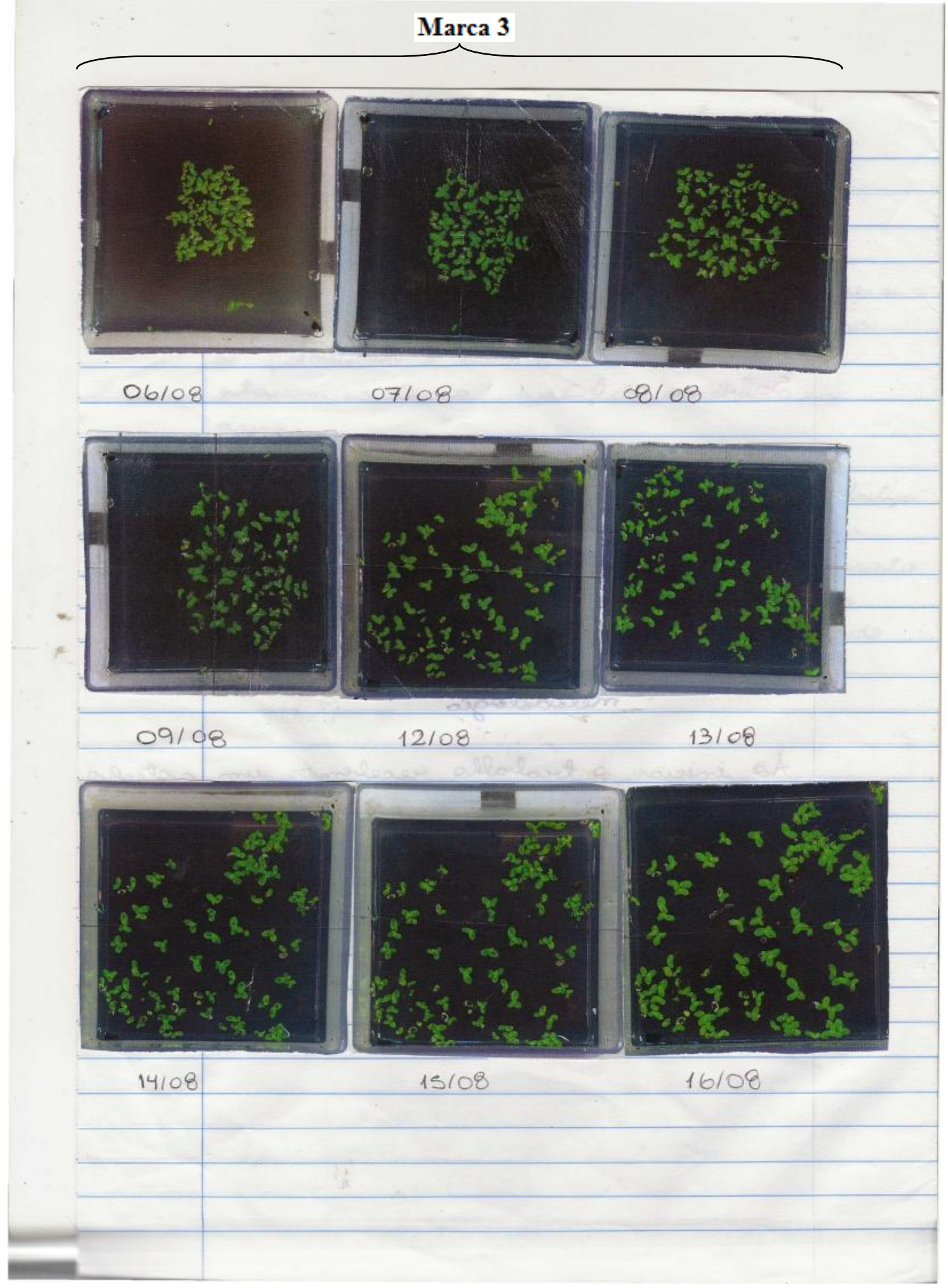


Thiago Marinho Del Corso

INDICADORES DE ALFABETIZAÇÃO CIENTÍFICA, ARGUMENTOS E EXPLICAÇÕES -

Análise de Relatórios no Contexto de uma Sequência de Ensino Investigativo
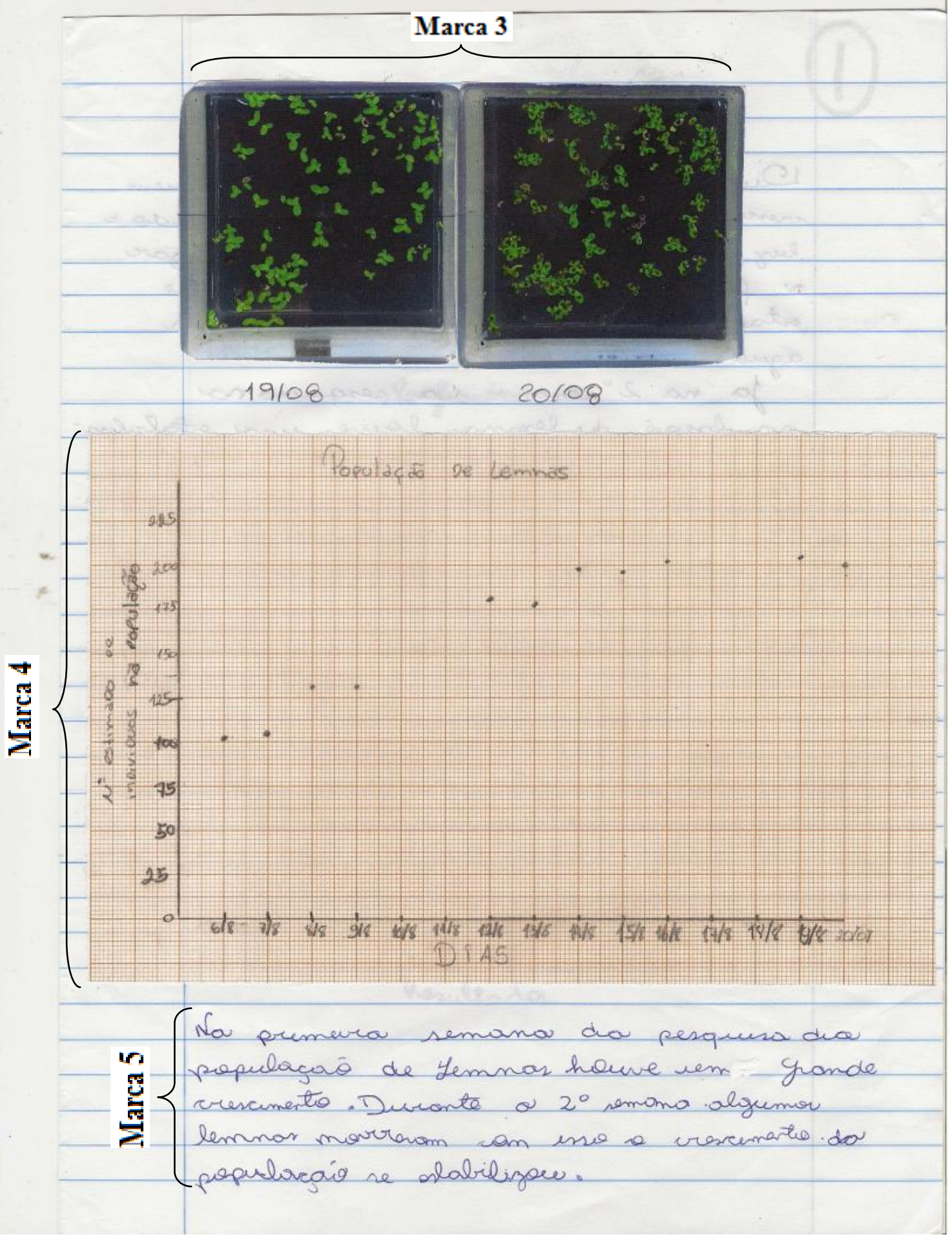
Thiago Marinho Del Corso

INDICADORES DE ALFABETIZAÇÃO CIENTÍFICA, ARGUMENTOS E EXPLICAÇÕES -

Análise de Relatórios no Contexto de uma Sequência de Ensino Investigativo

\section{interputaçó}

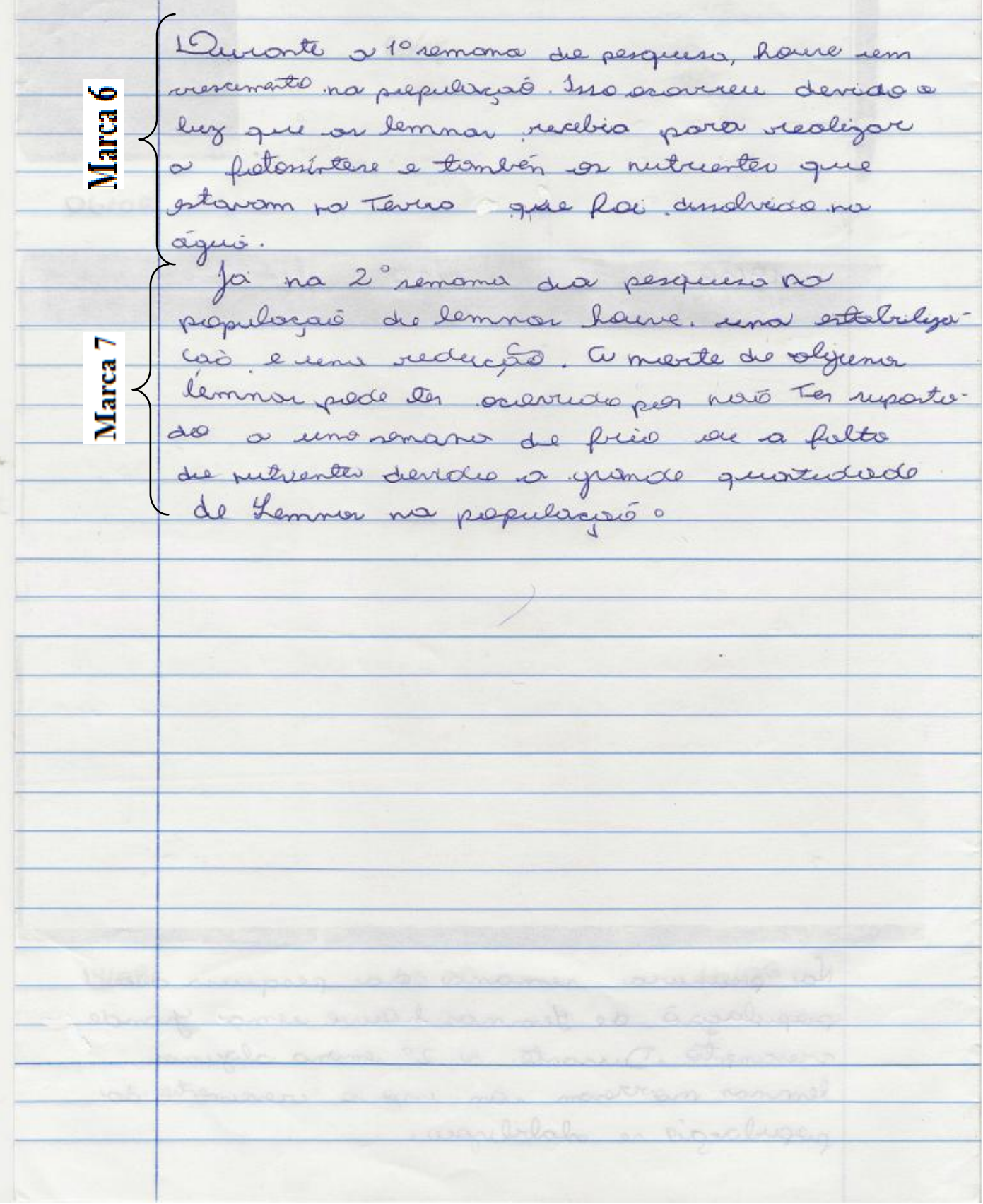


Análise de Relatórios no Contexto de uma Sequência de Ensino Investigativo

Quadro de identificação 01 - Identificação dos Indicadores de Alfabetização Científica presente no Relatório 1 de 2013 e conclusões individuais correspondentes

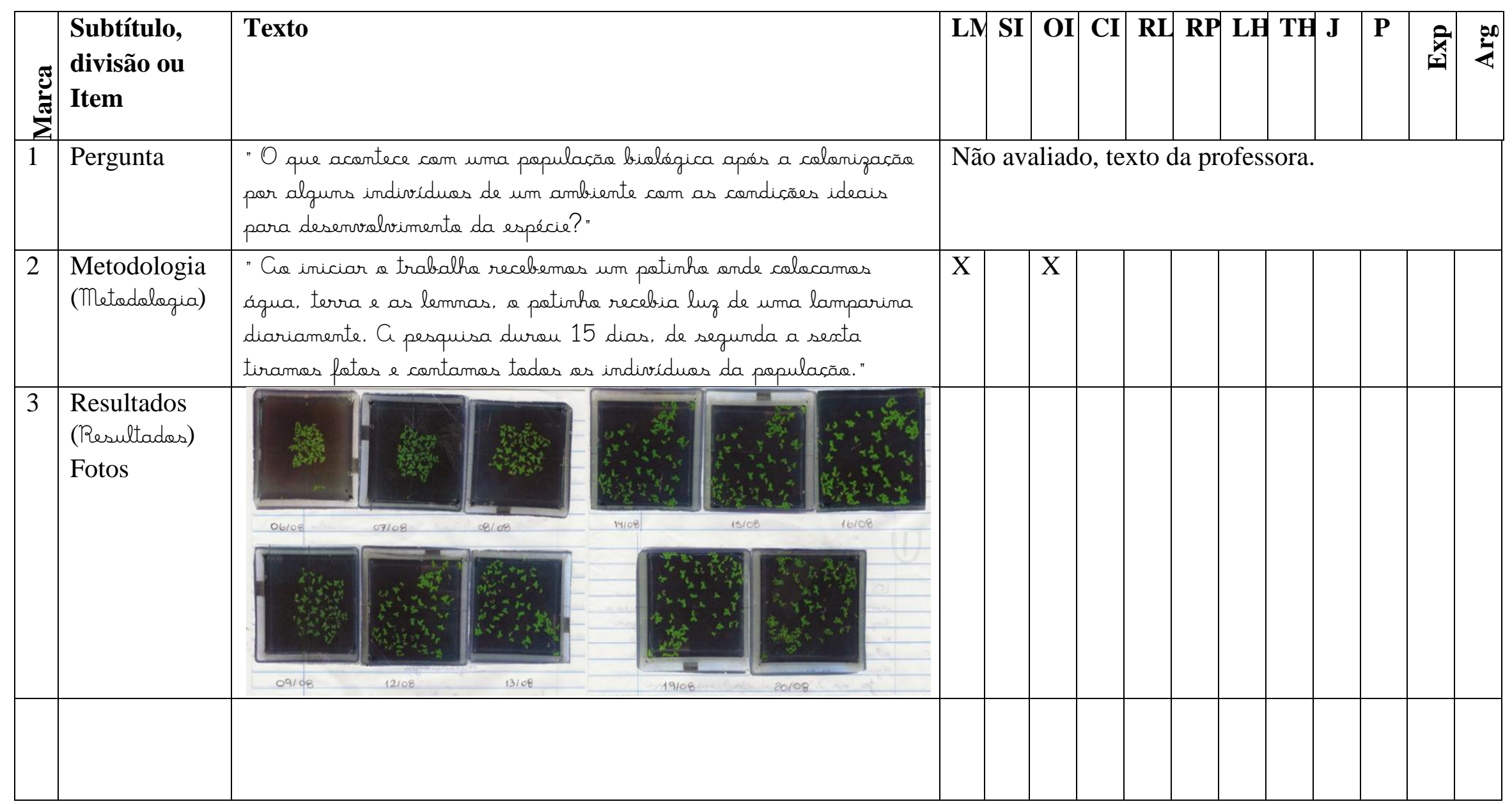


Thiago Marinho Del Corso

INDICADORES DE ALFABETIZAÇÃO CIENTÍFICA, ARGUMENTOS E EXPLICACCOES -

Análise de Relatórios no Contexto de uma Sequência de Ensino Investigativo

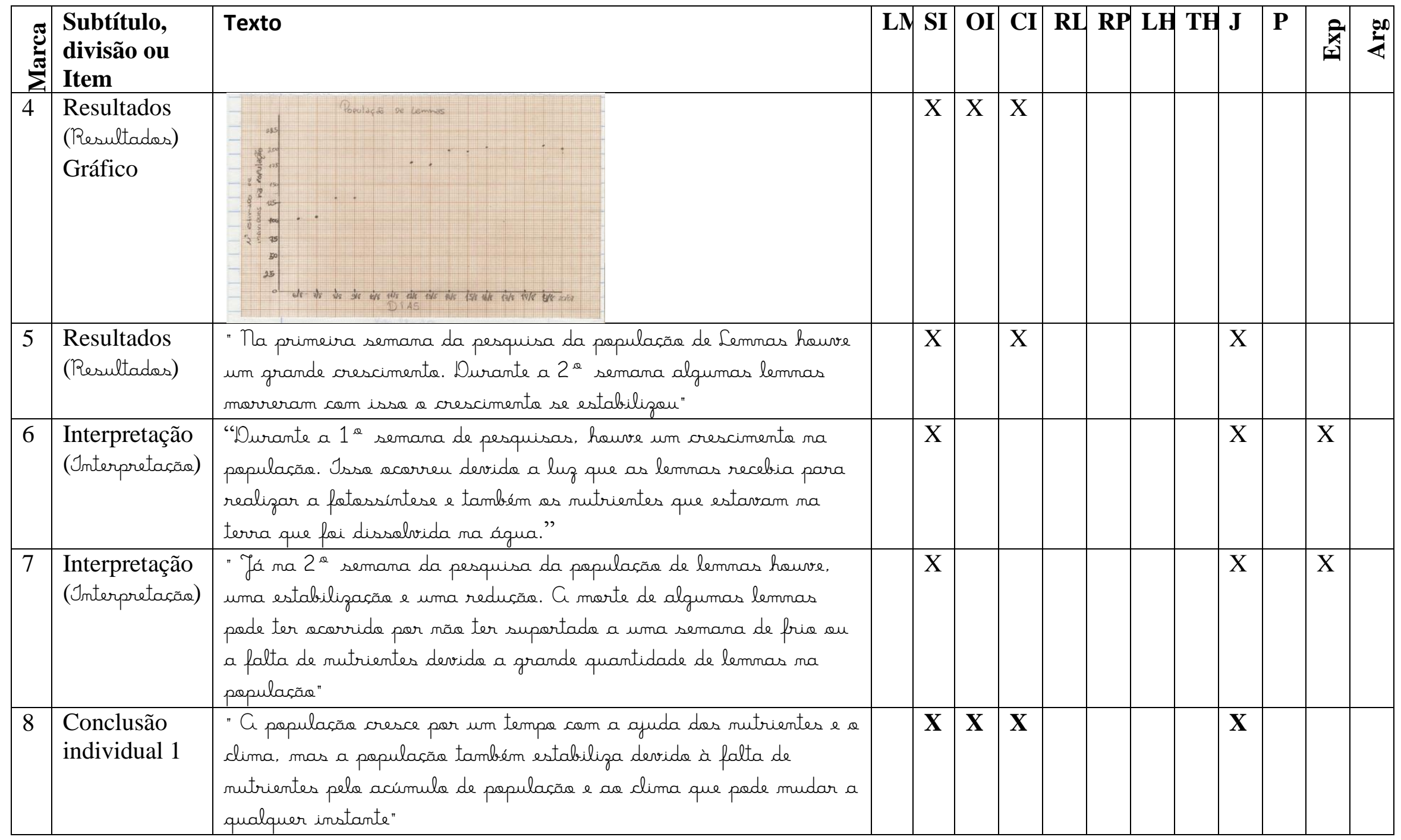


Thiago Marinho Del Corso

INDICADORES DE ALFABETIZAÇ̃̃o CIENTÍFICA, ARGUMENTOS E EXPLICAÇÕES -

Análise de Relatórios no Contexto de uma Sequência de Ensino Investigativo

\begin{tabular}{|c|c|c|c|c|c|c|c|c|c|c|c|c|c|}
\hline 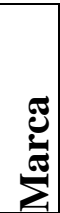 & $\begin{array}{l}\text { Subtítulo, } \\
\text { divisão ou } \\
\text { Item }\end{array}$ & Texto & LM SI & OI & CI & $\mathbf{R L}$ & $\mathbf{R P}$ & $\mathbf{L H}$ & TH & $\mathbf{J}$ & $\mathbf{P}$ & 党 & $\sum^{0}$ \\
\hline 9 & $\begin{array}{l}\text { Conclusão } \\
\text { individual } 2 \\
1^{\circ} \text { parágrafo }\end{array}$ & 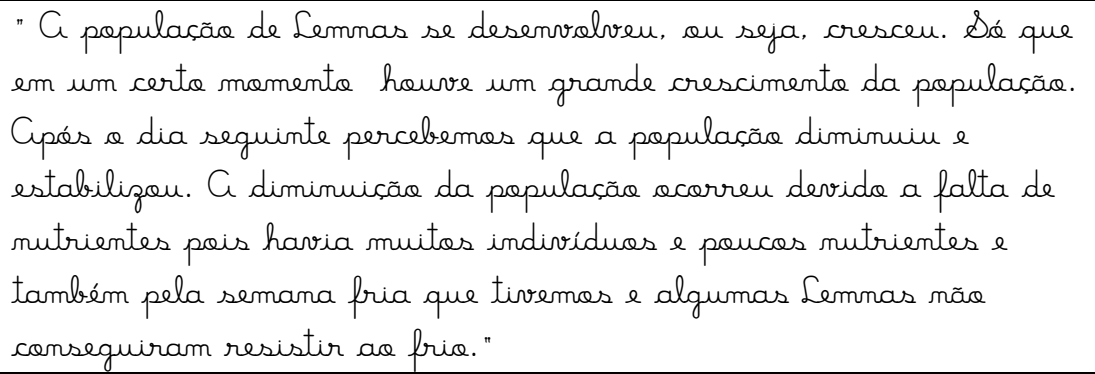 & $\mathbf{X}$ & $\mathbf{X}$ & $\mathbf{X}$ & & & & & $\mathbf{X}$ & & $\mathbf{X}$ & \\
\hline 10 & $\begin{array}{l}\text { Conclusão } \\
\text { individual } 2 \\
2^{\circ} \text { parágrafo }\end{array}$ & $\begin{array}{l}\text { "A papulaçãa de lemnas conseguiu se desenvalver pois recebia } \\
\text { luz diariamente para realizar a fatossintese e também utilizava as } \\
\text { nutrientes da terra que estava dissolvida na água para se } \\
\text { desenvalverem." }\end{array}$ & $\mathbf{X}$ & & & & & & & $\mathbf{X}$ & & $\mathbf{X}$ & \\
\hline 11 & $\begin{array}{l}\text { Conclusão } \\
\text { individual } 3 \\
1^{\circ} \text { parágrafo }\end{array}$ & $\begin{array}{l}\text { " Ta papulaça de Lemnas houve um crescimenta grande e rápida, } \\
\text { mas durante a } 2 \text { a semana algumas Lemnas morreram, no final } \\
\text { da pesquisa a populaça se estabilizau." }\end{array}$ & $\mathbf{X}$ & $\mathbf{X}$ & $\mathbf{X}$ & & & & & & & & \\
\hline 12 & $\begin{array}{l}\text { Conclusão } \\
\text { individual } 3 \\
2^{\circ} \text { parágrafo }\end{array}$ & $\begin{array}{l}\text { "Na primeira dia iniciau com 115. O dia hauve maior númera de } \\
\text { Lemnas foi } 211 \text {. E a dia mais baixa depais da estabilizaçãa foi } \\
\text { 201. Final da pesquisa: sobreviveram } 201 \text { e morreram 21." }\end{array}$ & $\mathbf{X}$ & $\mathbf{X}$ & & & & & & & & & \\
\hline
\end{tabular}


Thiago Marinho Del Corso

INDICADORES DE ALFABETIZAÇÃO CIENTÍFICA, ARGUMENTOS E EXPLICAÇÕES -

Análise de Relatórios no Contexto de uma Sequência de Ensino Investigativo

Relatório 1 - 2013 - Detalhando a identificação dos indicadores de AC

O relatório 1 de 2013 se inicia com um cabeçalho apresentando o nome da escola, seguido do da professora, disciplina e dos integrantes do grupo. Essas parte do relatório não é analisada pois faz parte da identificação do relatório e não inclui aspectos de conteúdo.

\section{Marca 1 (relatório 1):}

Após o cabeçalho é apresentada a pergunta geradora da investigação, que também não é analisada, já que o foco deste trabalho se dá nas produções escritas dos alunos e a pergunta geradora da investigação é dada pela professora e copiada na maioria dos relatórios, não sendo portanto uma produção dos alunos. Ainda assim, salientamos a importância dessa pergunta para a análise que visará diferenciar Argumentos de Explicações, já que as comandas dadas pela professora para a elaboração dos relatórios e das outras atividades tem grande influência na função epistêmica das produções dos alunos.

\section{Marca 2 (relatório 1):}

Pudemos identificar na primeira assertiva abaixo transcrita, na apresentação da metodologia do relatório dos alunos, os seguintes indicadores de Alfabetização Científica: Listagem de materiais e Organização de informações: "Go iniciar a trabalho recebemes um petenho onde colocames água, terra e as Lemnas, e potinho recebia lus de uma lamparena diariamente. A pesquisa durou 15 dias, de segunda a sexta tiramas fotas e contamas todos as individuas da populacãa."

Dentre os indicadores de alfabetização científica que estão ligados ao trabalho com os dados empíricos, esta primeira assertiva apresenta uma Listagem de materiais, que aparece aqui quando os alunos apresentam os materiais que foram utilizados na montagem do experimento de crescimento populacional das Lemnas: "potemho", "água", "terra", "Lemnas" e "lamparema". A Organização de informações aparece ao especificar que a pesquisa duraria quinze dias e as fotos e contagem ocorreriam de segunda a sexta; "A pesquisa durou 15 dias, de segunda a sexta tiramas fotas e contamos todos as 
Thiago Marinho Del Corso

INDICADORES DE ALFABETIZAÇÃO CIENTÍFICA, ARGUMENTOS E EXPLICAÇÕES -

Análise de Relatórios no Contexto de uma Sequência de Ensino Investigativo

individuos da populaçãa."; os alunos estão Organizando as informações. Isso, pois de

acordo com Sasseron e Carvalho (2008), este indicador "surge quando se procura preparar os dados existentes sobre o problema investigado" e aqui os alunos estão preparando dados quando afirmam que usaram fotos e a duração do experimento.

\section{Marca 3 (relatório 1):}

Na segunda página do relatório e início da terceira, sob o título "Resultados", os alunos apresentam as fotos tiradas dos recipientes montados para acondicionar as Lemnas e coletar os dados referentes ao crescimento populacional das mesmas. Estas inscrições literárias do tipo registro de instrumentos, segundo a classificação de Lehrer, Schauble e Petrosino (2001), não podem ser entendidas como indicadores de alfabetização científica, mesmo que entendamos que são práticas comuns da Ciência e por isso desejadas no ensino de Ciências.

\section{Marca 4 (relatório 1):}

Quando os dados são organizados em um gráfico, na terceira página, entendemos que essa inscrição literária apresenta os indicadores de Alfabetização Científica de Seriação, Organização e Classificação de informações. Isso porque os dados do número de indivíduos na população de Lemnas são apresentados como em uma relação,o que caracteriza uma Seriação de informações (Sasseron 2008; Sasseron e Carvalho 2008). A Organização de informações decorre do fato de que em um gráfico os dados sobre o problema investigado estão sendo preparados e organizados nessa inscrição literária. Já a Classificação de informações advém da atribuição de características a estes dados, uma vez que no gráfico estes são apresentados ordenadamente e a própria natureza do gráfico permite perceber relações e características dos dados do experimento. 
$\mathrm{Na}$ terceira página, logo abaixo do gráfico, encontramos uma assertiva que diz:

" Ta primeira semana da pesquisa da populacãa de Lemnas hauve um grande crescimenta.

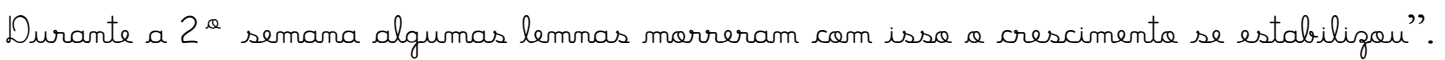

Este trecho apresenta indicadores de Seriação de informações, Classificação de informações e Justificativa.

A Seriação de informações se caracteriza, segundo Sasseron e Carvalho (2008) e Sasseron (2008), como uma apresentação de dados com os quais se trabalhou ou se vai trabalhar. Assim, quando os alunos afirmam que a população de Lemnas teve crescimento na primeira semana e crescimento e estabilização na segunda semana, estão listando dados e consecutivamente apresentando o indicador de Seriação de informações. Isso porque o tema central da SEI é a dinâmica populacional -- e crescimento, diminuição ou estabilização da população são, neste assunto, dados com os quais se analisa a dinâmica populacional da(s) determinada(s) populações(s) em estudo.

O primeiro trecho da assertiva; "Na primeira semana da pesquisa da populaçã de Lemnas houve um grande crescimenta." foi entendido como uma Classificação de informações, já que atribui características aos dados obtidos quando aponta que na primeira semana houve - "grande" - crescimento na população de Lemnas. Já na segunda

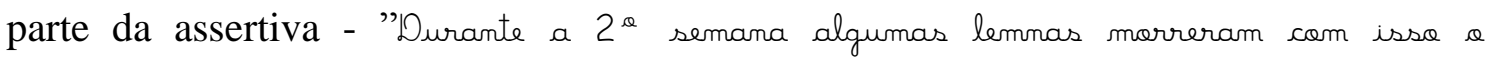
crescimenta se estabilizau" - podemos encontrar uma Justificativa para a causa dessa estabilização, a morte de algumas Lemnas - "algumas lemnas moerreram com issa a crescimento se estabilizau" - .

\section{Marca 6 (relatório 1):}

No parágrafo do último ítem do relatório 1 de 2013, denominado "Interpretaçãe" - , ocorre a retomada dos resultados obtidos e a análise dos padrões e interpretações destes padrões de resultados. Aqui podemos perceber uma prevalência de indicadores de Alfabetização Científica relacionados à procura do entendimento da situação analisada: - "Durante a 1' semana de pesquisas, houve um crescimenta na 
Thiago Marinho Del Corso

INDICADORES DE ALFABETIZAÇÃO CIENTÍFICA, ARGUMENTOS E EXPLICAÇÕES -

Análise de Relatórios no Contexto de uma Sequência de Ensino Investigativo

populașãa. Issa acorreu devida a luz que as lemnas recebia para realizar a fatassintese e

também as mutrientes que estavam na terra que foi dissolvida na água." - .

Nesse trecho encontramos os indicadores de Seriação de informações, Justificativa e Explicação. O primeiro ocorre quando os alunos afirmam que - "houve um crescimente ma populasãe"- . Aqui segue a mesma lógica discutida na marca anterior, em que entendemos como dados, quando a temática é dinâmica populacional, as variações no tamanho das populações em estudo. E que, já que o indicador de Seriação de informações ocorre quando estes dados são apresentados, temos neste trecho o referido indicador

As Justificativas aparecem para dar garantia à afirmação de que houve crescimento - "Isso acorreu devido a luz que as lemnas recebia para realizar a fotassintese" - e - "também as nutrientes que estaram na terra que foi dissolvida na água."-. De acordo com Sasseron e Carvalho (2008) e Sasseron (2008) uma Justificativa “... aparece quando, em uma afirmação qualquer proferida, lança-se mão de uma garantia para o que é proposto. Isso faz com que a afirmação ganhe aval, tornando-a mais segura".

A primeira assertiva do ítem "Interpretação" do relatório 1 de 2013 é identificada como uma Explicação. Já que o explanandum, fenômeno de crescimento populacional das Lemnas, não está sub-júdice, ele foi matematicamente comprovado e apresentado na forma de um gráfico. O que se segue à apresentação do explanandum -"Durante a 1" semana de pesquisas, houve um crescimenta na populacãa" -- é uma tentativa de deixar claro porque o fenômeno se dá dessa forma, que é igual ao modelo teórico apresentado em aula pela professora para crescimento de uma população. Os alunos apresentam que "Isso (se referindo ao explanandum) ocorreu devido a luz que as lemnas recebia para realizar a fotassintese" e "e também as nutrientes que estavam na terra que foi dissolvida na água." -- como os elementos que visam explicar porque o explanandum se deu daquela forma. Estes elementos podem ser chamados de explanans e funcionam como as justificativas para o explanandum da mesma forma como as justificativas de um Argumento. 
O segundo parágrafo da "Imterpretaçãe" transcrito abaixo apresenta os indicadores de Seriação de informações, Classificação de informações, Justificativa e Explicação.

"Já na 2 e semana da pesquisa da populaçãa de lemnas hauve, uma estabilizacsãa e uma reduçãa. A morte de algumas lemnas pode ter ecorrida por nãa ter suportado a uma semana de fria an a falta de nutrientes devida a grande quantidade de lemnas na populașãe".

O indicador de Seriação de informações é identificado, nessa assertiva, seguindo o mesmo raciocínio das marcas anteriores, em que consideramos dados os escritos pelos alunos de que houve "estabilizacãa e uma reduçãe". As Justificativas surgem para dar garantias à afirmativa de que houve "estabilizaçãe e uma reduçãa", sendo essas garantias "mãa ter suportado a uma semana de fric au a falta de mutrientes". Acreditamos que nessa marca encontra-se também uma Explicação. Isso porque os alunos afirmam que houve uma "estabilizacãa e uma reduçãe" e desenvolvem hipóteses explicativas concorrentes para esta afirmativa. Nomeamos essa afirmativa, que nada mais é que a conclusão da Explicação, como o explanandum e os elementos que estabelecem as relações causais com essa de explanans.

Entendemos que nessa marca os alunos não estão tentando convencer que existe uma "estabilizaçãe e uma reduçãe", já que o gráfico demonstraria isso, mas estão tentando sim deixar o fenômeno mais claro, apresentando as causas para este ter se dado da forma como ocorreu. Isso, somado ao fato de que os elementos que levam ao explanandum são menos certos que o próprio, serve de distinção entre Explicação e Argumento, reforçando nossa tese de que tratamos aqui de duas hipóteses explicativas. Para ambas as hipóteses o explanandum é o mesmo ("estabilizaçãe e uma reducãa"), mas para uma o explanans é que " $G$ morte de algumas lemnas pode ter acorrida por nãa ter suportada a uma semana de frie", enquanto que para o outro trata-se de "a falta de mutrientes devida a grande quantidade de lemnas na papulacãa". 
Após a elaboração em grupo do relatório os alunos, individualmente, escreveram cada um uma conclusão, para a qual foram disponibilizados uma cópia do relatório para cada aluno do grupo. Produzir esta conclusão visava finalizar de forma individual o relatório construído coletivamente. O comando utilizado para esta última etapa foi colocado na lousa e constituia-se da seguinte instrução: "Sabendo que a conclusão do relatório científico consiste na resposta à pergunta inicial, justificada com evidências (dados produzidos durante a investigação), conclua seu relatório.”.

\section{Marca 8 (relatório 1):}

A primeira conclusão escrita individualmente, diferentemente do relatório que foi escrito em grupo, apresenta os indicadores de Seriação, Organização e Classificação de informações e Justificativa.

Transcrita abaixo, podemos perceber o indicador de Seriação de informações quando o aluno afirma que a população "cresce" e depois "estabiliza". Pensando que o tema central do experimento era a dinâmica populacional, crescer e estabilizar podem ser entendidos como dados, e sua apresentação, indicador de Alfabetização Científica do tipo Seriação de informações.

A Organização de informações ocorre quando o aluno organiza cronologicamente os dados, afirmando que primeiro a população cresceu e depois estabilizou.

A Classificação de informações advém do estabelecimento de características para os dados. Neste trecho, ao dado de crescimento é atribuída uma característica: o crescimento foi "por um tempo".

As Justificativas aparecem tanto para o crescimento inicial ("ayuda dos mutrientes e a clima"), como para a estabilização posterior ("devida à falta de mutrientes pela acúmula de populacão e ae clima que pode mudar a qualquer instante").

Segue a transcrição completa referente a esta marca: "G populaçãe cresce por um tempo com a ayuda das nutrientes e a clima, mas a papulacãa também estabiliza devida à 
Thiago Marinho Del Corso

INDICADORES DE ALFABETIZAÇÃO CIENTÍFICA, ARGUMENTOS E EXPLICAÇÕES -

Análise de Relatórios no Contexto de uma Sequência de Ensino Investigativo

falta de mutrientes pela acúmula de populașãa e ae clima que pode mudar a qualquer

instante".

\section{Marca 9:}

A segunda conclusão individual apresenta indicadores de Seriação, Organização e Classificação de informações, Justificativa e Explicação.

Seriação de informações se caracteriza pela apresentação dos dados, e no trecho que segue ao final das análises podemos encontrar a apresentação destes dados: "crescimento", "diminuiu" e "estabilizau".

A divisão em três momentos do padrão de crescimento das Lemnas pode ser entendida como uma Organização de informações. De acordo com Sasseron e Carvalho (2008) e Sasseron (2008): “... este indicador de informações pode ser encontrado durante o arranjo das informações novas ou já elencadas anteriormente e ocorre tanto no início da proposição de um tema quanto na retomada de uma questão, quando ideias são relembradas.”.

A Classificação de informações ocorre quando características são estabelecidas aos dados, o que é evidenciado pelo "grande" associado ao crescimento inicial.

A Justificativa é desenvolvida para dar aval à afirmação de que houve um período de "diminuição da população" e a Justificativa para esta diminuição foi "a falta de nutrientes pais havia muitos individuos e poucos nutrientes e também pela semana fria que tivemas e algumas Lemnas nãa conseguiram resistir ace fria".

De acordo com Osborne e Patterson (2011), as Explicações começam com uma declaração de exploração (explanandum). A Explicação encontrada neste trecho tem como explanandum, fenômeno ao qual se busca estabelecer as causas, a "diminuiçãe da populaçãe" de Lemnas, e apresenta para este intuito dois diferentes explanans que ao invés de concorrerem como diferentes hipóteses explicativas se somam, como dois motivos que juntos justificam o porquê desse fenômeno ter se dado da forma como aconteceu. De acordo com nossa metodologia de diferenciação de Argumentos e Explicações, quando houver motivos que se somem para explicar o explanandum e não 
Thiago Marinho Del Corso

INDICADORES DE ALFABETIZAÇÃO CIENTÍFICA, ARGUMENTOS E EXPLICAÇÕES -

Análise de Relatórios no Contexto de uma Sequência de Ensino Investigativo

concorram como diferentes hipóteses explicativas, a afirmativa estaria relacionada a uma Explicação e não a um Argumento.

Segue a transcrição completa referente a esta marca: " $G$ populaçãa de Lemnas se desenvalveu, au seja, cresceu. Sá que em um certa momenta houve um grande crescimento da populașãa. Após a dia seguinte percebemas que a populaçãa diminuiu e estabilizau. A diminuiçãa da papulaçãa acarreu devida a falta de mutrientes pais havia muitas individuas e paucos nutrientes e também pela semana fria que tivemas e algumas Lemnas nãa conseguiram resistir ac fria.".

\section{Marca 10 (relatório 1):}

A segunda parte da segunda conclusão individual do relatório 1 apresenta os indicadores de Seriação de informações, Justificativa e Explicação e segue transcrita: "A populaçãa de lemnas conseguiu se desenvolver pois recebia luz diariamente para realizar a fotassintese e também utilizava as nutrientes da terra que estava dissolvida na água para se desenvolverem.".

$\mathrm{Na}$ descrição dos seus indicadores de Alfabetização Científica, Sasseron e Carvalho (2008) afirmam que a Seriação de informações está relacionada ao estabelecimento das bases para a ação investigativa, e que este indicador pode se apresentar como uma lista de dados com os quais se irá trabalhar. Acreditamos que no trecho acima, ao afirmar que "G populacäa de lemnas conseguiu se desenvolver", os alunos estão apresentando dados que serão em seguida trabalhados. Isso porque, como o assunto em questão é a dinâmica populacional, desenvolvimento da população pode ser entendido como um dado.

Pode-se entender que os alunos estão apresentando o indicador de Alfabetização Científica Justificativa, neste trecho, quando os alunos trazem duas garantias para o fenômeno "A papulaçãa de lemnas conseguiu se desenvolver". As Justificativas são "...pois recebia luz diariamente para realizar a fotossintese" e "A papulacãa de Lemnas... utilizarsa as mutrientes da terra que estava dissolvida na água para se desenvolverem".

A identificação do indicador de Explicação segue a mesma lógica da marca anterior. Há uma afirmativa, uma conclusão que recebe garantias. Como essas garantias 
Thiago Marinho Del Corso

INDICADORES DE ALFABETIZAÇÃO CIENTÍFICA, ARGUMENTOS E EXPLICAÇÕES -

Análise de Relatórios no Contexto de uma Sequência de Ensino Investigativo

não se configuram como hipóteses explicativas concorrentes, mas são motivos que se somam, acreditamos que este trecho apresenta uma Explicação e não um Argumento. Isso também porque, de acordo com Murcho (2003), numa Explicação os elementos que levam à conclusão são menos plausíveis que a própria conclusão, diferentemente do que acontece em um Argumento, onde a Conclusão (C) é que é mais incerta que os elementos que levam à ela.

Observamos que para justificar a conclusão de que houve desenvolvimento populacional das Lemnas, explanandum, os alunos afirmam que as plantas faziam fotossíntese e utilizavam nutrientes dissolvidos na água, explanans. O explanandum aqui foi aferido experimentalmente, já que a quantidade inicial de Lemnas é menor que a quantidade final,enquanto os explanans não podem ser aferidos, pois os fenômenos não são diretamente observáveis, uma vez que vieram, acredita-se, dos conhecimentos prévios dos alunos: "A papulacãa de lemnas conseguiu se desenvolver pois recebia luz diariamente para realizar a fotassintese e também utilizarsa as nutrientes da terra que estava dissolvida na água para se desenvolverem.".

\section{Marca 11:}

O primeiro parágrafo da terceira conclusão individual do primeiro relatório apresenta os indicadores de Seriação, Organização e Classificação de informações.

Como apresentado anteriormente, crescimento, diminuição e estabilização podem ser considerados como dados, quando o assunto é dinâmica populacional. Assim ao afirmar que "Ta populasãa de Lemnas houve um crescimento" e "mo final da pesquisa a populaçãe se estabilizau", temos dados sendo apresentados, o que configura como um indicador de Seriação de informações.

A preparação dos dados caracteriza o indicador de Organização de informações. Neste trecho, ao organizar em três momentos diferentes a dinâmica populacional da população de Lemnas do experimento, entendemos estar havendo uma Organização de informações.

A Classifcação de informações aparece quando se estabelecem características aos dados. Como "crescimenta" foi aqui considerado um dado, ao afirmar que este foi 
Thiago Marinho Del Corso

INDICADORES DE ALFABETIZAÇÃO CIENTÍFICA, ARGUMENTOS E EXPLICAÇÕES -

Análise de Relatórios no Contexto de uma Sequência de Ensino Investigativo

grande e rápido entendemos estar havendo uma Classificação de informações: "Пa

populaçãa de Lemnas houve um crescimenta grande e rápida, mas durante a 2 a semana

algumas Lemnas marreram, ne final da pesquisa a papulaçãa se estabilizau.".

\section{Marca 12:}

O segundo parágrafo da terceira conclusão individual do primeiro relatório apresenta os indicadores de Seriação e Organização de informações.

O número de indivíduos na população experimental de Lemnas configura-se num dado, e como neste trecho diversos dados (número de indivíduos) estão sendo apresentados, entendemos estar aqui havendo uma Seriação de informações.

A Organização de informações se identifica pela preparação dos dados, que ocorre pela apresentação do dia com maior número de Lemnas na população, menor número depois da estabilização e separação do número de Lemnas sobreviventes e mortas. Todos esses dados, quando arranjados e separados dessa forma, constituem uma organização de informações: "No primeire dia iniciou com 115. O dia houve maior númera de Lemnas foi 211. E e dia mais baixce depais da estabilizacãa foi 201. Final da perquisa: sobreviveram 201 e morreram 21.". 
Thiago Marinho Del Corso

INDICADORES DE ALFABETIZAÇÃO CIENTÍFICA, ARGUMENTOS E EXPLICAÇÕES -

Análise de Relatórios no Contexto de uma Sequência de Ensino Investigativo

6.1.2 Relatório $2-2013$

O Relatório 2 - 2013

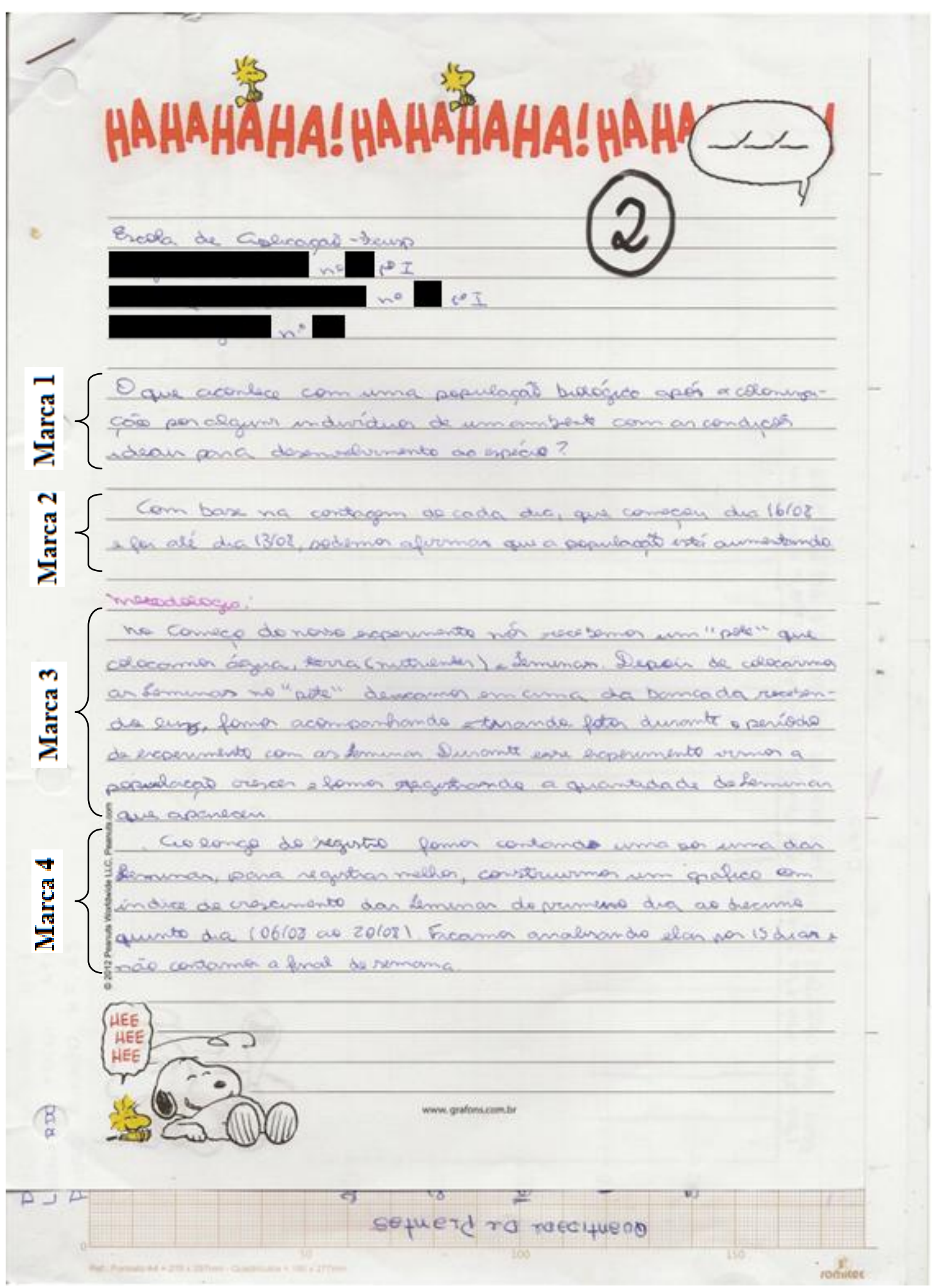


Thiago Marinho Del Corso

INDICADORES DE ALFABETIZAÇÃO CIENTÍFICA, ARGUMENTOS E EXPLICAÇÕES -

Análise de Relatórios no Contexto de uma Sequência de Ensino Investigativo

Rucuesos.

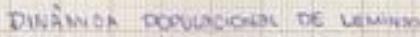

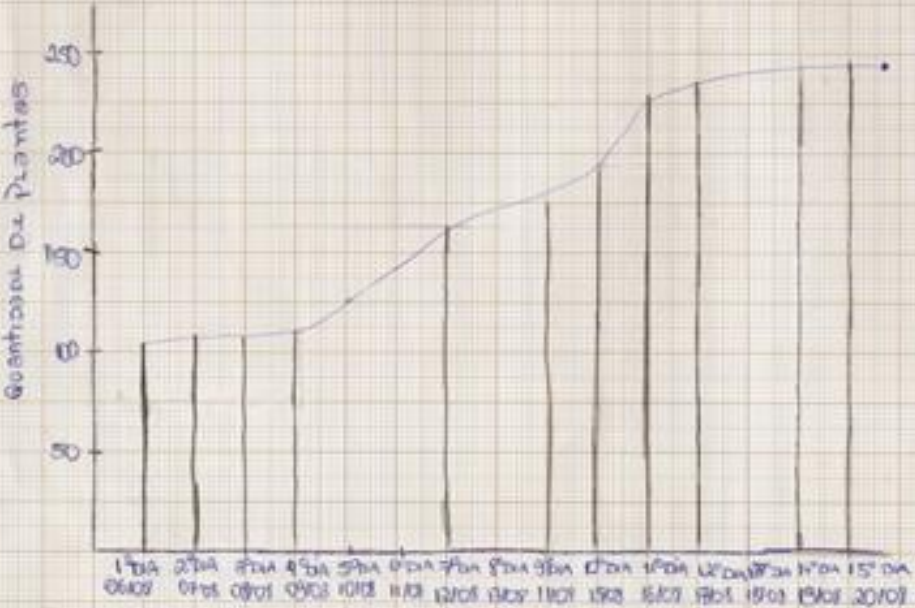

- grepica lo Puito aportic 700 paros aucoibivios nios Diasian Oovias ansotament P. ceescimanto nerestemos un $\sin 0.60$ 
Thiago Marinho Del Corso

INDICADORES DE ALFABETIZAÇÃO CIENTÍFICA, ARGUMENTOS E EXPLICAÇÕES -

Análise de Relatórios no Contexto de uma Sequência de Ensino Investigativo

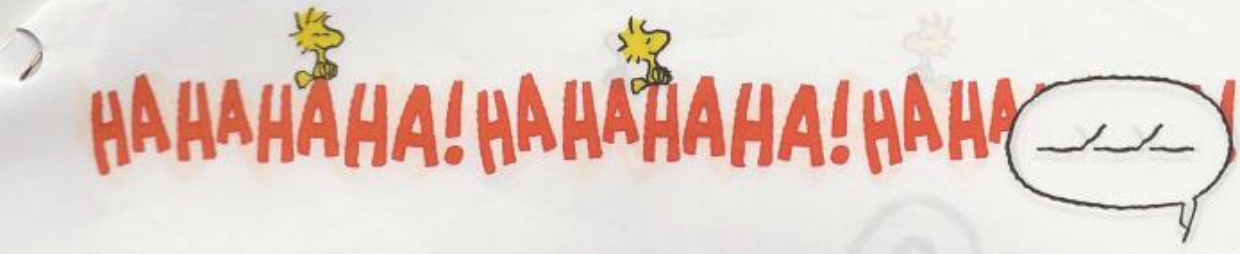

INTERPRETAC̄ÁO

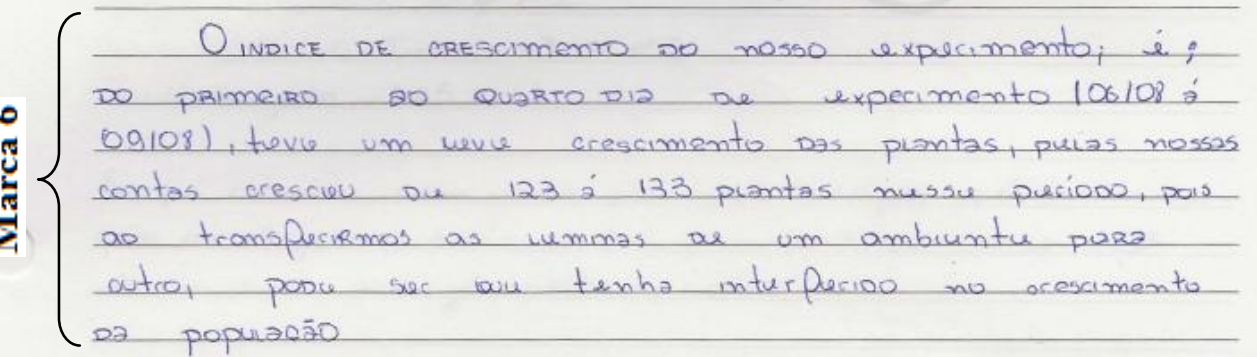

- C Do Quarto dia do dicimo primuiro pia de epenam-

I ento (09108: 16108$)$, tove un grandu ocescimento da popuaraj,

* $\{$ as puantas cresceram we

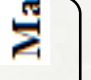

asaptoram ao novo ambiente e o novo ambientu ustava

Pornecentio Luz, agua, nutrientes e uspaco

$\infty$ (DO Diamo primuiro dia aO Dúamo ourntodia $(16) / 09$ \& 20109)

芯 \{ as piantos vocraram a ter um arescimento leve, creacusarm

ae 220 a 245, pas ýs näo havia mais uspaco pare a

populacío crescer
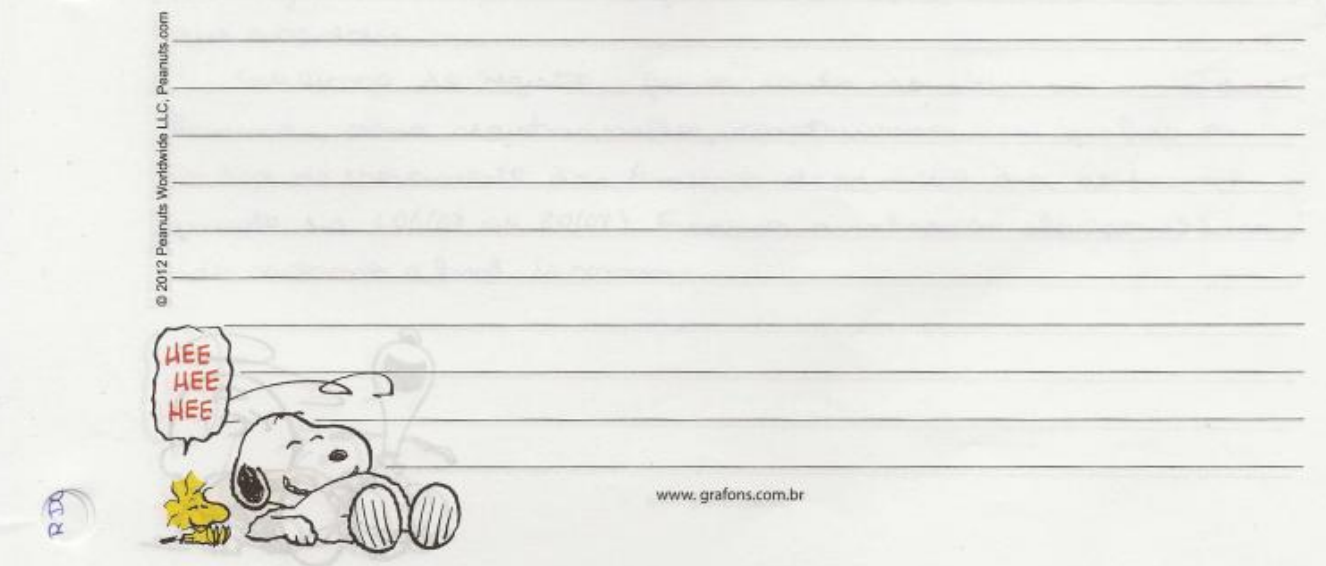

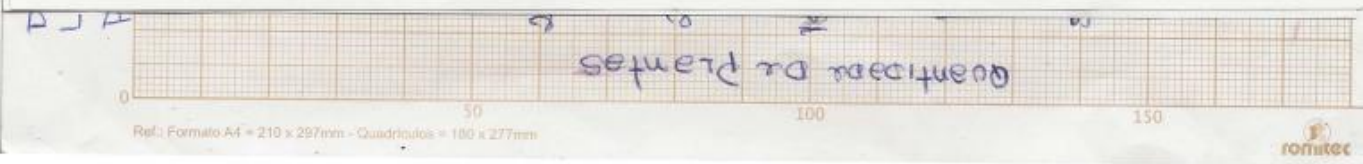


Análise de Relatórios no Contexto de uma Sequência de Ensino Investigativo

Quadro de identificação 02 - Identificação dos Indicadores de Alfabetização Científica no Relatório 2 - 2013 e conclusões individuais correspondentes

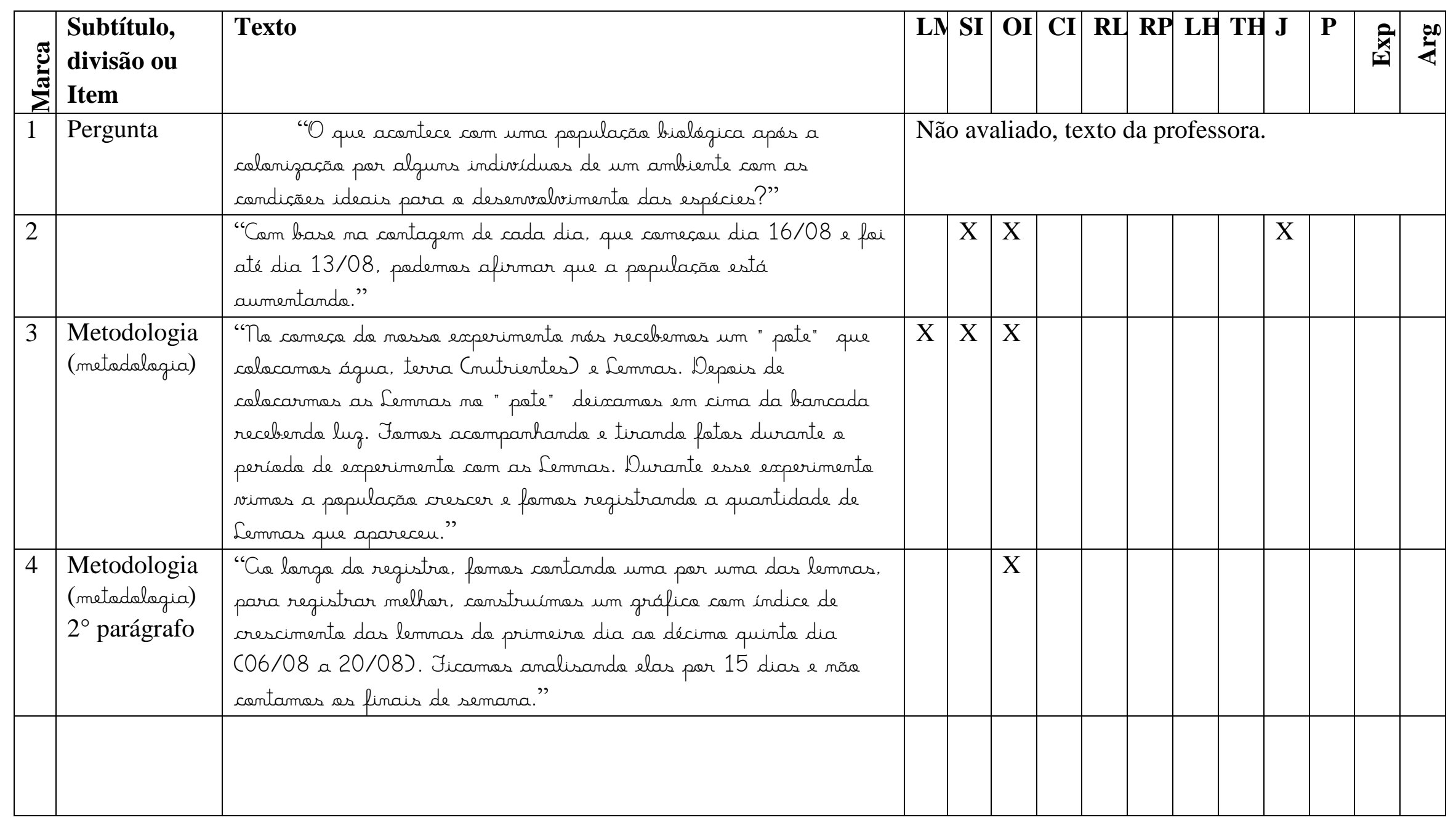


Thiago Marinho Del Corso

INDICADORES DE ALFABETIZAÇ̃̃o CIENTÍFICA, ARGUMENTOS E EXPLICAÇÕES -

Análise de Relatórios no Contexto de uma Sequência de Ensino Investigativo

\begin{tabular}{|c|c|c|c|c|c|c|c|c|c|c|c|c|c|}
\hline 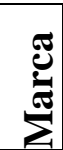 & $\begin{array}{l}\text { Subtítulo, } \\
\text { divisão ou } \\
\text { Item }\end{array}$ & Texto & LM SI & OI & CI & RL & $\mathbf{R P}$ & LH & $\mathbf{T H}$ & $\mathbf{J}$ & $\mathbf{P}$ & $\underset{x}{x}$ & $\underset{Z}{20}$ \\
\hline 5 & $\begin{array}{l}\text { Resultados } \\
\text { (Resultados) }\end{array}$ & 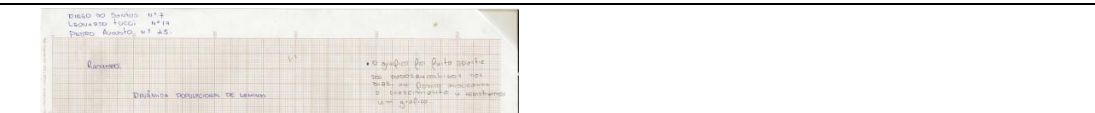 & $X$ & $\mathrm{X}$ & $X$ & & & & & & & & \\
\hline 6 & $\begin{array}{l}\text { Interpretação } \\
\text { (Interpretaçãa) } \\
1^{\circ} \text { parágrafo }\end{array}$ & $\begin{array}{l}\text { "O indice de crescimenta da nassa experimenta é: da primeira aa } \\
\text { quarta dia de experimenta (06/08 a 09/08), teve um leve } \\
\text { crescimenta das plantas, pelas nossas contas cresceu de } 123 \text { à } \\
133 \text { plantas messe períada, pais aa transferirmas as lemnas de } \\
\text { um ambiente para autra, pode ser que tenha interferida na } \\
\text { crescimenta da populasãa." }\end{array}$ & $X$ & $\mathrm{X}$ & $X$ & & $X$ & $X$ & & $X$ & & $X$ & $\mathrm{X}$ \\
\hline 7 & $\begin{array}{l}\text { Interpretação } \\
\text { (Interpretaçãa) } \\
2^{\circ} \text { parágrafo }\end{array}$ & 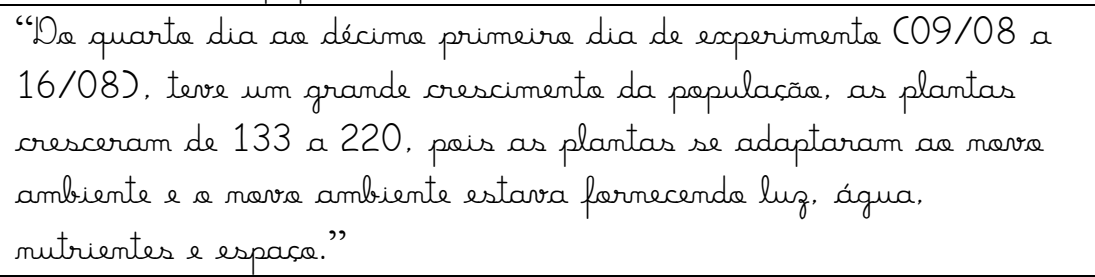 & $\mathrm{X}$ & $\mathrm{X}$ & $X$ & & $X$ & & & $X$ & & $X$ & $\mathrm{X}$ \\
\hline 8 & $\begin{array}{l}\text { Interpretação } \\
\text { (Interpretaçãa) } \\
3^{\circ} \text { parágrafo }\end{array}$ & $\begin{array}{l}\text { "Da décima primeira dia ae décima quinto dia (16/08 ì 20/08), as } \\
\text { plantas voltaram a ter um crescimenta leve, cresceram de } 220 \text { a } 245 \text {, } \\
\text { pois já nãa havia mais espaçe para a populaçãe crescer." }\end{array}$ & X & $\mathrm{X}$ & $\mathrm{X}$ & & $\mathrm{X}$ & & & X & & $\mathrm{X}$ & $\mathrm{X}$ \\
\hline 9 & $\begin{array}{l}\text { Conclusão } 1 \\
\left(1^{\circ} \text { parágrafo) }\right.\end{array}$ & $\begin{array}{l}\text { "Com base na contagem de cada dia, que comesceu dia 16/08 e fai } \\
\text { até 20/08, a populaça aumentau de } 123 \text { a 245, pois no inicia as } \\
\text { Lemnas estavam reconhecenda a local, a luz e a "pote" para fazer } \\
\text { a fatassintese e aumentar a papulaçãa." }\end{array}$ & $X$ & $X$ & & & & & & $X$ & & $X$ & \\
\hline
\end{tabular}


Thiago Marinho Del Corso

INDICADORES DE ALFABETIZAÇÃO CIENTÍFICA, ARGUMENTOS E EXPLICAÇÕES -

Análise de Relatórios no Contexto de uma Sequência de Ensino Investigativo

\begin{tabular}{|c|c|c|c|c|c|c|c|c|c|c|c|c|c|}
\hline 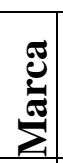 & $\begin{array}{l}\text { Subtítulo, } \\
\text { divisão ou } \\
\text { Item }\end{array}$ & Texto & $\mathbf{L M}$ & SI & $\mathbf{O I}$ & $\mathbf{C I}$ & RL & RPLH & $\mathbf{T H}$ & $\mathbf{J}$ & $\mathbf{P}$ & $\sqrt{x}$ & $\sum_{1}^{00}$ \\
\hline 10 & $\begin{array}{l}\text { Conclusão } 1 \\
\left(2^{\circ} \text { parágrafo }\right)\end{array}$ & 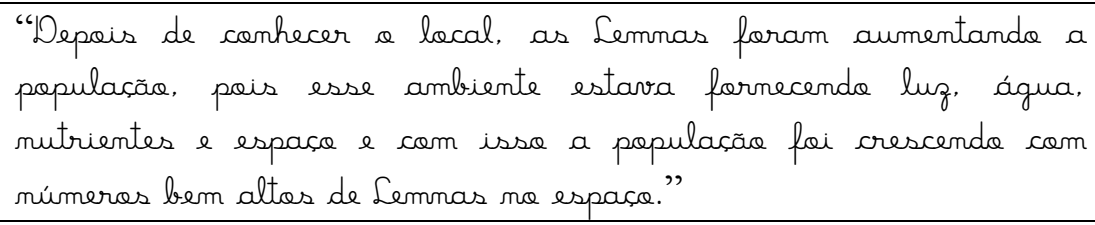 & & $\mathrm{X}$ & & $\mathrm{X}$ & & & & $\mathrm{X}$ & & $\mathrm{X}$ & \\
\hline 11 & $\begin{array}{l}\text { Conclusão } 1 \\
\left(3^{\circ} \text { parágrafo }\right)\end{array}$ & $\begin{array}{l}\text { "Co final da experimenta, as Lemnas nãa cresceram muita, teve } \\
\text { um indice baixa de crescimenta, depais de ter conhecida já a lacal. } \\
\text { a luz, água, nutrientes e espaca do ambiente." }\end{array}$ & & $\mathrm{X}$ & & $\mathrm{X}$ & & & & & & & \\
\hline 12 & Conclusão 2 & 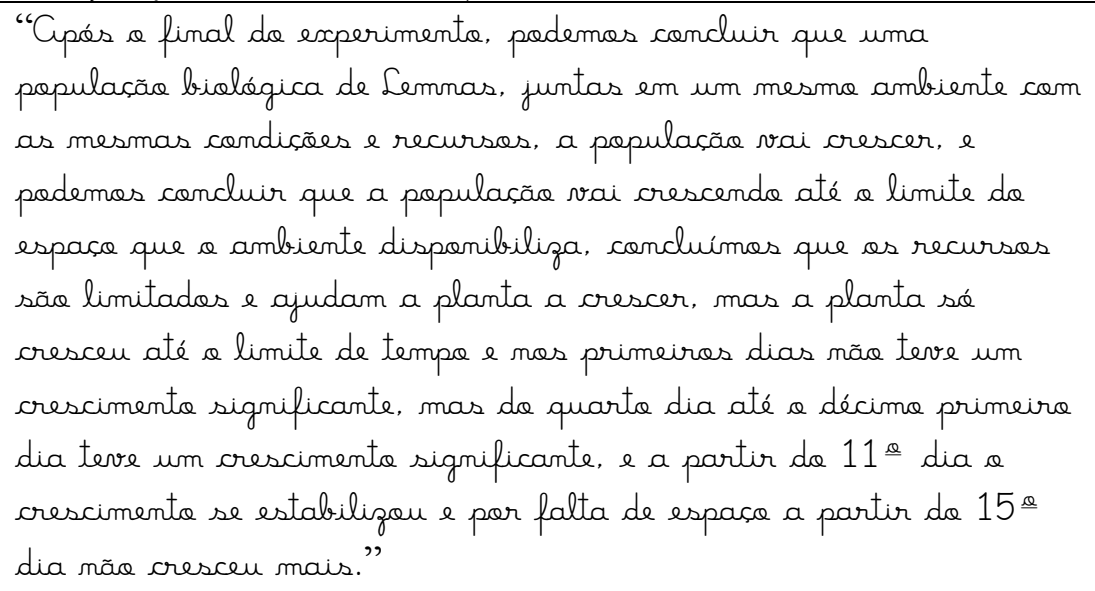 & & $\mathrm{X}$ & $\mathrm{X}$ & $\mathrm{X}$ & & & & $\mathrm{X}$ & $\mathrm{X}$ & $\mathrm{X}$ & \\
\hline
\end{tabular}




\section{Marca 1 (relatório 2):}

O relatório 2 de 2013 tem em seu cabeçalho o local (escola) em que foi desenvolvido e depois o nome dos alunos. A esse último segue a pergunta geradora que foi fornecida pela professora e por isso não analisada.

\section{Marca 2 (relatório 2):}

Depois desses elementos aparece uma afirmativa dos alunos que não se constitui em nenhum dos itens comumente encontrados nos outros relatórios. Esta afirmativa não era parte da metodologia, dos resultados ou da interpretação e se assemelha muito mais a uma conclusão. Vale ressaltar que as conclusões foram, diferentemente das outras partes do relatório, feitas individualmente e após o término da produção em grupo do relatório. Essa afirmativa, transcrita a seguir, apresentou os indicadores de Seriação de informações, Organização de informações e Justificativa: "Com base ma contagem de cada dia, que comescou dia 16/08 e foi até dia 13/08, podemos afirmar que a papulasãa está aumentanda."

O primeiro indicador, Seriação de informações, decorre da afirmativa dos alunos de que a população de Lemnas está "aumentando". Já que a o tema da sequência didática é dinâmica populacional, e esta estuda o padrão de crescimento das populações ao longo do tempo, diminuição, aumento ou estabilização no número de indivíduos são então entendidos como dados. Como Seriação de informações se caracteriza como uma listagem de dados, ao afirmar que a população está "aumentanda" os alunos estão listando um dado e consecutivamente apresentando o indicador de Seriação de informações.

Acreditamos que essa afirmativa da marca 2 apresenta uma tentativa de Organização de Informações quando mostra que os dados (contagem da Lemnas) ocorriam diariamente e de uma data até outra -- mas esta organização é frustrada quando os alunos erram as datas, pois apontam o início (16/08) da coleta para depois do final dela (13/08). 
Thiago Marinho Del Corso

INDICADORES DE ALFABETIZAÇÃO CIENTÍFICA, ARGUMENTOS E EXPLICAÇÕES -

Análise de Relatórios no Contexto de uma Sequência de Ensino Investigativo

Esta primeira afirmativa também é identificada como uma Justificativa, uma vez

que a afirmação de que a população de Lemnas está aumentando tem como garantia o fato de ter se baseado na contagem de cada dia -- e de acordo com Sasseron e Carvalho (2008), uma Justificativa “...aparece quando, em uma afirmativa qualquer proferida, lança-se mão de uma garantia para o que é proposto. Isso faz com que a afirmação ganhe aval, tornando-a mais segura"-.

\section{Marca 3 (relatório 2):}

O primeiro parágrafo da metodologia apresenta Listagem de materiais, Seriação de informações e Organização de informações. O primeiro destes indicadores aparece com a apresentação dos materiais utilizados para montar a parte experimental.

Os outros dois indicadores estão relacionados ao trabalho com os dados empíricos e aparecem comumente no começo de um trabalho onde estão se arranjando as informações novas. O primeiro destes indicadores é identificado pela mesma lógica da marca anterior -- ou seja, ao afirmar que a população de Lemnas "cresceu" os alunos estão apresentando dados e listar dados é indicador de Seriação de informações.

A identificação da Organização de informações ocorre quando se verifica que os alunos organizam estes materiais e apresentam uma cronologia de ações sobre os mesmos: "To comesa do massa experimenta nós recebemos um "pote" que colocamos água, terra (nutrientes) e Lemnas. Depais de colocarmas as Lemnas me "pote" deixamas em cima da bancada recebenda luz. Fomos acompanhanda e tiranda fotas durante a períado de experimenta com as Lemnas. Durante esse experimenta vimas a populacáa crescer e fomos registranda a quantidade de Lemnas que apareceu." (grifo nosso). De acordo com Sasseron (2008) e Sasseron e Carvalho (2008), este indicador “...surge quando se procura preparar os dados existentes sobre o problema investigado”, o que fica evidente quando os alunos mostram como o experimento foi organizado e a natureza dos dados conseguidos com este experimento (fotos da população de Lemnas). 
No segundo parágrafo da metodologia os alunos estão Organizando informações quando apresentam em seu relatório os dias de coleta de dados com uma data do início da coleta, data final, tempo total de dias de coleta e o fato de não ter havido coleta no final de semana. A Organização de informações corresponde a "momentos em que se discute sobre o modo como um trabalho foi realizado" e aqui entendemos que é isso que acontece quando os alunos mencionam o "... crescimenta das lemnas do primeira dia ae décima quinte dia (06/08 a 20/08). Ficamos analisanda elas por 15 dias e mãa contames as finais de semana."-.

\section{Marca 5 (relatório 2):}

Os resultados são apresentados diretamente em um gráfico, que para nossa interpretação constitui-se como Seriação de informações, já que os dados de crescimento populacional estão sendo apresentados. Mas ele também é uma Organização de informações, na medida em que os dados são organizados pela correlação do eixo y ("Quantidade de plantas") com o eixo x ("dias"). E acreditamos que este gráfico também constitui uma Classificação de informações, pois demonstra, como já apontado pelos alunos, que há um crescimento da população de Lemnas.

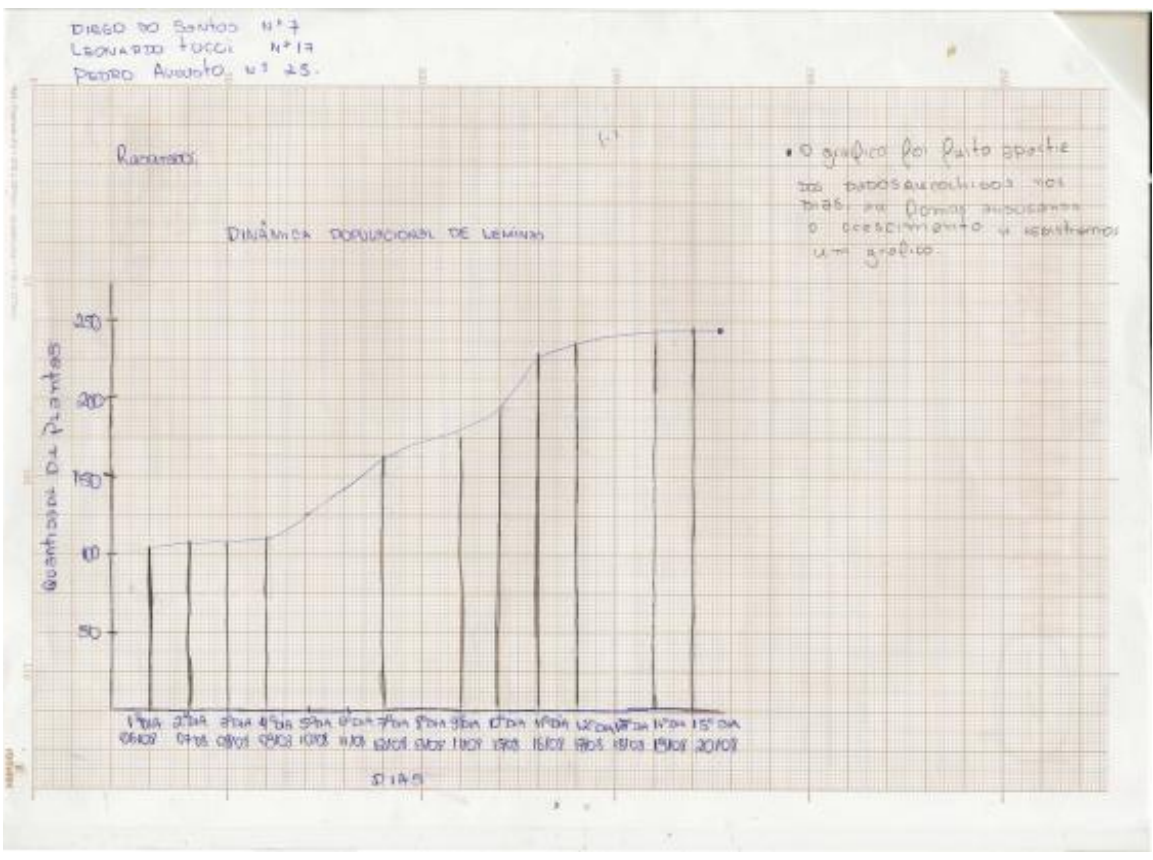


O primeiro parágrafo apresentado do sub-título "Interpretacãa" apresenta-se transcrito abaixo. Discorreremos sobre cada um dos indicadores de alfabetização científica identificados neste trecho: "O indice de crescimenta da massa experimenta é: da primeira ae quarta dia de experimenta (06/08 a 09/08), teve um leve crescimenta das plantas, pelas nossas contas cresceu de 123 à 133 plantas nesse período, pois ae transferirmos as lemnas de um ambiente para autro, pode ser que tenha interferida no crescimenta da populaçãe."

A identificação da Seriação de informações segue o raciocínio anteriormente apresentados nas marcas dois e três -- nos quais, devido à temática central da sequência didática ser dinâmica populacional, afirmativas do tipo "teve um leve crescimente" ou “crescen de 123 à 133" são entendidas como uma listagem de dados, caracterizadora deste indicador de Alfabetização Científica.

A Organização de informações, de acordo com Sasseron (2008) e Sasseron e Carvalho (2008), comumente se apresenta na retomada dos dados para análise; este indicador aparece neste parágrafo explicitando qual período está sendo analisado e qual o tamanho da população experimentalmente obtidos. Esta organização em períodos a serem separadamente analisados é entendida como evidência do indicador de Organização de informações: "do primeiro ae quarto dia de experimenta" e "pelas mossas contas cresceu de 123 ì 133 plantas messe periodo".

O indicador de Classificação de informações surge quando há a intenção de se estabelecer características para os dados obtidos. Quando os alunos consideram que o aumento populacional de 123 para 133 foi "leve", eles estão assim apresentando o indicador de Classificação de informações: "tevre um leve crescimenta das plantas, pelas mossas contas cresceu de 123 ì 133".

O Raciocínio lógico e o Raciocínio proporcional vão mostrar, de acordo com Sasseron e Carvalho (2008), como se estrutura o pensamento, e referem-se também à maneira como as variáveis se relacionam, ilustrando a interdependência que pode existir entre elas. Desta forma, acreditamos que o ato de considerar "leve" um crescimento 
Thiago Marinho Del Corso

INDICADORES DE ALFABETIZAÇÃO CIENTÍFICA, ARGUMENTOS E EXPLICAÇÕES -

Análise de Relatórios no Contexto de uma Sequência de Ensino Investigativo

populacional de apenas 10 indivíduos demonstra um Raciocínio proporcional, já que

no período subsequente o crescimento populacional das Lemnas é muito mais intenso.

Sasseron e Carvalho (2008) apontam que o Levantamento de hipóteses acontece quando as suposições são alçadas -- e que estas podem surgir tanto como uma afirmação quanto uma pergunta. Neste parágrafo, este indicador se faz presente no momento em que os alunos supõem que o "leve" crescimento das Lemnas se deu por causa da transferência destas para um novo recipiente: "...pois ac transferirmes as lemnas de um ambiente para outro, pode ser que tenha interferida mo crescimenta da populaçä.". Neste caso, o Levantamento de hipóteses surge como uma afirmação.

A Justificativa aqui apresentada pelos alunos tem o intuito de apoiar a afirmativa de que o crescimento da população de Lemnas foi leve: "teve um leve crescimento das plantas, pelas mossas contas cresceu de 123 à 133 plantas messe períada". Uma Justificativa é lançada como uma garantia a uma afirmação, tornando-a mais segura. Ou seja: ao apresentar os dados da contagem populacional das Lemnas no primeiro e quarto dia temos a Justificativa para a afirmação de que neste período houve crescimento, que foi considerado "leve" em comparação a outro período.

Esse primeiro parágrafo da "Interpretacãa" do relatório apresenta também os indicadores Explicação e Argumento.

"O indice de crescimenta da nossa experimenta é: da primeira ace quarta dia de experimenta (06/08 a 09/08), teve um leve crescimenta das plantas, pelas nossas contas cresceu de 123 à 133 plantas nesse perído, pois ac transferirmos as lemnas de um ambiente para autro, pode ser que tenha interferida no crescimenta da papulaçãa.".

Não é que estejamos admitindo que este trecho seja uma Explicação ou um Argumento, dependendo da interpretação do pesquisador, mas sim que ele contém tanto uma Explicação para o crescimento das Lemnas como um Argumento para o porquê deste crescimento ser menor que o esperado. Em outros momentos verificamos que os Argumentos surgiam quando os dados eram incongruentes, para os alunos, em relação ao modelo teórico de crescimento populacional apresentado pela professora em aulas que antecederam os experimentos com as Lemnas. 
Thiago Marinho Del Corso

INDICADORES DE ALFABETIZAÇÃO CIENTÍFICA, ARGUMENTOS E EXPLICAÇÕES -

Análise de Relatórios no Contexto de uma Sequência de Ensino Investigativo

Na Explicação, o explanandum, a conclusão da explicação, é que "teve um leve

crescimenta das plantas". O explanans desta Explicação é que "pelas noessas contas cresceu de 123 à 133 plantas messe periode". Na explicação não há a intenção de tentar convencer de que houve crescimento, já que 133 é maior que 123; tampouco há uma hipótese explicativa concorrente: existe apenas a intenção de deixar claro que o fenômeno tenha se dado como ocorreu. Ou seja: a função epistêmica aqui é deixar claro o porquê do fenômeno, o que é condizente com uma Explicação, assim como o fato de que não há contestação possível do explanandum, já que ele corresponde a uma relação matemática obvia.

Encontramos um Argumento neste parágrafo quando os alunos tentam convencer que o baixo crescimento populacional da população de Lemnas se deveu à transferência destas de um recipiente para outro.

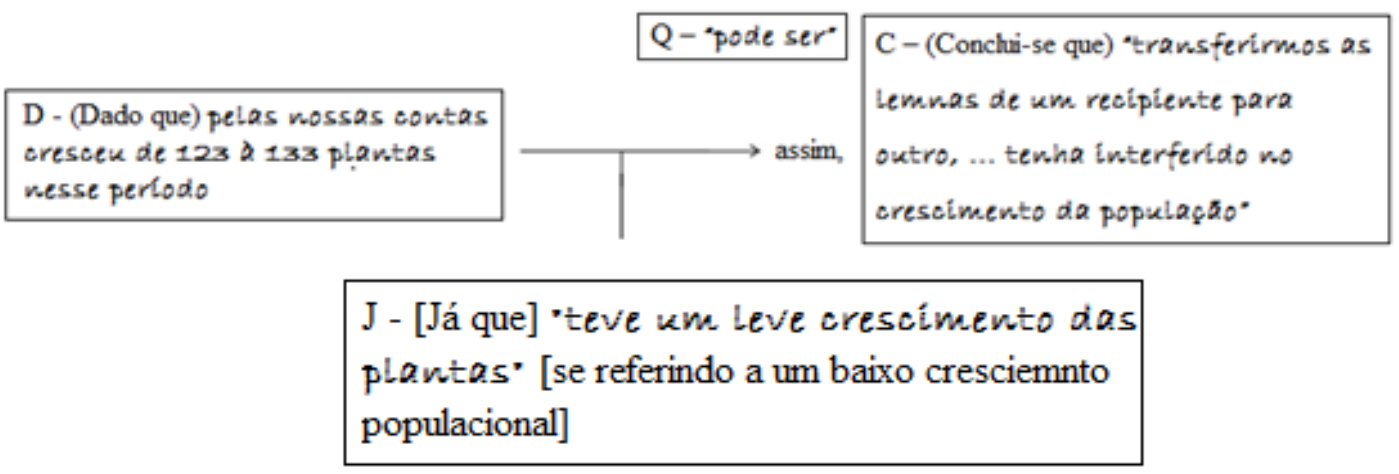

Aqui, como esperado, a Conclusão (C) não é uma certeza incontestável, e mesmo não havendo explicitamente outras hipóteses explicativas, que podem ou não ter sido pensadas pelos alunos, há a possibilidade de ser outro o motivo pelo qual o crescimento é baixo neste primeiro período. Uma Conclusão (C), contestável, de que a transferência tenha sido o motivo do baixo crescimento populacional, somada à intenção de convencer que a transferência foi responsável pelo baixo crescimento, assim como a possibilidade de existirem outras hipóteses para o baixo crescimento, são indicativos de que este parágrafo também continha um Argumento.

\section{Marca 7 (relatório 2):}

O trecho transcrito abaixo trata do segundo parágrafo apresentado na parte final do relatório, também sob a égide do subtítulo "Imterpretacãa" e apresenta os indicadores 

hipóteses, Justificativa, Explicação e Argumento.

"Do quarta dia ae décima primeira dia de experimenta (09/08 a 16/08), teve um grande crescimenta da populaçãa, as plantas cresceram de 133 a 220, pais as plantas se adaptaram ae nove ambiente e e novse ambiente estava fornecenda luz, água, nutrientes e espacse.".

Dos indicadores relacionados ao trabalho com os dados empíricos pudemos identificar a Seriação de informações, Organização de informações e Classificação de informações. Estes indicadores ocorrem na retomada dos dados que estão sendo interpretados pelos alunos neste parágrafo. No momento em que os alunos classificam os dados em três diferentes momentos, de acordo com as taxas de crescimento, e se dispõem a analisá-los e interpretá-los separadamente, aqui se dedicando ao segundo momento, entendemos esta divisão como Classificação de informações. Este indicador também fica evidente pela classificação do crescimento como grande. A Seriação de informações se apresenta aqui quando os alunos apresentam o número de indivíduos que compõe a população de Lemnas (133 no dia 09/08 e 220 no dia 16/08) e quando eles afirmam que a população "cresceu". A Organização de informações pode ser entendida quando os alunos separam em três momentos a variação populacional, sendo este trecho o segundo momento.

A Justificativa aparece nesta marca para dar garantia à afirmativa de que houve um grande crescimento "pois as plantas se adaptaram ar nove ambiente e a nove ambiente estava fornecenda luz, água, nutrientes e espace.".

O parágrafo em questão apresenta também, além dos anteriores, os indicadores de Explicação e Argumento. Nos procedimentos de análise apresentamos que uma assertiva será identificada como um Argumento ou Explicação quando essa não estiver se limitando a apresentar dados, resultados, descrevendo uma metodologia, exemplificando, desenvolvendo um raciocínio lógico ou proporcional, levantando hipóteses ou fazendo previsões, mas sim quando a assertiva apresentar uma afirmação e houver a tentativa de estabelecer uma relação causal entre o fenômeno e o(s) possível(eis) motivo(s) para que este tenha acontecido da forma como aconteceu. Neste parágrafo encontramos duas afirmativas: uma diz ter havido "um grande crescimento da 
população", e outra discorre acerca das causas para este grande crescimento: "pois as plantas se adaptaram ae nove ambiente"-.

Quando se toma a primeira afirmativa tem-se uma Explicação, já que o explanandum não está sob contestação: não há duvida de que houve um grande crescimento, visto que ele foi matematicamente calculado a partir dos dados obtidos e registrados anteriormente no relatório. Quando a afirmativa não está sub-júdici e nem há alternativa, esta se relaciona a uma Explicação. O explanans usado para explicar o fenômeno do grande crescimento, explanandum, é que "pois as plantas se adaptaram ae novro ambiente" e "a nove ambiente estava fornecenda luz, água, nutrientes e espace.".

Como já apresentado anteriormente, e segundo Osborne e Patterson (2011), uma Explicação pode pedir argumentos que as defendam. Aqui a afirmativa de que a população de Lemnas se adaptou ao novo ambiente, após um período de estresse, , pode ser considerada a Conclusão (C) de um Argumento. Quando assim o for temos:

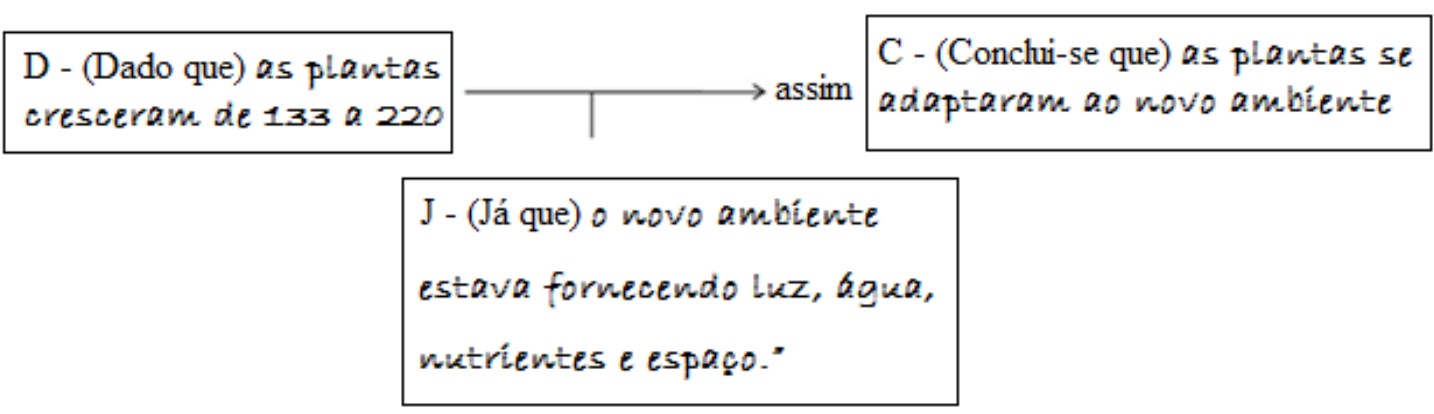

Aqui a Conclusão (C) não é a única possível e é menos certa que a Justificativa (J) que leva a ela. Quando a Conclusão (C) é menos certa que os elementos relacionados a ela, afirmam Osborne e Patterson (2008) e Murcho (2003), trata-se de um Argumento. Já numa Explicação esta lógica se inverte e a conclusão da explicação, que nós chamamos de explanandum, é mais certa que os elementos relacionados a ela.

\section{Marca 8 (relatório 2):}

Transcrito abaixo está o último parágrafo do relatório, também desenvolvido dentro do subtítulo "Interpretaçãe": "Da décima primeira dia ae décime quinto dia C16/08 à 20/08), as plantas voltaram a ter um crescimenta leve, cresceram de 220 a 245, pois já mãa havia mais espace para a populaçãa crescer.". 
Thiago Marinho Del Corso

INDICADORES DE ALFABETIZAÇÃO CIENTÍFICA, ARGUMENTOS E EXPLICAÇÕES -

Análise de Relatórios no Contexto de uma Sequência de Ensino Investigativo

$\mathrm{O}$ indicador de Alfabetização Científica de Seriação de informações ocorre aqui

pela apresentação dos dados, tanto do número de indivíduos como de que houve crescimento populacional.

A Organização de Informações se apresenta pela mesma lógica anteriormente descrita para os outros parágrafos da "Interpretaçåa", ou seja, a partir do momento em que os dados são reapresentados separados e organizados segundo a intensidade do crescimento populacional das Lemnas entende-se que a separação nestes três momentos, que correspondem também aos três parágrafos, são indicadores de que os alunos estão Organizando as informações.

A Classificação de informações decorre da consideração que o crescimento foi "leve". Estabelecer características para os dados é evidência deste indicador.

A afirmação de que "as plantas voltaram a ter um crescimenta leve," recebe como garantia que "pois já mãe havia mais espacse para a populacãa crescer.". Ao apresentar garantia para uma afirmativa, os alunos estão Justificando.

Assim como discutido em relação à marca anterior, a presença de duas diferentes afirmativas, mesmo que uma sirva de elemento justificador para a outra, acaba produzindo, no caso, uma Explicação e um Argumento. Para a Explicação a afirmativa é que "as plantas voltaram a ter um crescimenta leve", e esta torna-se o explanandum que requer elementos (explanans) capazes de deixar claro o motivo deste fenômeno ter ocorrido como se deu. O elemento (explanans) lançado pelos alunos é que "já mão havija mais espaçe para a populacãa crescer.". Este elemento também é uma afirmativa, e, em o sendo, torna-se a Conclusão (C) do seguinte Argumento:

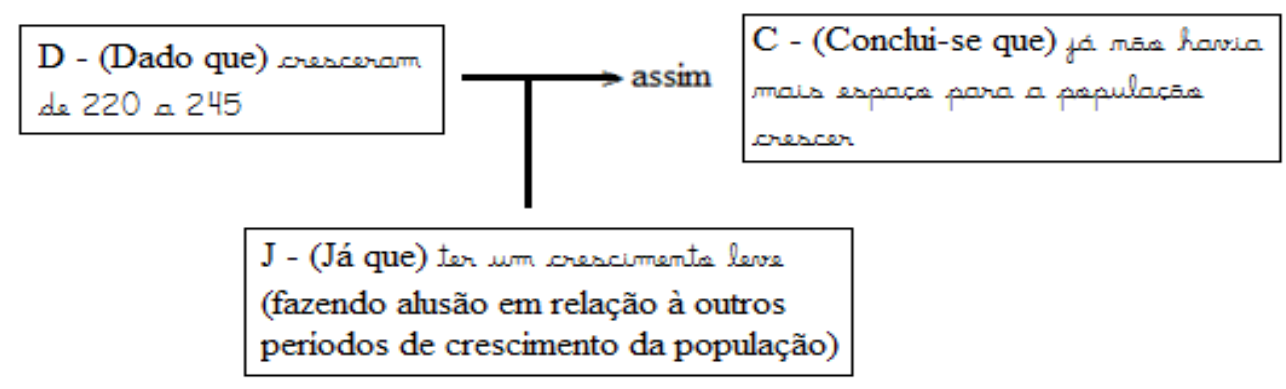


Após a elaboração em grupo do relatório, os alunos, individualmente, escreveram cada um uma conclusão. Para esta conclusão foram disponibilizados uma cópia do relatório para cada aluno do grupo. Produzir esta conclusão visava finalizar de forma individual o relatório construído coletivamente. O comando utilizado para esta última etapa foi colocado na lousa e constituia-se da seguinte instrução: "Sabendo que a conclusão do relatório científico consiste na resposta à pergunta inicial, justificada com evidências (dados produzidos durante a investigação), conclua seu relatório."

\section{Marca 9 (relatório 2):}

$$
\begin{aligned}
& \text { "Com base ma contagem de cada dia, que comesou dia 16/08 e foi até 20/08, a } \\
& \text { populaçã aumentau de } 123 \text { a 245, pois ne inicie as Lemnas estaram reconhecenda a local } \\
& \text { a luz e e "pote" para fazer a fotossintese e aumentar a populaçãe.". }
\end{aligned}
$$

Neste primeiro parágrafo da conclusão de um dos alunos do grupo identificamos o indicador de Seriação de informações na medida em que o aluno reapresenta os dados da contagem inicial da população de Lemnas e da contagem final desta população.

O indicador de Organização de informações se dá exatamente pela associação, mesmo que equivocada, entre as datas e seus respectivos tamanhos populacionais. $\mathrm{O}$ arranjo dos dados é característica do indicador de Organização de informações e aparece comumente na retomada de uma questão, quando as ideias são relembradas.

A Justificativa aparece quando o aluno tenta dar uma garantia que apóie a afirmação de que a população aumentou: "pois no inicio as Lemnas estavam reconhecendo a local, a luz e a "pote" para fazer a fotassintese e aumentar a populaçãa."-".

Identificamos neste parágrafo também uma Explicação. Para tal identificamos que a afirmação é que "a populaçã aumentau", e essa não está sub-júdici, não é contestável, já que deriva de uma relação matemática simples, assim sendo considerado o explanandum da Explicação. Os elementos trazidos para explicar este fenômeno do aumento da população (explanandum), os explanans para esta explicação, são menos certos que a afirmação em si, o que é característica de uma Explicação. Dizer que a população de Lemnas cresceu "pois me inicio as Lemnas estarsam reconhecenda a local, a luz e a "pote" para fazer a fotossintese e aumentar a populacãa.", apesar de 
Thiago Marinho Del Corso

INDICADORES DE ALFABETIZAÇÃO CIENTÍFICA, ARGUMENTOS E EXPLICAÇÕES -

Análise de Relatórios no Contexto de uma Sequência de Ensino Investigativo

conceitualmente discutível, já que atribui a habilidade de "reconhecer" para uma planta,

não inutiliza a validade da Explicação, já que é possível considerar que o aluno na verdade se referia a uma adaptação após um estresse de mudança de habitat. Pode-se entender que o aluno quer, com este explanans, deixar mais clara as causas para este fenômeno ter se dado da forma como se deu-- e este explanans é menos certo que o explanandum em si, já que este último deriva de uma relação matemática simples: "a populasãa aumentau de 123 a 245 "-.

\section{Marca 10 (relatório 2):}

O segundo parágrafo da conclusão do aluno 1 acerca do relatório 2 segue transcrita abaixo:

"Depois de conhecer a local, as Lemnas foram aumentando a populacão, pois esse ambiente estarva fornecenda lug, água, nutrientes e espacse e com isso a populasăa foi crescenda com númeras bem altas de Lemnas no espace."

A Seriação de informações aqui deriva da apresentação de dados: "aumentando a populacãa"e "a populaçãa foi crescenda".

A Classificação de informações aparece aqui pelo estabelecimento de características ao dado de que a população estava crescendo, ao afirmar que isso se deu "com númeras bem altas de Lemnas".

A Justificativa para que a afirmação de que houve crescimento ganhe aval é que "pois esse ambiente estava fornecenda luz, água, nutrientes e espace".

Consideramos também haver aqui uma Explicação, onde o explanandum é ter havido crescimento ("as Lemnas foram aumentando a populasăa") e o explanans que isso se deveu a "pois esse ambiente estava fornecendo luz, água, nutrientes e espace" ".

\section{Marca 11 (relatório 2):}

Este último parágrafo da conclusão do aluno 1 do relatório 2 apresenta o indicador de Seriação de informações e Classificação de informações. $O$ primeiro quando, assim como em relação à marca anterior, ele apresenta um dado ("cresceram"). A Classificação de informações decorre do estabelecimento de característica para este dado: "mãa cresceram muita". 
O parágrafo inteiro segue: "Go final de experimenta, as femnas näe cresceram muita, teve um indice baixce de crescimenta, depais de ter conhecida já a lacal, a luz, água, mutrientes e espace do ambiente".

\section{Marca 12}

Dos três alunos que faziam parte deste grupo apenas dois fizeram conclusões a pedido da professora. Segue a conclusão do aluno 2 do relatório 2, que apresentou indicadores de Seriação, Organização e Classificação de informações, Justificativa, Previsão e Explicação:

"Cupés a final da experimenta, pedemas concluir que uma papulacãa bialógica de Lemnas, funtas em um mesmo ambiente com as mesmas condisães e recursos, a populaçäo vai crescer, e podemos concluir que a populaçãa vai crescendo até a limite do espaca que a ambiente disponibiliza, concluimos que as recursos säo limitados e ajudam a planta a crescer, mas a planta sé crescen até a limite de tempo e mas primeiras dias näa teve um crescimento significante, mas de quarto dia até a décime primeire dia teve um crescimento significante, e a partir do $11^{\text {\& }}$ dia a crescimenta se estabilizan e por falta de espaco a partir do 15 @ dia mãa crescen mais."

Esta conclusão foi escrita como um único parágrafo e apresenta uma Seriação de informações na apresentação dos dados que refletem as taxas de crescimento populacional das Lemnas, tais como "crescen", "estabilizou" e "mäa crescen mais".

Identificamos também a Organização de informações quando os dados são organizados: primeiramente é feita uma consideração acerca dos resultados do experimento de forma geral, depois os três momentos apresentados na "Imterpretaçãe" são cronologicamente apresentados e discutidos.

Acreditamos haver uma Classificação de informações quando o aluno traz características dos três diferentes momentos de variação da taxa de crescimento populacional das Lemnas. Primeiro um baixo crescimento, depois uma alta taxa de crescimento e finalmente uma estabilização. Fazendo assim o aluno está estabelecendo características para os dados obtidos, o que caracteriza o indicador de Alfabetização Científica de Classificação de informações.

O indicador de Justificativa aparece nesta conclusão como garantia da afirmativa de que a população de Lemnas vai crescer até o limite de espaço que o ambiente 
Thiago Marinho Del Corso

INDICADORES DE ALFABETIZAÇ̃̃O CIENTÍFICA, ARGUMENTOS E EXPLICAÇÕES -

Análise de Relatórios no Contexto de uma Sequência de Ensino Investigativo

disponibiliza: "os recursos sãe limitados". A explicação "por falta de espaçe" também aparece como garantia para a afirmativa de que a partir do $15^{\circ}$ dia a população não cresceu mais.

Entendemos que ao afirmar que "Cupós a final do experimento, podemos concluir que uma papulacãa biológica de Lemnas, juntas em um mesme ambiente com as mesmas condicäes e recursos, a populaçãa vai crescer, e podemes concluir que a populaçãe vai crescenda até a limite do espace que a ambiente disponibiliza,", o aluno está fazendo uma Previsão, pois entendemos que o fenômeno observado do crescimento é expandido como uma generalização e o aluno está assim afirmando que sobre condições semelhantes qualquer população de Lemnas vai ter uma dinâmica populacional semelhante.

A Explicação tem na afirmação "a população vai crescenda até a limite do espaça que a ambiente disponibiliza" o fenômeno a ser explicado, o explanandum. E tem como explanans a afirmação de que "os recursos são limitados" e "vai crescenda até a limite do espaca que a ambiente disponibiliza,". A este explanans se seguem dizeres que têm o intuito de deixar mais claro o fenômeno, de descrever como este se deu ao longo do passar do tempo do experimento: "mos primeiras dias mäe teve um crescimenta significante, mas do quarta dia até a décima primeiro dia teve um crescimento significante, e a partir do 11 @ dia a crescimenta se estabilizan e por falta de espace a partir do 15 으 dia mäe crescen mais." -. 
Thiago Marinho Del Corso

INDICADORES DE ALFABETIZAÇÃO CIENTÍFICA, ARGUMENTOS E EXPLICAÇÕES -

Análise de Relatórios no Contexto de uma Sequência de Ensino Investigativo

6.1.3 Relatório $3-2013$

O Relatório 3 - 2013

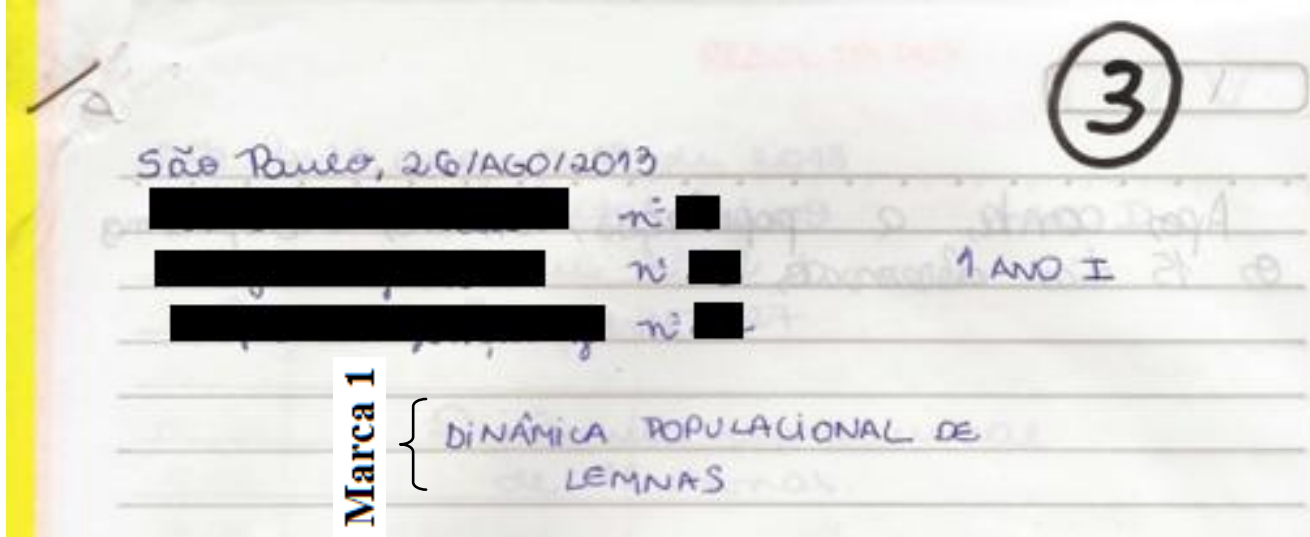

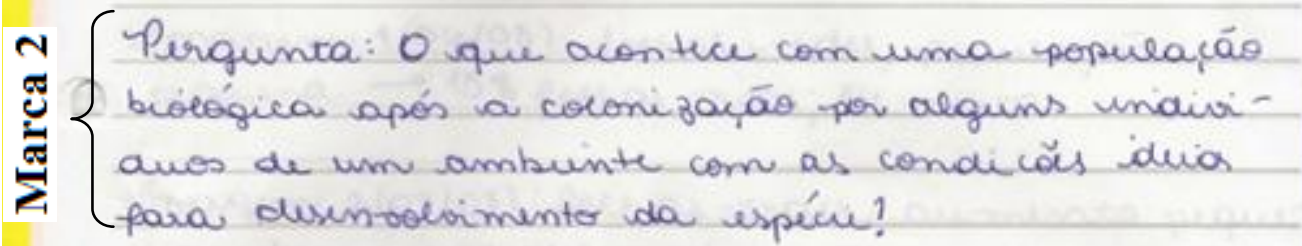

mutroderergia. No meb do agesto inicamos a investigagoo

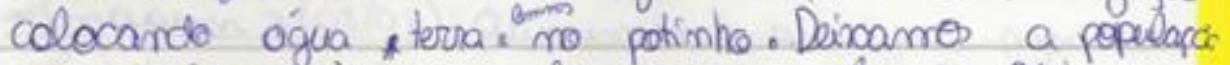

3 móiam à une luminaria ligodo $24 \mathrm{~h}$ pos

If dia. Oeserrames duante 15 das, tiramos foten

I par lacilitas a conte dos mato evios, com as dos impressas crianos unc maneira de contas as lemmas, diradimos am partes a

poperlacis por lacilita:

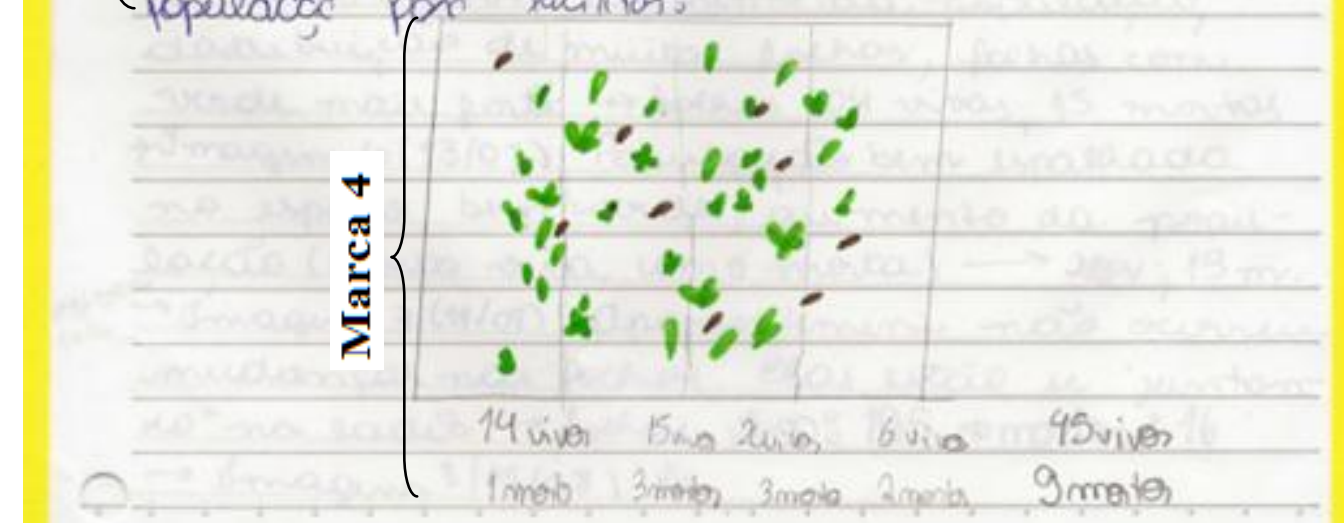


Thiago Marinho Del Corso

INDICADORES DE ALFABETIZAÇÃO CIENTÍFICA, ARGUMENTOS E EXPLICAÇÕES -

Análise de Relatórios no Contexto de uma Sequência de Ensino Investigativo

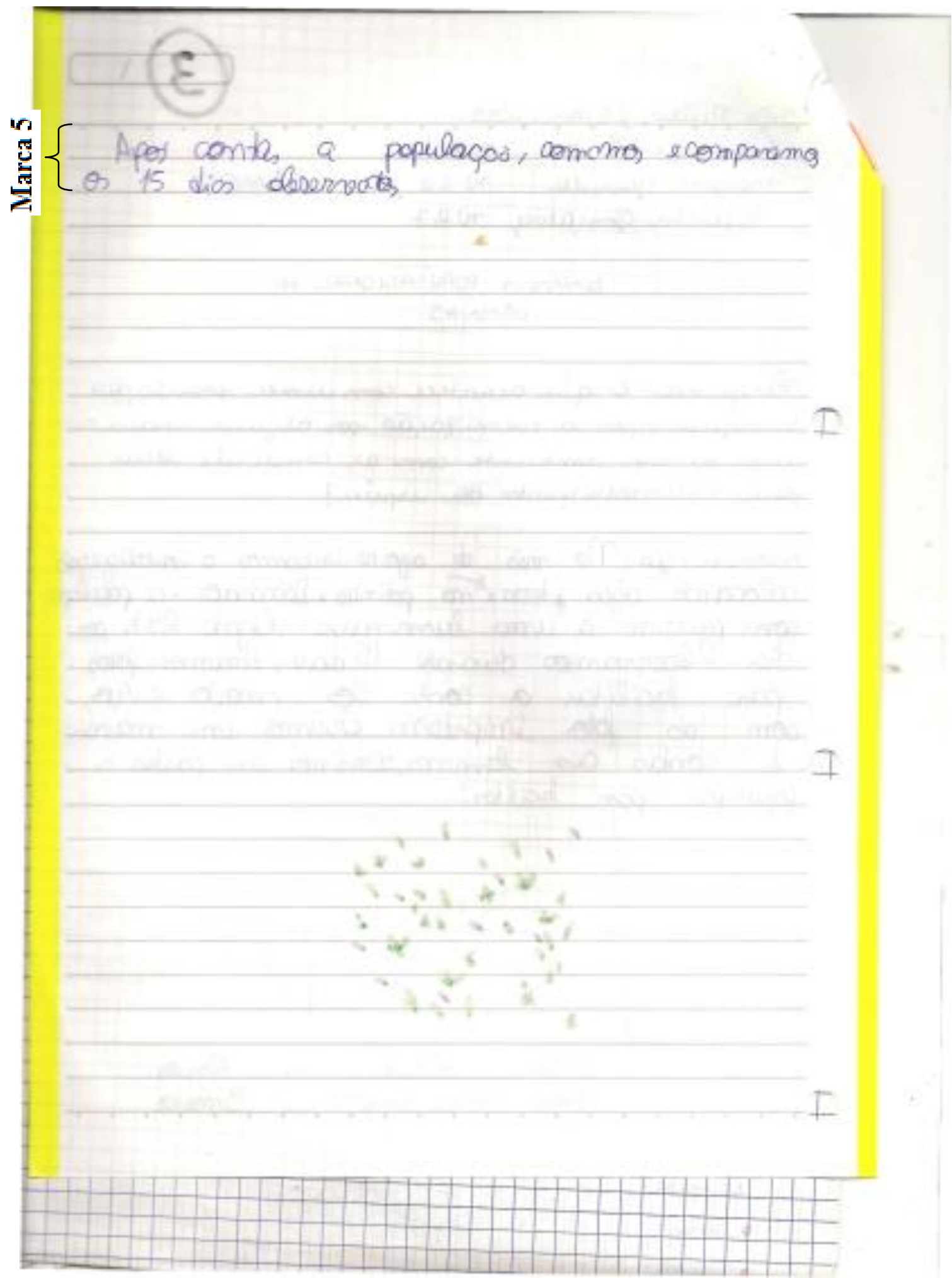


Thiago Marinho Del Corso

INDICADORES DE ALFABETIZAÇÃO CIENTÍFICA, ARGUMENTOS E EXPLICAÇÕES -

Análise de Relatórios no Contexto de uma Sequência de Ensino Investigativo

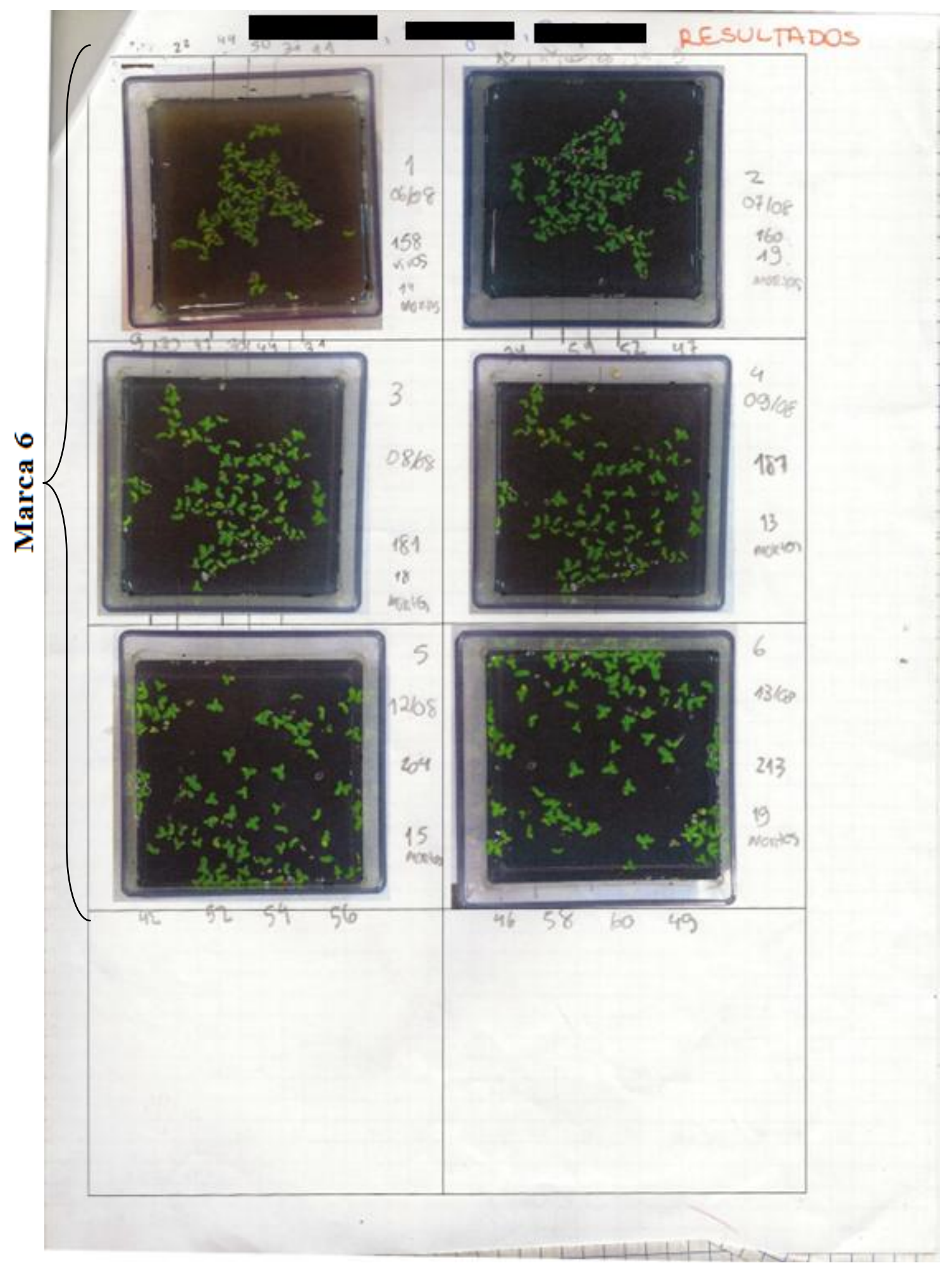


Thiago Marinho Del Corso

INDICADORES DE ALFABETIZAÇÃO CIENTÍFICA, ARGUMENTOS E EXPLICAÇÕES -

Análise de Relatórios no Contexto de uma Sequência de Ensino Investigativo

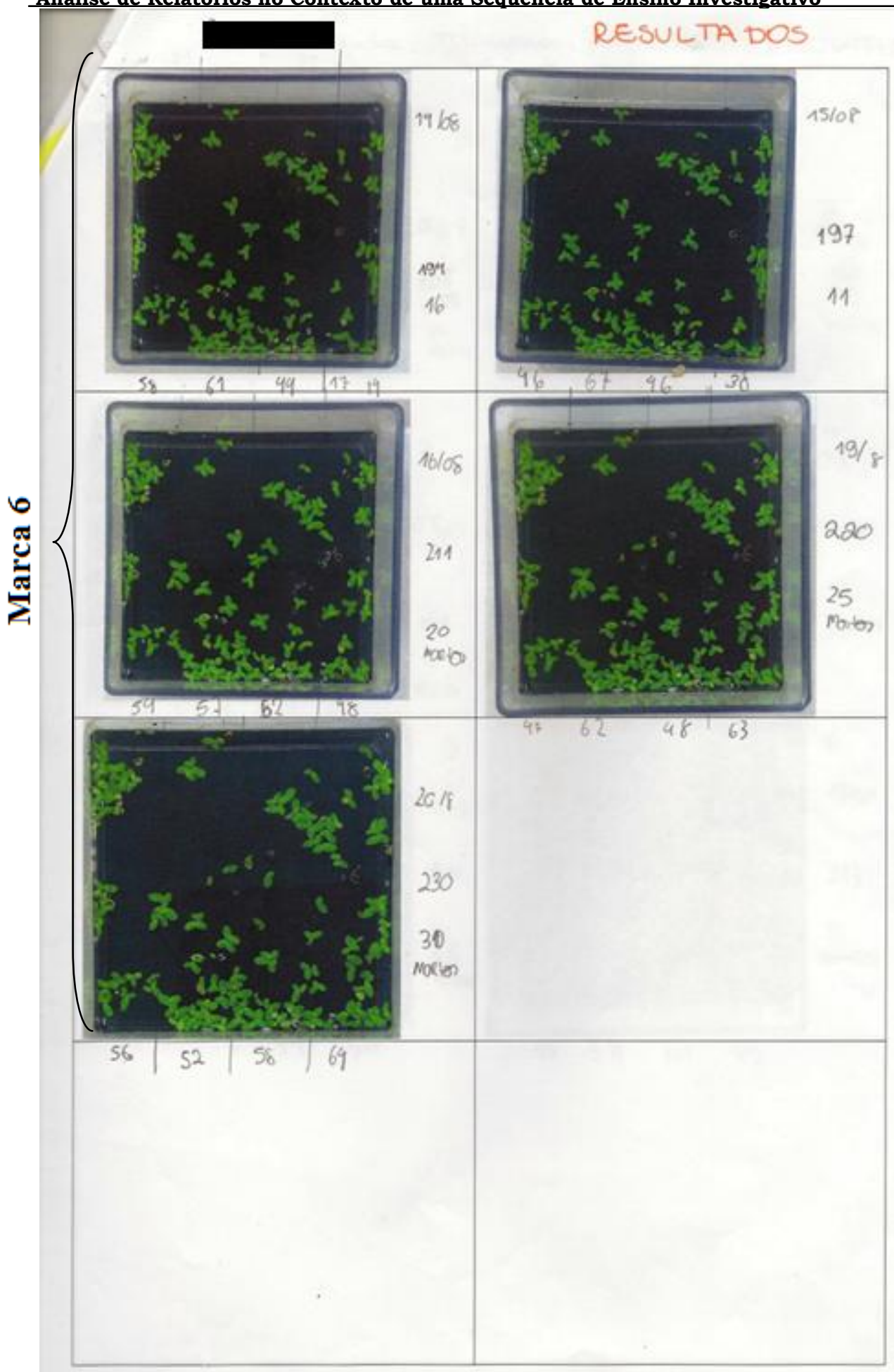


Thiago Marinho Del Corso

INDICADORES DE ALFABETIZAÇÃO CIENTÍFICA, ARGUMENTOS E EXPLICAÇÕES -

Análise de Relatórios no Contexto de uma Sequência de Ensino Investigativo

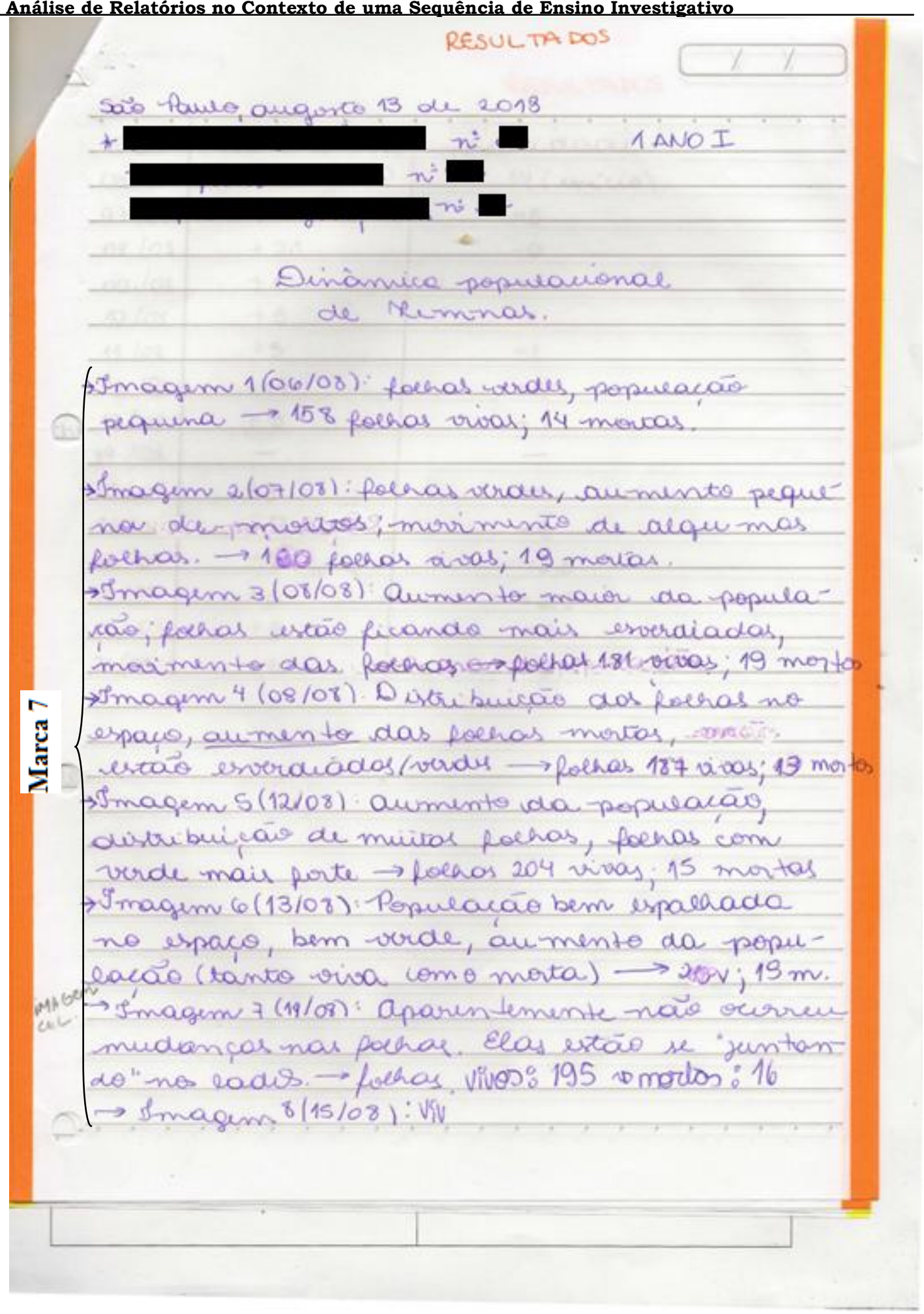




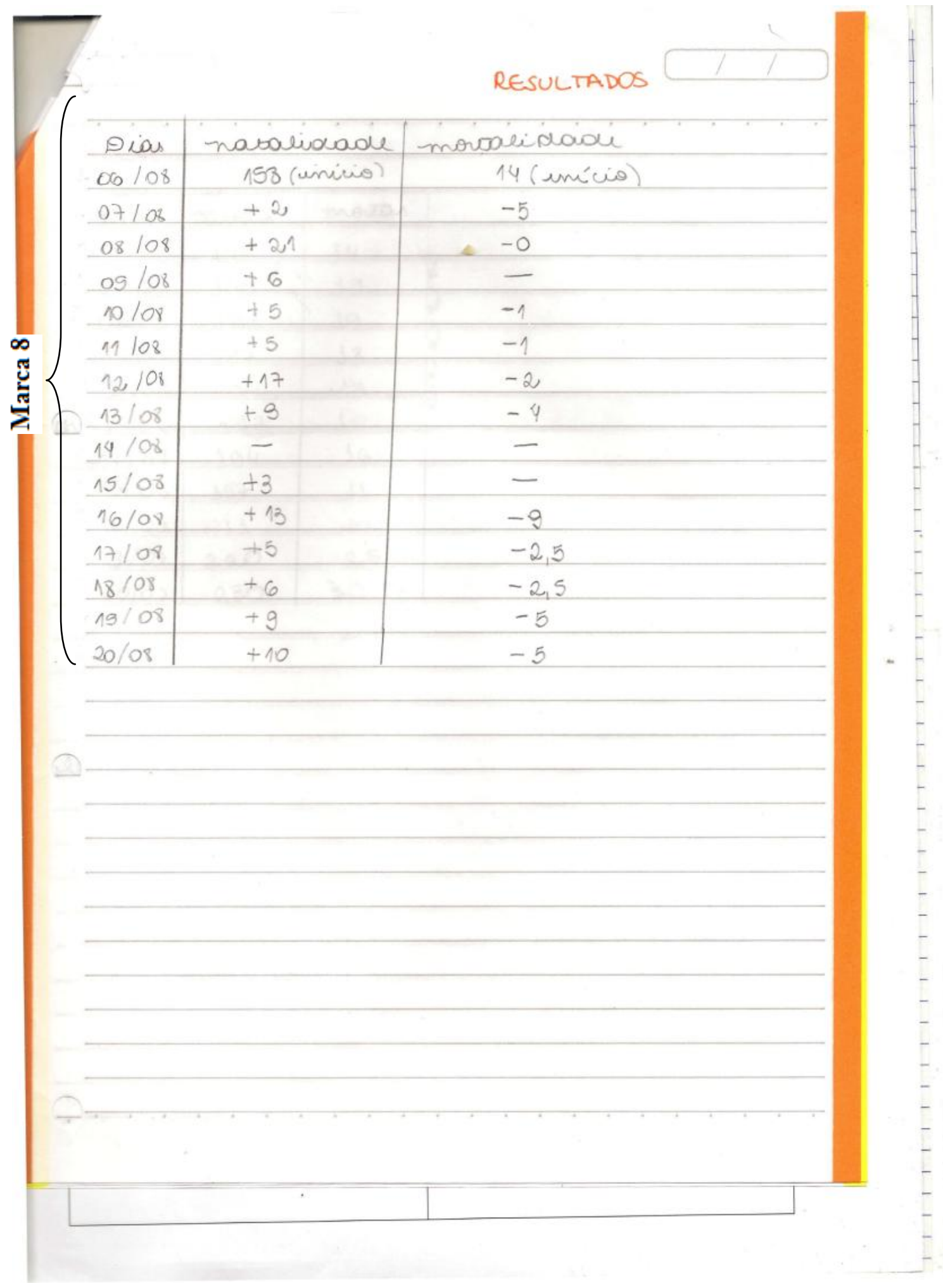




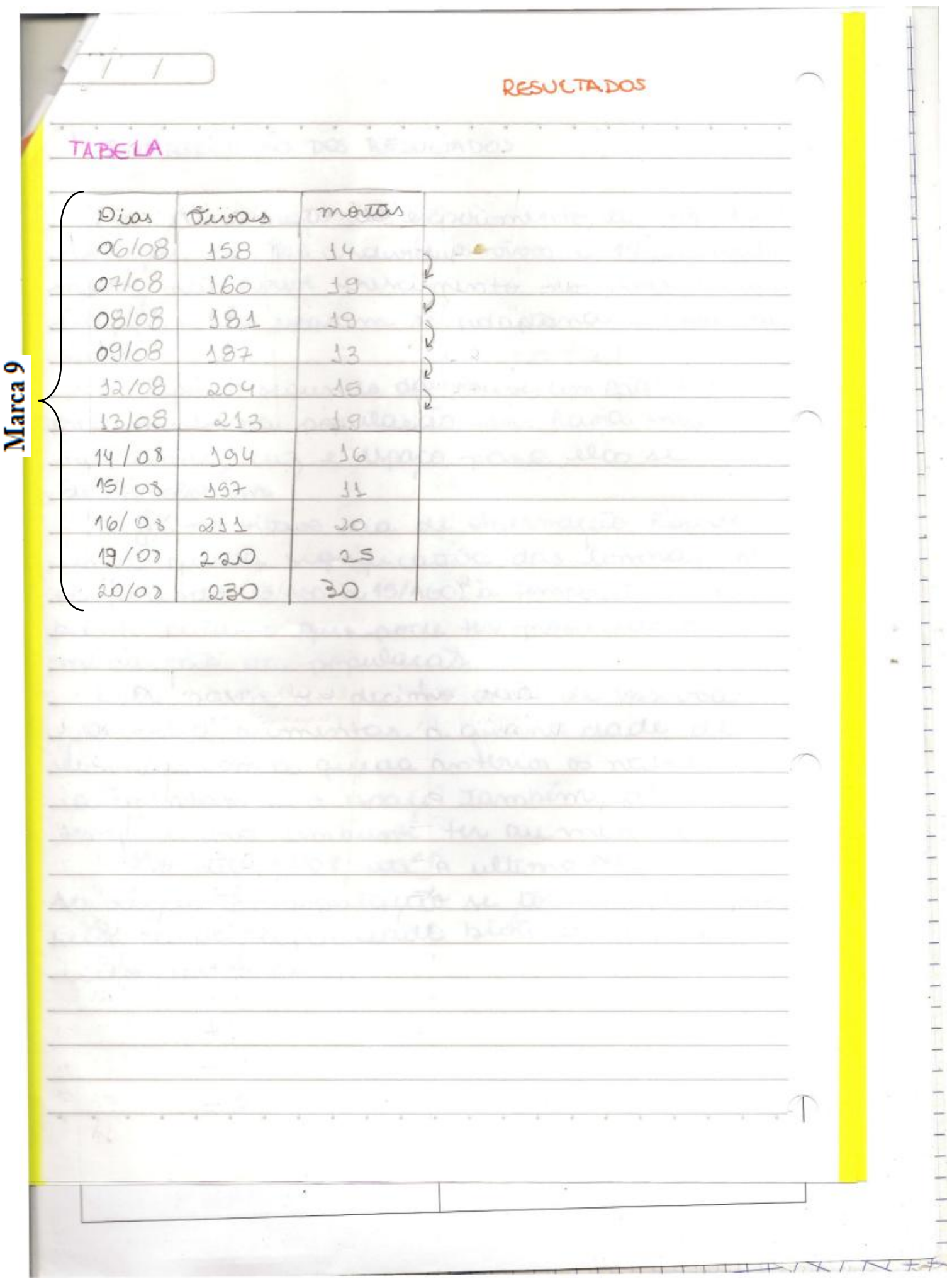


Thiago Marinho Del Corso

INDICADORES DE ALFABETIZAÇÃO CIENTÍFICA, ARGUMENTOS E EXPLICAÇÕES -

Análise de Relatórios no Contexto de uma Sequência de Ensino Investigativo

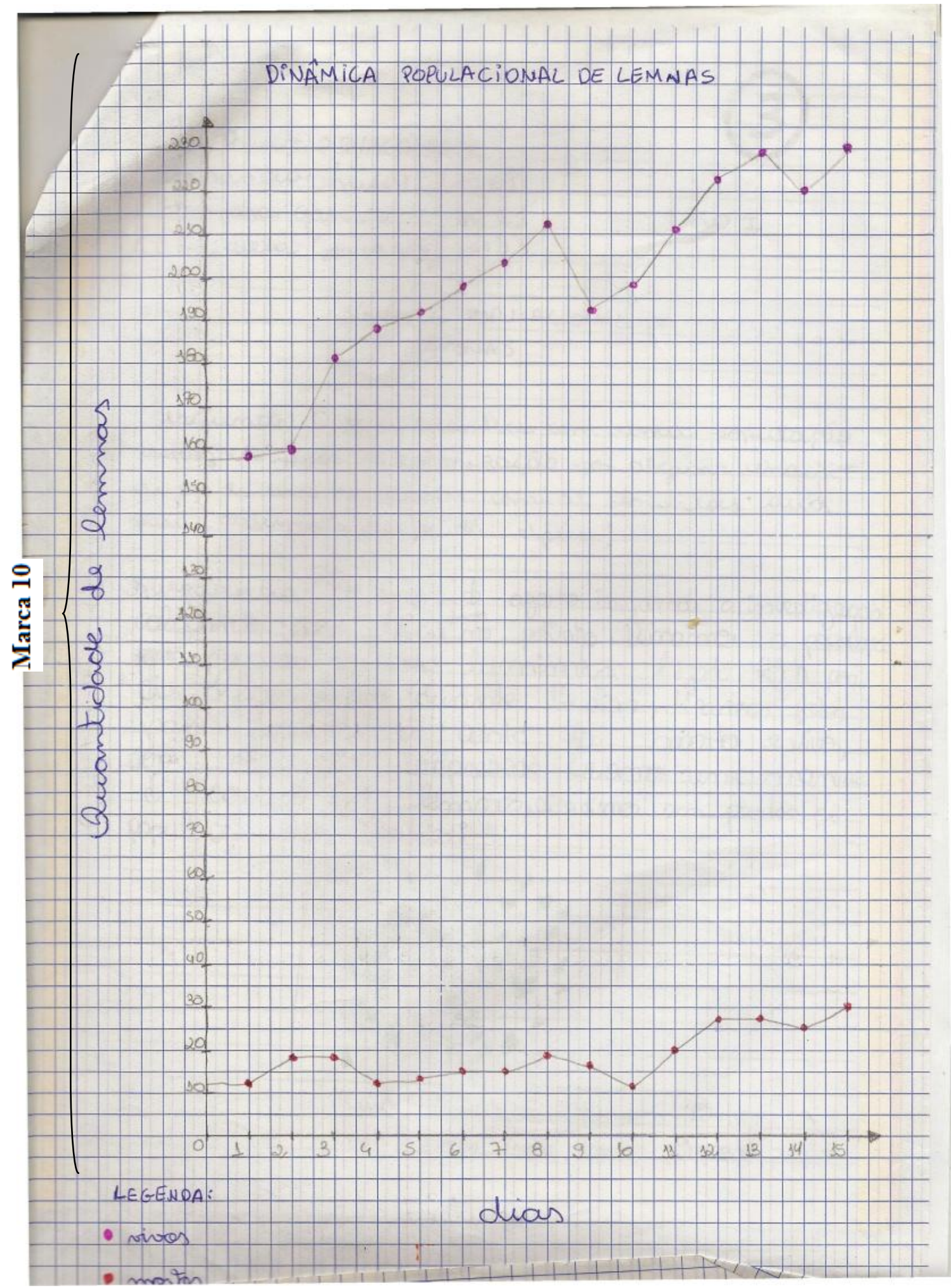




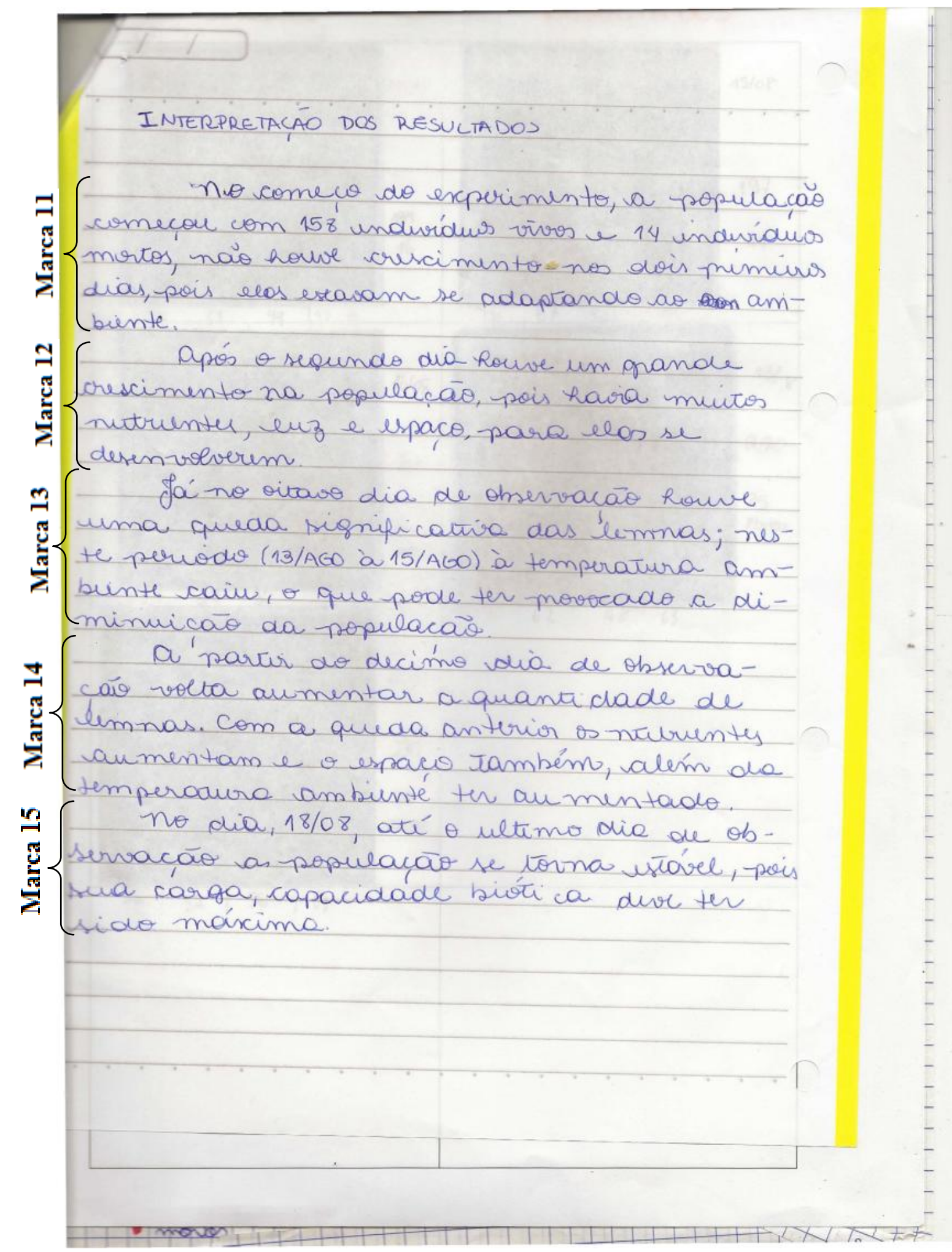


Análise de Relatórios no Contexto de uma Sequência de Ensino Investigativo

Quadro de identificação 03 - Identificação dos Indicadores de Alfabetização Científica no Relatório 3 de 2013 e conclusões individuais correspondentes

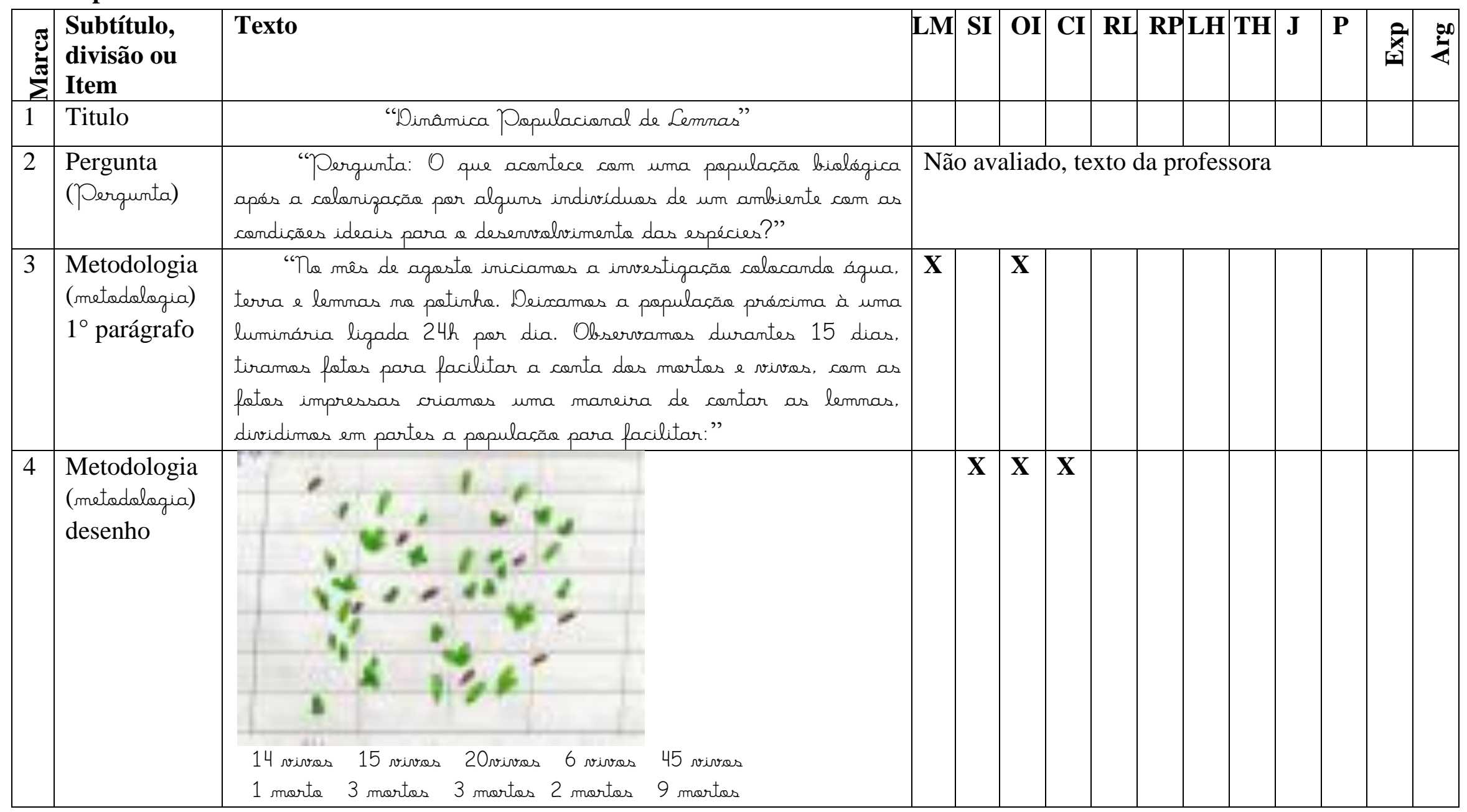


Thiago Marinho Del Corso

INDICADORES DE ALFABETIZAC̄̃o CIENTÍFICA, ARGUMENTOS E EXPLICAÇÕES -

Análise de Relatórios no Contexto de uma Sequência de Ensino Investigativo

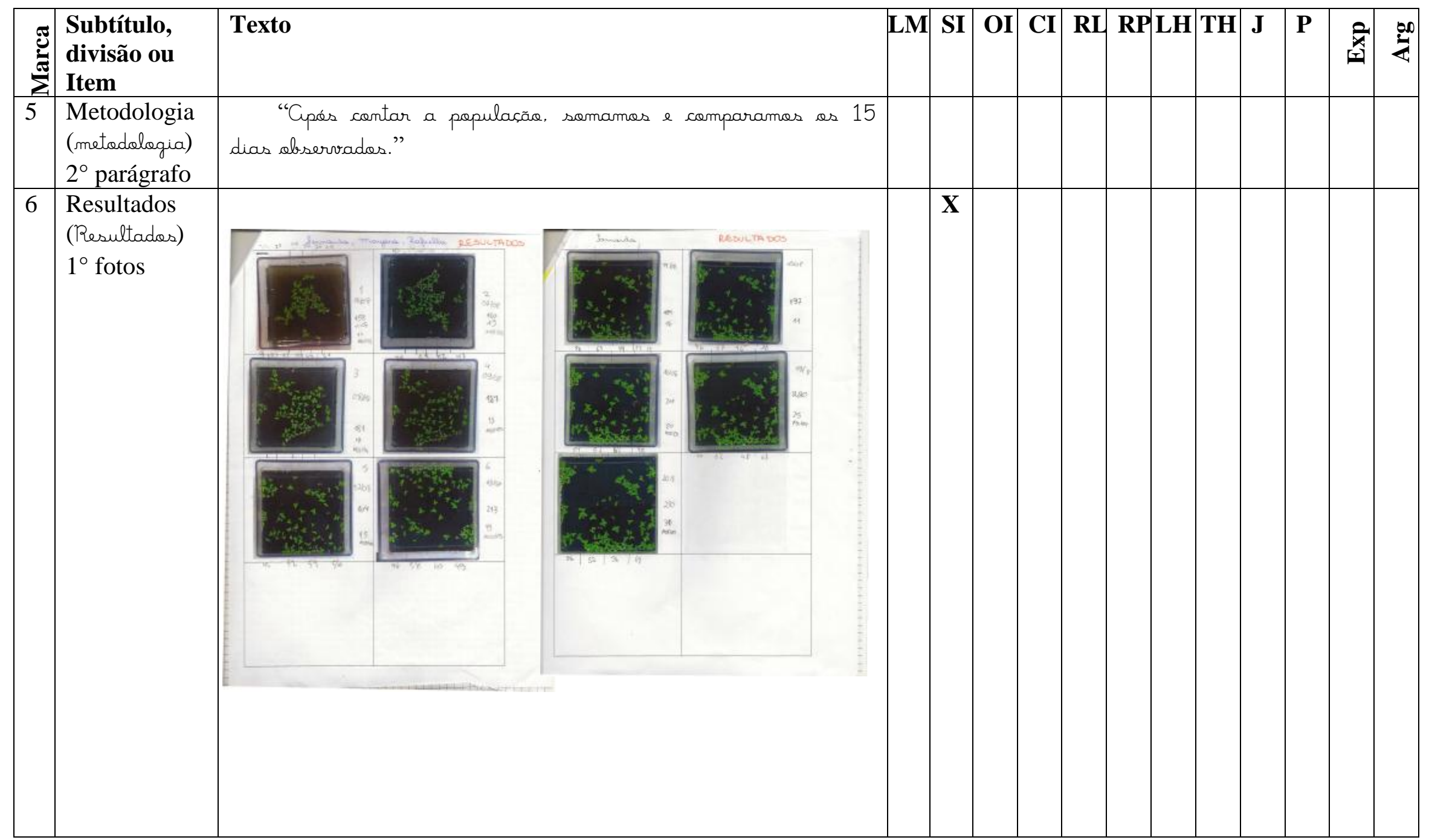


Thiago Marinho Del Corso

INDICADORES DE ALFABETIZAÇÃO CIENTÍFICA, ARGUMENTOS E EXPLICAÇÕES -

Análise de Relatórios no Contexto de uma Sequência de Ensino Investigativo

\begin{tabular}{|c|c|c|c|c|c|c|c|c|c|c|c|c|c|}
\hline 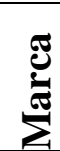 & $\begin{array}{l}\text { Subtítulo, } \\
\text { divisão ou } \\
\text { Item }\end{array}$ & Texto & $\mathbf{L M}$ & SI & OI & CI & $\mathbf{R L}$ & $\mathbf{R P} \mathbf{L H}$ & TH & $\mathbf{J}$ & $\mathbf{P}$ & $\stackrel{a}{a}$ & $\sum_{4}^{00}$ \\
\hline 7 & $\begin{array}{l}\text { Resultados } \\
\text { (Resultados) } \\
2^{\circ} \text { parte, } \\
\text { legenda das } \\
\text { fotos }\end{array}$ & 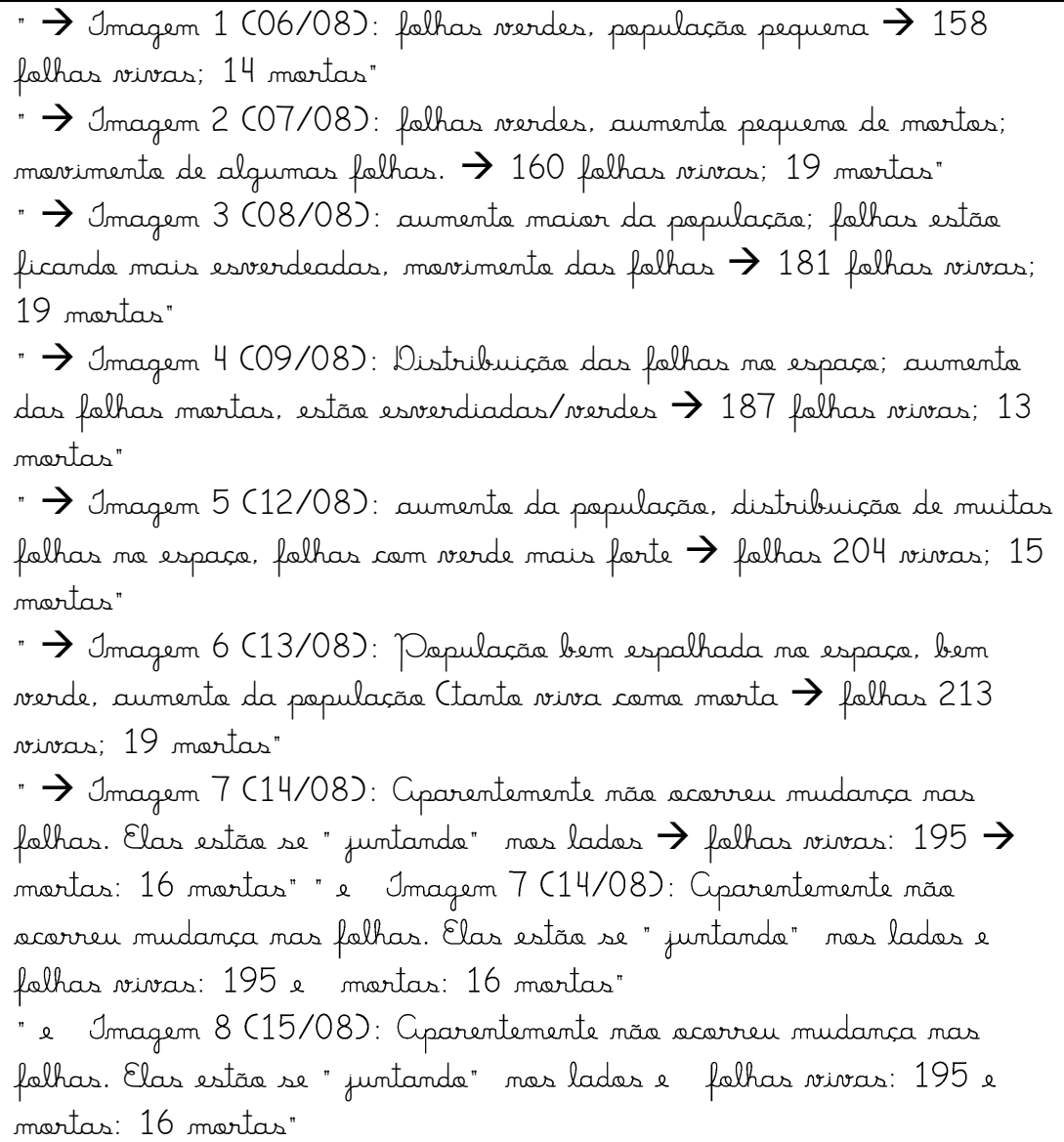 & & $\mathbf{X}$ & $\mathbf{X}$ & $\mathbf{X}$ & & & & & & & \\
\hline
\end{tabular}


Thiago Marinho Del Corso

INDICADORES DE ALFABETIZACÃO CIENTÍFICA, ARGUMENTOS E EXPLICAÇÕES -

Análise de Relatórios no Contexto de uma Sequência de Ensino Investigativo

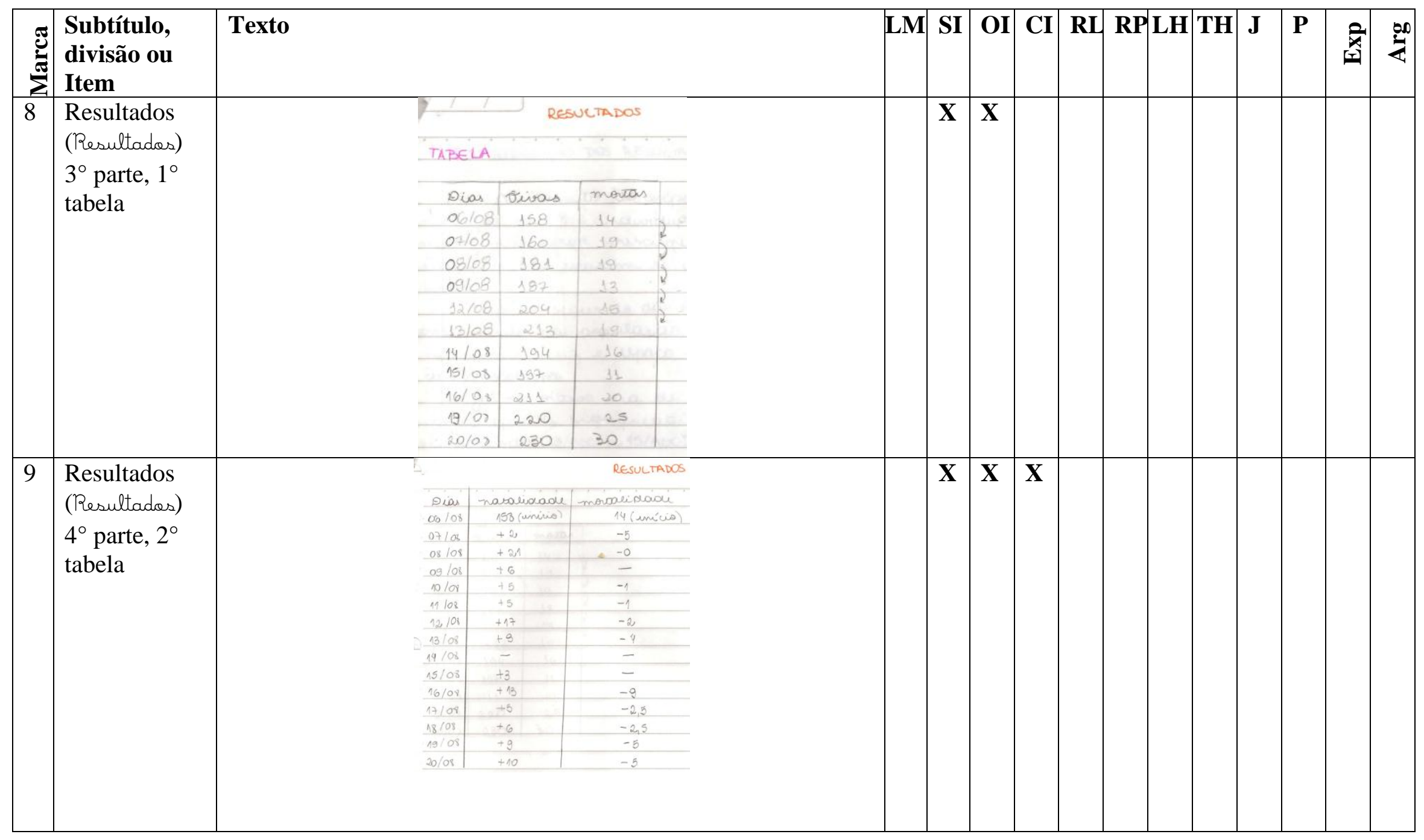


Thiago Marinho Del Corso

INDICADORES DE ALFABETIZACÃO CIENTÍFICA, ARGUMENTOS E EXPLICAÇÕES -

Análise de Relatórios no Contexto de uma Sequência de Ensino Investigativo

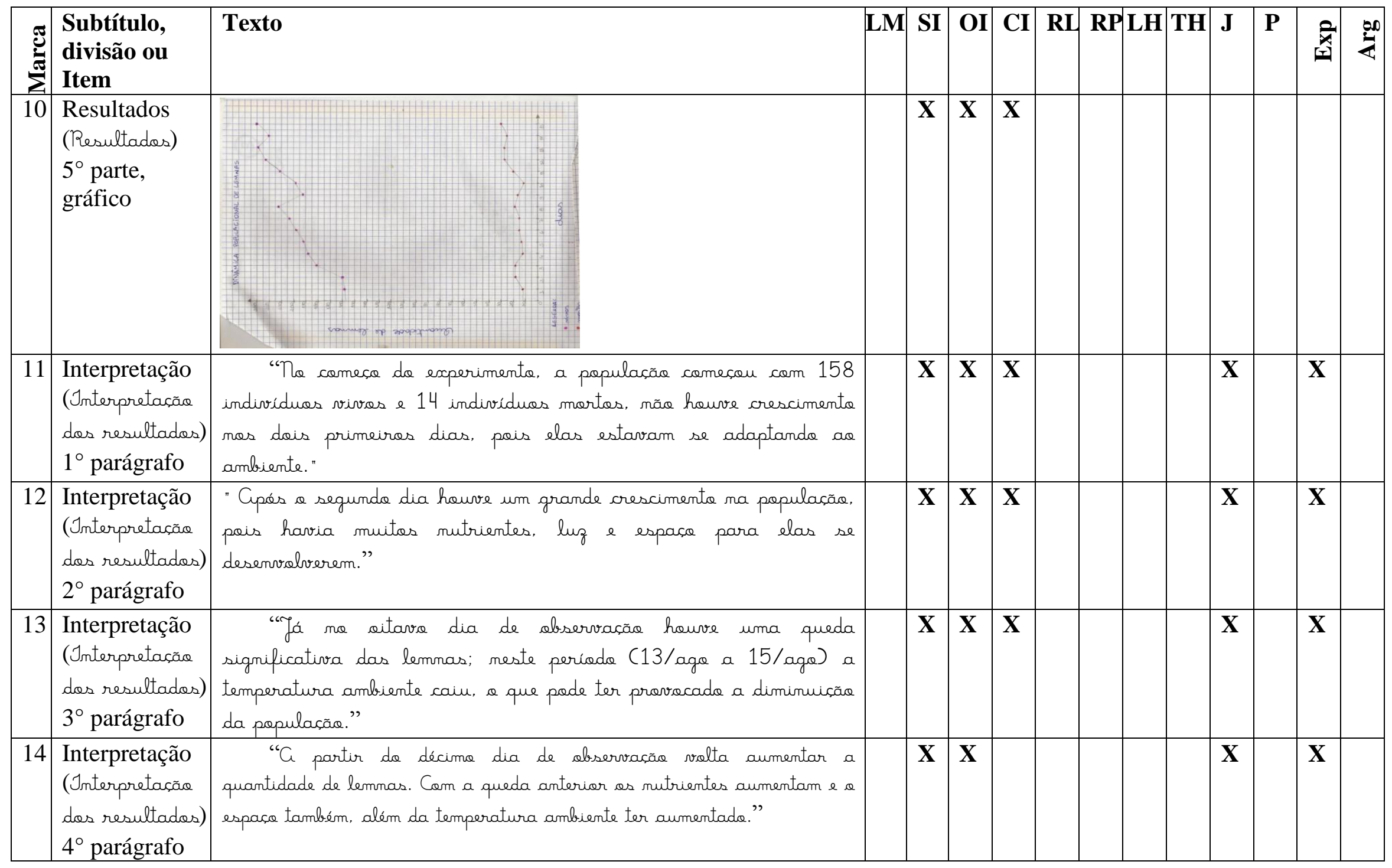


Thiago Marinho Del Corso

INDICADORES DE ALFABETIZAÇÃO CIENTÍFICA, ARGUMENTOS E EXPLICAÇÕES -

Análise de Relatórios no Contexto de uma Sequência de Ensino Investigativo

\begin{tabular}{|c|c|c|c|c|c|c|c|c|c|c|c|c|c|}
\hline 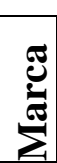 & $\begin{array}{l}\text { Subtítulo, } \\
\text { divisão ou } \\
\text { Item }\end{array}$ & Texto & LM & SI & OI & CI & RL & RP LH & TH & $\mathbf{J}$ & $\mathbf{P}$ & : & $\sum^{\infty}$ \\
\hline 15 & $\begin{array}{l}\text { Interpretação } \\
\text { (Interpretaçãa } \\
\text { dos resultados) } \\
5^{\circ} \text { e último } \\
\text { parágrafo }\end{array}$ & $\begin{array}{l}\text { "To dia } 18 / 08 \text { até a última dia de abservasãa a papulaçãa } \\
\text { se torna estável, pais sua carga capacidade biática deve ter sida } \\
\text { máxima." }\end{array}$ & & $\mathbf{X}$ & $\mathbf{X}$ & & & & & $\mathbf{X}$ & & $\mathbf{X}$ & \\
\hline 16 & $\begin{array}{l}\text { Conclusão } 1 \\
\text { (1 }{ }^{\circ} \text { parágrafo) }\end{array}$ & 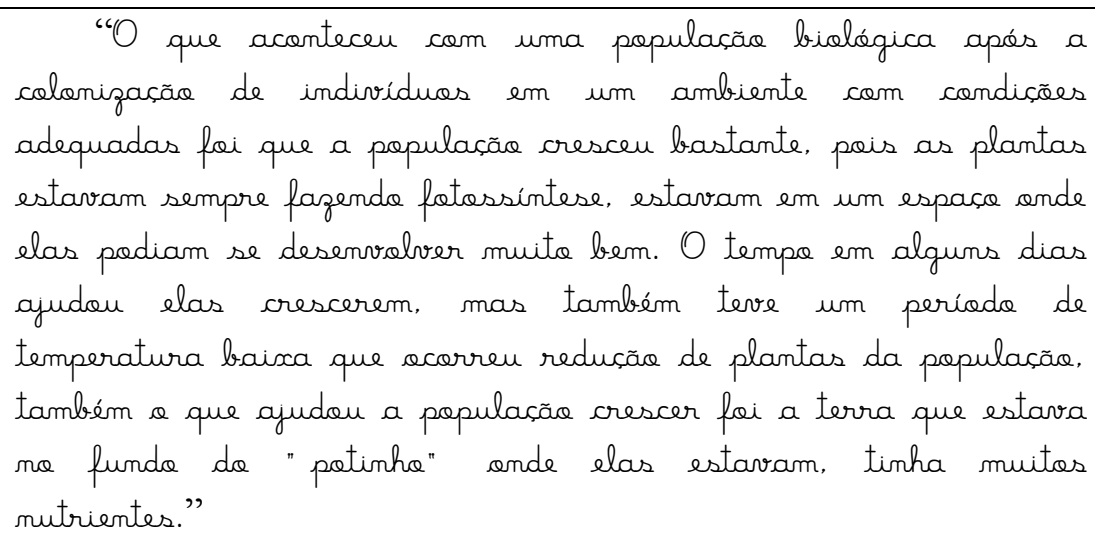 & & $\mathbf{X}$ & & $\mathbf{X}$ & $\mathbf{X}$ & & & $\mathbf{X}$ & & $\mathbf{X}$ & \\
\hline 17 & $\begin{array}{l}\text { Conclusão } 1 \\
\left(2^{\circ} \text { parágrafo }\right)\end{array}$ & $\begin{array}{l}\text { "Depais que as lemnas já estavam habituadas ace espaca, com } \\
\text { a luz } 24 \text { horas direcionada para elas, a populaçãe foi ficanda } \\
\text { estável." }\end{array}$ & & $\mathbf{X}$ & & & & & & $\mathbf{X}$ & & $\mathbf{X}$ & \\
\hline 18 & Conclusão 2 & 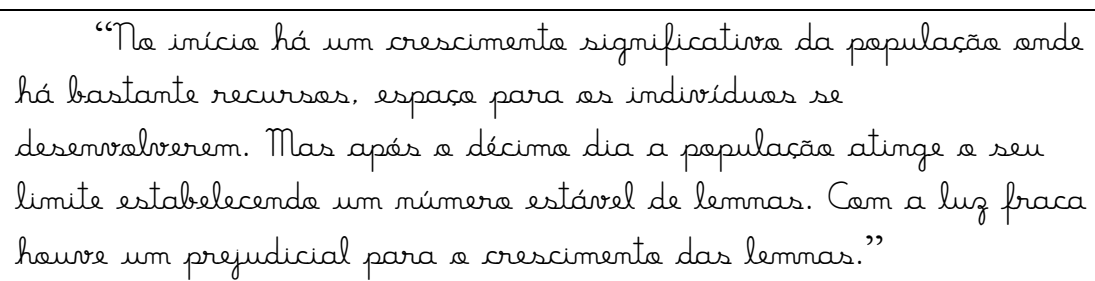 & & $\mathbf{X}$ & $\mathbf{X}$ & $\mathbf{X}$ & & & & $\mathbf{X}$ & & $\mathbf{X}$ & \\
\hline
\end{tabular}


Thiago Marinho Del Corso

INDICADORES DE ALFABETIZAÇ̃̃O CIENTÍFICA, ARGUMENTOS E EXPLICAÇÕES -

Análise de Relatórios no Contexto de uma Sequência de Ensino Investigativo

\begin{tabular}{|c|c|c|c|c|c|c|c|c|c|c|c|c|c|c|}
\hline 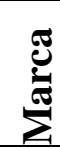 & $\begin{array}{l}\text { Subtítulo, } \\
\text { divisão ou } \\
\text { Item }\end{array}$ & Texto & $\mathbf{L M}$ & SI & OI & CI & RL & $\mathbf{R P} \mathbf{L H}$ & TH & $\mathbf{J}$ & $\mathbf{P}$ & & & $\sum^{\infty}$ \\
\hline 19 & $\begin{array}{l}\text { Conclusão } 3 \\
\text { (1 } 1^{\circ} \text { parágrafo) }\end{array}$ & $\begin{array}{l}\text { "Em uma papulascãa bialógica, após a calonizaçãa par alguns } \\
\text { individuas em um ambiente com as condicães ideais para a } \\
\text { desenvolvimenta da espécie, aconteceu um aumenta na papulaçãa } \\
\text { das Lemnas. Hauve um crescimenta por conta do consuma de luz." }\end{array}$ & & $\mathbf{X}$ & & & $\mathbf{X}$ & & & $\mathbf{X}$ & & & & \\
\hline 20 & $\begin{array}{l}\text { Conclusão } 3 \\
\left(2^{\circ} \text { parágrafo }\right)\end{array}$ & 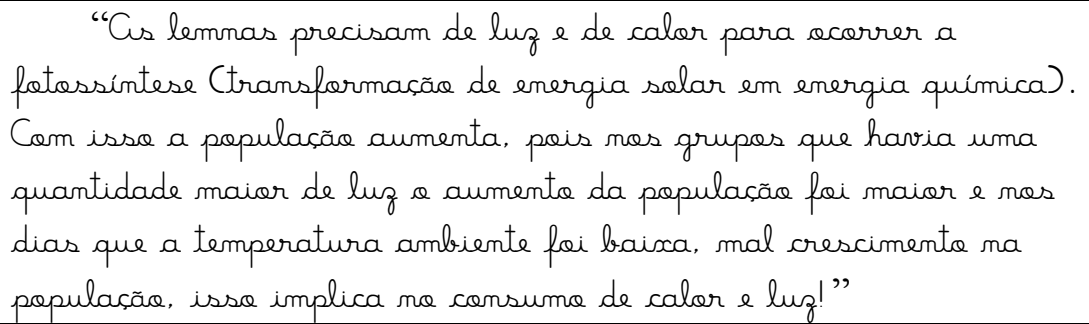 & & $\mathbf{X}$ & & & $\mathbf{X}$ & & & $\mathbf{X}$ & $\mathbf{X}$ & & & $\mathbf{X}$ \\
\hline
\end{tabular}




\section{Relatório 3 - 2013 - Detalhando a identificação dos indicadores de AC}

O relatório 3, como norma pedida pela professora, apresenta primeiramente a data e o nome dos integrantes. Estes não são analisados.

\section{Marca 1 (relatório 3):}

A primeira construção textual dos alunos é o título. Este, apesar de constituir uma prática típica e recorrente das construções da Ciência, não apresenta um indicador de Alfabetização Científica (Sasseron 2008; Sasseron e Carvalho 2008) que o abarque.

\section{Marca 2 (relatório 3):}

A segunda construção textual dos alunos é a pergunta proposta pela professora - assim, como estamos analisando as produções dos alunos, não há razão de se procurar indicadores de Alfabetização Científica aqui.

\section{Marca 3 (relatório 3):}

A descrição da metodologia aqui é confusa, mas pudemos identificar a Listagem de materiais, Seriação de informações e Organização de informações.

"No mês de agasta iniciamas a investigaçãa colocanda água, terra e lemnas ma patinho. Deixamos a populaçãa préxima à uma luminária ligada 24 h por dia. Observamas durantes 15 dias, tiramos fotos para facilitar a conta dos mortos e vivos, com as fotos impressas criamos uma maneira de contar as lemnas, dividimas em partes a populaçãa para facilitar:

A Listagem de materiais aparece aqui com a apresentação dos materiais usados para montar o experimento: "água, terra e lemmas mo potimhe.", "luminária"e "fotos impressas".

Como apresentado na discussão de relatórios anteriores, a Organização de informações surge como um indicador quando se procura preparar os dados sobre o problema investigado e o modo como o trabalho foi realizado. Nesta marca isso se evidencia quando os alunos apontam que os dados derivam de fotos da população, dizem que dividiram em partes a população para facilitar a contagem, separaram a contagem das Lemnas mortas e vivas. Ou seja: os alunos estão preparando os dados com os quais vão posteriormente trabalhar.

\section{Marca 4 (relatório 3):}

Esta quarta marca apresenta um desenho e um pequeno texto que tem a intenção de demonstrar como foi feita a contagem do número de indivíduos da população de Lemnas. 
Podemos identificar os três indicadores relacionados ao trabalho com os dados Organização e Classificação de informações. A Organização das informações ocorre quando os alunos apresentam que a contagem será efetuada separadamente por quadrantes das fotos e por Lemnas vivas e mortas, isso pode ser entendido como um arranjo ordenado dos dados, como uma preparação dos dados. Finalmente, a Classificação de informações se apresenta pela própria separação das Lemnas: estas são classificadas em vivas ou mortas e ambos os dados serão trabalhados. Sasseron (2008) afirma que: "ao se classificar as informações, elas podem ser apresentadas conforme uma hierarquia, mas o aparecimento desta hierarquia não é condição sine qua non para a classificação de informações". Aqui cada indivíduo de Lemna é classificado como vivo ou morto. Não havendo uma hierarquia estabelecida no tratamento destes dados, as tabelas construídas e o gráfico trabalharam sempre com as duas informações em paralelo.

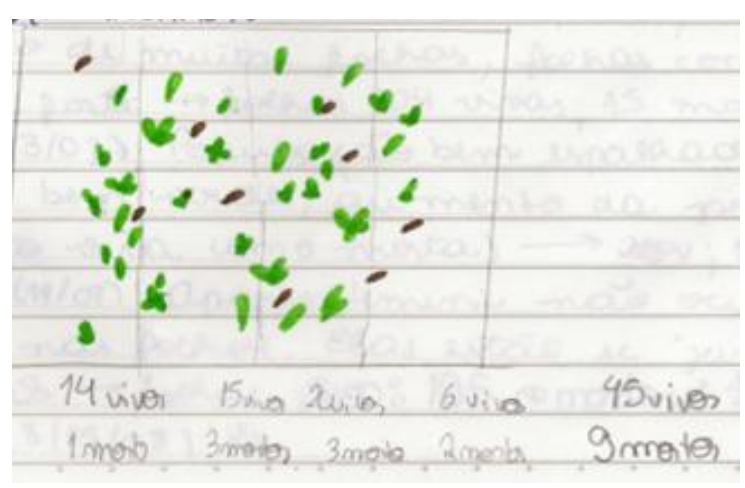

\section{Marca 5 (relatório 3):}

O pequeno trecho abaixo transcrito não apresenta nenhum indicador de Alfabetização Científica dos propostos por Sasseron e Carvalho (2008).

"Cpés contar a populacãa, somamos e comparamos as 15 dias observados."

\section{Marca 6 (relatório 3):}

Aqui, ao identificar nas fotos dos recipientes o número de Lemnas existentes em cada dia, os alunos estão claramente listando dados e assim apresentando o indicador Seriação de informações.

\section{Marca 7 (relatório 3):}

Esta marca foi estabelecida para as legendas das fotos. Nestas legendas os alunos reapresentam o número de indivíduos por dia e comentam se a população está crescendo ou não. Desta forma, estão apresentando uma lista de dados, característica do indicador Seriação 
de informações. Os indicadores Organização e Classificação de informações também estão presentes nesta sétima marca.

A Organização de informações ocorre pela apresentação dos dados dia a dia, numa clara preparação dos dados. A Classificação de informações ocorre na medida em que este indicador aparece quando se busca estabelecer características para os dados obtidos e aqui coloração, distribuição e a intensidade da variação populacional das Lemnas são apresentados.

\section{Marca 8 (relatório 3):}

Esta tabela contém dois indicadores de Alfabetização Científica: Seriação e Organização de informações. O primeiro está ligado ao estabelecimento de bases para a ação Investigativo e a reapresentação dos dados. $\mathrm{O}$ segundo surge quando se procura preparar os dados existentes, fazendo um novo arranjo para estes dados.

\section{Marca 9 (relatório 3):}

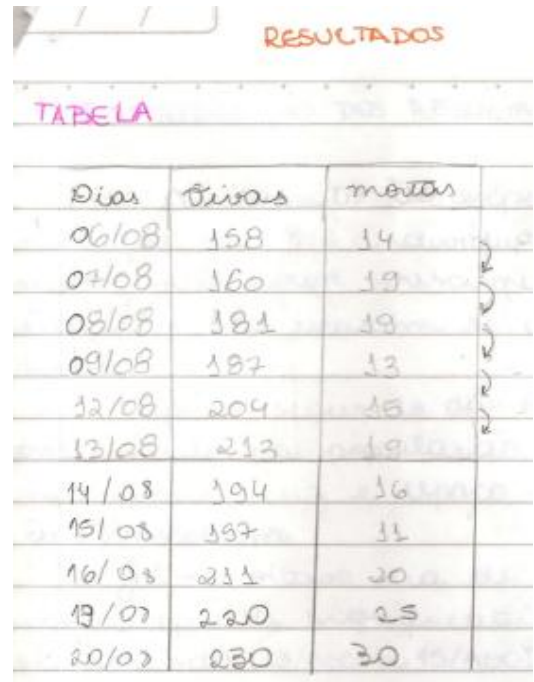

Nesta tabela pode-se reconhecer, por motivos semelhantes aos referentes à tabela anterior, os indicadores Seriação e Organização de informações. Mas aqui pode-se também identificar o indicador Classificação de informações, pois esta tabela busca estabelecer características para os dados obtidos, o que é apontado por Sasseron (2008) como característica deste indicador.

\section{Marca 10 (relatório 3):}

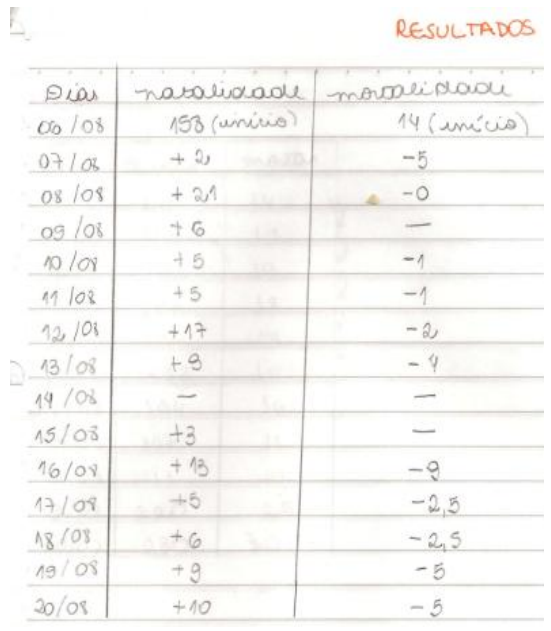

No gráfico que apresenta tanto a variação populacional das Lemnas ao longo dos dias de experimento quanto a variação na mortandade se apresentam os indicadores Seriação, Organização e Classificação de informações. Estes três indicadores são relacionados ao trabalho com os dados empíricos de uma atividade experimental. Podemos perceber a apresentação dos dados que servirão de base para a ação investigativa, característica da Seriação de informações, mas também a preparação dos dados existentes sobre o problema investigado (Organização de informações) e finalmente o estabelecimento de características 
para estes dados: Classificação de informações, que foram primordiais para as interpretações que se sucederam.

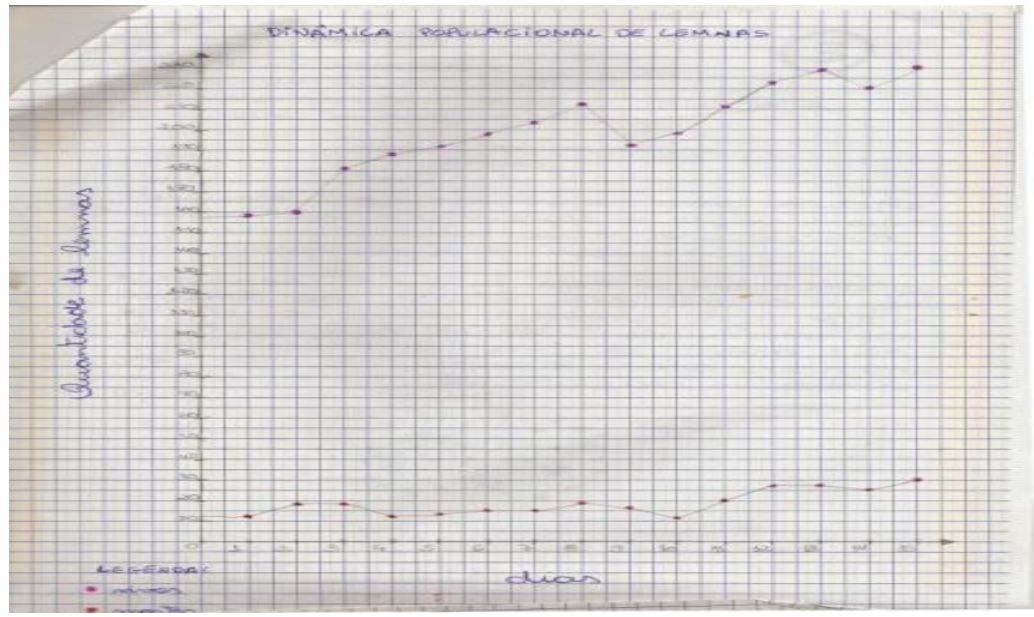

\section{Marca 11 (relatório 3):}

O primeiro parágrafo da "Interpretaçãe de Resultados", transcrito abaixo apresenta os indicadores de: Seriação, Organização e Classificação de informações, Justificativa e Explicação.

\footnotetext{
"To comesce de experimenta, a papulasăa comesau com 158 individuas vivros e 14 individuas mortas, näa houve crescimenta nas dois primeiras dias, pois elas estavam se adaptando as ambiente.".
}

Os dois primeiros podem ser percebidos quando os alunos retomam os dados obtidos experimentalmente para fazer conjecturas acerca destes. A Seriação de informações decorre da apresentação do número inicial de Lemnas na população e pela afirmativa de que houve "crescimenta". A Classificação de informações decorre da separação em Lemnas mortas e vivas, no que entendemos ser uma classificação desses dados. A Organização de informações decorre não de uma característica desta assertiva propriamente dita, mas da separação em cinco diferentes momentos com características próprias em relação à dinâmica populacional. Ou seja: os alunos organizaram os dados em cinco diferentes momentos com características e justificativas próprias, e este é apenas o primeiro momento. Isso pode ser percebido quando se analisam todos os parágrafos da "Imterpretaçãe dos resultados", e na medida em que os dados de crescimento são separados nesses diferentes grupos, com características próprias de variação populacional. 
O indicador de Justificativa aparece associado à afirmativa de que "mãa houve crescimente mos dois primeiros dias", quando os alunos lançam mão de uma garantia para o que é proposto: "pois elas estarram se adaptando ar ambiente". Vide que para Sasseron (2008) e Sasseron e Carvalho (2008), o indicador de Justificativa se faz presente quando: “... em uma afirmação qualquer proferida, lança-se mão de uma garantia para o que é proposto."

O último indicador que esta assertiva "Imterpretacãa dos resultados" apresenta é a Explicação. Uma Explicação se identifica, de acordo com Sasseron e Carvalho (2008), quando: “...se busca relacionar informações e hipóteses já levantadas. Normalmente a explicação é acompanhada de uma justificativa...”.

A afirmação aqui é que "mão houve crescimento nos dois primeiros dias" e a Justificativa é que "elas estaram se adaptando ae ambiente.". Para discernir este indicador de um Argumento busca-se analisar se a assertiva "mãa houve crescimenta mas dois primeiras dias" é contestável, se há dúvida. De acordo com Murcho (2003), se a conclusão da Explicação, por nós chamada de explanandum para evitar confusão com a Conclusão (C) do Argumento, for mais plausível que suas premissas, então tratar-se-ia de uma Explicação e não um Argumento. Aqui a ausência de crescimento nos dois primeiros dias é mais plausível, pois foi experimentalmente aferida, do que a Justificativa para não ter havido crescimento: "pois elas estaram se adaptando ar ambiente".

\section{Marca 12 (relatório 3):}

Nesta décima segunda marca, transcrita abaixo, encontramos indicadores de Seriação de informações, Classificação de informações, Justificativa e Explicação.

\footnotetext{
"Cupés a segunda dia houve um grande crescimenta na populaçäe, pois havia muitas mutrientes, luz e espace para elas se desenvolverem.".
}

O primeiro destes indicadores segue a idéia de que, em se tratando de dinâmica populacional, crescer é um dado e a apresentação de dados indica a Seriação de informações. Também ao considerar o "crescimenta" como um dado, ao atribuir características a este dado, entendemos haver uma Classificação de informações: "grande". 
A Organização de informações segue a mesma lógica da marca anterior, ou seja: não é característica intrínseca da assertiva, mas se refere à organização em diferentes momentos a serem discutidos.

Ao dizer que os nutrientes, a luz e o espaço foram os responsáveis por permitir "grande crescimente ma populacãa" os alunos estão Justificando as causas para este grande crescimento.

Identifica-se a Explicação quando este parágrafo apresenta uma afirmativa (“Cupés a segundo dia houve um grande crescimento na populacäa"), e que a Justificativa para esta afirmativa é a sentença "pois havia muitas nutrientes, luz e espace para elas se desenvolverem.". A desambiguação em relação a considerar que se trataria de um Argumento vem das considerações feitas por Osborne e Patterson (2011) e Murcho (2003), que apresentam que se em um Argumento a Conclusão (C) está em dúvida, é contestável, é menos certa que as premissas (Justificativas $(\mathbf{J})$ ), o que não acontece aqui, onde o explanandum (terminologia adotada para a conclusão de uma Explicação) é mais certo, menos discutível, experimentalmente obtido e por isso menos contestável que o explanans (termo adotado para se referir as justificativas de uma Explicação).

\section{Marca 13 (relatório 3):}

O terceiro parágrafo da "Interpretaçãe dos resultados", apresenta novamente os indicadores de Seriação, Organização e Classificação de informações, Justificativa e Explicação.

"Iá ne eitavse dia de ebservaçãa houve uma queda significativa das lemnas; meste períado (13/age a 15/age) a temperatura ambiente cail, a que pode ter provecado a diminuicäa da populacãa."

Novamente o primeiro destes indicadores se refere à apresentação da variação no número de indivíduos na população "houve uma queda... das lemnas" e "diminuiçã da pepulasãa". Listar dados é indicativo de Seriação de informações. Ao atribuir característica, "queda significativa", os alunos estão Classificando informações.

Como nas marcas 11 e 12, a Organização de informações deriva da organização em períodos com características próprias de variação populacional. 
Aqui a Justificativa se dá em relação à afirmativa de que "Tá me eitarse dia de observacãa houve uma queda significativa das lemnas" e se apresenta quando os alunos consideram que a causa para esta diminuição da população de Lemnas foi “ meste períado (13/age a 15/age) a temperatura ambiente cail, a que pode ter provracado a diminuição da papulaçãa.".

Neste parágrafo encontramos claramente uma Explicação, pois há uma afirmativa, e a tentativa de estabelecer uma relação causal entre o fenômeno e o(s) possível(eis) motivo(s) para que este tenha acontecido da forma como aconteceu. Verificando que o explanandum é mais plausível que o explanans, é eliminada a possibilidade de se tratar de um Argumento.

\section{Marca 14 (relatório 3):}

O penúltimo parágrafo da "Interpretaça dos resultadas" apresenta os mesmos indicadores que os dois parágrafos anteriores: Seriação de informações, Organização de informações, Justificativa e Explicação.

"A partir da décima dia de ebservacãa volta aumentar a quantidade de lemnas. Com a queda anterior as nutrientes aumentam e espace também, além da temperatura ambiente ter aumentado.".

O indicador de Seriação de informações decorre novamente da apresentação da variação populacional do período - "aumentar a quantidade de lemnas"-.

Este parágrafo é o penúltimo da divisão em diferentes momentos de variação populacional e seguindo a lógica dos anteriores entendido como uma Organização de informações.

Em relação ao indicador de Justificativa à afirmativa -"G partir de décime dia de elsservaçãe volta aumentar a quantidade de lemnas." - tem como Justificativa - "Com a queda anterior es nutrientes aumentam e espace tambím, além da temperatura ambiente ter aumentada."-.

No que tange a Explicação é interessante notar que aqui há explanans complementares - (1) "Com a queda anterior as nutrientes aumentam"-, - (2) "aumentam e e espace" - e - (3) "além da temperatura ambiente ter aumentada" - para o explanandum -"G partir do décime dia 
de elsservacãa volta aumentar a quantidade de lemnas."-- Os critérios de desambiguação em relação ao Argumento se fazem presentes aqui, da mesma forma que nos parágrafos anteriores, mas se somam ao fato que os explanans não são hipóteses explicativas concorrentes, o que indicaria um Argumento, mas sim complementares, o que apóia a identificação como uma Explicação.

\section{Marca 15 (relatório 3):}

A décima quinta marca apresenta assim como a anterior apresenta indicadores de Seriação de informações, Organização de informações, Justificativa e Explicação.

"To dia 18/08 até a últime dia de elsservacãa a populacãa se torna estável, pois sua carga capacidade biética deve ter sida máxima."

Ao organizar em cinco diferentes momentos com características próprias de variação populacional os dados obtidos, no que pode ser entendida como uma Organização de informações, e discuti-los separadamente em cada parágrafo da -"Imterpretaçãe dos resultadas"-, os alunos parecem adotar um modelo de interpretação, logo os mesmo indicadores são identificados também neste quinto parágrafo.

Aqui o interessante é notar que o explanans para a inferida estabilização populacional "To dia 18/08 até a últime dia de ebservacãa a populacãa se torna estável "- vem da teoria acerca de variação na dinâmica populacional -"pois sua carga capacidade biética deve ter sido máxima."-.

\section{Marca 16 (relatório 3):}

O aluno autor da primeira conclusão do relatório 3 têm em seu primeiro parágrafo, transcrito abaixo, os indicadores de Seriação de informações, Classificação de informações, Raciocínio lógico, Justificativa e Explicação.

"O que aconteceu com uma papulaşãa bialógica apás a colonizacãa de individuas em um ambiente com condicäes adequadas foi que a populasäo cresceu bastante, pois as plantas estaram sempre fasenda fotassintese, estavam em um espace onde elas podiam se desenvelver muito bem. O tempo em alguns dias afudau elas crescerem, mas também teve um períado de temperatura 


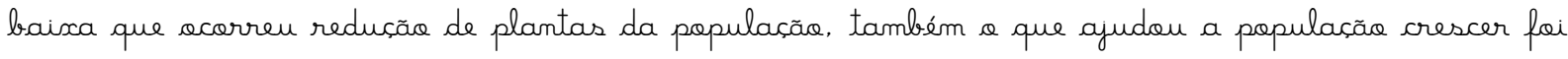
a terra que estava no fundo do "potinho" ande elas estavam, tinha muitas mutrientes."

Como abordado anteriormente, relacionado à dinâmica populacional, quando a variação da população é mencionada entendemos que os alunos estão listando dados e nesta décima sexta marca o aluno o faz quando afirma que -"cresceu"- ou -"reduça de plantas na populaçãe"-. Listar dados é indicio de Seriação de informações. A consideração acerca da intensidade do crescimento da população de Lemnas é entendida como uma Classificação de informações já que este indicador se caracteriza por estabelecer características aos dados.

O indicador de Raciocínio lógico é explicitado pela construção estruturada e coerente de suas idéias. A associação da temperatura com o crescimento pode ser apresentada como evidencia dessa construção estruturada de raciocínio, veja que o aluno diz que -“O tempe em alguns dias ajudau elas crescerem"- e que -"mas também teve um períado de temperatura baixa que ecorreu reduçãa de plantas da populaçãa"-. Estes não são apenas Justificativas para os fenômenos, mas explicitam uma coerência de raciocínio na medida em que há uma temperatura que -"ayuda"- as plantas a crescerem (fica subentendido tratar-se de uma temperatura mais alta) e uma temperatura que prejudica o crescimento -"temperatura mais baixa"-.

As Justificativas são várias, tanto as apresentadas acima para exemplificar o Raciocínio lógico como outras que tentam garantir afirmações -“também a que ajudau a populaçã crescer foi a terra que estava me funda do "potinho" onde elas estavam, tinha muitas mutrientes."-

O parágrafo dessa décima sexta marca pode ser entendido como uma interessante e completa Explicação. Esta Explicação tem como afirmativa central que a população de Lemnas cresceu bastante - "a populaçãe cresceu bastante”- e este é por conseguinte o explanandum, o fenômeno que precisa ser explicado, que precisa ter as possíveis causas que levaram ao seu desenrolar explicitadas. Os motivos que levaram o fenômeno (explanandum) a se dar como ele se deu, são por nós denominados explanans e aqui vários deles se somam "um ambiente com condicöes adequadas"-, " "pois as plantas estavam sempre fazendo fotassintese"-, "estavam em um espace onde elas podiam se desenvolver muito bem"-, -"O tempo em algurs dias afudau elas crescerem"-, " "também a que ajudou a populaçäe crescer foi a terra 
que estava no fundo do "potinho"- e "conde elas estavam, tinha muitas mutrientes"-. Todos estes explanans podem ser considerados, de acordo com Murcho (2003), premissas para a conclusão de uma Explicação, que é chamada por nós de explanandum, e de acordo com ele em uma Explicação estas premissas são menos plausíveis que a conclusão e aqui podemos entender que essas premissas são realmente menos plausíveis que a conclusão.

\section{Marca 17 (relatório 3):}

No segundo parágrafo da primeira conclusão do relatório 3 podemos verificar a presença de Seriação de informações, Justificativa e uma Explicação.

"Depois que as lemnas já estavam habituadas ace espacse, com a luz 24 horas direcionada para elas, a populaçãe foi ficando estável.".

A Seriação de informações se relaciona a afirmativa de que a população de Lemnas "foi ficando estável."-. A estabilidade é entendida como um dado e sua apresentação Seriação.

Uma Explicação surge, de acordo com Sasseron (2008) e Sasseron e Carvalho (2008), quando se intenta dar garantias para um fenômeno e estas são comumente acompanhadas de Justificativas. No caso o fenômeno é a estabilização da população de Lemnas e as Justificativas são a habituação ao espaço e a luminosidade. Nesta Explicação consideramos a estabilização da população como sendo o explanandum e os explanans a habituação ao espaço e a luminosidade e como estes são menos certos que o explanandum então trata-se de uma Explicação.

\section{Marca 18 (relatório 3):}

$\mathrm{Na}$ segunda conclusão escrita sobre o experimento do relatório 3 encontramos os indicadores de Seriação, Organização e Classificação de informações, Justificativa e Explicação.

"To inícia há um crescimenta significativse da populaçãe onde há bastante recursos, espacse para as individuos se desenvolverem. Mas apés a décima dia a papulasãa atinge a seu limite estabelecenda um númerce estável de lemnas. Com a luz fraca hauve um prejudicial para a crescimenta das lemnas." 
A Seriação de informações decorre da apresentação de dados acerca da variação populacional das Lemnas -"um crescimente significativoe"- e -"a populacão atinge es seu limite estabelecenda um número estável de lemnas"--. O indicador de Organização de informações se evidencia na separação das variações da população de Lemnas em dois diferentes momentos, ou seria, o aluno está organizando os dados, preparando os dados sobre o problema investigado. A Classificação de informações se dá quando o aluno estabelece características para estes dados que aqui acontece quando o aluno afirma que houve um -"crescimento significativo da papulaçäe"- (grifo nosso).

As Justificativas aparecem como tentativas de validação das afirmativas que caracterizam os dois momentos da população de Lemnas, lançadas na Organização das informações. Para o primeiro momento a Justificativa é que -"há bastante recursos, espace para as individuas se desenvolverem"- e o para o segundo momento - "a luz fraca hauve um prefudicial para o crescimento das lemnas"-.

Podemos entender que nesta conclusão o aluno apresenta duas Explicações, na primeira o explanandum é o -"crescimenta significativre"- e para a segunda é a estabilização da população de Lemnas. Os respectivos explanans são -"onde há bastante recursos, espacsos para as individuas se desenvolverem"- e -"Com a luz fraca houve um prejudicial para a crescimenta das lemnas"- . Ambos explanans são menos certos que seus explanandum sendo isso garantia de serem Explicações.

\section{Marca 19 (relatório 3):}

No primeiro parágrafo da terceira conclusão do relatório 3 encontramos indicadores de Seriação de informações, Raciocínio lógico, Justificativa e Explicação.

"Em uma populaçãa bialógica, apás a colonizacãa por alguns individuas em um ambiente com as condicães ideais para a desenvolvimento da espécie, acontecen um aumento na papulasãa das Lemnas. Hauve um crescimenta por conta do consume de luz."

O primeiro destes indicadores se vincula a afirmativa de que -"acenteceu um aumento ma populaçãa das Lemnas"- e esta afirmativa, dentro do espectro da dinâmica populacional, pode ser entendida como um dado, e listar dados esta relacionada à Seriação de informações. 
O Raciocínio lógico é evidenciado pela clareza com que o aluno estrutura as ideias apresentadas. As Justificativas dadas são para garantir a legitimidade ao fenômeno do aumento populacional das Lemnas -"em um ambiente com as condicães ideais para a desenvolvimenta da espécie"- e -"Hauve um crescimenta por conta do consuma de luz."-. A Explicação tem como conclusão, como explanandum, a ser aclarado o crescimento populacional, e os explanans com este fim são as justificativas anteriormente apresentadas.

\section{Marca 20 (relatório 3):}

No parágrafo transcrito abaixo, segundo parágrafo da terceira conclusão do relatório 3 , o aluno apresenta os indicadores de Alfabetização Científica de Seriação de informações, Raciocínio lógico, Justificativa, Previsão e Argumento.

"Cs lemnas precisam de luz e de calor para ocorrer a fotossintese Ctransformacãa de energia solar em energia quimica). Com isse a populasão aumenta, pois mos grupas que havia uma quantidade maior de luz a aumente da populacão foi maior e nos dias que a temperatura ambiente foi baixa, mal crescimento na populaçãe, isso implica ne consume de calor e luz!"

A Seriação ocorre quando os alunos apresentam dados da variação populacional das Lemnas -"a aumenta da populaçãa"- e -"mal crescimenta na papulaçãe"-.

O Raciocínio lógico pode, assim como em relação a marca 19, ser aferido pela estruturação clara das ideias deste aluno.

A Justificativa se encontra na relação estabelecida de que dado que as Lemnas fazem fotossíntese e essa é favorecida pela alta luminosidade e temperatura, o aumento populacional, afirmativa a ser justificada, ocorreu quando - "havia uma quantidade maior de luz a aumenta da populaçãa foi maior"-. A Justificativa também aparece para o fenômeno do "mal crescimento na populaçãe"- que se dá quando a "“temperatura foi baixa"-.

Acreditamos encontrar aqui o seguinte Argumento:

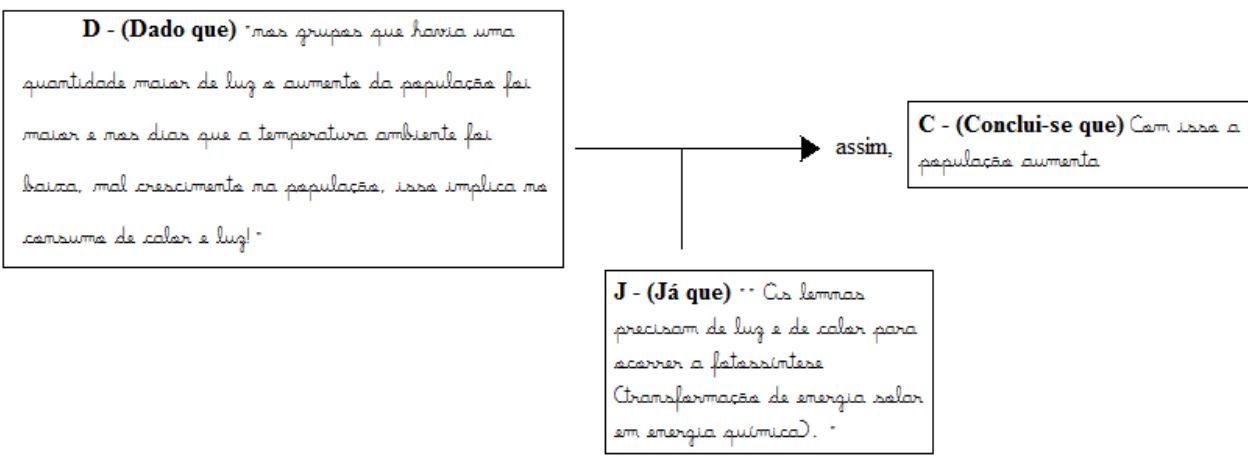


Entendemos que trata-se de um Argumento pois aqui o aluno não está se referindo apenas a população estudada quando diz que sob certas condições a população aumenta, aqui ele está fazendo uma generalização e dizendo que sob certas condições uma população de Lemnas sempre vai aumentar. Como isso é menos certo, menos garantido, que os dados amostrais do experimento ou o apoio da literatura, premissas para a Conclusão (C), temos aqui um Argumento. Neste os Dados (D) advêm do experimento e a Justificativa (J) da literatura.

Acreditamos que o aluno lançou mão aqui de uma Previsão, pois como discutido anteriormente a afirmação - "Com isse a populaçãa aumenta" - não se refere unicamente a população estudada, mas a idéia de que se as condições se repetirem, qualquer população de Lemnas irá crescer.

\subsection{Sistematização dos dados}

Neste capitulo são reunidos e tratados, em tabelas e gráficos, os dados obtidos de todos os relatórios e conclusões individuais, tanto os apresentados anteriormente como exemplo, como os que se encontram nos apêndices. Esse tratamento dos dados foi primordial para observar padrões nas distribuições dos indicadores de AC, Explicações e Argumentos, para dar uma visão global, para responder as questões de pesquisa, como base para fazer inferências.

A primeira tabela (Tabela 1) visa apresentar os dados reunidos das análises descritivas de todos os relatórios, não apenas daqueles que foram apresentados no item 6.1, como também dos demais que foram analisados e que estão dispostos nos apêndices. Essa tabela serve como um resumo das análises descritivas e permite inferências sobre se a Alfabetização Científica (AC) está em processo, quais os indicadores mais recorrentes, qual a porcentagem relativa de cada indicador, quais os relatórios que apresentam mais indicadores e outras conjecturas que serão discutidas nos próximos capítulos. Vale ressaltar que esta tabela não apresenta os dados referentes às conclusões individuais.

$\mathrm{Na}$ primeira coluna os relatórios estão identificados com um número seguido do ano correspondente; as demais colunas marcam o número de vezes em que cada indicador de Alfabetização Científica foi identificado em cada relatório, sendo que a última coluna marca o total de indicadores de AC por relatório. 
Thiago Marinho Del Corso

INDICADORES DE ALFABETIZAÇÃO CIENTÍFICA, ARGUMENTOS E EXPLICAÇÕES -

Análise de Relatórios no Contexto de uma Sequência de Ensino Investigativo

Tabela 1: Quantidade de indicadores de AC encontrados em cada relatório.

\begin{tabular}{|c|c|c|c|c|c|c|c|c|c|c|c|c|c|}
\hline Relatório & $\mathbf{L M}$ & SI & OI & CI & $\mathbf{R L}$ & $\mathbf{R P}$ & LH & TH & $\mathbf{J}$ & $\mathbf{P}$ & Expl & Arg & Total \\
\hline Relatório 12012 & 0 & 4 & 3 & 2 & 1 & 1 & 1 & 1 & 1 & 0 & 0 & 1 & 15 \\
\hline Relatório 22012 & 0 & 4 & 3 & 1 & 1 & 0 & 1 & 0 & 2 & 1 & 1 & 1 & 15 \\
\hline Relatório 32012 & 1 & 6 & 9 & 5 & 4 & 1 & 1 & 0 & 5 & 0 & 3 & 1 & 36 \\
\hline Relatório 42012 & 1 & 7 & 8 & 6 & 3 & 0 & 1 & 0 & 5 & 1 & 3 & 1 & 36 \\
\hline Relatório 52012 & 2 & 5 & 3 & 2 & 2 & 1 & 1 & 0 & 4 & 0 & 2 & 1 & 23 \\
\hline Relatório 62012 & 1 & 4 & 3 & 2 & 1 & 0 & 1 & 0 & 1 & 0 & 1 & 0 & 14 \\
\hline Relatório 72012 & 1 & 4 & 5 & 3 & 0 & 1 & 1 & 0 & 2 & 0 & 2 & 0 & 19 \\
\hline Relatório 82012 & 2 & 4 & 5 & 1 & 1 & 1 & 0 & 0 & 3 & 0 & 0 & 3 & 20 \\
\hline Relatório 92012 & 0 & 2 & 3 & 2 & 0 & 1 & 0 & 0 & 1 & 0 & 1 & 0 & 10 \\
\hline Relatório 102012 & 0 & 2 & 2 & 0 & 0 & 1 & 0 & 0 & 1 & 0 & 0 & 0 & 6 \\
\hline Relatório 112012 & 0 & 2 & 3 & 1 & 0 & 1 & 0 & 0 & 1 & 0 & 1 & 0 & 9 \\
\hline Relatório 12013 & 1 & 4 & 2 & 2 & 0 & 0 & 0 & 0 & 3 & 0 & 2 & 0 & 14 \\
\hline Relatório 22013 & 1 & 6 & 7 & 4 & 0 & 1 & 1 & 0 & 4 & 0 & 3 & 3 & 30 \\
\hline Relatório 32013 & 1 & 10 & 11 & 7 & 0 & 0 & 0 & 0 & 5 & 0 & 5 & 0 & 39 \\
\hline Relatório 42013 & 1 & 2 & 3 & 2 & 0 & 0 & 1 & 0 & 1 & 0 & 0 & 1 & 11 \\
\hline Relatório 52013 & 2 & 3 & 2 & 3 & 0 & 0 & 2 & 0 & 1 & 0 & 0 & 1 & 14 \\
\hline Relatório 62013 & 2 & 5 & 8 & 3 & 0 & 0 & 1 & 0 & 1 & 0 & 1 & 0 & 21 \\
\hline Relatório 72013 & 4 & 9 & 12 & 5 & 1 & 0 & 2 & 1 & 1 & 0 & 0 & 1 & 36 \\
\hline Relatório 82013 & 1 & 6 & 5 & 3 & 0 & 0 & 0 & 0 & 1 & 0 & 2 & 0 & 18 \\
\hline Relatório 92013 & 1 & 5 & 5 & 1 & 1 & 0 & 1 & 0 & 2 & 1 & 2 & 1 & 20 \\
\hline Relatório 102013 & 2 & 2 & 4 & 2 & 2 & 0 & 0 & 0 & 1 & 0 & 0 & 0 & 13 \\
\hline Relatório 112013 & 2 & 5 & 5 & 2 & 1 & 0 & 0 & 0 & 1 & 0 & 1 & 0 & 17 \\
\hline Relatório 122013 & 2 & 4 & 4 & 5 & 0 & 0 & 0 & 0 & 2 & 0 & 1 & 0 & 18 \\
\hline Relatório 132013 & 1 & 3 & 4 & 2 & 0 & 0 & 2 & 1 & 3 & 2 & 1 & 1 & 20 \\
\hline Relatório 142013 & 2 & 4 & 8 & 4 & 2 & 1 & 0 & 0 & 5 & 0 & 3 & 1 & 30 \\
\hline Relatório 152013 & 2 & 5 & 4 & 2 & 0 & 0 & 2 & 0 & 3 & 1 & 0 & 3 & 22 \\
\hline Relatório 162013 & 2 & 2 & 5 & 1 & 0 & 0 & 0 & 0 & 2 & 0 & 0 & 0 & 12 \\
\hline Relatório 172013 & 1 & 5 & 4 & 2 & 0 & 0 & 0 & 0 & 2 & 0 & 0 & 1 & 15 \\
\hline Relatório 182013 & 1 & 3 & 6 & 2 & 0 & 0 & 0 & 0 & 1 & 0 & 0 & 1 & 14 \\
\hline Total & 37 & 127 & 146 & 77 & 20 & 10 & 19 & 3 & 65 & 6 & 35 & 22 & 567 \\
\hline$\%$ representativa & 6,526 & 22,4 & 25,75 & 13,58 & 3,527 & 1,764 & 3,351 & 0,529 & 11,46 & 1,058 & 6,173 & 3,88 & 100 \\
\hline total 2013 & 29 & 83 & 99 & 52 & 7 & 2 & 12 & 2 & 39 & 4 & 21 & 14 & 364 \\
\hline total 2012 & 8 & 44 & 47 & 25 & 13 & 8 & 7 & 1 & 26 & 2 & 14 & 8 & 203 \\
\hline
\end{tabular}

Legenda: LM - Listagem de materiais, SI - Seriação de informações, OI - Organização de informações, CI - Classificação de informações, RL - Raciocínio lógico, RP - Raciocínio Proporcional, LH - Levantamento de hipóteses, TH - Teste de hipóteses, J - Justificativa, P - Previsão, Expl - Explicação, Arg - Argumento

A Tabela 2 apresenta a quantidade de cada tipo de indicador encontrado na soma das conclusões individuais referentes a cada relatório. Esses dados permitem uma visão abrangente da distribuição dos indicadores de AC nessas conclusões individuais e dessa tabela 
derivaram os gráficos comparando os indicadores encontrados em relatórios e conclusões individuais. Aqui podemos discernir quais indicadores se fazem mais amplamente presentes, ou ausentes, quais as porcentagens relativas desses indicadores nas conclusões individuais e outras diversas conjecturas que serão discutidas no capitulo seguinte.

Na tabela 2 são reunidos os dados obtidos após a análise descritiva de todas as conclusões individuais; vale relembrar que apenas os relatórios de 2013 apresentavam conclusões individuais, logo, compunham, um corpus de 52 conclusões, mesmo havendo 18 relatórios em 2013. Na primeira coluna da tabela são apontados os relatórios dos quais derivam as conclusões, identificados com um número seguido do ano correspondente; as demais colunas marcam o número de vezes em que cada indicador de Alfabetização Científica foi identificado na soma das conclusões referentes a esse relatório, sendo que a última coluna marca o total de indicadores de AC nas conclusões referentes a cada relatório. Apenas vale ressaltar que as comparações do número de vezes que cada indicador aparece não é uma comparação imediatamente válida, já que pode haver 2,3 ou 4 conclusões individuais referentes a cada relatório; não há um número fixo de conclusões por relatório.

Tabela 2: Quantidade de indicadores de AC encontrados nas conclusões individuais referentes a cada relatório

\begin{tabular}{|l|rrrrrrrrrrrrr}
\hline $\begin{array}{l}\text { Conclusões } \\
\text { individuais }\end{array}$ & LM & SI & OI & CI & RL & RP & LH & TH & J & P & Expl & Arg & Total \\
\hline Relatório 1 2013 & 0 & 5 & 4 & 1 & 0 & 0 & 0 & 0 & 3 & 0 & 2 & 0 & 15 \\
Relatório 2 2013 & 0 & 5 & 3 & 4 & 1 & 0 & 0 & 0 & 4 & 1 & 4 & 1 & 23 \\
Relatório 3 2013 & 0 & 5 & 2 & 2 & 0 & 0 & 0 & 0 & 5 & 1 & 4 & 1 & 20 \\
Relatório 4 2013 & 0 & 4 & 1 & 2 & 2 & 0 & 1 & 1 & 4 & 1 & 0 & 4 & 20 \\
Relatório 5 2013 & 0 & 3 & 0 & 1 & 0 & 0 & 1 & 0 & 2 & 2 & 0 & 0 & 9 \\
Relatório 6 2013 & 0 & 2 & 2 & 1 & 1 & 0 & 0 & 0 & 2 & 0 & 2 & 0 & 10 \\
Relatório 7 2013 & 0 & 5 & 2 & 3 & 1 & 3 & 1 & 0 & 5 & 4 & 0 & 3 & 27 \\
Relatório 8 2013 & 0 & 3 & 0 & 2 & 0 & 0 & 4 & 1 & 4 & 1 & 2 & 1 & 18 \\
Relatório 9 2013 & 0 & 6 & 0 & 3 & 0 & 0 & 4 & 0 & 7 & 5 & 0 & 2 & 27 \\
Relatório 10 2013 & 0 & 5 & 2 & 3 & 2 & 0 & 0 & 0 & 4 & 3 & 1 & 4 & 24 \\
Relatório 11 2013 & 0 & 2 & 2 & 1 & 2 & 0 & 0 & 0 & 4 & 4 & 0 & 4 & 19 \\
Relatório 12 2013 & 0 & 4 & 3 & 4 & 0 & 0 & 1 & 0 & 5 & 2 & 1 & 2 & 22 \\
Relatório 13 2013 & 0 & 5 & 2 & 3 & 1 & 0 & 2 & 0 & 6 & 7 & 0 & 4 & 30 \\
Relatório 14 2013 & 0 & 5 & 3 & 4 & 1 & 0 & 0 & 0 & 6 & 3 & 0 & 3 & 25 \\
Relatório 15 2013 & 0 & 5 & 0 & 1 & 0 & 0 & 2 & 0 & 3 & 5 & 1 & 4 & 21 \\
Relatório 16 2013 & 0 & 1 & 1 & 1 & 0 & 0 & 1 & 0 & 2 & 2 & 1 & 2 & 11 \\
Relatório 17 2013 & 0 & 5 & 0 & 4 & 0 & 0 & 1 & 1 & 3 & 2 & 2 & 3 & 21 \\
Relatório 18 2013 & 0 & 6 & 5 & 4 & 0 & 0 & 1 & 0 & 4 & 3 & 1 & 1 & 25 \\
Total & 0 & 76 & 32 & 44 & 11 & 3 & 19 & 3 & 73 & 46 & 21 & 39 & 367 \\
\% representativa & & & & & & & & & & & & \\
dos indicadores & 0 & 20,71 & 8,71 & 11,9 & 2,99 & 0,81 & 5,17 & 0,81 & 19,8 & 12,5 & 5,72 & 10,6 & 100 \\
& & & & & & & & & & &
\end{tabular}


Legenda: LM - Listagem de materiais, SI - Seriação de informações, OI - Organização de informações, CI - Classificação de informações, RL - Raciocínio lógico, RP - Raciocínio Proporcional, LH - Levantamento de hipóteses, TH - Teste de hipóteses, J - Justificativa, P Previsão, Expl - Explicação, Arg - Argumento

Das Tabelas 1 e 2 anteriores derivaram alguns gráficos que serão em seguida apresentados, acreditamos que esses favorecem e lançam luz sobre determinados aspectos os quais queremos ressaltar. Esse tratamento dos dados evidencia aspectos importantes dos resultados e, por conseguinte favorece o entendimento dos resultados e a resposta as questões de pesquisa.

O primeiro gráfico (Gráfico 1) apresenta a soma de todos os tipos de indicador presentes em cada relatório. Isso permite uma percepção de que há relatórios com muito mais indicadores de AC que outros, esses podem ser relatórios produzidos em 2013 (relatórios 2,3 e 7), mas também há relatórios produzidos em 2012 (relatórios 3 e 4) com muitos indicadores. O mesmo ocorre para relatórios com poucos indicadores: alguns deles são de 2013 (4, 10 e 16), outros 2012 (9, 10 e 11). Ou seja, esse gráfico, permite a percepção de que a variação da quantidade de indicadores em cada relatório não está diretamente atrelada ao ano de produção.

Gráfico 1: Quantidade de indicadores de AC presentes em cada relatório, sem considerar as conclusões individuais.

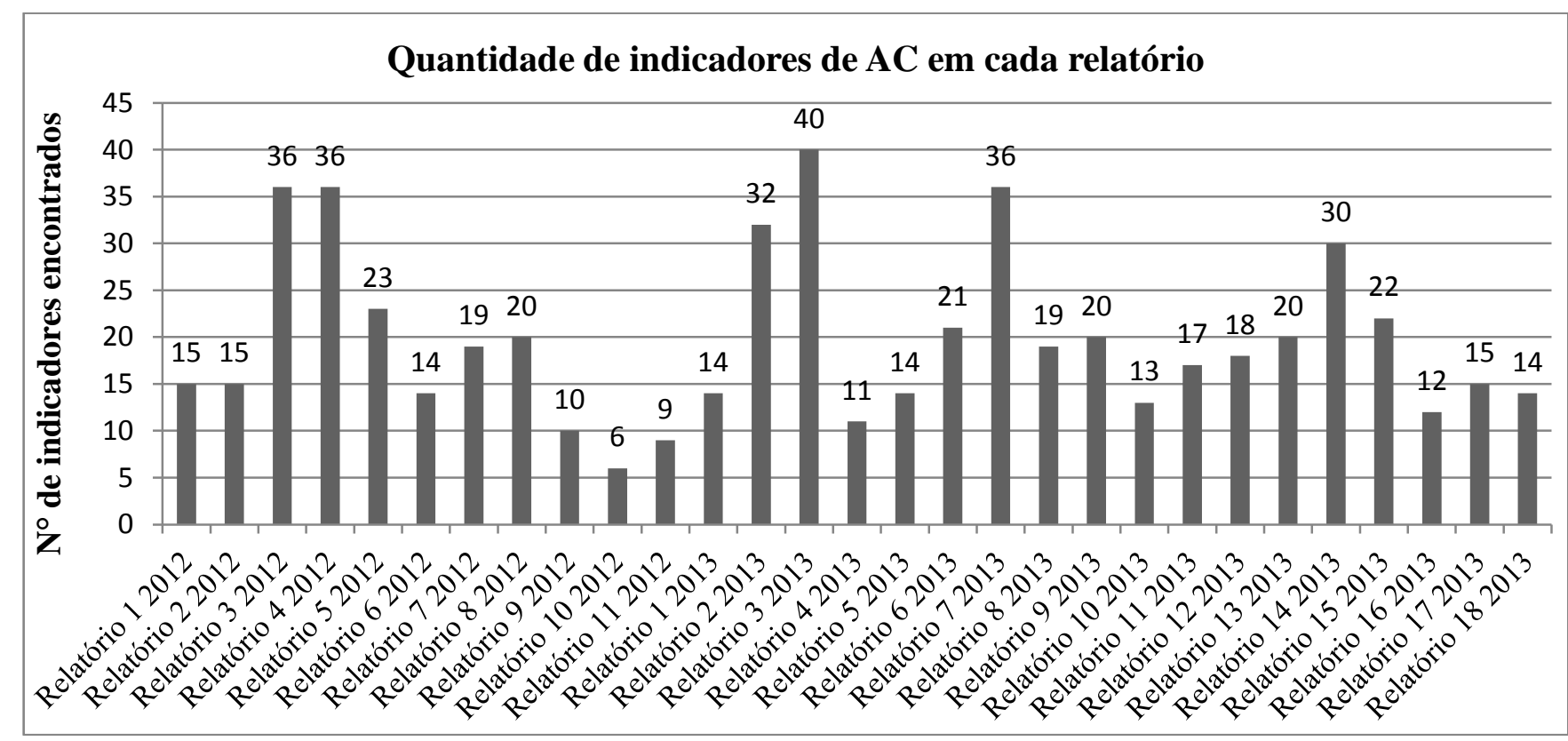

Esse segundo gráfico (Gráfico 2) apresenta a quantidade de cada tipo de indicador considerando os 29 relatórios. Com esse gráfico podemos ver quais são os indicadores de AC mais frequentes e disso fazer conjecturas acerca da natureza da SEI da qual derivaram os 
relatórios. Podemos ver nesse gráfico uma grande quantidade dos indicadores apontados como relacionados ao trabalho com dados, Seriação de informações, Organização de informações e Classificação de informações. O grande número desses indicadores nos permite inferir que uma atenção especial foi destinada à coleta e tratamento dos dados. $\mathrm{O}$ grande número de Justificativas nos permite inferir que um grande número de afirmativas com garantias é feita. Também podemos ver que o número de Levantamento de hipóteses é muito superior ao número de Teste de hipóteses, ou seja, muitas hipóteses estão sendo levantadas sem ser testadas.

Gráfico 2: Quantidades de cada tipo de indicador encontrados nos relatórios somados de 2012 e 2013

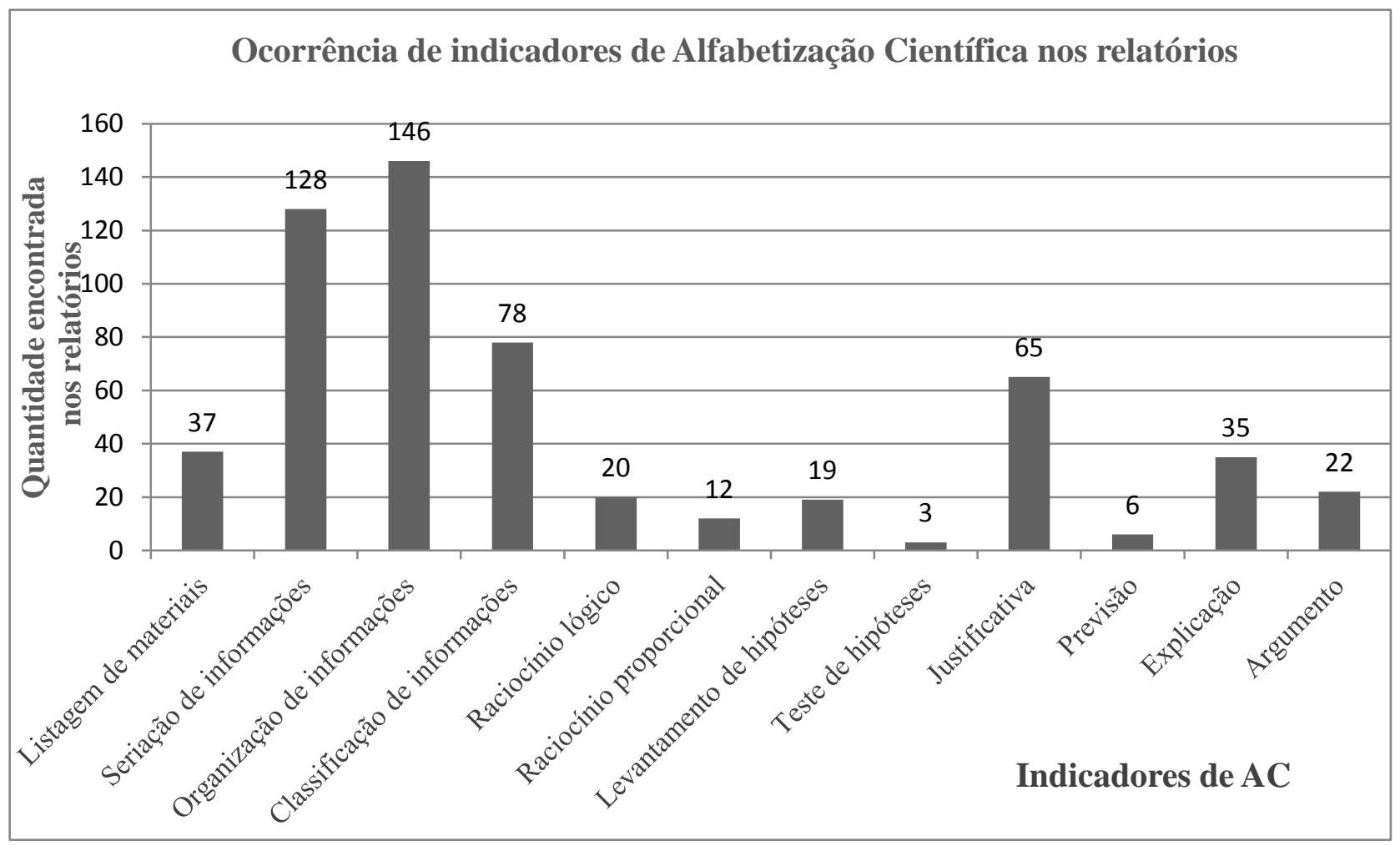

O terceiro gráfico (Gráfico 3) construído visa permitir a comparação entre os tipos mais frequentes de indicadores de $\mathrm{AC}$ nos relatórios e nas conclusões individuais. Para permitir comparações esse gráfico foi construído a partir da porcentagem relativa de cada indicador, isso já que a quantidade de conclusões individuais não é a mesma para cada relatório - há relatórios dos quais derivaram duas conclusões, outros três e alguns quatro. Também porque o número total de conclusões individuais é superior ao de relatórios - 52 conclusões individuais e 29 relatórios. 
As porcentagens nos permitem destacar, por exemplo, que a frequência de Seriação de informações é muito pouco diferente nos relatórios e nas conclusões individuais, enquanto que a frequência de Organização de informações é mais de duas vezes a meia superior, mesmo ambos os indicadores se relacionando ao trabalho com os dados. Ambos os tipos de raciocínio (Raciocínio lógico e Raciocínio proporcional) são pouco frequentes, não havendo grande variação entre relatórios e conclusões individuais. Outro aspecto é que a frequência de Levantamento e Teste de hipóteses também pouco varia, já a quantidade de Justificativas praticamente dobra. A frequência de Explicações é praticamente a mesma em relatórios e conclusões individuais, enquanto que Argumentos são quase três vezes mais frequentes nas conclusões individuais. Por último, apontamos que a Listagem de materiais apresenta frequência significativa nos relatórios, mas não aparece nas conclusões individuais.

Gráfico 3: Porcentagem de ocorrência de cada tipo de indicador em relação aos outros. Em vermelho as frequências relativas nos relatórios e em azul nas conclusões individuais.

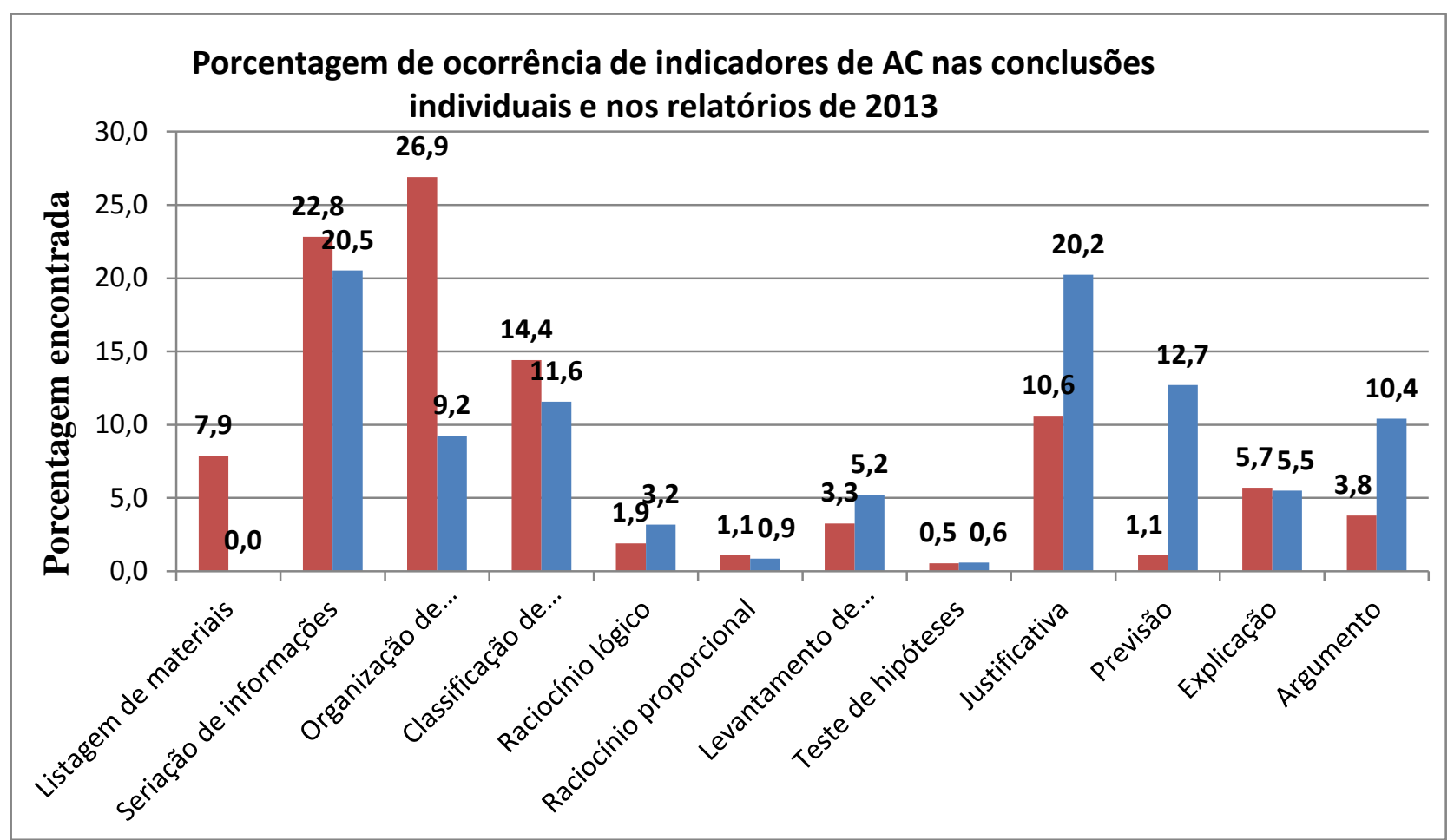

Porcentagem de ocorrência de indicadores de AC nos relatórios 2013

Porcentagem de ocorrência de indicadores de AC nas conclusões individuais

No tópico 5.1.1 são apresentados agrupamentos de indicadores, onde o grupo 1 contem os indicadores relacionados ao trabalho com os dados obtidos, o grupo 2 com a estruturação do pensamento e o grupo 3 com o entendimento da situação analisada. O Gráfico 4 abaixo, apresenta as comparação das somas dos indicadores de cada grupo, primeiramente 
considerando os relatórios de 2012 e 2013, depois apenas os relatórios de 2013, em seguida os de 2012 e por último nas conclusões individuais. Esse gráfico não permite comparações em relação aos números absolutos de cada grupo nos quatro conjuntos (Relatórios $2012+2013$; Relatórios 2013; Relatórios 2012; Conclusões individuais), porque o número de relatórios em 2012 e 2013 é diferente, além de as conclusões individuais terem sido confeccionadas apenas para os relatórios de 2013 e serem em número bem superior ao de relatórios.

O Gráfico 4 permite observar o padrão de distribuição desses grupos de indicadores. É possível observar que para os relatórios, independente de se considerar ambos os anos juntos, apenas 2012 ou apenas 2013, o grupo 1 de indicadores é o mais frequente, o grupo 3 em segundo lugar e o grupo 2 o menos frequente. Já nas conclusões individuais ocorre a inversão de posição entre o grupo 3 e o grupo 1, mas a freqüência do grupo 2 continua menor.

Gráfico 4: Quantidades de indicadores encontradas em cada um dos grupos de indicadores. São três grupos: Grupo 1 que contêm os indicadores de Listagem de materiais, Seriação de informações, Organização de informações e Classificação de informações; Grupo 2 que abrange os indicadores de Raciocínio lógico e Raciocínio proporcional; Grupo 3 com Levantamento de hipóteses, Teste de hipóteses, Justificativa, Previsão, Explicação e Argumento.

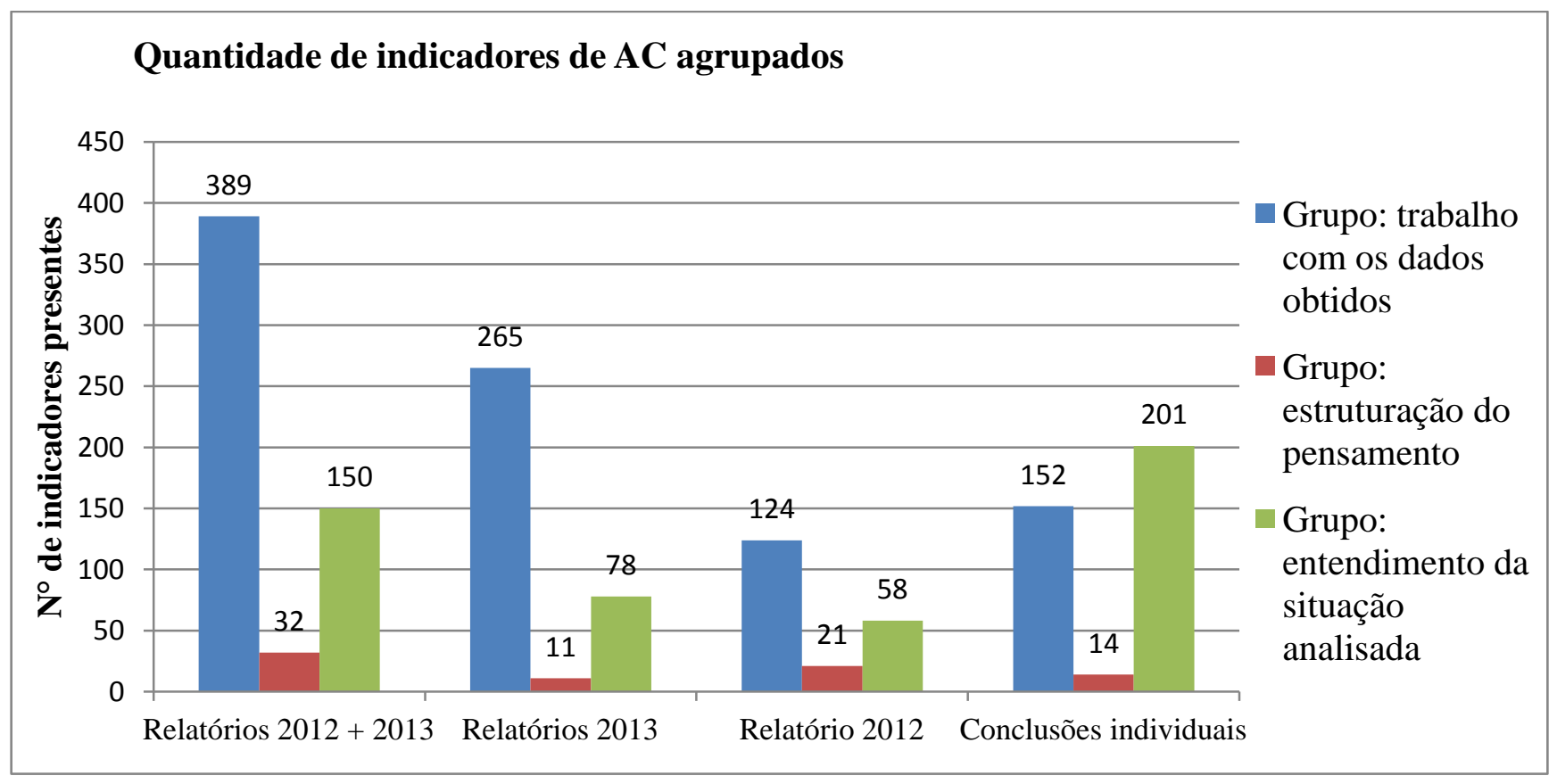

Nosso quinto gráfico (Gráfico 5) se presta a apontar quais indicadores de $\mathrm{AC}$ estão ou não presentes em cada relatório, não importando se estes indicadores aparecem uma ou muitas vezes. Desse gráfico podemos tirar que os indicadores de Seriação de informações, 
Organização de informações e Justificativa estão presentes em todos os relatórios e é interessante notar que apesar de a quantidade de Justificativas ser menor (encontrada 65 vezes nos relatórios) em comparação com Seriação de informações (128 aparições) e Organização de informações (146), ela também está presente em todos os relatórios. Podemos verificar também que a Classificação de informações, outro indicador relacionado ao trabalho com os dados, só não está presente em um relatório, no relatório 10 de 2012. Outro ponto a salientar é que 8 dos 12 indicadores estão presente em mais da metade dos relatórios, o que nos permite dizer que os relatórios apresentam uma ampla variedade de indicadores e consecutivamente que a SEI não estimulou um tipo específico de indicador. 
Gráfico 5: Presença de cada indicador nos diferentes relatórios, independente da frequência.

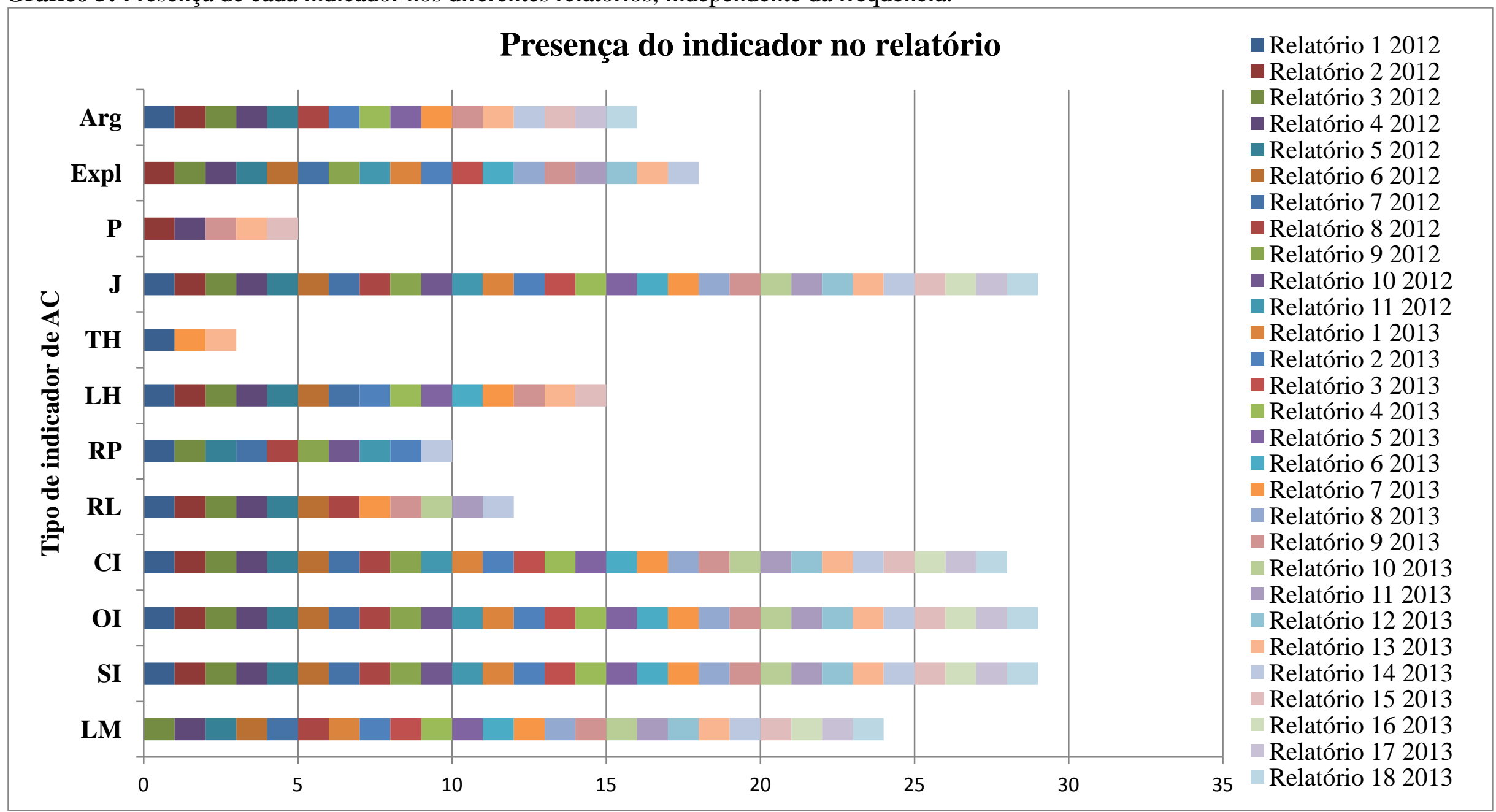

Legenda: LM - Listagem de materiais, SI - Seriação de informações, OI - Organização de informações, CI - Classificação de informações, RL Raciocínio lógico, RP - Raciocínio Proporcional, LH - Levantamento de hipóteses, TH - Teste de hipóteses, J - Justificativa, P - Previsão, Expl Explicação, Arg - Argumento. 


\section{Resposta às questões de pesquisa}

\subsection{Explicações e Argumentos}

A primeira de nossas questões de pesquisa se refere à polêmica questão levantada pelo artigo de Osborne e Patterson publicado em 2011, que teve reflexos nas produções nacionais e internacionais, e que apontava a necessidade de diferenciarem-se Argumentos de Explicações na área de ensino de Ciências. A resposta a esta questão foi a proposição de uma metodologia de desambiguação. Para chegar a isso, partimos de referenciais teóricos e nos engajamos no movimento de fazer a distinção entre Argumento e Explicações, e voltar aos referenciais teóricos e destes às produções analisadas vezes o suficiente para compor a metodologia que pudesse servir nas mais diferentes situações. Acreditamos por isso que essa metodologia poderá ser útil para distinguir Argumentos e Explicações em outros contextos.

A aplicação dessa metodologia de desambiguação nos permitiu identificar em 29 relatórios, 35 Explicações e 22 Argumentos; se considerarmos apenas os relatórios de 2013 teremos então 21 Explicações e 14 Argumentos. Nas 52 conclusões individuais que foram produzidas apenas no ano de 2013, verificou-se a presença de 40 Argumentos e 21 Explicações. O número de Explicações é maior que o de Argumentos nos relatórios e, nas conclusões individuais isso se inverte. Por que isso acontece? Por que temos uma quantidade maior de Explicações do que de Argumentos nos relatórios e uma quantidade maior de Argumentos do que de Explicações nas conclusões individuais?

Diversos são os fatores que podem ter influenciado essa diferença na relação entre a quantidade de Explicações e Argumentos nos relatórios e nas conclusões individuais; mas nossa aposta é que as comandas geradoras de relatórios e conclusões individuais podem ter tido grande influência. Para produzir os relatórios os alunos receberam a seguinte comanda: "O que acontece com uma população biológica após a colonização por alguns indivíduos de um ambiente com as condições ideais para desenvolvimento da espécie?". A comanda para a confecção das conclusões individuais foi: "Sabendo que a conclusão do relatório científico consiste na resposta à pergunta inicial, justificada com evidências (dados produzidos durante a investigação), conclua seu relatório.". Nosso trabalho não se debruçou sobre as ações pró-argumentação, então 
Thiago Marinho Del Corso

INDICADORES DE ALFABETIZAÇÃO CIENTÍFICA, ARGUMENTOS E EXPLICAÇÕES -

Análise de Relatórios no Contexto de uma Sequência de Ensino Investigativo

não vamos nos arriscar a aprofundar estas conjecturas, além de rememorar preceitos do ensino por investigação que se relacionam com o "Como o aluno constrói conhecimento?' desenvolvidos no trabalho de Carvalho (2011) acerca das Sequências de Ensino Investigativo (SEIs).

Carvalho (2011) a partir de referenciais sócio-interacionistas propõe 8 pontos que orientam as SEIs. O primeiro deles se refere à "participação ativa do estudante" e não entendemos como esta participação pode ter sido diferente na elaboração dos relatórios e das conclusões individuais de modo a gerar as diferentes relações entre Explicações e Argumentos produzidos em cada uma destas etapas.

O segundo ponto discorre sobre a "importância da interação aluno-aluno" e aqui são valorizadas essas interações, as quais poderiam ocasionar as diferentes relações de produção de Explicações e Argumentos, já que os relatórios foram confeccionados coletivamente e as conclusões individuais individualmente, mas quando se observa a porcentagem relativa desses indicadores (Gráfico 3) temos que as Explicações correspondem a 5,7\% e 5,5\%, dos indicadores apresentados respectivamente nos relatórios e nas conclusões individuais e os Argumentos 3,8\% e 10,4\%, também respectivamente a relatórios e conclusões individuais. Ou seja, a porcentagem de Explicações se mantém quase igual, enquanto que frequência de Argumentos praticamente triplica entre as porcentagens produzidas nos relatórios e nas conclusões individuais. Parece-nos que se a confecção em grupo dos relatórios tivesse uma relação direta como ação que estimulasse a produção de Argumentos, não haveria um aumento relativo de Argumentos nas conclusões individuais, mas a relação entre Explicações e Argumentos se manteria ou a porcentagem de Argumentos diminuiria quando os alunos estivessem sozinhos e não mais em grupo.

Um terceiro ponto trazido por Carvalho (2011) se refere à "criação de um ambiente encorajador" e o ambiente para confecção dos relatórios e das conclusões individuais foi o mesmo, a sala de aula, logo não podemos fazer uma correlação direta desse ponto com as diferentes quantidades relativas de Explicações e Argumentos.

Um quarto ponto tratado por Carvalho (2011) se refere à valorização do "ensino $a$ partir do conhecimento que o aluno traz para a sala de aula" e novamente não pensamos haver diferença nessa valorização quando os alunos estão confeccionando os 
Thiago Marinho Del Corso

INDICADORES DE ALFABETIZAÇÃO CIENTÍFICA, ARGUMENTOS E EXPLICAÇÕES -

Análise de Relatórios no Contexto de uma Sequência de Ensino Investigativo

relatórios e as conclusões individuais já que ambos são partes de uma mesma SEI. A

mesma inferência se dá quando é considerado um quinto ponto orientador das SEIs que é "o conteúdo (problema) tem que ser significativo para o aluno", uma vez que o problema central da sequência é único - dinâmica populacional.

Este raciocínio de equiparação entre os momentos de confecção dos relatórios e das conclusões individuais pode ser considerado para outros dois pontos orientadores das SEIs "a relação ciência, tecnologia e sociedade" e "a passagem da linguagem cotidiana para a linguagem científica" e dessa forma a relação mais Explicações do que Argumentos nos relatórios e mais Argumento do que Explicações nas conclusões individuais não poderia ser diretamente correlacionada a esses pontos da SEI. Mas então o que causaria essas diferenças?

Um último ponto se refere ao "papel do professor como elaborador de questões" e aqui reside nossa aposta para haver uma quantidade maior de Explicações nos relatórios (35) do que nas conclusões individuais (21) enquanto que Argumentos são mais numerosos nas conclusões individuais (39) do que nos relatórios (22). Carvalho discorre que o professor precisa elaborar questões que dirijam o raciocínio do aluno e trazemos novamente as questões formuladas pela professora para conjecturar sobre o que pode ter influenciado esta diferença na quantidade relativa de Explicações e Argumentos.

A questão geradora dos relatórios foi: "O que acontece com uma população biológica após a colonização por alguns indivíduos de um ambiente com as condições ideais para desenvolvimento da espécie?". Interpretamos que essa questão geradora pede mais o estabelecimento de uma relação causal que explique porque o fenômeno se deu da forma como ele se deu e assim as Explicações apareceriam mais que os Argumentos. Isso também pois, o fenômeno a ser explicado, o explanandum, foi obtido experimentalmente e era requerido dos alunos que apresentassem os motivos para esse fenômeno ter se dado como se deu, e esses motivos, explanans, eram dessa forma menos plausíveis que o explanandum, o que caracteriza uma Explicação. Some a isso o fato de haver um modelo teórico de crescimento populacional esperado e que como esse modelo foi apresentado em aula pela professora, ele é tratado como incontestável, logo os resultados que estiverem dentro do esperado pelo modelo dado em aula tornam-se certos e assim não é necessário defende-los (característica do Argumento), mas sim 
Thiago Marinho Del Corso

INDICADORES DE ALFABETIZAÇÃO CIENTÍFICA, ARGUMENTOS E EXPLICAÇÕES -

Análise de Relatórios no Contexto de uma Sequência de Ensino Investigativo

estabelecer as relações causais que levaram a eles (característica das Explicações).

Desta forma acreditamos que os Argumentos podem aparecer quando nos relatórios quando os dados divergem do modelo teórico esperado, apresentado pela professora, pois nesses casos os alunos teriam que defender motivos pelos quais o fenômeno divergiu do esperado.

A pergunta geradora das conclusões individuais foi: "Sabendo que a conclusão do relatório científico consiste na resposta à pergunta inicial, justificada com evidências (dados produzidos durante a investigação), conclua seu relatório.”. Interpretamos que esta questão pede um posicionamento dos alunos, pede que eles defendam os resultados obtidos, justificando com evidências, e não apenas descrevam o fenômeno e suas relações causais. Dessa forma os Argumentos são grandemente fomentados, já que defender conclusões é característico desses e que um Argumento é uma afirmação onde as premissas são declaradas para provar ou justificar uma Conclusão (C) e os Dados (D) reforçam as evidências para a validade da alegação (OSBORNE e PATTERSON, 2011).

A diferença na quantidade relativa de Explicações e Argumentos em diferentes etapas da SEI reforça nosso posicionamento por defender a diferenciação destes dois elementos, e nossa metodologia de desambiguação. Berland e McNeill (2012) em seu artigo resposta a Osborne e Patterson (2011) salientam a importância de ambas as práticas, mas contestam a necessidade de se diferenciar Argumentação e Explicação. As autoras e afirmam que: 1) a diferenciação resultaria em professores pedindo a construção, primeiro de Explicações e depois de Argumentos, de uma forma algorítmica e que desta forma não estariam respeitando um ponto comum para estas autoras e Osborne e Patterson, que é a sinergia existente entre essas duas práticas que se suportariam mutuamente; 2) ao explicitamente diferenciar essas práticas pode-se prejudicar o engajamento dos estudantes e estes podem acabar fazendo pseudoargumentações por hábito; 3) sugerem que a compreensão dos alunos sobre investigação em Ciências é fortalecida por um foco no panorama geral, em vez de facetas individuais dentro dele e, por conseguinte, diferenciar seria contraproducente. Por tais motivos as autoras postulam que as práticas escolares não deveriam replicar as diferenças filosóficas entre Argumentação e Explicação, apesar de reconhecer as diferenças entre ambas as práticas. 
Thiago Marinho Del Corso

INDICADORES DE ALFABETIZAÇÃO CIENTÍFICA, ARGUMENTOS E EXPLICAÇÕES -

Análise de Relatórios no Contexto de uma Sequência de Ensino Investigativo

O que acreditamos é que a desambiguação entre Argumento e Explicação deva

acontecer na pesquisa em ensino de Ciências, na produção dos materiais e na formação dos professores, mas não explicitamente para os alunos, já que aqui concordamos com Berland e Mcneill (2011) que a explicitação pode restringir o engajamento e a autenticidade nos alunos. Mas então por que desambiguar nessas esferas? Acreditamos que existam características das práticas que estimulem mais uma coisa que a outra e que ambas devam compor a gama de estratégias didáticas. Não que elas não possam ocorrer sem essa diferenciação, mas como mostram nossos dados, as questões formuladas pelos professores podem fomentar uma prática mais que a outra, e como concordam os autores citados (Berland, McNeill, Osborne e Patterson) Explicações não são mais importantes que Argumentos e nem o contrário e são sim coisas diferentes.

\subsection{Indicadores de Alfabetização Científica (AC)}

Nossa segunda questão de pesquisa aborda a Alfabetização Científica e quais indicadores podem ser encontrados nas produções escritas, após as SEIs, que sirvam como evidências de que esse processo está ocorrendo. Foram encontrados 938 indicadores de Alfabetização Científica, sendo 203 nos 11 relatórios referentes a SEI de 2012, 368 nos 18 relatórios referentes a SEI de 2013 e 367 nas 52 conclusões individuais. Podemos considerar, devido ao grande número de indicadores de Alfabetização Científica, que a Alfabetização Científica está em processo. Também podemos considerar que os alunos envolveram-se com as investigações e as discussões propostas.

A ampla distribuição dos indicadores de AC encontrados nos permite considerar que as competências mais comuns utilizadas para a resolução, discussão e divulgação de problemas de quaisquer Ciências foram abarcadas, uma vez que nenhum dos indicadores deixou de ser observado em pelo menos um relatório (gráfico 5); claro que houve prevalência de indicadores (gráficos 2 e 3) e mesmo de grupos de indicadores (gráfico 4). Como pode ser observado no gráfico 5, os indicadores de Teste de hipóteses e Previsão foram os que apareceram em menos relatórios, respectivamente em 3 e 5 relatórios dos 29, mas os indicadores de Seriação de informações, Organização de informações e Justificativa aparecem em todos os relatórios e Classificação de informações em 28 e Listagem de materiais em 24 relatórios. 
Thiago Marinho Del Corso

INDICADORES DE ALFABETIZAÇÃO CIENTÍFICA, ARGUMENTOS E EXPLICAÇÕES -

Análise de Relatórios no Contexto de uma Sequência de Ensino Investigativo

Também podemos observar no gráfico 5 que 8 dos 12 indicadores analisados aparecem

em mais da metade dos relatórios, então não se trata apenas do número de indicadores, mas da distribuição desses que valida o entendimento que a Alfabetização Científica está em processo.

Acreditamos que características da SEI analisada influenciaram a prevalência de alguns grupos de indicadores de AC mais que outros. Sasseron e Carvalho (2008) e Sasseron (2008) agruparam os indicadores de Alfabetização Científica em 3 grupos, anteriormente apresentados no capítulo 5: grupo 1 compreende os indicadores relacionados ao trabalho direto com os dados empíricos (Listagem de materiais, Seriação de informações, Organização de informações e Classificação de informações); grupo 2 se relaciona à estruturação do pensamento e à construção de uma ideia lógica e objetiva (Raciocínio lógico e Raciocínio proporcional); grupo 3 é vinculado à procura do entendimento da situação analisada (Levantamento de hipóteses, Teste de hipóteses, Justificativa, Previsão, Explicação e Argumento).

Quando se observa o gráfico 4 percebe-se que nos relatórios o grupo 1 de indicadores, correspondente a ao trabalho direto com os dados empíricos, é o mais prevalente; são 389 marcas contendo algum dos indicadores deste grupo contra 32 marcas contendo indicadores do grupo 2 e 150 do grupo 3. Acreditamos que isso se deve à natureza experimental das SEIs, em que os dados foram empiricamente produzidos, depois coletados pelos alunos e ainda precisaram ser sistematizados e tratados, podendo ser apresentados em forma de inscrições literárias (de 29 relatórios, 20 relatórios apresentam gráficos e 16 contêm tabelas).

O grupo 2 é aquele em que os indicadores aparecem com menor frequência nos relatórios e nas conclusões individuais. Isso pode derivar do fato de que este grupo apresenta apenas dois indicadores enquanto que o grupo 1 apresenta 4 e o grupo 3 contem 6, mas mesmo levando isso em conta o número de indicadores deste grupo é bem inferior. É interessante comparar a diferente quantidade desses indicadores nos relatórios 2012 e 2013. Apesar de serem respectivamente 11 e 18 relatórios os indicadores do grupo 2 aparecem mais em 2012; Raciocínio lógico 13 em 2012 contra 7 em 2013 e Raciocínio proporcional 8 contra 4. Pensamos que essa diferença possa estar de alguma forma relacionada à troca do recipiente em que se desenvolveram as populações de Lemnas; em 2012 o recipiente era circular e por isso demandava um 
Thiago Marinho Del Corso

INDICADORES DE ALFABETIZAÇÃO CIENTÍFICA, ARGUMENTOS E EXPLICAÇÕES -

Análise de Relatórios no Contexto de uma Sequência de Ensino Investigativo

raciocínio mais elaborado para o cálculo do número de indivíduos na população, diferentemente dos recipientes usado em 2013, os quais eram quadrados ou retangulares. A troca de formato dos recipientes foi uma decisão consciente da professora, que assim se expressa: "Minha avaliação, como professora, foi que o formato do recipiente (circular) dificultou a amostragem correta da população, pois os alunos tiveram que fazer relações exponenciais entre a área amostrada e área total ocupada". Outro fator que pode ter influenciado esta diferença é que a população em 2012 atingiu número de indivíduos muito superior do que em 2013 e isso pode, somado ao formato do recipiente, ter demandado um raciocínio mais elaborado dos alunos nos cálculos e, consecutivamente isso se refletiu nos relatórios.

O terceiro grupo de indicadores, que nos relatórios apareceu em quantidade significativa, mas inferior aqueles do grupo 1, nas conclusões individuais é o mais frequente, como se pode observar no gráfico 8. Para essa comparação é preferível analisar apenas os relatórios de 2013, já que as conclusões individuais derivam deles. Novamente apostamos nossas fichas que esta mudança de prevalência estaria de alguma forma relacionada às comandas dadas pela professora, agora não só as perguntas geradoras, mas também aquelas que explicavam a constituição de cada item dos relatórios. Vale ressaltar que Sasseron e Carvalho (2008) também valorizam as perguntas feitas pela professora no processo de Alfabetização Científica, evidenciando a importância de boas perguntas.

Possivelmente a pergunta das conclusões individuais fomentaria mais indicadores desse terceiro grupo que a pergunta geradora dos relatórios, já que explicitamente pedia uma conclusão justificada com evidências. Assim, o número de Justificativas que nos relatórios de 2013 constituía 10,6\% dos indicadores apresentados, nas conclusões individuais foram 20,6\%. Acreditamos que o reflexo de pedir conclusões justificadas com evidências contribua também para o aumento relativo de Argumentos, que nos relatórios constituiu 3,8\% dos indicadores contra 10,4\% nas conclusões individuais. Para reforçar a possível influência da comanda geradora, vale ressaltar que, as Explicações, são explicitamente pedidas na descrição do item interpretação dos relatórios e por isso podem aparecer tanto nestes quanto nas conclusões individuais.

Podemos entender que não só houve um aumento dos indicadores do grupo 3 nas conclusões individuais como houve uma diminuição dos indicadores do grupo 1. Essa 
Thiago Marinho Del Corso

INDICADORES DE ALFABETIZAÇÃO CIENTÍFICA, ARGUMENTOS E EXPLICAÇÕES -

Análise de Relatórios no Contexto de uma Sequência de Ensino Investigativo

diminuição pode estar relacionada às comandas dos itens que os relatórios deveriam

conter e que nas conclusões individuais não eram pedidos. Ao caracterizar que os relatórios deveriam conter uma metodologia assim descrita: "descrição detalhada dos materiais e dos procedimentos realizados para coleta e produção de dados.", é esperado que o indicador de Listagem de materiais esteja amplamente presente; nos relatórios de 2013 correspondeu a 7,8\% contra nenhuma aparição nas conclusões individuais e a Organização de informações passou de 26,9\% nos relatórios para 9,2\% na conclusões individuais.

É interessante notar que além das Explicações, anteriormente citadas, a Seriação de informações e a Classificação de informações também são quase tão freqüente em conclusões individuais que em relatórios. Isso é contrastante quando se consideram os grupos de indicadores, vide que nos relatórios o grupo 1 é mais freqüente que o grupo 3 e assim seria esperado que os indicadores que compõem o grupo 1 também fossem mais freqüentes nos relatórios que nas conclusões individuais, como pode ser observado em relação a Listagem de materiais e Organização de informações. Mas o que se observa (gráfico 3) é que a porcentagem de Seriação de informações e Classificaçãa de informações se matem mais próxima (respectivamente 22,8\% nos relatórios e 20,5\% nas conclusões individuais e 14,4\% contra 11,6\%). Acreditamos a diminuição da frequencia de indicadores do grupo 1 nas conclusões individuais não ocorra em relação a Seriação de informações e Classificação di informações devido à necessidade de retomar os dados empíricos obtidos para Justificar (J) Argumentos ou mesmo compor Explicações. Lembrando que e a apresentação dos dados empíricos constitui-se em uma Seriação de informações.

\subsection{Todas elas juntas (Respondendo as questões de pesquisa)}

No tocante às questões de pesquisa, acreditamos tê-las respondido na medida em que desenvolvemos uma metodologia que nos permitiu distinguir Argumentos e Explicações em produções escritas de alunos e identificamos os indicadores de Alfabetização Científica presentes nessas produções. Essa última tarefa culminou na proposição de dois novos indicadores em acréscimo aos que usamos como referência (Sasseron 2008; Sasseron e Carvalho 2008): um deles é o próprio Argumento, e outro, a Listagem de materiais. 
Thiago Marinho Del Corso

INDICADORES DE ALFABETIZAÇÃO CIENTÍFICA, ARGUMENTOS E EXPLICAÇÕES -

Análise de Relatórios no Contexto de uma Sequência de Ensino Investigativo

Um resultado indireto de nosso trabalho pode ser a corroboração dos indicadores

de AC propostos por Sasseron (2008) e Sasseron e Carvalho (2008) para uma diferente condição. Isso, pois esses indicadores foram propostos para verificar se a Alfabetização Científica (AC) está em processo e foram testados em atividades do ensino fundamental I (EFI), em aulas de Ciências, para dados transcritos da sistematização oral dessas atividades, mas nós aplicamos os mesmo indicadores, adicionados pelos dois por nós propostos (Listagem de materiais e construção de Argumentos), para uma SEI de biologia, aplicada no ensino médio ( $1^{\circ}$ E.M.) e com a busca desses indicadores em uma produção escrita. A enorme quantidade e variedade de indicadores de AC encontrados nos relatórios e conclusões individuais podem ser entendidas como a corroboração para o uso desses indicadores nessa nova e diferente situação.

Nossa metodologia de desambiguação entre Argumentos e Explicações foi proposta a partir de referenciais teóricos, mas passou por um intenso movimento de analisar os relatórios produzidos pelos alunos e voltar à teoria para refinar esta metodologia. Assim acreditamos que uma perspectiva que deriva de nosso trabalho é testar nossa metodologia em situações diferentes daquelas que testamos - outras Sequências Didáticas, que poderiam ou não ser investigativas; outros modelos de aulas; outros temas geradores; outras séries; outros modelos de atividades - ou seria, fazer com essa metodologia o que fizemos para os indicadores de Alfabetização Científica.

\section{Referências}

BERLAND, L. K.; MCNEILL, K. L. For whom is argument and explanation a necessary distinction? A response to Osborne and Patterson. Science Education, v. 96, n. 5, p. 808-813, 2012.

BORTOLETTO A.; SUTIL, N.; CARVALHO, W. L. P. Os usos da linguagem verbal na prática discursiva em sala de aula: Um panorama das pesquisas em periódicos brasileiros em ensino de ciências/física. In: Encontro de Pesquisa em Ensino de Física, 12., 2010, Águas de Lindóia. Anais eletrônicos... Disponível em: < http://www.sbf1.sbfisica.org.br/eventos/epef/xii/sys/resumos/T0048-1.pdf >. Acesso em: 12 jan. 2015. 
Ciências da Natureza, Matemática e suas Tecnologias. Brasília: MEC, Secretaria de Educação Básica, 2006.

BRASIL.Ministério da Educação. Parâmetros curriculares nacionais: Ciências Naturais. Brasília: MEC, SEMTEC, 1998.

BRASIL. Ministério da Ciência e Tecnologia. Percepção pública da ciência e tecnologia no Brasil: Resultados da Enquete de 2010. Departamento de Popularização e Difusão da C\&T/SECIS/MCT. Museu da Vida/COC/Fiocruz. 2011. Disponível em: <http://www.museudavida.fiocruz.br/media/enquete2010.pdf>. Acesso em: 04 nov. 2014.

BRICCIA, V. Sobre a natureza da Ciência e o ensino. In: CARVALHO, A. M. P. (Org.) Ensino de ciências por investigação: condições para implementação em sala de aula. São Paulo: Cengage Learning, 2013, cap.7, p. 111-128.

CAPECCHI, M. C. M.; CARVALHO, A. M. P. Atividades de laboratório como instrumentos para a abordagem de aspectos da cultura científica em sala de aula. ProPosições, v.17, n.1(49), p. 137-153, 2006.

CARVALHO, A. M. P. Ensino e aprendizagem de ciências: referenciais teóricos e dados empíricos das sequências de ensino investigativas. In: LONGHINI, M. D. (Org.) O uno e o diverso na educação. Uberlândia: EDUFU, 2011, cap. 18, p. 253-266.

CARVALHO, A. M. P. Introduzindo os alunos no universo das ciências. In: WERTHEIN, J.; CUNHA, C. (Orgs.) Educação científica e desenvolvimento: O que pensam os cientistas. Brasília: Unesco, 2005, p. 61-67

CARVALHO, A. M. P. Habilidades de professores para promover a enculturação científica. Contexto \& Educação, v. 22, n.77, p. 25-49, 2007.

CARVALHO, A. M. P. O ensino de ciências e a proposição de sequências de ensino investigativas. In: In: CARVALHO, A. M. P. (Org.) Ensino de ciências por 
Thiago Marinho Del Corso

INDICADORES DE ALFABETIZAÇÃO CIENTÍFICA, ARGUMENTOS E EXPLICAÇÕES -

Análise de Relatórios no Contexto de uma Sequência de Ensino Investigativo

investigação: condições para implementação em sala de aula. São Paulo: Cengage Learning, 2013, cap.1, p. 1-20.

COLOMBO, P. D.; LOURENÇO, A. B.; SASSERON, L. H.; CARVALHO, A. M. P.; Ensino de Física nos anos iniciais: Uma análise da argumentação na resolução de uma atividade de conhecimento físico. Investigações em Ensino de Ciências, v. 17, n. 2, p. 489-507, 2012.

DRIVER, R.; NEWTON, P.; OSBORNE, J. Establishing the norms of a scientific argumentation in classrooms. Science Education, v. 84, n. 3, p. 287-312, 2000.

DUSCHL, R. A.; OSBORNE, J. Supporting and promoting argumentation discourse in science education. Studies in Science Education, v. 38, n. , p. 39-72, 2002.

ERDURAN, S. Methodological foundations in the study of science classroom argumentation. In: JIMÉNEZ-ALEIXANDRE, M. P.; ERDURAN, S. (Eds.) Argumentation in Science Education: Perspectives from classroom-based research. Springer: Dordrecht, 2008, cap. 3, p. 47-69.

ERDURAN, S.; SIMON, S.; OSBORNE, J. TAPping into argumentation: developments in the application of Toulmin's argument pattern for studying science discourse. Science Education, v. 88, n. 6, p. 915-933, 2004.

HOCHMAN, G. A ciência entre a comunidade e o mercado: leituras de Kuhn, Bourdieu, Latour e Knorr-Cetina. In: PORTOCARRERO, V. (Org.) Filosofia, história e sociologia das ciências: abordagens contemporâneas. Rio de Janeiro: Fiocruz, 1994, cap. 8 , p. 199-231.

JIMÉNEZ-ALEIXANDRE, M. P. A argumentação sobre questões sócio-científicas: processos de construção e justificação do conhecimento na aula. In: Encontro Nacional de Pesquisa em Ensino de Ciências, 5., 2005, Bauru. Atas. 

"Doing the Lesson" or "Doing Science": Argument in High School Genetics, Science Education, v. 84, p. 757-792, 2000.

JIMÉNEZ-ALEIXANDRE, M. P.; DÍAZ DE BUSTAMENTE, J. Discurso de aula y argumentación en la clase de ciencias: cuestiones teóricas y metodológicas, Enseñanza de las Ciencias, v. 21, n. 3, p. 359-370, 2003.

JIMÉNEZ-ALEIXANDRE, M. P.; AGRASO, M. F. A argumentação sobre questões sócio-científicas: Processos de construção e justificação do conhecimento na sala de aula. Educação em Revista, n. 43, p. 13-33, 2006.

JIMÉNEZ-ALEIXANDRE, M. P.; FÉRNANDEZ-LÓPEZ, L. What are authentic practices? Analysis of students' generated projects in secondary. In: NARST Annual Meeting, 2010, Philadelphia. Abstracts...

JORDE, D. Inquiry-based science teaching: An overview of what we know and what we do. In: European Science Education Research Association, Istanbul, 2009. Abstracts...

KELLY, G. J.; TAKAO, A. Epistemic levels in argument: an analysis of university oceanography students' use of evidence in writing. Science Education, v. 86, n. 3, p. 314-342, 2002.

KRASILCHIK, M. Prática de Ensino de Biologia. 4ª Ed. São Paulo: Edusp, 2008.

LATOUR, B.; WOOLGAR, S. A Vida no Laboratório: A produção dos fatos científicos. Rio de Janeiro: Relume Dumará, 1997.

LEHRER, R.; SCHAUBLE, L.; PETROSINO, A. J. Reconsidering the role of experiment in science education. In CROWLEY, K.; SCHUNN, C. D.; OKADA, T. (Orgs.) Designing for science: Implications from every day, classroom, and professional settings. Mahwah: Lawrence Erlbaum Associates, 2001, cap. 1, p. 251-278.

LEMKE, J. L. Talking science: language, learning, and values. Ablex Publishing Corporation, 2009. 
LEMKE, J. L. Teaching all the languages of science: Words, symbols, images, and actions. In: Conference on Science Education, 2011, Barcelona. Abstracts... Disponível em < http://academic.brooklyn.cuny.edu/education/jlemke/papers/barcelon.htm>. Acesso em: 13 jan. 2015.

LEMKE, J. L. Investigar para el futuro de la educación científica: Nuevas formas de aprender, nuevas formas de vivir. Enseñanza de las Ciências, v. 24, n. 1, p. 5-12, 2006.

LÜDKE, M.; ANDRÉ, M. E. D. A. Pesquisa em educação: Abordagens qualitativas. São Paulo: Editora Pedagógica e Universitária, 1986.

MARTINS, I.; OGBORN. J.; KRESS, G. Explicando uma explicação. Ensaio Pesquisa em Educação em Ciências, v. 1, n. 1, 1999.

MURCHO, D. Argumento, persuasão e explicação. Lógica, Crítica. p. 1-7, 2003. Disponível em: < http://criticanarede.com/argforcaexpl.html >. Acesso em: 11/dez/2014, 14:30:30.

NASCIMENTO, S. S.; VIEIRA, R. D. Contribuições e limites no padrão de argumento de Toulmin aplicado em situações argumentativas de sala de aula de ciências. Revista Brasileira de Pesquisa em Educação em Ciências, v. 8, n. 2, p. 1-20, 2008.

OECD - Organisation for economic co-operation and development. Pisa 2003 Data Analysis Manual. Paris, 2005. Disponível em: <http://www.oecd.org/dataoecd/53/22/35014883.pdf>. Acesso em: nov. 2014.

OROFINO, R. P. Análise da argumentação e de seus processos formadores em uma aula de biologia. 2011. 187f. Dissertação (Mestrado) - Faculdade de.Educação da Universidade de São Paulo. São Paulo, 2011. 
ROTH, W. M. Authentic Science: Enculturation into the Conceptual Blind Sots of a Discipline. In: Anual Meeting of American Educational Research Association, 1999, Montréal, Québec. Abstracts...

OSBORNE, J. F.; PATTERSON, A. Scientific argument and explanation: A necessary distinction? Science Education, v. 95, n. 4, p. 627-638, 2011.

OSBORNE, J.; PATTERSON, A. Authors' Response to "For Whom Is Argument and Explanation a Necessary Distinction? A Response to Osborne and Patterson" by Berland and McNeill. Science Education, v. 96, n. 5, p. 814-817, 2012.

SANTOS, W. L. P.; MORTIMER, E. F. \& SCOTT, P. H. A argumentação em discussões sóciocientíficas: reflexões a partir de um estudo de caso. Revista Brasileira de Pesquisa em Educação em Ciências, v. 1, n. 1, p. 140-152, 2001.

SASSERON, L.H., Alfabetização Científica no Ensino Fundamental: Estrutura e Indicadores deste processo em sala de aula. 2008, 265p. Tese (Doutorado) - Faculdade de Educação, Universidade de São Paulo, São Paulo, 2008.

SASSERON, L. H.; CARVALHO, A. M. P. Construindo argumentação na sala de aula: a presença do ciclo argumentativo, os indicadores de alfabetização científica e o padrão de toulmin. Ciência \& Educação, v. 17, n. 1, p. 97-114, 2011 a.

SASSERON, L. H.; CARVALHO, A. M. P. 2011b. Alfabetização Científica: Uma Revisão Bibliográfica. Investigações em Ensino de Ciências, v. 16, n. 1, p. 59-77, $2011 b$.

SCARPA, D. L.; SILVA, M. B. A Biologia e o ensino de Ciências por investigação: dificuldades e possibilidades. In: CARVALHO, A. M. P. (Org.) Ensino de ciências por investigação: condições para implementação em sala de aula. São Paulo: Cengage Learning, 2013, cap. 8 p. 129-152. 
SIMON, S.; ERDURAN, S.; OSBORNE, J. Learning to Teach Argumentation: Research and development in the science classroom. International Journal of Science Education, v. 28, n. 2, p. 235-260, 2006.

SUTTON, C. New Perspectives on Lenguage in Science. In: FRASER, B. E TOBIN, K. G. (Eds.) International Handbook of Science Education. Klower Academic Publishes, 1998, cap. 3, p. 27-38.

TOULMIN, S. E. Os usos do argumento. 2. ed. São Paulo: Martins Fontes, 2006.

VIEIRA, A. T. Movimentos argumentativos em uma entrevista televisiva: Uma abordagem discursivo-interacional. Juiz de Fora: Clio Edições Eletrônicas, 2003. 


\section{APÊNDICES}

Os apêndices são constituídos dos relatórios originais escaneados e de suas correspondentes análises. Três relatórios foram apresentados no capitulo resultados, no tópico 6.1. Aqui começamos por apresentar sete relatórios desse mesmo ano que apresentam a análise completa, tanto o quadro que aponta qual indicador de AC está presente em cada marca bem como a discussão detalhada dos motivos para assim identificar, incluindo a desambiguação entre Argumentos e Explicações. Na sequencia, seguem os relatórios 11 a 18 de 2013 que apresentam além da cópia escaneada do original o quadro indicativo. Esses relatórios não apresentam a discussão detalhada das identificações ou desambiguações. Por fim, são apresentados os relatórios 1 a 11 de 2012 escaneados e com o quadro indicativo de AC preenchido. Importante ressaltar que os relatórios de 2012 não contêm conclusões individuais. 
Thiago Marinho Del Corso

INDICADORES DE ALFABETIZAÇÃO CIENTÍFICA, ARGUMENTOS E EXPLICAÇÕES -

Análise de Relatórios no Contexto de uma Sequência de Ensino Investigativo

\section{Relatórios 4 a 10 de 2013}

Aqui são apresentados os relatórios 4 a 10 de 2013 e suas análises, tanto os quadros que apenas apontam qual indicador foi identificado em que marca, bem como o detalhamento da identificação.

\section{O Relatório 4 - 2013}

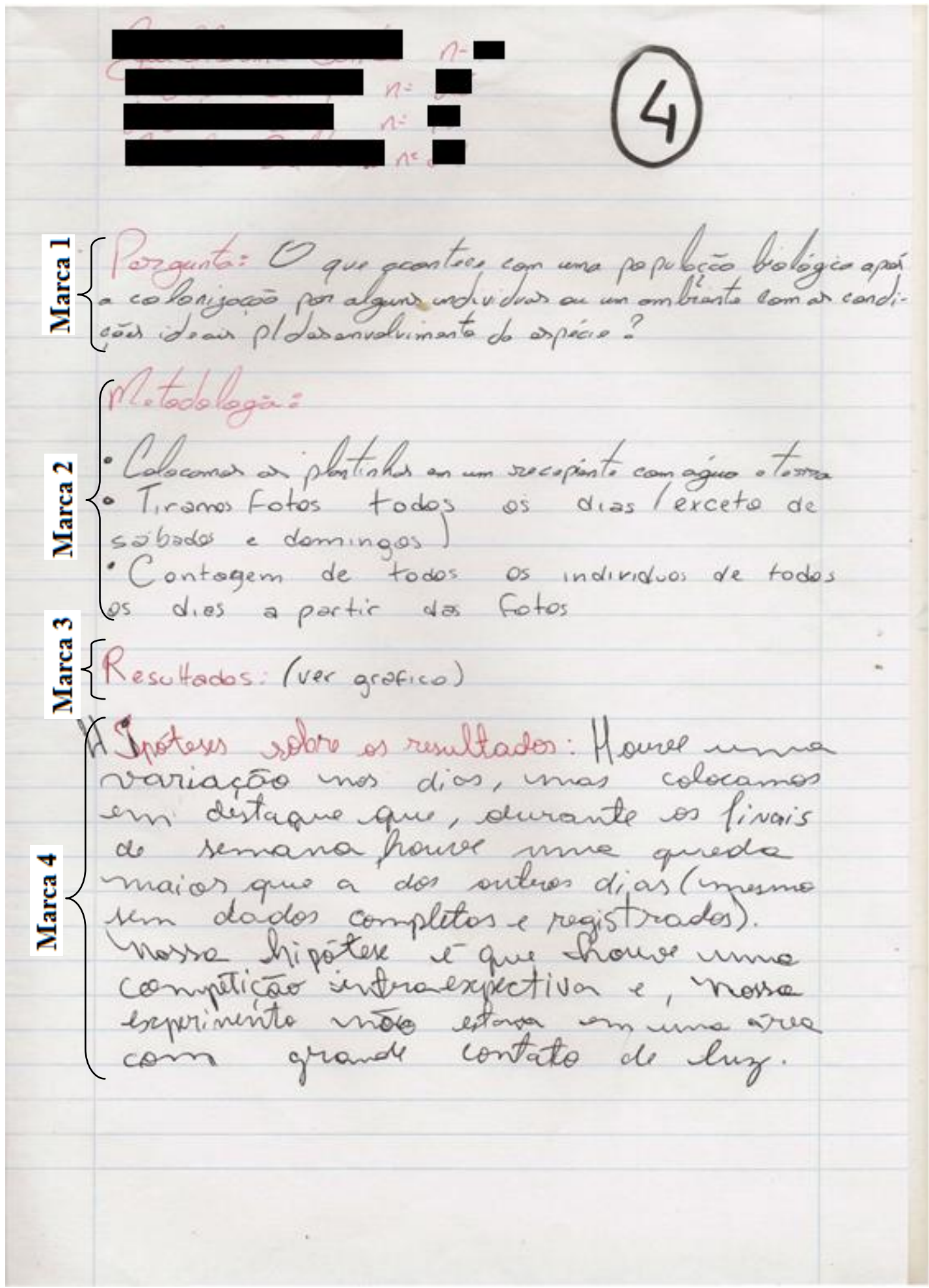


Thiago Marinho Del Corso

INDICADORES DE ALFABETIZAÇ̃̃O CIENTÍFICA, ARGUMENTOS E EXPLICAÇÕES -

Análise de Relatórios no Contexto de uma Sequência de Ensino Investigativo

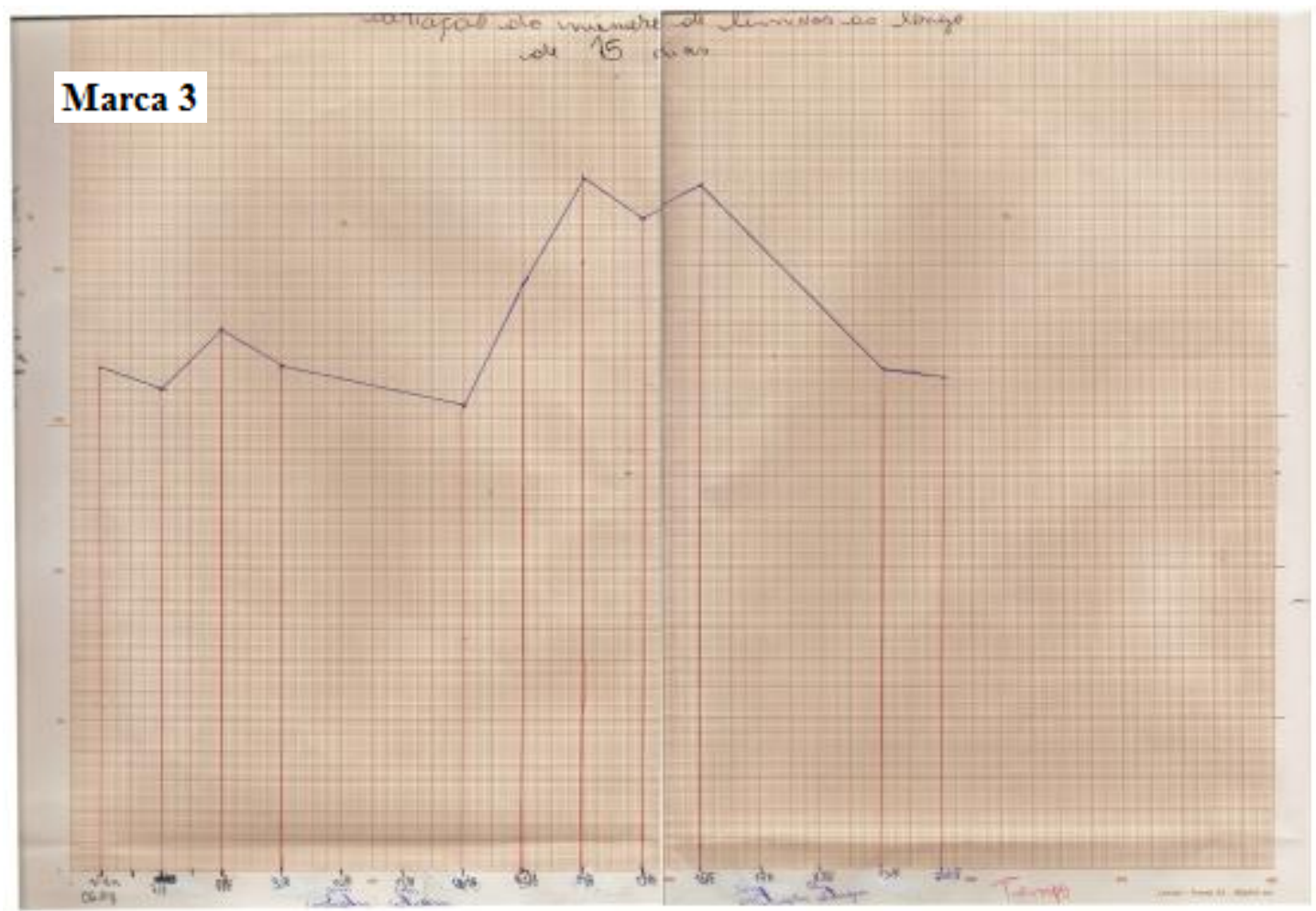


Análise de Relatórios no Contexto de uma Sequência de Ensino Investigativo

\section{Quadro 04 - Relatório 4 de 2013}

Identificação dos Indicadores de Alfabetização Científica no Relatório 4 de 2013 e conclusões individuais correspondentes.

\begin{tabular}{|c|c|c|c|c|c|c|c|c|c|c|c|c|c|c|}
\hline 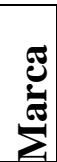 & $\begin{array}{l}\text { Subtítulo, } \\
\text { divisão ou } \\
\text { Item }\end{array}$ & Texto & $\mathbf{L M}$ & SI & $\mathbf{O I}$ & CI & $\mathbf{R L}$ & $\mathbf{R P}$ & LH & TH & $\mathbf{J}$ & $\mathbf{P}$ & 気 & $\sum_{4}^{\infty}$ \\
\hline 1 & Pergunta & $\begin{array}{l}\text { "O que acontece com uma populasaa bialógica apás a } \\
\text { colonizaçãa por alguns individuas de um ambiente com as } \\
\text { condiçães ideais para a desenvolvimenta das espécies?" }\end{array}$ & \multicolumn{12}{|c|}{ Não avaliado, texto da professora. } \\
\hline 2 & $\begin{array}{l}\text { Metodologia } \\
\text { (Metodologia) }\end{array}$ & 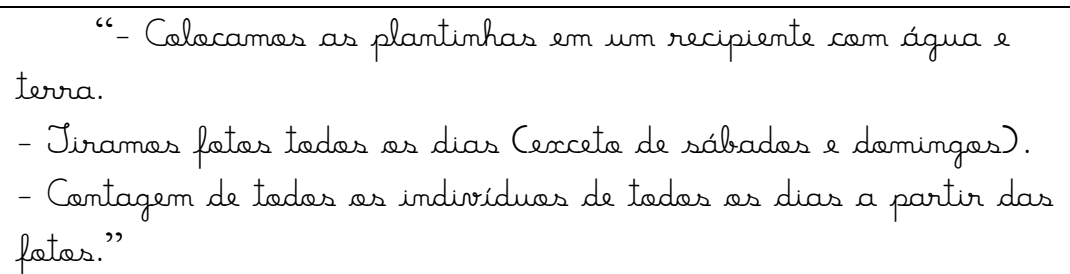 & $\mathrm{X}$ & & $\mathrm{X}$ & & & & & & & & & \\
\hline 3 & $\begin{array}{l}\text { Resultados } \\
\text { (Resultados) } \\
\text { O Gráfico }\end{array}$ & S & & $X$ & $\mathrm{X}$ & $\mathrm{X}$ & & & & & & & & \\
\hline 4 & $\begin{array}{l}\text { Resultados } \\
\text { (Resultados) }\end{array}$ & $\begin{array}{l}\text { "Hipéteses sabre as resultadas: Hauve uma variaçãa mas } \\
\text { dias, mas colocamas em destaque que, durante as finais de } \\
\text { semana hauve uma queda maiar que a dos autros dias (mesma } \\
\text { sem dadas completas e registradas). }\end{array}$ & & $\mathrm{X}$ & $\mathrm{X}$ & $\mathrm{X}$ & & & $\mathrm{X}$ & & $\mathrm{X}$ & & & $\mathrm{X}$ \\
\hline
\end{tabular}


Thiago Marinho Del Corso

INDICADORES DE ALFABETIZAÇ̃̃o CIENTÍFICA, ARGUMENTOS E EXPLICAÇÕES -

Análise de Relatórios no Contexto de uma Sequência de Ensino Investigativo

\begin{tabular}{|c|c|c|c|c|c|c|c|c|c|c|c|c|c|c|}
\hline & & $\begin{array}{l}\text { Nassa hipótese é que hauve uma competiçãa intraespecífica e nassa } \\
\text { experimenta nãa estava em uma área com grande contata de luz" }\end{array}$ & & & & & & & & & & & & \\
\hline 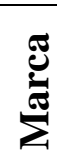 & $\begin{array}{l}\text { Subtítulo, } \\
\text { divisão ou } \\
\text { Item }\end{array}$ & Texto & LM & SI & OI & CI & $\mathbf{R L}$ & $\mathbf{R P}$ & LH & TH & $\mathbf{J}$ & $\mathbf{P}$ & $\underset{\substack{x \\
y}}{a}$ & $\sum$ \\
\hline 5 & $\begin{array}{l}\text { Conclusão } 1 \\
1^{\circ} \text { parágrafo }\end{array}$ & 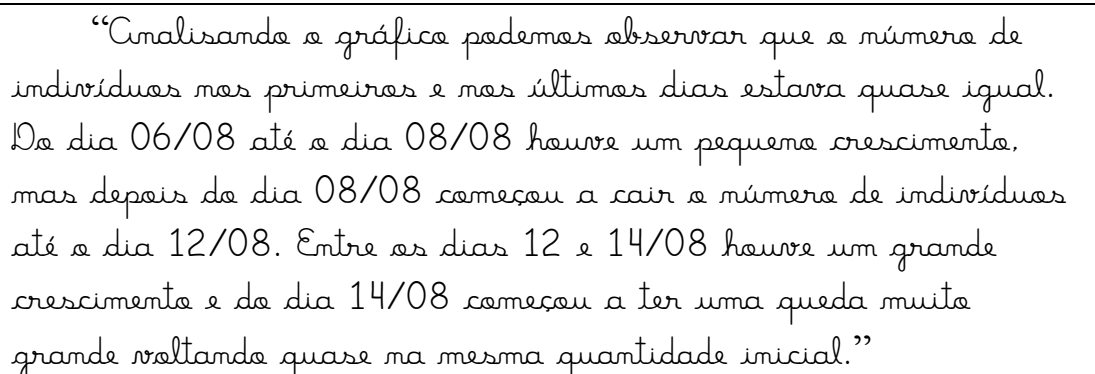 & & $X$ & $\mathrm{X}$ & $\mathrm{X}$ & & & & & & & & \\
\hline 6 & $\begin{array}{l}\text { Conclusão } 1 \\
2^{\circ} \text { parágrafo }\end{array}$ & $\begin{array}{l}\text { "Cis quedas podem ser devida a uma falta de luz, as plantas } \\
\text { ficaram em uma área que havia pauca luz e pode ter ocorrida } \\
\text { uma competiçãa intraespecífica" }\end{array}$ & & $X$ & & & $X$ & & & $X$ & $X$ & & & \\
\hline 7 & $\begin{array}{l}\text { Conclusão } 2 \\
\left(1^{\circ} \text { parágrafo }\right)\end{array}$ & $\begin{array}{l}\text { "Concluimas que as fatares ambientais influenciam muita } \\
\text { mais na desenvalvimenta de uma espécie, pais com base na nassa } \\
\text { gráfica hauve uma variaçãa muita grande na númera de } \\
\text { individuas." }\end{array}$ & & & & & $\mathrm{X}$ & & & & & & & $\mathrm{X}$ \\
\hline 8 & $\begin{array}{l}\text { Conclusão } 2 \\
\left(2^{\circ} \text { parágrafo }\right)\end{array}$ & $\begin{array}{l}\text { "A variaçäa seria muita pequena se houvesse colonizaçãa } \\
\text { por alguns individuos, na verdade a populaçãa apenas cresceria e } \\
\text { se tivesse uma queda seria muita leve (pequena)." }\end{array}$ & & & & & & & & & & $X$ & & \\
\hline 9 & $\begin{array}{l}\text { Conclusão } 2 \\
\left(3^{\circ} \text { parágrafo }\right)\end{array}$ & $\begin{array}{l}\text { "Um das fatas que podemas ver issa fai a grande queda que } \\
\text { acorreu mos fins de semana. Nãa temas certeza, mas temas a } \\
\text { hipétese de que a luz que estava sobre as plantas foram apagadas } \\
\text { ou movidas de lugar." }\end{array}$ & & $\mathrm{X}$ & & $\mathrm{X}$ & & & $\mathrm{X}$ & & $\mathrm{X}$ & & & \\
\hline
\end{tabular}


Thiago Marinho Del Corso

INDICADORES DE ALFABETIZAÇ̃̃O CIENTÍFICA, ARGUMENTOS E EXPLICAÇÕES -

Análise de Relatórios no Contexto de uma Sequência de Ensino Investigativo

\begin{tabular}{|c|c|c|c|c|c|c|c|c|c|c|c|c|c|c|}
\hline 10 & $\begin{array}{l}\text { Conclusão } 2 \\
\text { (quando } \\
\text { considerada } \\
\text { inteira) }\end{array}$ & 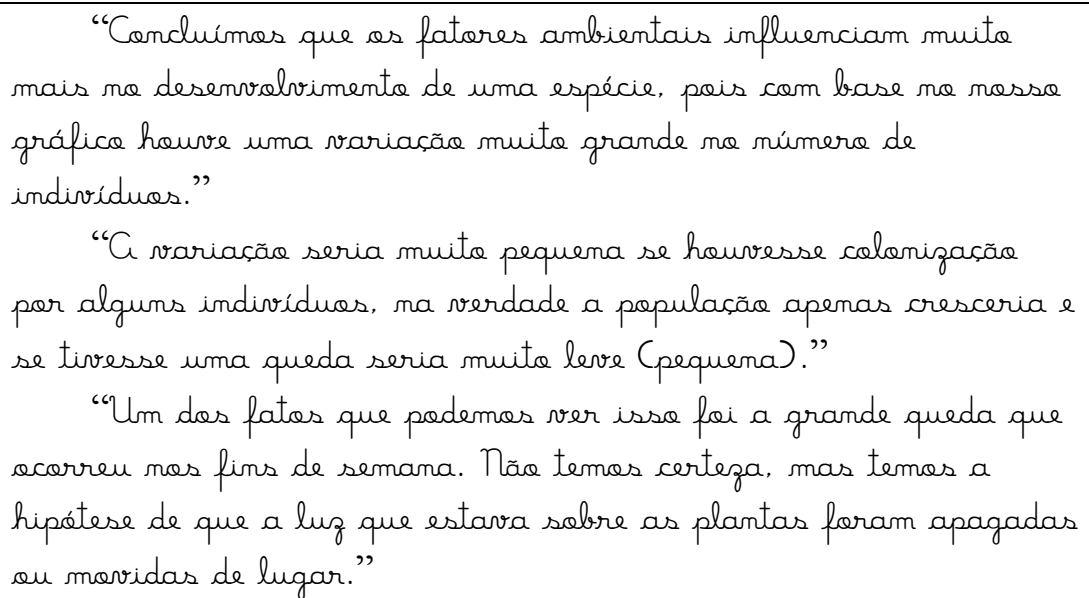 & & & & & & & & & & & & $X$ \\
\hline 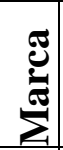 & $\begin{array}{l}\text { Subtítulo, } \\
\text { divisão ou } \\
\text { Item }\end{array}$ & Texto & $\mathbf{L M}$ & SI & OI & CI & RL & $\mathbf{R P}$ & $\mathbf{L H}$ & TH & $\mathbf{J}$ & $\mathbf{P}$ & $\underset{x}{a}$ & $\sum^{\infty}$ \\
\hline 11 & $\begin{array}{l}\text { Conclusão } 3 \\
1^{\circ} \text { parágrafo }\end{array}$ & $\begin{array}{l}\text { "Uma papulaçãa bialógica safre variaçãa de múmera de } \\
\text { individuas devida às competicães intraespecíficas." }\end{array}$ & & & & & & & & & $X$ & & & \\
\hline 12 & $\begin{array}{l}\text { Conclusão } 3 \\
2^{\circ} \text { parágrafo }\end{array}$ & $\begin{array}{l}\text { "Massa experimenta nãa fai muita bem elaborada, pais nãa } \\
\text { ficau em uma área com contata de luz considerável." }\end{array}$ & & & & & & & & & $\mathrm{X}$ & & & $X$ \\
\hline 13 & $\begin{array}{l}\text { Conclusão } 3 \\
3^{\circ} \text { parágrafo }\end{array}$ & $\begin{array}{l}\text { "Tãa sabemas por que, mas mas firs de semana a númera de } \\
\text { individuas diminuiu muita." }\end{array}$ & & $X$ & & & & & & & & & & \\
\hline
\end{tabular}


Análise Discursiva do Relatório 4- 2013

O relatório 4 de 2013 é mais simples que a maioria dos outros confeccionados pelos alunos e assim como outros 6 de 2013 não apresenta título e se inicia com os nomes e números dos seus 4 integrantes.

\section{Marca 1:}

A primeira redação dos alunos é a pergunta geradora, que como foi fornecida pela professora não será analisada.

\section{Marca 2:}

Os alunos optam por descrever a metodologia em tópicos e nós optamos por analisar os três tópicos juntos. Acreditamos que a metodologia apresenta apenas os indicadores de Listagem de materiais e Organização de informações. O primeiro destes indicadores aparece novamente com a apresentação dos materiais usados para a montagem do experimento.

Ao discorrer sobre o modo como o trabalho foi realizado os alunos estão Organização de informações. Considere que os dados com os quais os alunos irão trabalhar são as contagens do número de indivíduos de Lemnas sp. obtidos das fotografias tiradas ao longo dos dias em que se desenrolou o experimento.

- "Colacamas as plantinhas em um recipiente com água e terra.

- Tiramas fotas tadas as dias (exceta de sábadas e domingas).

- Contagem de todas as individuas de todas as dias a partir das fotas."

\section{Marca 3:}

O gráfico que apresenta os registros do número de indivíduos no eixo y pelos dias de experimento no eixo x. Este como outros gráficos analisados em relatórios anteriores apresenta os indicadores de Seriação, Organização e Classificação de informações já que estes estão relacionados ao trabalho com os dados empíricos. A Seriação pode ser entendida quando os alunos apresentam os dados coletados, do tamanho da população 

informações aqui na medida em que os dados são plotados, organizados, em um gráfico. E finalmente, a Classificação de informações, quando se buscam estabelecer características para os dados obtidos, aqui entendida pelas retas traçadas para demonstrar a variação na dinâmica populacional das Lemnas.

\section{Marca 4:}

"Hipéteses sobre as resultados: Hauve uma variaçäo nos dias, mas colocamos em destaque que, durante as finais de semana houve uma queda maior que a dos outros dias (mesma sem dadas completas e registrados).

Nassa hipétese é que hauve uma competiçãa intraespecifica e massa experimenta nãa estarra em uma área com grande contate de luz."

No parágrafo escrito pelos alunos acerca dos resultados dos experimentos encontramos os indicadores de Seriação de informações, Organização de informações, Classificação de informações, Levantamento de Hipóteses, Justificativa e Argumento.

Entendemos que quando os alunos afirmam que -" durante as finais de semana houve uma queda"- os alunos estão apresentando dados, o que configura uma Seriação de informações. Também ao afirmar que, -"Houve uma variaçãa mas dias,"-, entendemos que os alunos também estão apresentando dados, já que se referem à variação do tamanho populacional das Lemnas e com a referida afirmação caracterizam que o número de indivíduos na população não estava estável, mas variava, o que em se tratando do tema dinâmica populacional é um dado.

Ao fazer distinção entre o que aconteceu durante a semana e o que aconteceu no final de semana os alunos estão Organizando informações -"mas colocames em destaque que, durante as finais de semana... que a dos autros dias"-.

A caracterização da intensidade da queda do número de indivíduos durante o final de semana é entendida como uma Classificação de informações, já que este indicador se configura pelo estabelecimento de características para os dados e -"queda"(subentendidamente que referindo-se ao número de indivíduos na população de Lemna) 
Thiago Marinho Del Corso

INDICADORES DE ALFABETIZAÇÃO CIENTÍFICA, ARGUMENTOS E EXPLICAÇÕES -

Análise de Relatórios no Contexto de uma Sequência de Ensino Investigativo

foi entendido como um dado. Em negrito a caracterização ao dado - "houve uma queda maiar que a dos autros dias"- .

O Levantamento de hipótese é declarado pelos alunos -" hassa hipétese é que houve uma competicãa intraespecifica"- e por isso não precisa ser detalhado.

A Justificativa aparece aqui relacionada ao trecho em que os alunos afirmam que -"massa experimenta nãa estava em uma área com grande contata de luz."-. Neste trecho entendemos que os alunos estão tentando justificar tanto a queda no número de indivíduos da população, como a existência de uma possível competição intraespecífica, que aqui ocorreria então pela limitada iluminação.

Finalmente acreditamos que o parágrafo dos -"Resultados"- apresenta um Argumento já que os alunos afirmam que a partir dos dados podem afirmar ter havido a supracitada competição intraespecífica e tentam justificar esta pelo fato do experimento deles estar em uma área pouco iluminada. Neste caso a Conclusão (C) do argumento é menos certa que as premissas que levam a ela (Murcho 2003), esta Conclusão (C) é contestável, não é certa (Osborne e Patterson 2011).

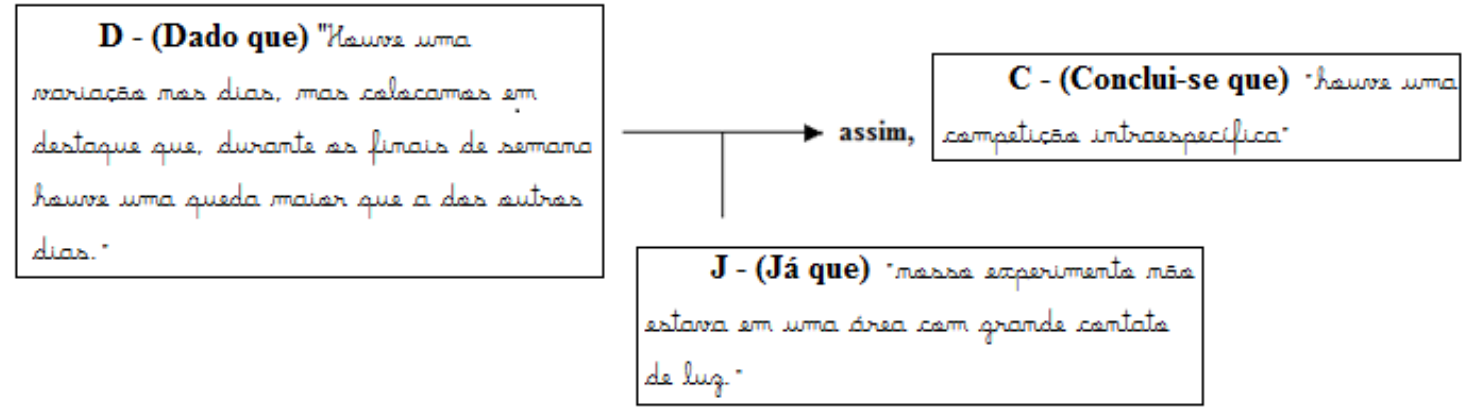

\section{Marca 5}

No primeiro parágrafo da primeira conclusão do relatório quatro o aluno apresenta os indicadores de Seriação, Organização e Classificação de informações.

"Cinalisanda a gráfica pademas abservar que a númera de individuas nos primeiras e nos últimas dias estarra quase igual. Da dia 06/08 até a dia 08/08 houre um pequena crescimenta. mas depois da dia 08/08 comescou a cair a númera de individuas até a dia 12/08. Entre as dias 12 e 14/08 houve um grande crescimento e do dia 14/08 comescen a ter uma queda muita grande voltando quase na mesma quantidade inicial." 
Thiago Marinho Del Corso

INDICADORES DE ALFABETIZAÇÃO CIENTÍFICA, ARGUMENTOS E EXPLICAÇÕES -

Análise de Relatórios no Contexto de uma Sequência de Ensino Investigativo

Como discutido anteriormente, em se tratando de dinâmica populacional, crescer,

diminuir, estabilizar são dados que apresentam o que houve com a população em estudo ao longo do tempo. Desta forma quando o aluno apresenta que -"Da dia 06/08 até a dia 08/08 hourve um pequeme crescimenta."-, -"mas depais do dia 08/08 comesou a cair a númera de individuas até a dia 12/08"-, "Entre as dias 12 e 14/08 hauve um grande crescimenta"- e - "do dia 14/08 comesou a ter uma queda muito grande voltanda quase ma mesma quantidade inicial."- o aluno está listando dados, que foram organizados em diferentes momentos.

A Organização ocorre quando o aluno divide em períodos as variações populacionais. De acordo com Sasseron (2008) e Sasseron e Carvalho (2008) este indicador - "Surge quando se procura preparar os dados existentes sobre o problema investigado"... "ocorre tanto no início da proposição de um tema quanto na retomada de uma questão, quando as idéias são relembradas" - e aqui o aluno está retomando as ideias sobre a variação populacional das Lemnas e preparando os dados para discuti-los, quando os organiza em períodos.

A Classificação decorre do estabelecimento de características para cada um dos dados apresentados anteriormente. Sasseron (2008) e Sasseron e Carvalho (2008) diz que este indicador aparece quando -"se buscam estabelecer características para os dados". Ao afirmar que o crescimento inicial foi -“pequeme”- (1 momento, de 06/08 a 08/08), quando diz que no terceiro momento (12 a 14/08) o crescimento foi - "grande"ou em relação ao ultimo momento (a partir de 14/08) houve uma queda -"muito grande"-.

\section{Marca 6}

O segundo parágrafo da primeira conclusão do relatório quatro apresenta os indicadores de Seriação de informações, Levantamento de hipóteses, Justificativa e Raciocínio lógico.

"Cis quedas podem ser devida a uma falta de luz, as plantas ficaram em uma área que havia pouca luz e pode ter acorrida uma competiçãa intraespecífica" 
Thiago Marinho Del Corso

INDICADORES DE ALFABETIZAÇÃO CIENTÍFICA, ARGUMENTOS E EXPLICAÇÕES -

Análise de Relatórios no Contexto de uma Sequência de Ensino Investigativo

A Seriação de informações decorre seguindo o mesmo raciocínio apresentado na marca anterior, a afirmativa de que houve -"queda"- é um dado, e listar dados se relaciona a Seriação de informações.

A Justificativa ocorre quando o aluno quer apresentar garantias do porque a população se comportou da forma como se comportou e a garantia apresentada é que que -"podem ser devida a uma falta de luz, as plantas ficaram em uma área que havia penca lug"-.

De acordo com Sasseron e Carvalho (2008) o Levantamento de hipóteses "aponta instantes em que são alçadas suposições acerca de certo tema". Acreditamos que, quando o aluno, após afirmar que houve uma -“queda"- no número de indivíduos e que esta queda ocorreu -"devida a uma falta de luz"-, levanta a suposição que neste cenário - "pode ter ocorrida uma competiçäo intraespecífica"- o aluno esta levantando uma suposição, está Levantando uma hipótese.

O Raciocínio lógico decorre da exposição clara das ideias apresentadas. Sendo que nesta marca podemos fazer correspondência com o padrão hipotético dedutivo de Lawson (2000) como apresentado abaixo:

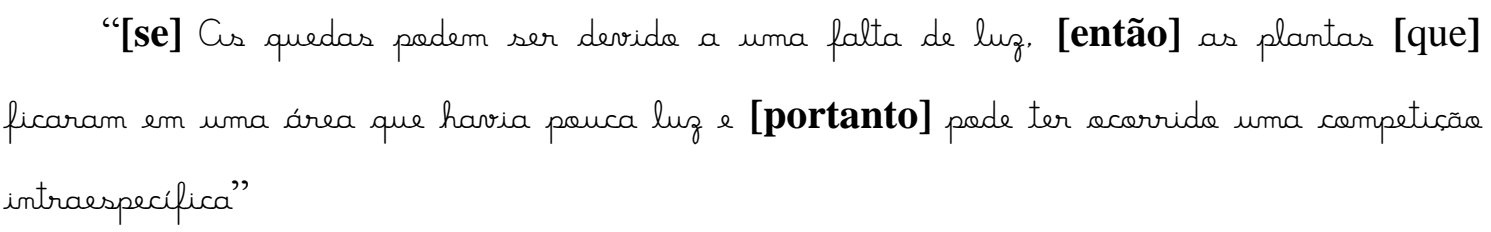

\section{Marca 7}

Acreditamos que no primeiro parágrafo da segunda conclusão do quarto relatório o aluno apresenta os indicadores de Raciocínio lógico e um Argumento.

uma espécie, pais com base no nassa gráfica houve uma variaça muita grande no númera de individuas."

O Raciocínio lógico se evidencia pela estruturação das ideias, na medida em que a grande variação populacional das Lemnas observada experimentalmente é associada à influencia dos fatores ambientais. Esta não é uma associação direta e obvia e por isso mesmo explicita um Raciocínio lógico. 
Thiago Marinho Del Corso

INDICADORES DE ALFABETIZAÇÃO CIENTÍFICA, ARGUMENTOS E EXPLICAÇÕES -

Análise de Relatórios no Contexto de uma Sequência de Ensino Investigativo

O Argumento é muito simples e com poucos elementos, mesmo assim configura-

se como um Argumento, já que apresenta uma Conclusão (C) e Dados (D), e a

Conclusão (C) é menos certa que o Dado (D). Este Argumento fica, estruturado segundo o layout de Toulmin (2006) como abaixo representado e deve-se salientar que mesmo não havendo uma Justificativa (J) que apóie, conduza destes dados a esta conclusão, entendemos haver um Argumento.

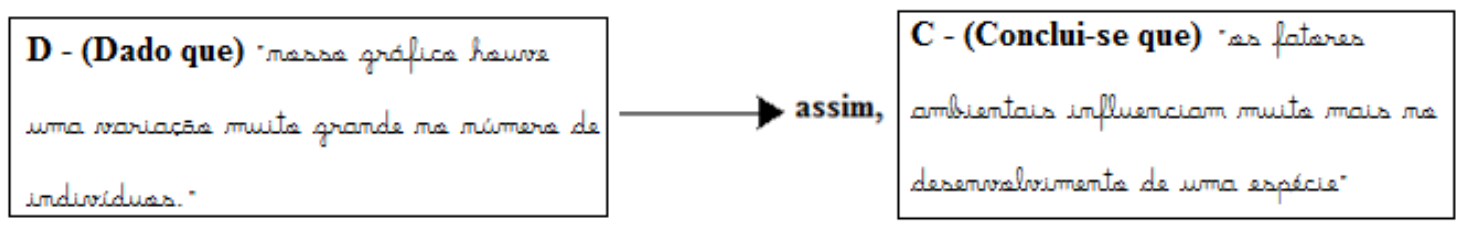

Marca 8

No segundo parágrafo da segunda conclusão do relatório quatro o aluno faz uso de uma Previsão.

"A variașãa seria muito pequena se houvesse colonizasãa por alguns individuas, na verdade a populaşãa apenas cresceria e se tivesse uma queda seria muita leve (pequena)."

De acordo com Sasseron (2008) e Sasseron e Carvalho (2008) -“Este indicador é explicitado quando se afirma uma ação elou fenômeno que sucede associado a certos acontecimentos" - e é exatamente isso que acontece aqui quando o aluno diz que - "a populaçäa apenas cresceria e se tivesse uma queda seria muita leve (pequena)"- caso estivesse sob a condição apontada -"se houvesse colonizacãa por alguns individuas"-.

\section{Marca 9}

O terceiro parágrafo da segunda conclusão do relatório quatro apresenta os indicadores de Seriação de informações, Classificação de informações e Levantamento de hipóteses e Justificativa.

"Um dos fatas que podemos ver isso (se referindo à afirmação de que os fatores ambientais influenciam muito no desenvolvimento populacional de uma espécie) foi a grande queda que ocorreu nas fins de semana. Nãa temas certeza, mas temas a hipétese de que a luz que estavia sobre as plantas foram apagadas on movidas de lugar."

A Seriação de informações ocorre relacionada à apresentação do dado de que ocorreu -“queda"- do número de indivíduos da população nos finais de semana. Apresentar dados se relaciona a este indicador. 
Thiago Marinho Del Corso

INDICADORES DE ALFABETIZAÇÃO CIENTÍFICA, ARGUMENTOS E EXPLICAÇÕES -

Análise de Relatórios no Contexto de uma Sequência de Ensino Investigativo

O Levantamento de hipóteses se dá quando o aluno afirma que -"Tãa temas

certeza, mas temos a hipétese de que a luz que estava sobre as plantas foram apagadas ou movidas de lugar."-- Este indicador é explicito, já que o aluno afirma ter uma hipótese para a diminuição que ocorria na população de Lemnas nos finais de semana.

A Justificativa se encontra no trecho -"Um dos fatas que podemas ver isso foi a grande queda que acorreu nos firs de semana."- e esta é uma Justificativa para uma afirmação feita no primeiro parágrafo da conclusão, de que os fatores ambientais influenciam muito na dinâmica populacional.

\section{Marca 10}

Pudemos também, acerca da segunda conclusão do quarto relatório quando considerada inteira, verificar a construção de um Argumento em que os elementos constituintes deste aparecem distribuídos ao longo dos três parágrafos da conclusão. Este Argumento é apresentado abaixo, estruturado segundo o layout de Toulmin (2006):
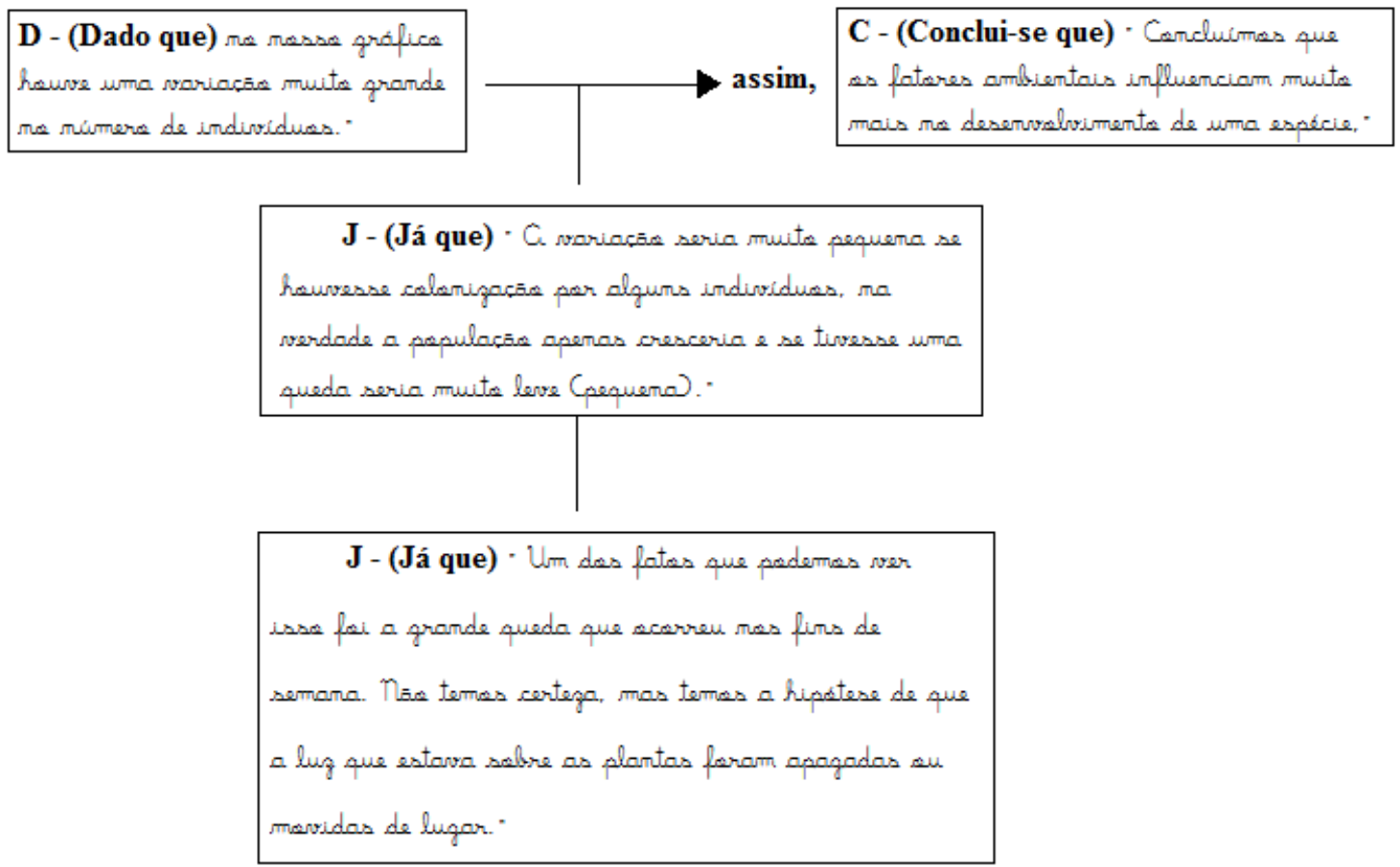

Para a identificação deste argumento procuramos a afirmativa principal, que é proferida no primeiro parágrafo, esta foi considerada a Conclusão (C) do Argumento. Esta Conclusão (C) é uma generalização, não fala especificamente das Lemnas mas generaliza para o -"desenvolvimenta de uma espécie" - e como Murcho (2003) traz em seu 
Thiago Marinho Del Corso

INDICADORES DE ALFABETIZAÇÃO CIENTÍFICA, ARGUMENTOS E EXPLICAÇÕES -

Análise de Relatórios no Contexto de uma Sequência de Ensino Investigativo

artigo isto é menos certo, menos plausível, que considerações específicas acerca do que

aconteceu com as Lemnas ao longo do experimento, e isso é uma característica que serve para diferenciar Explicações de Argumentos.

Os Dados (D) falam especificamente do gráfico produzido com o experimento, a primeira Justificativa (J) pode tanto se referir ao experimento em específico ou a uma generalização, mas mesmo neste ultimo caso esta é mais incerta que a própria Conclusão (C). A segunda Justificativa (J) trata de uma garantia que conduz dos Dados (D) a Conclusão (C) e que parte também dos experimentos, sendo assim mais certa que a Conclusão (C) a qual ela conduz.

\section{Marca 11}

"Uma papulaçãa bialégica safre variaçãa de númera de individuas devida às competiçaes intraespecificas."

O primeiro parágrafo da terceira conclusão do relatório quatro, transcrito acima, apresenta como indicadores de Alfabetização Científica uma Justificativa. A afirmativa a ser Justificada para este fenômeno é que -"Uma populaçãa safre variacãa de múmera de individuas"- e a Justificativa para este fenômeno é que isso se deve -“ás competiçães intraespecificas"-.

\section{Marca 12}

O segundo parágrafo da terceira conclusão do relatório quatro de 2013 apresenta os indicadores de Justificativa e Argumento. O primeiro destes indicadores aparece quando o aluno diz - "pois mãa ficou em uma área com contato de luz considerável."- para dar garantia/aval a afirmativa de que "Tossa experimenta nãa foi muita bem elaborada"-O Argumento foi estruturado conforme uma adaptação do layout de Toulmin (2006). Podemos entender que a observação do local aonde o -“experimento"- foi colocado é mais certa que a consideração de que o -“experimento"- foi mal elaborado. Acredita-se aqui que este Argumento visa validar os resultados obtidos pelos alunos, que não corresponderam a estabilização da população apresentada na aula teórica como modelo ideal de crescimento populacional. Por ter dados que divergiam do que foi apresentado 
Thiago Marinho Del Corso

INDICADORES DE ALFABETIZAÇÃO CIENTÍFICA, ARGUMENTOS E EXPLICAÇÕES -

Análise de Relatórios no Contexto de uma Sequência de Ensino Investigativo

pela professora acreditamos que o aluno buscava defender seus resultados e para isso

trazia aspectos práticos observados.

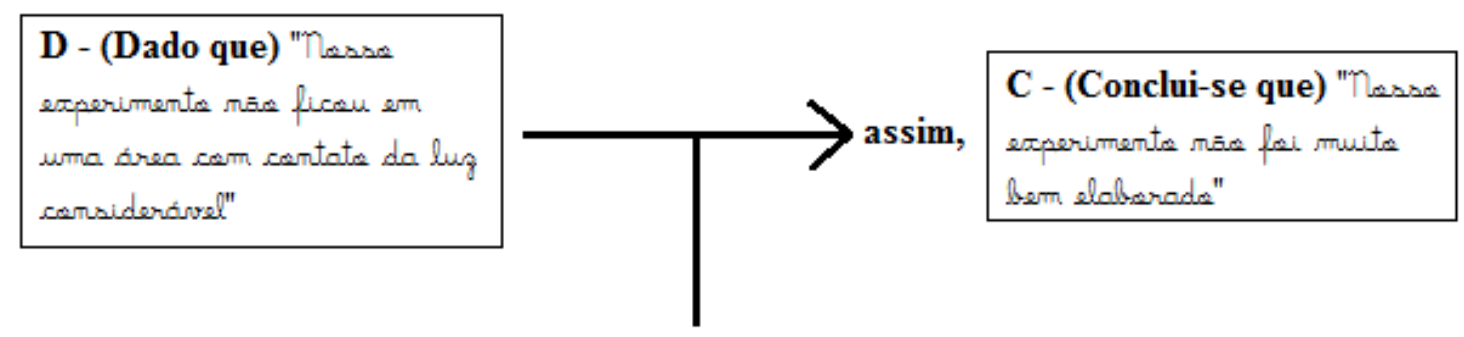

O parágrafo inteiro transcrito segue abaixo:

"Nassa experimenta nãa fai muita bem elaborada, pais nãa ficau em uma área com contata de luz considerável."

\section{Marca 13}

O terceiro e ultimo parágrafo da terceira conclusão do quarto relatório de 2013 segue abaixo transcrito, e apresentou o indicador de Alfabetização Científica de Seriação e Classificação de informações. O primeiro destes indicadores ocorre pela apresentação do dado de que houve -“diminuiçãe”- no número de indivíduos da população de Lemnas nos finais de semana. A Classificação de informações ocorre pelo estabelecimento de características ao dado da -“diminuicãa"-, o aluno afirma que esta foi intensa -"a númera de individuas diminuiu muita."-.

" Tãa sabemas por que, mas nas fins de semana a númera de indivíduas diminuiu muite." 
Thiago Marinho Del Corso

INDICADORES DE ALFABETIZAÇÃO CIENTÍFICA, ARGUMENTOS E EXPLICAÇÕES -

Análise de Relatórios no Contexto de uma Sequência de Ensino Investigativo

O Relatório 5 - 2013

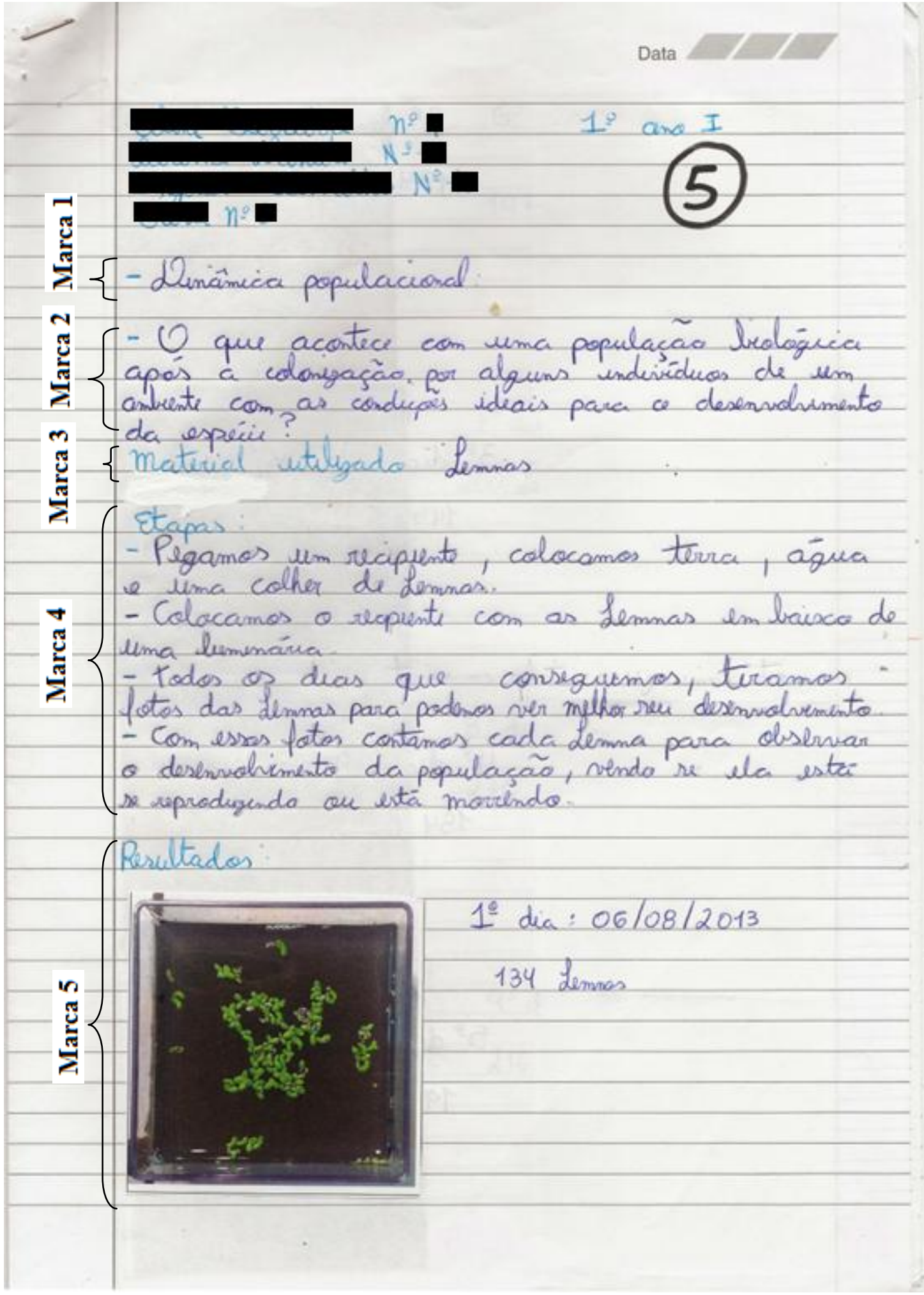


Thiago Marinho Del Corso

INDICADORES DE ALFABETIZAÇÃO CIENTÍFICA, ARGUMENTOS E EXPLICAÇÕES -

Análise de Relatórios no Contexto de uma Sequência de Ensino Investigativo

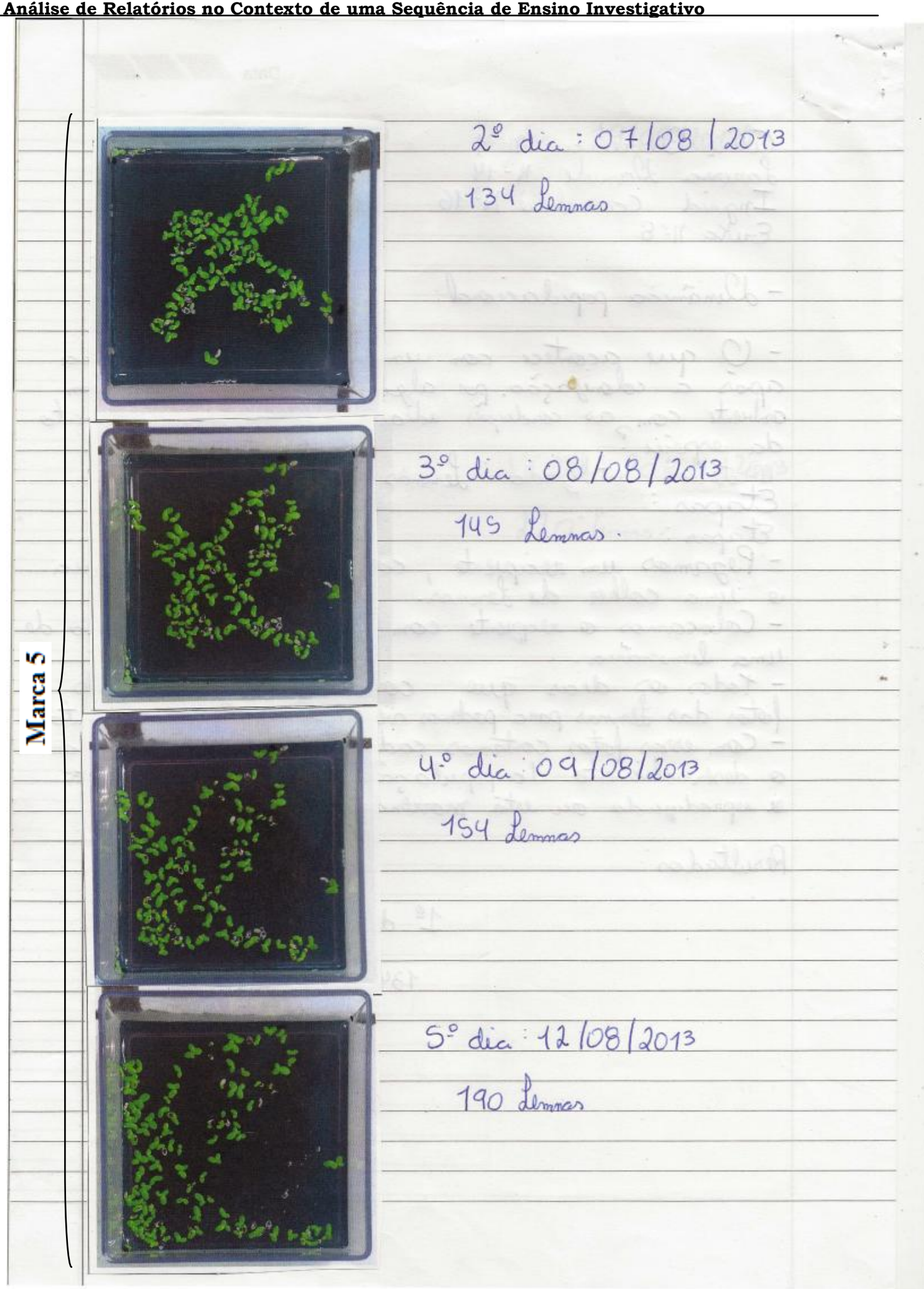


Thiago Marinho Del Corso

INDICADORES DE ALFABETIZAÇÃO CIENTÍFICA, ARGUMENTOS E EXPLICAÇÕES -

Análise de Relatórios no Contexto de uma Sequência de Ensino Investigativo

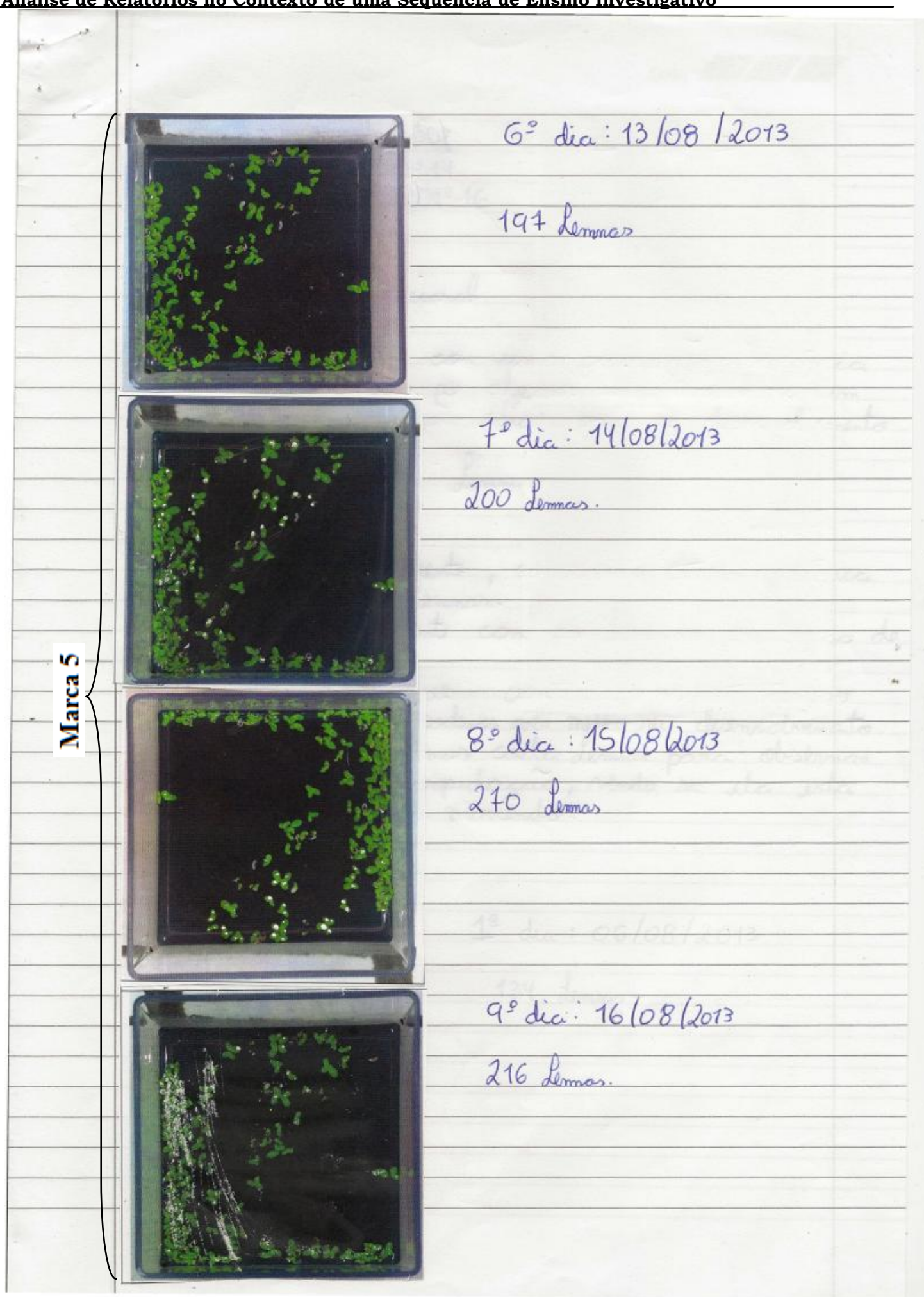


Thiago Marinho Del Corso

INDICADORES DE ALFABETIZAÇÃO CIENTÍFICA, ARGUMENTOS E EXPLICAÇÕES -

Análise de Relatórios no Contexto de uma Sequência de Ensino Investigativo

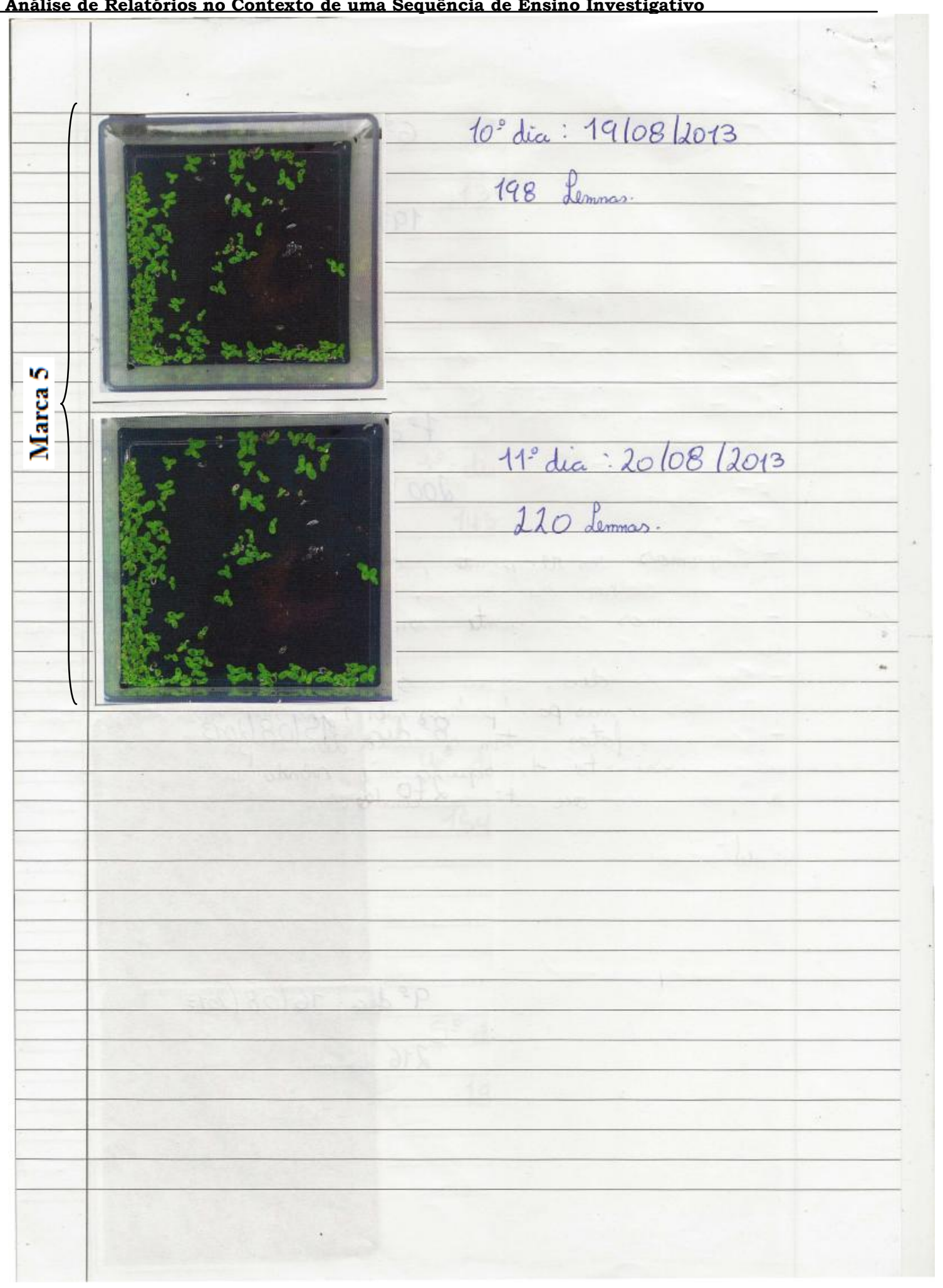


Thiago Marinho Del Corso

INDICADORES DE ALFABETIZAÇÃr

Análise de Relatórios no Contexto Marca 6 uência de Ensino Investigativo

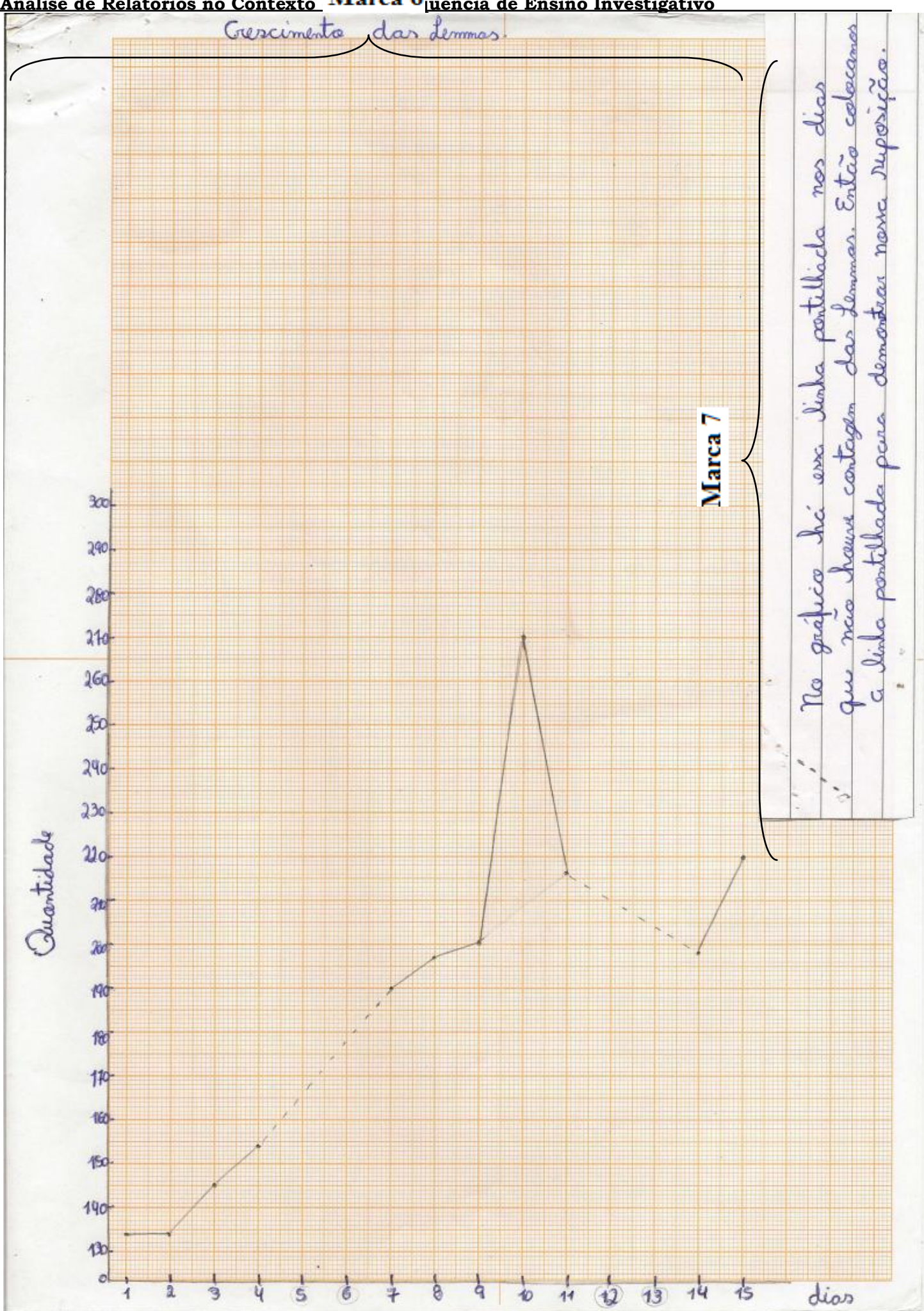


Thiago Marinho Del Corso

INDICADORES DE ALFABETIZAÇÃO CIENTÍFICA, ARGUMENTOS E EXPLICAÇÕES -

Análise de Relatórios no Contexto de uma Sequência de Ensino Investigativo

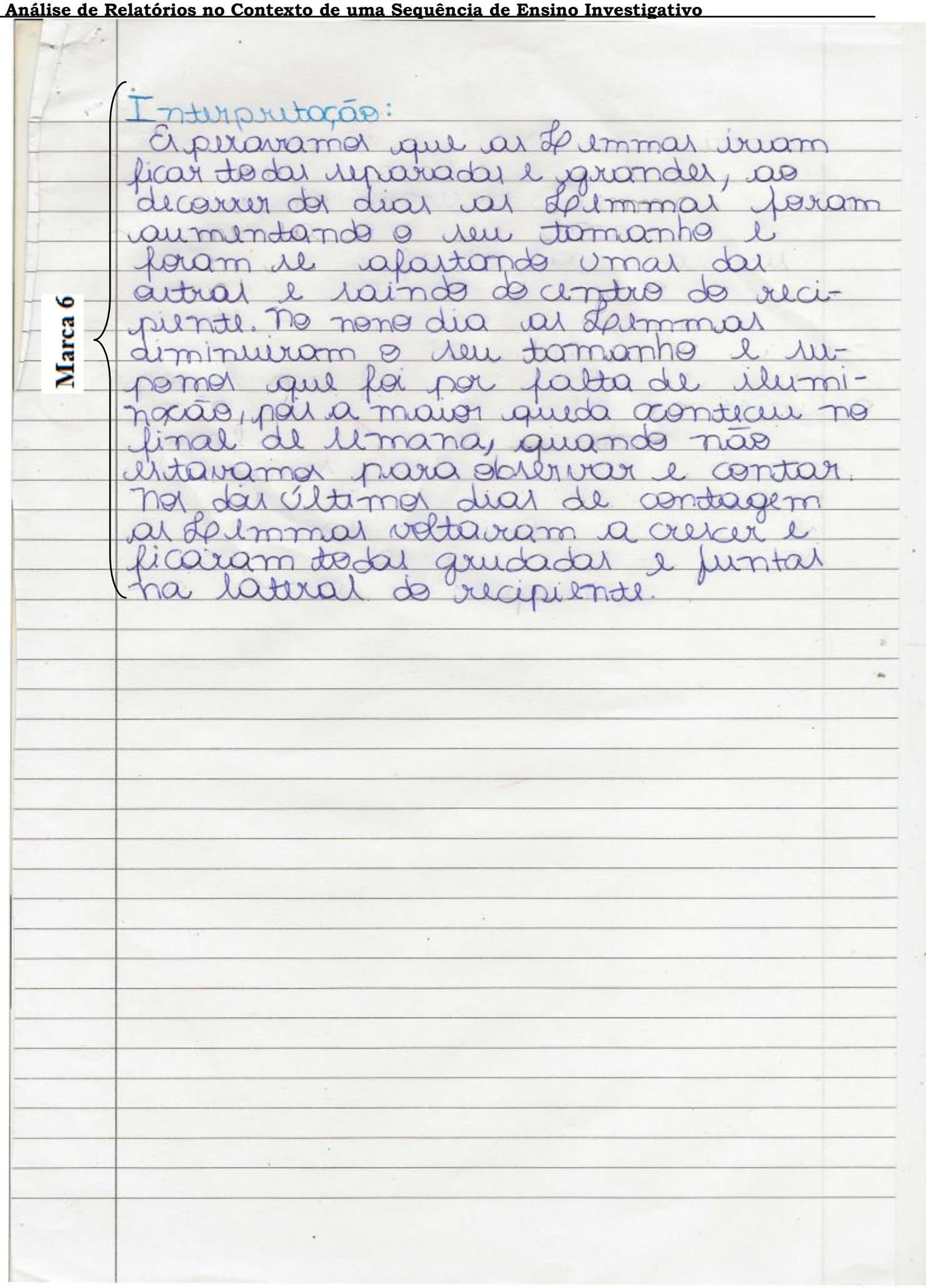


Análise de Relatórios no Contexto de uma Sequência de Ensino Investigativo

\section{Quadro 05 - Relatório 5 de 2013}

Identificação dos Indicadores de Alfabetização Científica no Relatório 5 de 2013 e conclusões individuais correspondentes.

\begin{tabular}{|c|c|c|c|c|c|c|c|c|c|c|c|c|c|}
\hline 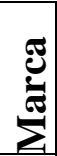 & $\begin{array}{l}\text { Subtítulo, } \\
\text { divisão ou } \\
\text { Item }\end{array}$ & Texto & $\mathbf{L M}$ & SI & OI & $\mathbf{C I}$ & \begin{tabular}{l|l|}
$\mathbf{R L P}$ \\
\end{tabular} & $\mathbf{L H}$ & TH & $\mathbf{J}$ & $\mathbf{P}$ & $\frac{a}{x}$ & $\sum_{4}^{\infty 00}$ \\
\hline 1 & Titulo & "Dinâmica populacional" & & & & & & & & & & & \\
\hline 2 & Pergunta & $\begin{array}{l}\text { "O que acontece com uma populaçãa bialógica após a colonizaçãa } \\
\text { por alguns individuas de um ambiente com as condiçäes ideais } \\
\text { para a desenvalvimenta das espécies?" }\end{array}$ & Nãc & $\mathrm{o}$ av & aliad & $\mathrm{o}$, te & xto da pr & rofes: & sora. & & & & \\
\hline 3 & $\begin{array}{l}\text { Metodologia } \\
\text { (Material } \\
\text { utilizada) }\end{array}$ & "Lemnas" & $\mathrm{X}$ & & & & & & & & & & \\
\hline 4 & $\begin{array}{l}\text { Metodologia } \\
\text { (Etapas) }\end{array}$ & 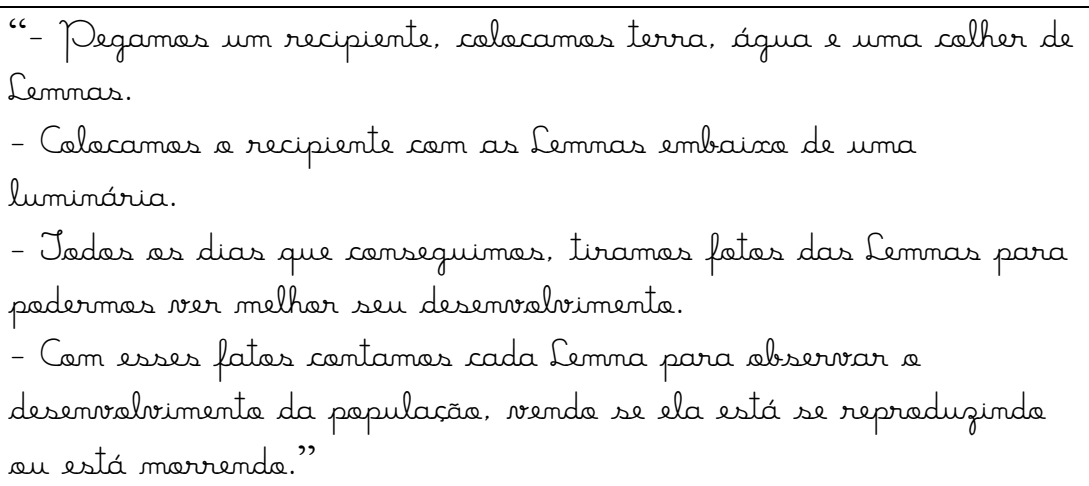 & $\mathrm{X}$ & & $\mathrm{X}$ & $\mathrm{X}$ & & & & & & & \\
\hline
\end{tabular}


INDICADORES DE ALFABETIZAÇÃO CIENTÍFICA, ARGUMENTOS E EXPLICAÇÕES -

Análise de Relatórios no Contexto de uma Sequência de Ensino Investigativo

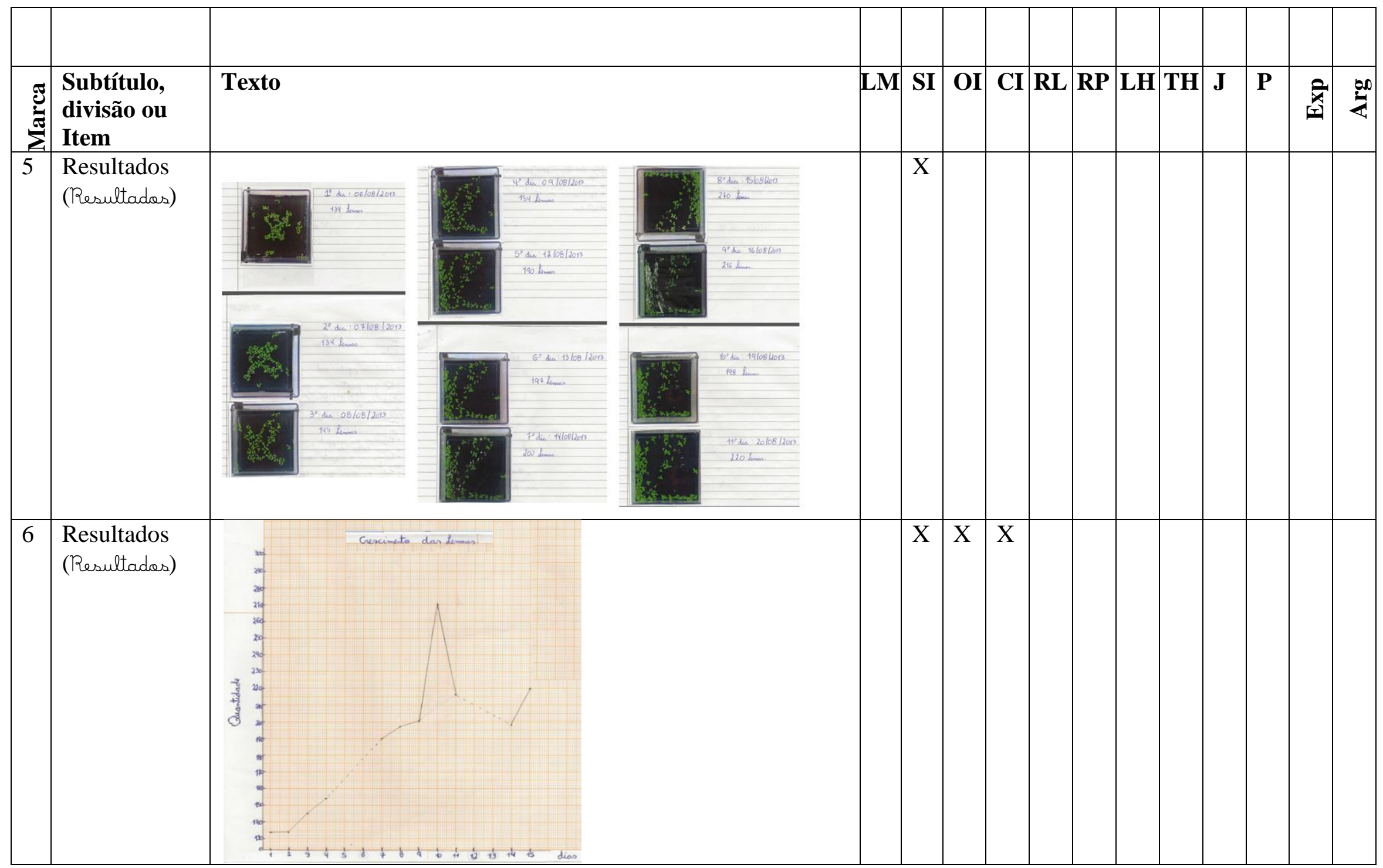


Thiago Marinho Del Corso

INDICADORES DE ALFABETIZAÇ̃̃O CIENTÍFICA, ARGUMENTOS E EXPLICAÇÕES -

Análise de Relatórios no Contexto de uma Sequência de Ensino Investigativo

\begin{tabular}{|c|c|c|c|c|c|c|c|c|c|c|c|c|c|}
\hline 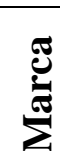 & $\begin{array}{l}\text { Subtítulo, } \\
\text { divisão ou } \\
\text { Item }\end{array}$ & Texto & $\mathbf{L M}$ & SI & OI & CI & RL RP & $\mathbf{L H}$ & TH & $\mathbf{J}$ & $\mathbf{P}$ & : & $\underset{Z}{\infty}$ \\
\hline 7 & $\begin{array}{l}\text { Resultados } \\
\text { (Resultados) }\end{array}$ & $\begin{array}{l}\text { "No gráfice há essa linha pontilhada mes dias que mãa houve } \\
\text { contagem das Lemnas. Então colocames a linha pontilhada para } \\
\text { demonstrar nossa suposiçãa" }\end{array}$ & & & & & & $X$ & & & & & \\
\hline 8 & $\begin{array}{l}\text { Interpretação } \\
\text { (Interpretaçã) }\end{array}$ & 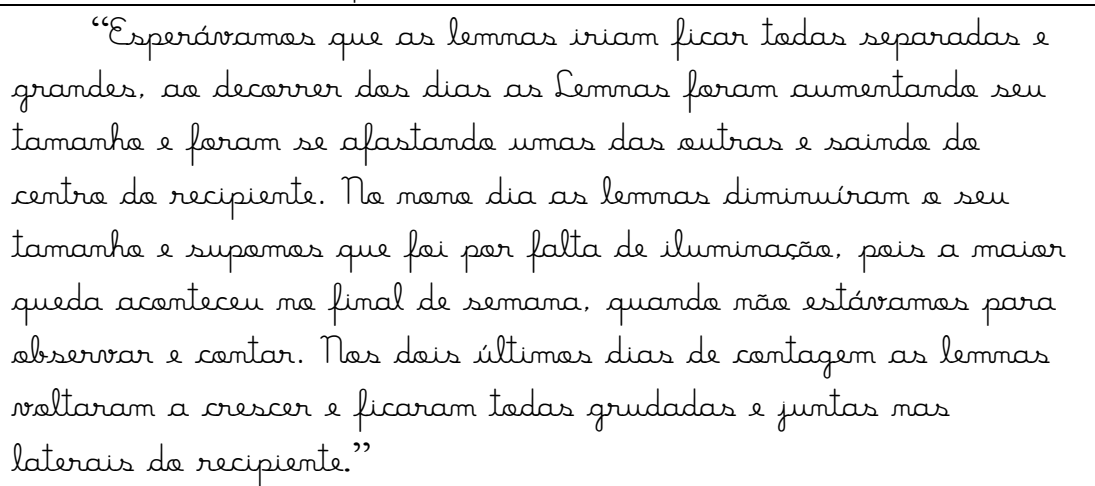 & & $X$ & & $X$ & & $X$ & & $\mathrm{X}$ & & & $X$ \\
\hline 9 & $\begin{array}{l}\text { Conclusão } \\
\text { individual } 1\end{array}$ & 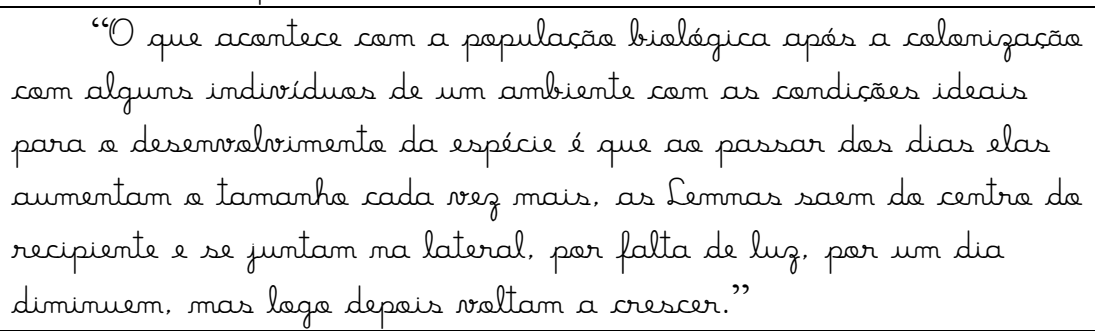 & & $\mathrm{X}$ & & & & & & $\mathrm{X}$ & $X$ & & \\
\hline 10 & $\begin{array}{l}\text { Conclusão } \\
\text { individual } 2\end{array}$ & 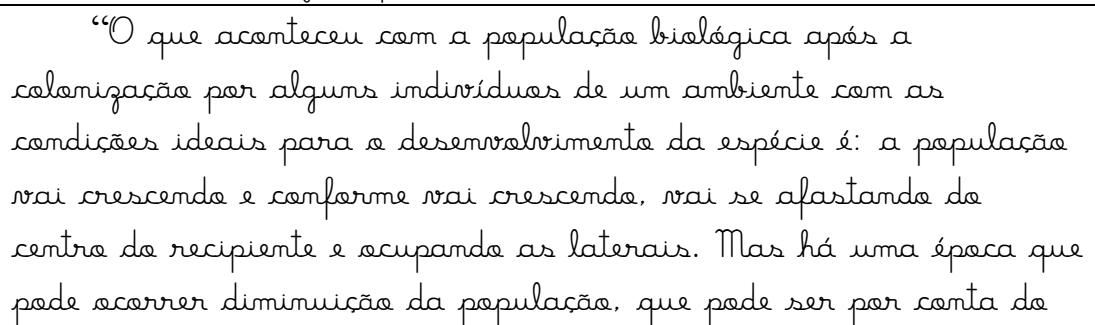 & & $X$ & & & & $\mathrm{X}$ & & $\mathrm{X}$ & $\mathrm{X}$ & & \\
\hline
\end{tabular}


Thiago Marinho Del Corso

INDICADORES DE ALFABETIZAÇ̃̃o CIENTÍFICA, ARGUMENTOS E EXPLICAÇÕES -

Análise de Relatórios no Contexto de uma Sequência de Ensino Investigativo

\begin{tabular}{|c|c|c|c|c|c|c|c|c|c|c|c|c|c|c|}
\hline & & $\begin{array}{l}\text { ambiente, que pode ter faltada iluminaçãa au algo do tipa. O ideal } \\
\text { que deve acontecer com a papulaçãa que está em um ambiente certa } \\
\text { para seu desenvolvimenta é a aumenta da espécie e do seu } \\
\text { tamanho e a afastamenta do centro, acupando as laterais." }\end{array}$ & & & & & & & & & & & & \\
\hline లై & $\begin{array}{l}\text { Subtítulo, } \\
\text { divisão ou } \\
\text { Item }\end{array}$ & Texto & $\mathbf{L M}$ & SI & $\mathbf{O I}$ & CI & RL & $\mathbf{R P}$ & LH & TH & $\mathbf{J}$ & $\mathbf{P}$ & $\underset{x}{a}$ & $\sum^{00}$ \\
\hline 11 & $\begin{array}{l}\text { Conclusão } \\
\text { individual } 3\end{array}$ & $\begin{array}{l}\text { "O que acontece com a populaçãa apés a colonizaçãa é que } \\
\text { cada dia muda as resultados, aumentanda as Lemnas cada dia que } \\
\text { passa, nos últimas dias de contagem as Lemnas voltaram a } \\
\text { crescer e ficaram tadas grudadas e juntas na lateral da } \\
\text { recipiente." }\end{array}$ & & $\mathrm{X}$ & & & & & & & & & & \\
\hline
\end{tabular}


Thiago Marinho Del Corso

INDICADORES DE ALFABETIZAÇÃO CIENTÍFICA, ARGUMENTOS E EXPLICAÇÕES -

Análise de Relatórios no Contexto de uma Sequência de Ensino Investigativo

Detalhamento da identificação dos indicadores de AC - Relatório 5 - 2013

Este quinto relatório se inicia, como todos os outros, com o nome dos integrantes do grupo, a série e o ano.

\section{Marca 1:}

A primeira construção dos alunos nesse relatório é o título -“Dinâmica populacional"- o qual não encontramos correspondência com nenhum indicador de Alfabetização Científica. Acreditamos que atribuir um título a um relatório ou trabalho científico seja prática importante na ciência e que por conseguinte também no ensino de ciências. Não que tenhamos a concepção de que o ensino de ciências vise formar cientistas como proposto na década de 1950-60 (KRASILCHICK, 200), mas acreditamos que passa pelo âmbito da Alfabetização Científica a atribuição de títulos aos relatórios e trabalhos escolares das disciplinas de ciências.

\section{Marca 2:}

A segunda marca no relatório 5 trata-se da pergunta proposta pela professora e por se tratar de texto apenas copiado pelos alunos não foi analisada.

\section{Marca 3:}

A terceira marca apresenta apenas um sub-título -"Material utilizade"- e o gênero da planta aquática utilizada na Sequência Didática Experimental Investigativa (SDEI) "Lemma"-. Não identificamos correspondência entre esta produção e algum dos indicadores Alfabetização Científica propostos por Sasseron (2008) e Sasseron e Carvalho (2008). Em um raciocínio semelhante à discussão da primeira marca acreditamos que, mesmo não existindo um roteiro áureo para relatórios de experimentos, uma subdivisão é prática comum na ciência, e a apresentação dos materiais utilizados também, daí entendermos haver aqui o indicador por nós proposto, de Listagem de materiais. Acreditamos que aqui os alunos demonstram familiaridade com a confecção de uma prática comum das ciências, mesmo tendo apresentado de forma falha os materiais utilizados no experimento. 


\section{Marca 4:}

Nesta quarta marca do relatório 5, transcrita abaixo, pudemos identificar os indicadores de Alfabetização Científica de Listagem de materiais, Organização de informações e Classificação de informações.

"Etapas

- Pegamos um recipiente, colocamos terra, água e uma colher de Lemnas.

- Colocamas a recipiente com as Lemnas embaixa de uma luminária.

- Todos as dias que conseguimas, tiramos fotos das Lemnas para podermos ver melhor seu desenvolvimenta.

- Com esses fatas contamos cada Lemna para ebservar a desenvolvimenta da papulacãa. vendo se ela está se reproduzindo ou está morrenda."

A Listagem de materiais é evidente nos seguintes trechos: " terra, água e uma colther de Semnas"-, "recipiente"-, "luminária"-e -" fotos"-. A Organização de informações ocorre pela descrição dos procedimentos adotados na montagem do experimento.

A Classificação de informações identificada está vinculada ao ultimo item desta marca, quando os alunos tentam estabelecer características para os dados ao caracterizar que irão observar no desenvolvimento da população se as Lemnas estão reproduzindo ou morrendo.

\section{Marca 5:}

Optamos por considerar todas as fotos e seus respectivos registros das contagens do número de indivíduos na população de Lemnas como uma única marca, para a qual entendemos estar ocorrendo uma Seriação de informações. Este indicador se caracteriza, de acordo com Sasseron (2008) e Sasseron e Carvalho (2008), "por ser uma lista ou relação dos dados trabalhados ou com os quais se vá trabalhar" e ao apresentar o número de indivíduos na população dia após dia consideramos isto uma espécie de listagem de dados. 


\section{Marca 6:}

A sexta marca foi atribuída ao gráfico construído pelos alunos com o número de indivíduos contados na população experimental em um eixo (y) e os dias de contagem no outro eixo (x). Os alunos traçaram retas ligando os pontos, as quais podiam ser contínuas ou pontilhadas segundo critério descrito por eles e analisado na próxima marca.

Como em todos os gráficos, acreditamos haver os indicadores de Seriação de informações, já que os dados são reapresentados, Organização de informações pela organização dos dados em uma diferente inscrição literária, o que pode ser entendido como uma preparação dos dados para posterior análise e finalmente a Classificação de informações quando são estabelecidas características para os dados, o traçar de retas ligando os pontos evidencia o estabelecimento de características.

\section{Marca 7:}

" No gráfica há essa linha pontilhada nos dias que nãe houve contagem das Lemnas. Entäa colocamos a linha pontilhada para demonstrar massa suposiçäa"

Os alunos consideram que ao ligar estes pontos estão fazendo uma suposição acerca de como se deu a variação populacional nos finais de semana e por conseguinte entendemos que por se tratar de suposição os alunos estão Levantando hipóteses.

\section{Marca 8:}

Sob a égide do sub-título - "Imterpretacãe"- temos o texto transcrito abaixo, no qual identificamos os indicadores de, Seriação de informações, Classificação de informações, Levantamento de hipóteses, Justificativa, Explicação e Argumento.

Neste parágrafo consideramos que quando os alunos dizem que as Lemnas ficam grandes ou estão aumentando ou diminuindo de tamanho na verdade os alunos estão se referindo ao crescimento populacional e não literalmente ao aumento do tamanho dos indivíduos. E assim estas afirmativas tornam-se dados acerca da variação populacional, e consecutivamente evidenciam uma Seriação de informações -“as Lemnas foram 
aumentanda seu tamanha"-, " "la nona dia as lemnas diminuiram a seu tamanha"- e -"

Tos dois últimas dias de contagem as lemnas voltaram a crescer"-.

Ainda considerando esse equivoco na forma de se expressar, entendemos que quando os alunos expressam que -"a maior queda aconteceu me final de semana"-, eles estão estabelecendo características para os dados.

O Levantamento de hipóteses é verificado logo no início do parágrafo quando os alunos dizem que - "Esperávamas que as Lemnas iriam ficar todas separadas e grandes"-Este indicador se caracteriza pela ação de levantar suposições, o que esses alunos afirmam que fizeram. Também consideramos haver o Levantamento de hipóteses quando os alunos dizem que -"supomas que foi por falta de iluminacãa"-.

A Justificativa aparece aqui como uma tentativa de dar garantia a hipótese dos alunos de que a falta de iluminação é que causou a diminuição da população. Quando os alunos afirmam que - "pois a maior queda aconteceu ne final de semana"- eles estão tentando legitimar sua hipótese.

Acreditamos que no momento em que os alunos fazem considerações sobre o que ocorreu no nono dia temos um Argumento, já que há uma afirmativa e a tentativa de defende-la. Neste caso a Conclusão (C) é menos certa que as premissas que levaram a ela, o que é característico de um Argumento e não de uma Explicação.

O Argumento reestruturado fica assim apresentado:

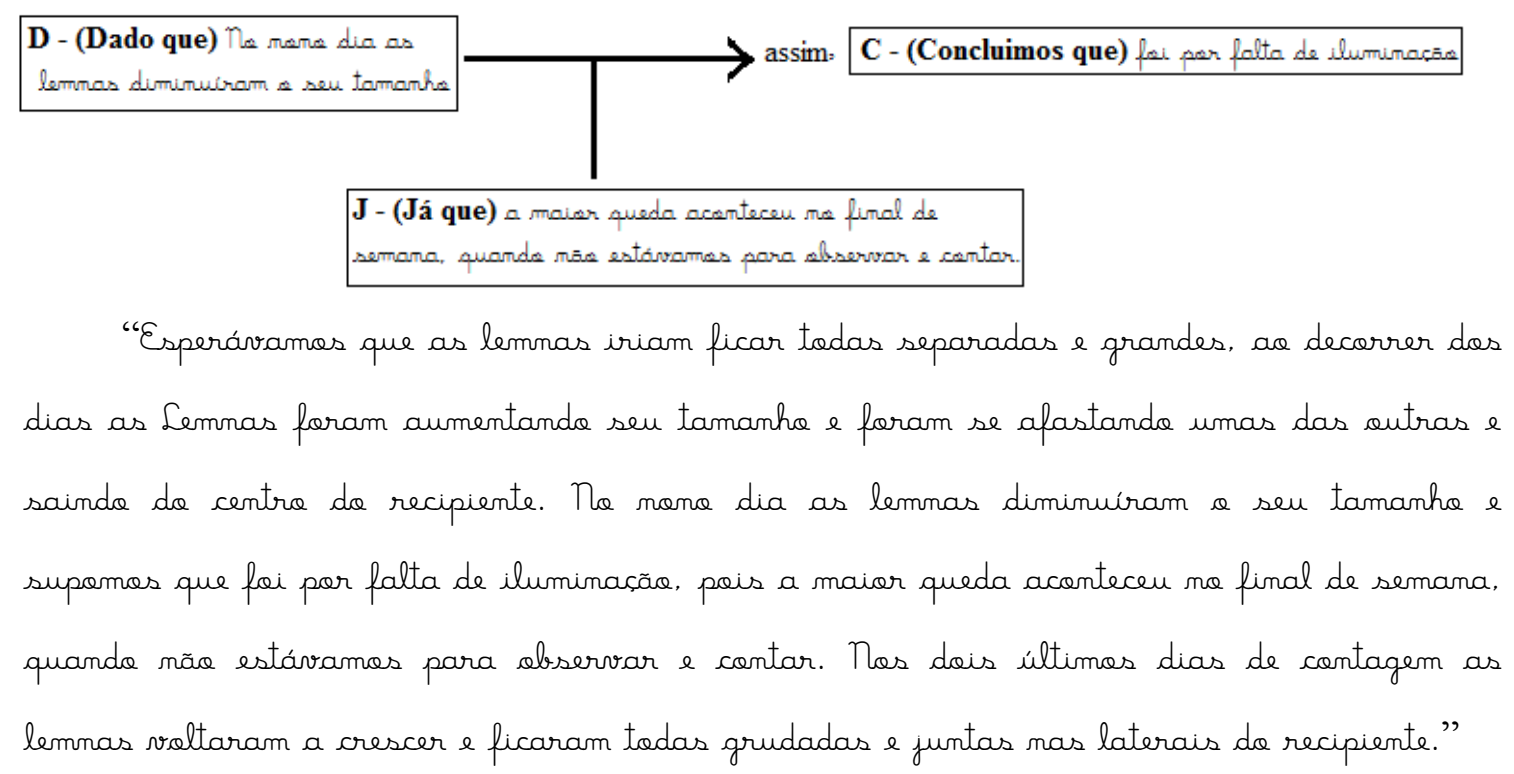




\section{Marca 9:}

A primeira conclusão individual do relatório 5, que segue transcrita, apresenta os indicadores de Seriação de informações, Justificativa e Previsão.

"O que acontece com a populascãa bialágica apás a colonizaçãa com alguns indivíduas de um ambiente com as condis̄ees ideais para a desenvolvimenta da espécie é que ae passar das dias elas aumentam a tamanho cada vez mais, as Lemnas saem da centra do recipiente e se juntam na lateral, por falta de luz, por um dia diminuem, mas logo depais voltam a crescer."

Ao apresentar o que acontece com a população de Lemnas ao longo do tempo os alunos estão listando dados - "ae passar dos dias elas aumentam a tamanho cada vez mais (se referindo ao aumento da população e não dos indivíduos em si)"-, também com -"diminuem,"- e -"crescer."-. Listar dados está relacionado ao indicador de Seriação de informações.

A Justificativa é desenvolvida para a afirmação de que as Lemnas apresentam uma diminuição em algum momento do experimento e que isso se deveu a -"por falta de luz"-. Assim a falta de luz é a Justificativa para o fenômeno.

A Previsão apresentada pelos alunos é que quando em um ambiente com condições ideais as populações vão aumentar, mesmo que em alguns momentos hajam diminuições, no compito geral elas aumentarão -"O que acontece com a papulacãa bialógica após a colonizacãa com alguns individuas de um ambiente com as condicáes ideais para a desenvolvimento da espécie é que ar passar dos dias elas aumentam"--

\section{Marca 10:}

A segunda conclusão individual do relatório 5 apresenta os indicadores de Seriação de informações, Levantamento de Hipóteses, Justificativa, Previsão e Explicação.

A Seriação de informações, caracterizada segundo Sasseron e Carvalho (2008) por se constituir em uma lista de dados com os quais se vai trabalhar, aparece neste trecho quando os alunos afirmam que a população de Lemnas está -“crescenda"-, pode ocorrer -"diminuiçäe"- e -"aumente"-. Como discutido anteriormente estes termos configuram-se como dados quando o tema é dinâmica populacional. 
O Levantamento de hipóteses se dá quando o aluno diz que - "há uma época que pode ecorrer diminuicãa da populaçãe"-. De acordo com Sasseron e Carvalho (2008) o

Levantamento de hipóteses ocorre nos momentos em que são feitas suposições acerca de certo tema e podem surgir como afirmações. São apresentadas duas Justificativas para esta hipótese -"pode ser por conta do ambiente"- e -"pode ter faltado iluminaçãa ou alga do tipa"'-.

A Previsão está relacionada com a afirmação do aluno de que: -"O ideal que deve acontecer com a população que está em um ambiente certa para seu desenvolvimento é a aumenta da espécie e do seu tamanho e a afastamento do centro, ocupando as laterais."-. Isso, pois este indicador é explicitado quando se afirma que um fenômeno se sucederia associado a certos acontecimentos. Os acontecimentos aqui seriam a colocação de indivíduos em um ambiente certo para seu desenvolvimento (o que na pergunta comanda dada pela professora é chamado de ambiente ideal para o desenvolvimento), o que se sucederia a esses acontecimentos é que a população apresentaria crescimento e o afastamento do centro e ocupação das laterais.

"O que aconteceu com a populașãa bialógica após a colonizaçãa par algurs individuas de um ambiente com as condișaes ideais para a desenvolvimenta da espécie é: a populaçãa vai crescenda e conforme vai crescenda, vai se afastanda do centro da recipiente e ocupanda as laterais. Mas há uma época que pode ocorrer diminuișãa da papulasaao, que pade ser por conta do ambiente, que pade ter faltada iluminaçãa an alga do tipa. $O$ ideal que deve acontecer com a populasãa que está em um ambiente certa para seu desenvalvimenta é a aumenta da espécie e da seu tamanho e a afastamenta do centra. ocupando as laterais.".

\section{Marca 11:}

A terceira e ultima conclusão individual do relatório 5 apresenta apenas o indicador de Seriação de informações. Este indicador, como apresentado anteriormente, se configura numa relação de dados, que aqui, devido à natureza da investigação ser a dinâmica populacional, configuram-se em -"aumentando"- e -"soltam a crescer"- em relação ao tamanho populacional ao longo da investigação. 
Thiago Marinho Del Corso

INDICADORES DE ALFABETIZAÇ̃̃O CIENTÍFICA, ARGUMENTOS E EXPLICAÇÕES -

Análise de Relatórios no Contexto de uma Sequência de Ensino Investigativo

"O que acontece com a populasãa apés a colonizaçãa é que cada dia muda as resultados. aumentanda as Lemnas cada dia que passa, nos últimas dias de contagem as Lemnas voltaram a crescer e ficaram todas grudadas e juntas na lateral do recipiente." 
Thiago Marinho Del Corso

INDICADORES DE ALFABETIZAÇÃO CIENTÍFICA, ARGUMENTOS E EXPLICAÇÕES -

Análise de Relatórios no Contexto de uma Sequência de Ensino Investigativo

O Relatório 6 - 2013

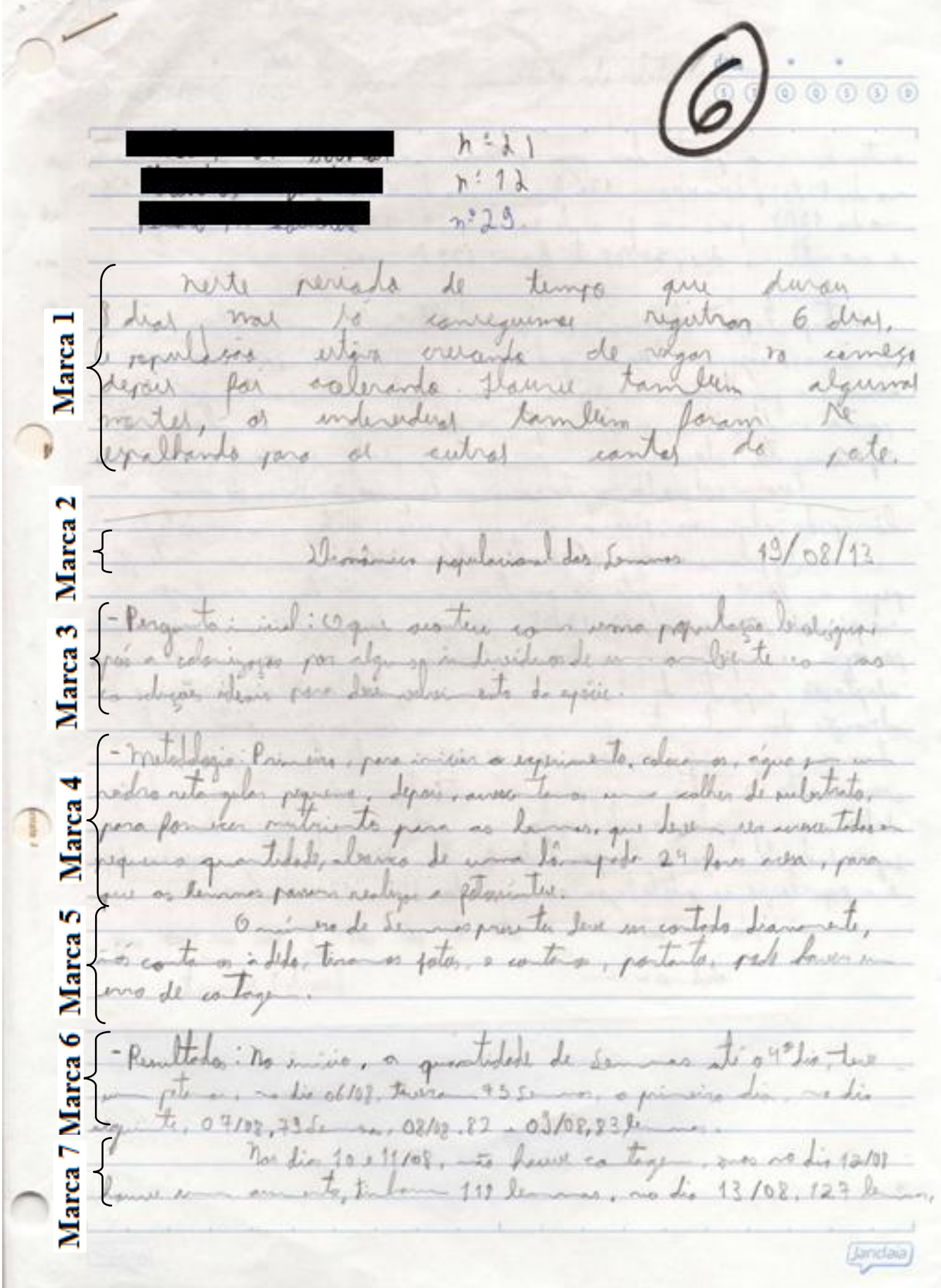


Thiago Marinho Del Corso

INDICADORES DE ALFABETIZAÇ̃̃O CIENTÍFICA, ARGUMENTOS E EXPLICAÇÕES -

Análise de Relatórios no Contexto de uma Sequência de Ensino Investigativo

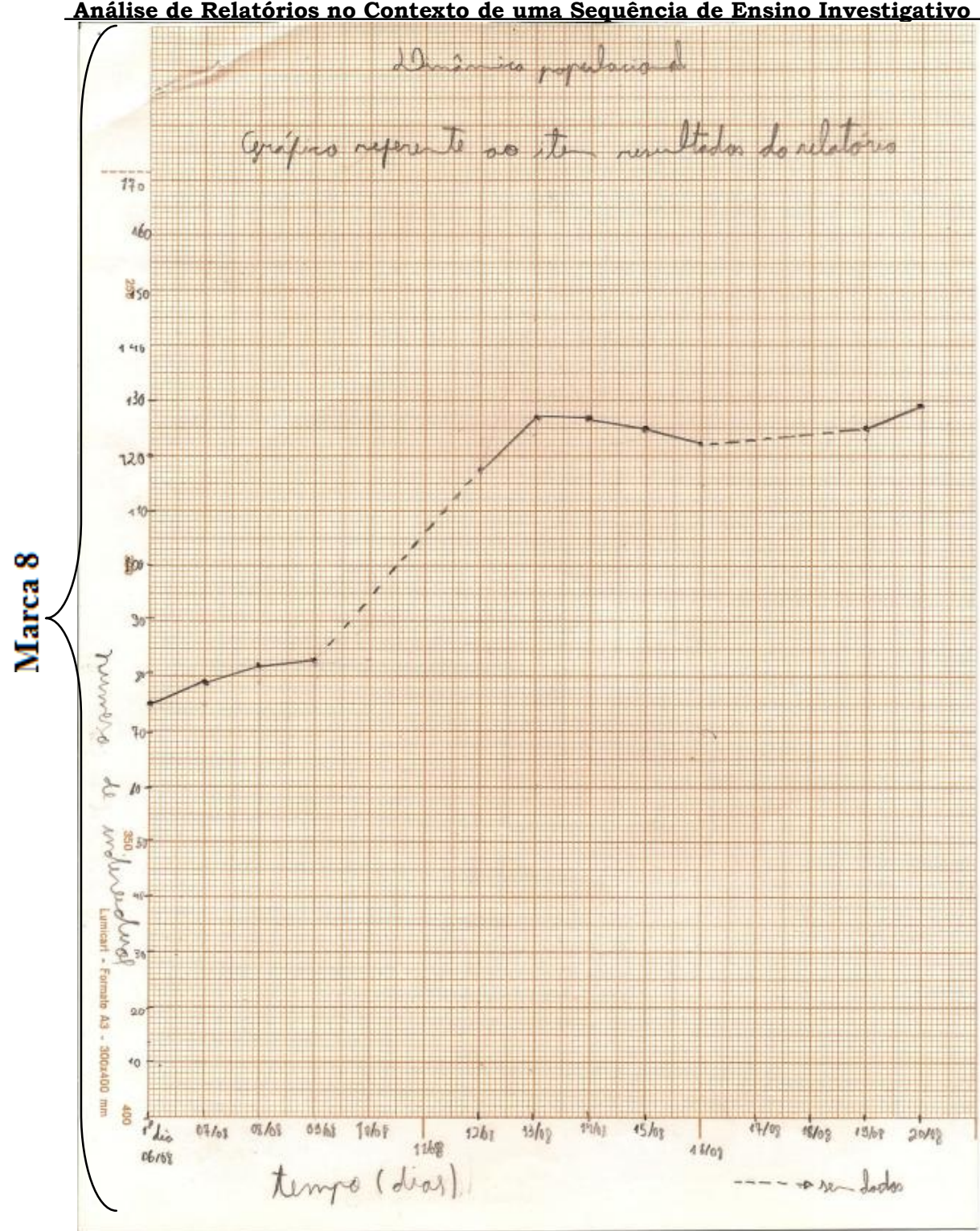




\section{$\frac{\text { data } \cdot \cdots}{\text { (5) (1) (1) (4) (5) (5) (2) }}$}

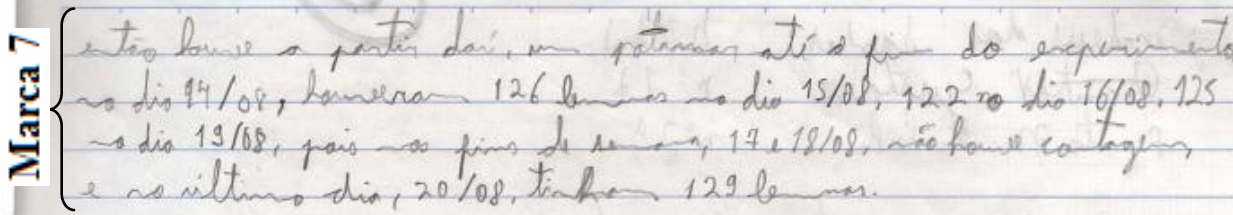

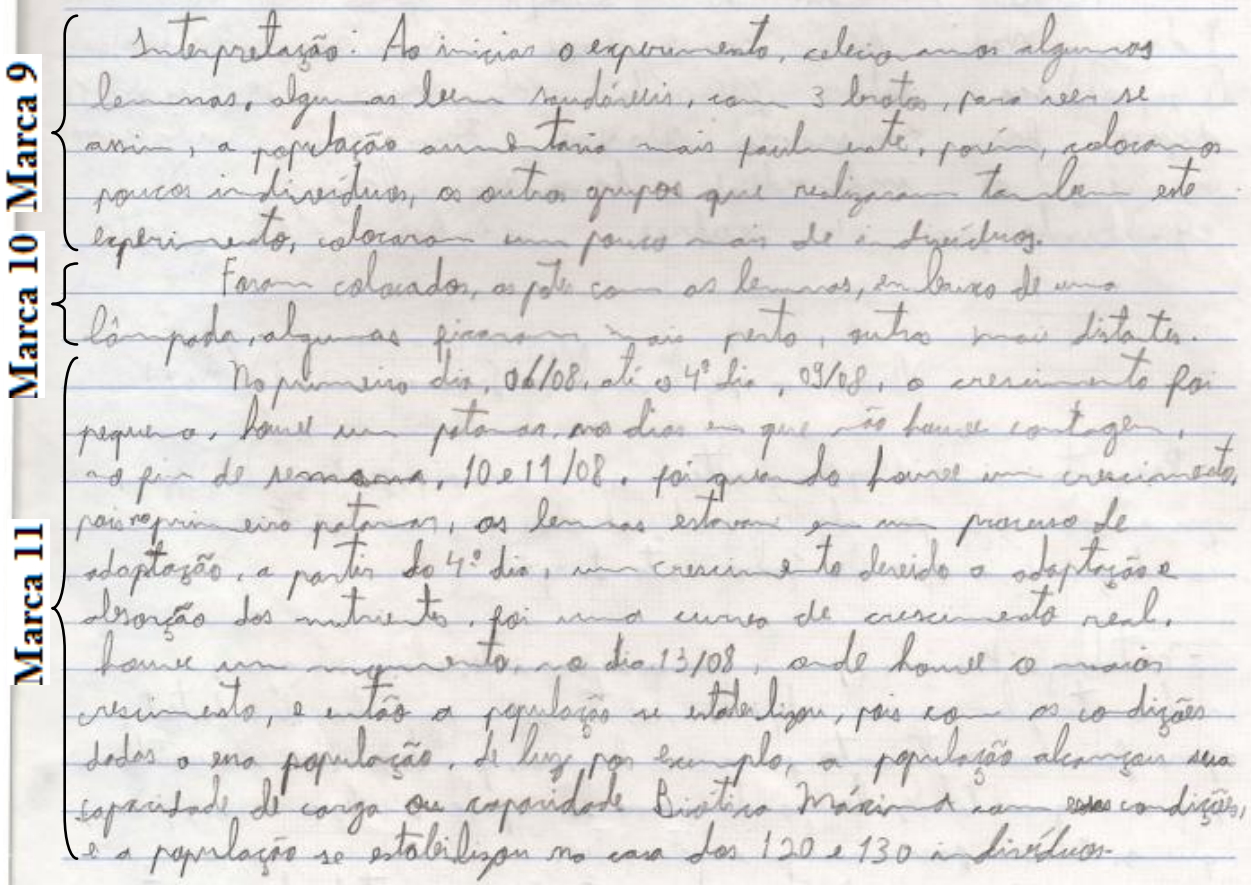


Thiago Marinho Del Corso

INDICADORES DE ALFABETIZAÇ̃̃o CIENTÍFICA, ARGUMENTOS E EXPLICAÇÕES -

Análise de Relatórios no Contexto de uma Sequência de Ensino Investigativo

\section{Quadro 06 - Relatório 6 de 2013}

Identificação dos Indicadores de Alfabetização Científica no Relatório 6 de 2013 e conclusões individuais correspondentes

\begin{tabular}{|c|c|c|c|c|c|c|c|c|c|c|c|c|c|}
\hline 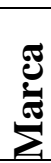 & $\begin{array}{l}\text { Subtítulo, } \\
\text { divisão ou } \\
\text { Item }\end{array}$ & Texto & $\mathbf{L M}$ & SI & $\mathbf{O I}$ & $\mathbf{C I}$ & $\mathbf{R L} \mathbf{R P}$ & $\mathbf{L H}$ & TH & $\mathbf{J}$ & $\mathbf{P}$ & 䒽 & $\sum^{\infty}$ \\
\hline 1 & & 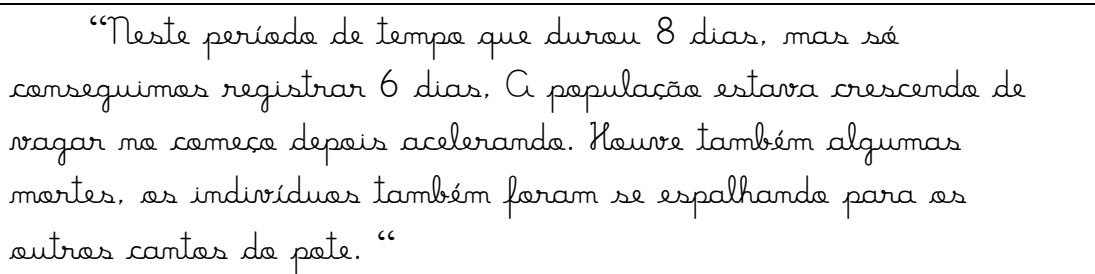 & & $X$ & $X$ & $X$ & & & & & & & \\
\hline 2 & Título & "Dinâmica populacional das Lemnas" & & & & & & & & & & & \\
\hline 3 & Pergunta & 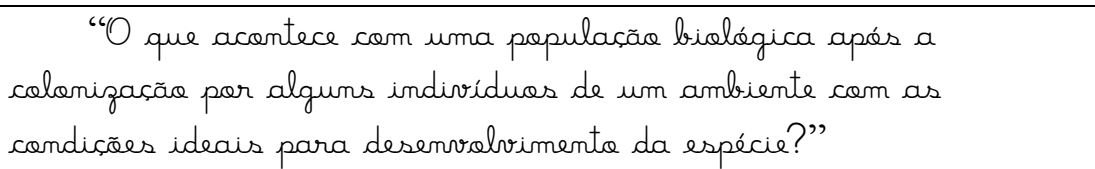 & Não & $\mathrm{av}$ & aliad & t & xto da pr & ofes & sora. & & & & \\
\hline 4 & $\begin{array}{l}\text { Metodologia } \\
\text { (Metodologia) } \\
1^{\circ} \text { parágrafo }\end{array}$ & $\begin{array}{l}\text { "Primeira, para iniciar a experimenta, colocamos água em } \\
\text { um vidra retangular pequena, depois, acrescentamas uma colher de } \\
\text { substrata, para fornecer nutrientes para as lemnas, que devem } \\
\text { ser acrescentadas em pequena quantidade, abaixa de uma lâmpada } \\
24 \text { horas acesa, para que as lemnas possam realizar a } \\
\text { fotassintese." }\end{array}$ & $X$ & & $X$ & & & & & $X$ & & & \\
\hline 5 & $\begin{array}{l}\text { Metodologia } \\
\text { (Metodologia) } \\
2^{\circ} \text { parágrafo }\end{array}$ & $\begin{array}{l}\text { "O númera de Lemnas presentes deve ser contada diariamente, } \\
\text { nós contamas a deda, tiramos fotas e contamos, portanta pade } \\
\text { haver um erra de contagem." }\end{array}$ & & & $X$ & & & $X$ & & & & & \\
\hline 6 & $\begin{array}{l}\text { Resultados } \\
\text { (Resultados) }\end{array}$ & $\begin{array}{l}\text { "No inicia, a quantidade de Lemnas até a } 4 \text { a dia, teve um } \\
\text { patamar, ne dia } 06 / 08 \text { tiveram } 75 \text { Lemnas, a primeira dia, no }\end{array}$ & & $X$ & $X$ & & & & & & & & \\
\hline
\end{tabular}


Thiago Marinho Del Corso

INDICADORES DE ALFABETIZAÇ̃̃O CIENTÍFICA, ARGUMENTOS E EXPLICAÇÕES -

Análise de Relatórios no Contexto de uma Sequência de Ensino Investigativo

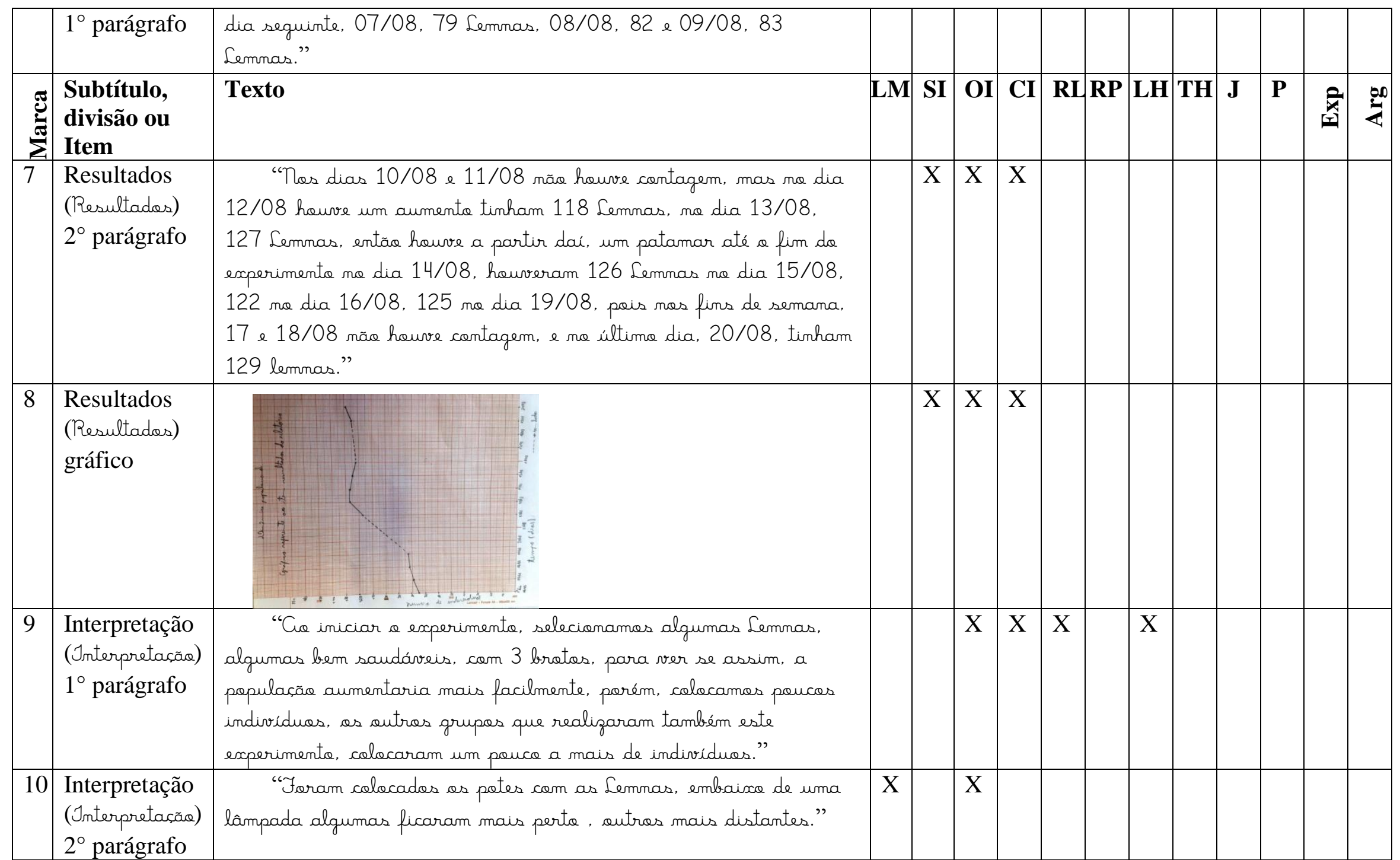


Thiago Marinho Del Corso

INDICADORES DE ALFABETIZAÇ̃̃O CIENTÍFICA, ARGUMENTOS E EXPLICAÇÕES -

Análise de Relatórios no Contexto de uma Sequência de Ensino Investigativo

\begin{tabular}{|c|c|c|c|c|c|c|c|c|c|c|c|c|c|c|}
\hline 11 & $\begin{array}{l}\text { Interpretação } \\
\text { (Jnterpretaçãa) } \\
3^{\circ} \text { parágrafo }\end{array}$ & 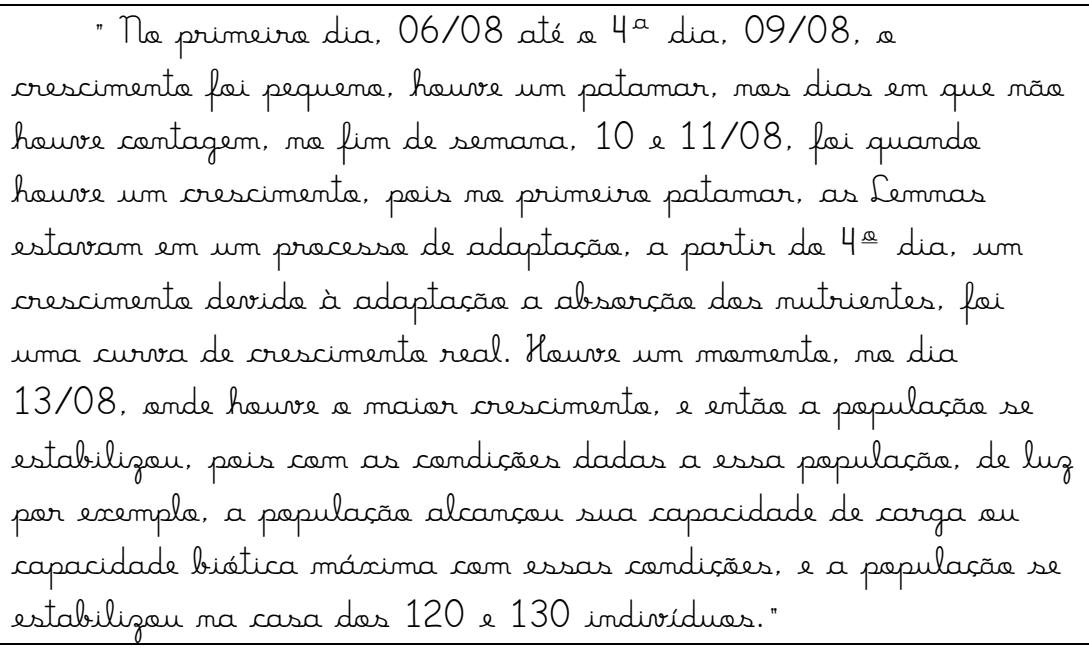 & & X & $X$ & $X$ & & & & & $X$ & & X & \\
\hline 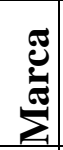 & $\begin{array}{l}\text { Subtítulo, } \\
\text { divisão ou } \\
\text { Item }\end{array}$ & Texto & $\mathbf{L M}$ & SI & $\mathbf{O I}$ & $\mathbf{C I}$ & $\mathbf{R L}$ & $\mathbf{R P}$ & $\mathbf{L H}$ & TH & $\mathbf{J}$ & $\mathbf{P}$ & 商 & $\underset{4}{20}$ \\
\hline 12 & Conclusão 1 & 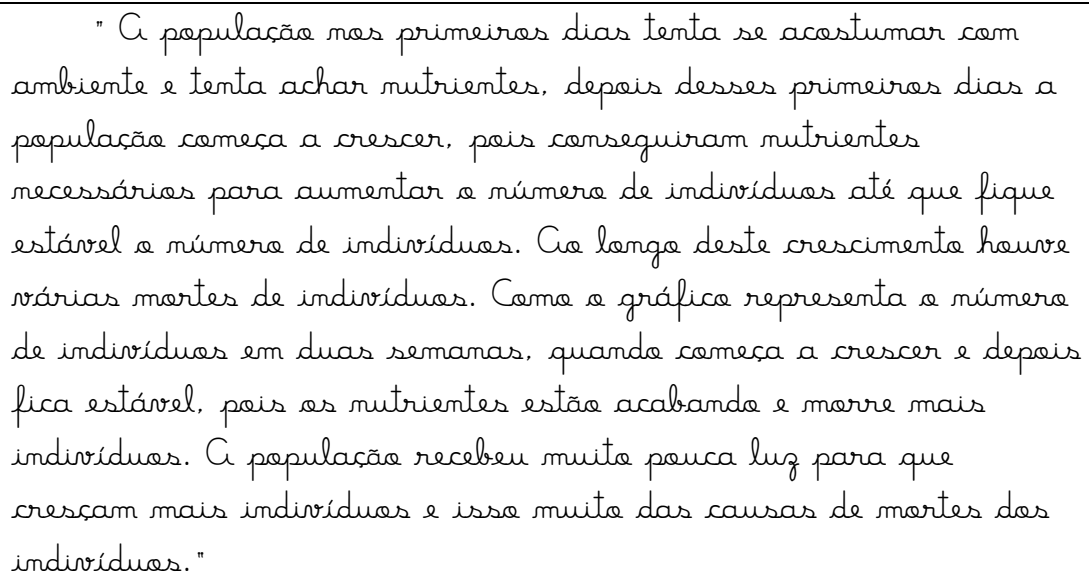 & & $\mathrm{X}$ & $\mathrm{X}$ & & & & & & $\mathrm{X}$ & & $X$ & \\
\hline
\end{tabular}


Thiago Marinho Del Corso

INDICADORES DE ALFABETIZAÇÃO CIENTÍFICA, ARGUMENTOS E EXPLICAÇÕES -

Análise de Relatórios no Contexto de uma Sequência de Ensino Investigativo

\begin{tabular}{|c|c|c|c|c|c|c|c|c|c|c|c|c|c|c|}
\hline$\sum^{\mathbb{3}}$ & $\begin{array}{l}\text { Subtítulo, } \\
\text { divisão ou } \\
\text { Item }\end{array}$ & Texto & $\mathbf{L M}$ & SI & $\mathbf{O I}$ & CI & RL & $\mathbf{R P}$ & $\mathbf{L H}$ & TH & $\mathbf{J}$ & $\mathbf{P}$ & 商 & $\sum^{00}$ \\
\hline 13 & Conclusão 2 & 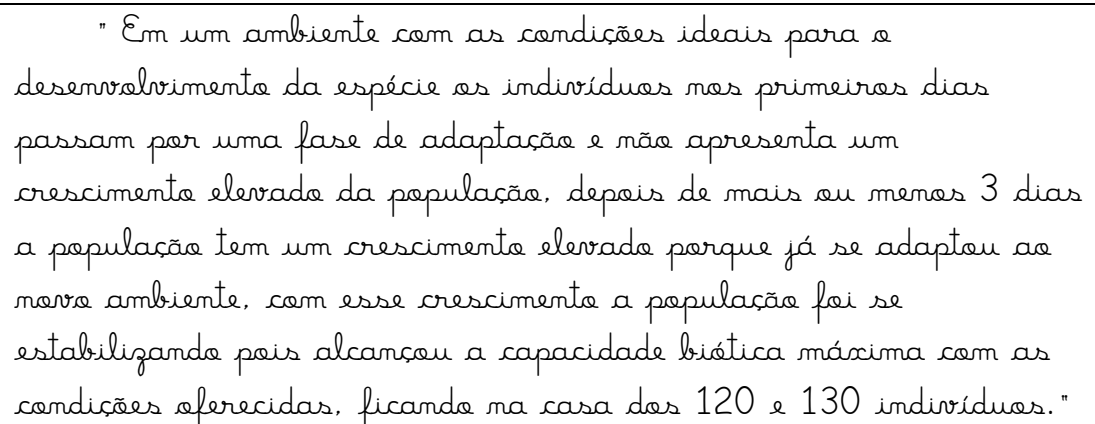 & & $\mathrm{X}$ & $\mathrm{X}$ & $\mathrm{X}$ & $\mathrm{X}$ & & & & $\mathrm{X}$ & & $\mathrm{X}$ & \\
\hline
\end{tabular}




\section{Marca 1:}

Este relatório apresenta um parágrafo antes do título e logo após os nomes dos membros do grupo. Neste parágrafo, que não foi considerado sob nenhum subtítulo, encontramos o indicador de Alfabetização Científica de Seriação de informações, quando os alunos apresentam dados -"populacão estava crescende"-, -"depeis acelerande"-, - "Houve também algumas mortes"- e -"es individuas também foram se espalhando para as autras cantas do pate"-.

Encontramos também o indicador de Organização de informações, quando os alunos dividem este período em dois momentos com diferentes padrões de variação populacional das Lemnas no que pode ser entendido como uma preparação dos dados para um posterior desenvolvimento do assunto, também pela descrição sobre como o trabalho foi realizado.

A Classificação de informações ocorre pela atribuição de intensidade aos dois períodos de crescimento, no primeiro -“devagar"- e no segundo -"aceleranda"-Entendemos, como discutido em relatórios anteriores, que trata-se de um estabelecimento de características, o que é típico deste indicador.

Abaixo segue o parágrafo completo:

"Neste períada de tempa que durau 8 dias, mas só conseguimas registrar 6 dias, A populaçãa estava crescenda de vagar no comesce depois aceleranda. Houve também algumas mortes, as individuos também foram se espalhando para es outros cantos do pote."

\section{Marca 2:}

Colocar um título, apesar de pratica epistêmica típica das ciências, não se encaixa em nenhum dos indicadores de Alfabetização Científica.

\section{Marca 3:}

Por se tratar de texto da professora e estarmos avaliando as produções dos alunos esta pergunta geradora não será avaliada. 


\section{Marca 4:}

O primeiro parágrafo da metodologia apresenta o indicador Listagem de materiais, Organização de informações e Justificativa. O ultimo desses aparece em dois trechos diferentes deste parágrafo - "para formecer nutrientes para as lemnas" - e "para que as lemnas possam realizar a fatossintese.". Estas Justificativas visam dar garantias respectivamente para as seguintes afirmações - "acrescentamos uma colher de substrate" - e - "abaixa de uma lâmpada 24 horas acesa"-.

A Listagem de materiais ocorre quando os alunos estão listando os materiais utilizados: -" água"-, -" vidra retangular pequene"-, -"uma colher de substrate"- e "lâmpada"-. A Organização de informações pela descrição dos procedimentos adotados para montar o experimento.

Abaixo segue o texto completo:

"Primeira, para iniciar a experimenta, colocamos água em um vidra retangular pequeno, depois, acrescentames una colher de substrato, para fornecer nutrientes para as lemnas, que devem ser acrescentadas em pequena quantidade, abaixa de uma lâmpada 24 horas acesa, para que as lemnas possam realizar a fotossíntese.".

\section{Marca 5:}

O segundo parágrafo da metodologia, que segue transcrito abaixo, apresenta os indicadores de Organização de informações e Levantamento de hipóteses. Entendemos que quando os alunos escrevem que -" poertanto pode haver um erro de contagem." - estes estão alçando suposições, o que é indicador de um Levantamento de hipóteses e quando descrevem os procedimentos adotados estão Organizando informações.

"O número de Lemnas presentes deve ser contado diariamente, nés contamos a deda. tiramos fotas e contamos, portante pode haver um erro de contagem." 


\section{Marca 6:}

O primeiro parágrafo dos resultados do relatório seis segue transcrito abaixo e apresentou o indicador de Seriação de informações. Este indicador se evidencia na lista de dados apresentada, número de Lemnas na população a cada dia.

"To inície, a quantidade de Lemnas até a 4 e dia, teve um patamar, no dia 06/08 tiveram 75 Lemnas, a primeira dia, ne dia seguinte, 07/08, 79 Lemnas, 08/08, 82 e 09/08, 83 Lemnas."

\section{Marca 7:}

O segundo parágrafo, transcrito abaixo, dos resultados do relatório 6 apresentou os indicadores de Seriação e Organização informações.

"Mas dias 10/08 e 11/08 nãe houve contagem, mas me dia 12/08 houve um aumenta tinham 118 Lemnas, ne dia 13/08, 127 Lemnas, entãa houve a partir daí, um patamar até a fim da experimenta na dia 14/08, houveram 126 Lemnas na dia 15/08, 122 me dia 16/08, 125 me dia 19/08, pais mas firs de semana, 17 e 18/08 mãa houve contagem, e ne últime dia, 20/08, timham 129 lemnas."

A Seriação de informações acontece com a apresentação dos dados, ou seria do numero de indivíduos na população de Lemnas, contados diariamente, aqui a partir do dia 10/08 e até 20/08. A Organização das informações deriva da cronologia de apresentação dos dados e da divisão em períodos, sendo o primeiro de crescimento e depois patamar (estabilização populacional).

\section{Marca 8:}

Os resultados do relatório 6 se encerram com a apresentação do gráfico construído pelos alunos, e que, como apresentado nos relatórios anteriores, se configura como Seriação, Organização e Classificação de informações. 


\section{Marca 9:}

O primeiro parágrafo da interpretação, abaixo transcrito, do relatório 6 apresenta o indicador de Organização de informações, Levantamento de hipóteses e Raciocínio lógico.

"Ca iniciar a experimenta, selecionamas algumas Lemnas, algumas bem saudáveis. com 3 bratos, para ver se assim, a populasãa aumentaria mais facilmente, porém. colocamas poucos individuas, es outros grupos que realizaram também este experimenta. colocaram um pauca a mais de individuas."

A Organização de informações volta a se fazer presente relacionada à descrição dos procedimentos adotados durante o trabalho realizado. O Levantamento de hipóteses se verifica neste trecho na suposição feita pelos alunos que a escolha de Lemnas -"bem saudáveis, com 3 bratas"- para serem as fundadoras da nova população ocasionaria um -"aumenta mais fácil"- da população.

Identificamos o Raciocínio lógico nesta marca pela exposição clara do raciocínio perpetrado pelos alunos, ao qual podemos fazer uma correspondência com o padrão hipotético dedutivo de Lawson (2000) como segue apresentado:

\footnotetext{
"[se] Co iniciar a experimenta, selecionamas algumas Lemnas, algumas bem saudáveis, com 3 bratos, para ver se assim, a população aumentaria mais facilmente, porém, [então] colocamos poucos individuos. [portanto] as outros grupos que realizaram também este experimenta, colocaram um pouce a mais de individuas.".
}

\section{Marca 10}

Esta décima marca do relatório seis apresenta indicadores de Listagem de materiais e Organização de informações. O primeiro destes por retomar que - "potes"e - "Lemnas"- foram utilizados e o segundo destes por descrever procedimentos do trabalho.

"Foram colocados as potes com as Lemnas, embaixa de uma lâmpada algumas ficaram mais perta , autros mais distantes.". 


\section{Marca 11}

O grupo de indicadores que se relaciona mais intimamente com os dados, Seriação, Organização e Classificação de informações foram identificados neste parágrafo, assim como os indicadores de Justificativa e Explicação.

"To primeira dia, 06/08 até a 4 a dia, 09/08, a crescimenta fai pequena, hauve um patamar, nas dias em que nãa houve contagem, ne fim de semana, 10 e 11/08, fai quanda houve um crescimento, pois no primeira patamar, as Lemnas estavam em um processa de

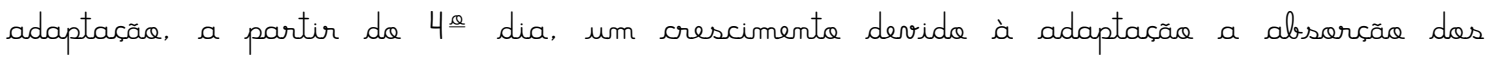
mutrientes, foi uma curva de crescimenta real. Houve um momenta, no dia 13/08, ande houve a maiar crescimenta, e entãa a populaçãa se estabilizau, pais com as condiçães dadas a essa populaçãa. de luz por exempla, a populaçãa alcanscon sua capacidade de carga ou capacidade biética máxima com essas condiçães, e a papulaçãa se estabilizau na casa das 120 e 130 individuas.".

Ao apresentar diferentes datas em que foram feitas estimativas do numero de indivíduos na população de Lemnas em estudo e ao apresentar o número de indivíduos de Lemnas na população final temos uma Seriação de informações. Os alunos aqui apresentam considerações sobre a dinâmica populacional das Lemnas em uma Organização cronológica das informações. Essas considerações podem ser entendidas como uma Classificação de informações e a sua organização cronológica como uma Organização de informações.

Há três momentos que podem ser entendidos como Justificativas. Em cada um deles os alunos estão lançando mão de garantias a afirmativas acerca da dinâmica populacional das Lemnas.

\begin{tabular}{|c|c|}
\hline Afirmativa & Garantia \\
\hline pois no primeira patamar & as Lemnas estavam em um processe de adaptaçãa \\
\hline 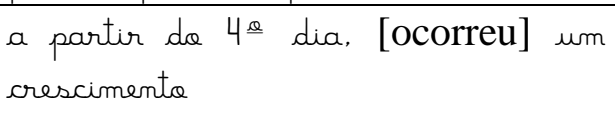 & devida à adaptaçãa a absarçãa das nutrientes. \\
\hline e entãa a papulaçãa se estabilizan & $\begin{array}{l}\text { - pais com as condiçães dadas a essa papulaçãa, de } \\
\text { luz por exempla, a papulasãa alcanscau sua } \\
\text { capacidade de carga ou capacidade biética máxima }\end{array}$ \\
\hline
\end{tabular}

Acreditamos que apenas na ultima afirmativa, do quadro apresentado acima, os alunos constroem uma Explicação, já que nas anteriores temos apenas afirmativas justificadas e não há o estabelecimento de relações de causa e efeito explicitadas. A 
Thiago Marinho Del Corso

INDICADORES DE ALFABETIZAÇÃO CIENTÍFICA, ARGUMENTOS E EXPLICAÇÕES -

Análise de Relatórios no Contexto de uma Sequência de Ensino Investigativo

afirmativa aqui é chamada de explanandum e é para quem os alunos buscam as causas,

os explanans, sendo estes - "as condicães dadas a essa populaçãa, de luz por exempla"- e

- "alcansou sua capacidade de carga ou capacidade biética máxima com essas condiç̃ees"-.

\section{Marca 12}

Nesta marca encontram-se indicadores de Seriação de informações, Organização de informações Justificativa e Explicação. $O$ primeiro destes indicadores deriva da apresentação de dados acerca do comportamento da população de Lemnas ao longo do tempo -"crescer"-, -"aumentar a múmero de individuas"- e -"fique estárvel a múmera de individuas"-, -"crescimenta"-, -"estável”- e etc.

Esta Organização de informações ocorre na retomada dos dados para discussão da questão, e aqui ocorre quando o aluno organiza os dados em diferentes momentos, com características próprias em relação a dinâmica populacional.

A Justificativas neste parágrafo surgem em dois momentos diferentes, sempre para dar garantia a afirmativas, como apresentado na tabela abaixo.

\begin{tabular}{|c|c|}
\hline Afirmativa & Garantia \\
\hline $\begin{array}{l}\text { depois desses primeiras dias a } \\
\text { populacão comesa a crescer }\end{array}$ & $\begin{array}{l}\text { pois conseguiram nutrientes necessários para } \\
\text { aumentar a número de individuas }\end{array}$ \\
\hline depois fica estável. & $\begin{array}{l}\text { pois as mutrientes estäa acabanda e morre mais } \\
\text { individuas } \\
\text { A populacäa recebeu muita pouca luz para que } \\
\text { crescam mais individuas }\end{array}$ \\
\hline
\end{tabular}

Acreditamos que os alunos perpetram tentativas de estabelecer relação causa e efeito para ambas afirmativas acima apresentadas no quadro, e que por conseguinte, cada uma delas pode ser identificada como uma Explicação. Em ambos os casos o explanandum é a própria afirmativa acerca do fenômeno da dinâmica populacional e as causas para este fenômeno se dar da forma como ele se deu são as garantias, chamadas aqui de explanans.

\footnotetext{
"A populaçãa nos primeiros dias tenta se acostumar com ambiente e tenta achar mutrientes, depais desses primeiros dias a populaçãa comesca a crescer, pais conseguiram mutrientes necessários para aumentar a númerce de individuas até que fique estável a
} 
Thiago Marinho Del Corso

INDICADORES DE ALFABETIZAÇÃO CIENTÍFICA, ARGUMENTOS E EXPLICAÇÕES -

Análise de Relatórios no Contexto de uma Sequência de Ensino Investigativo

númera de individuas. Ca langa deste crescimenta hauve várias martes de individuas. Coma

a gráfica representa a númera de individuas em duas semanas, quanda comecsa a crescer e depais fica estável, pois as nutrientes estãa acabanda e morre mais individuas. A populaçãa recebeu muita pouca luz para que cressam mais individuas e isso muito das causas de mortes dos individuas.".

\section{Marca 13}

Nesta parágrafo, que é a ultima conclusão do relatório 6 de 2013 e que se apresenta transcrita logo a seguir, temos os indicadores de Seriação de informações, Organização de informações, Classificação de informações, Justificativa, Explicação e Raciocínio lógico.

"Em um ambiente com as condiçaes ideais para a desenvolvimenta da espécie as individuas nos primeiras dias passam por uma fase de adaptaçãa e nãa apresenta um crescimenta elevada da papulaçãa, depois de mais an menos 3 dias a papulaçãa tem um crescimenta elevado porque já se adaptau ae nove ambiente, com esse crescimenta a populaçãa fai se estabilizanda pois alcanşau a capacidade biética máxima com as condiçäes aferecidas, ficanda ma casa dos 120 e 130 individuos."

Novamente a Seriação deriva da apresentação de dados como -"crescimente"-, -" a populaçãe foi se estabilizanda"- e etc. A Organização de informações se dá pela retomada dos dados para discução, quando os alunos apresentam os números de Lemnas na população organizados em três momentos característicos, primeiro momento de adaptação, segundo de crescimento e terceiro de estabilização. As características de intensidade admitidas a cada um desses momentos é indicativo de Classificação de informações, mas a separação em três momentos é Organização de informações.

O indicador de Justificativa é identificado em três momentos como garantias a afirmativas. Estes seguem apresentados no quadro abaixo:

\begin{tabular}{|c|c|}
\hline Afirmativa & Garantia \\
\hline $\begin{array}{l}\text { mãa apresenta um crescimenta elevada da } \\
\text { populaçãa }\end{array}$ & $\begin{array}{l}\text { os individuas nos primeiras dias passam } \\
\text { por uma fase de adaptaçãe }\end{array}$ \\
\hline $\begin{array}{l}\text { depais de mais an menos } 3 \text { dias a papulaçãa } \\
\text { tem um crescimenta elevada }\end{array}$ & porque já se adaptou ae novro ambiente \\
\hline a populaçãa foi se estabilizanda & pois alcansou a capacidade biética máxima \\
\hline
\end{tabular}


Acerca das três afirmativas os alunos tentam, mesmo que de forma ineficiente, estabelecer relações causais entre o fenômeno da dinâmica populacional nos três diferentes momentos e as causas para estes. Em cada um dos casos podemos entender a afirmativa como o explanandum e as garantias como explanans de uma Explicação. Em nenhum dos casos podemos considerar que se tratava de um Argumento, pois para ser um Argumento é necessário ao menos Dados (D) que levem a uma Conclusão (C) Toulmin (2006).

O Raciocínio lógico decorre da estrutura clara das ideias apresentadas por esse aluno, em que podemos identificar o padrão hipotético dedutivo de Lawson (2000), conforme apresentado abaixo:

"[se] Em um ambiente com as condiçäes ideais para a desenvolvimenta da espécie as individuas nos primeiros dias passam por uma fase de adaptaçãa e [então] nãa apresenta um crescimenta elevado da populaçãa. [portanto] depois de mais an menos 3 dias a papulașãa tem um crescimenta elevada parque já se adaptau ac novra ambiente. [então] com esse crescimenta a populaçãa foi se estabilizanda pais [portanto] alcançou a capacidade biática máxima com as condișaes oferecidas, ficanda na casa dos 120 e 130 individuos." 
Thiago Marinho Del Corso

INDICADORES DE ALFABETIZAÇÃO CIENTÍFICA, ARGUMENTOS E EXPLICAÇÕES -

Análise de Relatórios no Contexto de uma Sequência de Ensino Investigativo

O Relatório 7 - 2013

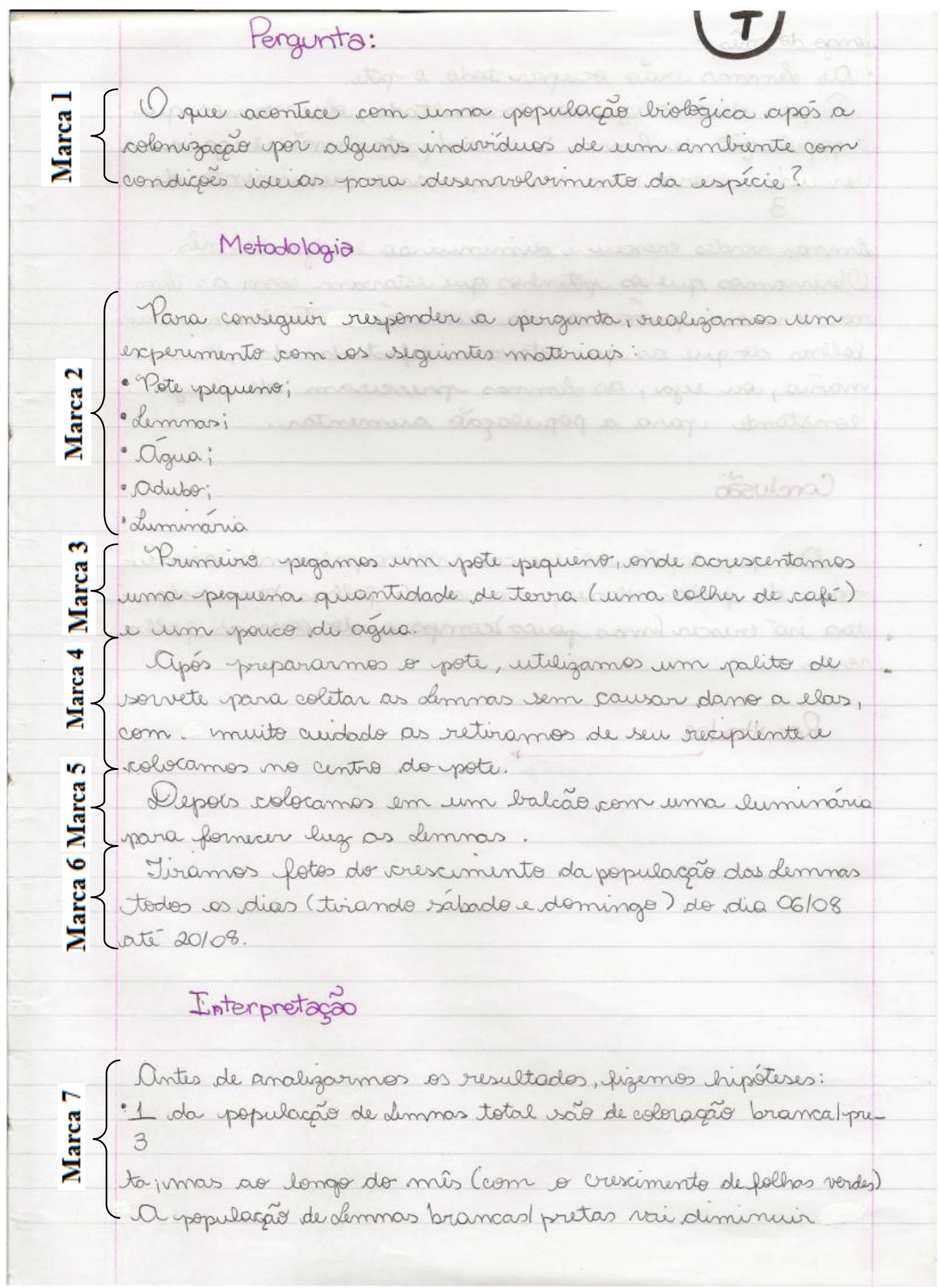


Thiago Marinho Del Corso

INDICADORES DE ALFABETIZAÇÃO CIENTÍFICA, ARGUMENTOS E EXPLICAÇÕES -

Análise de Relatórios no Contexto de uma Sequência de Ensino Investigativo

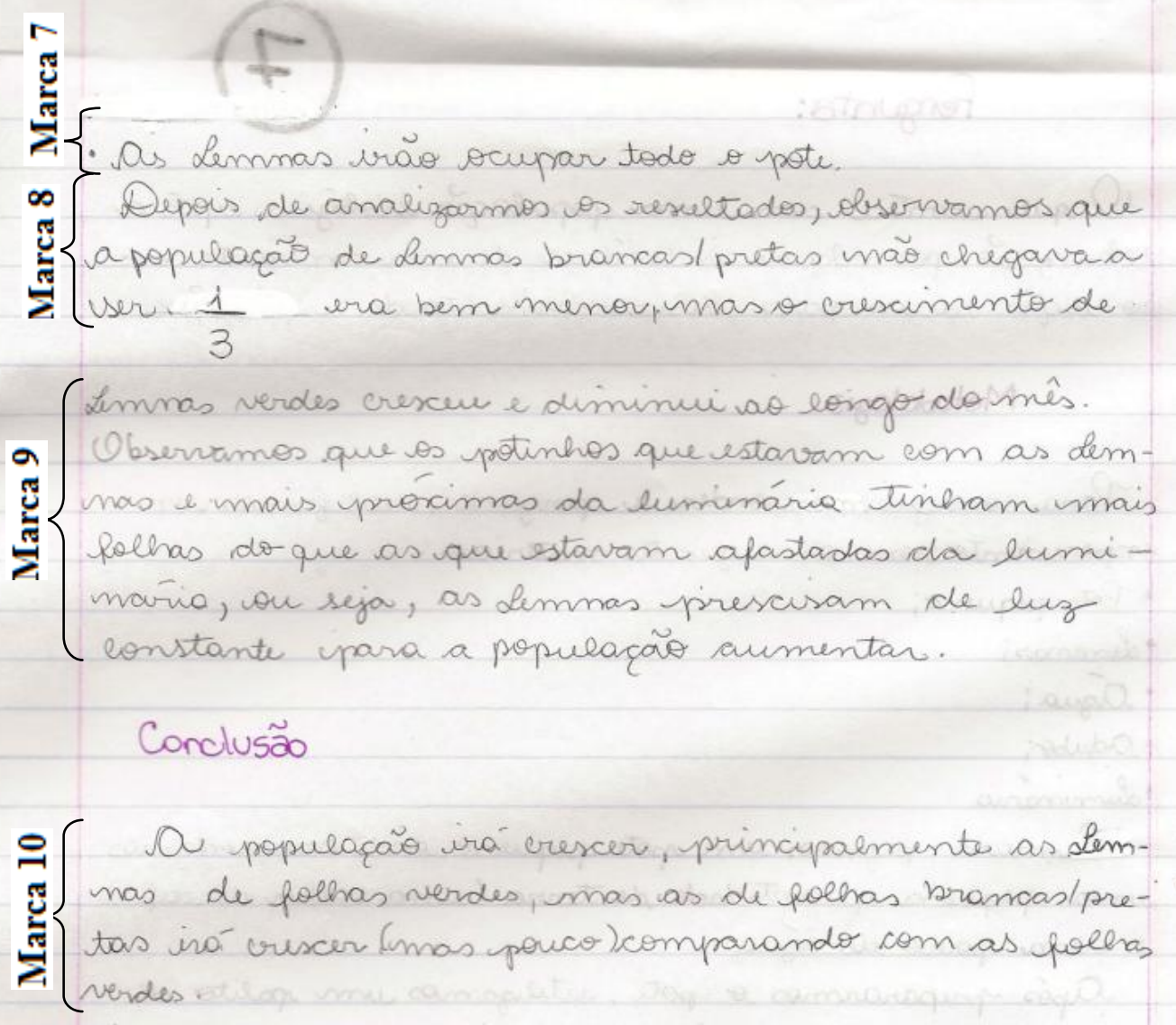

Resultados 
Thiago Marinho Del Corso

INDICADORES DE ALFABETIZAÇÃO CIENTÍFICA, ARGUMENTOS E EXPLICAÇÕES -

Análise de Relatórios no Contexto de uma Sequência de Ensino Investigativo

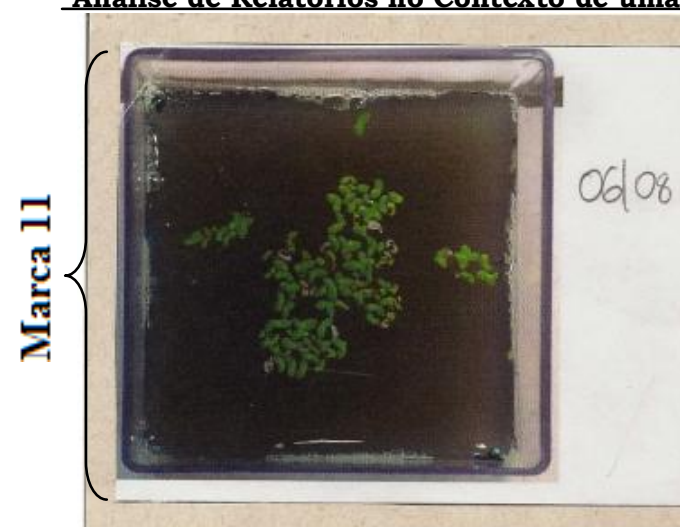

Dia 06108 - primeiro dia

Colocomios as lemmas no cen tro do pote, algumas já es -

torram mortas, mas a maio. ria erom verdes.

TOTAL DE FOLHAS: 152

TOTAL DEFOLHAS VERDES: 130

TOTAL DE FOLHAS PRETAS E BRANCAS: 22

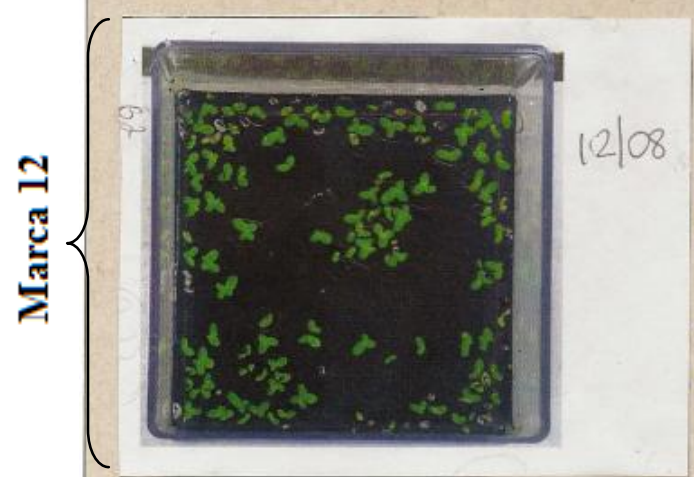

Dia 12108 - sétimo dia.

Oepois do firm de semana, hourve um pico de crescimer to muito grande como mos. tra no gráfico. As polhas estōo cada vez mais espalho. dos pelo pote

TOTAL DEFOLHAS: 273 TOTAL FOLHAS VERDES: 247 FOLHASPRETAS : 26

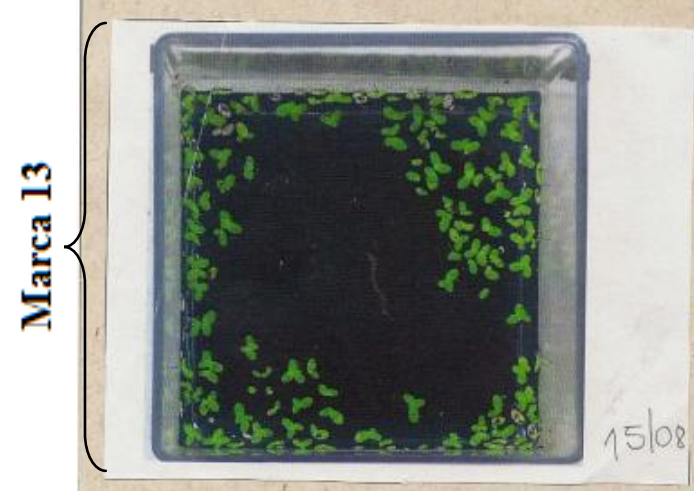

Dia 15108 - dícimo dia de olservacãor. As lemnas se espalharam para. os cantos do pote, a quantidode de folhas aumentaram

TOTAL DE FOLHAS: 303

TOTAL DE FOLHAS VERDES: 276

TOTAL DE FOLHAS PRETAS EBRPNCAS: 27

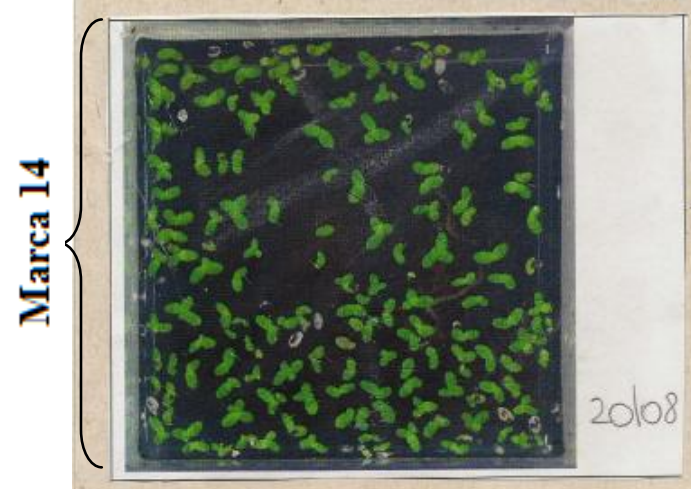

20108 - último dia de expe rimento: as lemnas se espalharam. pelo pote, o tamanho e a quantidade de folhas aumentaram.

TOTAL DE. FOLHAS: 319

TOTAL DE FOLHAS VERDES: 289

TOTAL DE Folhas PRETA ebrancas:30 
Thiago Marinho Del Corso

INDICADORES DE ALFABETIZAÇÃO CIENTÍFICA, ARGUMENTOS E EXPLICAÇÕES -

Análise de Relatórios no Contexto de Marca 15 :ia de Ensino Investigativo

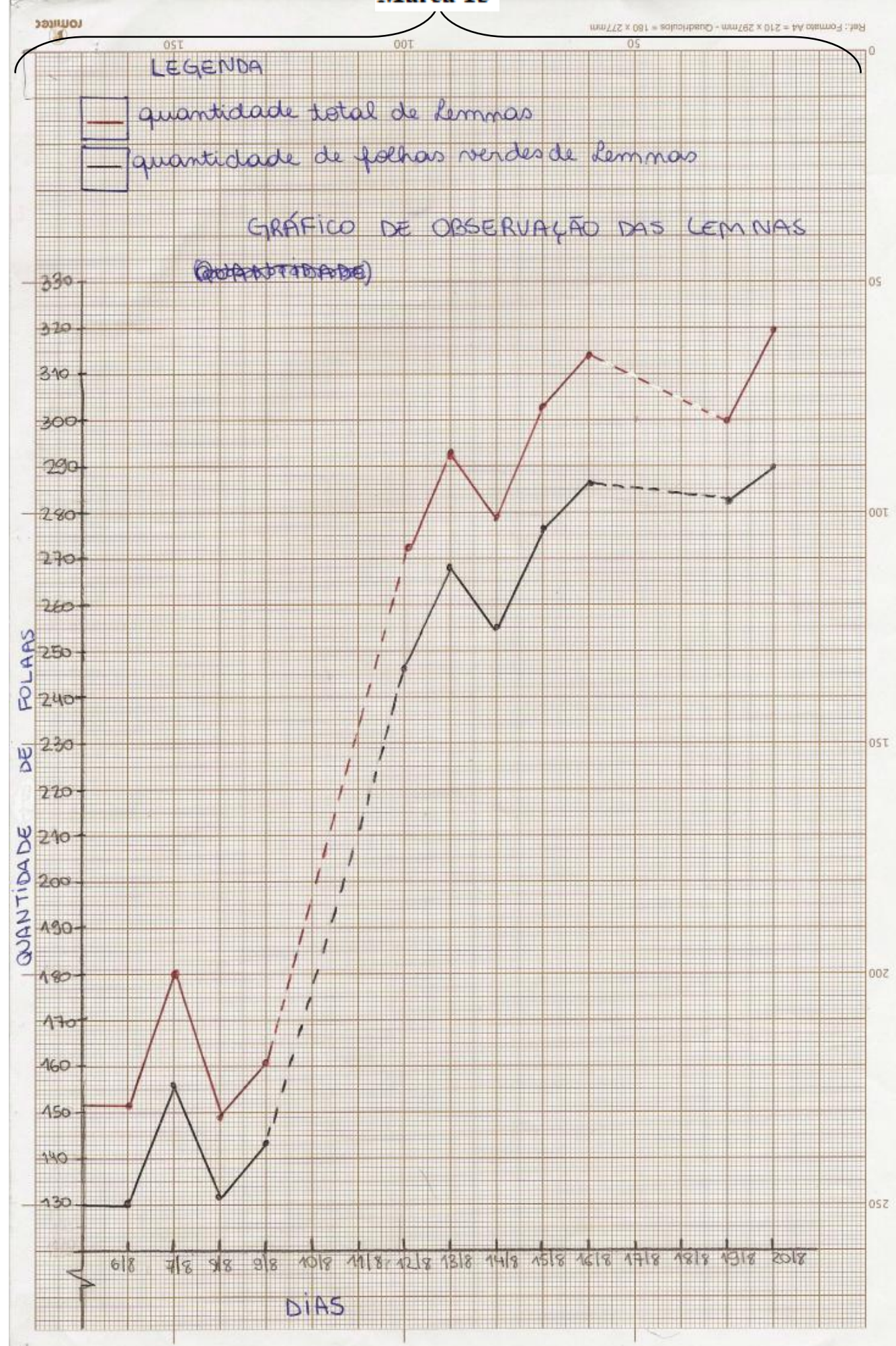


Thiago Marinho Del Corso

INDICADORES DE ALFABETIZAÇÃO CIENTÍFICA, ARGUMENTOS E EXPLICAÇÕES -

Análise de Relatórios no Contexto de uma Sequência de Ensino Investigativo

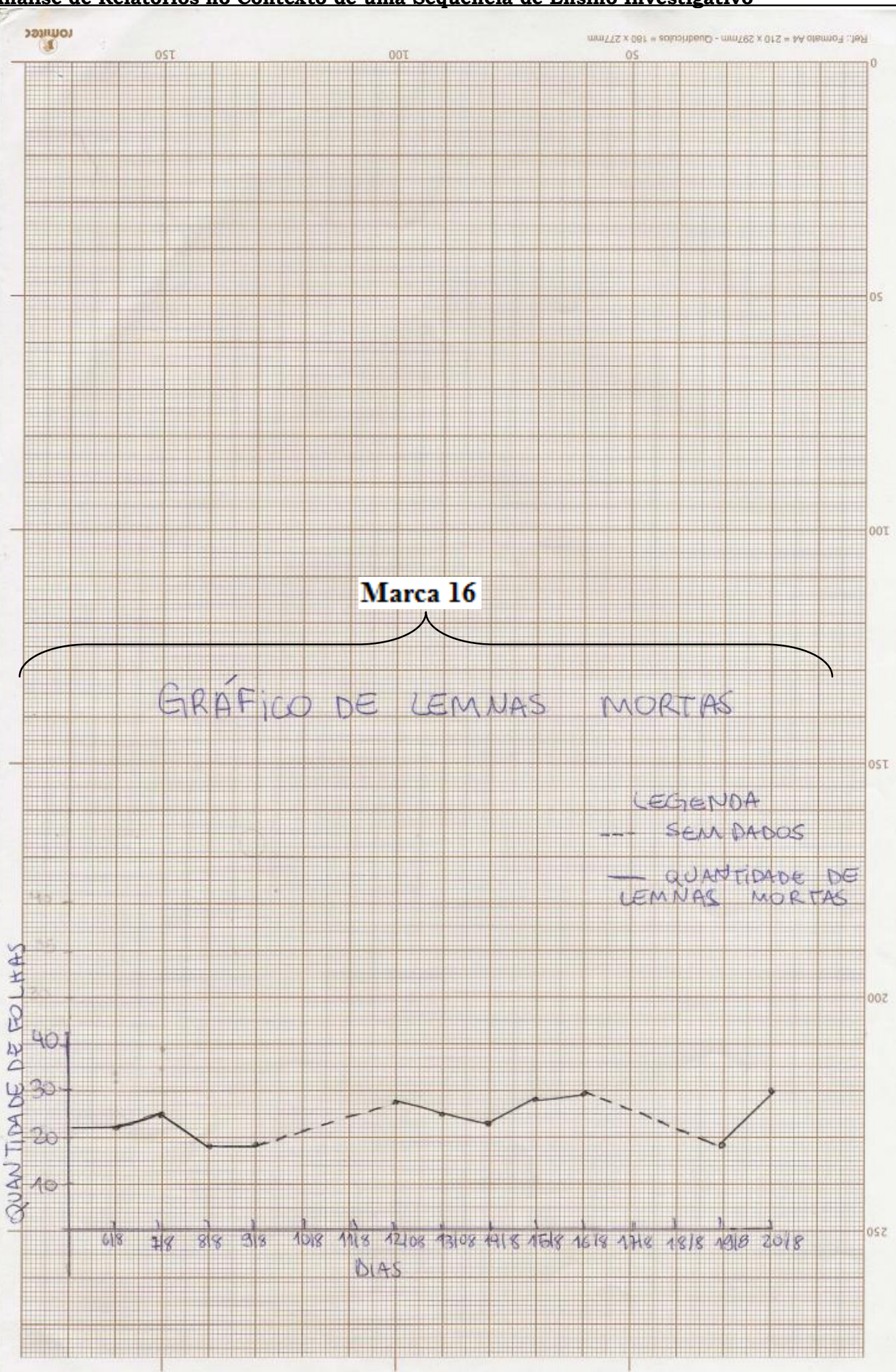


Thiago Marinho Del Corso

INDICADORES DE ALFABETIZAÇÃO CIENTÍFICA, ARGUMENTOS E EXPLICAÇÕES -

Análise de Relatórios no Contexto de uma Sequência de Ensino Investigativo

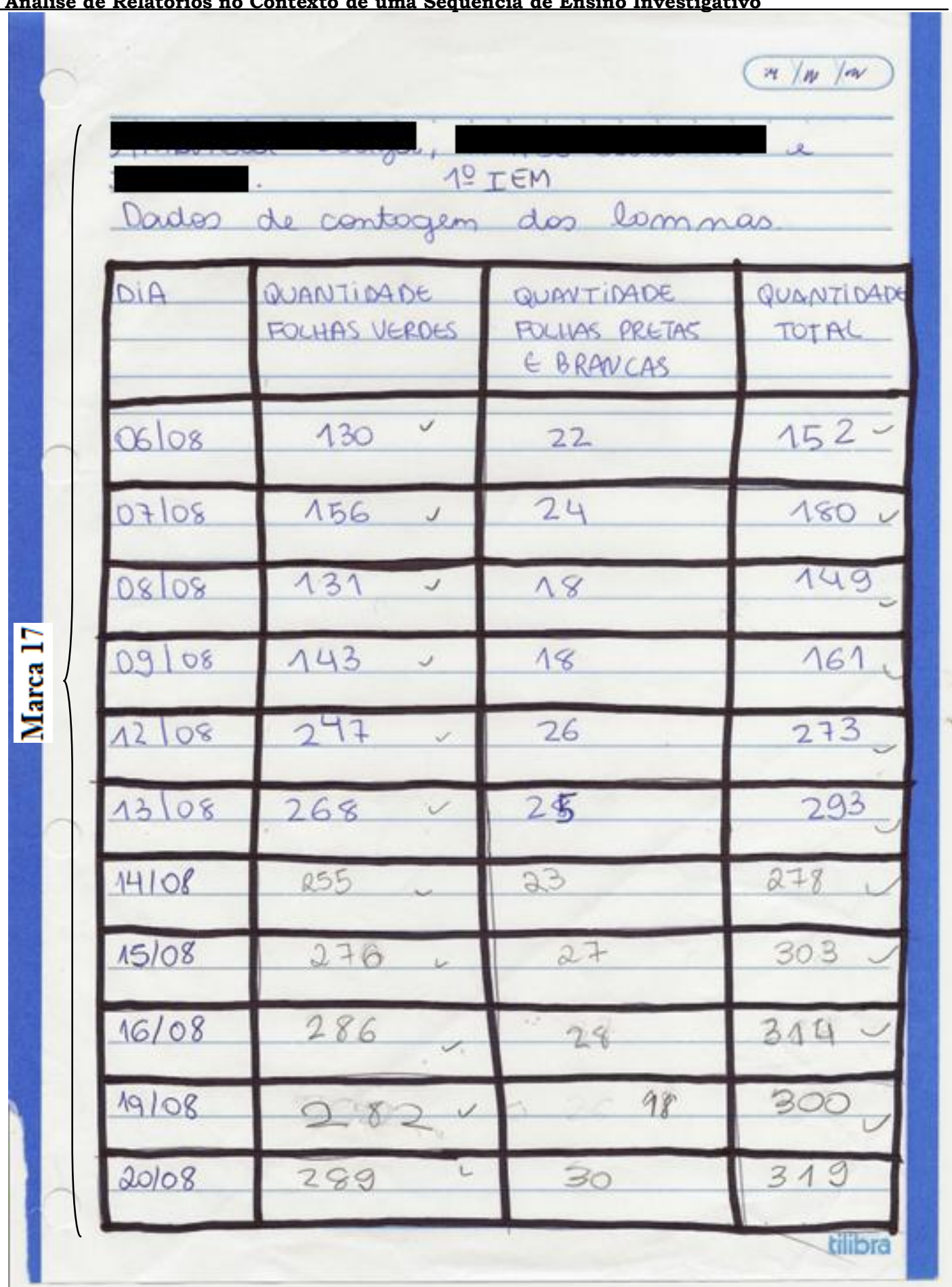


Thiago Marinho Del Corso

INDICADORES DE ALFABETIZAÇÃO CIENTÍFICA, ARGUMENTOS E EXPLICAÇÕES -

Análise de Relatórios no Contexto de uma Sequência de Ensino Investigativo

\section{Quadro 07 - Relatório 7 de 2013}

Identificação dos Indicadores de Alfabetização Científica no Relatório 7 de 2013 e conclusões individuais correspondentes.

\begin{tabular}{|c|c|c|c|c|c|c|c|c|c|c|c|c|c|}
\hline 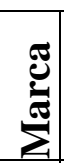 & $\begin{array}{l}\text { Subtítulo, } \\
\text { divisão ou } \\
\text { Item }\end{array}$ & Texto & $\mathbf{L M}$ & SI & $\mathbf{O I}$ & CI & \begin{tabular}{l|l|} 
RL & RP \\
\end{tabular} & LH & $\mathbf{T H}$ & $\mathbf{J}$ & $\mathbf{P}$ & 엇 & $\sum^{\infty}$ \\
\hline 1 & $\begin{array}{l}\text { Pergunta } \\
\text { (Pergunta) }\end{array}$ & $\begin{array}{l}\text { "Pergunta: O que acontece com uma populaşãa bialágica } \\
\text { após a colonizaçãa por alguns individuas de um ambiente com as } \\
\text { condiçães ideais para a desenvolvimenta das espécies?" }\end{array}$ & Não & aval & iado, & texto & da profess & sora & & & & & \\
\hline 2 & $\begin{array}{l}\text { Metodologia } \\
\text { (Metodologia) } \\
1^{\circ} \text { parágrafo }\end{array}$ & $\begin{array}{l}\text { "Para conseguir responder a pergunta, realizamas um } \\
\text { experimenta com as seguintes materiais: } \\
\text { - Pate pequena; } \\
\text { - Lemnas; } \\
\text { - Ćgua; } \\
\text { - Aduba; } \\
\text { - Luminária" }\end{array}$ & $\mathbf{X}$ & & & & & & & & & & \\
\hline 3 & $\begin{array}{l}\text { Metodologia } \\
\text { (Metodologia) } \\
2^{\circ} \text { parágrafo }\end{array}$ & $\begin{array}{l}\text { "Primeira pegamas um pote pequena, ande acrescentamos } \\
\text { uma pequena quantidade de terra (uma colher de café) e um pouca } \\
\text { de água." }\end{array}$ & $\mathbf{X}$ & & $\mathbf{X}$ & & & & & & & & \\
\hline 4 & $\begin{array}{l}\text { Metodologia } \\
\text { (Metodologia) } \\
3^{\circ} \text { parágrafo }\end{array}$ & $\begin{array}{l}\text { "Cpós prepararmas a pote, utilizamas um palita de sorvete } \\
\text { para coletar as Lemnas sem causar danos a elas, com muito } \\
\text { cuidado as retiramas de seu recipiente e colocamos no centro do } \\
\text { pote." }\end{array}$ & $\mathbf{X}$ & & $\mathbf{X}$ & & & & & & & & \\
\hline 5 & $\begin{array}{l}\text { Metodologia } \\
\text { (Metodologia) } \\
4^{\circ} \text { parágrafo }\end{array}$ & $\begin{array}{l}\text { "Depais colocamas em um balcãa com uma luminária para } \\
\text { fornecer luz às Lemnas." }\end{array}$ & $\mathbf{X}$ & & $\mathbf{X}$ & & & & & & & & \\
\hline
\end{tabular}


Thiago Marinho Del Corso

INDICADORES DE ALFABETIZAÇ̃̃O CIENTÍFICA, ARGUMENTOS E EXPLICAÇÕES -

Análise de Relatórios no Contexto de uma Sequência de Ensino Investigativo

\begin{tabular}{|c|c|c|c|c|c|c|c|c|c|c|c|c|c|c|}
\hline 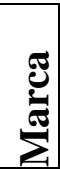 & $\begin{array}{l}\text { Subtítulo, } \\
\text { divisão ou } \\
\text { Item }\end{array}$ & Texto & $\mathbf{L M}$ & SI & OI & CI & $\mathbf{R L}$ & $\mathbf{R P}$ & LH & TH & $\mathbf{J}$ & $\mathbf{P}$ & $\underset{x}{x}$ & $\sum_{1}^{\infty}$ \\
\hline 6 & $\begin{array}{l}\text { Metodologia } \\
\text { (Metodologia) } \\
5^{\circ} \text { parágrafo }\end{array}$ & $\begin{array}{l}\text { "Iiramas fotas da crescimenta da papulascãa das Lemnas } \\
\text { todas as dias (tiranda sábada e dominga) de dia 06/08 até } \\
\text { 20/08." }\end{array}$ & & & $\mathbf{X}$ & & & & & & & & & \\
\hline 7 & $\begin{array}{l}\text { Interpretação } \\
\text { (Interpretaçãa) } \\
1^{\circ} \text { parágrafo }\end{array}$ & 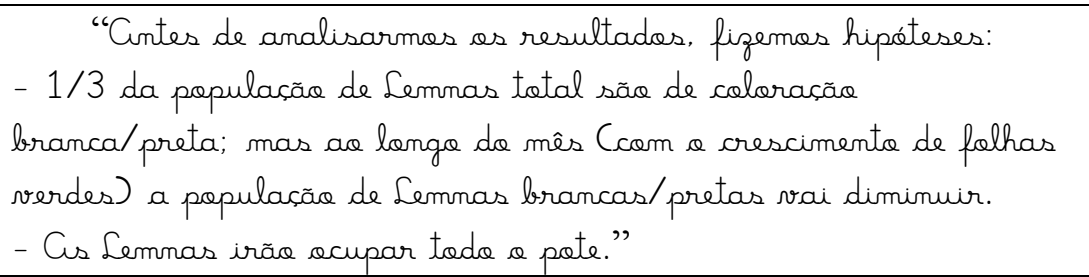 & & $\mathbf{X}$ & & $\mathbf{X}$ & & & $\mathbf{X}$ & & $\mathbf{X}$ & & & \\
\hline 8 & $\begin{array}{l}\text { Interpretação } \\
\text { (Jnterpretaçãa) } \\
2^{\circ} \text { parágrafo }\end{array}$ & $\begin{array}{l}\text { "Depais de analisarmas as resultadas, abservamas que a } \\
\text { populacãa de Lemnas brancas/pretas nãa chegarva a ser } 1 / 3 \text { era } \\
\text { bem menor, mas a crescimenta de Lemnas verdes cresceu e } \\
\text { diminuiu ao langa do mês." }\end{array}$ & & $\mathbf{X}$ & $\mathbf{X}$ & & & & & $\mathbf{X}$ & & & & \\
\hline 9 & $\begin{array}{l}\text { Interpretação } \\
\text { (Jnterpretaçãa) } \\
3^{\circ} \text { parágrafo }\end{array}$ & $\begin{array}{l}\text { "Observamas que as potinhos que estavam com as Lemnas e } \\
\text { mais próximas da luminária tinham mais folhas do que as que } \\
\text { estavam afastadas da luminária, au seja, as Lemnas precisam de } \\
\text { luz constante para a populaçãa aumentar." }\end{array}$ & $\mathbf{X}$ & $\mathbf{X}$ & $\mathbf{X}$ & & $\mathbf{X}$ & & & & & & & $\mathbf{X}$ \\
\hline 10 & $\begin{array}{l}\text { Conclusão } \\
\text { (Conclusãa) }\end{array}$ & $\begin{array}{l}\text { "A populacãa irá crescer, principalmente as Lemnas de folhas } \\
\text { verdes, mas as de folhas brancas/pretas irá crescer (mas pouca) } \\
\text { comparando com as folhas verdes." }\end{array}$ & & & & & & & $\mathbf{X}$ & & & $\mathbf{X}$ & & \\
\hline
\end{tabular}


Thiago Marinho Del Corso

INDICADORES DE ALFABETIZAÇÃO CIENTÍFICA, ARGUMENTOS E EXPLICAÇÕES -

Análise de Relatórios no Contexto de uma Sequência de Ensino Investigativo

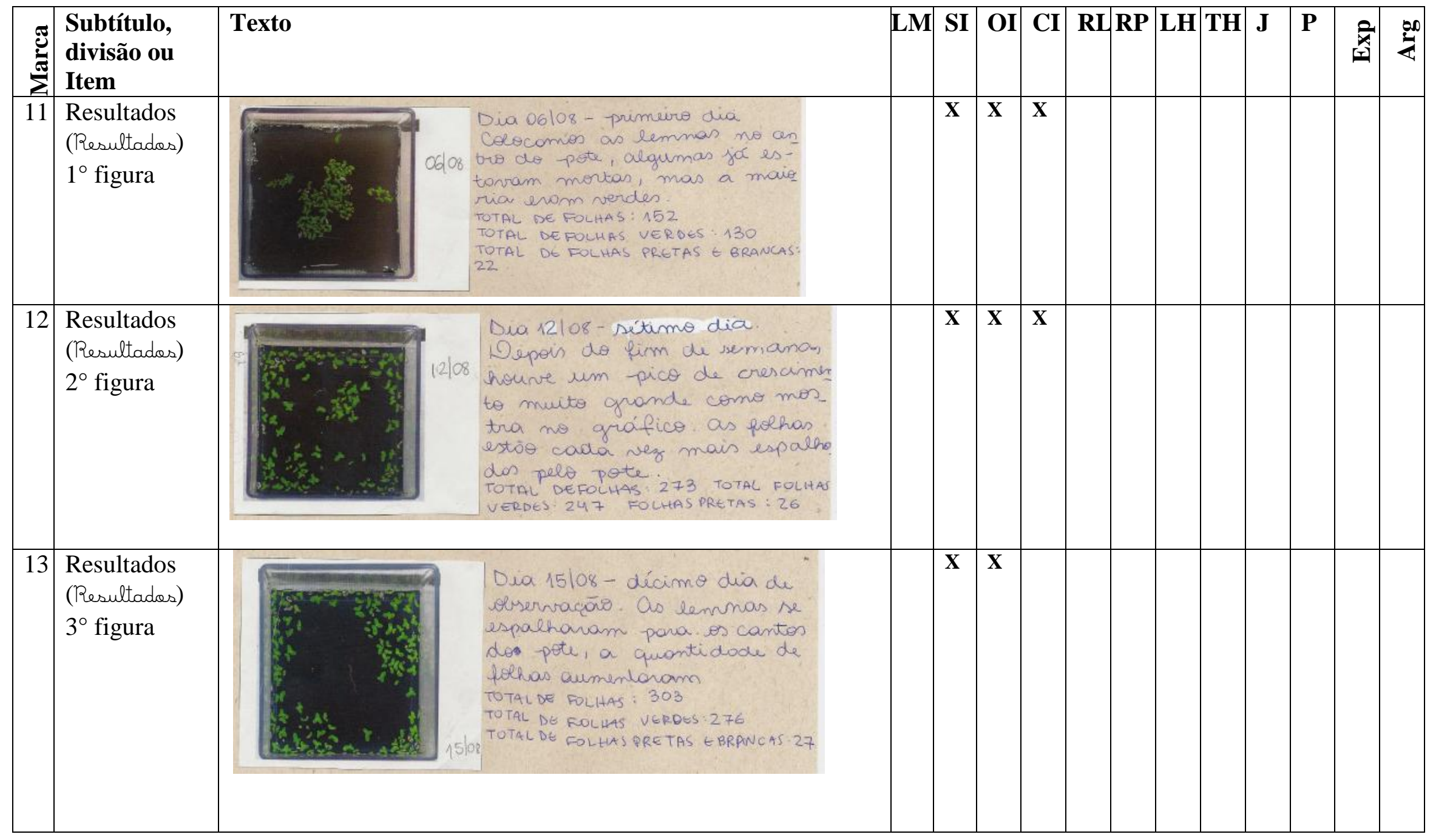


Thiago Marinho Del Corso

INDICADORES DE ALFABETIZAÇ̃̃o CIENTÍFICA, ARGUMENTOS E EXPLICAÇÕES -

Análise de Relatórios no Contexto de uma Sequência de Ensino Investigativo

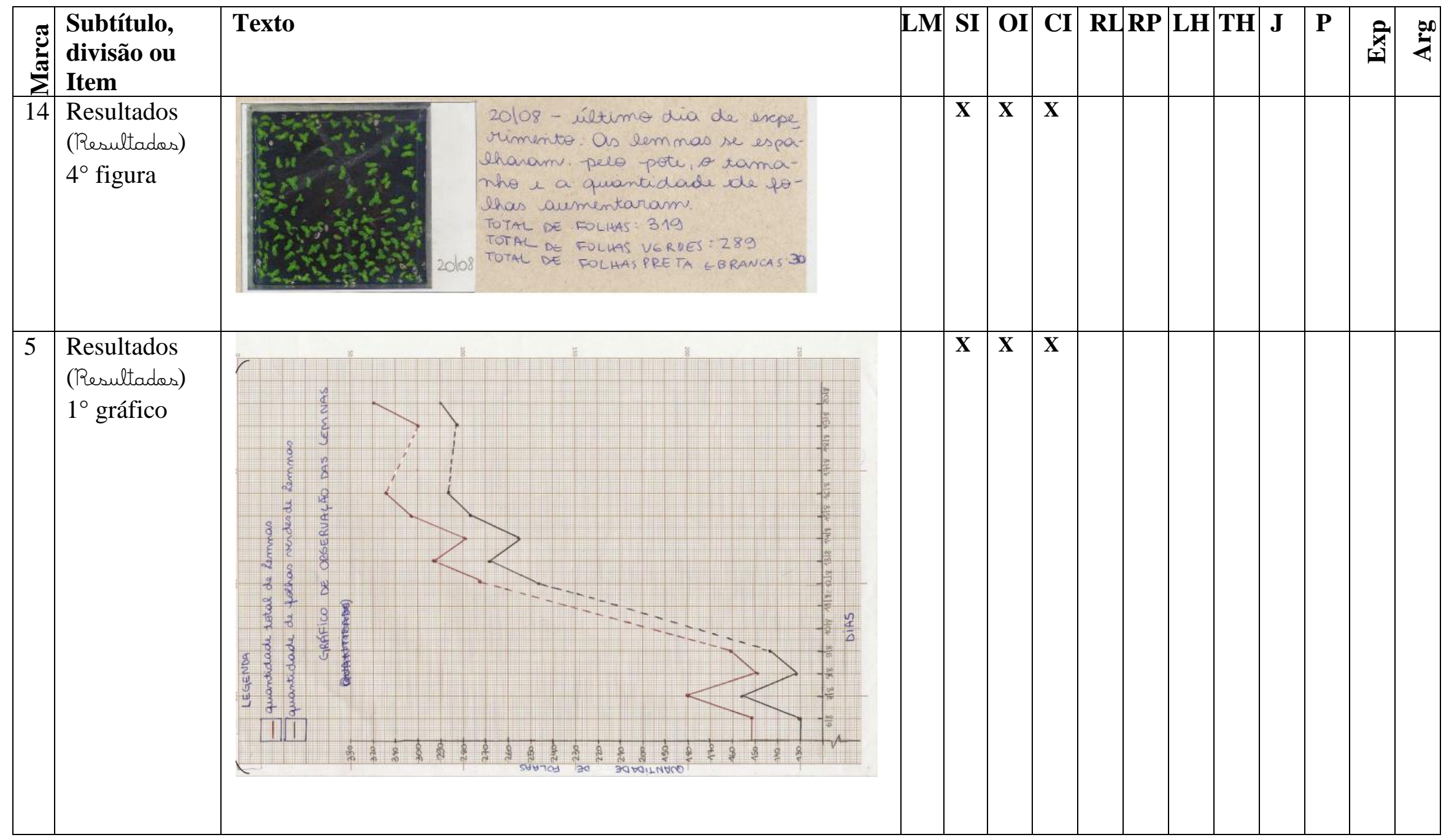


Thiago Marinho Del Corso

INDICADORES DE ALFABETIZACÃO CIENTÍFICA, ARGUMENTOS E EXPLICACÕ̃ES -

Análise de Relatórios no Contexto de uma Sequência de Ensino Investigativo

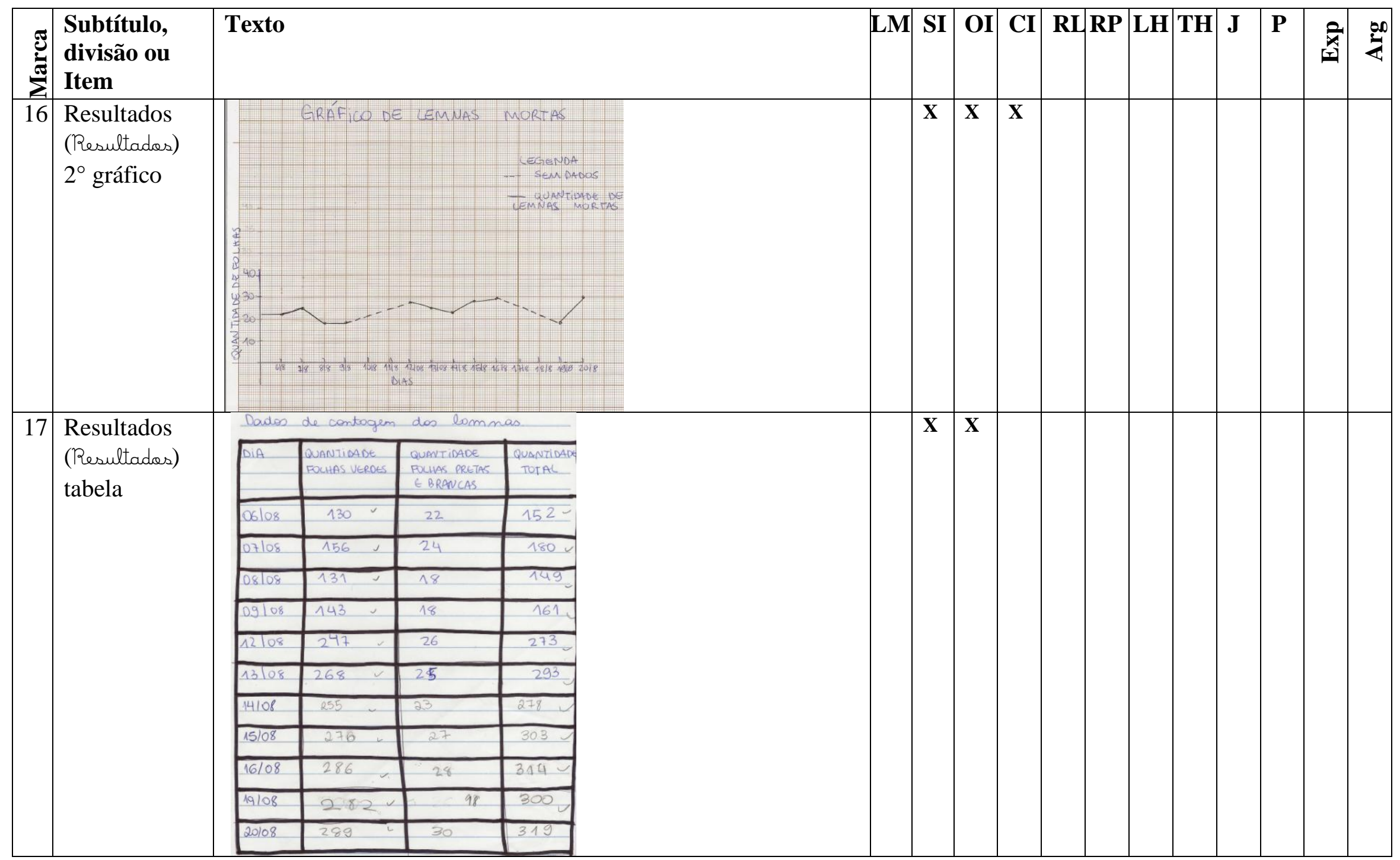


Thiago Marinho Del Corso

INDICADORES DE ALFABETIZAÇ̃̃o CIENTÍFICA, ARGUMENTOS E EXPLICAÇÕES -

Análise de Relatórios no Contexto de uma Sequência de Ensino Investigativo

\begin{tabular}{|c|c|c|c|c|c|c|c|c|c|c|c|c|c|}
\hline 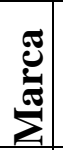 & $\begin{array}{l}\text { Subtítulo, } \\
\text { divisão ou } \\
\text { Item }\end{array}$ & Texto & $\mathbf{L M}$ & SI & OI & CI & \begin{tabular}{l|l|} 
RL & RP \\
\end{tabular} & $\mathbf{L H}$ & TH & $\mathbf{J}$ & $\mathbf{P}$ & $\underset{x}{a}$ & $\sum^{\infty}$ \\
\hline 18 & $\begin{array}{l}\text { Conclusão } \\
\text { individual } 1 \\
1^{\circ} \text { parágrafo }\end{array}$ & $\begin{array}{l}\text { "Observamas a desenvolvimenta da papulaçãa de lemnas em } \\
\text { condicães ideais por } 2 \text { semanas, anotanda sempre seus dadas de } \\
\text { crescimenta (quantidade de folhas vivas e mortas), senda que nãa } \\
\text { temas dados das finais de semana (no casa foram 2). " }\end{array}$ & & & $\mathbf{X}$ & & & & & & & & \\
\hline \begin{tabular}{l|}
19 \\
\end{tabular} & $\begin{array}{l}\text { Conclusão } \\
\text { individual } 1 \\
2^{\circ} \text { parágrafo }\end{array}$ & $\begin{array}{l}\text { "Respondenda a pergunta dada inicialmente, podemas concluir } \\
\text { que, nas lemnas, em situaçãa ideal para seu desenvolvimenta } \\
\text { (com luz 24h por dia, sem muita venta), predomina a } \\
\text { crescimenta" }\end{array}$ & & & & & & & & $\mathbf{X}$ & $\mathbf{X}$ & & $\mathbf{X}$ \\
\hline 20 & $\begin{array}{l}\text { Conclusão } \\
\text { individual } 1 \\
3^{\circ} \text { parágrafo }\end{array}$ & 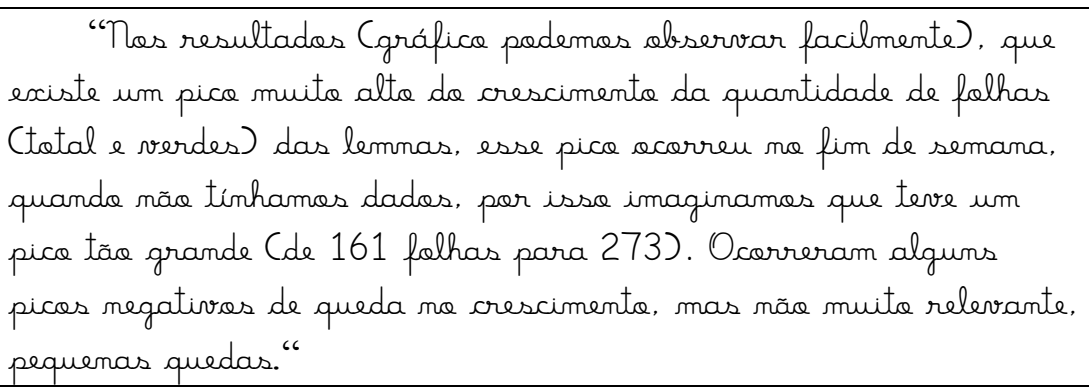 & & $\mathbf{X}$ & & $\mathbf{X}$ & $\mathbf{X}$ & & & $\mathbf{X}$ & & & \\
\hline 21 & $\begin{array}{l}\text { Conclusão } \\
\text { individual } 1 \\
4^{\circ} \text { parágrafo }\end{array}$ & $\begin{array}{l}\text { "Em relacãa a quantidade de folhas mortas, a númera ficau } \\
\text { um pouce mais estabilizados, sem picos (variou de } 18 \text { a } 30 \\
\text { folhas)" }\end{array}$ & & $\mathbf{X}$ & & $\mathbf{X}$ & & & & & & & \\
\hline 22 & $\begin{array}{l}\text { Conclusão } \\
\text { individual } 1 \\
5^{\circ} \text { parágrafo }\end{array}$ & $\begin{array}{l}\text { "Observanda a gráfica, a crescimenta sá tende a crescer, } \\
\text { entãa sim, em situaçães ideais para a desenvolvimenta das } \\
\text { lemnas, a crescimenta da populaçãa aumenta." }\end{array}$ & & $\mathbf{X}$ & & & & & & $\mathbf{X}$ & $\mathbf{X}$ & & $\mathbf{X}$ \\
\hline
\end{tabular}


Thiago Marinho Del Corso

INDICADORES DE ALFABETIZAÇ̃̃O CIENTÍFICA, ARGUMENTOS E EXPLICAÇÕES -

Análise de Relatórios no Contexto de uma Sequência de Ensino Investigativo

\begin{tabular}{|c|c|c|c|c|c|c|c|c|c|c|c|c|c|}
\hline$\sum^{\mathbb{J}}$ & $\begin{array}{l}\text { Subtítulo, } \\
\text { divisão ou } \\
\text { Item }\end{array}$ & Texto & $\mathbf{L M}$ & SI & $\mathbf{O I}$ & CI & \begin{tabular}{l|l|} 
RL & RP \\
\end{tabular} & LH & TH & $\mathbf{J}$ & $\mathbf{P}$ & $\underset{x}{a}$ & $\underset{4}{+\infty}$ \\
\hline 23 & $\begin{array}{l}\text { Conclusão } \\
\text { individual 2, } \\
\text { parágrafo } \\
\text { único }\end{array}$ & 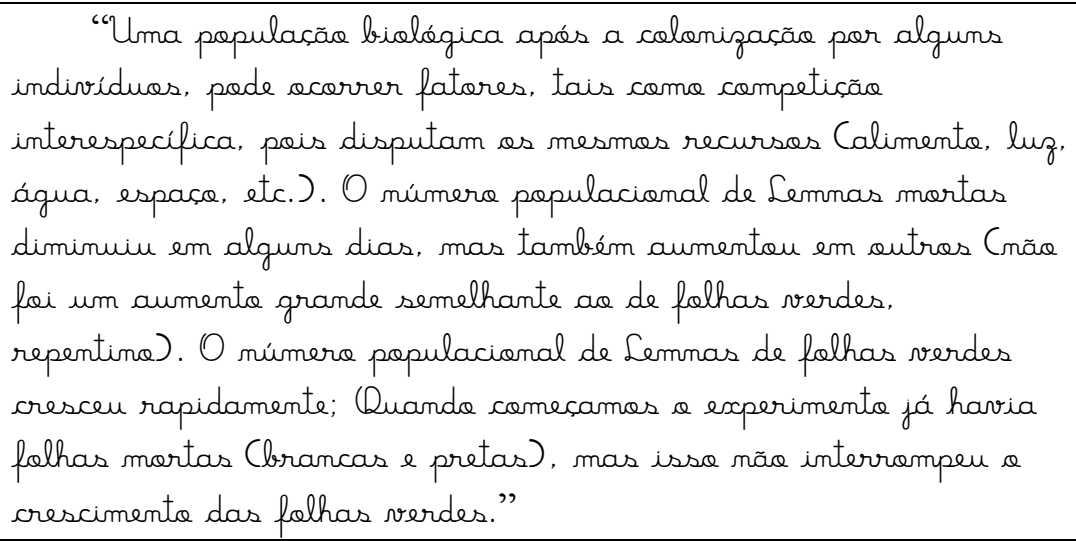 & & $\mathbf{X}$ & $\mathbf{X}$ & $\mathbf{X}$ & & & & $\mathbf{X}$ & & & \\
\hline 24 & $\begin{array}{l}\text { Conclusão } \\
\text { individual } 3 \text {, } \\
1^{\circ} \text { parágrafo }\end{array}$ & 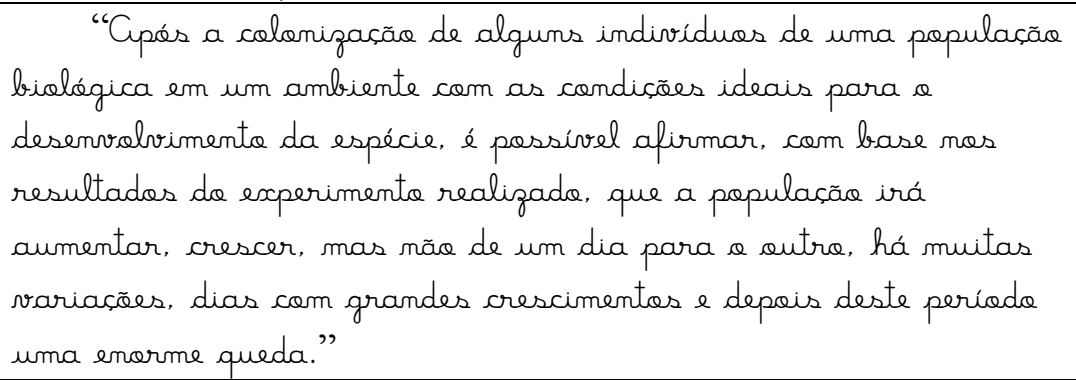 & & & & & & & & & $\mathbf{X}$ & & $\mathbf{X}$ \\
\hline 25 & $\begin{array}{l}\text { Conclusão } \\
\text { individual } 3 \text {, } \\
2^{\circ} \text { parágrafo }\end{array}$ & 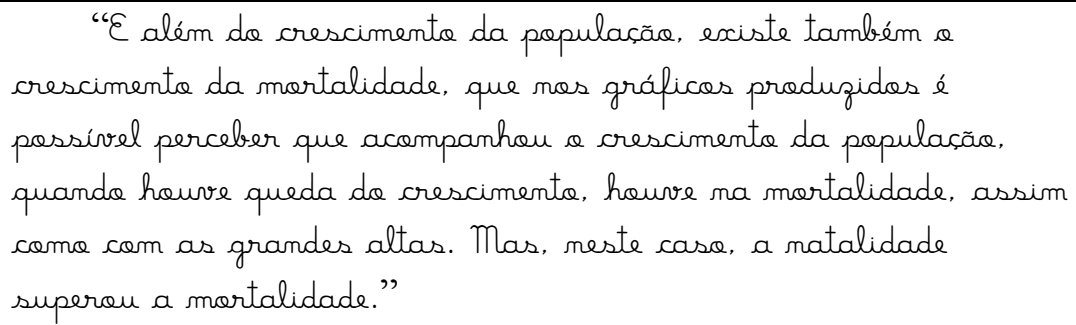 & & $\mathbf{X}$ & & & $\mathbf{X}$ & & & & & & \\
\hline
\end{tabular}


Thiago Marinho Del Corso

INDICADORES DE ALFABETIZAÇÃO CIENTÍFICA, ARGUMENTOS E EXPLICAÇÕES -

Análise de Relatórios no Contexto de uma Sequência de Ensino Investigativo

\begin{tabular}{|c|c|c|c|c|c|c|c|c|c|c|c|c|c|c|c|}
\hline 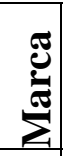 & $\begin{array}{l}\text { Subtítulo, } \\
\text { divisão ou } \\
\text { Item } \\
\end{array}$ & Texto & $\mathbf{L M}$ & SI & \begin{tabular}{|l|}
$\mathrm{OI}$ \\
\end{tabular} & CI & & $\mathbf{R P}$ & $\mathbf{L H}$ & $\mathbf{T H}$ & $\mathbf{J}$ & $\mathbf{P}$ & & & $\frac{00}{4}$ \\
\hline 26 & $\begin{array}{l}\text { Conclusão } \\
\text { individual } 3 \text {, } \\
3^{\circ} \text { parágrafo }\end{array}$ & 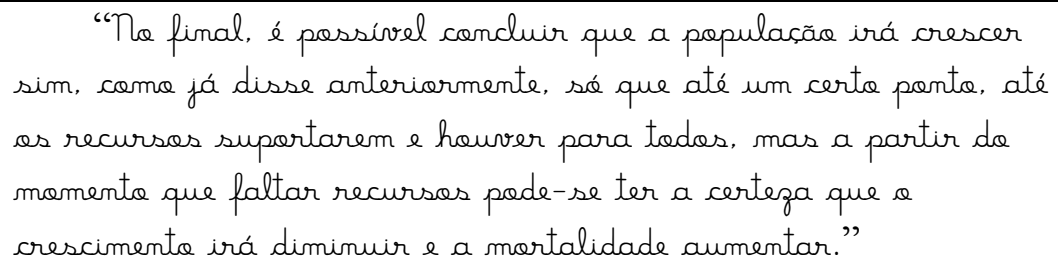 & & & & & $\mathbf{X}$ & $\mathbf{X}$ & $\mathbf{X}$ & & $\mathbf{X}$ & $\mathbf{X}$ & & & \\
\hline
\end{tabular}


Este relatório se inicia com a pergunta data pela professora, sem apresentar antes um título ou o nome dos integrantes.

\section{Marca 1:}

Como trata-se da cópia da pergunta fornecida pela professora e assim não é produção dos alunos não é analisada.

\section{Marca 2:}

Esta Listagem de materiais é o indicador aqui presente.

"Para conseguir responder a pergunta, realizamas um experimenta com as seguintes materiais:

- Pate pequenc:

- Lemnas;

- Água;

- Aduba:

- Luminária"

\section{Marca 3:}

Este parágrafo também apresenta os indicadores de Listagem de materiais e Organização de informações. O primeiro ao listar materiais e o segundo por apresentar como o experimento foi feito.

"Primeira pegamas um pote pequeno, ande acrescentamos uma pequena quantidade de terra (uma colher de café) e um pauca de água."

\section{Marca 4:}

Aqui se repetem os indicadores de Alfabetização Científica (Listagem de materiais e Organização de informações) das marcas anteriores, assim como os motivos pelos quais os identificamos. 
"Cupés prepararmas a pote, utilizamas um palita de sarvete para coletar as Lemnas sem causar danos a elas, com muite cuidado as retiramos de seu recipiente e calocamos no centro da pate."

\section{Marca 5:}

A descrição dos procedimentos de trabalho continua nesta marca e assim os indicadores de Listagem de materiais e Organização de informações continuam aparecendo e pelos mesmos motivos.

"Depais colocamas em um balcãa com uma luminária para fornecer luz às Lemnas."

\section{Marca 6:}

Neste parágrafo os alunos estão Organizando informações quando apresentam em seu relatório os dias de coleta de dados com uma data do inicio da coleta e o fato de não ter havido coleta no final de semana. Isto, pois, de acordo com Sasseron e Carvalho (2008) "A organização de informações ocorre nos momentos em que se discute sobre o modo como um trabalho foi realizado".

"Tiramas fotas de crescimenta da populasãa das Lemnas todas es dias (tiranda sábada e domingo) de dia 06/08 até 20/08."

\section{Marca 7:}

O primeiro parágrafo sob a égide do subtítulo - "Interpretaçãe"-, abaixo transcrito, apresenta os indicadores de Seriação de informações, Classificação de informações, Levantamento de hipóteses e Justificativa.

"Antes de analisarmas as resultados, fizemas hipéteses:

- 1/3 da papulaçãa de Lemnas tatal sãa de coloraçãa branca/preta; mas aa langa da mês

(com a crescimenta de folhas verdes) a populaçãa de Lemnas brancas/pretas vai diminuir.

- Cis Lemnas irãa acupar toda a pate."

A Seriação de informações se deve a apresentação da informação de que -“1/3 da papulaçãa de Lemnas tatal sãa de coloraçãa branca/ preta"-. Desta forma os alunos estão 
Thiago Marinho Del Corso

INDICADORES DE ALFABETIZAÇÃO CIENTÍFICA, ARGUMENTOS E EXPLICAÇÕES -

Análise de Relatórios no Contexto de uma Sequência de Ensino Investigativo

apresentando dados, referentes a distribuição das Lemnas brancas/pretas em relação aos

2/3 de Lemnas verdes (subentendido). Este indicador está ligado às bases para a ação investigativa e no caso esta distinção será posteriormente, neste mesmo relatório, usada na análise dos dados de crescimento populacional. A Classificação de informações deriva do estabelecimento de uma característica para os indivíduos da população de Lemnas, que podem ser verdes/pretas (mortas) ou vivas, as quais estão verdes. A distinção entre esses dois indicadores é que a Seriação deriva da razão de indivíduos mortos e vivos, já a Classificação deriva da separação e estabelecimento destas características aos indivíduos da população de Lemnas.

O Levantamento de hipóteses é explicito, os alunos afirmam estar levantando hipóteses - "Antes de analisarmas as resultados, fizemas hipóteses: " - e efetivamente levantam duas hipóteses - (1) "a populaçã de Lemnas brancas/pretas vai diminuir."- e (2) "Cus Lemnas irão acupar todo a pote."-. A Justificativa aparece para dar garantia ao porque os alunos esperam uma diminuição da quantidade de Lemnas brancas e pretas "Ccom a crescimenta de folhas verdes) a populacäa de Lemmas brancas/pretas vai diminuir."-.

\section{Marca 8:}

Nesta marca encontramos os indicadores de Seriação de informações, Organização de informações, Teste de hipóteses e Justificativa.

Os alunos analisam os resultados, que são apresentados no relatório após a "Interpretaçãe", e verificam que conforme sua hipótese inicial, a quantidade de Lemnas brancas e pretas se reduz a bem menos de 1/3 - "observamas que a papulacãa de Lemnas brancas/pretas mãa chegava a ser $1 / 3$ era bem memor,"- e entendemos que este movimento pode ser interpretado como um Teste de hipóteses. A Seriação de informações deriva da apresentação deste novo dado, não exato, de que a razão de Lemnas brancas/pretas era bem inferior a razão inicial.

Este parágrafo apresenta também a Organização de informações por dizer que "Q crescimenta de Lemnas verdes crescen e diminuiu ae longo do mês." - numa clara organização dos dados de dinâmica populacional em dois momentos, um inicial de crescimento e outro final de diminuição. 
Thiago Marinho Del Corso

INDICADORES DE ALFABETIZAÇÃO CIENTÍFICA, ARGUMENTOS E EXPLICAÇÕES -

Análise de Relatórios no Contexto de uma Sequência de Ensino Investigativo

"Depois de analisarmos as resultados, ebservamas que a populaçãa de Lemnas

brancas/pretas nãa chegava a ser $1 / 3$ era bem menor, mas a crescimenta de Lemnas verdes

cresceu e diminuiu ae longa do mês."

\section{Marca 9:}

O ultimo parágrafo da interpretação, transcrito a seguir, apresenta os indicadores de Seriação de informações, Raciocínio lógico, Justificativa e Argumento.

\footnotetext{
"Observamas que as potinhos que estavam com as Lemnas e mais próximas da luminária tinham mais folhas do que as que estavam afastadas da luminária, ou seja, as Lemnas precisam de luz constante para a populaça aumentar."
}

Como os alunos estão discutindo a variação na quantidade de indivíduos entre os diferentes potinhos dos diferentes grupos, ao afirmar que determinados potinhos têm mais indivíduos que outros os alunos estão apresentando dados e por conseguinte Seriando informações.

Ao associar o tamanho populacional, com a proximidade da luminária e a necessidade de luz para o crescimento populacional os alunos estão demonstrando a estrutura de seu pensamento no que consideramos como sendo o indicador de Raciocínio lógico.

O Argumento considerado segue estruturado segundo o layout modificado de Toulmin (2006):
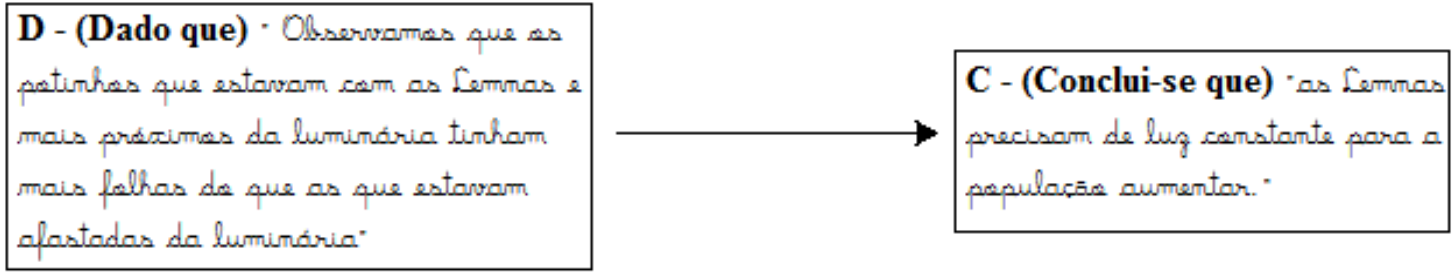

Este Argumento não apresenta Justificativas (J) que conduzam os Dados (D) até

a Conclusão $(\mathbf{C})$. A desambiguação em relação à possibilidade de tratar-se de uma Explicação e não um Argumento deriva da consideração de que a Conclusão (C) é menos certa que os Dados (D) e de acordo com Murcho (2003) esta é uma característica diferenciadora. 
Thiago Marinho Del Corso

INDICADORES DE ALFABETIZAÇÃO CIENTÍFICA, ARGUMENTOS E EXPLICAÇÕES -

Análise de Relatórios no Contexto de uma Sequência de Ensino Investigativo

\section{Marca 10:}

Neste relatório sete, mesmo que não tenha sido pedido explicitamente pela professora até o momento de sua confecção, os alunos escrevem uma conclusão acerca da atividade. Esta conclusão, diferentemente das apresentadas nos relatórios anteriores e final deste, foi escrita coletivamente. Sua localização no relatório é estranha pois se encontra entre os itens "Interpretaçåa" e "Resultados", também estranhamente apresentados nesta ordem.

Da forma como é escrita esta "Conclusãe" apresenta os indicadores de Previsão e

Levantamento de hipóteses quando os alunos afirmam que - "G populacãa irá crescer, principalmente as Lemnas de folhas verdes"- e - "mas as de folhas brancas/pretas irá crescer (mas pouce) comparando com as folhas verdes"-.

Entendemos que a assertiva do aluno apresenta tanto Previsão como Levantamento de hipóteses. Essa duplicidade de indicadores é verificada nos trabalhos de Sasseron e Carvalho (2008) e Sasseron (2008), onde estes indicadores aparecem juntos na maioria dos casos. O Levantamento de hipóteses acontece quando suposições são alçadas acerca de determinado tema, e aqui os alunos estão supondo que a população de Lemnas irá crescer. Este entendimento fica mais claro se pensarmos onde se localiza esta assertiva, ela esta antes da apresentação dos resultados e assim entendemos que os alunos estão alçando suposições sobre o que acontecerá com esta população.

A Previsão se caracteriza quando se afirma uma ação e/ou fenômeno que se sucede associado a certos acontecimentos. A localização desta assertiva também auxilia no entendimento desta como um indicador de Previsão, já que está localizada após a "Interpretaçãe"-, em que os alunos discorrem sobre o que aconteceu com a população de Lemnas antes de apresentar os resultados das contagens, descrevem o que aconteceu de forma mais geral e ampla. Daí que ao afirmar que -" $G$ populacăa irá crescer, principalmente as Lemnas de folhas verdes, mas as de folhas brancas/pretas irá crescer (mas pouce) comparando com as folhas verdes."- entendermos que os alunos estão explicitando um fenômeno que eles acreditam se sucede associado a estes eventos descritos anteriormente. 
Thiago Marinho Del Corso

INDICADORES DE ALFABETIZAÇÃO CIENTÍFICA, ARGUMENTOS E EXPLICAÇÕES -

Análise de Relatórios no Contexto de uma Sequência de Ensino Investigativo

\section{Marca 11:}

Esta $11^{\mathrm{a}}$ marca apresenta uma figura associada a uma data e um texto, nos quais foram identificadas a Seriação, Organização e Classificação de informações. $O$ primeiro destes indicadores se dá pela apresentação da quantidade de Lemnas presentes nesta população nesta data, tanto para folhas verdes quanto pretas e brancas.

A Organização de informações surge da separação entre folhas verdes como um grupo e pretas e brancas como outro grupo, no que pode ser entendido como uma organização que visa preparar os dados para futuras considerações.

Ao associar Lemnas vivas a coloração verde e mortas a coloração preta ou branca os alunos estão estabelecendo características dos dados no que consideramos uma Classificação de informações.

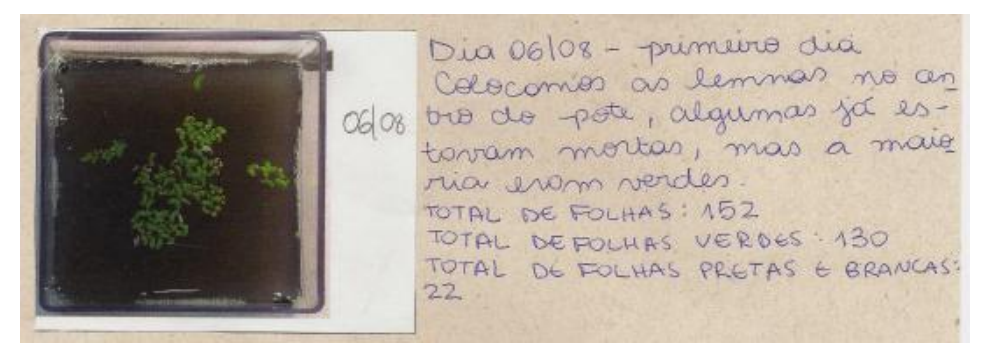

\section{Marca 12:}

Nesta marca, semelhantemente a anterior, também encontramos os indicadores de Seriação, Organização e Classificação de informações. O primeiro ocorre pela apresentação da contagem do número de indivíduos e pela afirmativa de que -“houve ... crescimenta"-. Como discutido em outros relatórios e marcas, quando o tema central é dinâmica populacional, crescimento populacional, diminuição ou estabilidade se configuram como dados e listar dados se relaciona ao indicador de Seriação de informações.

A Organização de informações se dá pela cronologia, identificada pelo ordenal - "sétima dia" - e pelo novo arranjo que os dados recebem, organizados nestes quatro momentos que são apresentados, no que podemos entender como uma preparação dos dados. A Classificação de informações evidencia-se pelo estabelecimento de características aos dados, como por exemplo ao dizer que - "houve um pice de crescimenta muita grande" - os alunos estão estabelecendo características para o dado do crescimento populacional, tanto ao afirmar que este crescimento foi -"muita grande"como ao descrever que ocorreu como um -"pice"-. 


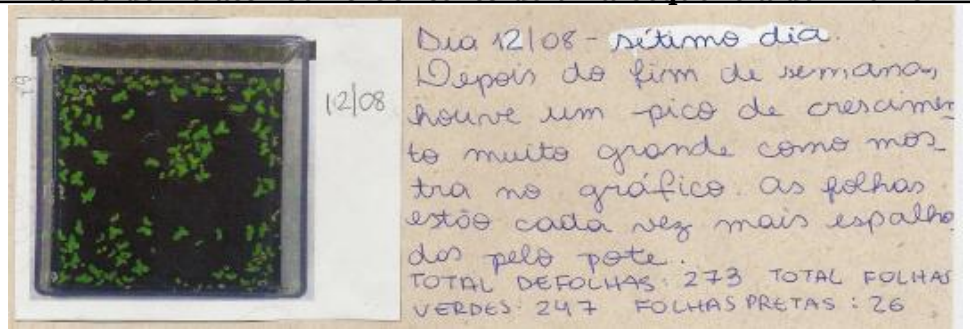

\section{Marca 13:}

Nesta $13^{\text {a }}$ marca ocorrem os indicadores de Seriação e Organização de informações. Estes indicadores ocorrem pelos mesmo motivos que nas marcas anteriores, apenas diferentemente das marcas anteriores não ocorre o indicador de Classificação de informações.

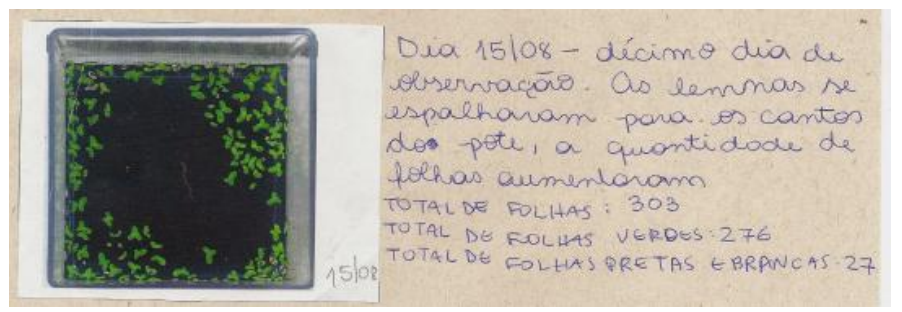

\section{Marca 14:}

Os indicadores aqui presentes são Seriação, Organização, Classificação de informações e os dois primeiros ocorrem pelos mesmos motivos que nas três marcas anteriores. A Classificação de informações ocorre aqui pelo estabelecimento de característica aos indivíduos da população de Lemnas que não só aumentaram em quantidade (dado apresentado na Seriação de informações) como estes novos indivíduos são descritos como maiores, o que é uma característica dos dados.

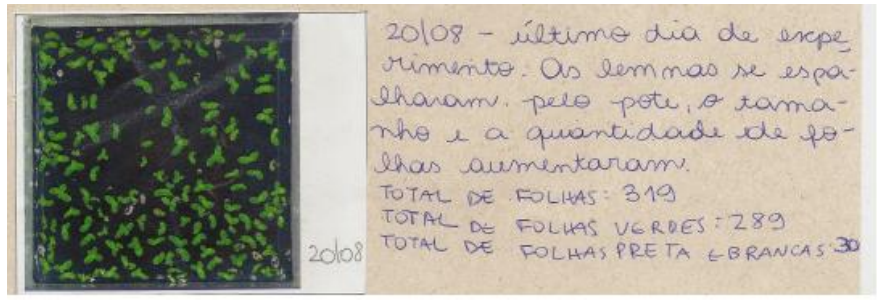


Marcas 15 e 16:

Os dois gráficos podem ser entendidos como Seriações, Organizações e Classificações de informação. Isso porque os gráficos apresentam a contagem do número de indivíduos, vivos na $15^{\mathrm{a}}$ marca e mortos na $16^{\mathrm{a}}$ marca, ao longo dos dias e esta apresentação dos dados caracteriza a Seriação de informações. A Organização de informações se dá pelo novo arranjo dado as informações, agora na forma de um gráfico. A Classificação de informações é aferida pelo estabelecimento de características que ocorre com os traços ligando os pontos obtidos pelo número de Lemnas presentes em cada dia amostrado e estimado para os finais de semana. Estes traçados permitem visualizar se a população está crescendo, diminuindo ou possivelmente se estabilizando.

\section{Marca 17:}

Aqui temos uma tabela que apresenta os dias amostrados, o número de indivíduos vivos, mortos e total. Desta forma consideramos que há uma Seriação de informações na medida em que esta tabela é também uma lista de dados e uma Organização de informações pelo novo arranjo de apresentação destes dados.

\section{Marca 18:}

O primeiro parágrafo da primeira conclusão individual do relatório sete apresenta o indicador de Organização de informações, pois o aluno aqui procura descrever o modo como o trabalho foi realizado e de acordo com Sasseron e Carvalho (2008) este indicador "ocorre nos momentos em que se discute sobre o modo como um trabalho foi realizado...".

\footnotetext{
"Observamas a desenvalvimenta da papulaçãa de lemnas em condisães ideais por 2 semanas, anotando sempre seus dados de crescimenta Cquantidade de folhas vivas e mortas), senda que nãa temas dados dos finais de semana (mo casa foram 2). "
} 
Thiago Marinho Del Corso

INDICADORES DE ALFABETIZAÇÃO CIENTÍFICA, ARGUMENTOS E EXPLICAÇÕES -

Análise de Relatórios no Contexto de uma Sequência de Ensino Investigativo

\section{Marca 19:}

Este segundo parágrafo escrito individualmente pelo aluno autor da primeira conclusão do relatório sete apresenta os indicadores de Justificativa, Previsão e Argumento. A afirmativa para a qual o aluno apresenta Justificativa é que as Lemnas estão em uma situação ideal, sendo a garantia - "Ccom luz 24 h por dia, sem muito venta)"-.

O Argumento já estruturado segundo o padrão proposto em nossa metodologia se encontra abaixo:

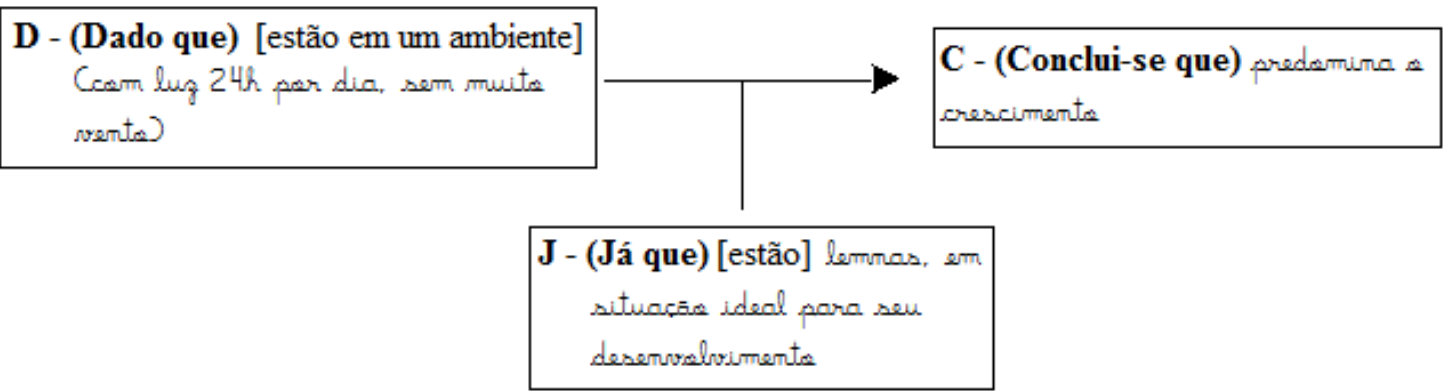

Neste Argumento os Dados (D) são empíricos e do desenho experimental, que deixava as lâmpadas que iluminavam as populações acesas todo o tempo, e a Justificativa é obtida de um argumento de autoridade, já que a pergunta geradora é feita pela professora, que é a autoridade máxima em sala de aula, dizia que as Lemnas estavam em uma condição ideal.

A Previsão ocorre aqui associada ao que foi considerado a Conclusão (C) do Argumento, ou seria que a população de Lemnas nas condições ideias terá predomínio de crescimento. Esse indicador (Previsão) "é explicitado quando se afirma uma ação elou fenômeno que sucede associado a certos acontecimentos". O fenômeno que sucederia aqui seria o predomínio de crescimento e os acontecimentos aos quais esse fenômeno estaria associado seria a colocação destas Lemnas em condições ideais, como afirmado pela professora na pergunta geradora que seria o ambiente do experimento.

\footnotetext{
"Respondenda a pergunta dada inicialmente, podemos concluir que, nas lemnas, em situaçãa ideal para seu desenvolvimenta (com luz 24 h por dia, sem muito venta). predomina a crescimente".
} 


\section{Marca 20:}

Este terceiro parágrafo, transcrito abaixo, da primeira conclusão individual do relatório sete apresenta indicadores de Seriação de informações, Classificação de informações, Raciocínio proporcional e Justificativa.

"Nas resultadas (gráfica podemas observar facilmente), que existe um pica muita alto do crescimento da quantidade de folhas (tatal e verdes) das lemnas, esse pica acorreu no firm de semana, quando nãa tínhamas dadas, por isso imaginamas que teve um pica tãa grande (de 161 folhas para 273). Ocorreram algurs picas megatives de queda ne crescimento, mas mäa muito relevante, pequenas quedas."

A Seriação de informações acontece pela citação da quantidade de Lemnas na população antes e depois do final de semana, quando é apontado um grande crescimento - "Cde 161 folhas para 273)" - e pelos dados de variação populacional -"crescimento"-, "algurs picas negativos"-, -"pequemas quedas"- etc.

Ao estabelecer características para os dados, como ao dizer - "um pice muite alte de crescimenta da quantidade de folhas"- ou " "alguns picas negativos de queda me crescimenta, mas mãa muita relevante"- os alunos estão Classificando informações. Entendemos que o Raciocínio proporcional se dá quando os alunos explicitam que determinada variação pode ser considerada uma grande variação, enquanto que outra pode ser considerada irrelevante.

O aluno atribui ao final de semana, quando não há registro, o pico de aumento na população de Lemnas -"esse pice ecorreu me fim de semana, quando mãe tínhamos dados,"-, mesmo esse não sendo uma associação biologicamente coerente, entendemos que o aluno está aqui Justificando uma afirmação - "por isso imaginamos que teve um pice tãe grande (de 161 folhas para 273)"-.

\section{Marca 21:}

Neste penúltimo parágrafo da primeira conclusão individual do relatório 7 temos os indicadores de Seriação de informações pela apresentação da variação no número de Lemnas mortas e a estabilização populacional. O indicador de Classificação de 
Thiago Marinho Del Corso

INDICADORES DE ALFABETIZAÇÃO CIENTÍFICA, ARGUMENTOS E EXPLICAÇÕES -

Análise de Relatórios no Contexto de uma Sequência de Ensino Investigativo

informações pela atribuição de uma característica a esses dados - "a númera ficou um parce mais estabilizados, sem picos"-.

"Em relaça a quantidade de folhas mortas, a númera ficou um pauca mais

estabilizados, sem picas (varian de 18 a 30 folhas)".

\section{Marca 22:}

Neste ultimo parágrafo da primeira conclusão individual entendemos haver uma Seriação de informações, Justificativa, Previsão e um Argumento.

"Observanda a gráfica, a crescimenta sá tende a crescer, entãa sim, em situaçaes ideais para a desenvolvimenta das lemnas, a crescimenta da papulaça aumenta.".

A Seriação de informações ocorre na apresentação de dados, observados a partir do gráfico de que a população cresceu - "Observanda a gráfice, a crescimenta sá tende a crescer"-.

De acordo com Sasseron e Carvalho (2008) uma Previsão é explicitada quando se afirma que uma ação e/ou fenômeno sucede associada a certos eventos. A Previsão aqui decorre da afirmativa de que a tendência da população é crescer. Ou seria que o fenômeno é crescer para populações colocadas em situações ideais, o evento em que está associada -"em situasães ideais para a desenvolvimento das lemmas, a crescimenta da populaçãe aumenta."-.

Entendemos que o aluno está afirmando que a população tende a crescer -“ a crescimenta sé tende a crescer"- e que este lança mão de uma garantia para esta afirmativa -"entãe sim, em situaçẽes ideais para a desenvolvimenta das lemnas

Estruturado segundo nossa metodologia o Argumento fica da seguinte forma:

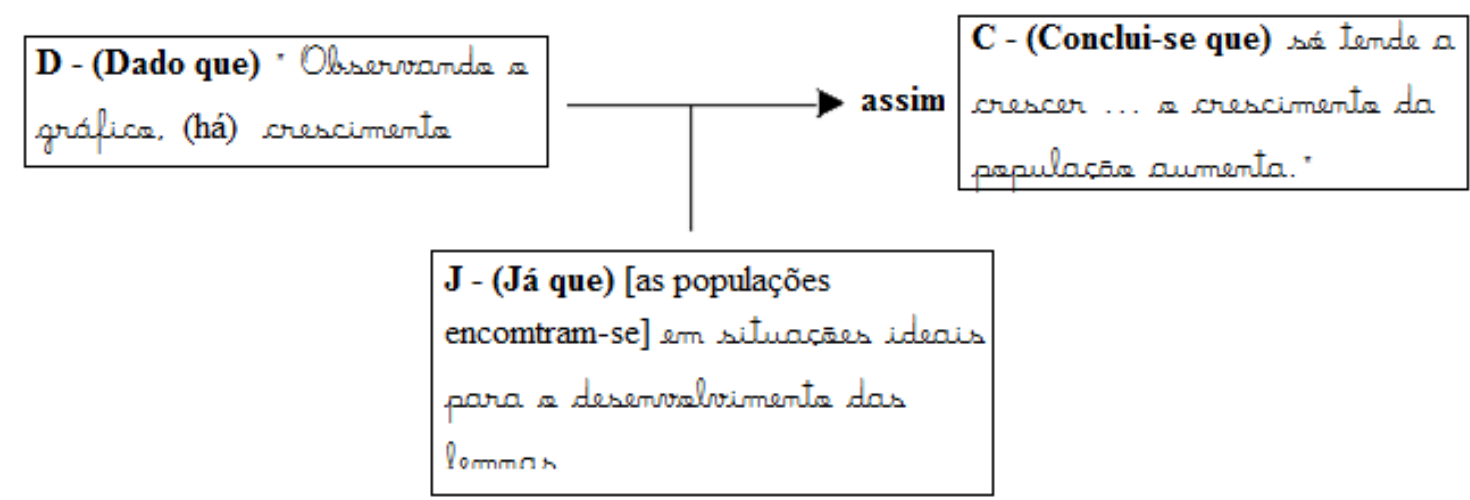


Thiago Marinho Del Corso

INDICADORES DE ALFABETIZAÇÃO CIENTÍFICA, ARGUMENTOS E EXPLICAÇÕES -

Análise de Relatórios no Contexto de uma Sequência de Ensino Investigativo

A interpretação do gráfico que serve aqui como Dado (D) para o Argumento esta

mal elaborada e assim a qualidade conceitual deste Argumento é colocada em cheque.

Mas podemos imaginar que estando muito familiarizados com este gráfico, por ter sido construído por eles a partir de dados empíricos coletados e tratados também por eles, o aluno tenha apenas se expressado mal. A Justificativa (J) do Argumento advêm da afirmativa da professora, que é a autoridade em sala de aula, e por isso serve como apoio à Conclusão (C).

Entendemos que aqui trata-se realmente de um Argumento e não uma Explicação porque a Conclusão (C) é menos plausível que os elementos que levaram a ela.

\section{Marca 23:}

$\mathrm{Na}$ segunda conclusão individual, que segue transcrita abaixo, do relatório 7, temos os indicadores de Seriação, Organização e Classificação de informações e Justificativa.

\footnotetext{
"Uma populacãa biológica após a colonizacãa por alguns individuas, pode acorrer fatores, tais come competicäa interespecifica, pois disputam as mesmos recursos Calimento. luz, água, espacse, etc.). O númera populacional de Lemnas mortas diminuiu em alguns dias, mas também aumentau em autros (mãa foi um aumenta grande semelhante a de folhas verdes, repentina). (O númera papulacional de Lemnas de folhas verdes cresceu rapidamente; (Duando comescames e experimento já havia folhas mortas (brancas e pretas). mas isso näa interrompen a crescimento das folhas verdes."
}

A Seriação de informações se dá tanto quando o aluno apresenta os fatores que seriam disputados em uma competição interespecífica - "alimenta, luz, água, espacse. etc.)”- como pela listagem de dados de variação populacional -“ $O$ múmero populacional de Lemnas mortas diminuiu em algurs dias"-, -", mas também aumentau em autros"-, ,- 0 múmero populacional de Lemnas de folhas verdes cresceu"- e -" crescimento das folhas verdes"-.

A Organização de informações surge da tentativa do aluno de organizar os dados, falando separadamente do que aconteceu com as Lemnas mortas (identificadas pelo aluno através da coloração diferente de verde) e com as Lemnas vivas. A 
Thiago Marinho Del Corso

INDICADORES DE ALFABETIZAÇÃO CIENTÍFICA, ARGUMENTOS E EXPLICAÇÕES -

Análise de Relatórios no Contexto de uma Sequência de Ensino Investigativo

Classificação de informações ocorre com a atribuição de características aos dados, como ao afirmar que o crescimento das Lemnas verdes foi rápido.

A Justificativa é proferida para dar garantia, aval, a afirmativa de que - "pode acorrer fatores, tais come competiçãa interespecifica,"- e se constitui na apresentação do que pode ser disputado nesta competição - "pois disputam as mesmos recursos Calimenta, luz, água, espacs, etc.).”--. Deve-se levar em conta que ocorre um erro conceitual, já que a competição aqui possível é intraespecífica (entre organismos da mesma espécie) e não interespecífica (entre organismos de espécies diferentes) como proferido pelo aluno.

\section{Marca 24:}

No primeiro parágrafo da terceira conclusão do relatório 7 , transcrito abaixo, encontramos uma Previsão e um Argumento.

"Cpás a colonizacãa de alguns individuas de uma populaçãa bialógica em um ambiente com as condicães ideais para a desenvolvimenta da espécie, é passivel afirmar. com base nos resultadas do experimenta realizado, que a populaça irá aumentar, crescer. mas mãe de um dia para e eutra, há muitas variașés, dias com grandes crescimentas e depois deste períado uma enorme queda."

A Previsão ocorre quando o aluno afirma que associado ao acontecimento de povoar com alguns indivíduos um ambiente com condições ideais a população formada irá se desenvolver. Ou seria o aluno está afirmando que um fenômeno irá suceder associado a certos acontecimentos.

Estruturado segundo apresentado em nossa metodologia o parágrafo acima fica da seguinte forma:

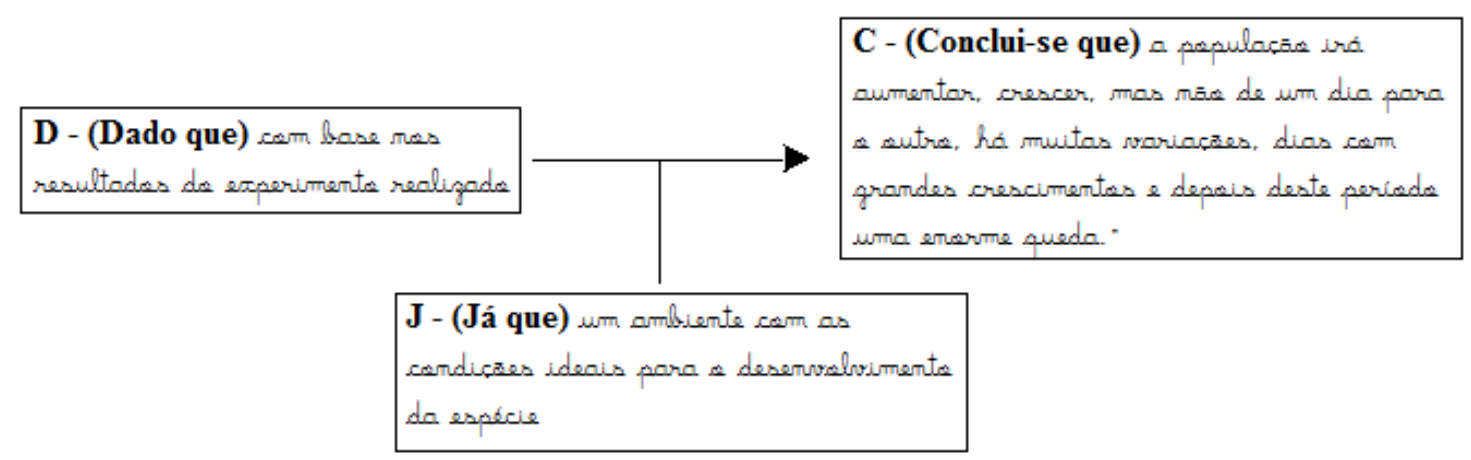


Thiago Marinho Del Corso

INDICADORES DE ALFABETIZAÇÃO CIENTÍFICA, ARGUMENTOS E EXPLICAÇÕES -

Análise de Relatórios no Contexto de uma Sequência de Ensino Investigativo

Vale notar que novamente, como nas conclusões individuais anteriores, a

afirmativa da professora de que as Lemnas estão em condições ideais é utilizada como Justificativa (J) no Argumento.

\section{Marca 25:}

No segundo parágrafo da terceira conclusão do relatório sete, transcrito abaixo, observamos o indicador de Seriação de informações e Raciocínio proporcional.

"E além da crescimenta da populaça existe também a crescimenta da mortalidade. que nos gráficos produzidas é passivel perceber que acompanhou a crescimenta da populaçãa, quanda houve queda do crescimenta, houve na mortalidade, assim como com as grandes altas. Mas, meste casa, a matalidade superou a mortalidade."

A Seriação de informações decorre da apresentação de dados de variação populacional como -"crescimenta da populasãa"- e -"crescimenta da mortalidade"-.

O indicador de Raciocínio proporcional, de acordo com Sasseron (2008) e Sasseron e Carvalho (2008): "É o que da conta de mostrar o modo como se estrutura o pensamento, além de se referir também à maneira como as variáveis têm relacão entre

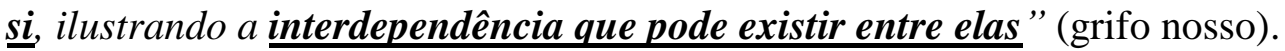

Podemos perceber que o aluno infere uma interdependência entre as variáveis de crescimento de Lemnas e mortalidade das mesmas e por isso enxergamos aqui o indicador de Raciocínio proporcional.

\section{Marca 26:}

Neste terceiro e ultimo parágrafo da terceira conclusão do sétimo relatório, transcrito abaixo encontramos os indicadores de Levantamento de hipóteses, Justificativa, Previsão, Raciocínio lógico e Raciocínio proporcional.

\footnotetext{
"To final, é passivel concluir que a populaçãa irá crescer sim, coma já disse anteriormente, só que até um certo ponto, até as recursos suportarem e houver para todos. mas a partir do momenta que faltar recursos pode-se ter a certeza que a crescimento irá diminuir e a mortalidade aumentar."
}

O Levantamento de hipóteses se dá quando os alunos supõe que - “populaçãa irá crescer sim, coma fá disse anteriormente, sá que até um certa ponta" - esta afirmação se configura como uma hipótese generalizante do comportamento de uma população de 
Lemnas. Após esta suposição os alunos Justificam porque têm esta suposição, que é pelo fato de - "até as recursos suportarem e houver para todos,"- esta funciona como uma garantia para a afirmação acerca do crescimento da população de Lemnas.

O trecho em que o aluno diz que - "mas a partir do momenta que faltar recursos pode-se ter a certeza que a crescimenta irá diminuir e a mortalidade aumentar."- foi entendido como uma Previsão, já que os alunos estão prevendo o comportamento da população de Lemnas no futuro, para quando houver uma escassez de recursos.

O Raciocínio lógico decorre da estruturação clara do raciocínio do aluno, que apresenta que o crescimento da população ocorrerá apenas enquanto houver recursos que sustentem esse crescimento. O Raciocínio proporcional ocorre pela exposição clara das relações entre as variáveis, pela interdependência dessas variáveis, enquanto houver recursos a população apresentará crescimento, quando os recursos se tornarem escassos o crescimento irá diminuir e a mortalidade aumentar. 
Thiago Marinho Del Corso

INDICADORES DE ALFABETIZAÇÃO CIENTÍFICA, ARGUMENTOS E EXPLICAÇÕES -

Análise de Relatórios no Contexto de uma Sequência de Ensino Investigativo

O Relatório 8 - 2013

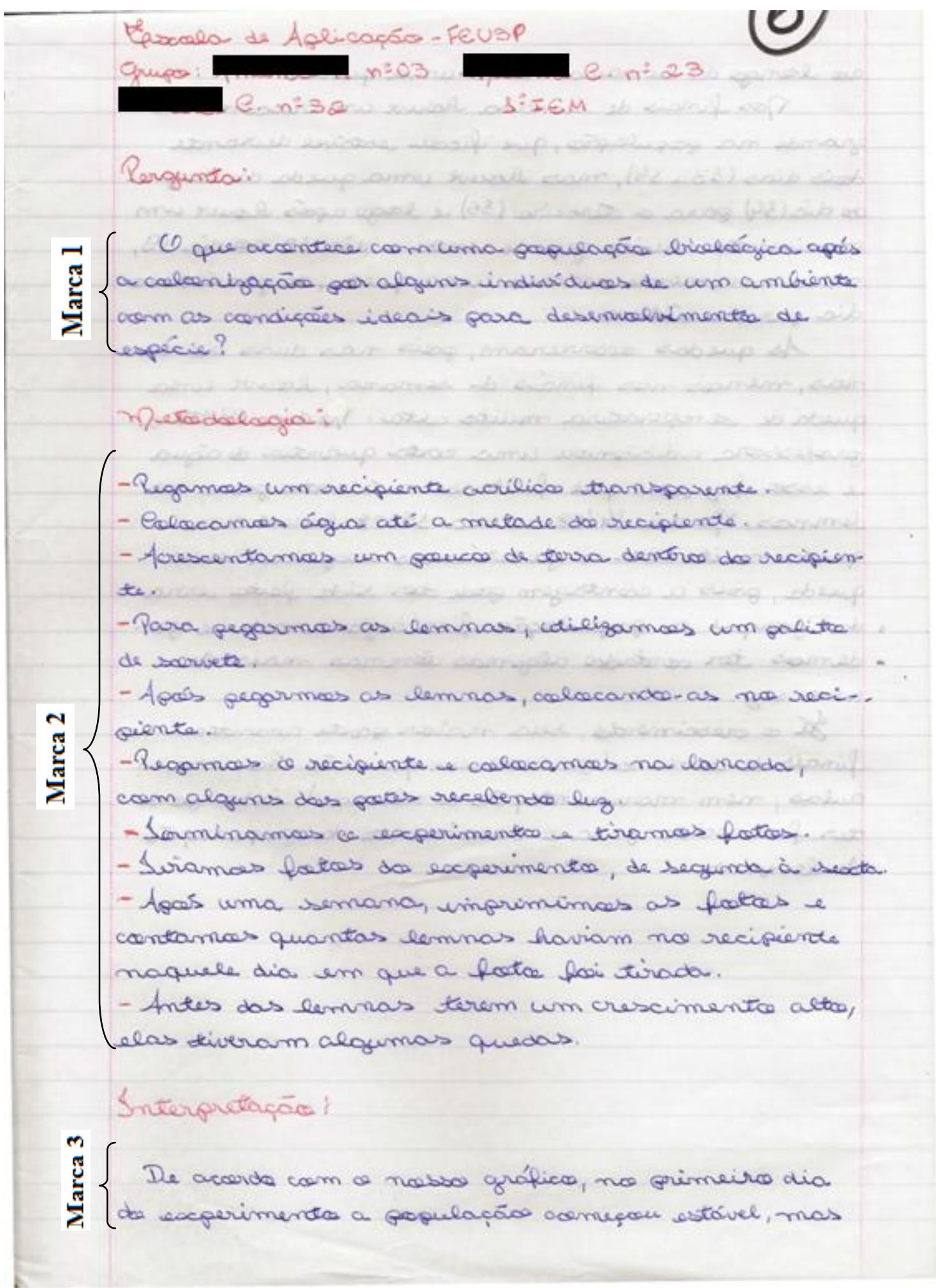


do longo da semana houve uma queda.

pos finais de semana bouve um crescimento grande na papulaçaco, que ficau estável devrante deis dias (s 3 a 84), mas bouve uma queda de segun.

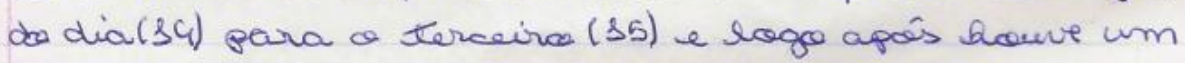
crescimento muito grande entre e dia 15 ace dia 19 , mas novemente ocorreu uma queda, do penuéltimo dia para ce léltime.

As quedas ocoureram, pais nas duas semanas, menas nos finais de semana, bauve una queda de temperatura muito alta. Pa dia s9/08 a orofessora adicianou uma certa quantia de ć́gua " a isse floz com que faltasse nutrientas para as \{lemnas, Ne dia $84 / 08$ ace dia $15 / 08$ houve uma queda muita alta e poderíamas explicar essa queda, poirs a contagem gade ter sida faita erra. da, parque a papulaçäa fiea aglamerada e pe. demas ter contadeo algumas lemnas mais de uma vezz.

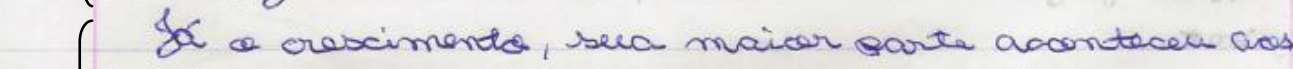
- finais de semana ( geríca de em que náo hauveram : aulas, nem mavinentapaês de alunos), isso por de * ter farearecide para e crescimenta de peepulaçäo (de lemanas. 
Thiago Marinho Del Corso

INDICADORES DE ALFABE M

Análise de Relatórios no C Marca 7 lma Sequência de Ensino Investigativo

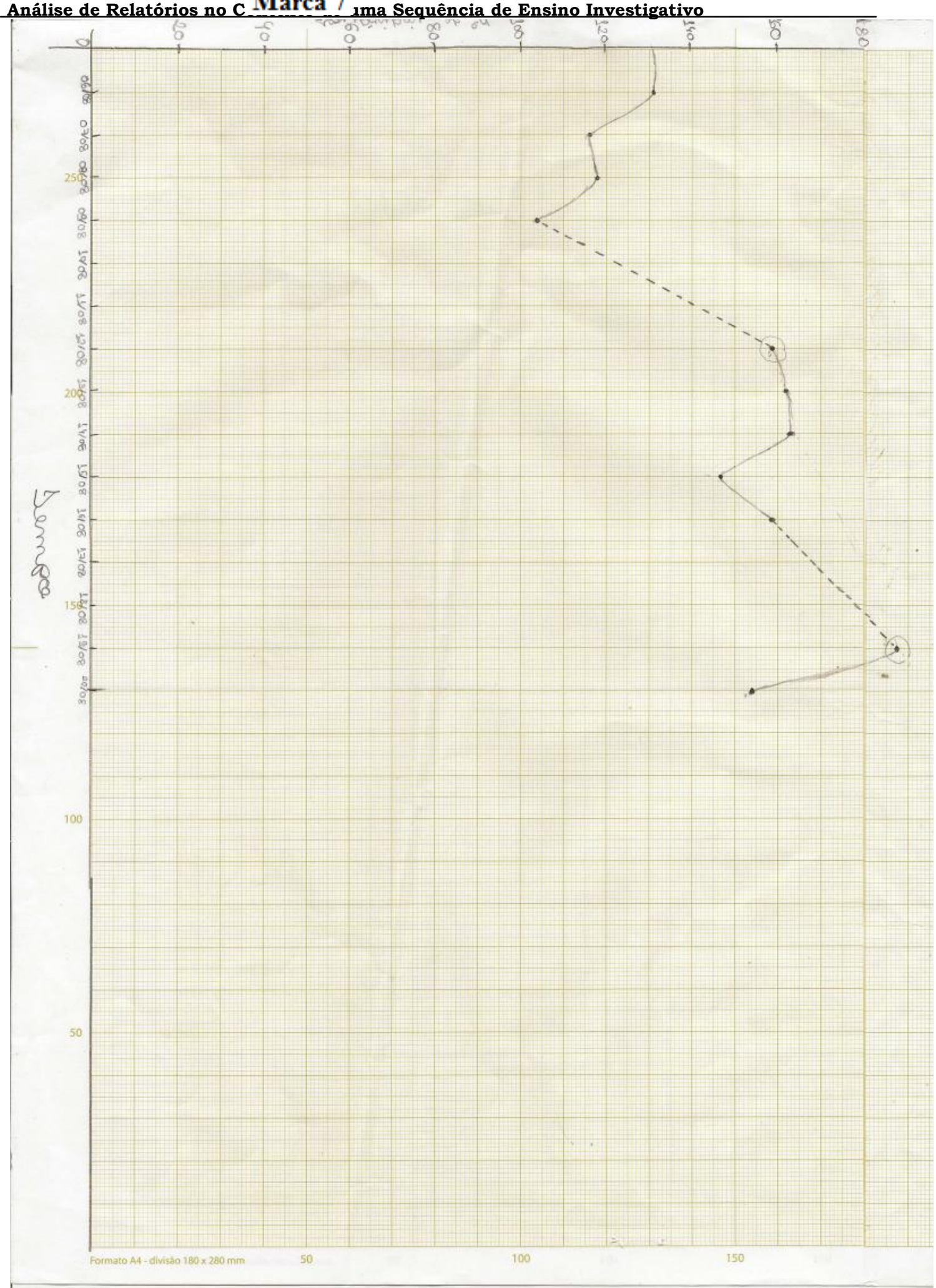


Thiago Marinho Del Corso

INDICADORES DE ALFABETIZAÇ̃̃o CIENTÍFICA, ARGUMENTOS E EXPLICAÇÕES -

Análise de Relatórios no Contexto de uma Sequência de Ensino Investigativo

\section{Quadro 08}

Identificação dos Indicadores de Alfabetização Científica no Relatório 8 de 2013 e conclusões individuais correspondentes

\begin{tabular}{|c|c|c|c|c|c|c|c|c|c|c|c|c|c|}
\hline 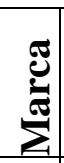 & $\begin{array}{l}\text { Subtítulo, } \\
\text { divisão ou } \\
\text { Item }\end{array}$ & Texto & $\mathbf{L M}$ & SI & $\mathbf{O I}$ & CI & \begin{tabular}{l|l|} 
RL & RP \\
\end{tabular} & $\mathbf{L H}$ & TH & $\mathbf{J}$ & $\mathbf{P}$ & $\underset{x}{a}$ & $\sum^{\infty}$ \\
\hline 1 & $\begin{array}{l}\text { Pergunta } \\
\text { (Pergunta) }\end{array}$ & $\begin{array}{l}\text { "Pergunta: O que acontece com uma papulaşãa bialógica } \\
\text { após a colonizaçãa par alguns individuas de um ambiente com as } \\
\text { condiçães ideais para a desenvolvimenta das espécies?" }\end{array}$ & Não & aval & iado, & texto & da profess & sora & & & & & \\
\hline 2 & $\begin{array}{l}\text { Metodologia } \\
\text { (Metodologia) }\end{array}$ & 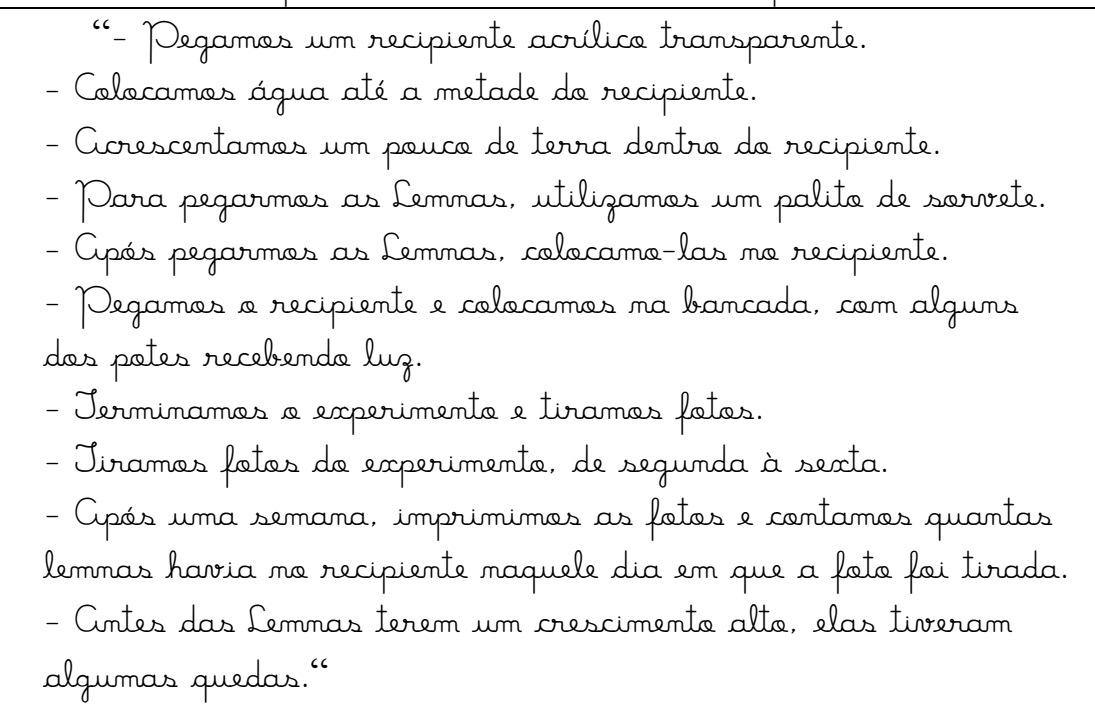 & $\mathbf{X}$ & $\mathbf{X}$ & $\mathbf{X}$ & & & & & & & & \\
\hline 3 & $\begin{array}{l}\text { Interpretação } \\
\text { (Jnterpretaçãa) } \\
1^{\circ} \text { parágrafo }\end{array}$ & $\begin{array}{l}\text { "De acorda com a massa gráfica, ne primeira dia da } \\
\text { experimenta a populaçãa comesceu estável. mas ae longa da semana } \\
\text { houve uma queda." }\end{array}$ & & $\mathbf{X}$ & $\mathbf{X}$ & & & & & & & & \\
\hline
\end{tabular}


Thiago Marinho Del Corso

INDICADORES DE ALFABETIZAÇ̃̃O CIENTÍFICA, ARGUMENTOS E EXPLICAÇÕES -

Análise de Relatórios no Contexto de uma Sequência de Ensino Investigativo

\begin{tabular}{|c|c|c|c|c|c|c|c|c|c|c|c|c|c|}
\hline 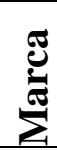 & $\begin{array}{l}\text { Subtítulo, } \\
\text { divisão ou } \\
\text { Item } \\
\end{array}$ & Texto & $\mathbf{L M}$ & SI & OI & CI & \begin{tabular}{l|l|l|} 
RLP & \\
\end{tabular} & $\mathbf{L H}$ & TH & $\mathbf{J}$ & $\mathbf{P}$ & $\underset{\text { 워 }}{2}$ & $\sum_{4}^{00}$ \\
\hline 4 & $\begin{array}{l}\text { Interpretação } \\
\text { (Interpretaçãa) } \\
2^{\circ} \text { parágrafo }\end{array}$ & 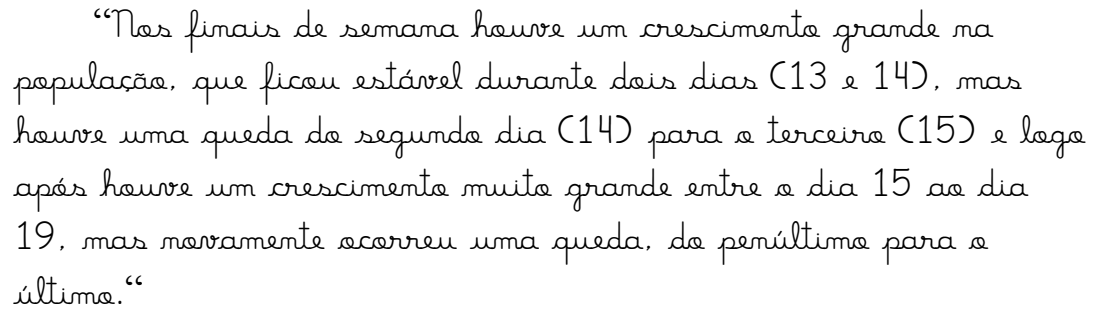 & & $\mathbf{X}$ & $\mathbf{X}$ & $\mathbf{X}$ & & & & & & & \\
\hline 5 & $\begin{array}{l}\text { Interpretação } \\
\text { (Interpretaçãa) } \\
3^{\circ} \text { parágrafo }\end{array}$ & 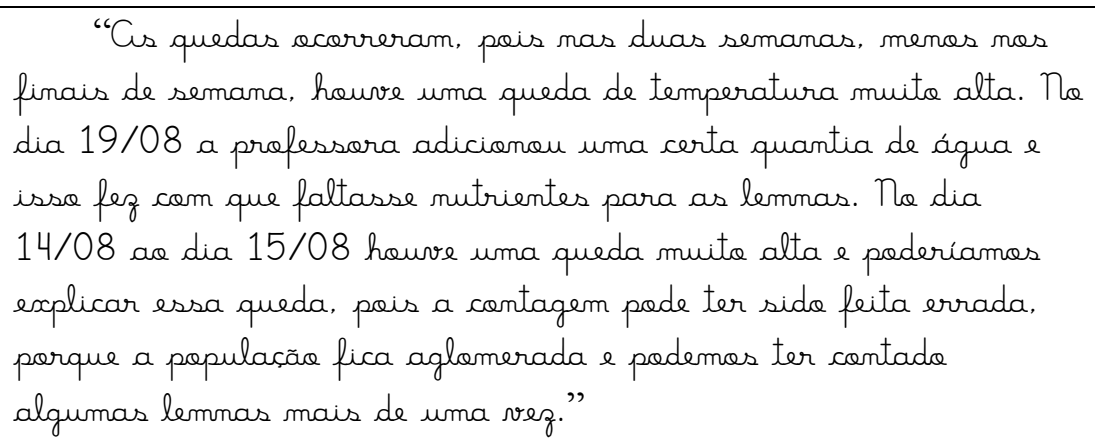 & & $\mathbf{X}$ & $\mathbf{X}$ & & & & & $\mathbf{X}$ & & $\mathbf{X}$ & \\
\hline 6 & $\begin{array}{l}\text { Interpretação } \\
\text { (Imterpretaçãa) } \\
4^{\circ} \text { parágrafo }\end{array}$ & $\begin{array}{l}\text { "Iá a crescimenta, sua maior parte aconteceu aos finais de } \\
\text { semana (perioda em que nãa houve aulas, nem movimentacões de } \\
\text { alunas), issa pode ter favorecida para a crescimenta da papulaça a } \\
\text { de lemnas." }\end{array}$ & & $\mathbf{X}$ & & & & & & $\mathbf{X}$ & & $\mathbf{X}$ & \\
\hline
\end{tabular}


Thiago Marinho Del Corso

INDICADORES DE ALFABETIZAÇÃO CIENTÍFICA, ARGUMENTOS E EXPLICAÇÕES -

Análise de Relatórios no Contexto de uma Sequência de Ensino Investigativo

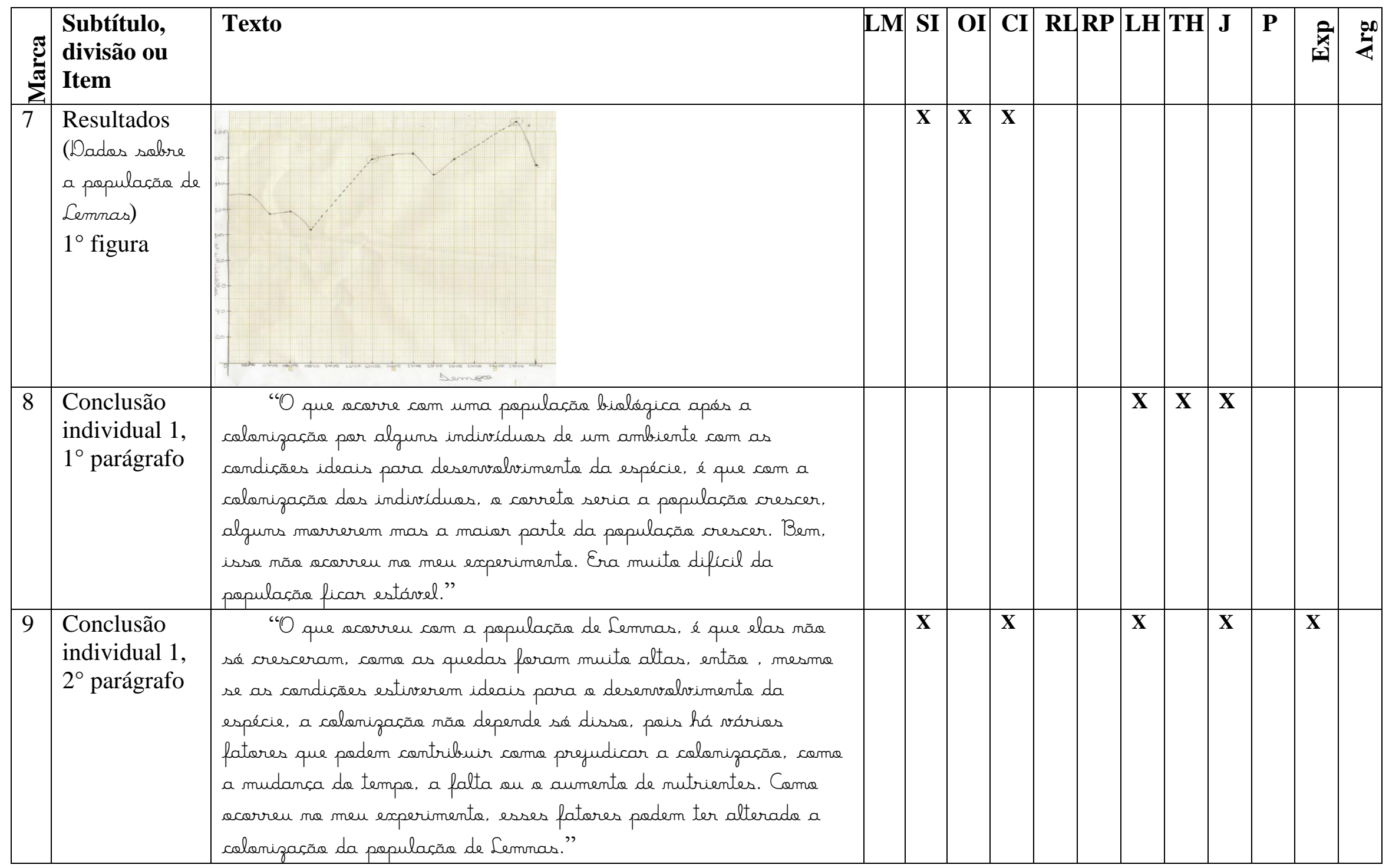


Thiago Marinho Del Corso

INDICADORES DE ALFABETIZAÇÃO CIENTÍFICA, ARGUMENTOS E EXPLICAÇÕES -

Análise de Relatórios no Contexto de uma Sequência de Ensino Investigativo

\begin{tabular}{|c|c|c|c|c|c|c|c|c|c|c|c|c|c|}
\hline 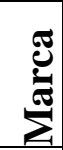 & $\begin{array}{l}\text { Subtítulo, } \\
\text { divisão ou } \\
\text { Item }\end{array}$ & Texto & $\mathbf{L M}$ & SI & OI & CI & \begin{tabular}{|l|l|}
$\mathbf{R L}$ & $\mathbf{R P}$ \\
\end{tabular} & $\mathbf{L H}$ & TH & $\mathbf{J}$ & $\mathbf{P}$ & $\underset{x}{x}$ & $\sum^{\infty}$ \\
\hline 10 & $\begin{array}{l}\text { Conclusão } \\
\text { individual } 2 \\
1^{\circ} \text { parágrafo }\end{array}$ & $\begin{array}{l}\text { "A populaçãa pode ficar estável mas também cair aa longa da } \\
\text { tempa." }\end{array}$ & & & & & & $\mathbf{X}$ & & & & & \\
\hline 11 & $\begin{array}{l}\text { Conclusão } \\
\text { individual } 2 \text {, } \\
2^{\circ} \text { parágrafo }\end{array}$ & 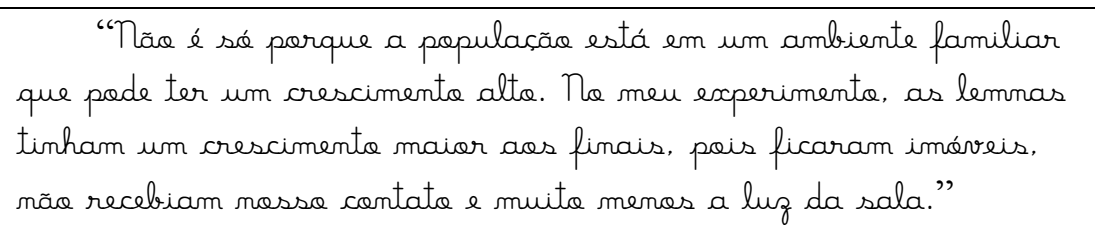 & & $\mathbf{X}$ & & $\mathbf{X}$ & & & & $\mathbf{X}$ & & $\mathbf{X}$ & \\
\hline 12 & $\begin{array}{l}\text { Conclusão } \\
\text { individual } 2 \\
3^{\circ} \text { parágrafo }\end{array}$ & $\begin{array}{l}\text { "Cis lemnas se desenvalvem melhor cam um ambiente calma e } \\
\text { sem mavimenta." }\end{array}$ & & & & & & $\mathbf{X}$ & & & $\mathbf{X}$ & & \\
\hline 13 & $\begin{array}{l}\text { Conclusão } \\
\text { individual } 3, \\
\text { Parágrafo } \\
\text { único }\end{array}$ & 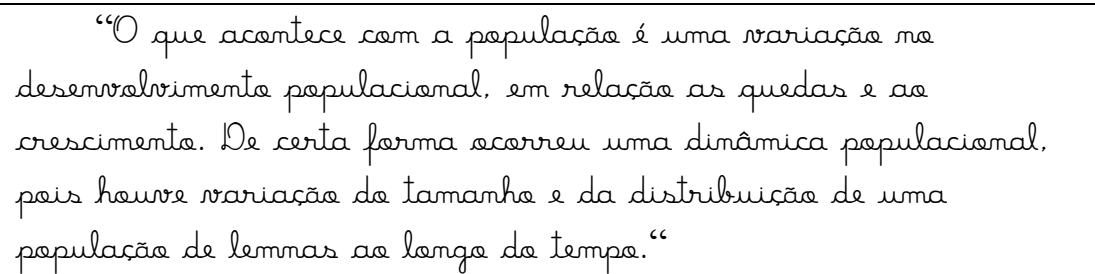 & & $\mathbf{X}$ & & & & & & $\mathbf{X}$ & & & $\mathbf{X}$ \\
\hline
\end{tabular}


Este relatório não apresenta título e se inicia com um cabeçalho e depois a pergunta geradora, dada pela professora.

\section{Marca 1:}

Por se tratar de uma pergunta fornecida pela professora e consequentemente não ser de autoria dos alunos esta não será analisada.

\section{Marca 2:}

Após a pergunta geradora os alunos apresentam a -"metodologia"- em tópicos que por isso são analisados conjuntamente em uma única marca. Pudemos identificar os indicadores de Listagem de materiais, Seriação e Organização de informações. O primeiro destes indicadores aparece aqui, quando são apresentados os materiais usados na SEI.

A Seriação aparece aqui apenas no último item quando são listados dados -"Cintes das Lemnas terem um crescimenta alto, elas tiveram algumas quedas." -.

A Organização de informações também só se verifica no ultimo tópico quando os alunos organizam um panorama geral de como se distribuiu o crescimento populacional ao longo da coleta dos dados, esta cronologia é uma preparação dos dados sobre o problema de investigação -"Gntes das Lemnas terem um crescimenta alto, elas tiveram algumas quedas."-.

- Pegamas um recipiente acrilice tramsparente.

- Colocamos água até a metade do recipiente.

- Corescentamas um pauca de terra dentra do recipiente.

- Para pegarmas as Semnas, utilizamas um palita de sorvete.

- Cpós pegarmas as Lemnas, colocame-las ne recipiente.

- Pegamas a recipiente e colocamos ma bancada, com algurs dos potes recebenda luz.

- Terminamas a experimenta e tiramas fotas.

- Tiramas fotas da experimenta, de segunda à sexta. 
- Cpós uma semana, imprimimas as fotas e contamas quantas lemnas havia no recipiente naquele dia em que a fata foi tirada.

- Antes das Lemnas terem um crescimenta alta, elas tiveram algumas quedas.

\section{Marca 3:}

Neste primeiro parágrafo da -"Interpretacäa"- encontramos os indicadores de Seriação, Organização de informações. A Seriação dá se pela apresentação dos dados de que há um período de estabilidade e outro de queda -“comecou estárel”-, -“mas ae longe da semana houve uma queda."-. A Organização ocorre pela apresentação cronológica dos dados, no que entendemos ser uma preparação dos dados sobre o problema investigado e ao longo da semana houve uma queda

"De acorda com a nassa gráfica, ne primeira dia da experimenta a papulasãa comesceu estável, mas ae longe da semana houvre uma queda.".

\section{Marca 4:}

O segundo parágrafo da interpretação apresenta também indicadores de Seriação,

\section{Organização e Classificação de informações.}

A Seriação é identificada pela descrição do que acontece com a população, haver crescimento, estabilidade ou diminuição pode ser entendida como dados que são a base para a investigação da dinâmica populacional das Lemnas ao longo do experimento "Nas finais de semana houve um crescimenta grande na papulaşãa"-, -"ficou estável durante dais dias (13 e 14)"-, "houve uma queda da segunda dia (14) para a terceira (15)"-, "houve um crescimenta muite grande entre a dia 15 ae dia 19"- e -"mas novamente acorreu uma queda, da penúltima para a última"-.

A Organização de informações decorre da divisão em momentos com características próprias do que está acontecendo com a população, esta separação pode ser entendida como uma Organização, uma preparação dos dados. Também entendemos haver Organização pela ordenação cronológica de apresentação dos dados.

A Classificação de informações é verificada quando os alunos estabelecem características para os dados, isso fica evidente ao classificar o crescimento ocorrido 
Thiago Marinho Del Corso

INDICADORES DE ALFABETIZAÇÃO CIENTÍFICA, ARGUMENTOS E EXPLICAÇÕES -

Análise de Relatórios no Contexto de uma Sequência de Ensino Investigativo

entre os dias 15 à 19 como muito grande -"houve um crescimento muito grande entre a dia 15 ae dia 19"-.

"Nas finais de semana houvre um crescimenta grande na populașãa, que ficau estável durante dois dias (13 e 14), mas houve uma queda da segunda dia (14) para a terceira (15) e loge após houve um crescimenta muita grande entre a dia 15 ac dia 19. mas movamente acorreu uma queda, de penuiltima para a última."

\section{Marca 5:}

Este parágrafo considerado a quinta marca do relatório apresenta os indicadores de Seriação, Organização e Classificação de informações, além de Justificativas e Explicações.

"Cis quedas acorreram, pois nas duas semanas, menos nos finais de semana, houve uma queda de temperatura muita alta. No dia $19 / 08$ a professora adicionou uma certa quantia de água e issa fez com que faltasse nutrientes para as lemnas. To dia 14/08 ae dia 15/08 houve uma queda muita alta e poderíamos explicar essa queda, pois a contagem pade ter sida feita errada, parque a populaçãa fica aglomerada e pademas ter contada algumas lemnas mais de uma vez."

O tema central do relatório é dinâmica populacional, e neste caso, crescimento ou diminuição do tamanho da população modelo, constitui-se em um dado, logo, quando os alunos afirmam que -"Cls quedas scorreram... mas duas semanas"- eles estão apresentando dados, no que é entendido como uma Seriação de informações.

A Organização de informações ocorre com a divisão em dois períodos a serem discutidos, a queda da primeira e da segunda semana. Esta divisão evidencia uma preparação dos dados existentes, que estão sendo retomados para análise e discussão.

O estabelecimento de características aos dados é indicativo de Classificação de informações e ocorre neste trecho quando os alunos afirmam que a queda (dado) foi muito alta (característica deste dado) -“ No dia 14/08 ae dia 15/08 houve uma queda muita alta"-.

Justificativas são perpetradas para dar garantia à afirmações e neste trecho encontramos duas afirmativas e suas respectivas garantias:

\begin{tabular}{|l|l|}
\hline Afirmativa & Garantia \\
\hline "Cs quedas ocorreram," & "pois nas duas semanas, menos nos finais de semana, houve \\
\hline
\end{tabular}


INDICADORES DE ALFABETIZAÇÃO CIENTÍFICA, ARGUMENTOS E EXPLICAÇÕES -

Análise de Relatórios no Contexto de uma Sequência de Ensino Investigativo

\begin{tabular}{|c|c|}
\hline & $\begin{array}{l}\text { uma queda de temperatura muita alta. To dia } 19 / 08 \text { a } \\
\text { professora adicionou uma certa quantia de água e issa fez com } \\
\text { que faltasse nutrientes para as lemnas." }\end{array}$ \\
\hline $\begin{array}{l}\text { "We dia } 14 / 08 \text { ae dia } \\
15 / 08 \text { houve uma queda } \\
\text { muite alta" }\end{array}$ & $\begin{array}{l}\text { "poderíamas explicar essa queda, pais a contagem pode ter sida } \\
\text { feita errada, porque a populaça fica aglomerada e podemos ter } \\
\text { contada algumas lemnas mais de uma vez." }\end{array}$ \\
\hline
\end{tabular}

Encontramos também três Explicações, que não são concorrentes. A primeira apresenta uma causa para a diminuição do numero de indivíduos na população para ambos os momentos. Nesta o explanandum é que as -"Cls quedas acorreram"- e o explanans -"houve uma queda de temperatura muita alta."-- Nesta primeira Explicação os alunos não estão tentando convencer que houve diminuições no número de indivíduos da população de Lemnas, já que estas estão evidentes no gráfico, mas estão tentando apresentar as causas para estes fenômenos. Esta última consideração somada à evidente maior plausibilidade do explanandum em relação ao explanans são indicativos de que aqui trata-se de uma Explicação e não um Argumento.

Depois os alunos apresentam causas especificas para cada momento de diminuição do número de indivíduos na população. Vale notar que não são hipóteses explicativas concorrentes, mas motivos que se somam para explicar as causas que levaram a diminuição do numero de indivíduos na população de Lemnas. A Justificativa, causa, geral para a diminuição nos dois momentos é -"houve uma queda de temperatura muito alta."-. Especificamente para o primeiro momento (14/8 - 15/8) um possível erro na contagem é apontado como causa -"poderíames explicar essa queda. pois a contagem pode ter sida feita errada, porque a populacäa fica aglomerada e podemas ter contada algumas lemnas mais de uma vez." -. E para o segundo momento de queda, a falta de nutrientes causada pela adição de água pela professora, é considerada a causa do decréscimo populacional -"a professora adicionou uma certa quantia de água e isso fez com que faltasse nutrientes para as lemnas"-.

\section{Marca 6:}

Neste parágrafo, que constitui a sexta marca e segue transcrito abaixo, encontramos os indicadores de Seriação de informações, Justificativa e Explicação. 
"Já a crescimenta, sua maior parte aconteceu aos finais de semana (períado em que nãe houve aulas, nem movimentacães de alunos), isso pode ter favorecida para a crescimenta da pepulaçãa de lemnas."

A apresentação do dado, de que nos finais de semana houve crescimento, se configura como uma Seriação de informações - “Já a crescimenta, sua maiar parte acontecen ass finais de semana"-.

A Explicação foi desenvolvida para a afirmativa de que há crescimento nos finais de semana e a Justificativa para este aumento no número de indivíduos na população nos finais de semana é a não movimentação em sala de aula, já que se tratavam dos finais de semana. Esta não nos parece uma Justificativa válida dentro da biologia, mas de qualquer forma é menos plausível que o explanandum, - "a crescimenta, sua maior parte acontecen aos finais de semana"- e por isso consideramos tratar-se de uma Explicação e não um Argumento. E também pois não há a intenção de convencer que o maior crescimento aconteceu nos finais de semana, já que isso é demonstrado pelo gráfico, o que reforça a caracterização como Explicação.

\section{Marca 7:}

A sétima marca deste relatório se refere ao gráfico de crescimento populacional e como apresentado em relatórios anteriores, é considerado haver indicadores de Seriação, Organização e Classificação de informações.

\section{Marca 8:}

Esta oitava marca se refere ao primeiro parágrafo da primeira conclusão escrita individualmente. Neste os indicadores de Levantamento de hipóteses, Teste de hipóteses e Justificativa se fizeram presentes.

\footnotetext{
"O que acorre com uma populaçãa bialógica após a colonizaçãa par alguns individuas de um ambiente com as condiçoes ideais para desenvolvimenta da espécie, é que com a colonizaçãa dos individuos, a correta seria a papulaça crescer, alguns morrerem mas a maior parte da populașa crescer. Bem, issa nãa ocorreu no meu experimenta. Era muita difícil da papulaçãa ficar estável."
} 
Thiago Marinho Del Corso

INDICADORES DE ALFABETIZAÇÃO CIENTÍFICA, ARGUMENTOS E EXPLICAÇÕES -

Análise de Relatórios no Contexto de uma Sequência de Ensino Investigativo

Quando o aluno afirma que -"O que ecorre com uma papulaçãa bialógica apés a colonizaçãa por alguns individuas de um ambiente com as condicães ideais para desenvalvimenta da espécie, é que com a colonizaçãa das indivíduas, a correta seria a populacão crescer, alguns morrerem mas a maior parte da populaçãa crescer."- 0 aluno está Levantando hipóteses acerca do que deveria acontecer. De acordo com Sasseron e Carvalho (2008) este indicador: "Aponta instantes em que são alçadas suposições acerca de certo tema. Esse levantamento pode surgir ...como uma afirmação".

Agora no momento em que o aluno afirma que -"Bem, issa näa ocorreu na meu experimenta. Era muita difícil da papulacãa ficar estável."- ele esta apresentando o indicador de Teste de hipóteses já que as suposições foram postas a prova e não se confirmaram. De acordo com Sasseron e Carvalho (2008) este indicador: "Trata-se das etapas em que as suposições anteriormente levantadas são colocadas à prova. Pode ocorrer ... no nível das ideias...”.

Uma Justificativa visa dar aval, garantia, a uma afirmação. Neste parágrafo a Hipótese levantada se constitui em uma afirmativa e o acontecimento que levaria a este fenômeno se constitui na Justificativa propriamente dita - "um ambiente com as condičées ideais para desenvolvimenta da espécie "-.

\section{Marca 9:}

O segundo parágrafo da primeira conclusão individual do oitavo relatório apresenta os indicadores de Seriação e Classificação de informações, Levantamento de Hipóteses, Justificativa e Explicação.

\footnotetext{
"O que acorren com a populaçãa de Lemnas, é que elas mãa só cresceram, coma as quedas foram muita altas, entãa, mesma se as condiçaes estiverem ideais para a desenvalvimenta da espécie, a colonizacãa nãa depende sć dissa, pais há várias fatares que podem contribuir come prejudicar a colonizasãa, come a mudansca de tempo, a falta eu a aumento de nutrientes. Come ocorreu no meu experimento, esses fatores podem ter alterado a colonizaçãa da papulaçãa de Lemnas. "
}

Como apresentado na marca cinco, ao afirmar que houve crescimento e queda os alunos estão apresentando dados e a isto consideramos uma Seriação de informações "cresceram"-, "qquedas"-. A Classificação ocorre quando os alunos atribuem 
características a este dado, no caso afirmar que houveram quedas bruscas no número de indivíduos na população - "as quedas foram muito altas,"--

A Explicação tem como fenômeno, explanandum, ao qual se buscam as causas, à dinâmica populacional como um todo. No caso, não foram apresentados explanans para os períodos de crescimento, já que o esperado, de acordo com o modelo teórico apresentado pela professora, era haver crescimento, já para as acentuadas quedas que ocorreram em determinados momentos foram apresentados explanans. As Justificativas apresentadas visavam explicar as causas para os momentos de diminuição -"mudança de tempa, a falta ou a aumenta de nutrientes"-.

A assertiva que diz que -"fatores podem ter alterado a colonizacãa da populaçãa de Lemnas. "- pode ser entendida como um Levantamento de hipóteses.

\section{Marca 10:}

A primeira frase da segunda conclusão individual do relatório 8 apresenta o indicador de Levantamento de hipóteses, já que, estabilidade e queda, são apresentados como duas diferentes suposições acerca do que pode acontecer com a população.

"A populaçãe pode ficar estável mas também cair ae longe de tempe."

\section{Marca 11:}

No segundo parágrafo da segunda conclusão individual encontramos Seriação e Classificação de informações alem de Justificativas e Explicação.

"Tãa é só porque a populaçãa está em um ambiente familiar que pode ter um crescimento alta. No meu experimento, as lemnas tinham um crescimento maior aos finais, pais ficaram imóveis, nãa recebiam nassa contato e muita menas a luz da sala."

Como anteriormente tratado, crescimento é, neste contexto, um dado que esta sendo listado, ou seria, o aluno está apresentando o indicador de Seriação de informações -"crescimenta"-. Já ao estabelecer características a este dado o aluno está Classificando informações -"crescimenta alto"-. 
Thiago Marinho Del Corso

INDICADORES DE ALFABETIZAÇÃO CIENTÍFICA, ARGUMENTOS E EXPLICAÇÕES -

Análise de Relatórios no Contexto de uma Sequência de Ensino Investigativo

O fenômeno a ser Explicado é o alto crescimento nos finais de semana -“as

lemnas tinham um crescimente maior as finais"-. Esta afirmativa tem como

Justificativa -" pais ficaram imórveis, nãe recebiam nosso contato e muito menos a luz da sala."-. Uma Explicação é segundo Sasseron e Carvalho (2008) comumente acompanhada de Justificativas que lhe dêem aval, como identificado para este parágrafo. A desambiguação da Explicação em relação a um Argumento dá-se pela análise do explanandum (fenômeno) que não está sub-júdici, não está sendo colocado a prova, já que foi observado no gráfico e os elementos que levam a este explanandum são menos plausíveis que o próprio.

\section{Marca 12:}

Como verificado nos trabalhos de Sasseron e Carvalho (2008) e Sasseron (2008) comumente os indicadores de Levantamento de hipóteses e a Previsão encontram-se juntos. Como verificado nesse terceiro parágrafo da segunda conclusão.

O Levantamento de hipóteses aqui é perpetrado como uma suposição acerca do tema em questão e surge como uma afirmação, e a Previsão, faz conjecturas do que aconteceria com uma população de Lemnas em determinadas condições. É uma afirmativa associada a certos acontecimentos, a qual derivou da análise dos resultados do experimento todo.

"Cis lemnas se desenvolvem melhor com um ambiente calma e sem movimenta."

\section{Marca 13:}

Nesta terceira e ultima conclusão do relatório 8 encontramos indicadores de Seriação de informações, Justificativa e Argumento.

\footnotetext{
"O que acontece com a populaçãa é uma variașãa no desenvolvimenta populacional. em relaçãa as quedas e ae crescimenta. De certa forma ocorreu uma dinâmica papulacional. pois houve variaçãa da tamanho e da distribuiçãa de uma papulaçãa de lemnas aa lango da tempe."
}

Ao trazer que houveram -"quedas"- e -"crescimenta"- o aluno está apresentando dados obtidos no experimento e conseqüentemente está Seriando informações. 
Thiago Marinho Del Corso

INDICADORES DE ALFABETIZAÇÃO CIENTÍFICA, ARGUMENTOS E EXPLICAÇÕES -

Análise de Relatórios no Contexto de uma Sequência de Ensino Investigativo

O Argumento ocorre quando os alunos estão tentando convencer que o fenômeno

que se deu ao longo do experimento constitui-se em uma dinâmica populacional. Como há uma Conclusão (C) que está sendo defendida e esta é menos certa que as premissas que levam a esta, entendemos tratar-se de um Argumento e não uma Explicação. A Justificativa identificada é a Justificativa (J) do Argumento, e este fica assim disposto no layout adaptado de Toulmin (2006).

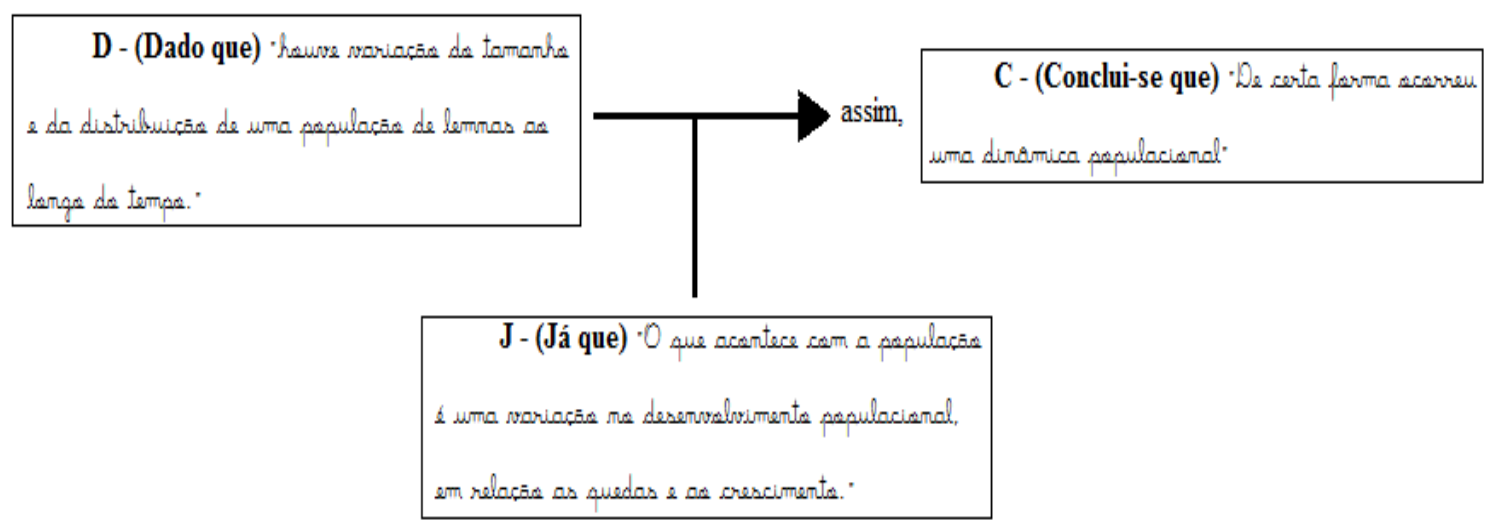


Thiago Marinho Del Corso

INDICADORES DE ALFABETIZAÇÃO CIENTÍFICA, ARGUMENTOS E EXPLICAÇÕES -

Análise de Relatórios no Contexto de uma Sequência de Ensino Investigativo

\section{O Relatório 9 - 2013}

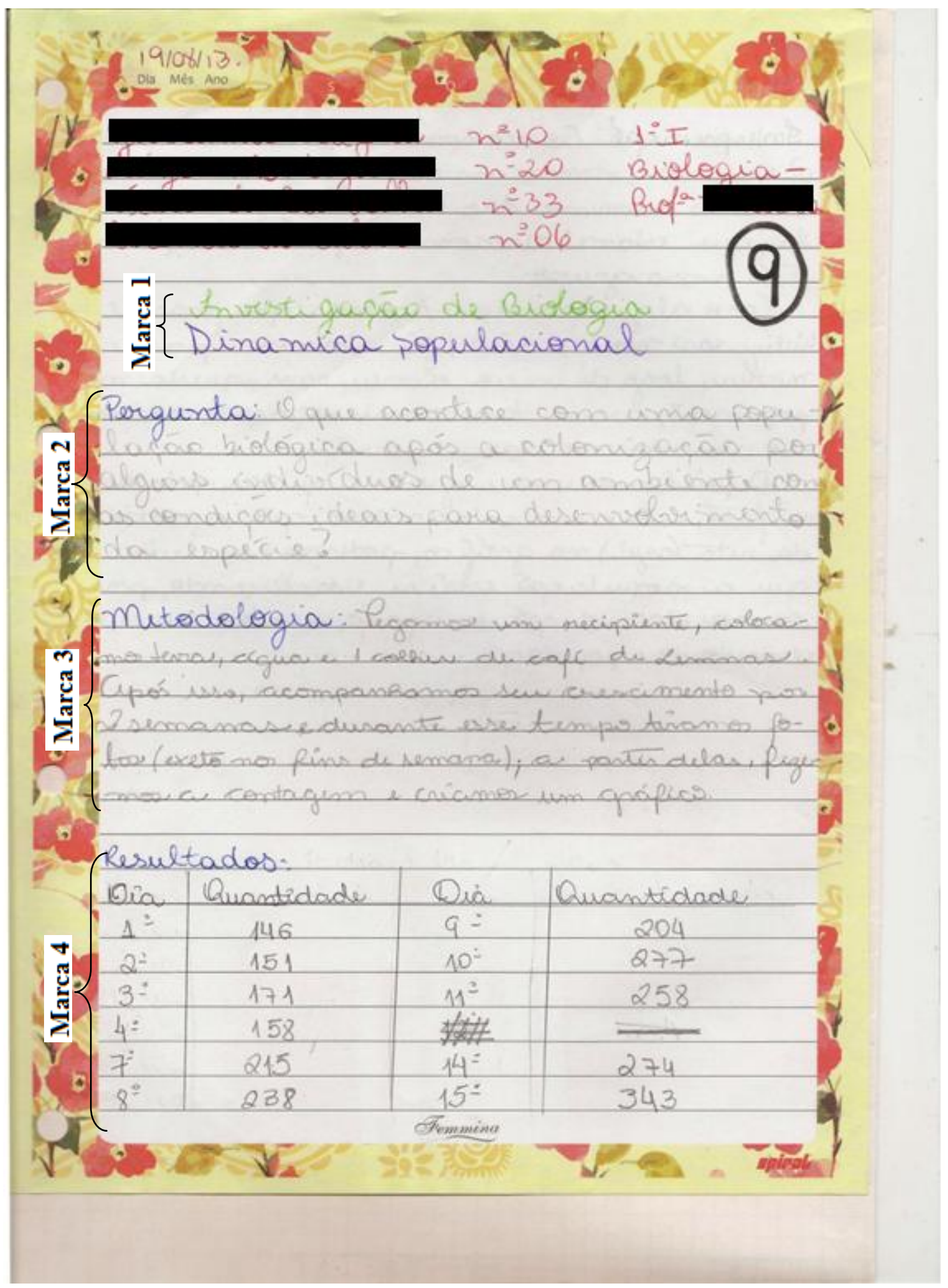




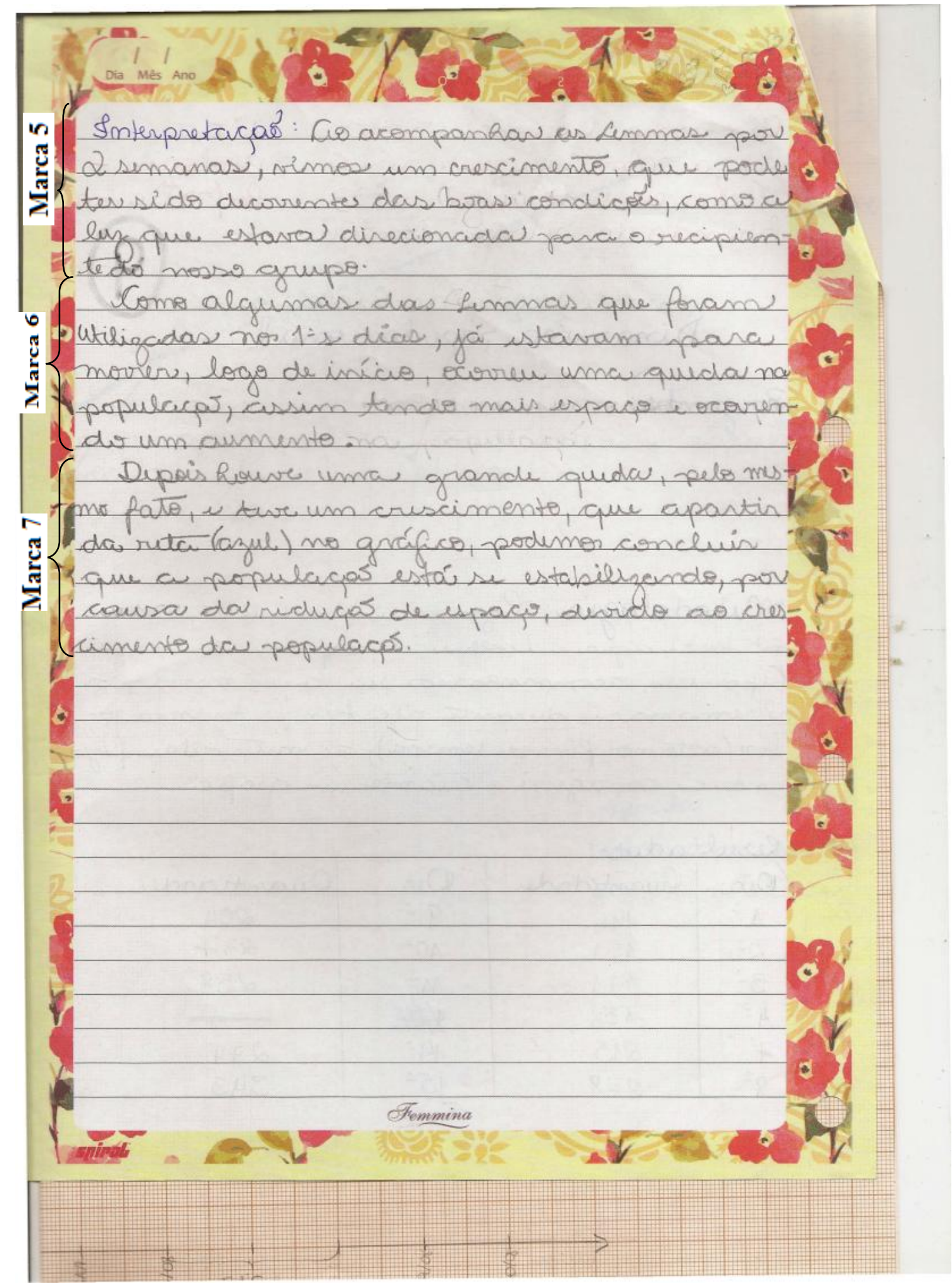


Thiago Marinho Del Corso

INDICADORES DE ALFABETIZAÇ̃̃o CIENTÍFICA, ARGUMENTOS E EXPLICAÇÕES -

Análise de Relatórios no Contexto de uma Sequência de Ensino Investigativo

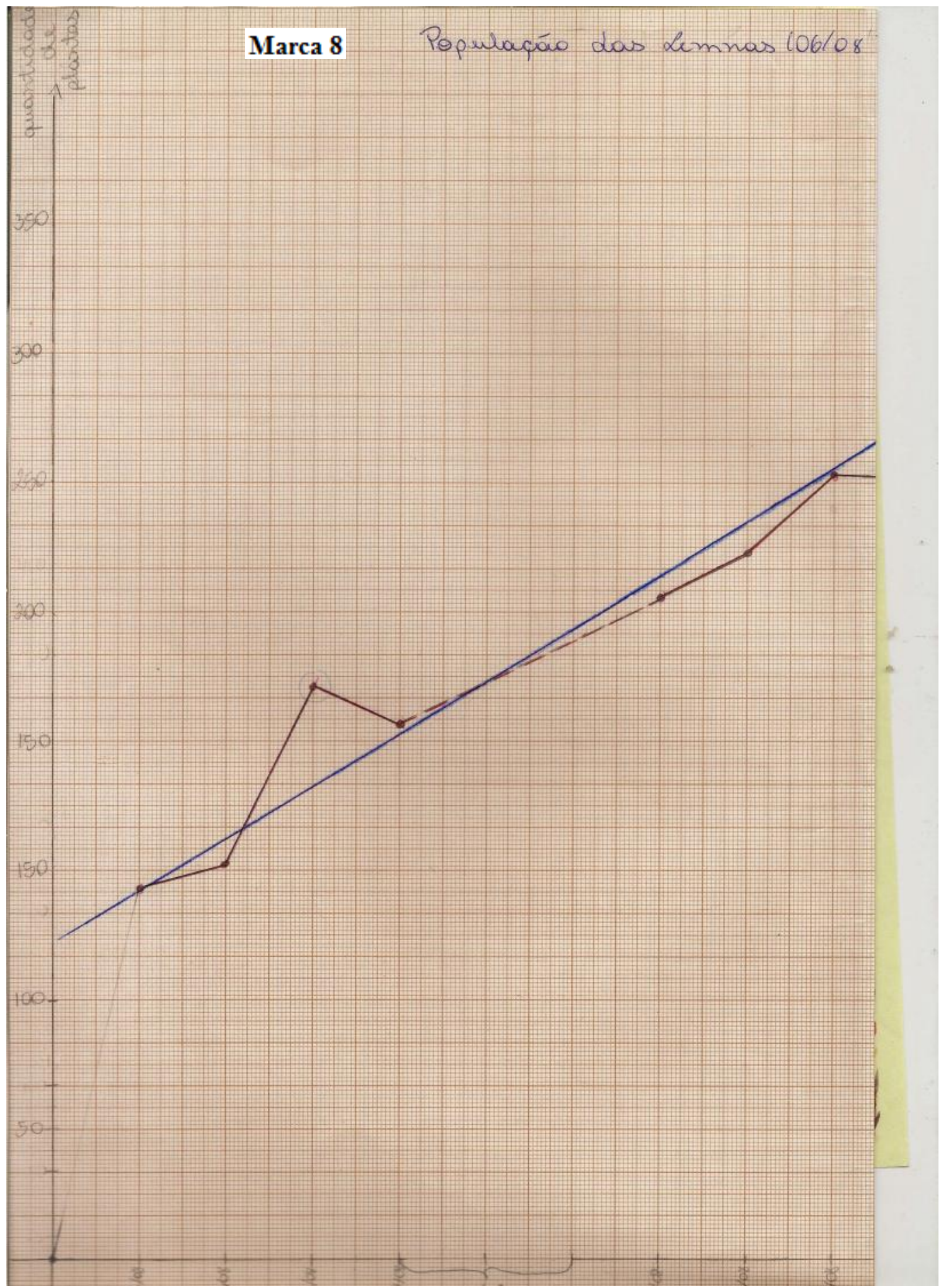


Thiago Marinho Del Corso

INDICADORES DE ALFABETIZAÇ̃̃o CIENTÍFICA, ARGUMENTOS E EXPLICAÇÕES -

Análise de Relatórios no Contexto de uma Sequência de Ensino Investigativo

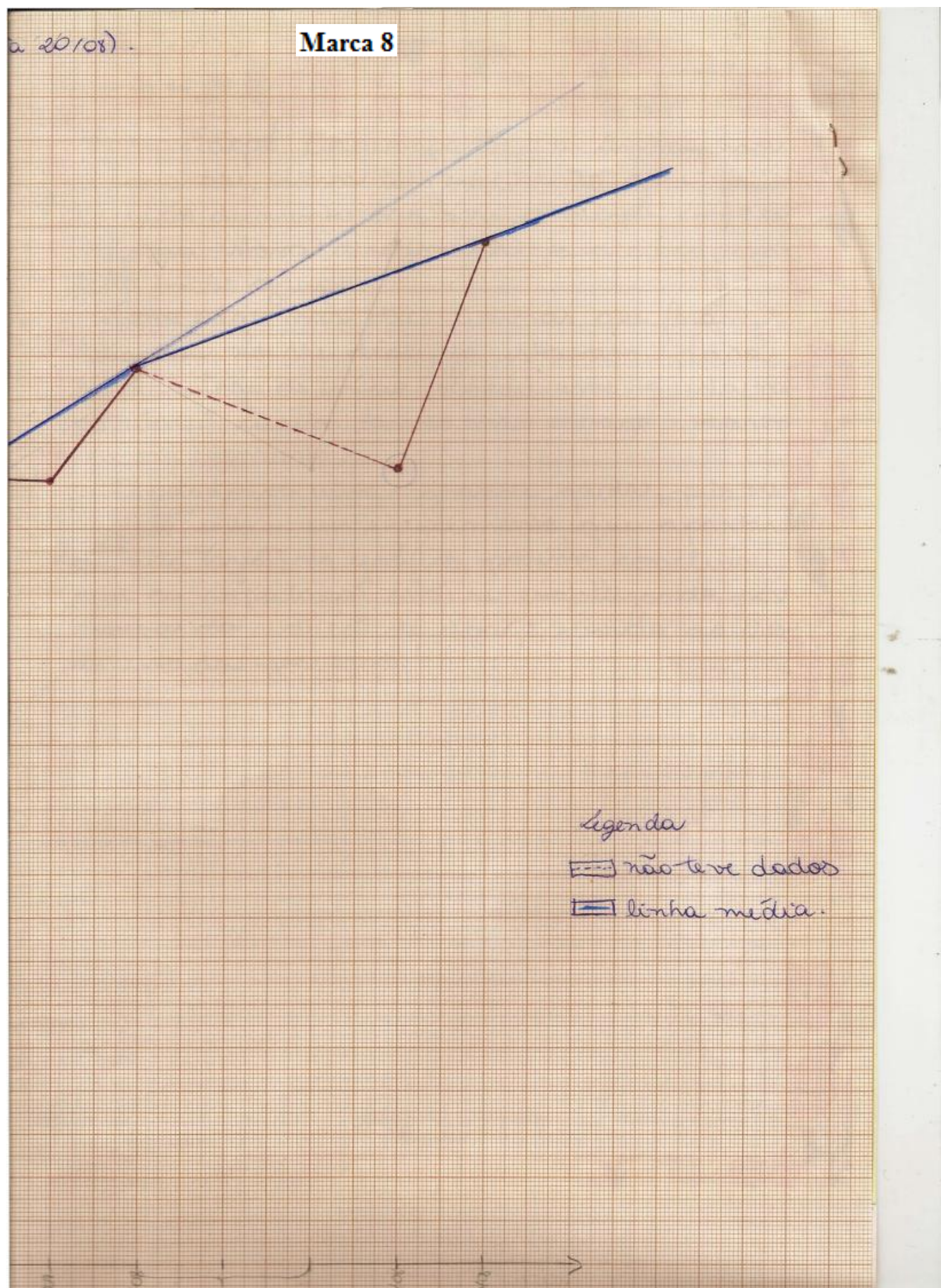


Thiago Marinho Del Corso

INDICADORES DE ALFABETIZAÇ̃̃ CIENTÍFICA, ARGUMENTOS E EXPLICAÇÕES -

Análise de Relatórios no Contexto de uma Sequência de Ensino Investigativo

Quadro 09

Identificação dos Indicadores de Alfabetização Científica no Relatório 9 de 2013 e conclusões individuais correspondentes.

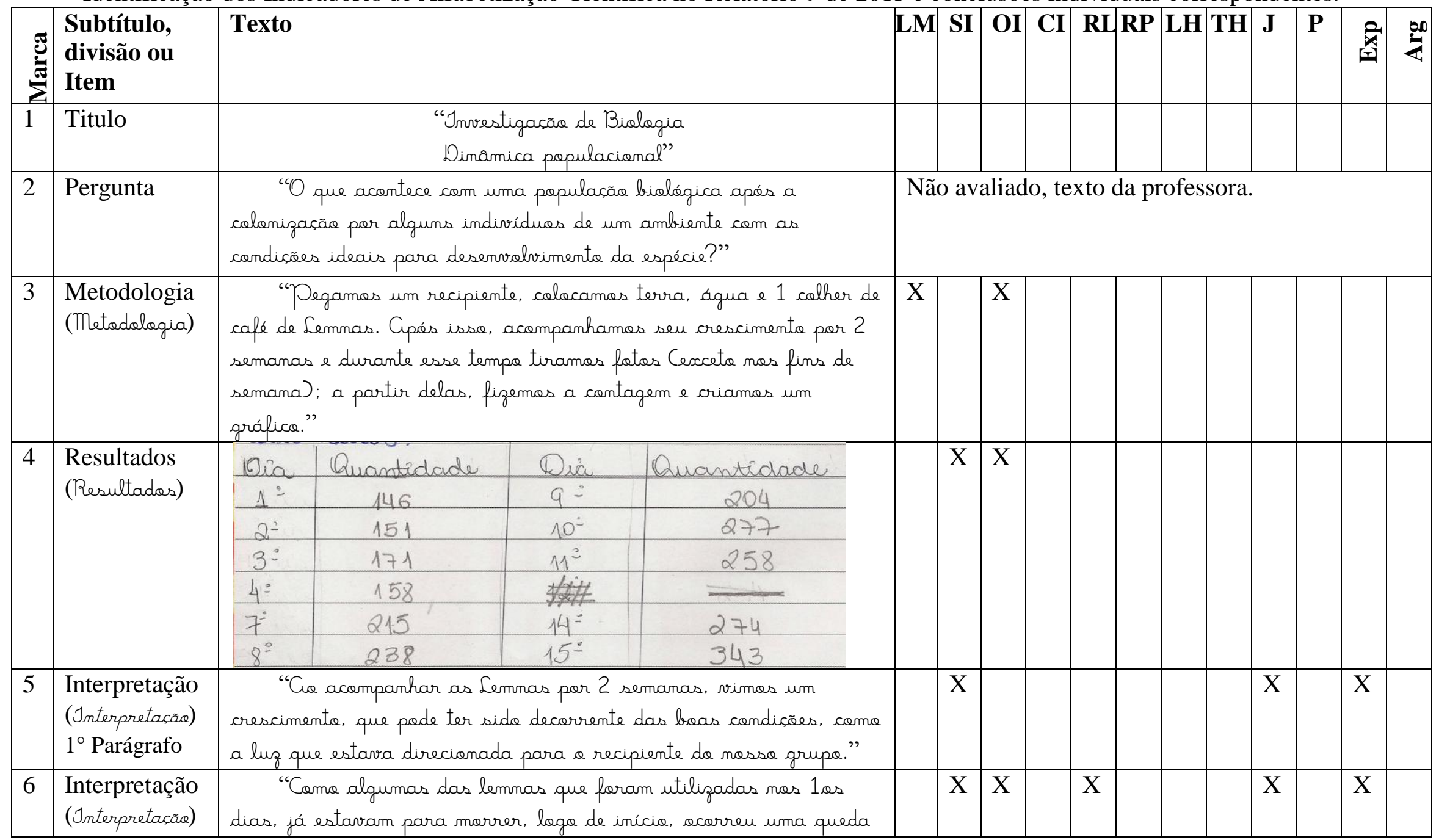


Thiago Marinho Del Corso

INDICADORES DE ALFABETIZAÇÃO CIENTÍFICA, ARGUMENTOS E EXPLICAÇÕES -

Análise de Relatórios no Contexto de uma Sequência de Ensino Investigativo

\begin{tabular}{|c|c|c|c|c|c|c|c|c|c|c|c|c|c|c|}
\hline & $2^{\circ}$ Parágrafo & ma papulascão, assim tenda mais espaçe e acorrenda um aumenta." & & & & & & & & & & & & \\
\hline 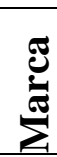 & $\begin{array}{l}\text { Subtítulo, } \\
\text { divisão ou } \\
\text { Item }\end{array}$ & Texto & $\mathbf{L M}$ & SI & $\mathbf{O I}$ & $\mathbf{C I}$ & $\mathbf{R L}$ & $\mathbf{R P}$ & $\mathbf{L H}$ & TH & $\mathbf{J}$ & $\mathbf{P}$ & $\underset{7}{2}$ & $\sum^{\infty}$ \\
\hline 7 & $\begin{array}{l}\text { Interpretação } \\
\text { (Interpretaçãe) } \\
3^{\circ} \text { Parágrafo }\end{array}$ & 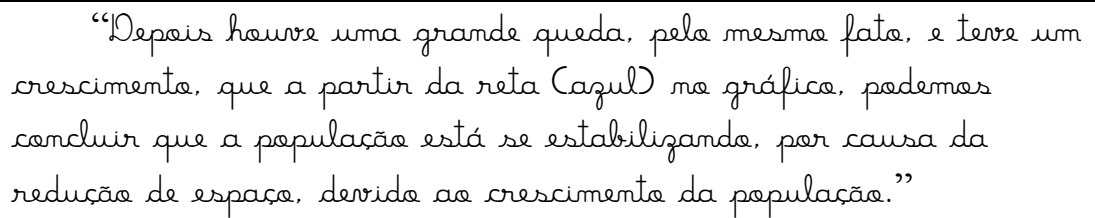 & & $X$ & $\mathrm{X}$ & & & & $X$ & & $X$ & $X$ & & $X$ \\
\hline 8 & $\begin{array}{l}\text { Resultados } \\
\text { gráfico }\end{array}$ & & & $X$ & $X$ & $X$ & & & & & & & & \\
\hline 9 & $\begin{array}{l}\text { Conclusão } \\
\text { individual } 1 \\
1^{\circ} \text { parágrafo }\end{array}$ & $\begin{array}{l}\text { "Se as condiçaés da ambiente forem favoráveis, a } \\
\text { crescimenta da populaçãa é grande." }\end{array}$ & & & & & & & $X$ & & & $X$ & & \\
\hline 10 & $\begin{array}{l}\text { Conclusão } \\
\text { individual } 1 \\
2^{\circ} \text { parágrafo }\end{array}$ & $\begin{array}{l}\text { "O nossa experimenta recebeu mais luz da que as autras; } \\
\text { issa favoreceu para a crescimenta da populaçãa de Lemnas." }\end{array}$ & & $X$ & & & & & & & $X$ & & & \\
\hline 11 & $\begin{array}{l}\text { Conclusão } \\
\text { individual } 1 \\
3^{\circ} \text { parágrafo }\end{array}$ & $\begin{array}{l}\text { "Fivemas duas quedas na populasãa, mas issa fai } \\
\text { consequencia de autras fatores, coma a quantidade de água e a } \\
\text { temperatura." }\end{array}$ & & $X$ & & & & & & & $\mathrm{X}$ & & $\mathrm{X}$ & \\
\hline 12 & $\begin{array}{l}\text { Conclusão } \\
\text { individual } 2 \\
1^{\circ} \text { parágrafo }\end{array}$ & 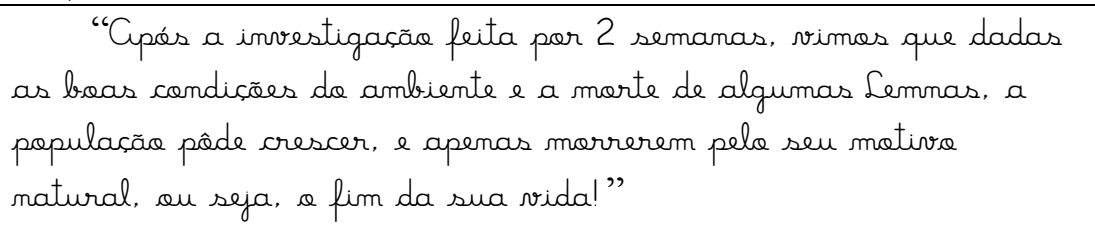 & & $\mathrm{X}$ & & & & & $\mathrm{X}$ & & $\mathrm{X}$ & $X$ & & \\
\hline
\end{tabular}


Thiago Marinho Del Corso

INDICADORES DE ALFABETIZAÇÃO CIENTÍFICA, ARGUMENTOS E EXPLICAÇÕES -

Análise de Relatórios no Contexto de uma Sequência de Ensino Investigativo

\begin{tabular}{|c|c|c|c|c|c|c|c|c|c|c|c|c|c|}
\hline 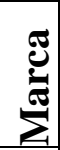 & $\begin{array}{l}\text { Subtítulo, } \\
\text { divisão ou } \\
\text { Item }\end{array}$ & Texto & $\mathbf{L M}$ & SI & OI & CI & \begin{tabular}{l|l|} 
RL & RP \\
\end{tabular} & $\mathbf{L H}$ & TH & $\mathbf{J}$ & $\mathbf{P}$ & 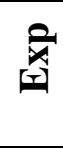 & $\frac{100}{4}$ \\
\hline 13 & $\begin{array}{l}\text { Conclusão } \\
\text { individual } 2 \\
2^{\circ} \text { parágrafo }\end{array}$ & $\begin{array}{l}\text { "Entãa chega um ponta da pesquisa, em que a papulacãa se } \\
\text { estabiliza, devida ar fata de nãa haver mais espaça para a } \\
\text { populaçãa que tanta crescia." }\end{array}$ & & $\mathbf{X}$ & & $\mathbf{X}$ & & & & $\mathbf{X}$ & & & \\
\hline 14 & $\begin{array}{l}\text { Conclusão } \\
\text { individual } 2 \\
3^{\circ} \text { parágrafo }\end{array}$ & $\begin{array}{l}\text { "Com issa podemas concluir que a populaçãa, se estiver em } \\
\text { um local com boas condiçäes, irá crescer até momenta em que terá } \\
\text { que se estabilizar, pela fata de algo impedir seu crescimenta." }\end{array}$ & & & & & & $\mathbf{X}$ & & $\mathbf{X}$ & $\mathbf{X}$ & & \\
\hline 15 & $\begin{array}{l}\text { Conclusão } \\
\text { individual } 3\end{array}$ & 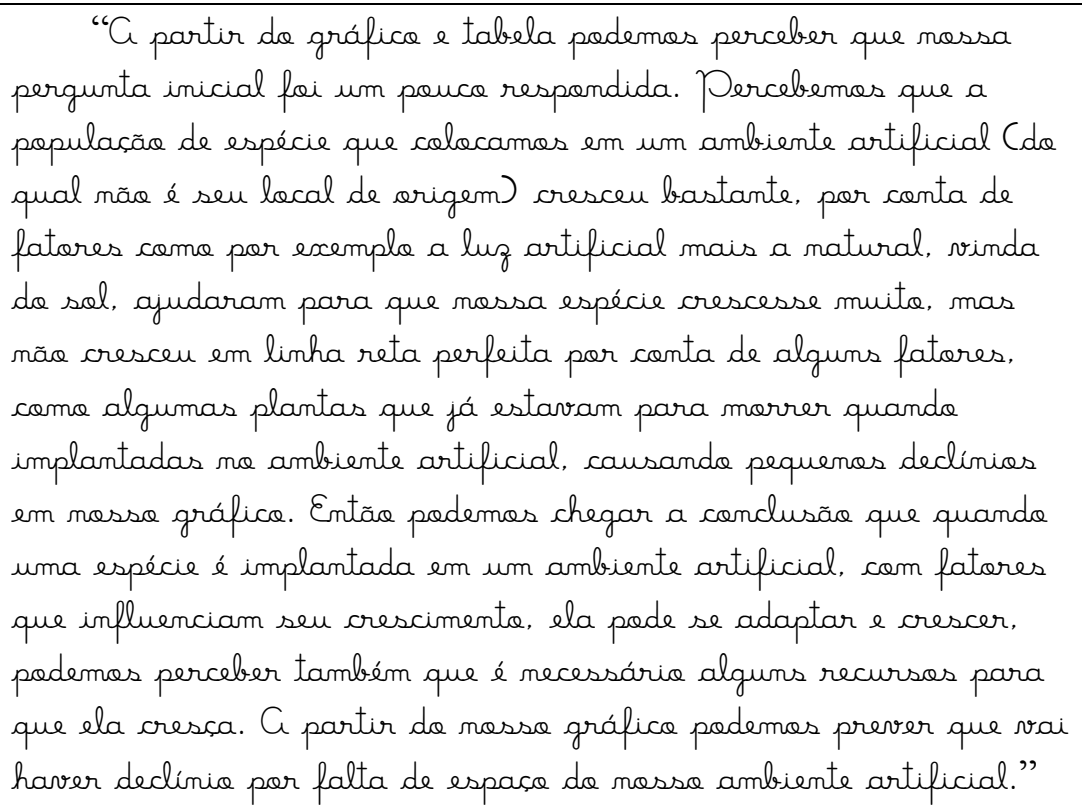 & & $\mathbf{X}$ & & $\mathbf{X}$ & & $\mathbf{X}$ & & $\mathbf{X}$ & $\mathbf{X}$ & & $\mathbf{X}$ \\
\hline
\end{tabular}


Thiago Marinho Del Corso

INDICADORES DE ALFABETIZAÇÃO CIENTÍFICA, ARGUMENTOS E EXPLICAÇÕES -

Análise de Relatórios no Contexto de uma Sequência de Ensino Investigativo

\begin{tabular}{|c|c|c|c|c|c|c|c|c|c|c|c|c|c|}
\hline 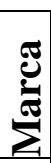 & $\begin{array}{l}\text { Subtítulo, } \\
\text { divisão ou } \\
\text { Item }\end{array}$ & Texto & $\mathbf{L M}$ & SI & OI & CI & \begin{tabular}{l|l|} 
RL & RP
\end{tabular} & $\mathbf{L H}$ & TH & $\mathbf{J}$ & $\mathbf{P}$ & $\underset{x}{a}$ & $\underset{Z}{+\infty}$ \\
\hline 16 & $\begin{array}{l}\text { Conclusão } \\
\text { individual } 4\end{array}$ & 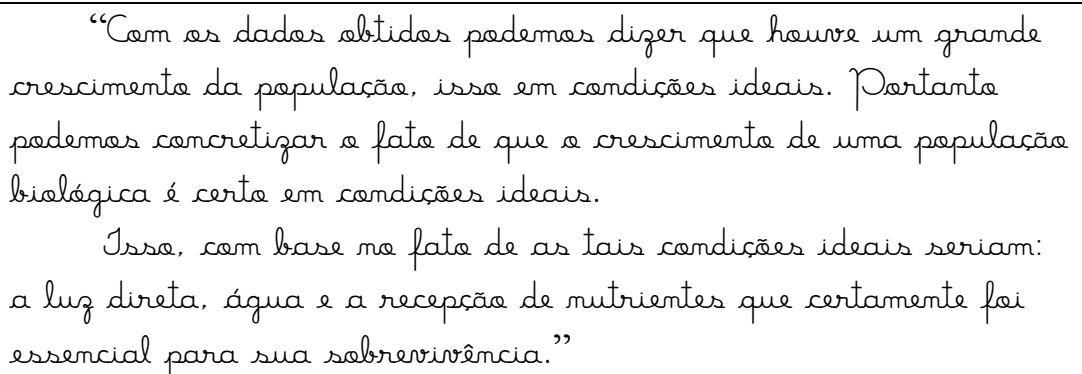 & & $\mathbf{X}$ & & $\mathbf{X}$ & & & & $\mathbf{X}$ & $\mathbf{X}$ & & $\mathbf{X}$ \\
\hline
\end{tabular}


Detalhamento da identificação dos indicadores de AC - Relatório 9 - 2013

\section{Marca 1:}

A primeira marca neste relatório 9 foi atribuída ao título do relatório. Para esta não há correspondência com nenhum indicador de Alfabetização Científica.

\section{Marca 2:}

Esta segunda marca do relatório 9 contem a pergunta proposta pela professora e por isso não é analisada, já que não se trata de composição própria dos alunos.

\section{Marca 3:}

A terceira marca deste relatório 9 é atribuída à -"metodologia"- que segue transcrita abaixo, apresenta indicadores de Listagem de materiais e Organização de informações.

"Pegamas um recipiente, colocamos terra, água e 1 colher de café de Lemnas. Após isso, acompanhamos seu crescimente por 2 semanas e durante esse tempo tiramos fotos (exceta nes firs de semana); a partir delas, figemas a contagem e criames um gráfice."

O primeiro destes indicadores é evidente quando os alunos listam os materiais usados no experimento - "Pegamos um recipiente, colocamos terra, água e 1 colher de café de Lemnas"-.

A Organização de informações "ocorre nos momentos que se discute sobre o modo como um trabalho foi realizado... quando se busca mostrar um arranjo para informações novas" e neste parágrafo não só isso é evidente no trecho -“acompanhamos seu crescimenta por 2 semanas e durante esse tempo tiramos fotas Cexceto nos fins de semana); a partir delas, fizemas a contagem e criamos um gráfica."- que descreve como foi feito o experimento, como na organização cronológica de ações e preparação dos 
Thiago Marinho Del Corso

INDICADORES DE ALFABETIZAÇÃo CIENTÍFICA, ARGUMENTOS E EXPLICAÇÕES -

Análise de Relatórios no Contexto de uma Sequência de Ensino Investigativo

dados, como a apresentação de que a contagem do número de indivíduos de Lemnas foi a partir de fotos.

\section{Marca 4:}

A quarta marca do relatório nove contem uma tabela que lista e organiza os dados, quantidade de indivíduos na população de Lemnas por dia de contagem, e assim apresenta respectivamente os indicadores de Seriação e Organização de informações.

\begin{tabular}{|c|c|c|c|}
\hline Bia & Quantidade & Diá & Quantidade \\
\hline $1^{\circ}$ & 146 & $9-$ & 204 \\
\hline $2^{2}$ & 151 & $10^{\circ}$ & 277 \\
\hline $3^{\circ}$ & 171 & $11^{2}$ & 258 \\
\hline $4^{\circ}$ & 158 & 4 & \\
\hline $7^{\circ}$ & 215 & $14^{\circ}$ & 274 \\
\hline $8^{\circ}$ & 238 & $15^{\circ}$ & 343 \\
\hline
\end{tabular}

\section{Marca 5:}

A quinta marca, transcrita ao final, contém o primeiro parágrafo da "Interpretaçãe" do relatório nove. Aqui identificamos indicadores de Seriação de informações, Justificativa e Explicação.

Como discutido na análise de relatórios anteriores, já que o tema central desta Sequência Didática Investigativa (SEI) trata de dinâmica populacional, e neste contexto, crescimento, é considerado um dado com o qual os alunos irão trabalhar, a apresentação deste -" vimes um crescimenta"- neste parágrafo, configura uma Seriação de informações.

Uma Explicação visa relacionar informações, no caso o crescimento, com hipóteses levantadas e comumente pede Justificativas que dêem garantia a esta afirmação. Numa Explicação, diferentemente de em um Argumento, o fenômeno em questão não está sub-júdici, não está sendo colocado a prova (Osborne e Patterson 2011) e os elementos que levam ao explanandum (fenômeno) são menos plausíveis que o próprio (Murcho 2003).

"Co acompanhar as Lemnas por 2 semanas, vimos um crescimento, que pode ter sido decorrente das boas condicães, come a luz que estava direcionada para a recipiente da massa grupa." 


\section{Marca 6:}

Nesta sexta marca que contem o segundo parágrafo da "Interpretaçãe" apresenta indicadores de Seriação e Organização de informações, Justificativa, Explicação e Raciocínio lógico.

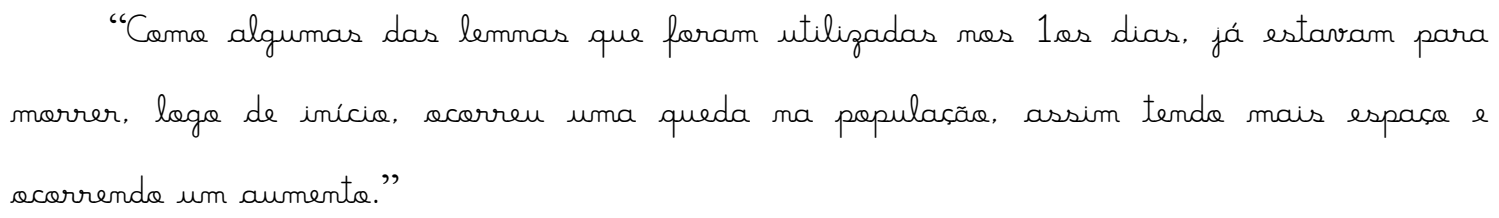

A Seriação de informações ocorre por apresentar dados, no caso -“queda"- e "aumenta"- populacional, que em um trabalho sobre dinâmica populacional podem ser considerados dados. A separação em dois momentos pode ser entendida como uma Organização de informações, já que dividir e apresentar cronologicamente e com justificativas o que acontece em cada momento, -“queda"- e -"aumente"-, é uma forma de organizar os dados.

Nesta parágrafo encontramos duas Explicações, uma para a -“queda”- e outra para o -"aumenta"- da população de Lemnas, e Justificativas para ambos os fenômenos. A Justificativa (explanans da Explicação) para o fenômeno de -“queda"- (explanandum da Explicação) é que -"lemnas que foram utilizadas nos 1os dias, já estarvam para morrer,"-. Já para o fenômeno de -"aumenta"- (explanandum da $2^{\circ}$ Explicação) a Justificativa (explanans da $2^{\circ}$ Explicação) é que há - "mais espaçe" - liberado após as mortes indivíduos na população inicial de Lemnas.

O Raciocínio lógico ocorre pela apresentação estruturada das ideias na construção desta assertiva. Aqui os alunos evidenciam seu raciocínio pelo encadeamento de acontecimentos e suas justificativas e consequências, o uso de indivíduos de Lemnas decrépitos para compor a população inicial resultou em uma diminuição do número de indivíduos na população nos primeiros dias, isso liberou espaço para que os outros indivíduos se multiplicassem, o que teve como consequência o aumento da população. 
O ultimo parágrafo da - "Interpretaçäa"- do relatório nove apresenta os indicadores de Seriação e Organização de informações, Levantamento de hipóteses, Justificativa, Previsão e Argumento.

\footnotetext{
"Depois houve uma grande queda, pela mesma fata, e teve um crescimenta, que a partir da reta (azul) me gráfica, podemas concluir que a papulaçãa está se estabilizando. por causa da reduçãe de espaca, devide ae crescimenta da populacãa."
}

A Seriação de informações ocorre, neste trecho, por apresentar dados, que no caso foram -"queda"-, -crescimenta"- e -"estabilizacãa"- populacional, que como discutido anteriormente, se constituem, em um trabalho sobre dinâmica populacional, como dados. A separação em três momentos pode ser entendida como uma Organização de informações, já que dividir e apresentar cronologicamente e com justificativas o que acontece em cada momento, "“queda"-, -crescimento"- e "estabilizacãa"-, é uma forma de organizar os dados.

O Levantamento de hipóteses novamente aparece, como nos trabalhos de Sasseron e Carvalho (2008) e Sasseron (2008) juntamente com a Previsão. O primeiro destes, de acordo com estes trabalhos, "aponta instantes em que são alçadas suposições acerca de certo tema e podem surgir como afirmativas". Quando os alunos estão afirmando que a partir do gráfico podem - "podemos concluir que a populaçãe está se estabilizanda"- estes estão fazendo suposições sobre o desenvolvimento da dinâmica populacional da população de Lemnas, ou seria estão Levantando hipóteses sobre como esta população se desenvolverá.

Pensamos que ao afirmar que -"a partir da reta (azul) ne gráfice, pedemos concluir que a populacãa está se estabilizando," - os alunos estão prevendo uma estabilização que ainda não se efetivou, e a isso consideramos uma Previsão. Este indicador se dá quando se afirma uma ação e/ou fenômeno que sucede associado a certos acontecimentos. Acreditamos que na afirmação de que a população de Lemnas esta estabilizando há, pelos alunos, a intenção de tentar convencer de que a estabilização está ocorrendo, e esta intenção se relaciona com o indicador proposto de Argumento. Também porque a Conclusão $(\mathbf{C})$ deste é menos certa que as premissas que levaram a 


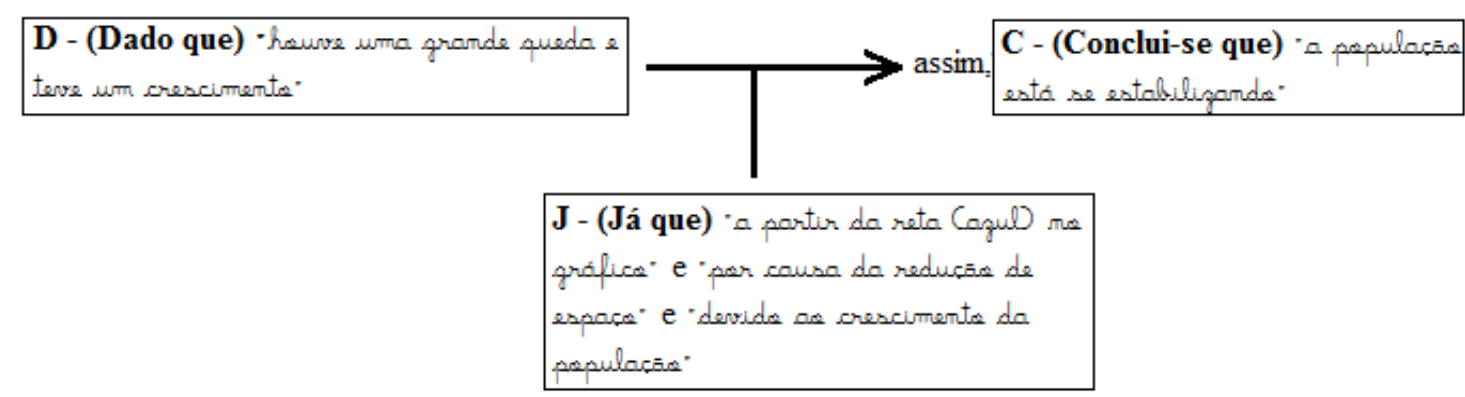

\section{Marca 8:}

A oitava marca se refere ao gráfico construído pelos alunos para representar a dinâmica populacional da população de Lemnas ao longo do experimento, e assim como todos os outros gráficos, entendemos que aqui se encontram indicadores de Seriação, Organização e Classificação de informações.

O primeiro destes indicadores ocorre já que os alunos apresentam as quantidades de Lemnas na população ao longo dos dias, como em uma listagem. O que é característica deste indicador.

A Organização de informações decorre, de acordo com Sasseron e Carvalho (2008), da preparação dos dados, o que pelo próprio arranjo destes em um gráfico já se caracterizaria.

Estabelecer características para dados é o que configura uma Classificação de informações. Ao plotar os dados em um gráfico onde a quantidade de Lemnas marca os pontos e estes pontos são ligados por retas, estas retas estão estabelecendo características para estes dados, já que pela inclinação destas retas fica evidente se a população esta crescendo ou diminuindo velozmente ou lentamente, ou mesmo se a população esta estabilizando. 


\section{Marca 9:}

No primeiro parágrafo da primeira conclusão individual, transcrito abaixo, identificamos um Levantamento de hipótese que é também uma Previsão. Isso porque entendemos que o aluno está alçando suposições sobre o comportamento da população de Lemnas e desta forma está fazendo uma hipótese sobre o que acontecerá com a população. Esta hipótese acaba contendo também uma Previsão, já que este "crescimente"- é um fenômeno que sucederia associado a certos acontecimentos -" De as condicães do ambiente forem favoráveis"-.

"De as condicães do ambiente forem favoráreis, e crescimento da populacãa é grande."

\section{Marca 10:}

Esta nona marca se refere ao segundo parágrafo escrito como conclusão individual do relatório nove. Nesta identificamos indicadores de Seriação de informações e Justificativa.

A Seriação de informações, que se caracteriza pela listagem de dados, é identificada quando o aluno apresenta que houve -"crescimenta da populaçãe de Lemmas"-Ao afirmar que - "O masso experimenta recebeu mais luz da que as autras" - entendemos que o aluno está Justificando o -“erescimente”- ocorrido para a população de Lemnas do grupo.

\footnotetext{
"O masso experimenta recebeu mais luz do que as autros; isso favorecen para a crescimenta da populacãa de Lemnas."
}

\section{Marca 11:}

Nesta décima marca temos a ultima parte da primeira conclusão individual do relatório nove que apresenta os indicadores de Seriação de informações, Justificativa e Explicação.

A Seriação de informações novamente é perpetra pela apresentação do comportamento da população de Lemnas, o que em um experimento sobre dinâmica 
Thiago Marinho Del Corso

INDICADORES DE ALFABETIZAÇÃO CIENTÍFICA, ARGUMENTOS E EXPLICAÇÕES -

Análise de Relatórios no Contexto de uma Sequência de Ensino Investigativo

populacional se constitui em dados -" Jivermes duas quedas ma populaçãe"-. A

Explicação aqui têm como explanandum as -"quedas"- no número de indivíduos na população e a Justificativa se apresenta como causa, explanans, para esta queda - "isse foi consequência de autros fatores, come a quantidade de água e a temperatura" -.

O que nos serve de evidencia de aqui termos identificado uma Explicação e não um Argumento é que este último tenta convencer e a afirmativa aqui de que -"Tivsemos duas quedas ma populaçãe"- foi obtida dos dados empíricos e é evidenciada pelo gráfico, logo não é algo que precise ser defendido, algo que esteja sub-júdici. Também pois os elementos que levam a esta afirmativa são menos plausíveis que a própria afirmativa.

"Iivemas duas quedas na populaçãa, mas issa fai consequência de outros fatores. como a quantidade de água e a temperatura."

\section{Marca 12:}

Esta décima primeira marca, transcrita abaixo e que se constitui do primeiro parágrafo de uma segunda conclusão individual do relatório nove, apresenta indicadores de Levantamento de hipóteses, Previsão, Justificativa e Seriação de informações.

"Cpós a investigacãa feita por 2 semanas, vimos que dadas as boas condiçaes do ambiente e a morte de algumas Lemnas, a populasãa pâde crescer, e apenas moerrerem pela seu mativa natural, ou seja, a fim da sua vida!"

O Levantamento de hipóteses ocorre novamente em conjunto com a Previsão, este Levantamento de hipóteses contem uma Previsão, já que as suposições são acerca de um fenômeno que sucederia à determinados acontecimentos -“ dadas as breas condicäes do ambiente e a morte de algumas Lemnas, a populaçã pôde crescer"-.

A Previsão aqui é feita como consideração ao que aconteceria com uma população de Lemnas em condições ideais (-"beas condiçães"-) - "a pepulaçãe pôde crescer, e apenas morrerem pelo sen motivs matural, an seja, a fim da sua vida" -. A Justificativa é perpretada para dar aval à consideração feita na Previsão, e diz que as Lemnas estavam em um ambiente com boas condições -"dadas as breas condiçães do ambiente"- e por isso iriam crescer. O aluno diz também que, mesmo em condições 
Thiago Marinho Del Corso

INDICADORES DE ALFABETIZAÇÃO CIENTÍFICA, ARGUMENTOS E EXPLICAÇÕES -

Análise de Relatórios no Contexto de uma Sequência de Ensino Investigativo

ideais, haveriam mortes, Justificado pelo aluno ao -"matural ... fim de sua(s) vida(s)"-.

Finalmente, entendemos que ao verificar que apesar das condições ideais da população de Lemnas ocorre a - "morte de algumas Lemnas" - o aluno esta apresentando um dado e apresentar dados é entendido como uma Seriação de informações.

\section{Marca 13:}

Nesta décima terceira marca encontramos os indicadores de Seriação de informações, Justificativa e Classificação de informações. O primeiro desses se dá pela apresentação de dados - "estabilizaçãa"- e - "tanto crescia" -, e a Justificativa é perpretada para dar aval/garantia para a afirmativa de que há uma estabilização -“devido ae fato de mão haver mais espace para a populacãa que tante crescia."-. Podemos também entender que há uma Classificação de informações quando o aluno afirma que antes de estabilizar a população crescia muito - "tanta crescia" -, já que estabelecer características para os dados é segundo Sasseron e Carvalho (2008) indicativo para este indicador.

"Entãa chega um ponta da pesquisa, em que a populașäa se estabiliza, devida ar fata de mãe haver mais espace para a população que tanto crescia."

\section{Marca 14:}

Esta marca constitui-se no ultimo parágrafo da segunda conclusão individual do relatório nove e apresenta os indicadores de Levantamento de hipóteses, Previsão e Justificativa.

\footnotetext{
"Com issa podemas conduir que a populaçãa, se estiver em um local com boas condiçães, irá crescer até momento em que terá que se estabilizar, pela fato de algo impedir seu crescimento."
}

Ao afirmar que uma população -“" se estiver em um local com boas condicães, irá crescer até momento em que terá que se estabilizar, pelo fato de algo impedir seu crescimenta."- o aluno está Levantando hipóteses sobre o que acontecerá. 
Thiago Marinho Del Corso

INDICADORES DE ALFABETIZAÇÃO CIENTÍFICA, ARGUMENTOS E EXPLICAÇÕES -

Análise de Relatórios no Contexto de uma Sequência de Ensino Investigativo

Acreditamos que há aqui também uma Previsão, pois o aluno faz conjecturas acerca do que aconteceria com uma população genérica de Lemnas em condições ideias, o aluno não esta mais se referindo à sua população experimental, mas extrapolando seus resultados, no que entendemos ser uma previsão. A Justificativa serve aqui como um qualificador para a Previsão, já que diz que -"se estiver em um local com boas condiçães" - é que a Previsão será verificada.

\section{Marca 15:}

Na décima quarta marca, que se constitui da terceira conclusão individual e segue transcrita abaixo, encontramos indicadores de Seriação e Classificação de informações, Levantamento de hipóteses, Justificativa, Previsão e Argumento.

"A partir da gráfica e tabela podemas perceber que nossa pergunta inicial foi um pauca respondida. Percebemas que a papulaçãa de espécie que colocamas em um ambiente artificial (do qual não é seu local de origem) cresceu bastante, por conta de fatores como por exempla a luz artificial mais a natural, vinda do sol, ajudaram para que mossa espécie crescesse muita, mas nãa cresceu em linha reta perfeita por conta de alguns fatores. come algumas plantas que já estavam para morrer quando implantadas ne ambiente artificial, causanda pequenos declínias em nossa gráfica. Entãa pademas chegar a conclusãa que quanda uma espécie é implantada em um ambiente artificial, com fatores que influenciam seu crescimento, ela pode se adaptar e crescer, podemos perceber também que é necessário alguns recursos para que ela cresça. A partir da nossa gráfica pademas prever que vai haver declínia por falta de espacso do nossa ambiente artificial."

A Seriação de informações ocorre no momento em que os alunos apresentam dados sobre o comportamento da população de Lemnas como: "cresce", "cresceram", "declinia", "cressca" e etc. A Classificação de informações ocorre quando são estabelecidas características para os dados acima apresentados como: "crescen bastante", "mãa cresceu em linha reta perfeita" ou "pequenos declinias".

Acreditamos que há um Levantamento de hipóteses no que se refere à como os alunos esperavam que se daria o crescimento, e que na interpretação deste aluno, esta 
Thiago Marinho Del Corso

INDICADORES DE ALFABETIZAÇÃO CIENTÍFICA, ARGUMENTOS E EXPLICAÇÕES -

Análise de Relatórios no Contexto de uma Sequência de Ensino Investigativo

hipótese, não se verificou. Isso fica evidente na frase - "mas mãe cresceu em linha reta perfeita"-. Esta ultima frase é entendida com um Teste de hipóteses.

São várias as Justificativas presentes nesta marca, por exemplo para Justificar porque o crescimento não se deu como na Hipótese levantada (crescer como uma reta) - "por conta de alguns fatores, come algumas plantas que já estavam para morrer quando implantadas ne ambiente artificial, causando pequenes declinios em nosso gráfice"- ou antes quando o alunos Justificam o resultado final do experimento que foi um grande crescimento -" por conta de fatores come por excemplo a luz artificial mais a natural. vinda do sol,"-.

Enxergamos também dois momentos onde se encontram Previsões, primeiro quando o aluno prevê, numa generalização, o que aconteceria com qualquer espécie em uma ambiente propicio - "Entãa podemos chegar a conclusãa que quanda uma espécie é implantada em um ambiente artificial, com fatores que influenciam seu crescimento, ela pode se adaptar e crescer,"-. Segundo quando o aluno prevê o que acontecerá com esta população - "A partir do masso gráfica podemos prever que vai haver declínio par falta de espace do nasso ambiente artificial."-.

O Argumento, que segue rearranjado no layout simplificado ao proposto por Toulmin (2006), foi desambiguado em relação a uma Explicação, pois sua Conclusão (C) é menos certa, menos plausível, que as premissas que levaram a ela, já que a Conclusão (C) é uma generalização que pressupõe-se vá servir para qualquer situação análoga, diferentemente dos Dados (D) que foram experimentalmente obtidos e da Justificativa (J) que se baseiam em conhecimentos conceituais (influencia da luminosidade para o crescimento de plantas). 


\section{Marca 16:}

A décima quarta marca constitui-se dos dois parágrafos da quarta conclusão individual do relatório 9. Optamos por analisar este dois parágrafos como uma única marca devido à intrínseca relação entre os parágrafos, que juntos formaram um Argumento. Nela identificamos também indicadores de Seriação e Classificação de informações e Justificativa.

"Com as dados obtidas podemas dizer que houve um grande crescimento da populaçãe, isso em condis̄és ideais. Portanta podemos concretizar a fato de que a crescimenta de uma papulacãa biolágica é certa em condič̃es ideais.

Isse, com base me fate de as tais condič̃es ideais seriam: a luz direta, água e a recepsäa de mutrientes que certamente foi essencial para sua sobrevvivência.".

A Seriação de informações, como em outras marcas anteriormente discutidas se apresenta ao listar dados -"crescimenta"-. A Classificação de informações, da mesma forma se dá pelo estabelecimento de características à estes dados -“grande crescimenta"-

O Argumento aqui é verificado para a generalização de que sob condições ideais uma população biológica vai obrigatoriamente crescer. Esta generalização é menos certa e plausível que as premissas que levaram a ela e têm a intenção de convencer. 
Thiago Marinho Del Corso

INDICADORES DE ALFABETIZAÇÃO CIENTÍFICA, ARGUMENTOS E EXPLICAÇÕES -

Análise de Relatórios no Contexto de uma Sequência de Ensino Investigativo

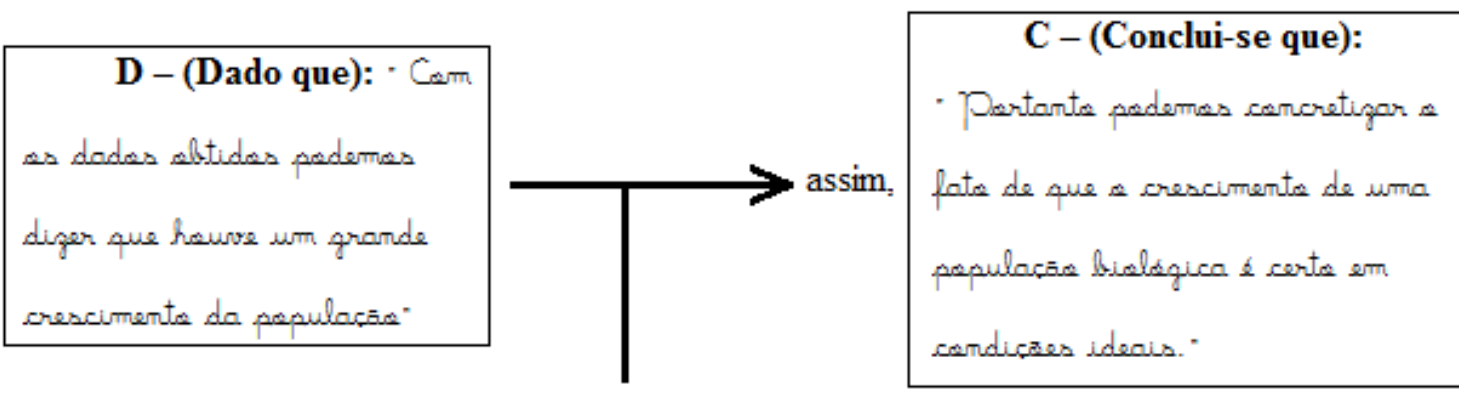

J - (Já que): (a população encontrava-se sob)

"candicares ideais." e" Issa, cam base ma fata de as

tais candicaes ideais seriam: a lug direta, bqua e a

recepcio de mutrientes que certamente foi essencial

para swa sabrevisolmcia." 

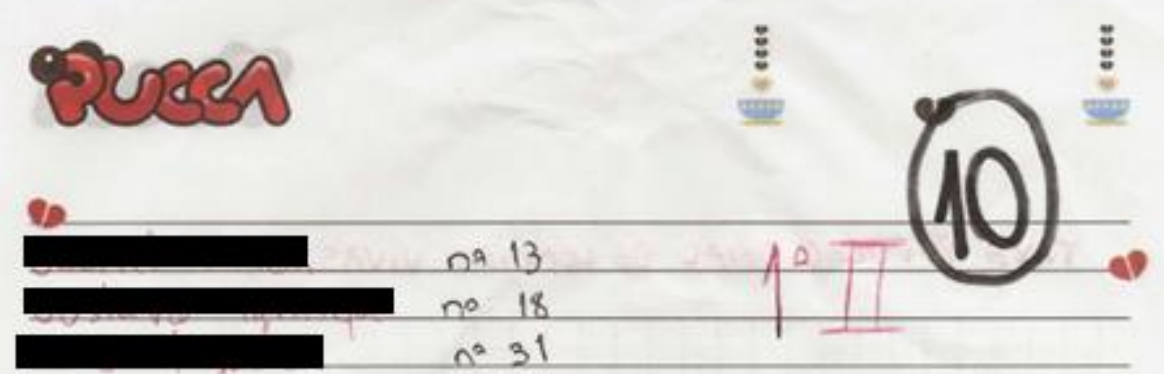

(b.

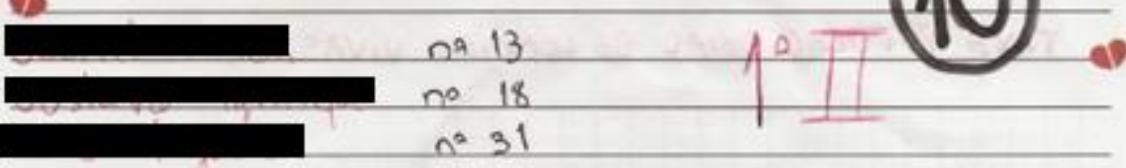

N 6 que acontece com uma populaçäs bioloigica

IDapós a coolanizaçio por alguns individuos do um Zimbiente cam as condigores deais para e desenvol.

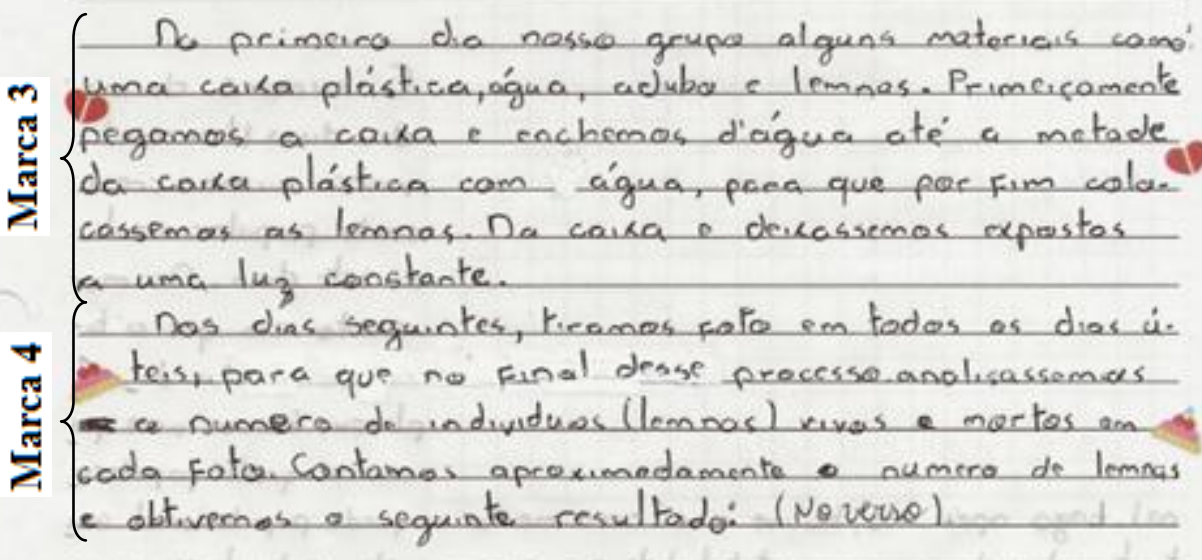

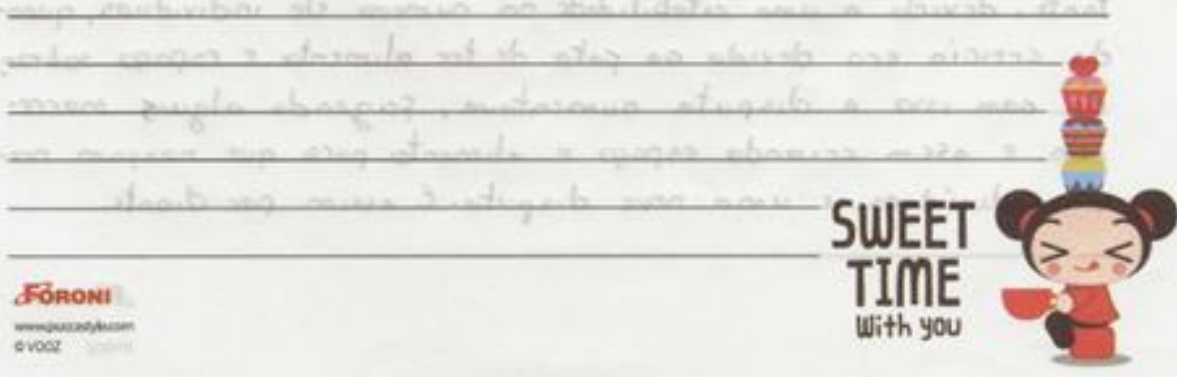




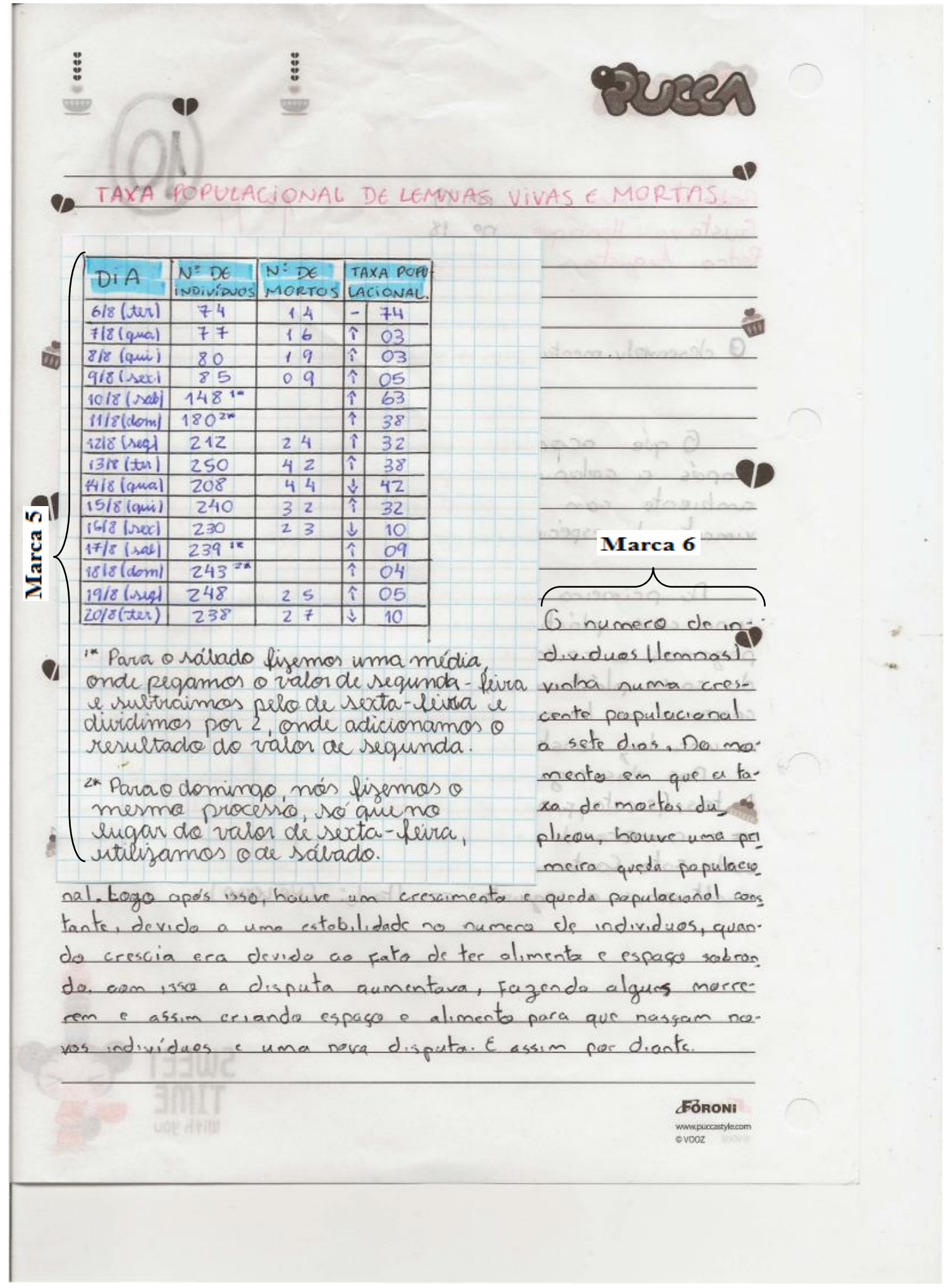


Thiago Marinho Del Corso

INDICADORES DE ALFABETIZAÇ̃̃o CIENTÍFICA, ARGUMENTOS E EXPLICAÇÕES -

Análise de Relatórios no Contexto de uma Sequência de Ensino Investigativo

Quadro 10

Identificação dos Indicadores de Alfabetização Científica no Relatório 10 de 2013 e conclusões individuais correspondentes.

\begin{tabular}{|c|c|c|c|c|c|c|c|c|c|c|c|c|c|}
\hline 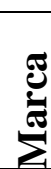 & $\begin{array}{l}\text { Subtítulo, } \\
\text { divisão ou } \\
\text { Item }\end{array}$ & Texto & $\mathbf{L M}$ & SI & $\mathbf{O I}$ & CI & RL RP & $\mathbf{L H}$ & TH & $\mathbf{J}$ & $\mathbf{P}$ & 20 & $\sum^{00}$ \\
\hline 1 & Titulo & "O desenvolvimenta populacional de lemnas" & & & & & & & & & & & \\
\hline 2 & Pergunta & $\begin{array}{l}\text { "O que acontece com uma papulaçãa bialógica após a } \\
\text { colonizacãa par alguns individuos de um ambiente com as } \\
\text { condičaes ideais para a desenvalvimenta da espécie?" }\end{array}$ & \multicolumn{11}{|c|}{ Não avaliado, texto da professora. } \\
\hline 3 & $\begin{array}{l}\text { Metodologia } \\
1^{\circ} \text { parágrafo }\end{array}$ & $\begin{array}{l}\text { "No primeira dia nassa grupa alguns materiais coma uma } \\
\text { caixa plástica, água, aduba, e lemnas. Primeiramente pegamas } \\
\text { a caixa e enchemos de água até a metade da caixa plástica com } \\
\text { água, para que por fim calacássemas as lemnas. Ma caixa e } \\
\text { deixássemas expostas a uma luz constante." }\end{array}$ & $\mathrm{X}$ & & $\mathrm{X}$ & & & & & & & & \\
\hline 4 & $\begin{array}{l}\text { Metodologia } \\
2^{\circ} \text { Parágrafo }\end{array}$ & $\begin{array}{l}\text { "Mas dias seguintes, tiramas fota em todas as dias úteis, } \\
\text { para que na final desse processa analisássemas a númera de } \\
\text { individuas (lemnas) vivas e mortas em cada fota. Contamas } \\
\text { apraximadamente a númera de lemnas e abtivemas a seguinte } \\
\text { resultada: (na versa)." }\end{array}$ & $X$ & & $\mathrm{X}$ & $X$ & & & & & & & \\
\hline
\end{tabular}


Thiago Marinho Del Corso

INDICADORES DE ALFABETIZAÇ̃̃o CIENTÍFICA, ARGUMENTOS E EXPLICAÇÕES -

Análise de Relatórios no Contexto de uma Sequência de Ensino Investigativo

\begin{tabular}{|c|c|c|c|c|c|c|c|c|c|c|c|c|c|c|c|}
\hline 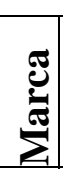 & $\begin{array}{l}\text { Subtítulo, } \\
\text { divisão ou } \\
\text { Item }\end{array}$ & Texto & & $\mathbf{L M}$ & SI & OI & CI & RL & LP & $\mathbf{L H}$ & TH & $\mathbf{J}$ & $\mathbf{P}$ & 름 & $\stackrel{+00}{Z}$ \\
\hline 5 & $\begin{array}{l}\text { Resultados } \\
\text { (Jaxa } \\
\text { populacional } \\
\text { de Lemnas } \\
\text { Vivas e } \\
\text { Mortas) }\end{array}$ & 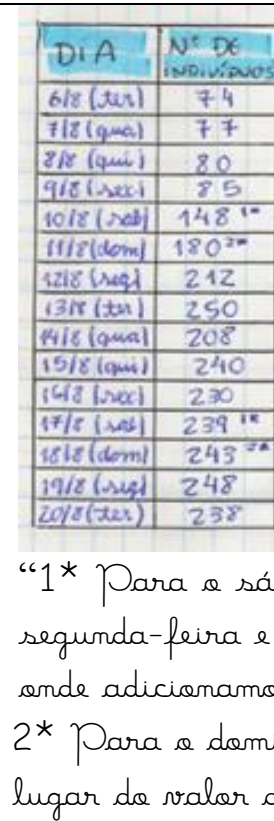 & 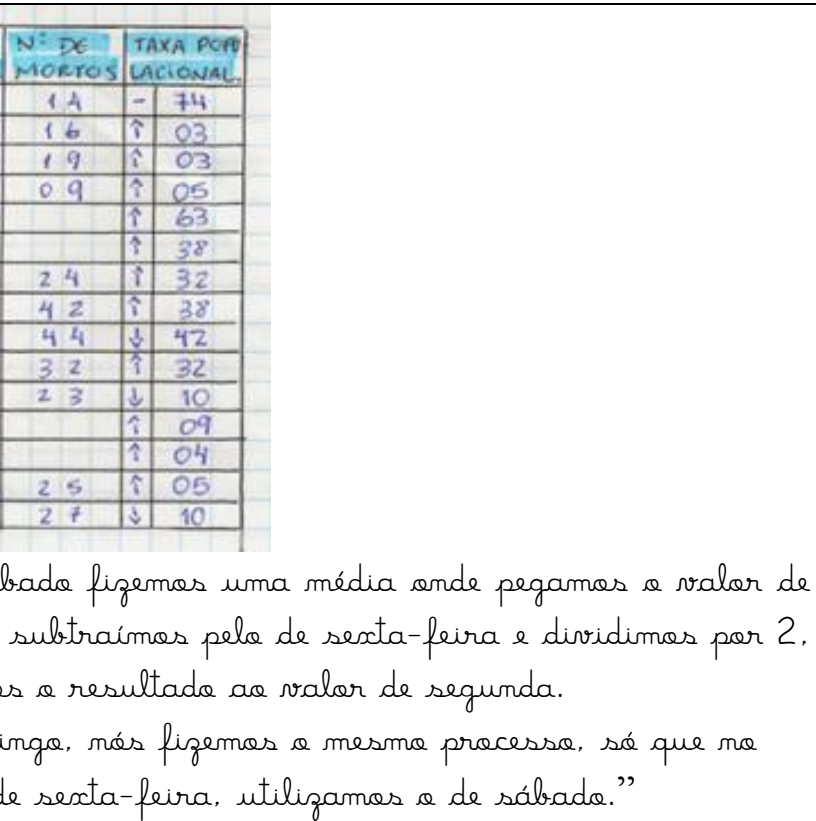 & & $X$ & $X$ & $X$ & $X$ & & & & & & & \\
\hline 6 & Interpretação & $\begin{array}{l}\text { "O númera } \\
\text { populacional a s } \\
\text { duplicau, houve } \\
\text { houve um cresci } \\
\text { uma estabilidade } \\
\text { devida ac fata d } \\
\text { disputa aumenta } \\
\text { espaco e aliment } \\
\text { disputa. E assim }\end{array}$ & 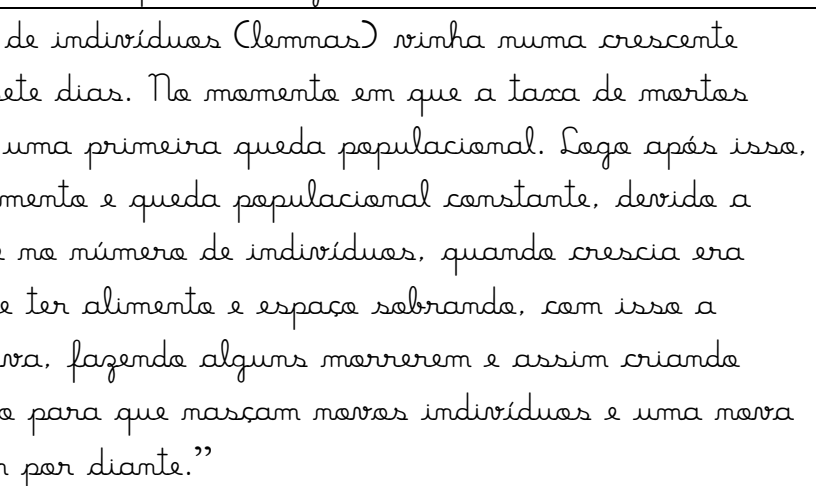 & & $\mathrm{X}$ & $\mathrm{X}$ & & $\mathrm{X}$ & & & & $\mathrm{X}$ & & & \\
\hline
\end{tabular}


Thiago Marinho Del Corso

INDICADORES DE ALFABETIZAÇÃO CIENTÍFICA, ARGUMENTOS E EXPLICAÇÕES -

Análise de Relatórios no Contexto de uma Sequência de Ensino Investigativo

\begin{tabular}{|c|c|c|c|c|c|c|c|c|c|c|c|c|c|c|c|}
\hline 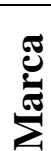 & $\begin{array}{l}\text { Subtítulo, } \\
\text { divisão ou } \\
\text { Item }\end{array}$ & Texto & $\mathbf{L M}$ & SI & OI & CI & $\mathbf{R L}$ & $\mathbf{R P}$ & $\mathbf{L H}$ & TH & $\mathbf{J}$ & $\mathbf{P}$ & & & $\overbrace{}^{+\infty}$ \\
\hline 7 & $\begin{array}{l}\text { Conclusão } \\
\text { individual } 1 \\
1^{\circ} \text { parágrafo }\end{array}$ & 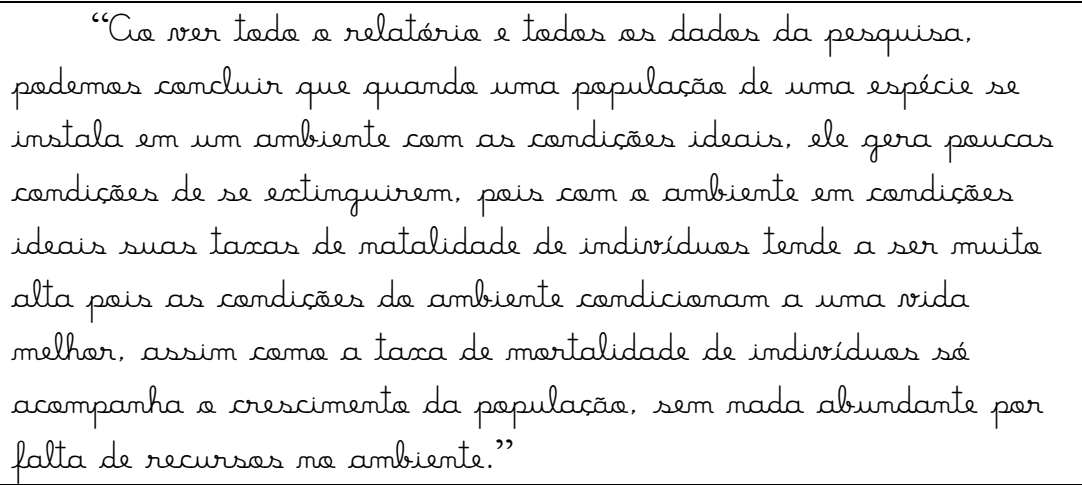 & & & & & & & & & $\mathbf{X}$ & $\mathbf{X}$ & & & $\mathbf{X}$ \\
\hline 8 & $\begin{array}{l}\text { Conclusão } \\
\text { individual } 1 \\
2^{\circ} \text { parágrafo }\end{array}$ & $\begin{array}{l}\text { "Mas havenda uma estabilidade da prápria populaçãa no fim } \\
\text { da pesquisa, pela fato de que se continuar a crescimenta grande } \\
\text { da populaçãa a ambiente nãa ia poder proporcionar os recursos } \\
\text { suficientes para as individuas nascerem e continuarem vivenda." }\end{array}$ & & $\mathbf{X}$ & $\mathbf{X}$ & $\mathbf{X}$ & & & & & $\mathbf{X}$ & $\mathbf{X}$ & & & $\mathbf{X}$ \\
\hline 9 & $\begin{array}{l}\text { Conclusão } \\
\text { individual } 2 \\
1^{\circ} \text { parágrafo }\end{array}$ & $\begin{array}{l}\text { "Concluimas que apés a colonizaçãa de Lemnas em um } \\
\text { ambiente com condičoes ideais para a desenvolvimenta, a taxa } \\
\text { populacional cresceu e em alguns períados dobrou a númera de } \\
\text { individuos." }\end{array}$ & & $\mathbf{X}$ & & $\mathbf{X}$ & & & & & & & & & \\
\hline 10 & $\begin{array}{l}\text { Conclusão } \\
\text { individual } 2 \\
2^{\circ} \text { parágrafo }\end{array}$ & 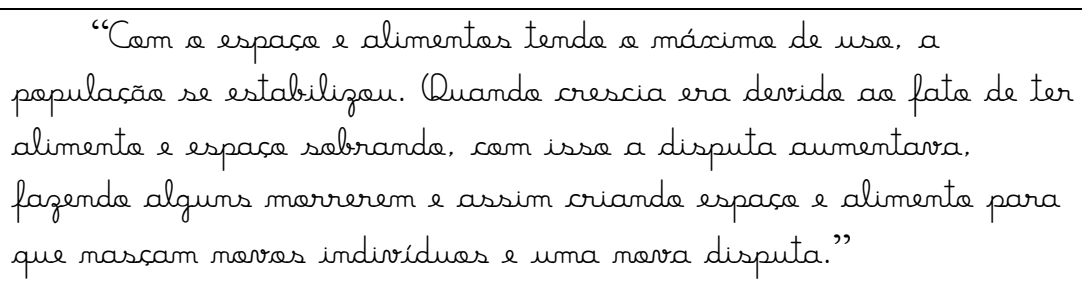 & & $\mathbf{X}$ & & & $\mathbf{X}$ & & & & $\mathbf{X}$ & & $\mathrm{X}$ & & \\
\hline
\end{tabular}


Thiago Marinho Del Corso

INDICADORES DE ALFABETIZAÇÃO CIENTÍFICA, ARGUMENTOS E EXPLICAÇÕES -

Análise de Relatórios no Contexto de uma Sequência de Ensino Investigativo

\begin{tabular}{|c|c|c|c|c|c|c|c|c|c|c|c|c|c|c|}
\hline 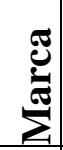 & $\begin{array}{l}\text { Subtítulo, } \\
\text { divisão ou } \\
\text { Item }\end{array}$ & Texto & $\mathbf{L M}$ & SI & OI & CI & $\mathbf{R L}$ & LRP & $\mathbf{L H}$ & TH & $\mathbf{J}$ & $\mathbf{P}$ & 网 & $\frac{100}{4}$ \\
\hline 11 & $\begin{array}{l}\text { Conclusão } \\
\text { individual } 2 \\
3^{\circ} \text { parágrafo }\end{array}$ & 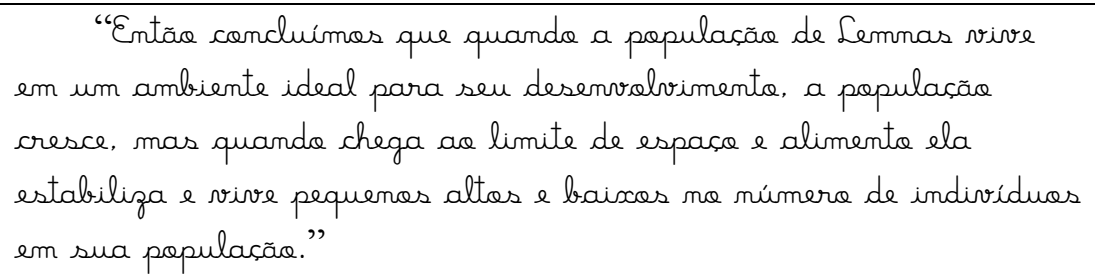 & & $\mathbf{X}$ & & $\mathbf{X}$ & & & & & $\mathbf{X}$ & & & $\mathbf{X}$ \\
\hline 12 & $\begin{array}{l}\text { Conclusão } \\
\text { individual } 3 \\
\text { parágrafo } \\
\text { único }\end{array}$ & 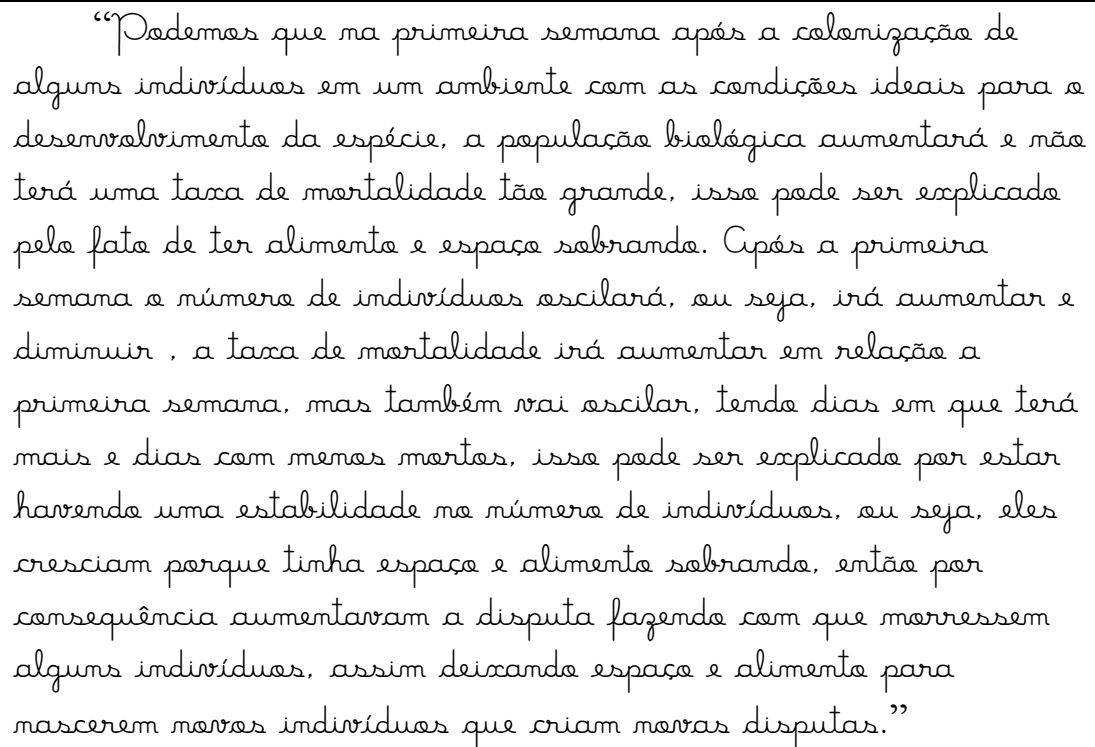 & & $\mathbf{X}$ & $\mathbf{X}$ & & $\mathbf{X}$ & & & & $\mathbf{X}$ & $\mathbf{X}$ & & $\mathbf{X}$ \\
\hline
\end{tabular}


Detalhamento da identificação dos indicadores de AC - Relatório 10 - 2013

\section{Marca 1:}

A primeira marca deste décimo relatório foi atribuída ao título do relatório. Nenhum indicador de Alfabetização Científica (AC) foi identificado aqui.

\section{Marca 2:}

A segunda marca foi atribuída à pergunta geradora fornecida pela professora como comanda para a execução dos trabalhos e por não se tratar de composição dos alunos não é avaliada.

\section{Marca 3:}

$\mathrm{Na}$ terceira marca temos a primeira produção dos alunos neste relatório que apresenta indicadores de AC, Listagem de materiais e Organização de informações. O primeiro é identificado pela listagem de materiais que irão gerar os dados trabalhados. O segundo se configura como: "momentos em que se discute sobre o modo como um trabalho foi realizado...", o que é exatamente o que esta sendo descrito nesta marca.

\footnotetext{
"To primeira dia nossa grupa alguns materiais coma uma caixa plástica, água, adubse e lemnas. Primeiramente pegamos a caixa e enchemos de água até a metade da caixa plástica com água, para que por fim colocássemos as lemnas. Ma caixa e deixássemos expostas a uma luz constante."
}

\section{Marca 4:}

A quarta marca, transcrita abaixo, apresenta os indicadores de Listagem de materiais, Organização e Classificação de informações.

A Listagem de materiais aparece quando os alunos apontam que utilizaram fotos dos experimentos com as Lemnas para análise. A Organização de informações decorre da descrição dos procedimentos adotados para a realização do trabalho - "tirames foto em tadas as dias úteis"-, "Contamas apraximadamente a númera de lemnas"- etc. 
Por último a Classificação de informações aparece já que esta visa estabelecer características para os dados e aqui temos que haverão dados de Lemnas vivas (uma característica) e mortas (outra característica).

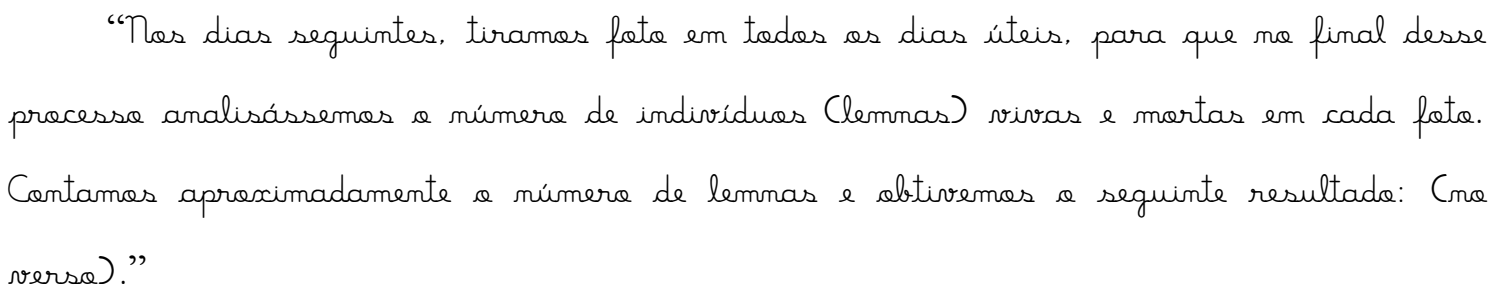

\section{Marca 5:}

Nesta quinta marca encontramos uma tabela e dois parágrafos que explicam como foram produzidos os dados do numero de indivíduos na população de Lemnas nos finais de semana. A tabela apresenta os indicadores de Seriação, Organização e Classificação de informações e os parágrafos abaixo dela o indicador de Raciocínio lógico. Acreditamos que a tabela apresenta a Seriação de informações, pois ela se constitui em uma lista de dados, a Organização de informações, pois estes dados foram preparados e organizados em uma tabela, e, finalmente, acreditamos haver uma Classificação de informações aqui, quando os alunos apresentam setas, que indicam se houve crescimento ou diminuição no numero de indivíduos na população de Lemnas. Vale realçar que esta tabela é a única que estabelece características para os dados e que este relatório é o único que não apresenta construção de gráfico.

Acreditamos que o texto que acompanha a tabela indica Raciocínio lógico, já que os alunos estão expondo o raciocínio utilizado para inferir a quantidade de Lemnas na população nos finais de semana, quando não houve contagem. A exposição do raciocínio utilizado é clara e coerente e assim pensamos que aqui este indicador se fez presente. 
Thiago Marinho Del Corso

INDICADORES DE ALFABETIZAÇÃO CIENTÍFICA, ARGUMENTOS E EXPLICAÇÕES -

Análise de Relatórios no Contexto de uma Sequência de Ensino Investigativo

\begin{tabular}{|c|c|c|c|c|}
\hline DiA & $\begin{array}{l}N^{0} D E \\
\text { indivinuas }\end{array}$ & $\begin{array}{l}\text { N: DE } \\
\text { Morros }\end{array}$ & & $\begin{array}{l}\text { XA POA } \\
\text { CIONAL. }\end{array}$ \\
\hline $6 / 8(\operatorname{ter})$ & 74 & 14 & - & 74 \\
\hline 718 (qua) & 77 & 16 & $\hat{\imath}$ & 03 \\
\hline 8 is (qui) & 80 & 19 & $\hat{i}$ & 03 \\
\hline 918 (sec) & 85 & 09 & $\hat{\imath}$ & 05 \\
\hline 1018 ( $\mathrm{sel})$ & $148^{\circ}$ & & $\hat{\imath}$ & 63 \\
\hline $11 / 8(d 6 \mathrm{~m})$ & $180^{27}$ & & $\hat{3}$ & 38 \\
\hline 1218 Vhagd & 212 & 24 & 7 & 32 \\
\hline $13 \pi(\tan )$ & 250 & 42 & $\hat{\imath}$ & 38 \\
\hline Ais lqual & 208 & 44 & $\sqrt{3}$ & 42 \\
\hline $15 / 8$ (onit) & 240 & 32 & $\hat{\imath}$ & 32 \\
\hline 14: |rec| & 230 & 23 & 2 & 10 \\
\hline $17 / 8$ (xal) & $239^{11}$ & & $\hat{i}$ & 09 \\
\hline $1818(\mathrm{dcm})$ & $243^{72}$ & 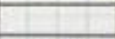 & $\hat{\imath}$ & 04 \\
\hline $19 / 8$ (ses) & 248 & 25 & $\hat{\imath}$ & 05 \\
\hline $20 y \bar{g}(\mathrm{ter})$ & 238 & 27 & 2 & 10 \\
\hline
\end{tabular}

1 * Para a sábada fizemas uma média onde pegames a valor de segunda-feira e subtraimos pela de sexta-feira e dividimos por 2, onde adicionamas a resultado ace valor de segunda.

2* Para a dominga, nós fizemas a mesma processa, sé que na lugar da valor de sextafeira, utilizamas a de sábada."

\section{Marca 6:}

A sexta marca está sob a égide do sub-título - "Imterpretacãa"- e contem indicadores de Seriação e Organização de informações, Justificativa e Raciocínio lógico.

"O número de individuas (lemnas) vinha numa crescente populacional a sete dias. To momenta em que a taxa de mortos duplicou, houve uma primeira queda populacional. Lago após issa, hauve um crescimenta e queda papulacional constante, devida a uma estabilidade no númera de individuas, quanda crescia era devida aa fata de ter alimenta e espacse sobrando, com issa a disputa aumentava, fagendo alguns morrerem e assim criando espaca e alimenta para que nasçam novos individuos e uma nova disputa. E assim por diante."

A Seriação de informações se dá pela listagem de dados -“crescente populacional"-, -“taxa de mortas duplicau"-, -"primeira queda populacional”-, -"estabilidade mo número de individuas"- acerca da dinâmica populacional das Lemnas ao longo do experimento. A Organização de informações decorre da preparação destes dados, que fica evidente tanto na apresentação cronológica dos mesmos, como na divisão em dois momentos distintos, um de crescimento constante e outro de oscilação ao redor de um 
Thiago Marinho Del Corso

INDICADORES DE ALFABETIZAÇÃO CIENTÍFICA, ARGUMENTOS E EXPLICAÇÕES -

Análise de Relatórios no Contexto de uma Sequência de Ensino Investigativo

tamanho próximo de indivíduos. Ao tentar Justificar que - "alimenta e espace sobranda"-

são os responsáveis por haver crescimento é que percebemos o indicador de Justificativa, também quando trazem a liberação de -"espaçe e alimenta"- após a morte de alguns indivíduos, como Justificativa para a retomada do crescimento.

Sasseron (2008) associa o indicador de Raciocínio lógico com o argumento hipotético-dedutivo de Lawson (2000) e no trecho final dessa assertiva podemos identificar uma exposição clara de ideias com este padrão. Os alunos afirmam que [se] "crescia era devida ae fato de ter alimento e espacse sabrando", [então] "com isso a disputa aumentava, fazendo alguns morrerem" [portanto] "criando espaco e alimento" e [então] "masçam novros individuas e uma mova disputa" [portanto] "E assim por diante." ".

\section{Marca 7:}

Justificativa, Previsão e Argumento foram encontrados nesta assertiva do relatório 10 que segue transcrita abaixo.

"Co ver toda a relatória e todas as dados da pesquisa, podemas concluir que quando uma populașãa de uma espécie se instala em um ambiente com as condiçaes ideais, ele gera paucas condiç̃es de se extinguirem, pais com a ambiente em condiçâes ideais suas taxas de matalidade de individuas tende a ser muito alta pois as condiçäes do ambiente condicionam a uma vida melhor, assim coma a taxa de mortalidade de individuas sé acompanha a crescimenta da populaçãe. sem nada abundante por falta de recursos no ambiente."

A Justificativa aparece como elemento do Argumento, mas também para dar aval a afirmação de que o crescimento não apresenta uma taxa abundante -“sem rada abundante por falta de recursos ne ambiente"-.

Podemos entender que ocorre uma Previsão quando os alunos dizem, generalizando, que sobre certas condições há pouca probabilidade que uma população se extinga -"quanda uma populacãa de uma espécie se instala em um ambiente com as condič̃es ideais, ele gera poucas condicães de se extinguirem"--

O Argumento segue abaixo estruturado e novamente se apresenta para convencer o leitor de que a generalização (Previsão) é coerente e plausível. Para isso o aluno lança mão de premissas que são mais plausíveis que a própria Conclusão (C) do Argumento. 


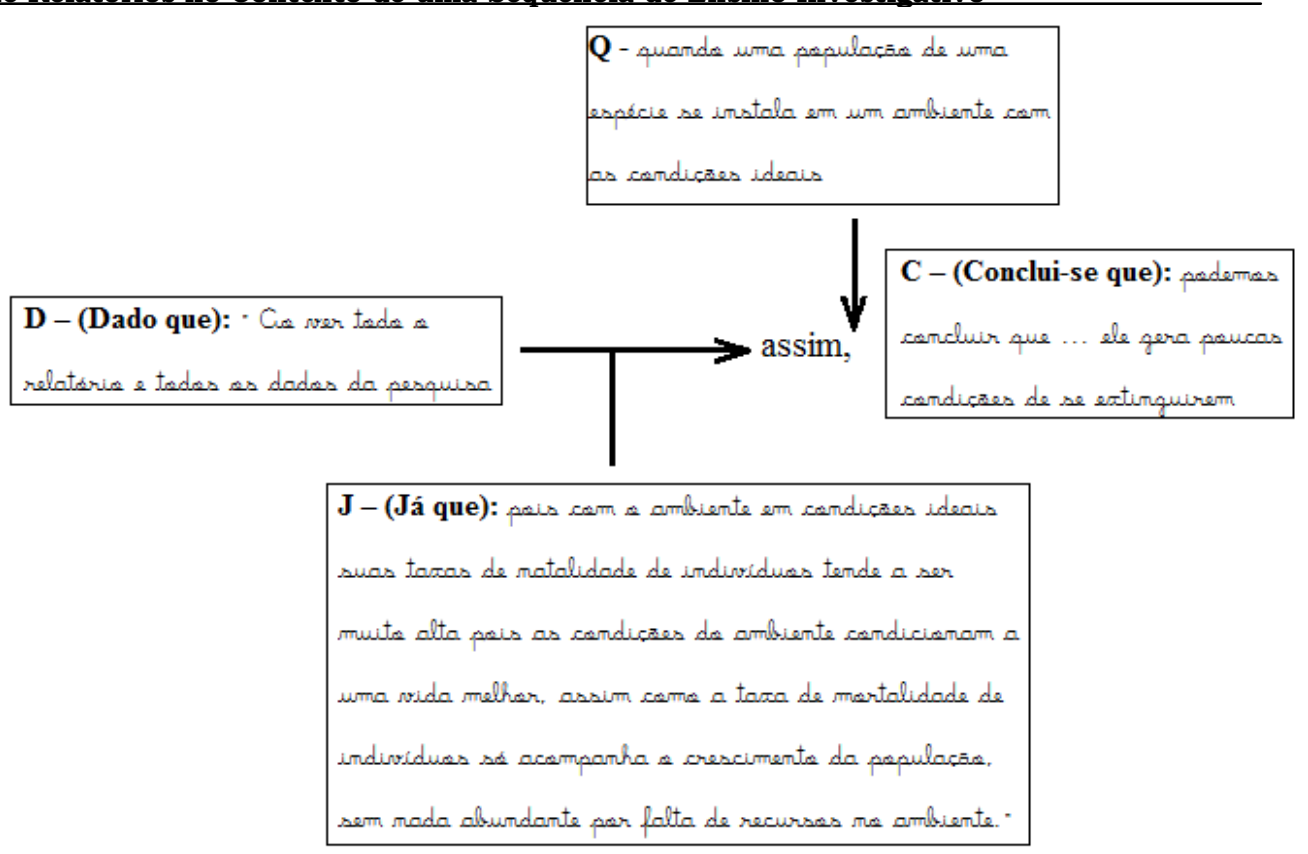

\section{Marca 8:}

A oitava marca se refere ao segundo parágrafo da primeira conclusão individual do relatório 10 e apresenta os indicadores de Seriação, Organização e Classificação de informações, além de Levantamento de hipóteses, Justificativa, Previsão e Argumento.

"Mas havenda uma estabilidade da própria população mo fim da pesquisa, pela fata de que se continuar a crescimenta grande da populacãa a ambiente nãa ia poder proporcionar as recursas suficientes para as individuas nascerem e continuarem vivenda."

A Seriação se configura pela apresentação dos dados - "estabilidade"- e "crescimenta"-. A Organização de informações pela separação dos dados em dois grupos, estabilidade e crescimento, que são retomados para discussão, o que é característico deste indicador. A Classificação de informações se faz presente quando o aluno estabelece característica para um dos dados -"crescimente grande"-.

O Levantamento de hipóteses ocorre como uma suposição de que a população se estabilizaria caso o experimento continuasse. Esta suposição é também uma Previsão em que o fenômeno previsto seria a estabilização que ocorreria com a continuação do crescimento, já que em algum momento os recursos do ambiente se tornariam escassos e isso limitaria o desenvolvimento da população. 
Esta Previsão torna-se a Conclusão (C) do Argumento a ser defendida. E a

Justificativa (J) se faz presente também como elemento do Argumento.

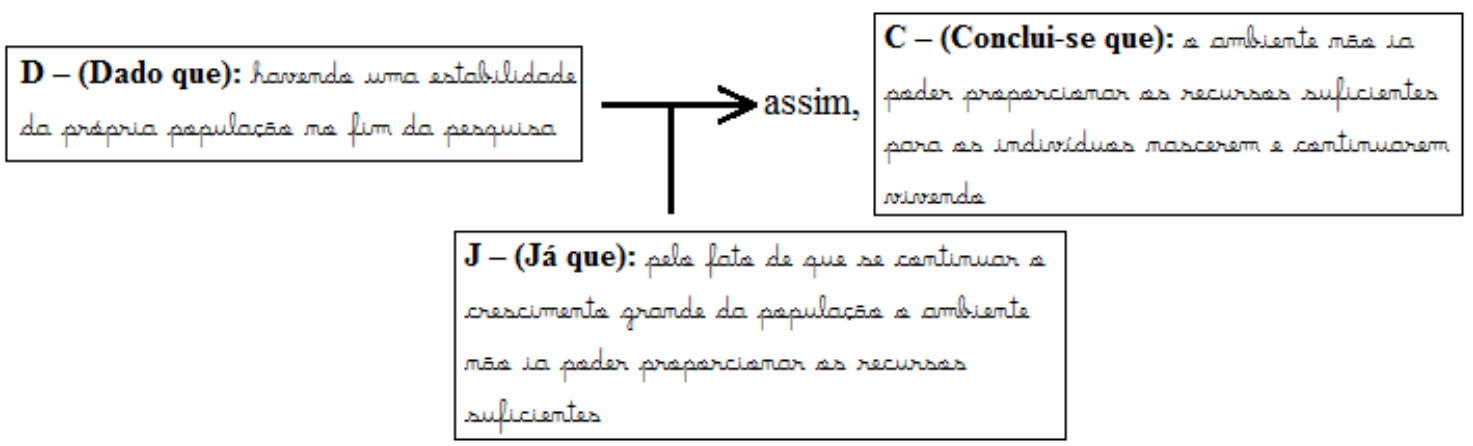

\section{Marca 9:}

O primeiro parágrafo da segunda conclusão individual do relatório 10 contem indicadores de Seriação de informações e Classificação de informações.

"Concluimas que após a colonizaçãa de Lemnas em um ambiente com condiçães ideais para a desenvolvimenta, a taxa populacional cresceu e em alguns períados dobrau a númera de individuas."

A Seriação de informações novamente acontece por listar dados -"a taxa populacional cresceu"- e a Classificação por atribuir características para este dado, no caso que -"e em alguns períadas dobrou a múmero de individuas."-.

\section{Marca 10:}

O segundo parágrafo da segunda conclusão individual do décimo relatório apresenta indicadores de Seriação de informações, Justificativa, Explicação e Raciocínio lógico.

"Com a espacsa e alimentas tenda a máxima de usa, a papulasãa se estabilizau. Quando crescia era devida ae fato de ter alimenta e espaca sabranda, com issa a disputa aumentava, fazendo alguns morrerem e assim criando espacse e alimenta para que nascam movras individuas e uma nova disputa."

A Seriação de informações é também verificada aqui pela listagem de dados - "a populaçãe se estabilizau" -, - "crescia” -. O aluno aqui apresenta um modelo explicativo para o fenômeno inferido de a população ter se estabilizado, assim a estabilidade é 
Thiago Marinho Del Corso

INDICADORES DE ALFABETIZAÇÃO CIENTÍFICA, ARGUMENTOS E EXPLICAÇÕES -

Análise de Relatórios no Contexto de uma Sequência de Ensino Investigativo

considerada o explanandum da Explicação e as Justificativas para que este fenômeno

tenha acontecido da forma como o aluno afirma que aconteceu são os explanans -“ espace e alimentas tenda a máxima de use"- "a disputa aumentarsa, fazenda algurs morrerem" - "e assim criando espace e alimento para que nascam novos individuas" "Duanda crescia era devida ae fato de ter alimenta e espaca sobrando"- o que causaria "movers individuas e uma movra disputa"-.

O Raciocínio lógico ocorre aqui quando os alunos expõem seu raciocínio sobre a explicação para o fenômeno da estabilização da população. [se] "crescia era devida ae fata de ter alimenta e espacse sobranda" [então] "com isso a disputa aumentara, fazenda alguns merrerem" [portanto] "assim criando espace e alimente para que nascam noves individuas e uma mova disputa".

\section{Marca 11:}

Aqui no ultimo parágrafo da segunda conclusão do décimo relatório o aluno apresenta indicadores de Seriação de informações, Justificativa e Argumento.

"Entãa concluimas que quanda a populacãa de Lemnas vive em um ambiente ideal para seu desenvolvimenta, a populaça cresce, mas quando chega ar limite de espaca e alimenta ela estabiliza e vive pequenos altas e baixas no número de individuas em sua populaçãe."

A Seriação de informações se fez presente segunda a lógica anteriormente apresentada, listagem de dados -"a populaçãe cresce"- "estabiliza"- "vivve pequemas altas e baixces no múmera de individuas"-. A Justificativa (J) se apresenta como elemento do Argumento e o mesmo segue rearranjado segundo o padrão simplificado de Toulmin (2006). 

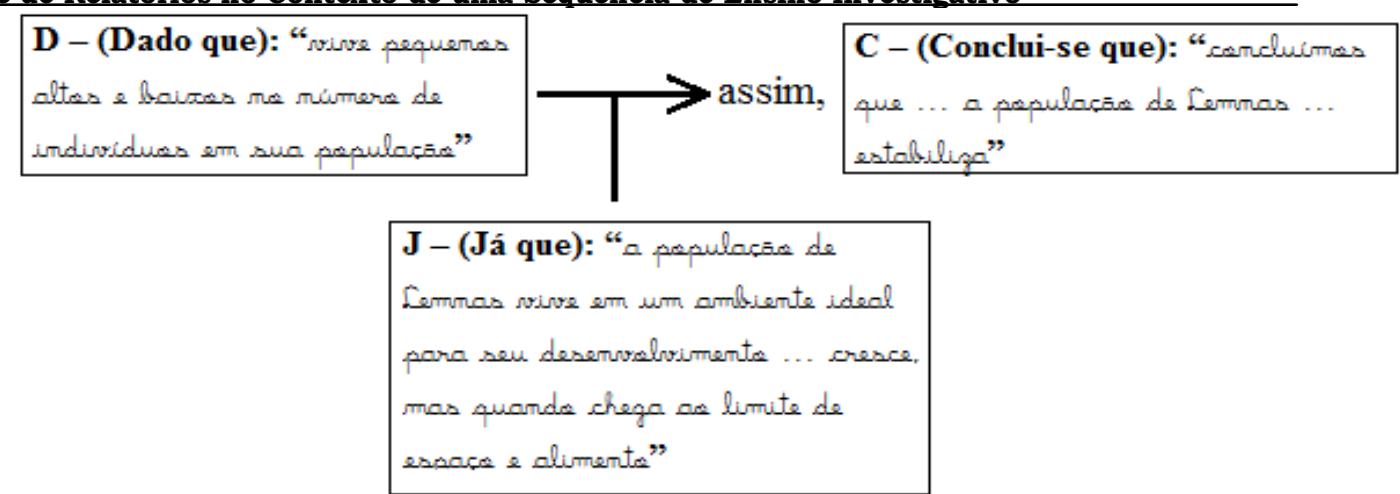

\section{Marca 12:}

A última conclusão individual do décimo relatório é escrita como um único parágrafo, que segue transcrito abaixo, e apresenta indicadores de Seriação de informações, Organização de informações, Raciocínio lógico, Justificativa, Previsão e Argumento.

"Podemas que na primeira semana apés a colonizaçãa de alguns individuas em um ambiente com as condiçães ideais para a desenvolvimenta da espécie, a papulaçãa bialágica aumentará e mãa terá uma taxa de mortalidade tãa grande, issa pode ser explicada pela fata de ter alimenta e espaca sobranda. Cpós a primeira semana a númera de individuas ascilará, eu seja, irá aumentar e diminuir, a taxa de mortalidade irá aumentar em relaçãe a primeira semana, mas também vai ascilar, tenda dias em que terá mais e dias com menos mortos, issa pade ser explicado por estar havendo uma estabilidade no númera de individuas, ou seja, eles cresciam porque tinha espaca e alimenta sabranda, entãa por consequência aumentavam a disputa fagenda com que morressem alguns individuas, assim deixando espace e alimenta para nascerem novos individuas que criam novas disputas."

Uma Seriação de informações se refere, de acordo com Sasseron e Carvalho (2008) a apresentação de dados. Neste parágrafo o tempo verbal usado pelos alunos dá a entender uma generalização que caracteriza uma Previsão, mas pode-se perceber que os alunos estão também descrevendo o comportamento da população de Lemnas do experimento, e neste afazer listam dados coletados, no que é entendido como uma Seriação de informações -"a populaçã bialógica aumentará"-, -"mãa terá uma taxa de martalidade tãa grande"-, "a númera de individuas ascilará, eu seja, irá aumentar e diminuir"-, " "dias em que terá mais e dias com menos mortas"-, -"estar havendo uma 
estabilidade na númera de individuas."-. Acreditamos também, pela escolha do tempo

verbal, que o aluno esta também fazendo Previsão sobre como seria o comportamento de uma população biológica hipotética, tomando o desenrolar da dinâmica populacional do próprio experimento como um modelo e por conseguinte fazendo Previsões.

Quando o aluno divide as variações populacionais em diferentes momentos com características próprias e causas idem, acreditamos que esteja Organizando

\section{informações.}

O Raciocínio lógico decorre da exploração clara feita sobre as relações entre o crescimento e a liberação de nutrientes e a mortandade -"eles cresciam porque tinha espacse e alimento sobrando, então por consequência aumentavam a disputa fazendo com que morressem alguns individuas, assim deixando espaco e alimenta para nascerem novos individuas que criam movas disputas."-, aqui é fácil acompanhar a estrutura do raciocínio, e por conseguinte pensamos haver o indicador de Raciocínio lógico.

A Justificativas (J) aparecem como elementos dos Argumentos.

Acreditamos haver dois Argumentos distintos nesta marca, o primeiro se relaciona à afirmativa sobre um primeiro momento da dinâmica populacional, prevendo o que se sucederia após uma colonização por uma população biológica de um ambiente com condições ideais. O segundo se refere ao desenrolar após este primeiro momento, para quando a população entra em equilíbrio, atingindo a capacidade suporte do ambiente.

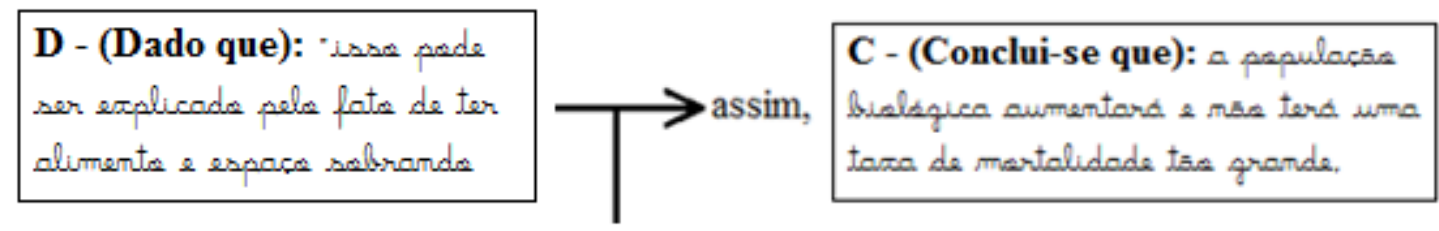

$$
\begin{aligned}
& \text { J - (Já que): "um ambiente cam } \\
& \text { a candicaes ideais para a } \\
& \text { desernvalvismenta do especie }
\end{aligned}
$$

O primeiro destes Argumentos tem em sua Conclusão (C) uma generalização, que exatamente por isso torna-se menos plausível que os elementos que levaram a ela, já que os Dados (D) vêm da observação das condições iniciais do experimento, e a Justificativa (J) corresponde à afirmação da professora de que o ambiente do experimento continha condições ideais. O que tendo em mente o fazer escola (Jiménez, Rodríguez, Duschl, 2000) torna-se para os alunos um apoio suficiente para permitir a 
Thiago Marinho Del Corso

INDICADORES DE ALFABETIZAÇÃO CIENTÍFICA, ARGUMENTOS E EXPLICAÇÕES -

Análise de Relatórios no Contexto de uma Sequência de Ensino Investigativo

Conclusão (C). Como os elementos são mais plausíveis que a Conclusão (C)

entendemos que trata-se de Argumento e não Explicação.

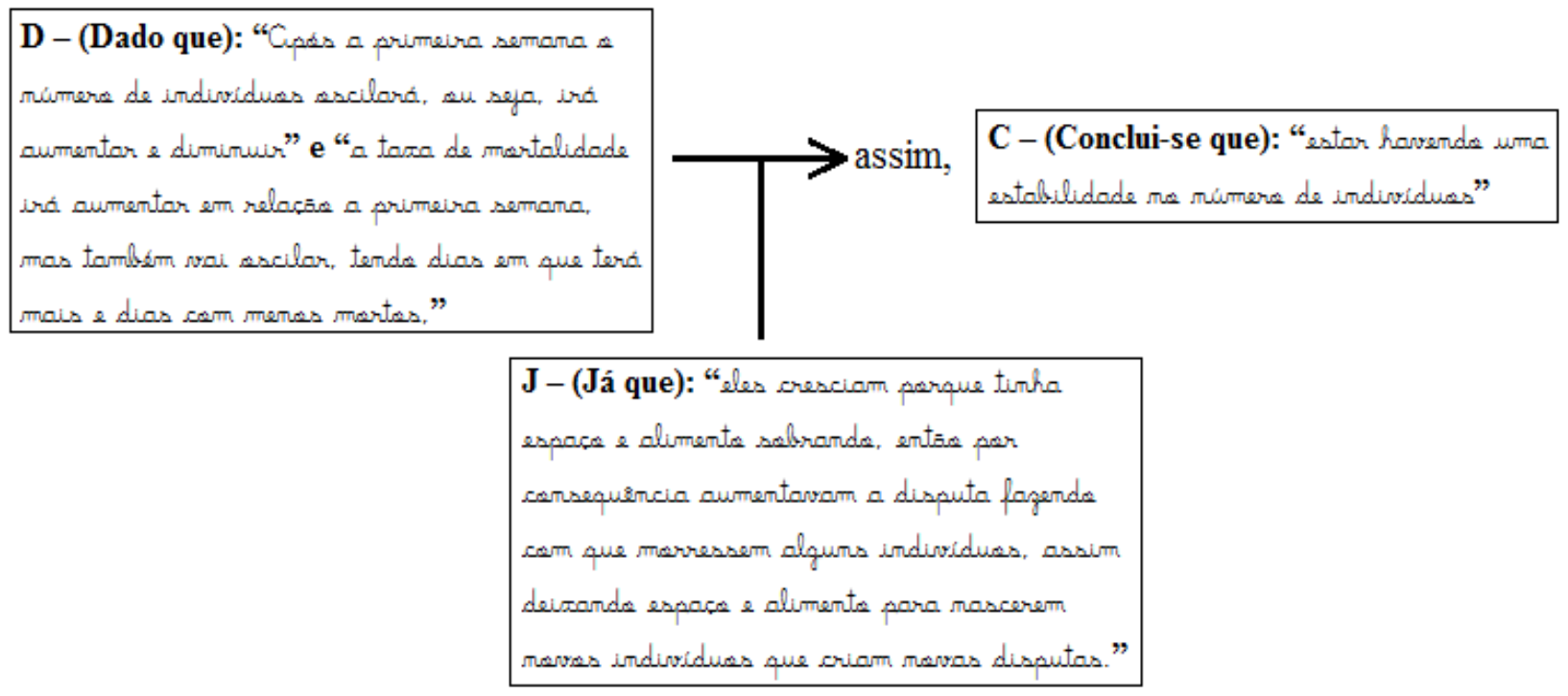

O segundo Argumento trata de tentar convencer o leitor de que a população esta se estabilizando, Conclusão (C), esta intenção de convencimento é característica dos Argumentos e não das Explicações e aqui se fez necessária pois a população está oscilando e não perfeitamente igual ao longo dos dias. O aluno apresenta Dados (D) empíricos da observação da variação da população que corresponderiam ao modelo teórico apresentado pela professora e que caracterizam uma estabilização quando a população atinge a capacidade suporte do ambiente. A Justificativa (J) aponta também para uma retomada do modelo teórico apresentado pela professora acerca de dinâmica populacional, com apresentação indireta dos conceitos de capacidade suporte, competição intra-específica, fatores limitantes. 
Thiago Marinho Del Corso

INDICADORES DE ALFABETIZAÇÃO CIENTÍFICA, ARGUMENTOS E EXPLICAÇÕES -

Análise de Relatórios no Contexto de uma Sequência de Ensino Investigativo

\section{Relatórios 11 a 18 de 2013}

\section{Relatório 11 - 2013}

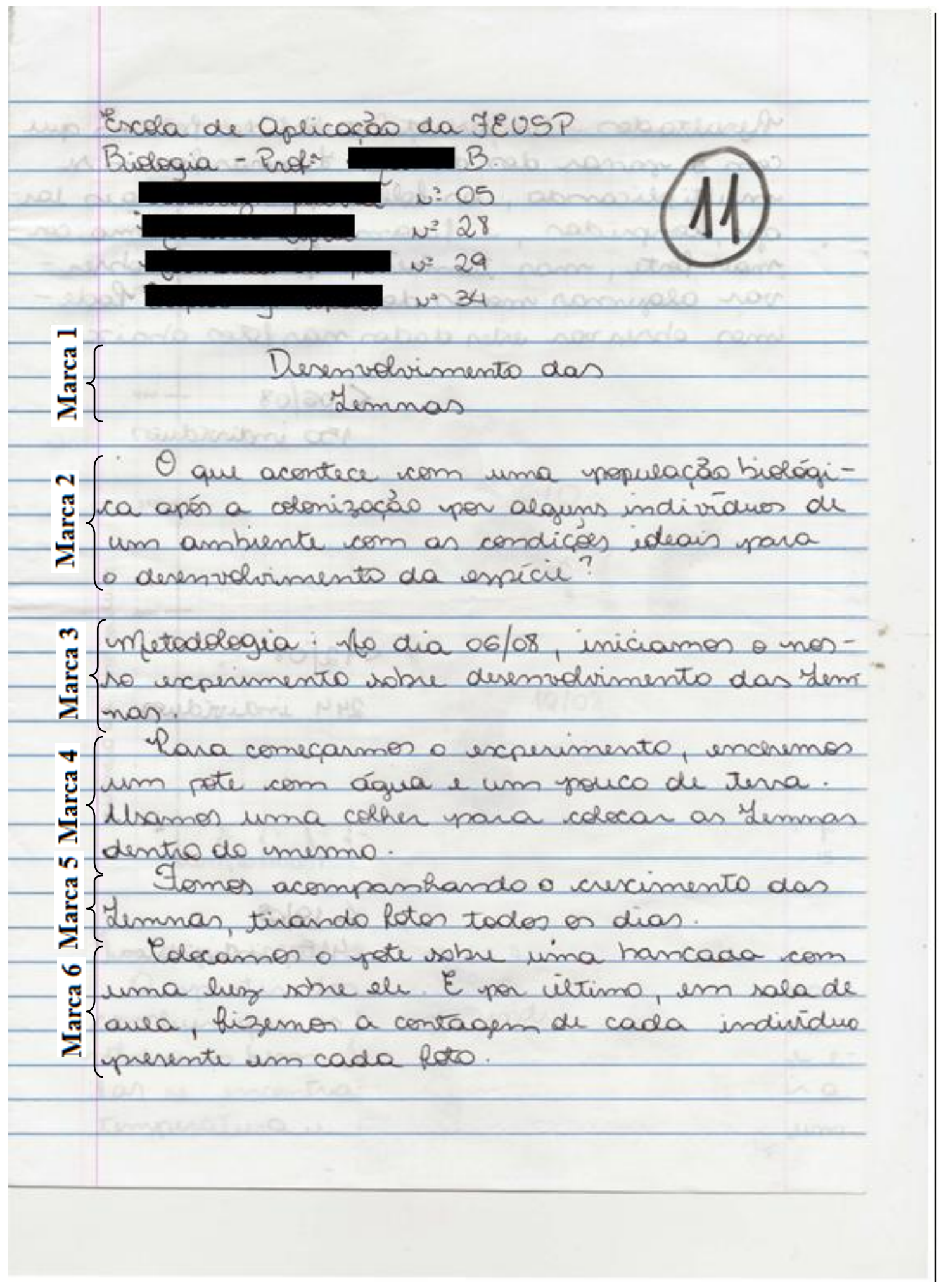


Thiago Marinho Del Corso

INDICADORES DE ALFABETIZAÇÃO CIENTÍFICA, ARGUMENTOS E EXPLICAÇÕES Análise de Relatórios no Contexto de uma Sequência de Ensino Investigativo

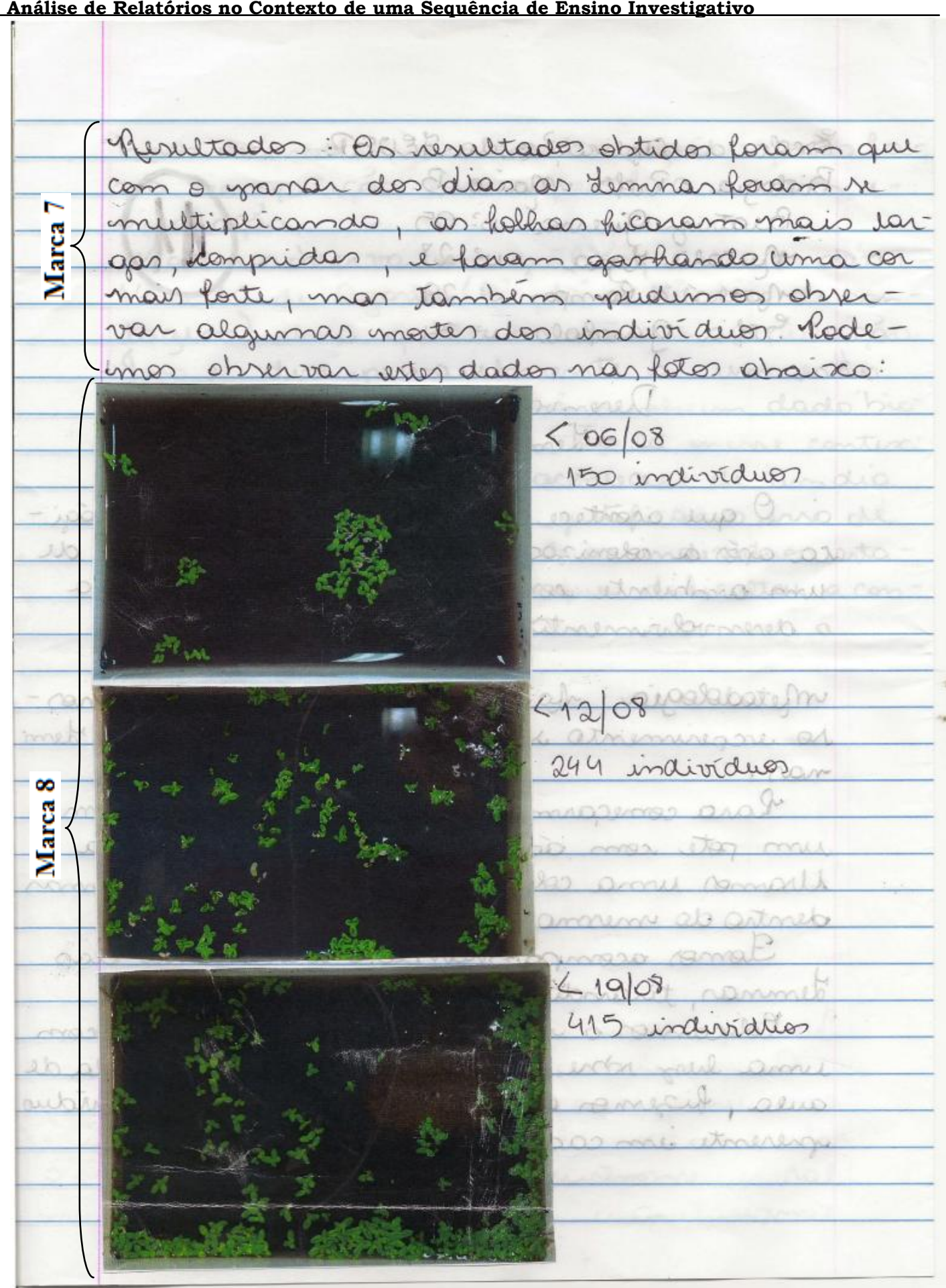




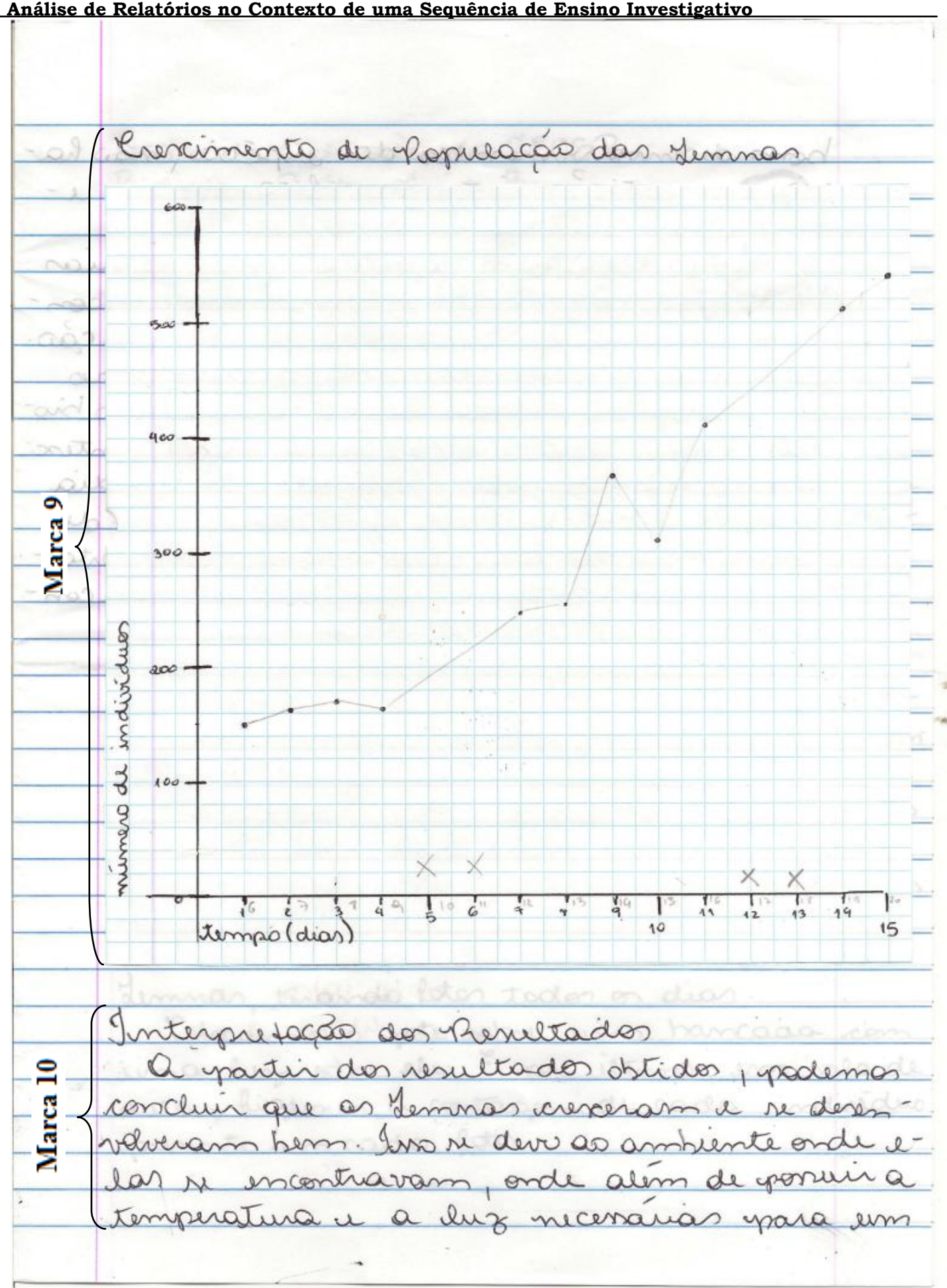


Thiago Marinho Del Corso

INDICADORES DE ALFABETIZAÇÃO CIENTÍFICA, ARGUMENTOS E EXPLICAÇÕES -

Análise de Relatórios no Contexto de uma Sequência de Ensino Investigativo

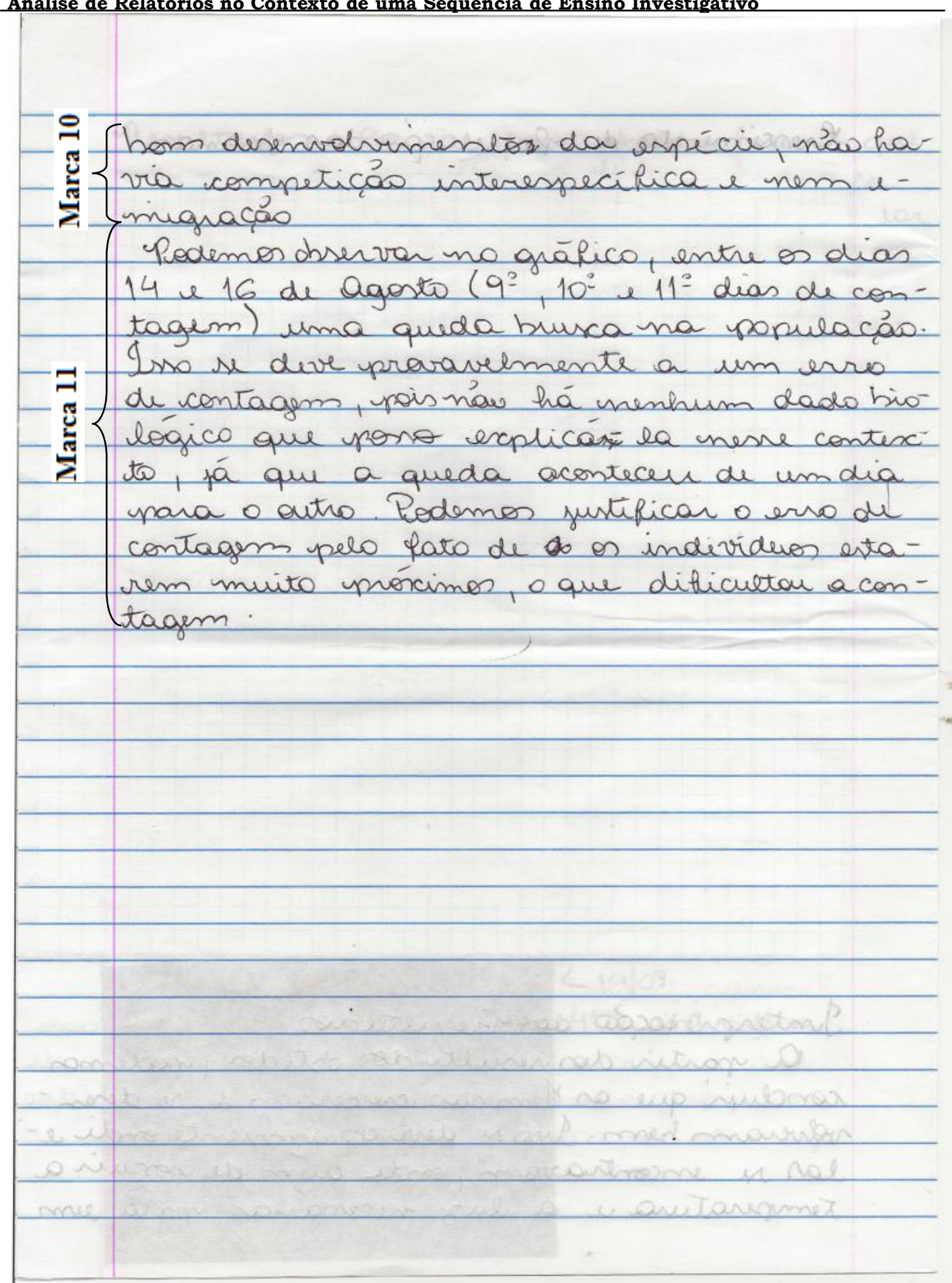


Thiago Marinho Del Corso

INDICADORES DE ALFABETIZAÇÃO CIENTÍFICA, ARGUMENTOS E EXPLICAÇÕES -

Análise de Relatórios no Contexto de uma Sequência de Ensino Investigativo

Quadro 11

Identificação dos Indicadores de Alfabetização Científica no Relatório 11 de 2013 e conclusões individuais correspondentes

\begin{tabular}{|c|c|c|c|c|c|c|c|c|c|c|c|c|c|}
\hline 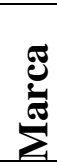 & $\begin{array}{l}\text { Subtítulo, } \\
\text { divisão ou } \\
\text { Item }\end{array}$ & Texto & $\mathbf{L M}$ & SI & OI & CI & \begin{tabular}{l|l} 
RL & RP
\end{tabular} & $\mathbf{L H}$ & TH & $\mathbf{J}$ & $\mathbf{P}$ & a & $\sum$ \\
\hline 1 & Titulo & "O desenvalvimenta das Lemnas" & & & & & & & & & & & \\
\hline 2 & Pergunta & $\begin{array}{l}\text { "O que acontece com uma papulasaa bialágica apás a } \\
\text { colonizaçãa par alguns individuas de um ambiente com as } \\
\text { condișaes ideais para a desenvolvimenta da espécie?" }\end{array}$ & \multicolumn{11}{|c|}{ Não avaliado, texto da professora. } \\
\hline 3 & $\begin{array}{l}\text { Metodologia } \\
\text { (metodologia) } \\
1^{\circ} \text { parágrafo }\end{array}$ & $\begin{array}{l}\text { "No dia 06/08, iniciamas a massa experimenta sabre } \\
\text { desenvalvimenta das Lemnas" }\end{array}$ & & & & & & & & & & & \\
\hline 4 & $\begin{array}{l}\text { Metodologia } \\
\text { (metodologia) } \\
2^{\circ} \text { parágrafo }\end{array}$ & $\begin{array}{l}\text { "Para comecarmas a experimenta, enchemas um pote com } \\
\text { água e um pouca de terra. Usamas uma colher para colocar as } \\
\text { Lemnas dentra da mesma." }\end{array}$ & $\mathrm{X}$ & & $\mathrm{X}$ & & & & & & & & \\
\hline 5 & $\begin{array}{l}\text { Metodologia } \\
\text { (metodologia) } \\
3^{\circ} \text { parágrafo }\end{array}$ & $\begin{array}{l}\text { "Fomas acompanhanda a crescimenta das Lemnas, tiranda } \\
\text { fatos todas as dias." }\end{array}$ & & & $\mathrm{X}$ & & & & & & & & \\
\hline 6 & $\begin{array}{l}\text { Metodologia } \\
\text { (metodologia) } \\
4^{\circ} \text { parágrafo }\end{array}$ & $\begin{array}{l}\text { "Calacamas a pate sabre uma bancada cam uma luz sabre } \\
\text { ele. E por última, em sala de aula, fizemas a contagem de cada } \\
\text { individua presente em cada fota." }\end{array}$ & $\mathrm{X}$ & & $\mathrm{X}$ & & & & & & & & \\
\hline 7 & $\begin{array}{l}\text { Resultados } \\
\text { (Resultados) }\end{array}$ & $\begin{array}{l}\text { "Os resultadas abtidas foram que com a passar dos dias as } \\
\text { Lemnas foram se multiplicando, as folthas ficaram mais largas, } \\
\text { compridas e foram ganhando uma cor mais forte, mas também pudemas } \\
\text { abservar algumas mortes de individuas. Podemos observar estes dados } \\
\text { mas fotas abaixa:" }\end{array}$ & & $\mathbf{X}$ & & & & & & & & & \\
\hline
\end{tabular}


Thiago Marinho Del Corso

INDICADORES DE ALFABETIZAC̄̃O CIENTÍFICA, ARGUMENTOS E EXPLICAÇÕES -

Análise de Relatórios no Contexto de uma Sequência de Ensino Investigativo

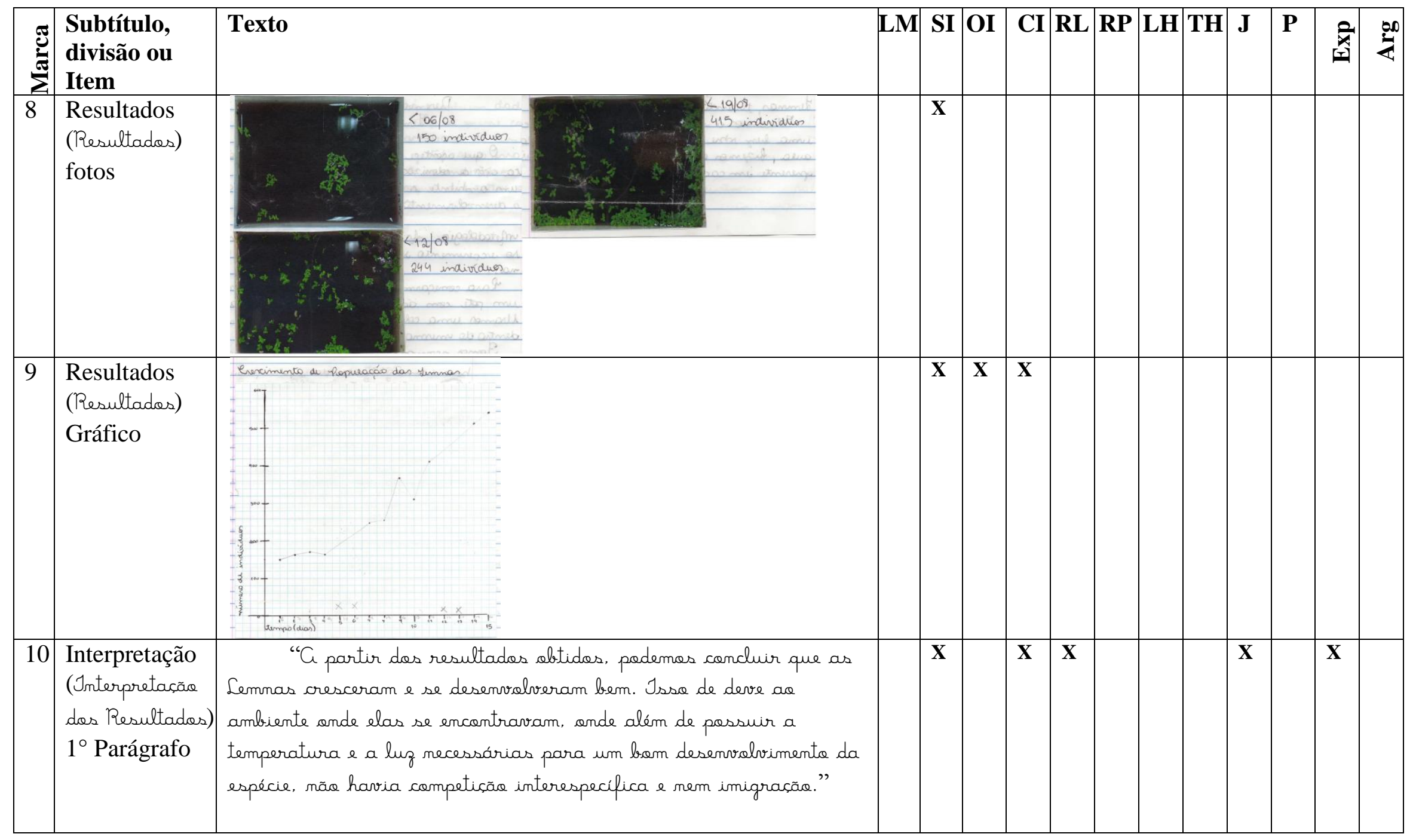


Thiago Marinho Del Corso

INDICADORES DE ALFABETIZAÇ̃̃O CIENTÍFICA, ARGUMENTOS E EXPLICAÇÕES -

Análise de Relatórios no Contexto de uma Sequência de Ensino Investigativo

\begin{tabular}{|c|c|c|c|c|c|c|c|c|c|c|c|c|c|c|}
\hline 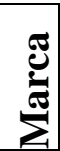 & $\begin{array}{l}\text { Subtítulo, } \\
\text { divisão ou } \\
\text { Item }\end{array}$ & Texto & $\mathbf{L M}$ & SI & OI & CI & RL & $\mathbf{R P}$ & $\mathbf{L H}$ & TH & $\mathbf{J}$ & $\mathbf{P}$ & $\frac{2}{x}$ & $\sum^{000}$ \\
\hline 11 & $\begin{array}{l}\text { Interpretação } \\
\text { (Jnterpretaçãa } \\
\text { dos Resultados) } \\
2^{\circ} \text { Parágrafo }\end{array}$ & 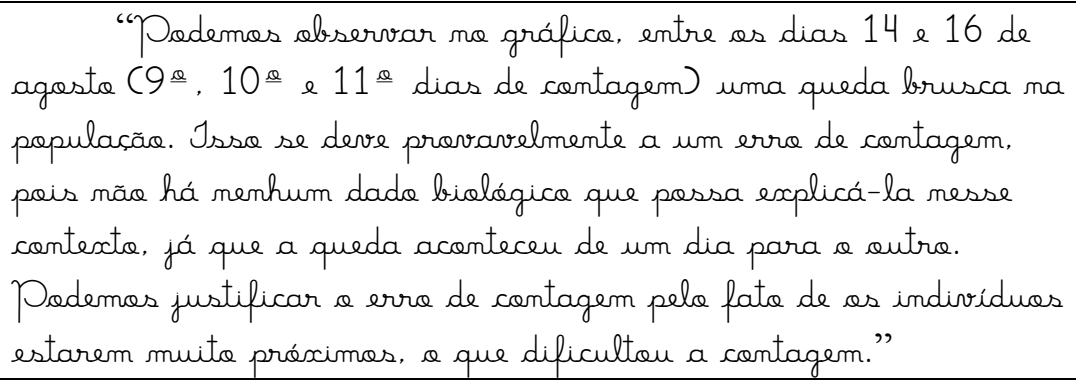 & & $\mathbf{X}$ & $\mathbf{X}$ & $\mathbf{X}$ & & & & & $\mathbf{X}$ & & & $\mathbf{X}$ \\
\hline 12 & $\begin{array}{l}\text { Conclusão } \\
\text { individual } 1\end{array}$ & 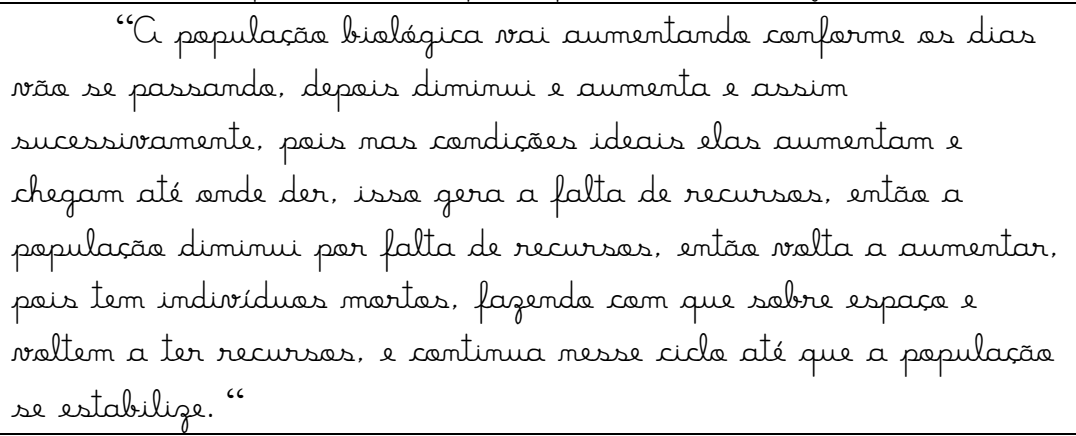 & & $\mathbf{X}$ & $\mathbf{X}$ & & $\mathbf{X}$ & & & & $\mathbf{X}$ & $\mathbf{X}$ & & $\mathbf{X}$ \\
\hline 13 & $\begin{array}{l}\text { Conclusão } \\
\text { individual } 2 \\
1^{\circ} \text { Parágrafo }\end{array}$ & 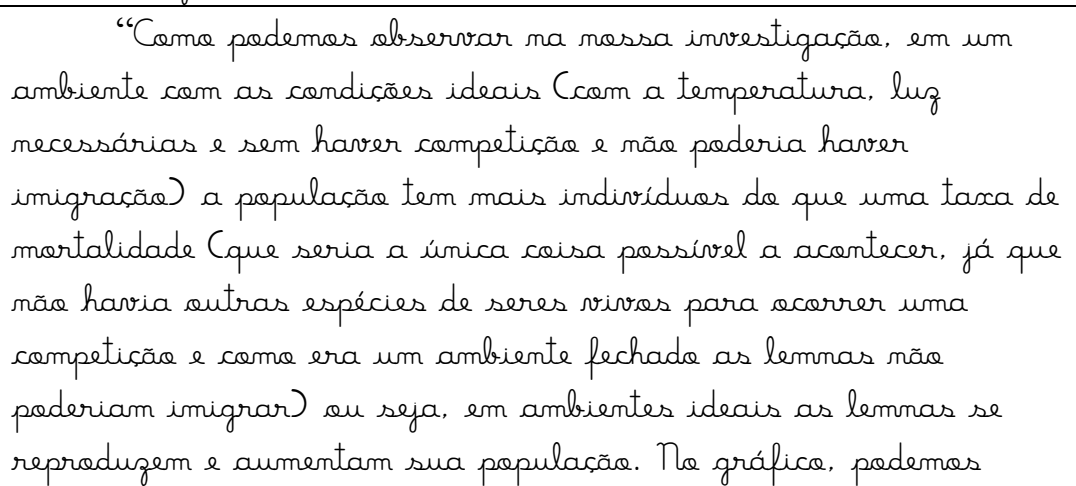 & & $\mathbf{X}$ & $\mathbf{X}$ & $\mathbf{X}$ & $\mathbf{X}$ & & & & $\mathbf{X}$ & $\mathbf{X}$ & & $\mathbf{X}$ \\
\hline
\end{tabular}


Thiago Marinho Del Corso

INDICADORES DE ALFABETIZAÇ̃̃o CIENTÍFICA, ARGUMENTOS E EXPLICAÇÕES -

Análise de Relatórios no Contexto de uma Sequência de Ensino Investigativo

\begin{tabular}{|c|c|c|c|c|c|c|c|c|c|c|c|c|c|c|}
\hline & & 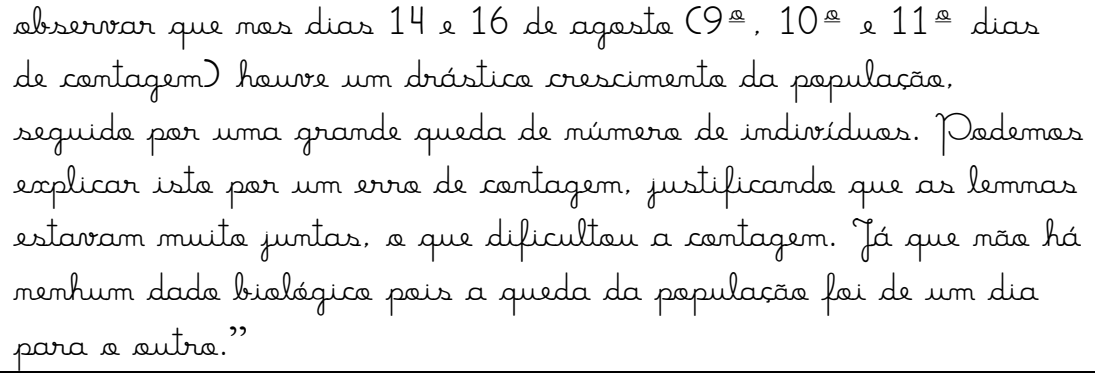 & & & & & & & & & & & & \\
\hline 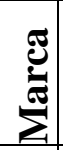 & $\begin{array}{l}\text { Subtítulo, } \\
\text { divisão ou } \\
\text { Item } \\
\end{array}$ & Texto & $\mathbf{L M}$ & SI & OI & CI & $\mathbf{R L}$ & $\mathbf{R P}$ & $\mathbf{L H}$ & TH & $\mathbf{J}$ & $\mathbf{P}$ & 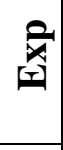 & $\sum_{4}^{\infty}$ \\
\hline 14 & $\begin{array}{l}\text { Conclusão } \\
\text { individual } 2 \\
2^{\circ} \text { Parágrafo }\end{array}$ & $\begin{array}{l}\text { "Conduimas entãa, que em uma papulaçãa bialágica após a } \\
\text { colonizaçãa por alguns individuos de um ambiente com as } \\
\text { condiçäes ideais para a desenvolvimenta da espécie, há a } \\
\text { crescimenta ideal, atinginda a que seria a capacidade de carga, } \\
\text { com um crescimenta gradual." }\end{array}$ & & & & & & & & & $\mathbf{X}$ & $\mathbf{X}$ & & $\mathbf{X}$ \\
\hline 15 & $\begin{array}{l}\text { Conclusão } \\
\text { individual } 3\end{array}$ & 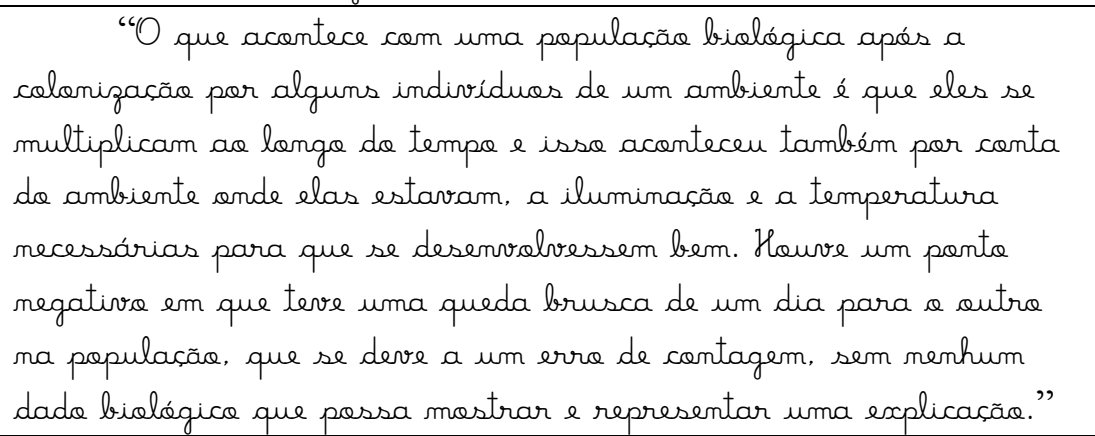 & & & & & & & & & $\mathbf{X}$ & $\mathbf{X}$ & & $\mathbf{X}$ \\
\hline
\end{tabular}


Thiago Marinho Del Corso

INDICADORES DE ALFABETIZAÇÃO CIENTÍFICA, ARGUMENTOS E EXPLICAÇÕES -

Análise de Relatórios no Contexto de uma Sequência de Ensino Investigativo

\section{Relatório 12 - 2013}

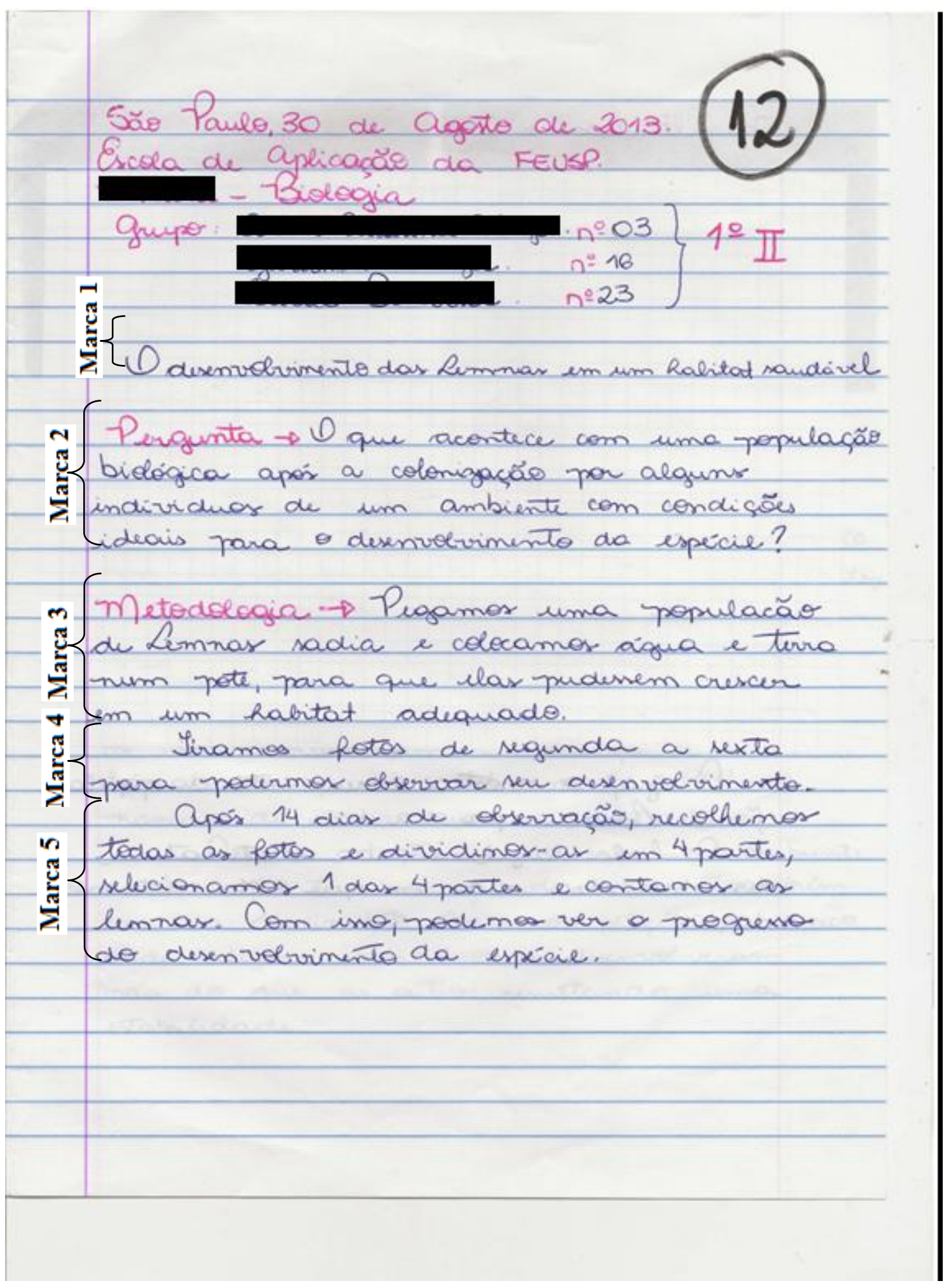


Thiago Marinho Del Corso

INDICADORES DE ALFABETIZAÇÃO CIENTÍFICA, ARGUMENTOS E EXPLICAÇÕES -

Análise de Relatórios no Contexto de uma Sequência de Ensino Investigativo

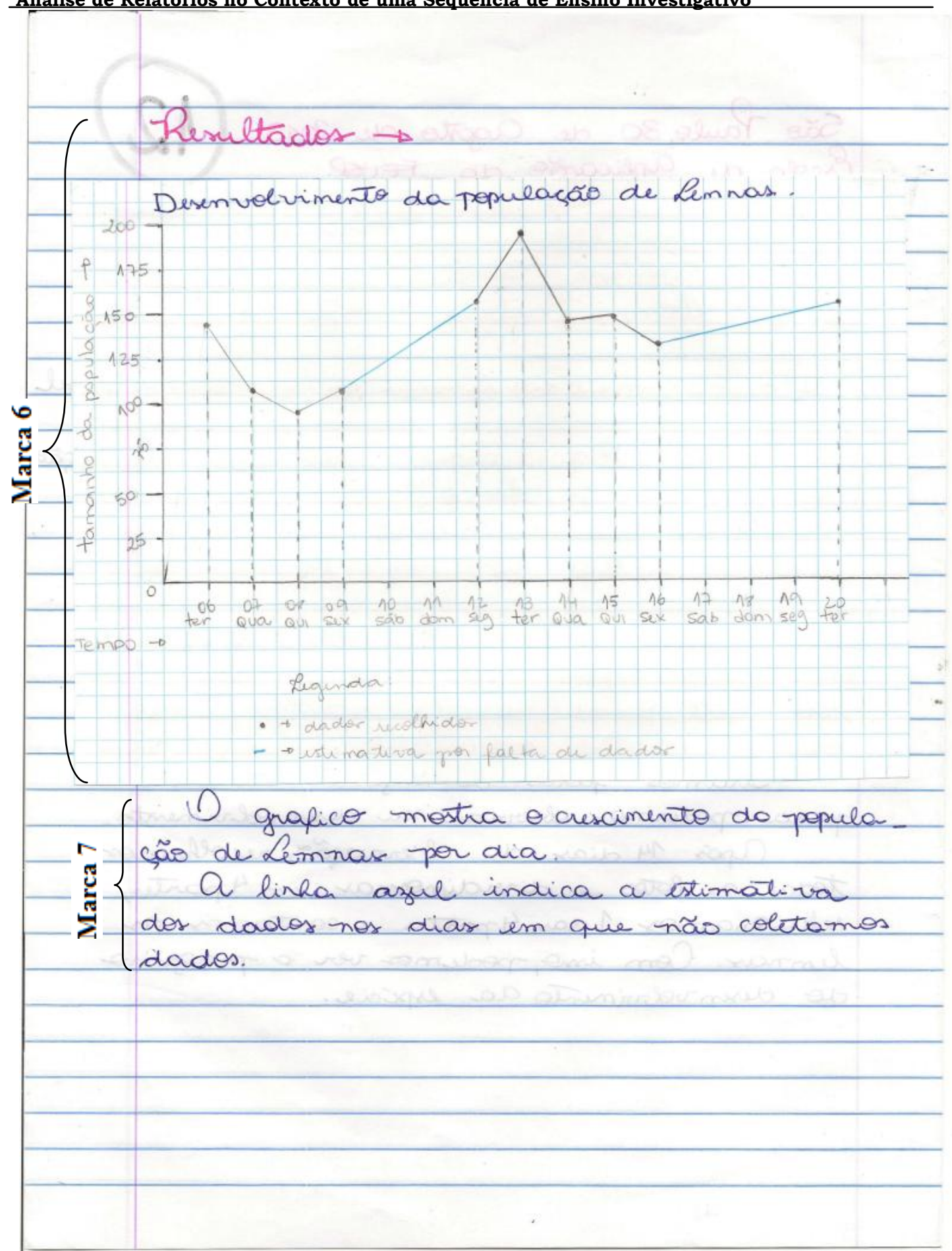


Thiago Marinho Del Corso

INDICADORES DE ALFABETIZAÇÃO CIENTÍFICA, ARGUMENTOS E EXPLICAÇÕES -

Análise de Relatórios no Contexto de uma Sequência de Ensino Investigativo

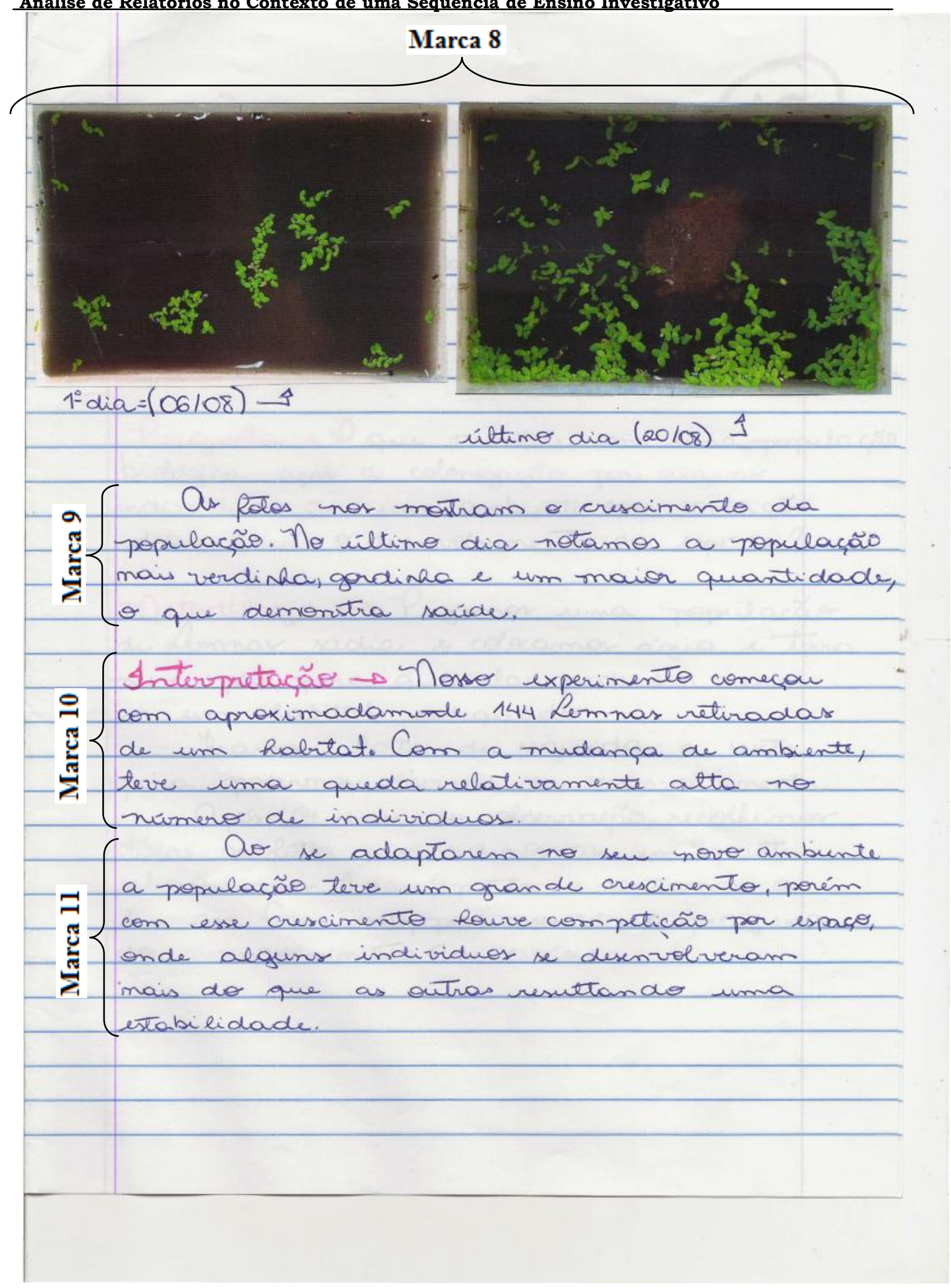


Thiago Marinho Del Corso

INDICADORES DE ALFABETIZAÇ̃̃O CIENTÍFICA, ARGUMENTOS E EXPLICAÇÕES -

Análise de Relatórios no Contexto de uma Sequência de Ensino Investigativo

\section{Quadro 12}

Identificação dos Indicadores de Alfabetização Científica no Relatório 12 de 2013 e conclusões individuais correspondentes

\begin{tabular}{|c|c|c|c|c|c|c|c|c|c|c|c|c|c|c|}
\hline 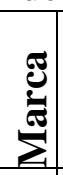 & $\begin{array}{l}\text { Subtítulo, } \\
\text { divisão ou } \\
\text { Item }\end{array}$ & 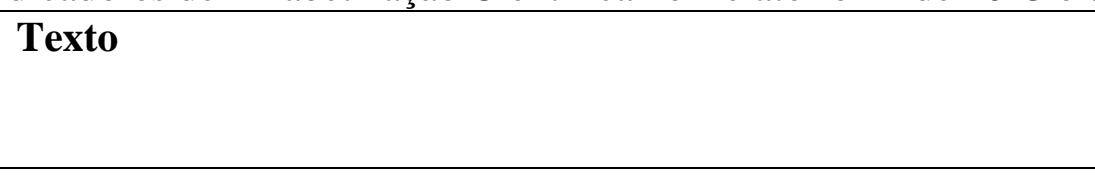 & $\mathbf{L M}$ & SI & $\mathbf{O I}$ & CI & $\mathbf{R L}$ & $\mathbf{R P}$ & $\mathbf{L H}$ & $\mathbf{T H}$ & $\mathbf{J}$ & $\mathbf{P}$ & : & $\sum_{4}^{\infty}$ \\
\hline 1 & Titulo & "O desenvalvimenta das Lemnas em um habitat saudável" & & & & & & & & & & & & \\
\hline 2 & Pergunta & $\begin{array}{l}\text { "O que acontece com uma papulaçãa bialógica após a } \\
\text { colonizaçãa por alguns individuas de um ambiente com as } \\
\text { condicães ideais para desenvolvimenta da espécie?" }\end{array}$ & Nãc & $\mathrm{av}$ & aliad & $\mathrm{o}, \mathrm{te}$ & exto & da pr & rofes & ssora. & & & & \\
\hline 3 & $\begin{array}{l}\text { Metodologia } \\
\text { (metodologia) } \\
1^{\circ} \text { Parágrafo }\end{array}$ & $\begin{array}{l}\text { "Pegamas uma populaçãa de Lemnas sadia e colocamas água } \\
\text { e terra num pote, para que elas pudessem crescer em um habitat } \\
\text { adequada." }\end{array}$ & $\mathbf{X}$ & & $\mathbf{X}$ & & & & & & & & & \\
\hline 4 & $\begin{array}{l}\text { Metodologia } \\
\text { (metodologia) } \\
2^{\circ} \text { Parágrafo }\end{array}$ & $\begin{array}{l}\text { "Tiramos fotas de segunda a sexta para podermas observar } \\
\text { seu desenvolvimenta." }\end{array}$ & & & $\mathbf{X}$ & & & & & & & & & \\
\hline 5 & $\begin{array}{l}\text { Metodologia } \\
\text { (metodologia) } \\
3^{\circ} \text { Parágrafo }\end{array}$ & $\begin{array}{l}\text { "Cupés } 14 \text { dias de observaçãa, recalhemas todas as fotas e } \\
\text { dividima-las em quatro partes, selecionamas } 1 \text { das partes e } \\
\text { contamos as Lemnas. Com issa, podemas ver a progressa da } \\
\text { desenvolvimenta da espécie." }\end{array}$ & $\mathbf{X}$ & & $\mathbf{X}$ & & & & & & & & & \\
\hline 6 & $\begin{array}{l}\text { Resultados } \\
\text { (Resultados) } \\
\text { Gráfico }\end{array}$ & 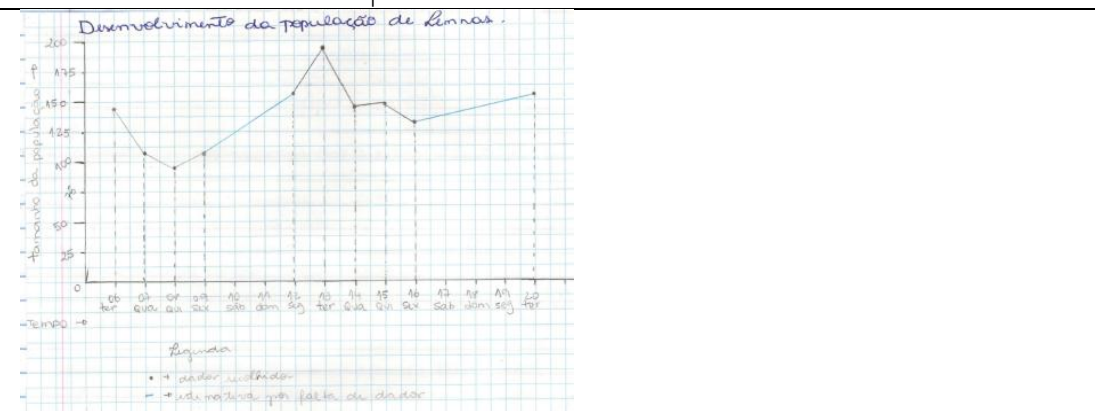 & & $\mathbf{X}$ & $\mathbf{X}$ & $\mathbf{X}$ & & & & & & & & \\
\hline
\end{tabular}


Thiago Marinho Del Corso

INDICADORES DE ALFABETIZAÇ̃̃o CIENTÍFICA, ARGUMENTOS E EXPLICAÇÕES -

Análise de Relatórios no Contexto de uma Sequência de Ensino Investigativo

\begin{tabular}{|c|c|c|c|c|c|c|c|c|c|c|c|c|c|c|}
\hline$\sum^{\mathbb{J}}$ & $\begin{array}{l}\text { Subtítulo, } \\
\text { divisão ou } \\
\text { Item }\end{array}$ & Texto & $\mathbf{L M}$ & SI & OI & CI & RL & $\mathbf{R P}$ & $\mathbf{L H}$ & TH & $\mathbf{J}$ & $\mathbf{P}$ & 武 & $\sum_{4}^{0.0}$ \\
\hline 7 & $\begin{array}{l}\text { Resultados } \\
\text { (Resultados) } \\
\text { texto após } \\
\text { gráfico }\end{array}$ & $\begin{array}{l}\text { "O gráfica mastra a crescimenta populacional de Lemnas por } \\
\text { dia. linha azul indica a estimativa dos dadas nos dias em que } \\
\text { nãa coletamas dados." }\end{array}$ & & & & $\mathbf{X}$ & & & & & & & & \\
\hline 8 & $\begin{array}{l}\text { Resultados } \\
\text { (Resultados) } \\
\text { Fotos }\end{array}$ & in & & & & & & & & & & & & \\
\hline 9 & $\begin{array}{l}\text { Resultados } \\
\text { (Resultados) } \\
\text { texto após } \\
\text { fotos }\end{array}$ & 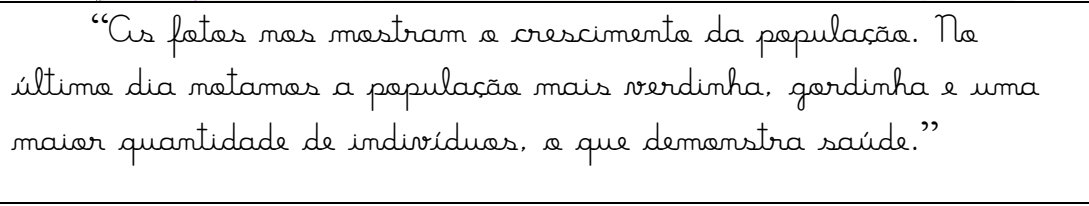 & & $\mathbf{X}$ & & $\mathbf{X}$ & & & & & & & & \\
\hline 10 & $\begin{array}{l}\text { Interpretação } \\
\text { (Interpretaçãa) } \\
1^{\circ} \text { Parágrafo }\end{array}$ & $\begin{array}{l}\text { "Massa experimenta comesceu com aproximadamente } 144 \\
\text { Lemnas retiradas de um habitat. Com a mudansca de ambiente, teve } \\
\text { uma queda relativamente alta no número de individuos." }\end{array}$ & & $\mathbf{X}$ & & $\mathbf{X}$ & & & & & $\mathbf{X}$ & & & \\
\hline 11 & $\begin{array}{l}\text { Interpretação } \\
\text { (Interpretaçãa) } \\
2^{\circ} \text { Parágrafo }\end{array}$ & 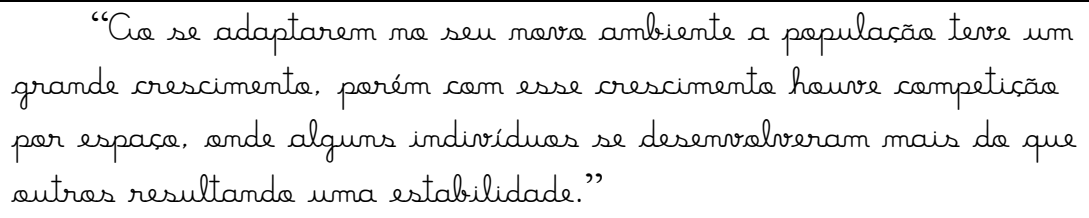 & & $\mathbf{X}$ & & $\mathbf{X}$ & & & & & $\mathbf{X}$ & & $\mathbf{X}$ & \\
\hline 12 & $\begin{array}{l}\text { Conclusão } \\
\text { individual } 1 \\
1^{\circ} \text { parágrafo }\end{array}$ & $\begin{array}{l}\text { "Uma papulaçãa bialógica pode diminuir au aumentar. To } \\
\text { casa do meu grupo, as Lemnas tiveram um comecse relativamente }\end{array}$ & & $\mathbf{X}$ & $\mathbf{X}$ & $\mathbf{X}$ & & & & & $\mathbf{X}$ & & & \\
\hline
\end{tabular}


Thiago Marinho Del Corso

INDICADORES DE ALFABETIZAÇ̃̃O CIENTÍFICA, ARGUMENTOS E EXPLICAÇÕES -

Análise de Relatórios no Contexto de uma Sequência de Ensino Investigativo

\begin{tabular}{|c|c|c|c|c|c|c|c|c|c|c|c|c|c|c|}
\hline & & $\begin{array}{l}\text { alta, loga depais da mudança de ambiente teve uma queda, em } \\
\text { seguida aumento, depois houve uma outra queda e depois dissa } \\
\text { houve uma estabilidade." }\end{array}$ & & & & & & & & & & & & \\
\hline 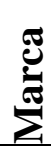 & $\begin{array}{l}\text { Subtítulo, } \\
\text { divisão ou } \\
\text { Item }\end{array}$ & Texto & $\mathbf{L M}$ & SI & OI & CI & $\mathbf{R L}$ & $\mathbf{R P}$ & $\mathbf{L H}$ & TH & $\mathbf{J}$ & $\mathbf{P}$ & $\underset{x}{a}$ & 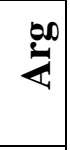 \\
\hline 13 & $\begin{array}{l}\text { Conclusão } \\
\text { individual } 1 \\
2^{\circ} \text { parágrafo }\end{array}$ & $\begin{array}{l}\text { "Com issa, conseguimas perceber que a que acontece com uma } \\
\text { populaçãa bialágica após a colonizaçãa de um ambiente com } \\
\text { condiç̃oes ideais para a desenvalvimenta da espécie é uma } \\
\text { competiçãa, eles disputam nutrientes, e entãa alguns conseguem } \\
\text { mais nutrientes e sabrevivem, as que nãa conseguem morrem." }\end{array}$ & & & & & & & $\mathbf{X}$ & & $\mathbf{X}$ & $\mathbf{X}$ & & $\mathbf{X}$ \\
\hline 14 & $\begin{array}{l}\text { Conclusão } \\
\text { individual } 2\end{array}$ & 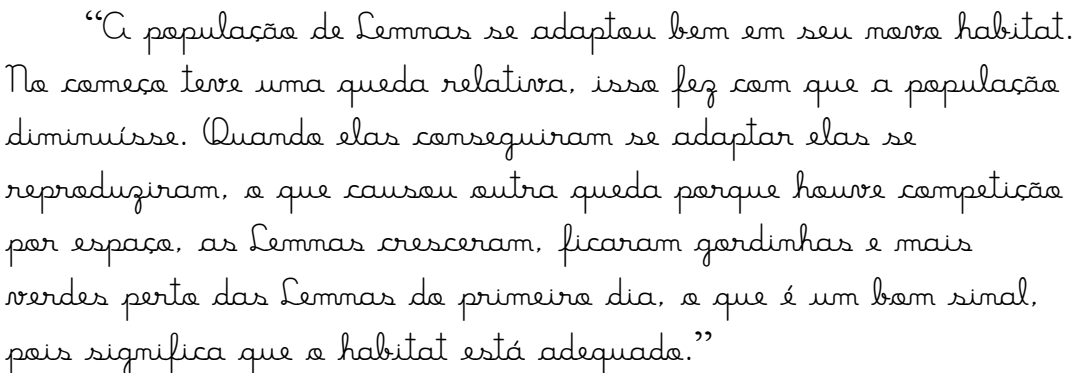 & & $\mathbf{X}$ & $\mathbf{X}$ & $\mathbf{X}$ & & & & & $\mathbf{X}$ & & & \\
\hline 15 & $\begin{array}{l}\text { Conclusão } \\
\text { individual } 3 \\
1^{\circ} \text { parágrafo }\end{array}$ & $\begin{array}{l}\text { "O que acontece com uma papulaçãa, no casa, as Lemnas, } \\
\text { após a calonizaçãa par alguns indivíduas em um ambiente ideal } \\
\text { para a desenvalvimenta da espécie é: A papulaçãa se estabiliza em } \\
\text { um ambiente saudável, onde tados as seres podem viver." }\end{array}$ & & & & & & & & & $\mathbf{X}$ & $\mathbf{X}$ & & $\mathbf{X}$ \\
\hline 16 & $\begin{array}{l}\text { Conclusão } \\
\text { individual } 3 \\
2^{\circ} \text { parágrafo }\end{array}$ & 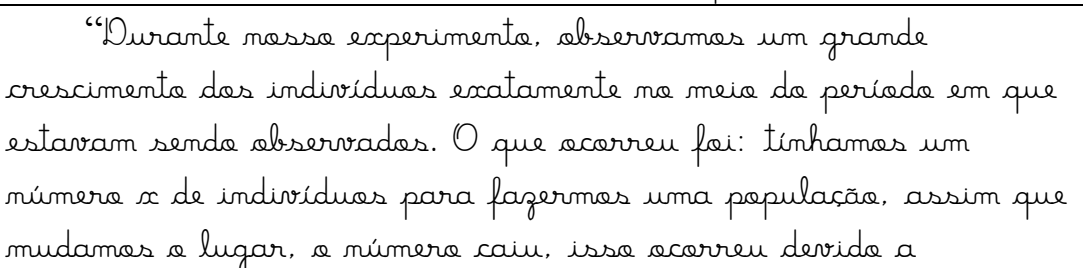 & & $\mathbf{X}$ & $\mathbf{X}$ & $\mathbf{X}$ & & & & & $\mathbf{X}$ & & $\mathbf{X}$ & \\
\hline
\end{tabular}


Thiago Marinho Del Corso

INDICADORES DE ALFABETIZAÇÃO CIENTÍFICA, ARGUMENTOS E EXPLICAÇÕES -

Análise de Relatórios no Contexto de uma Sequência de Ensino Investigativo

\begin{tabular}{|c|c|c|c|c|c|c|c|c|c|c|c|c|c|c|}
\hline & & 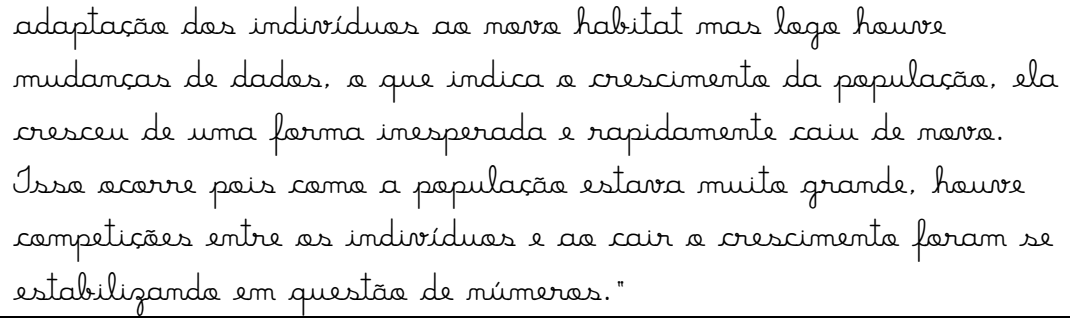 & & & & & & & & & & & & \\
\hline 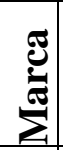 & $\begin{array}{l}\text { Subtítulo, } \\
\text { divisão ou } \\
\text { Item }\end{array}$ & Texto & $\mathbf{L M}$ & SI & OI & CI & $\mathbf{R L}$ & $\mathbf{R P}$ & $\mathbf{L H}$ & $\mathbf{T H}$ & $\mathbf{J}$ & $\mathbf{P}$ & 気 & $\sum^{00}$ \\
\hline 17 & $\begin{array}{l}\text { Conclusão } \\
\text { individual } 3 \\
3^{\circ} \text { parágrafo }\end{array}$ & $\begin{array}{l}\text { "No final do experimenta tinhamas uma grande populaçãa de } \\
\text { Lemnas fortes e saudáveis em um habitat natural e igualmente } \\
\text { saudável." }\end{array}$ & & $X$ & & $\mathbf{X}$ & & & & & & & & \\
\hline
\end{tabular}


Thiago Marinho Del Corso

INDICADORES DE ALFABETIZAÇÃO CIENTÍFICA, ARGUMENTOS E EXPLICAÇÕES -

Análise de Relatórios no Contexto de uma Sequência de Ensino Investigativo

\section{Relatório 13 - 2013}

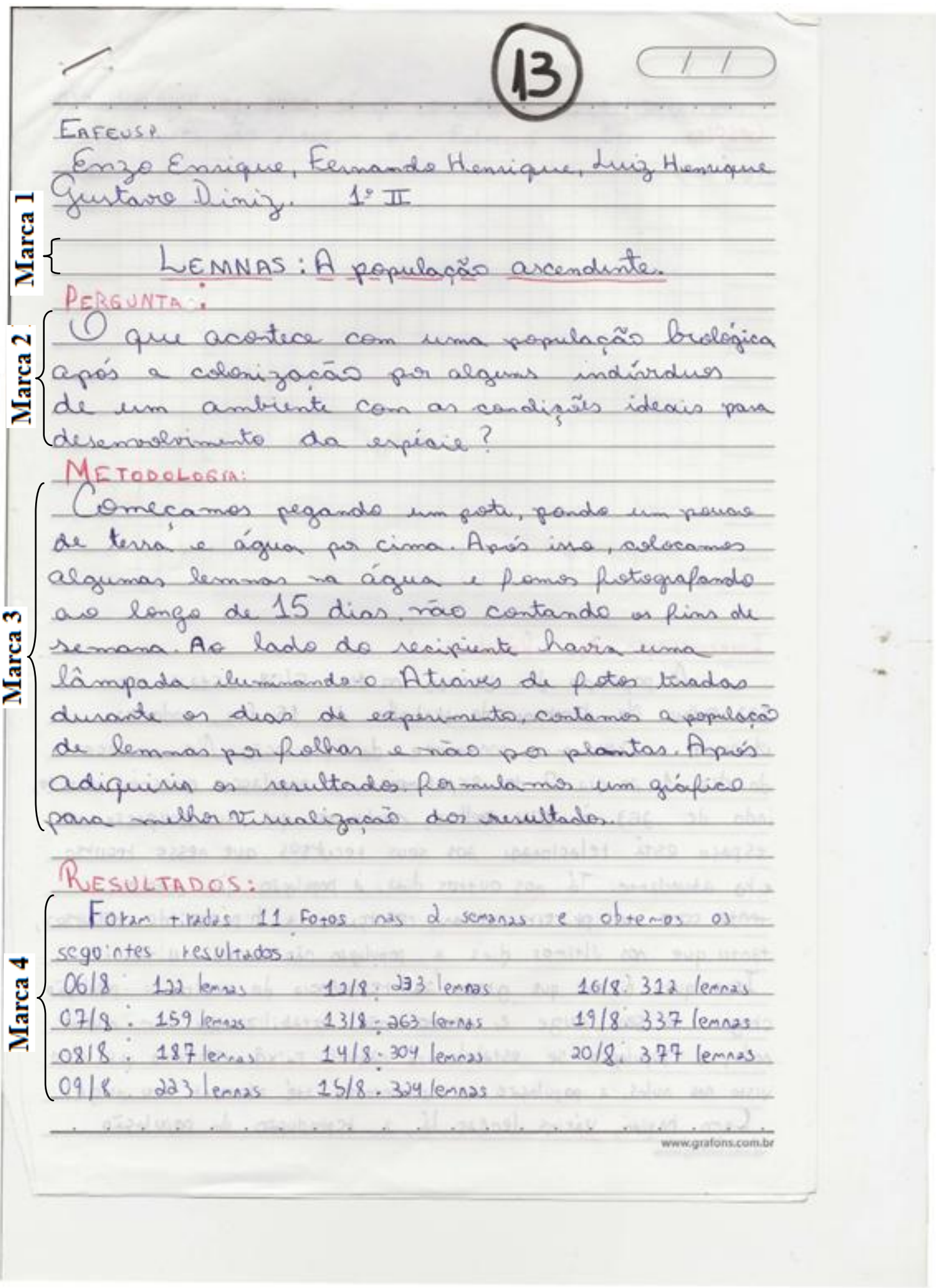


Thiago Marinho Del Corso

INDICADORES DE ALFABETIZAÇÃO CIENTÍFICA, ARGUMENTOS E EXPLICAÇÕES -

Análise de Relatórios no Contexto de uma Sequência de Ensino Investigativo

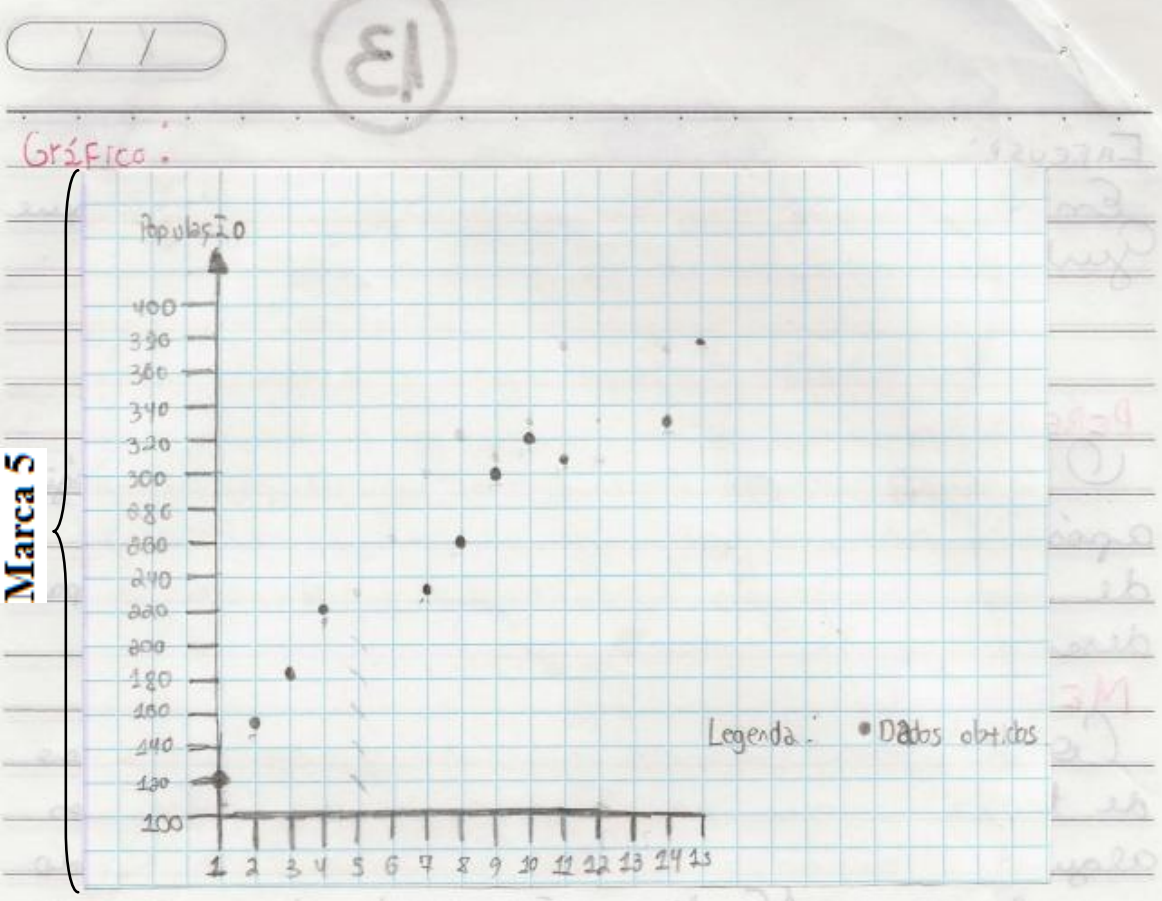

Interpletacáo dos Resulaidos

A populacáo de Lemnas no dia $6 / 08$ estava com
122 folhas. No decorter do trabatho de 15 dias, poderas

observar o crescimento constante da populayão. No começo

do dia 1200127 do experimento, a populacaso cresceu muito,

indo de 2632304 follhas, rostrando que sua ocupaça no

espaco está relacionadz as seus recultsos, que nesse caso

e ra abundante. Tá nos outras dias, a populacazo, cresceu

zanto cono na primerira semana, reforcando a hipótes de recursas,

tanto que nos viltimes fias a populagio vaprou mito.

N Isso quer dizer que gracas a resistênciz do meio, a ponulaqaio

J chegou 20 sev avge $e_{1}$ mesno nâ estabilizando sem mudat

nada, a populasão se estabelecerá naquela faixa, rostiondo que, coro

$\infty$ Visto nas sulas, a populasăo vai aurentardo até alcancat seu auge.

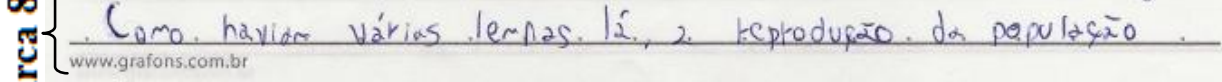


Thiago Marinho Del Corso

INDICADORES DE ALFABETIZAÇÃO CIENTÍFICA, ARGUMENTOS E EXPLICAÇÕES -

Análise de Relatórios no Contexto de uma Sequência de Ensino Investigativo

$\int$ nzo diminuiv or passo, Jj que o espaco e, apdentemento,

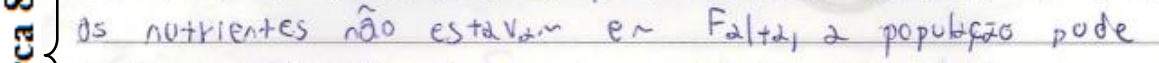

continuat crescendo já que 23 condiceses sjo propíctas para 0

$\sum$ ainda crascinento da populagão.

$$
\text { (20) }
$$

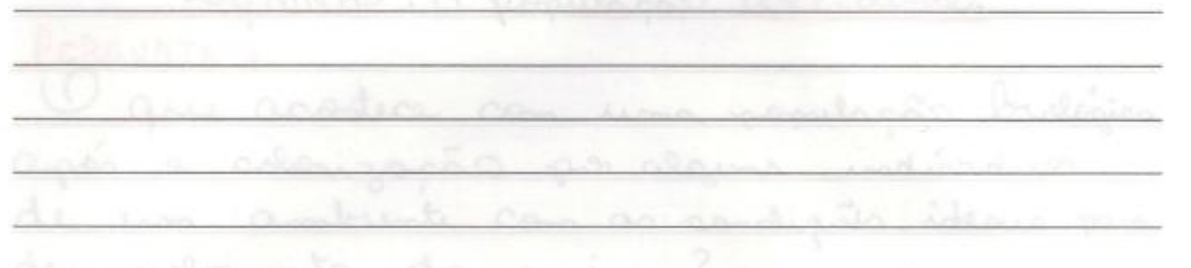


Thiago Marinho Del Corso

INDICADORES DE ALFABETIZAÇÃO CIENTÍFICA, ARGUMENTOS E EXPLICAÇÕES -

Análise de Relatórios no Contexto de uma Sequência de Ensino Investigativo

Quadro 13

Identificação dos Indicadores de Alfabetização Científica no Relatório 13 de 2013 e conclusões individuais correspondentes

\begin{tabular}{|c|c|c|c|c|c|c|c|c|c|c|c|c|c|c|}
\hline 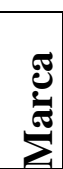 & $\begin{array}{l}\text { Subtítulo, } \\
\text { divisão ou } \\
\text { Item }\end{array}$ & Texto & $\mathbf{L M}$ & SI & $\mathbf{O I}$ & $\mathbf{C I}$ & $\mathbf{R L}$ & $\mathbf{R P}$ & $\mathbf{L H}$ & TH & $\mathbf{J}$ & $\mathbf{P}$ & & $\sum^{\infty}$ \\
\hline 1 & Titulo & "Lemnas: A populașãa ascendente." & & & & & & & & & & & & \\
\hline 2 & $\begin{array}{l}\text { Pergunta } \\
\text { ( Pergunta) }\end{array}$ & $\begin{array}{l}\text { "O que acontece com uma papulaçãa bialágica apás a colonizaçãa } \\
\text { par alguns individuas de um ambiente com as condicãés ideais } \\
\text { para a desenvalvimenta da espécie?" }\end{array}$ & \multicolumn{12}{|c|}{ Não avaliado, texto da professora. } \\
\hline 3 & $\begin{array}{l}\text { Metodologia } \\
\text { (metadologia) }\end{array}$ & 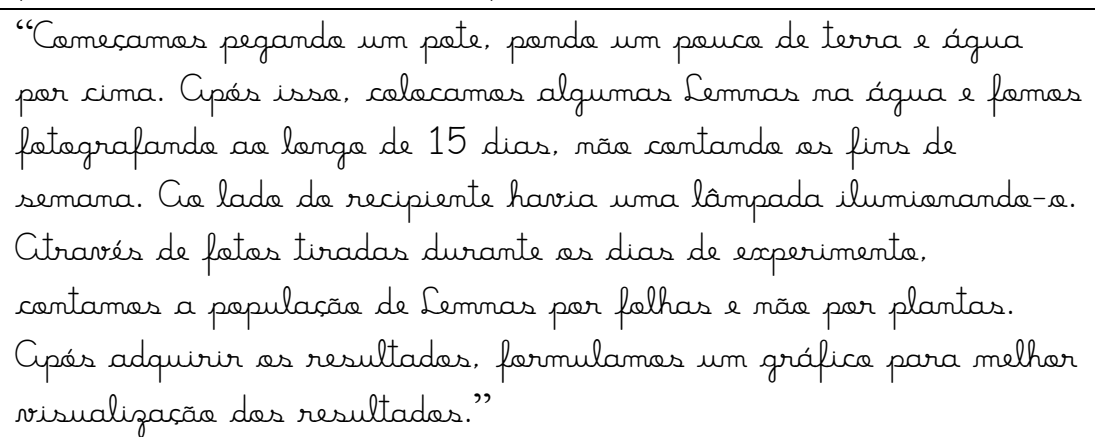 & $\mathbf{X}$ & & $\mathbf{X}$ & & & & & & & & & \\
\hline 4 & $\begin{array}{l}\text { Resultados } \\
\text { (Resultados) } \\
\text { tabela }\end{array}$ & $\begin{array}{l}\text { "Foram tiradas } 11 \text { fotas nas } 2 \text { semanas e abtivemas as seguintes } \\
\text { resultados:" } \\
\begin{array}{lll}06 / 8: 122 \text { lemnas } & 12 / 8: 233 \text { lemnas } & 16 / 8: 312 \text { lemnas } \\
07 / 8: 159 \text { lemnas } & 13 / 8: 263 \text { lemns } & 19 / 8: 337 \text { lemnas } \\
0818: 187 \text { lemnas } & 14 / 8: 304 \text { lemnas } & 20 / 8: 377 \text { lemnas } \\
09 / 8: 223 \text { lemnas } & 15 / 8: 324 \text { lemnas }\end{array}\end{array}$ & & $\mathbf{X}$ & $\mathbf{X}$ & & & & & & & & & \\
\hline
\end{tabular}


Thiago Marinho Del Corso

INDICADORES DE ALFABETIZAÇÃO CIENTÍFICA, ARGUMENTOS E EXPLICAÇÕES -

Análise de Relatórios no Contexto de uma Sequência de Ensino Investigativo

\begin{tabular}{|c|c|c|c|c|c|c|c|c|c|c|c|c|c|c|}
\hline 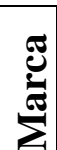 & $\begin{array}{l}\text { Subtítulo, } \\
\text { divisão ou } \\
\text { Item }\end{array}$ & Texto & $\mathbf{L M}$ & SI & OI & CI & RI & $\mathbf{R P}$ & $\mathbf{L H}$ & TH & $J$ & $\mathbf{P}$ & $\stackrel{x}{x}$ & $\sum_{4}^{00}$ \\
\hline 5 & $\begin{array}{l}\text { Resultados } \\
\text { (Resultados) } \\
\text { gráfico }\end{array}$ & 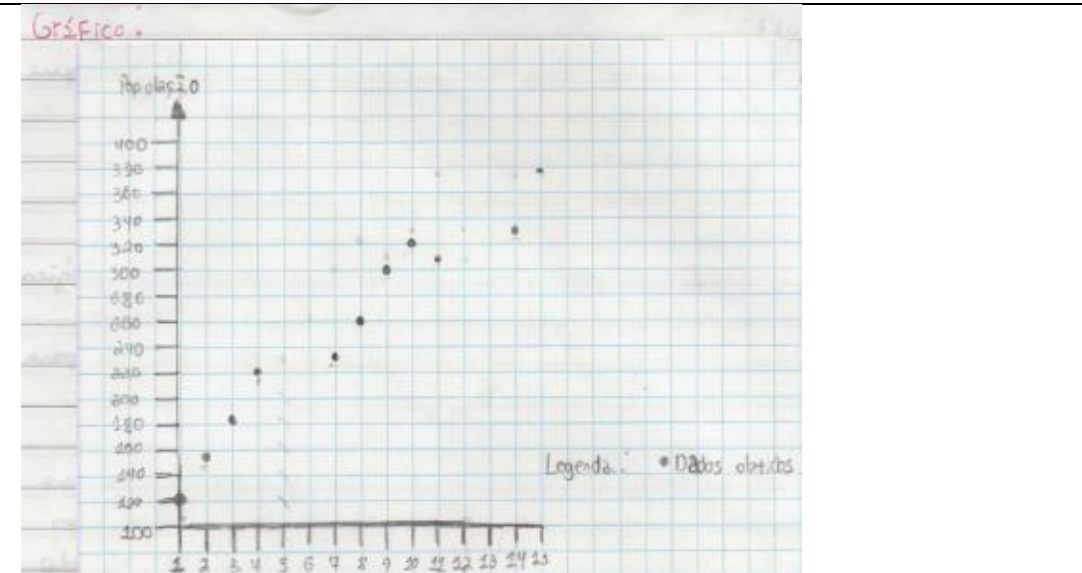 & & $\mathbf{X}$ & $\mathbf{X}$ & $\mathbf{X}$ & & & & & & & & \\
\hline 6 & $\begin{array}{l}\text { Interpretação } \\
\text { (Interpretaçãa) } \\
1^{\circ} \text { parágrafo }\end{array}$ & 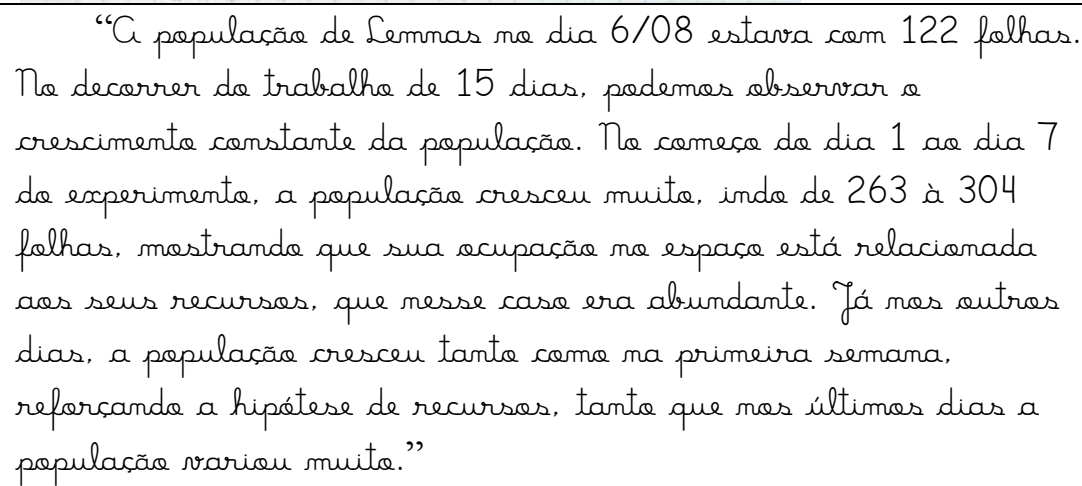 & & $\mathbf{X}$ & $\mathbf{X}$ & $\mathbf{X}$ & & & $\mathbf{X}$ & $\mathbf{X}$ & $I$ & & $\mathbf{X}$ & \\
\hline 7 & $\begin{array}{l}\text { Interpretação } \\
\text { (Jnterpretaçãa) } \\
2^{\circ} \text { parágrafo }\end{array}$ & 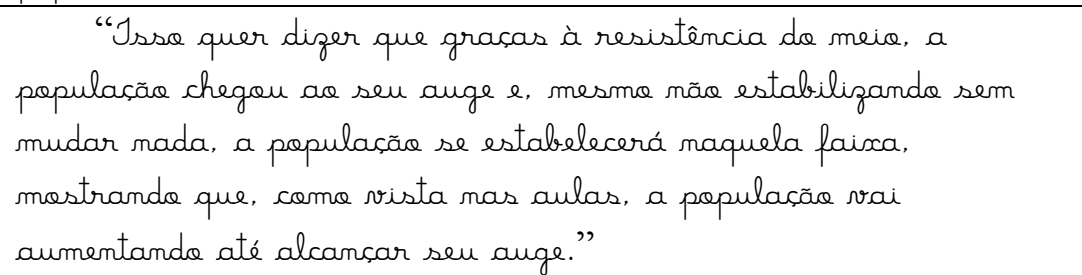 & & & & & & & & & $Y$ & $\mathbf{X}$ & & \\
\hline
\end{tabular}


Thiago Marinho Del Corso

INDICADORES DE ALFABETIZAÇÃO CIENTÍFICA, ARGUMENTOS E EXPLICAÇÕES -

Análise de Relatórios no Contexto de uma Sequência de Ensino Investigativo

\begin{tabular}{|c|c|c|c|c|c|c|c|c|c|c|c|c|c|c|}
\hline 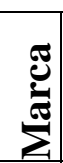 & $\begin{array}{l}\text { Subtítulo, } \\
\text { divisão ou } \\
\text { Item }\end{array}$ & Texto & $\mathbf{L M}$ & SI & OI & CI & RL & RP & $\mathbf{L H}$ & TH & $\mathbf{J}$ & $\mathbf{P}$ & 엇 & $\underset{\psi}{+\infty}$ \\
\hline 8 & $\begin{array}{l}\text { Interpretação } \\
\text { (Jnterpretaçãa) } \\
3^{\circ} \text { parágrafo }\end{array}$ & 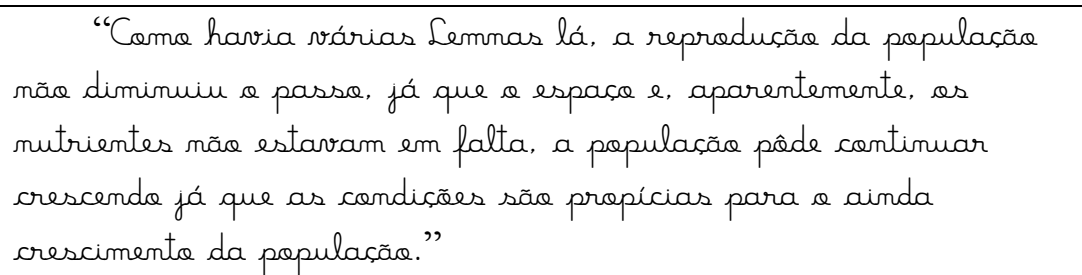 & & & & & & & $\mathbf{X}$ & & $\mathbf{X}$ & $\mathbf{X}$ & & $\mathbf{X}$ \\
\hline 9 & $\begin{array}{l}\text { Conclusão } \\
\text { individual } 1 \\
1^{\circ} \text { parágrafo }\end{array}$ & 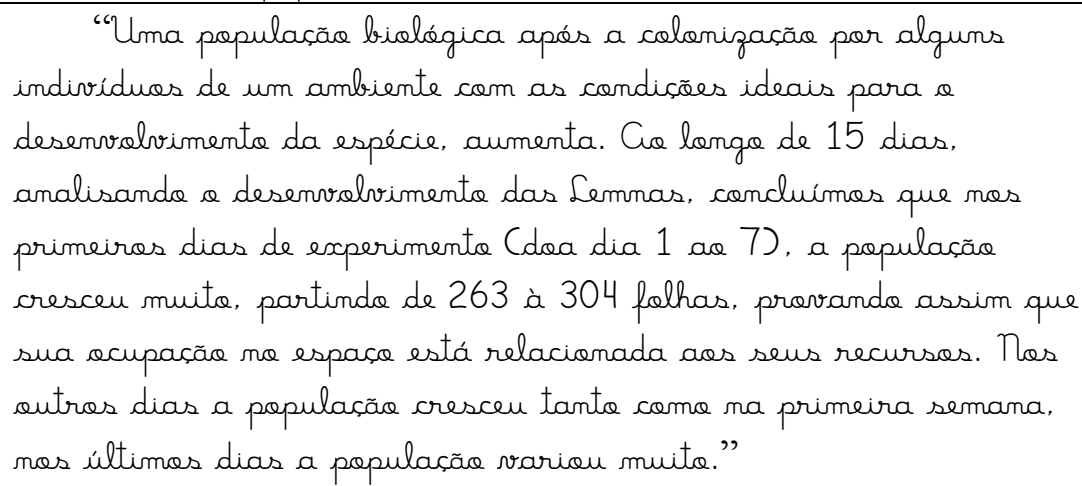 & & $\mathbf{X}$ & $\mathbf{X}$ & $\mathbf{X}$ & & & & & $\mathbf{X}$ & $\mathbf{X}$ & & \\
\hline 10 & $\begin{array}{l}\text { Conclusão } \\
\text { individual } 1 \\
2^{\circ} \text { parágrafo }\end{array}$ & 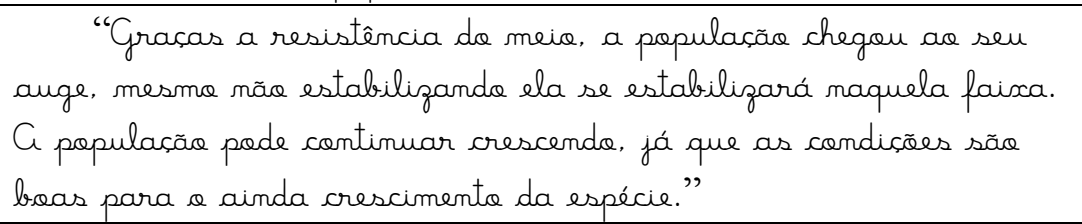 & & $\mathbf{X}$ & & & & & & & $\mathbf{X}$ & $\mathbf{X}$ & & $\mathbf{X}$ \\
\hline 11 & $\begin{array}{l}\text { Conclusão } \\
\text { individual } 2\end{array}$ & 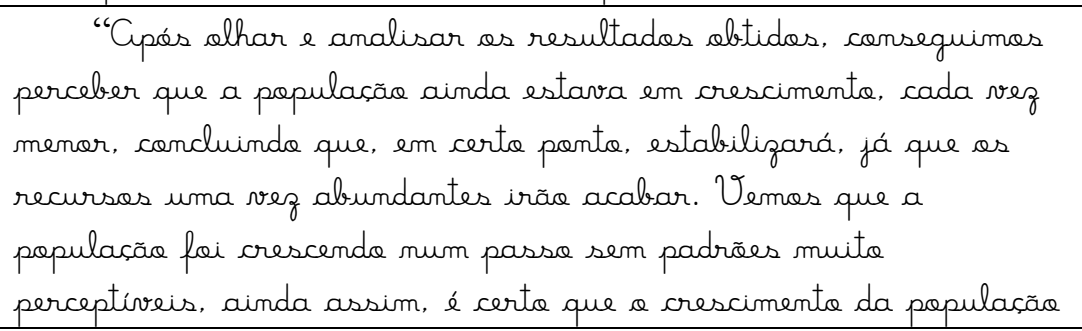 & & $\mathbf{X}$ & & $\mathbf{X}$ & & & & & $\mathbf{X}$ & $\mathbf{X}$ & & $\mathbf{X}$ \\
\hline
\end{tabular}


Thiago Marinho Del Corso

INDICADORES DE ALFABETIZAÇÃO CIENTÍFICA, ARGUMENTOS E EXPLICAÇÕES -

Análise de Relatórios no Contexto de uma Sequência de Ensino Investigativo

\begin{tabular}{|c|c|c|c|c|c|c|c|c|c|c|c|c|c|c|}
\hline & & 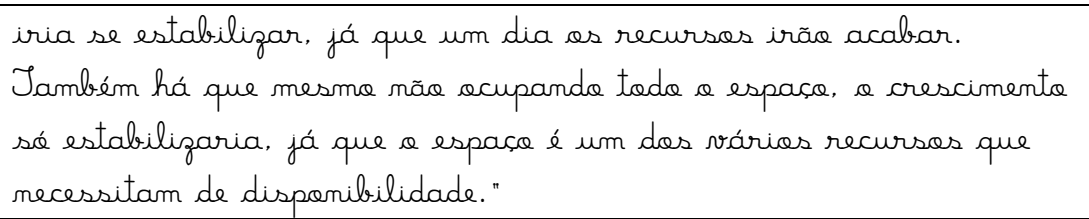 & & & & & & & & & & & & \\
\hline 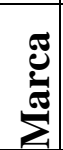 & $\begin{array}{l}\text { Subtítulo, } \\
\text { divisão ou } \\
\text { Item }\end{array}$ & Texto & LM & SI & OI & CI & RL & RP & $\mathbf{L H}$ & TH & $\mathbf{J}$ & $\mathbf{P}$ & $\underset{x}{a}$ & $\sum^{\infty}$ \\
\hline 12 & $\begin{array}{l}\text { Conclusão } \\
\text { individual } 3 \\
1^{\circ} \text { parágrafo }\end{array}$ & 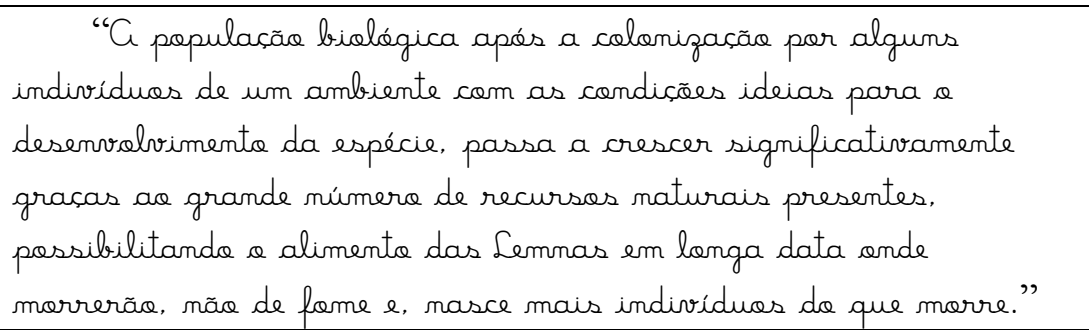 & & & & & & & & & $\mathbf{X}$ & $\mathbf{X}$ & & $\mathbf{X}$ \\
\hline 13 & $\begin{array}{l}\text { Conclusão } \\
\text { individual } 3 \\
2^{\circ} \text { parágrafo }\end{array}$ & 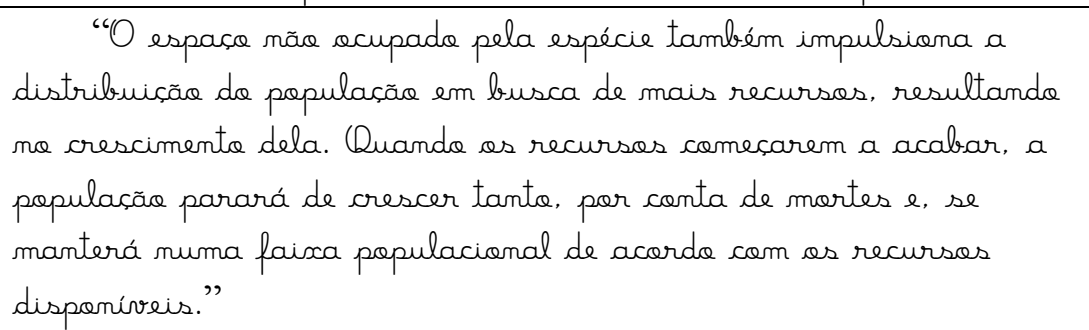 & & & & & $\mathbf{X}$ & & $\mathbf{X}$ & & $\mathbf{X}$ & $\mathbf{X}$ & & \\
\hline 14 & $\begin{array}{l}\text { Conclusão } \\
\text { individual } 4 \\
1^{\circ} \text { parágrafo }\end{array}$ & 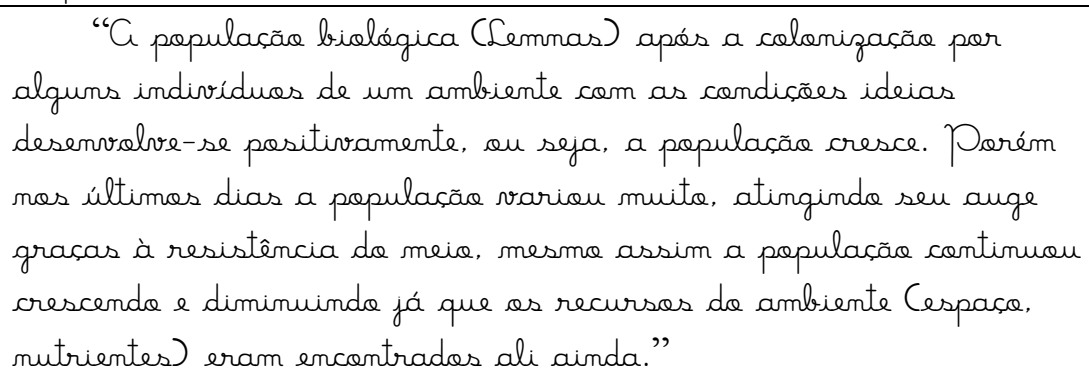 & & $\mathbf{X}$ & $\mathbf{X}$ & $\mathbf{X}$ & & & & & $\mathbf{X}$ & $\mathbf{X}$ & & $\mathbf{X}$ \\
\hline
\end{tabular}


Thiago Marinho Del Corso

INDICADORES DE ALFABETIZAÇÃO CIENTÍFICA, ARGUMENTOS E EXPLICAÇÕES -

Análise de Relatórios no Contexto de uma Sequência de Ensino Investigativo

\begin{tabular}{|c|c|c|c|c|c|c|c|c|c|c|c|c|c|c|}
\hline 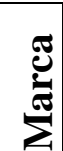 & $\begin{array}{l}\text { Subtítulo, } \\
\text { divisão ou } \\
\text { Item }\end{array}$ & Texto & $\mathbf{L M}$ & SI & OI & CI & RL & $\mathbf{R P}$ & $\mathbf{L H}$ & I TH & $\mathbf{J}$ & $\mathbf{P}$ & 엇 & $\sum^{\infty}$ \\
\hline 15 & $\begin{array}{l}\text { Conclusão } \\
\text { individual } 4 \\
2^{\circ} \text { parágrafo }\end{array}$ & $\begin{array}{l}\text { "Cis Lemnas acuparam quase toda e espacse e em algums dias } \\
\text { ou semanas as recursos acabarãa e tuda se estabilizará de forma } \\
\text { que a tamanha variaça vista anteriormente diminua." }\end{array}$ & & $\mathbf{X}$ & & & & & $\mathbf{X}$ & & & $X$ & & \\
\hline
\end{tabular}


Thiago Marinho Del Corso

INDICADORES DE ALFABETIZAÇÃO CIENTÍFICA, ARGUMENTOS E EXPLICAÇÕES -

Análise de Relatórios no Contexto de uma Sequência de Ensino Investigativo

O Relatório 14 - 2013

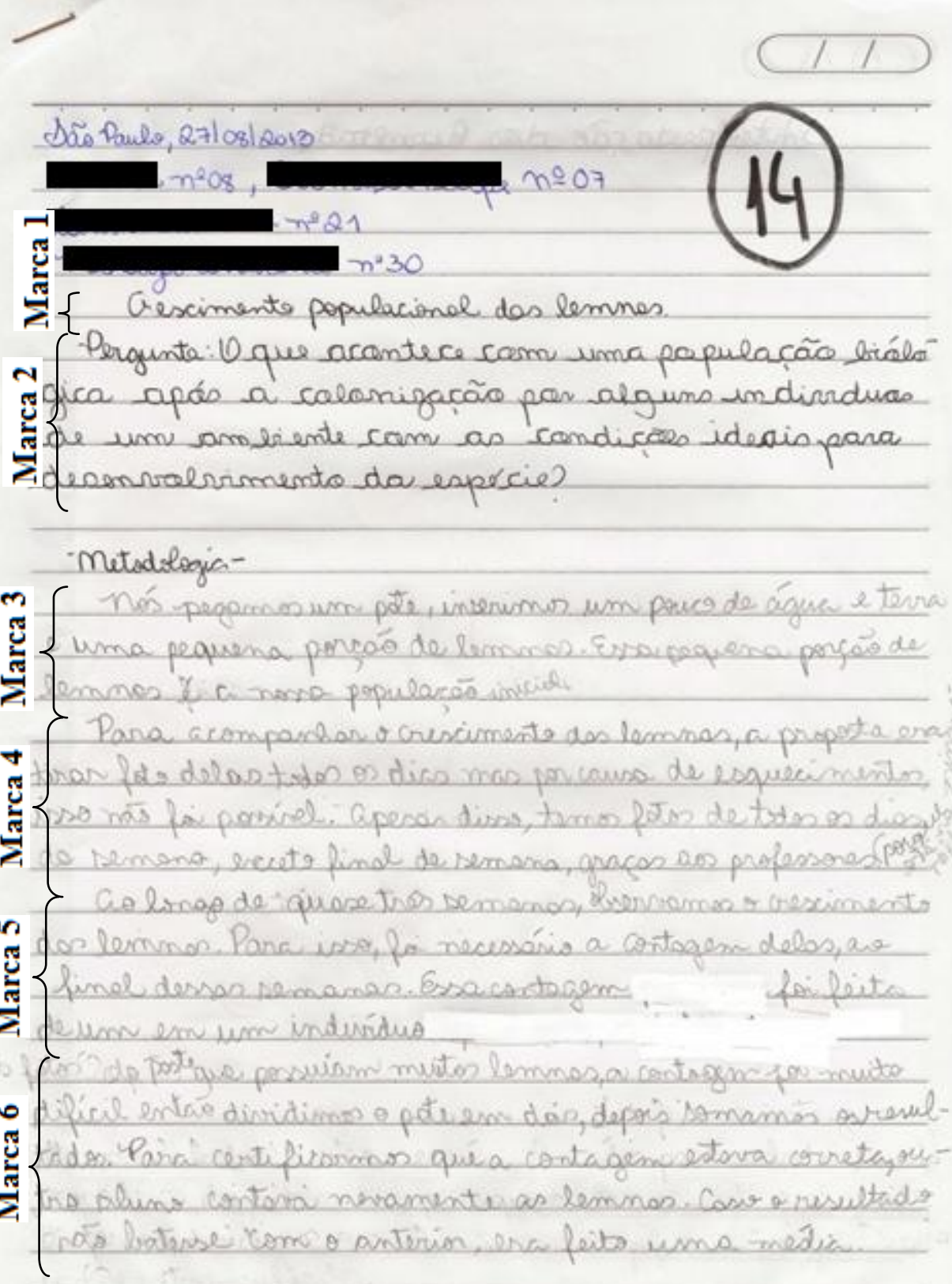

$-5$ 


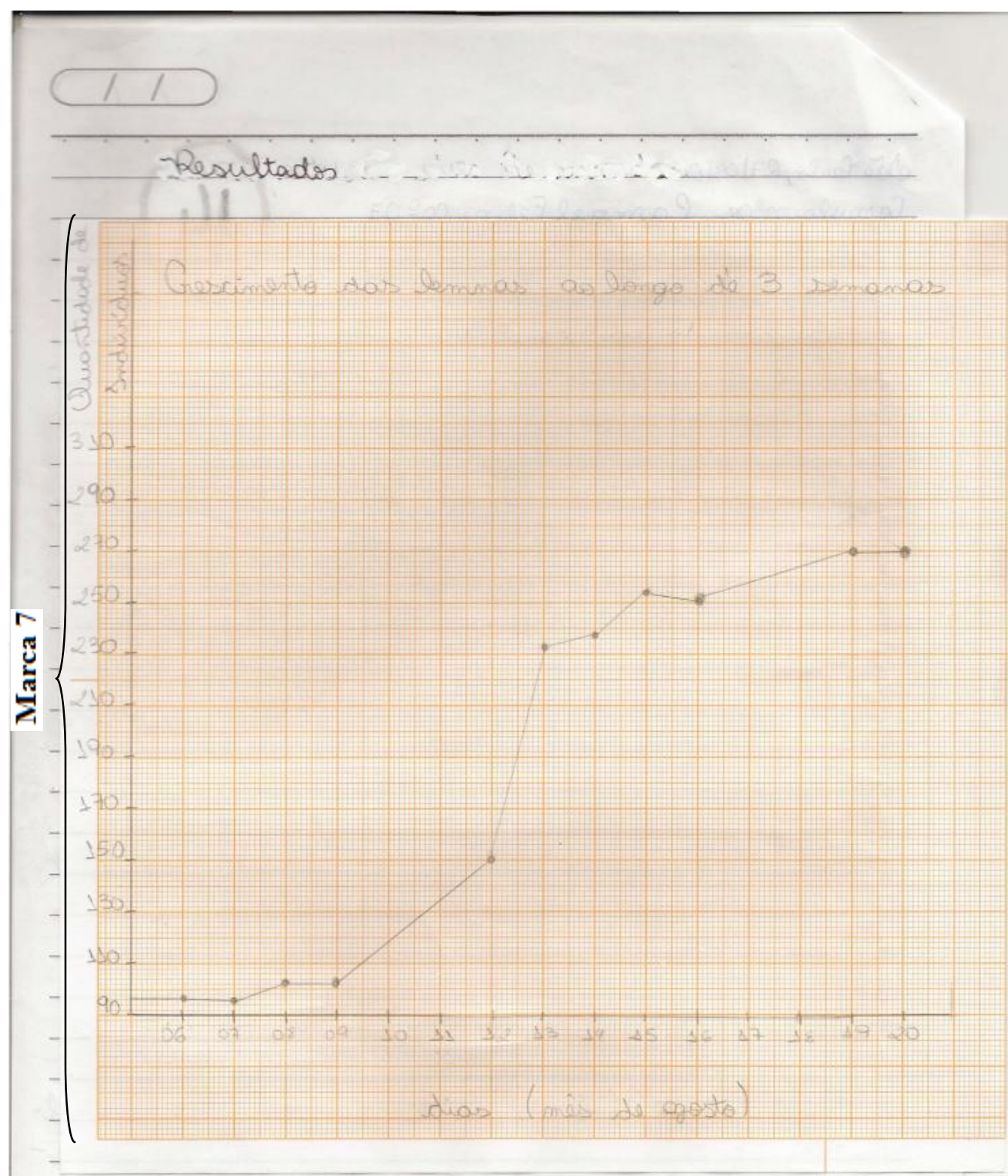

tilibra 


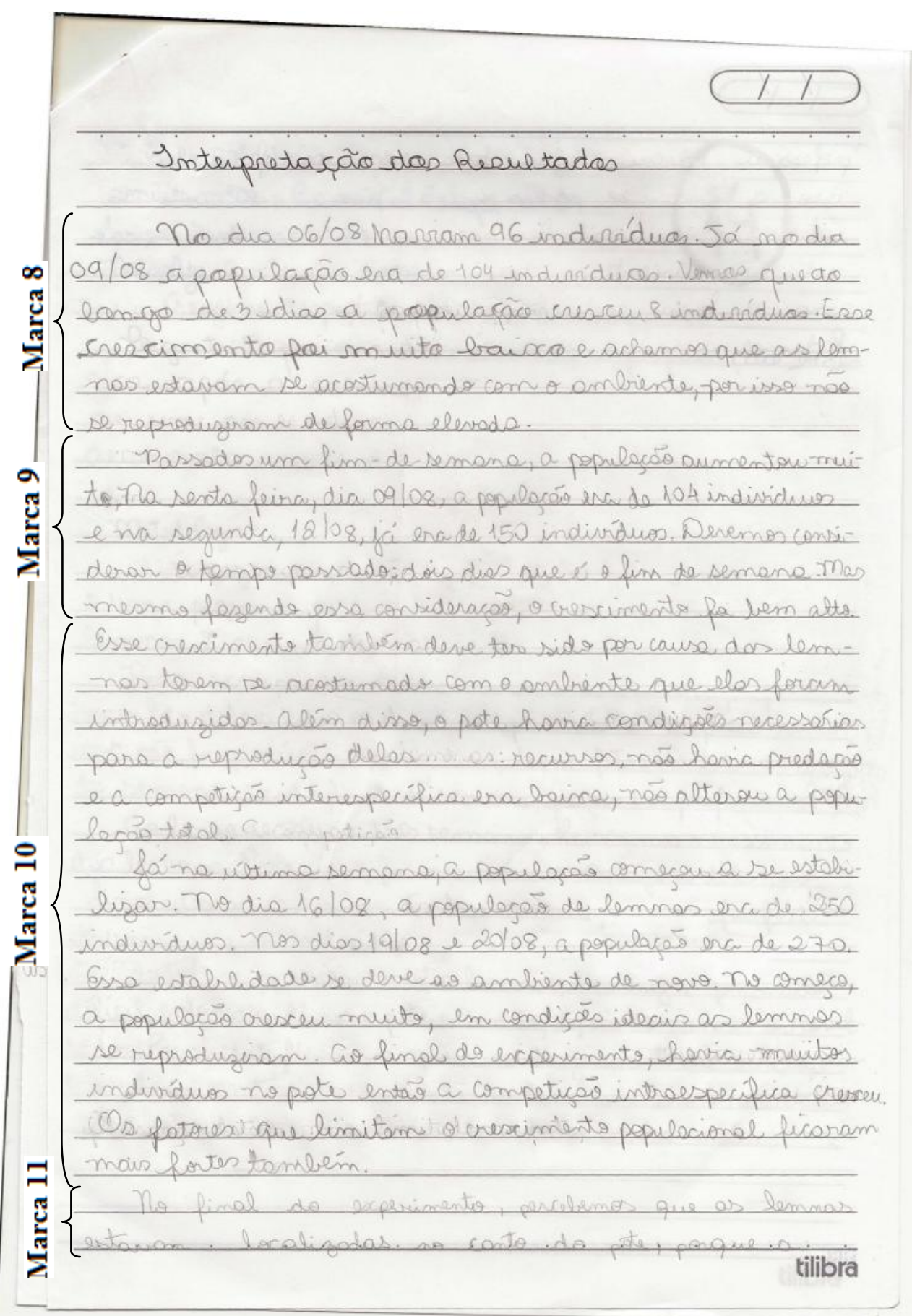


Thiago Marinho Del Corso

INDICADORES DE ALFABETIZAÇÃO CIENTÍFICA, ARGUMENTOS E EXPLICAÇÕES -

Análise de Relatórios no Contexto de uma Sequência de Ensino Investigativo

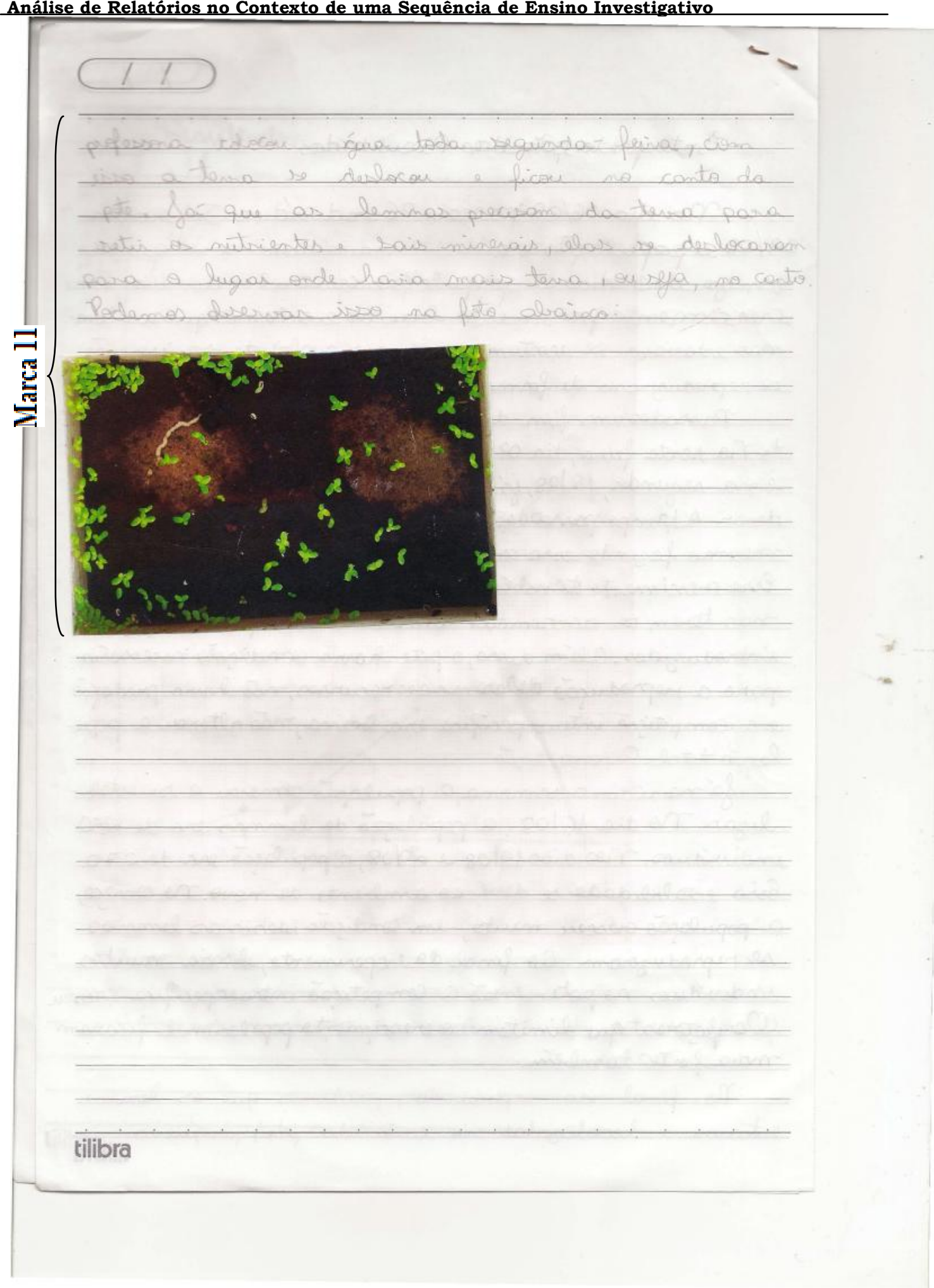


Thiago Marinho Del Corso

INDICADORES DE ALFABETIZAÇÃo CIENTÍFICA, ARGUMENTOS E EXPLICAÇÕES -

Análise de Relatórios no Contexto de uma Sequência de Ensino Investigativo

Quadro 14

Identificação dos Indicadores de Alfabetização Científica no Relatório 14 de 2013 e conclusões individuais correspondentes

\begin{tabular}{|c|c|c|c|c|c|c|c|c|c|c|c|c|c|}
\hline 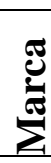 & $\begin{array}{l}\text { Subtítulo, } \\
\text { divisão ou } \\
\text { Item }\end{array}$ & Texto & $\mathbf{L M}$ & SI & OI & CI & $\mathbf{R L}$ & $\mathbf{R P}$ & $\mathbf{L H}$ & TH & $\mathbf{J}$ & & $\underset{\square}{20}$ \\
\hline 1 & Titulo & "Crescimenta papulacional de lemnas" & & & & & & & & & & & \\
\hline 2 & Pergunta & $\begin{array}{l}\text { "O que acontece com uma populascãa bialógica após a colonizaçãa } \\
\text { por alguns individuas de um ambiente com as condiçães ideais } \\
\text { para desenvolvimenta da espécie?" }\end{array}$ & $\mathrm{Nã}$ & $\mathrm{o}$ av & alia & o, te & exto & da pr & rofes & sora & & & \\
\hline 4 & $\begin{array}{l}\text { Metodologia } \\
\text { (Metodologia) } \\
2^{\circ} \text { parágrafo }\end{array}$ & 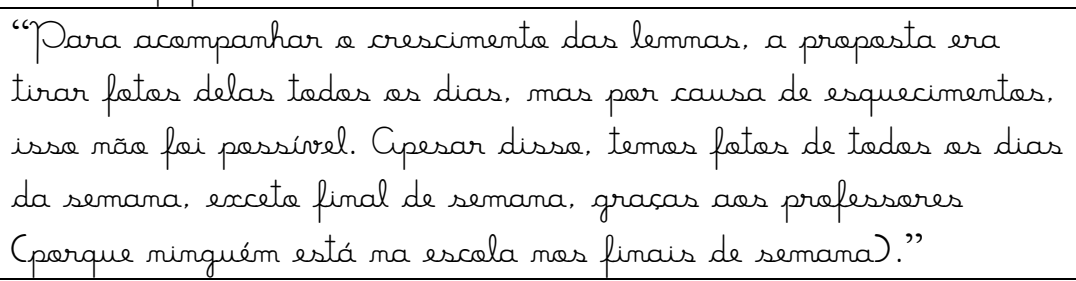 & $\mathbf{X}$ & & $\mathbf{X}$ & & & & & & $X$ & & \\
\hline 5 & $\begin{array}{l}\text { Metodologia } \\
\text { (Metodologia) } \\
3^{\circ} \text { parágrafo }\end{array}$ & $\begin{array}{l}\text { "Co longe de quase três semanas, ebservamas a crescimenta das } \\
\text { lemnas. Para issa, foi necessária a contagem delas, ae final } \\
\text { dessas semanas. Essa contagem foi feita de um em um } \\
\text { individue." }\end{array}$ & & & $\mathbf{X}$ & & & & & & & & \\
\hline 6 & $\begin{array}{l}\text { Metodologia } \\
\text { (Metodologia) } \\
4^{\circ} \text { parágrafo }\end{array}$ & $\begin{array}{l}\text { "As fatas das potes que passuiam muitas lemnas, a contagem fai } \\
\text { muita dificil, entãa dividimas a pate em dais, depais somamas as } \\
\text { resultadas. Para certificarmas que a contagem estava correta, } \\
\text { autra aluna contava novamente as lemnas. Casa a resultada nãa } \\
\text { batesse com a anterior, era feita uma média." }\end{array}$ & & & $\mathbf{X}$ & & $\mathbf{X}$ & & & & & & \\
\hline
\end{tabular}


Thiago Marinho Del Corso

INDICADORES DE ALFABETIZAÇÃO CIENTÍFICA, ARGUMENTOS E EXPLICAÇÕES -

Análise de Relatórios no Contexto de uma Sequência de Ensino Investigativo

\begin{tabular}{|c|c|c|c|c|c|c|c|c|c|c|c|c|c|c|}
\hline 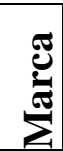 & $\begin{array}{l}\text { Subtítulo, } \\
\text { divisão ou } \\
\text { Item }\end{array}$ & Texto & $\mathbf{L M}$ & SI & OI & $\mathbf{C I}$ & RL & $\mathbf{R P}$ & $\mathbf{L H}$ & TH & $\mathbf{J}$ & $\mathbf{P}$ & : & $\sum_{4}^{00}$ \\
\hline 7 & $\begin{array}{l}\text { Resultados } \\
\text { (Resultados) } \\
\text { Gráfico }\end{array}$ & & & $\mathbf{X}$ & $\mathbf{X}$ & $\mathbf{X}$ & & & & & & & & \\
\hline 8 & $\begin{array}{l}\text { Interpretação } \\
\text { (Interpretaçãa } \\
\text { dos } \\
\text { Resultados) } \\
1^{\circ} \text { parágrafo }\end{array}$ & $\begin{array}{l}\text { "No dia } 06 / 08 \text { havia } 96 \text { individuas. Já ma dia 09/08 a } \\
\text { populaçãa era de } 104 \text { individuas. Vemas que aa longa de } 3 \text { dias a } \\
\text { populaçãa cresceu } 8 \text { individuas. Esse crescimenta foi muita baixa } \\
\text { e achamas que as lemnas estavam se acastumanda com a } \\
\text { ambiente, por issa nãa se reproduziram de forma elevada." }\end{array}$ & & $\mathbf{X}$ & $\mathbf{X}$ & $\mathbf{X}$ & & & & & $\mathbf{X}$ & & $\mathbf{X}$ & \\
\hline 9 & $\begin{array}{l}\text { Interpretação } \\
\text { (Interpretaçãa } \\
\text { das } \\
\text { Resultados) } \\
2^{\circ} \text { parágrafo }\end{array}$ & 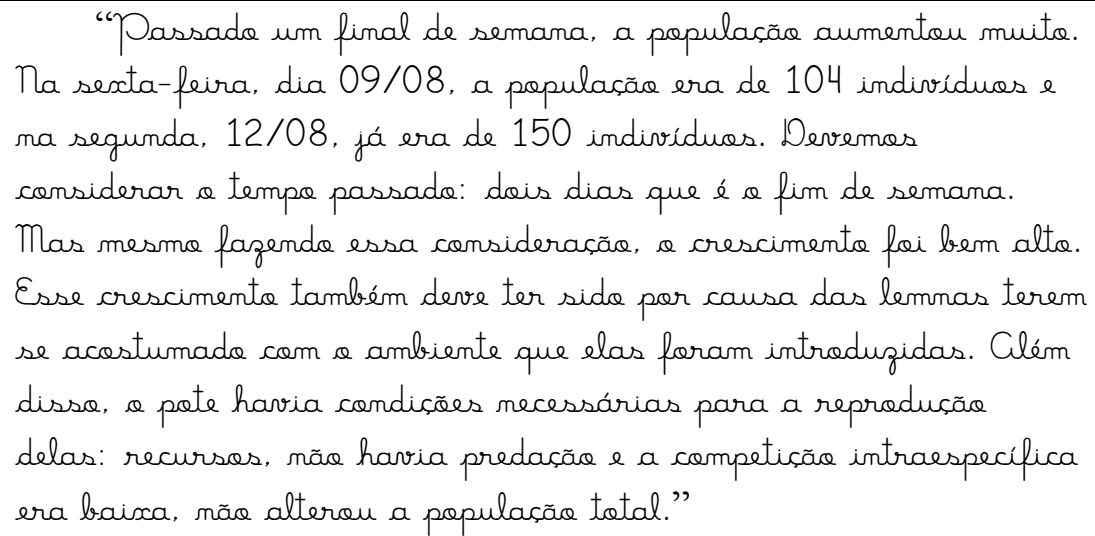 & & $\mathbf{X}$ & $\mathbf{X}$ & $\mathbf{X}$ & & $\mathbf{X}$ & & & $\mathbf{X}$ & & $\mathbf{X}$ & \\
\hline 10 & $\begin{array}{l}\text { Interpretação } \\
\text { (Interpretaçãa } \\
\text { dos }\end{array}$ & 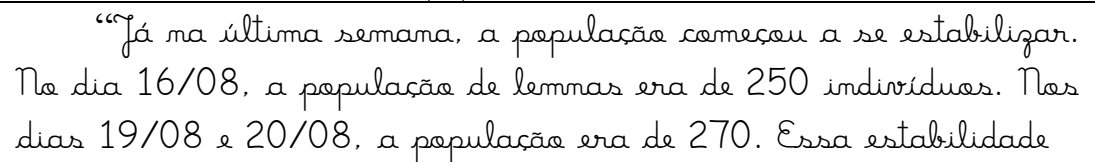 & & $\mathbf{X}$ & $\mathbf{X}$ & $X$ & $\mathbf{X}$ & & & & $\mathbf{X}$ & & $\mathbf{X}$ & \\
\hline
\end{tabular}


Thiago Marinho Del Corso

INDICADORES DE ALFABETIZAÇÃO CIENTÍFICA, ARGUMENTOS E EXPLICACÕES -

Análise de Relatórios no Contexto de uma Sequência de Ensino Investigativo

\begin{tabular}{|c|c|c|c|c|c|c|c|c|c|c|c|c|c|c|}
\hline & $\begin{array}{l}\text { Resultados) } \\
3^{\circ} \text { parágrafo }\end{array}$ & 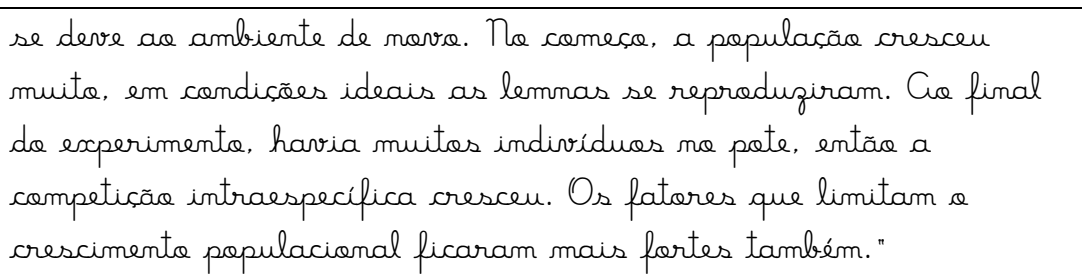 & & & & & & & & & & & & \\
\hline 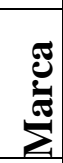 & $\begin{array}{l}\text { Subtítulo, } \\
\text { divisão ou } \\
\text { Item }\end{array}$ & Texto & $\mathbf{L M}$ & SI & $\mathbf{O I}$ & CI & $\mathbf{R L}$ & $\mathbf{R P}$ & $\mathbf{L H}$ & TH & $\mathbf{J}$ & $\mathbf{P}$ & 矛 & $\sum^{\infty}$ \\
\hline 11 & $\begin{array}{l}\text { Interpretação } \\
\text { (Interpretaçãa } \\
\text { dos } \\
\text { Resultados) } \\
4^{\circ} \text { parágrafo }\end{array}$ & 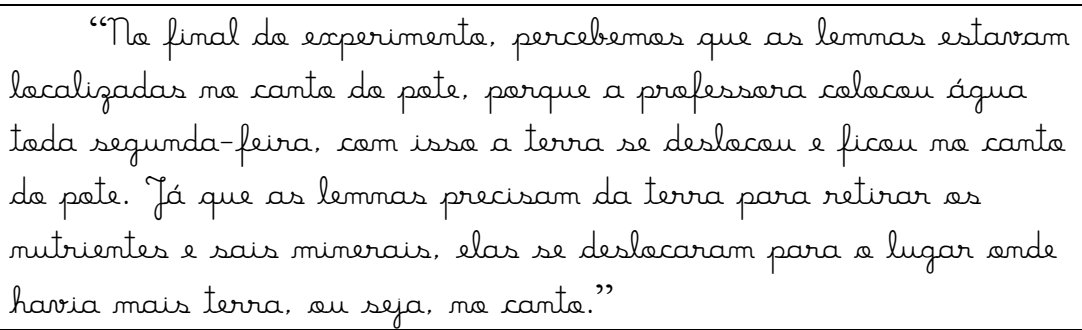 & & & & & & & & & $\mathbf{X}$ & & & $\mathbf{X}$ \\
\hline 12 & $\begin{array}{l}\text { Interpretação } \\
\text { Figura e } \\
\text { legenda }\end{array}$ & "Pademas observar issa na fata abaixa:" & & & & & & & & & & & & \\
\hline 13 & $\begin{array}{l}\text { Conclusão } \\
\text { individual } 1 \\
1^{\circ} \text { parágrafo }\end{array}$ & $\begin{array}{l}\text { "Uma papulasãa bialógica apés a calonizaçãa par alguns } \\
\text { individuas de um ambiente com as condicães ideais para } \\
\text { desenvolvimenta da espécie, cresce muita e depais se estabiliza. } \\
\text { Issa é bem marcada pelas dados de quantidade de individuas aa } \\
\text { langa das semanas." }\end{array}$ & & & & & & & & & $\mathbf{X}$ & $\mathbf{X}$ & & $\mathbf{X}$ \\
\hline 14 & $\begin{array}{l}\text { Conclusão } \\
\text { individual } 1\end{array}$ & "Foram três semanas que se dividem em três momentas: & & $\mathbf{X}$ & $\mathbf{X}$ & $\mathbf{X}$ & & & & & & & & \\
\hline
\end{tabular}


Thiago Marinho Del Corso

INDICADORES DE ALFABETIZAÇÃO CIENTÍFICA, ARGUMENTOS E EXPLICAÇÕES -

Análise de Relatórios no Contexto de uma Sequência de Ensino Investigativo

\begin{tabular}{|c|c|c|c|c|c|c|c|c|c|c|c|c|c|c|}
\hline & $2^{\circ}$ parágrafo & $\begin{array}{l}\text { Lemnas se acostumanda com a nova ambiente no qual foram } \\
\text { introduzidas -> crescimenta populacional muita baixa, a } \\
\text { crescimenta elevada da populaçãa e a estabilidade da quantidade de } \\
\text { lemnas." }\end{array}$ & & & & & & & & & & & & \\
\hline 预 & $\begin{array}{l}\text { Subtítulo, } \\
\text { divisão ou } \\
\text { Item }\end{array}$ & Texto & $\mathbf{L M}$ & SI & OI & CI & RL & $\mathbf{R P}$ & $\mathbf{L H}$ & TH & $\mathbf{J}$ & $\mathbf{P}$ & $\underset{x}{a}$ & $\sum^{\infty}$ \\
\hline 15 & $\begin{array}{l}\text { Conclusão } \\
\text { individual } 1 \\
3^{\circ} \text { parágrafo }\end{array}$ & $\begin{array}{l}\text { "A papulaçãa de lemnas cresceu até a capacidade biética máxima, } \\
\text { ista é, a limite máxima de individuas que a ambiente pode } \\
\text { suportar. Após alcançar essa capacidade, tanta lemnas, quanta } \\
\text { qualquer populaçãa de seres vivos, irá se estabilizar em um } \\
\text { ambiente com as condiçaes ideias para desenvolvimenta da } \\
\text { espécie." }\end{array}$ & & $\mathbf{X}$ & & $\mathbf{X}$ & & & & & $\mathbf{X}$ & $\mathbf{X}$ & & $\mathbf{X}$ \\
\hline 16 & $\begin{array}{l}\text { Conclusão } \\
\text { individual } 1 \\
4^{\circ} \text { parágrafo }\end{array}$ & $\begin{array}{l}\text { "Issa acontece porque há fatores que limitam a crescimenta } \\
\text { populacional, coma por exempla: recursas, competiçãa } \\
\text { intraespecífica, predaçãa. Nesse casa, predaçãa nãa é um fator que } \\
\text { limitau a crescimenta populacional, mas em autra ambiente poderia } \\
\text { ter sida um fator." }\end{array}$ & & & & & & & & & $\mathbf{X}$ & & & \\
\hline 17 & $\begin{array}{l}\text { Conclusão } \\
\text { individual } 2 \\
1^{\circ} \text { parágrafo }\end{array}$ & $\begin{array}{l}\text { "Concluimas que após pegarmas uma papulaçãa bialógica, na casa } \\
\text { as lemnas, e colocarmas em um ambiente com as condiçäes ideais } \\
\text { para seu desenvolvimenta, essa papulaçãa cresce, mas se } \\
\text { reproduzem lentamente durante um determinada tempa, até se } \\
\text { acostumarem com a local onde foram colonizadas." }\end{array}$ & & $\mathbf{X}$ & $\mathbf{X}$ & $\mathbf{X}$ & & & & & $\mathbf{X}$ & $\mathbf{X}$ & & $\mathbf{X}$ \\
\hline 18 & $\begin{array}{l}\text { Conclusão } \\
\text { individual } 2 \\
2^{\circ} \text { parágrafo }\end{array}$ & $\begin{array}{l}\text { "O experimenta durau quase três semanas e vimas que, nos } \\
\text { primeiras dias, as lemnas nãa se repraduziram de forma elevada, } \\
\text { concluimas que fai devida ae pauca tempa na ambiente. Depais de } \\
\text { uma semana no ambiente, elas cresceram muita e depois se }\end{array}$ & & $\mathbf{X}$ & $\mathbf{X}$ & $\mathbf{X}$ & & & & & $\mathbf{X}$ & & & \\
\hline
\end{tabular}


Thiago Marinho Del Corso

INDICADORES DE ALFABETIZAÇÃo CIENTÍFICA, ARGUMENTOS E EXPLICAÇÕES -

Análise de Relatórios no Contexto de uma Sequência de Ensino Investigativo

\begin{tabular}{|c|c|c|c|c|c|c|c|c|c|c|c|c|c|c|}
\hline & & estabilizaram." & & & & & & & & & & & & \\
\hline 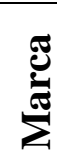 & $\begin{array}{l}\text { Subtítulo, } \\
\text { divisão ou } \\
\text { Item }\end{array}$ & Texto & LM & SI & OI & CI & RL & $\mathbf{R P}$ & $\mathbf{L H}$ & TH & $\mathbf{J}$ & $\mathbf{P}$ & $\underset{\mathbf{x}}{\stackrel{x}{2}}$ & $\sum_{4}^{\infty}$ \\
\hline 19 & $\begin{array}{l}\text { Conclusão } \\
\text { individual } 2 \\
3^{\circ} \text { parágrafo }\end{array}$ & 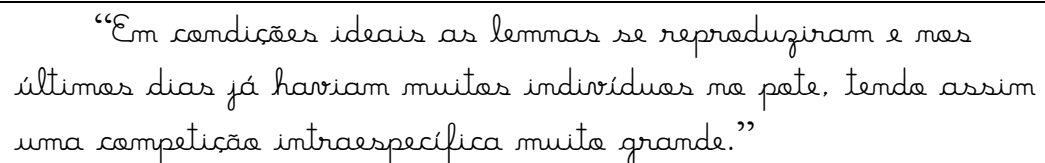 & & $\mathbf{X}$ & & & $\mathbf{X}$ & & & & $\mathbf{X}$ & & & $\mathbf{X}$ \\
\hline
\end{tabular}


Thiago Marinho Del Corso

INDICADORES DE ALFABETIZAÇÃO CIENTÍFICA, ARGUMENTOS E EXPLICAÇÕES -

Análise de Relatórios no Contexto de uma Sequência de Ensino Investigativo

\section{O Relatório 15 - 2013}

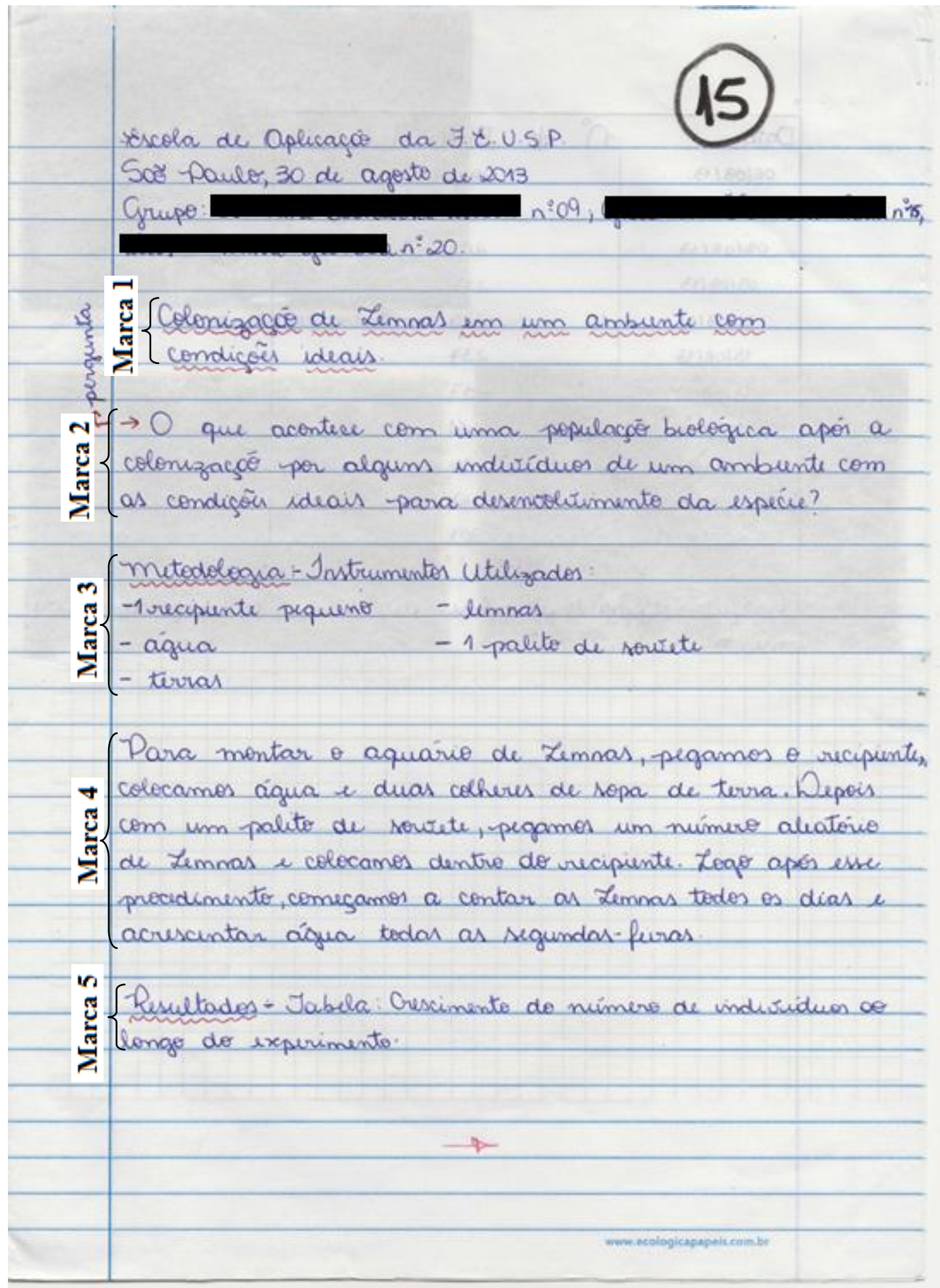


Thiago Marinho Del Corso

INDICADORES DE ALFABETIZAÇÃO CIENTÍFICA, ARGUMENTOS E EXPLICAÇÕES -

Análise de Relatórios no Contexto de uma Sequência de Ensino Investigativo

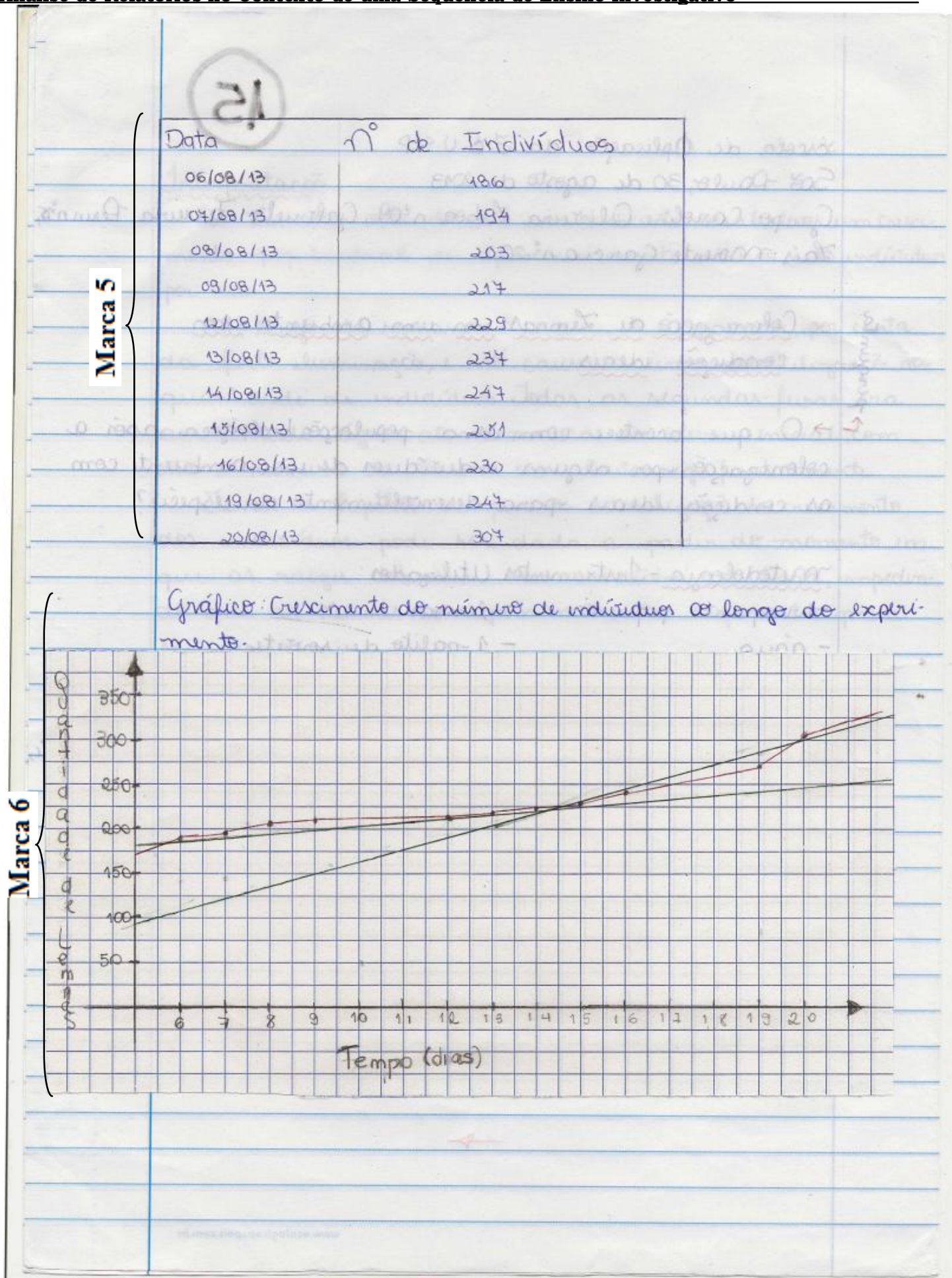


Thiago Marinho Del Corso INDICADORES DE ALFABETIZAÇÃO CIENTÍFICA, ARGUMENTOS E EXPLICAÇÕES -

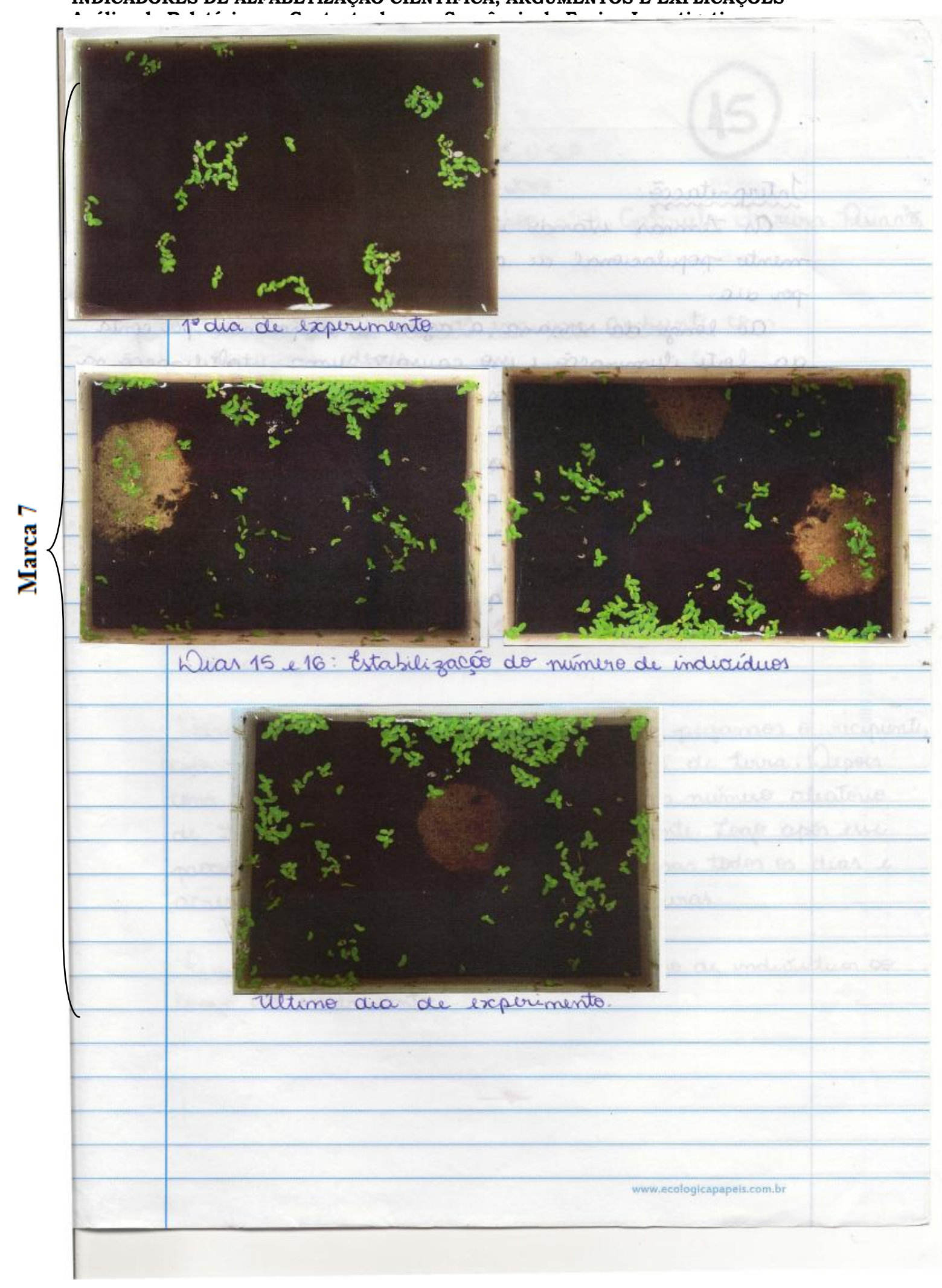


Thiago Marinho Del Corso

INDICADORES DE ALFABETIZAÇÃO CIENTÍFICA, ARGUMENTOS E EXPLICAÇÕES -

Análise de Relatórios no Contexto de uma Sequência de Ensino Investigativo

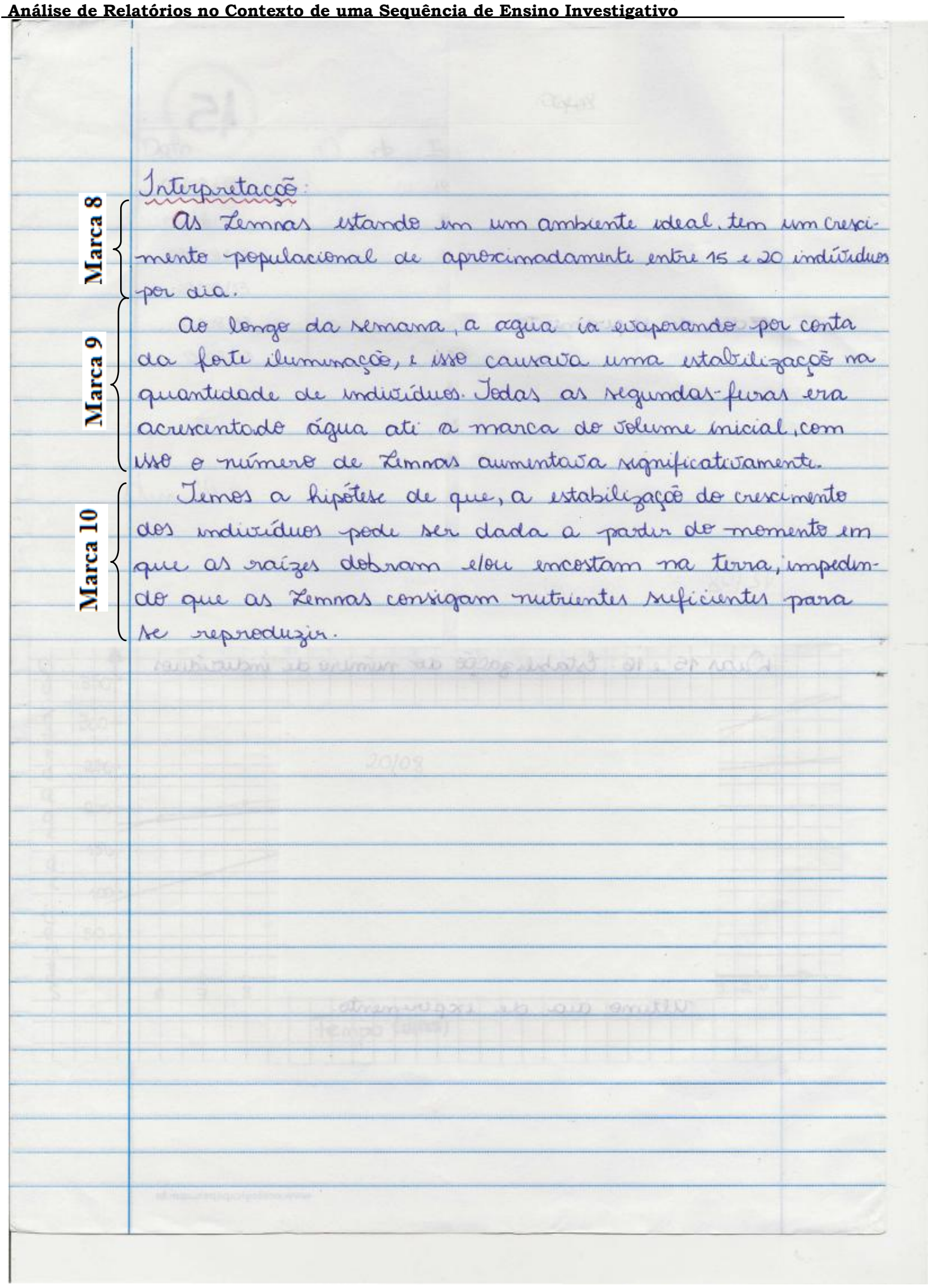


Thiago Marinho Del Corso

INDICADORES DE ALFABETIZAÇÃO CIENTÍFICA, ARGUMENTOS E EXPLICAÇÕES -

Análise de Relatórios no Contexto de uma Sequência de Ensino Investigativo

Quadro 15

Identificação dos Indicadores de Alfabetização Científica no Relatório 15 de 2013 e conclusões individuais correspondentes

\begin{tabular}{|c|c|c|c|c|c|c|c|c|c|c|c|c|c|c|}
\hline 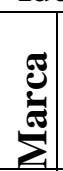 & $\begin{array}{l}\text { Subtítulo, } \\
\text { divisão ou } \\
\text { Item }\end{array}$ & 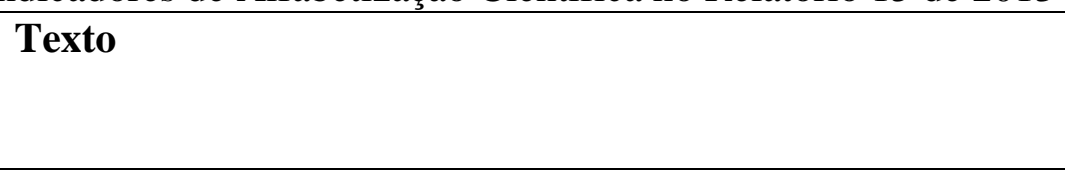 & $\mathbf{L M}$ & SI & OI & $\mathbf{C I}$ & RL & $\mathbf{R P}$ & LH & $\mathbf{T} \mathbf{T H}$ & $\mathbf{J}$ & $\mathbf{P}$ & 齐 & $\underset{\psi}{4}$ \\
\hline 1 & Titulo & "Colonizaçäe de Lemnas em um ambiente com condiçäes ideais" & & & & & & & & & & & & \\
\hline 2 & Pergunta & $\begin{array}{l}\text { "O que acantece com uma papulaçäe bialégica apés a } \\
\text { colonizacäa por alguns individuas de um ambiente com as } \\
\text { condič̃es ideais para desemvolvimenta da espécie?" }\end{array}$ & Nãc & $\mathrm{o} \mathrm{av}$ & alia & o, te & xto & da pr & rofes & ssora & & & & \\
\hline 3 & $\begin{array}{l}\text { Metodologia } \\
\text { (Metodologia) }\end{array}$ & $\begin{array}{l}\text { "Instrumentas utilizadas: } \\
\text { - } 1 \text { recipiente pequence } \\
\text { - lemnas } \\
\text { - água } \\
\text { - } 1 \text { palite de sorvete } \\
\text { - terras" }\end{array}$ & $\mathbf{X}$ & & & & & & & & & & & \\
\hline 4 & $\begin{array}{l}\text { Metodologia } \\
\text { (Metodologia) } \\
1^{\circ} \text { parágrafo }\end{array}$ & 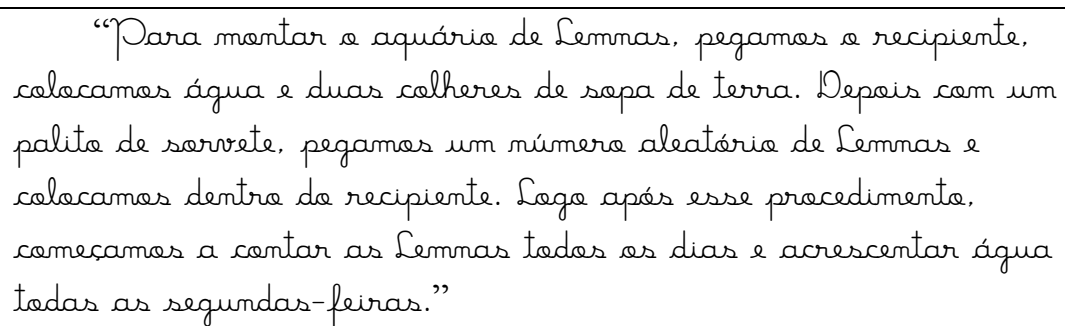 & $\mathbf{X}$ & & $\mathbf{X}$ & & & & & & & & & \\
\hline
\end{tabular}


Thiago Marinho Del Corso

INDICADORES DE ALFABETIZACÃO CIENTÍFICA, ARGUMENTOS E EXPLICACOÕES -

Análise de Relatórios no Contexto de uma Sequência de Ensino Investigativo

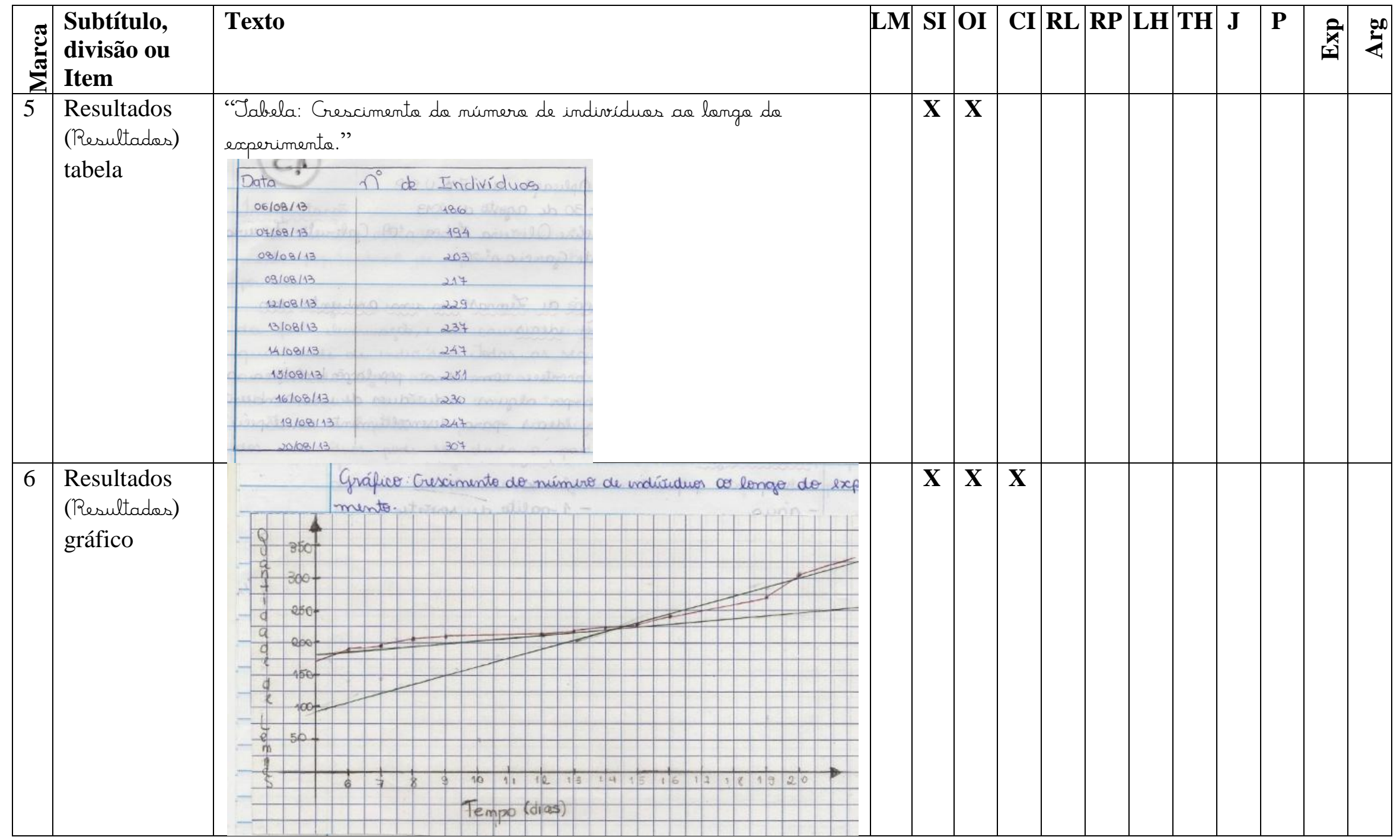


Thiago Marinho Del Corso

INDICADORES DE ALFABETIZAC̄̃o CIENTÍFICA, ARGUMENTOS E EXPLICAÇÕES -

Análise de Relatórios no Contexto de uma Sequência de Ensino Investigativo

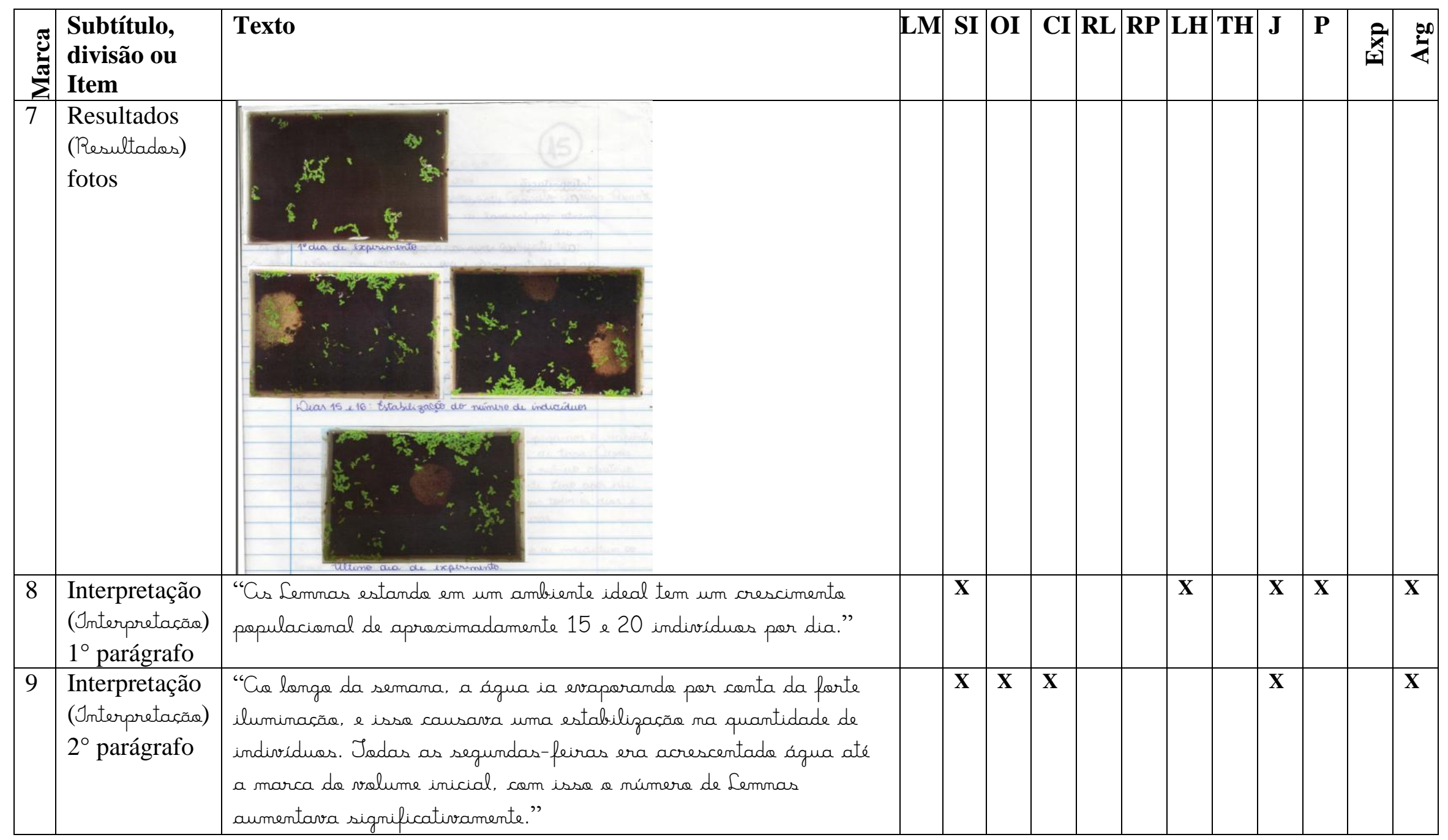


Thiago Marinho Del Corso

INDICADORES DE ALFABETIZAÇ̃̃O CIENTÍFICA, ARGUMENTOS E EXPLICAÇÕES -

Análise de Relatórios no Contexto de uma Sequência de Ensino Investigativo

\begin{tabular}{|c|c|c|c|c|c|c|c|c|c|c|c|c|c|c|}
\hline 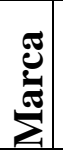 & $\begin{array}{l}\text { Subtítulo, } \\
\text { divisão ou } \\
\text { Item }\end{array}$ & Texto & $\mathbf{L M}$ & SI & OI & CI & RL & $\mathbf{R P}$ & $\mathbf{L H}$ & TH & $\mathbf{J}$ & $\mathbf{P}$ & $\underset{x}{a}$ & $\sum^{\infty}$ \\
\hline 10 & $\begin{array}{l}\text { Interpretação } \\
\text { (Jnterpretaçãa) } \\
\text { ( } 3^{\circ} \text { parágrafo) }\end{array}$ & $\begin{array}{l}\text { "Temos a hipótese de que a estabilizaça do crescimenta das } \\
\text { individuos pode ser dada a partir do momenta em que as raiges } \\
\text { dobram e/ ou encostam na terra, impedindo que as Lemnas } \\
\text { consigam nutrientes suficientes para se reproduzir." }\end{array}$ & & $\mathbf{X}$ & & & & & $\mathbf{X}$ & & $\mathbf{X}$ & $\mathbf{X}$ & & $\mathbf{X}$ \\
\hline 11 & $\begin{array}{l}\text { Conclusão } 1 \\
\left(1^{\circ} \text { parágrafo }\right)\end{array}$ & $\begin{array}{l}\text { "De acarda com a pergunta, apás a calonizaçãa de alguns } \\
\text { individuas em um ambiente nas condiç̃es ideais para } \\
\text { desenvalvimenta da espécie, tivemas um crescimenta significativa e } \\
\text { em alguns momentas uma estabilizaçãa." }\end{array}$ & & $\mathbf{X}$ & & & & & & & & & & $\mathbf{X}$ \\
\hline 12 & $\begin{array}{l}\text { Conclusão } 1 \\
\left(2^{\circ} \text { parágrafo }\right)\end{array}$ & $\begin{array}{l}\text { "Pademas concluir que quanda as lemnas estabilizaram, elas } \\
\text { ainda tinham espaca para se reproduzir. Mas com um pauca mais } \\
\text { de estuda, poderíamos saber com certeza porque as lemnas se } \\
\text { estabilizaram em um certo perioda (dados no gráfica)." }\end{array}$ & & $\mathbf{X}$ & & & & & & & & $\mathbf{X}$ & & \\
\hline 13 & $\begin{array}{l}\text { Conclusão } 1 \\
\left(3^{\circ} \text { parágrafo }\right)\end{array}$ & $\begin{array}{l}\text { "Entãa podemas concluir que, se as Lemnas estiverem em um } \\
\text { ambiente adequado, elas vãa conseguir se reproduzir } \\
\text { tranquilamente." }\end{array}$ & & & & & & & $\mathbf{X}$ & & & $\mathbf{X}$ & & \\
\hline 14 & $\begin{array}{l}\text { Conclusão } 2 \\
\left(1^{\circ} \text { parágrafo }\right)\end{array}$ & $\begin{array}{l}\text { "Podemas concluir que, estanda em um ambiente ideal, as } \\
\text { lemnas têm um crescimenta papulacional com uma média de } 15 \text { a } \\
20 \text { individuas por dia." }\end{array}$ & & $\mathbf{X}$ & & & & & & & & $\mathbf{X}$ & & $\mathbf{X}$ \\
\hline 15 & $\begin{array}{l}\text { Conclusão } 2 \\
\left(2^{\circ} \text { parágrafo }\right)\end{array}$ & $\begin{array}{l}\text { "Analisanda a tabela e a gráfica, podemas notar essa } \\
\text { pequena diferencsa na quantidade de individuas, sendo assim, } \\
\text { podemas natar que sempre haverá crescimenta de individuas se as } \\
\text { lemnas estiverem em um ambiente ideal." }\end{array}$ & & & & & & & & & $\mathbf{X}$ & $\mathbf{X}$ & & $\mathbf{X}$ \\
\hline
\end{tabular}


Thiago Marinho Del Corso

INDICADORES DE ALFABETIZAÇÃO CIENTÍFICA, ARGUMENTOS E EXPLICAÇÕES -

Análise de Relatórios no Contexto de uma Sequência de Ensino Investigativo

\begin{tabular}{|c|c|c|c|c|c|c|c|c|c|c|c|c|c|c|}
\hline 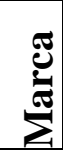 & $\begin{array}{l}\text { Subtítulo, } \\
\text { divisão ou } \\
\text { Item }\end{array}$ & Texto & $\mathbf{L M}$ & SI & OI & CI & $\mathbf{R L}$ & $\mathbf{R P}$ & $\mathbf{L H}$ & TH & $\mathbf{J}$ & $\mathbf{P}$ & $\underset{x}{2}$ & 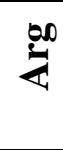 \\
\hline 16 & $\begin{array}{l}\text { Conclusão } 3 \\
\left(1^{\circ} \text { parágrafo }\right)\end{array}$ & $\begin{array}{l}\text { "Cus lemnas em um ambiente ideal têm um crescimenta de } \\
\text { apraximadamente } 15 \text { a } 20 \text { individuas diariamente." }\end{array}$ & & & & & & & & & & $\mathbf{X}$ & & $\mathbf{X}$ \\
\hline 17 & $\begin{array}{l}\text { Conclusão } 3 \\
\left(2^{\circ} \text { parágrafo }\right)\end{array}$ & $\begin{array}{l}\text { "Em alguns momentas a populaçãa se estabilizava. } \\
\text { Goreditamos que isso acoerria pois ae longo da semana a água } \\
\text { era evoparada, fazendo com que as raizes das lemnas dobrassem } \\
\text { e impedissem-nas de crescer, se reproduzir e adquirir nutrientes." }\end{array}$ & & $\mathbf{X}$ & & & & & $\mathbf{X}$ & & $\mathbf{X}$ & & $\mathbf{X}$ & \\
\hline 18 & $\begin{array}{l}\text { Conclusão } 3 \\
\left(3^{\circ} \text { parágrafo }\right)\end{array}$ & $\begin{array}{l}\text { "Mas segundas-feiras, ae acrescentar mais água, as Lemnas } \\
\text { voltavam a seu estado inicial (condiçoes ideais) e davam um } \\
\text { salta no crescimento populacional." }\end{array}$ & & $\mathbf{X}$ & & $\mathbf{X}$ & & & & & $\mathbf{X}$ & & & $\mathbf{X}$ \\
\hline
\end{tabular}


Thiago Marinho Del Corso

INDICADORES DE ALFABETIZAÇÃO CIENTÍFICA, ARGUMENTOS E EXPLICAÇÕES -

Análise de Relatórios no Contexto de uma Sequência de Ensino Investigativo

\section{O Relatório 16 - 2013}

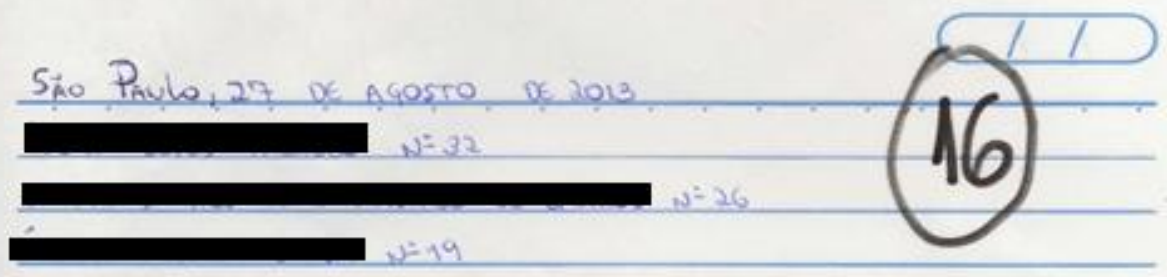

RELAT́́nio de Biologia - ProfeSSORA.

- Biologia

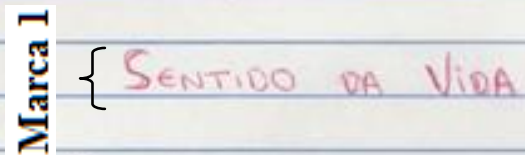

골

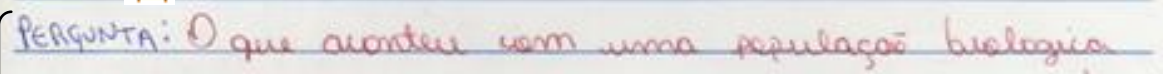

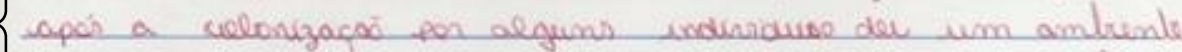

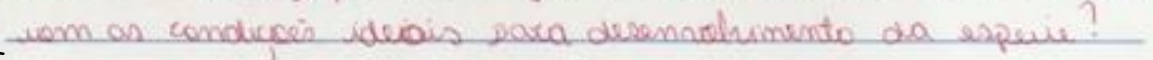

水

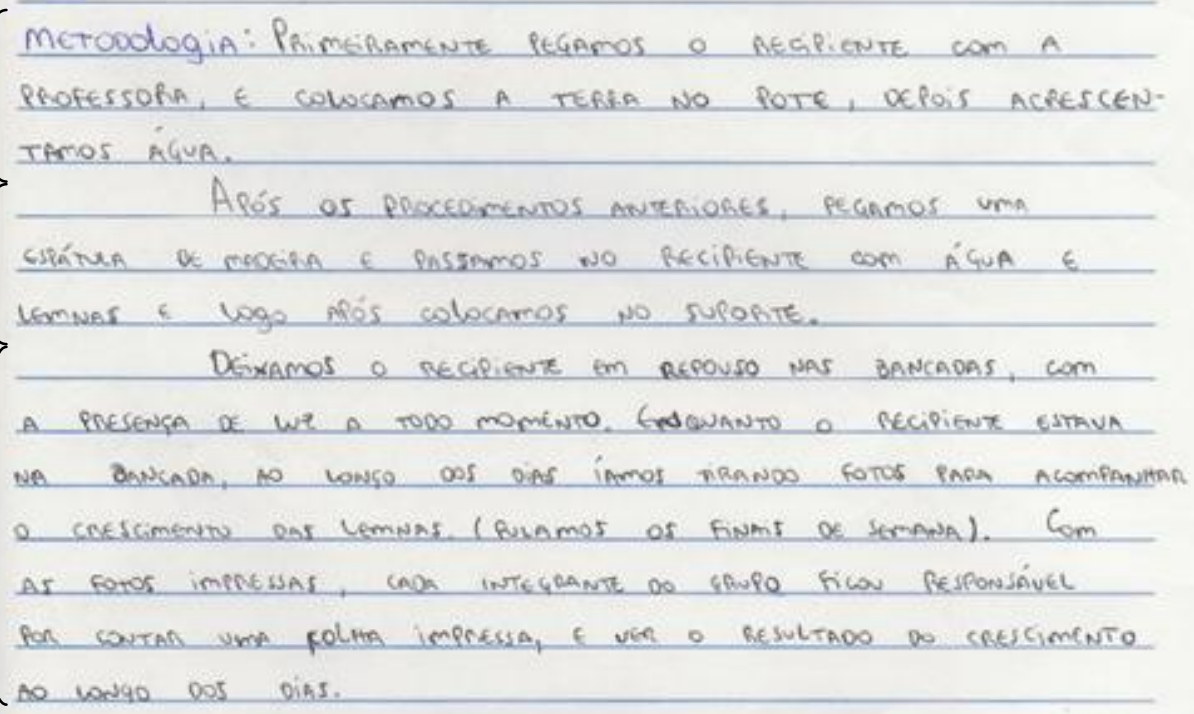


Thiago Marinho Del Corso

INDICADORES DE ALFABETIZAÇÃO CIENTÍFICA, ARGUMENTOS E EXPLICAÇÕES -

Análise de Relatórios no Contexto de uma Sequência de Ensino Investigativo

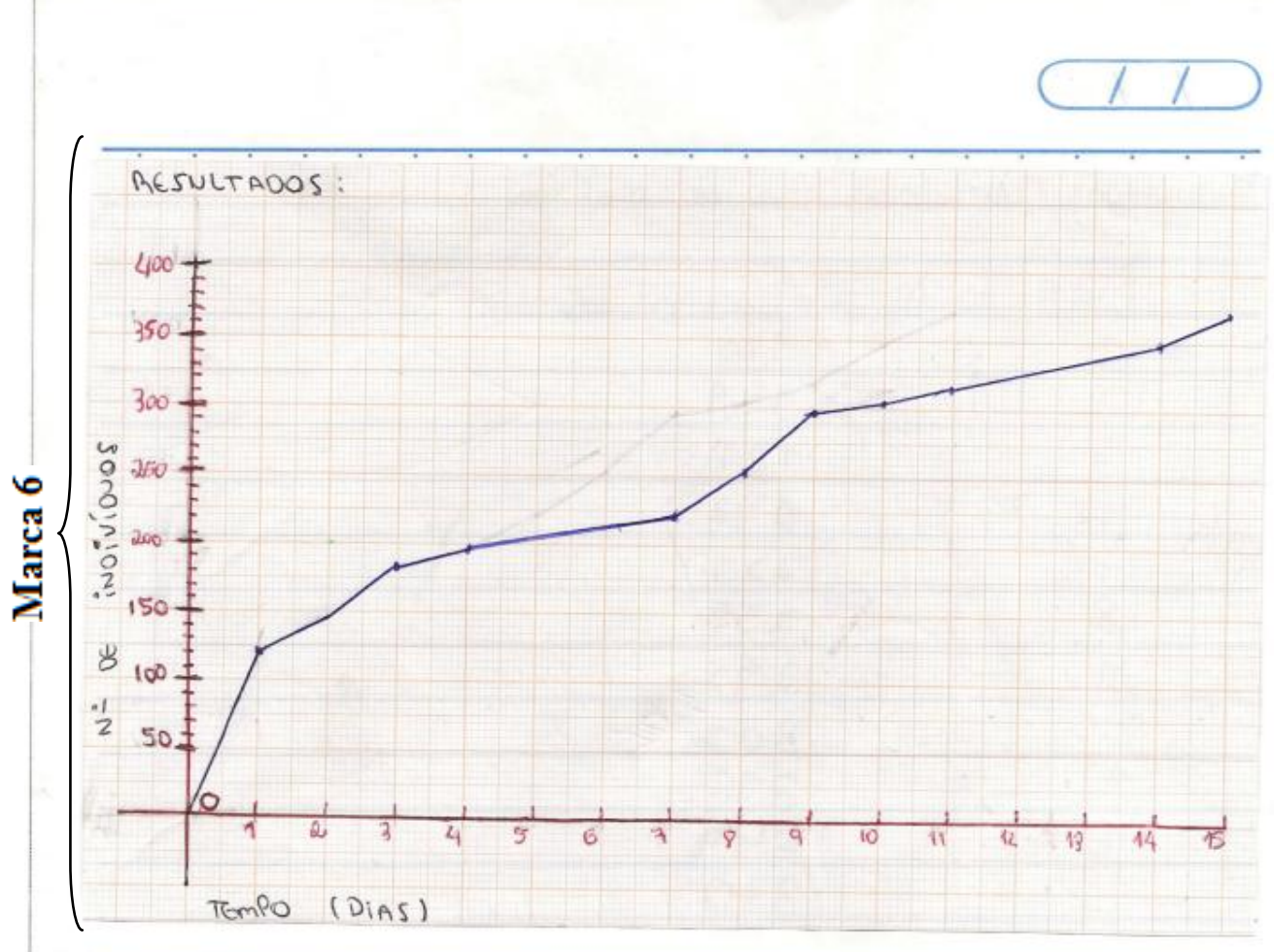


Thiago Marinho Del Corso

INDICADORES DE ALFABETIZAÇÃO CIENTÍFICA, ARGUMENTOS E EXPLICAÇÕES -

Análise de Relatórios no Contexto de uma Sequência de Ensino Investigativo

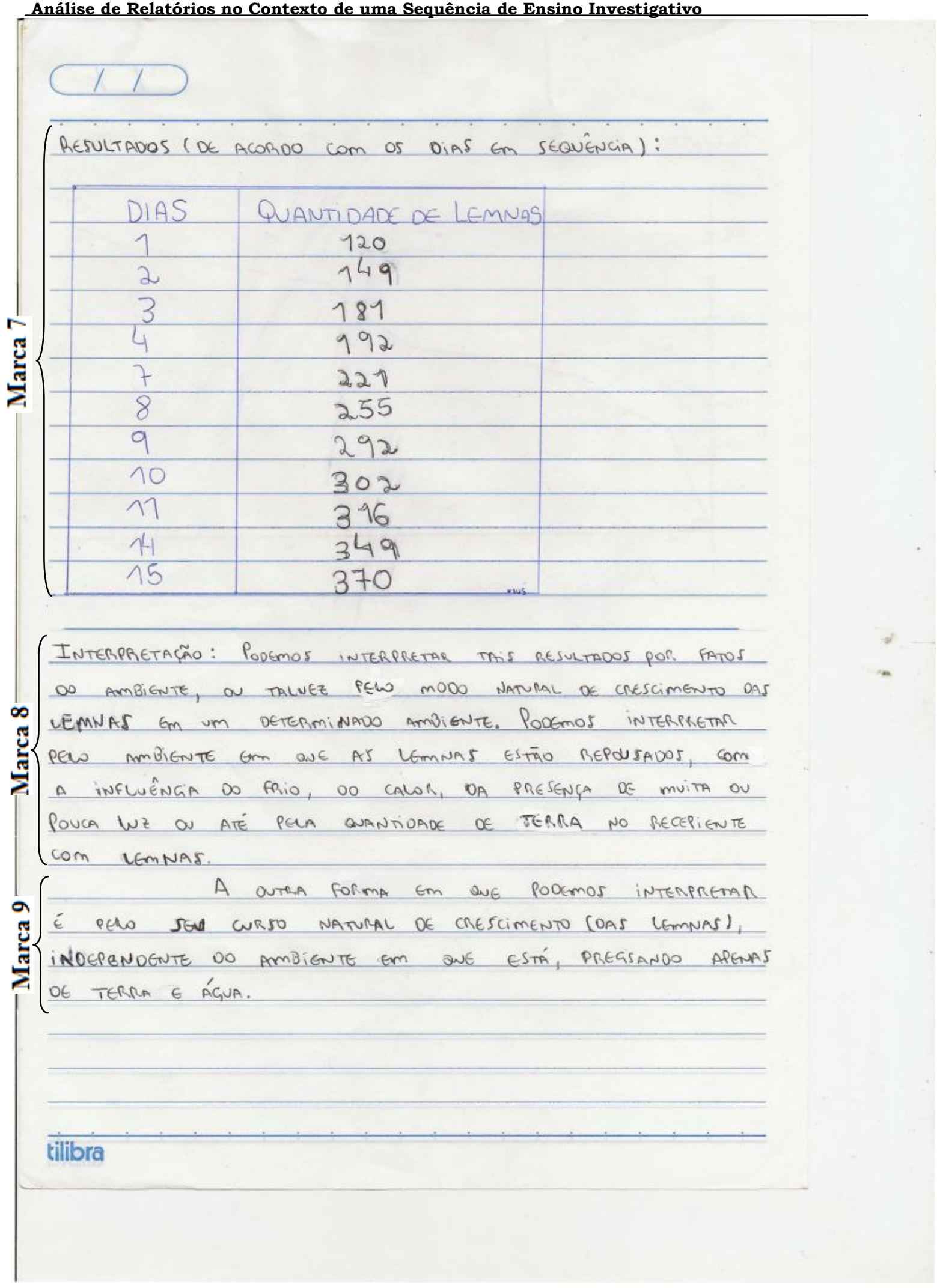


Thiago Marinho Del Corso

INDICADORES DE ALFABETIZAÇÃO CIENTÍFICA, ARGUMENTOS E EXPLICAÇÕES -

Análise de Relatórios no Contexto de uma Sequência de Ensino Investigativo

Quadro 16

Identificação dos Indicadores de Alfabetização Científica no Relatório 16 de 2013 e conclusões individuais correspondentes

\begin{tabular}{|c|c|c|c|c|c|c|c|c|c|c|c|c|c|c|}
\hline 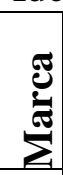 & $\begin{array}{l}\text { Subtítulo, } \\
\text { divisão ou } \\
\text { Item }\end{array}$ & 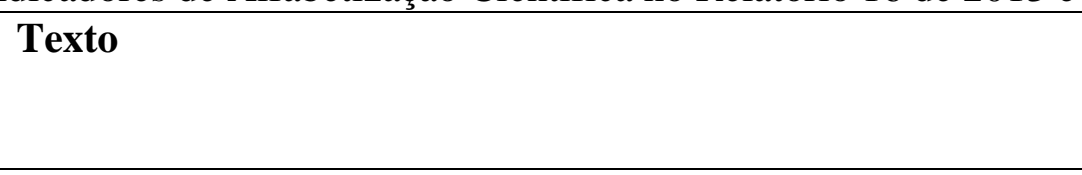 & $\mathbf{L M}$ & SI & $\mathbf{O I}$ & $\mathbf{C I}$ & $\mathbf{R L}$ & $\mathbf{R P}$ & $\mathbf{L H}$ & TH & $\mathbf{J}$ & $\mathbf{P}$ & 엇 & $\sum^{00}$ \\
\hline 1 & Titulo & "Sentida da Vida" & & & & & & & & & & & & \\
\hline 2 & $\begin{array}{l}\text { Pergunta } \\
\text { (Pergunta) }\end{array}$ & $\begin{array}{l}\text { "O que acontece com uma papulaçãa bialágica apás a colonizaçãa } \\
\text { par alguns individuas de um ambiente com as condicãés ideais } \\
\text { para desenvalvimenta da espécie?" }\end{array}$ & \multicolumn{12}{|c|}{ Não avaliado, texto da professora. } \\
\hline 3 & $\begin{array}{l}\text { Metodologia } \\
\text { (Metodologia) } \\
1^{\circ} \text { parágrafo }\end{array}$ & $\begin{array}{l}\text { "Primeiramente pegamas a recipiente com a professora e } \\
\text { colocamas a terra no pote, depois acrescentamos água." }\end{array}$ & $\mathbf{X}$ & & $\mathbf{X}$ & & & & & & & & & \\
\hline 4 & $\begin{array}{l}\text { Metodologia } \\
\text { (metodologia) } \\
2^{\circ} \text { parágrafo }\end{array}$ & 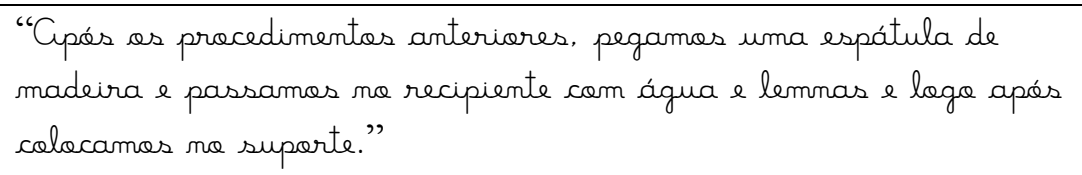 & $\mathbf{X}$ & & $\mathbf{X}$ & & & & & & & & & \\
\hline 5 & $\begin{array}{l}\text { Metodologia } \\
\text { (Metodologia) } \\
3^{\circ} \text { parágrafo }\end{array}$ & 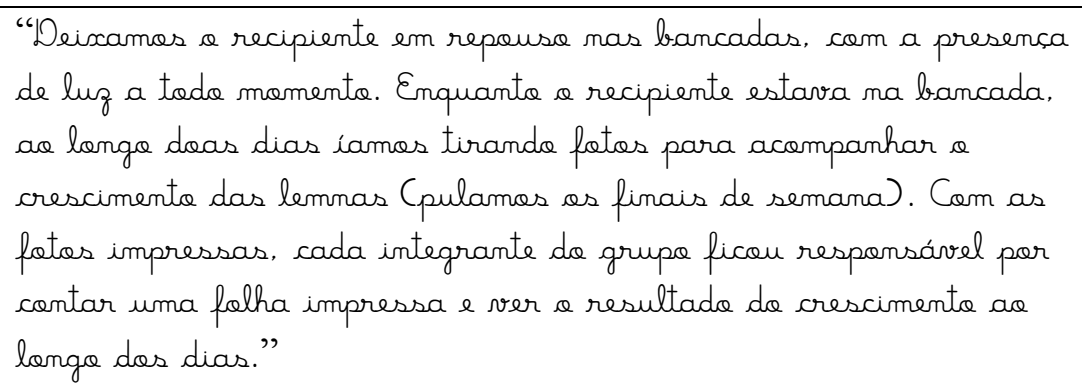 & & & $\mathbf{X}$ & & & & & & & & & \\
\hline
\end{tabular}


Thiago Marinho Del Corso

INDICADORES DE ALFABETIZAÇÃO CIENTÍFICA, ARGUMENTOS E EXPLICACÕES -

Análise de Relatórios no Contexto de uma Sequência de Ensino Investigativo

\begin{tabular}{|c|c|c|c|c|c|c|c|c|c|c|c|c|c|c|c|}
\hline 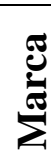 & $\begin{array}{l}\text { Subtítulo, } \\
\text { divisão ou } \\
\text { Item }\end{array}$ & \multicolumn{2}{|l|}{ Texto } & $\mathbf{L M}$ & SI & OI & CI & RL & $\mathbf{R P}$ & $\mathbf{L H}$ & $\mathbf{T H}$ & $\mathbf{J}$ & $\mathbf{P}$ & 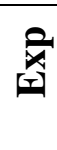 & $\sum^{\infty}$ \\
\hline 6 & $\begin{array}{l}\text { Resultados } \\
\text { (Resultados) } \\
\text { Gráfico }\end{array}$ & \multicolumn{2}{|c|}{ Resultadoos: } & & $\mathbf{X}$ & $\mathbf{X}$ & $\mathbf{X}$ & & & & & & & & \\
\hline 7 & Resultados & \multirow{3}{*}{\multicolumn{2}{|c|}{ 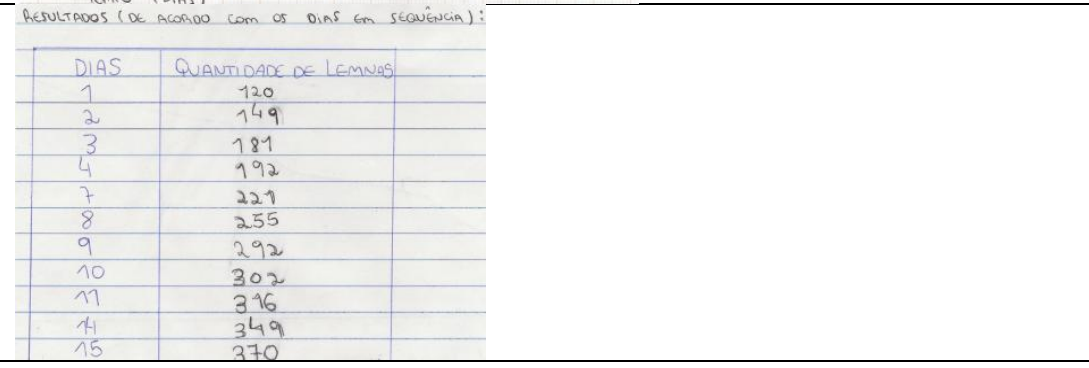 }} & & $\mathbf{X}$ & $\mathbf{X}$ & & & & & & & & & \\
\hline & (Resultadas) & & & & & & & & & & & & & & \\
\hline & Tabela & & & & & & & & & & & & & & \\
\hline 8 & $\begin{array}{l}\text { Interpretação } \\
\text { (Interpretaçãa) } \\
1^{\circ} \text { parágrafo }\end{array}$ & \multicolumn{2}{|c|}{ 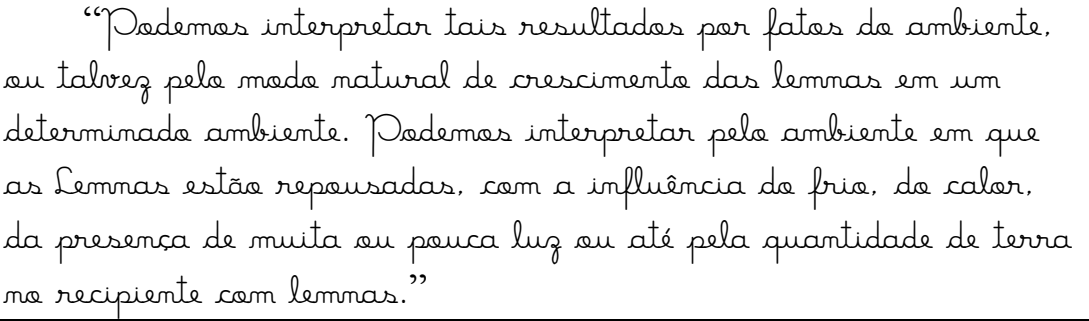 } & & & & & & & & & $\mathbf{X}$ & & & \\
\hline 9 & $\begin{array}{l}\text { Interpretação } \\
\text { (Interpretaçãa) } \\
2^{\circ} \text { parágrafo }\end{array}$ & \multicolumn{2}{|c|}{$\begin{array}{l}\text { "A autra forma em que podemas interpretar é pelo seu cursa } \\
\text { natural de crescimenta (das lemnas). independente do ambiente em } \\
\text { que está, precisanda apenas de terra e água." }\end{array}$} & & & & & & & & & $\mathbf{X}$ & & & \\
\hline
\end{tabular}


Thiago Marinho Del Corso

INDICADORES DE ALFABETIZAÇÃO CIENTÍFICA, ARGUMENTOS E EXPLICAÇÕES -

Análise de Relatórios no Contexto de uma Sequência de Ensino Investigativo

\begin{tabular}{|c|c|c|c|c|c|c|c|c|c|c|c|c|c|c|}
\hline 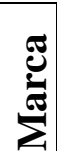 & $\begin{array}{l}\text { Subtítulo, } \\
\text { divisão ou } \\
\text { Item }\end{array}$ & Texto & $\mathbf{L M}$ & SI & OI & CI & $\mathbf{R L}$ & $\mathbf{R P}$ & $\mathbf{L H}$ & TH & $\mathbf{J}$ & $\bar{P}$ & & $\sum$ \\
\hline 10 & Conclusão 1 & 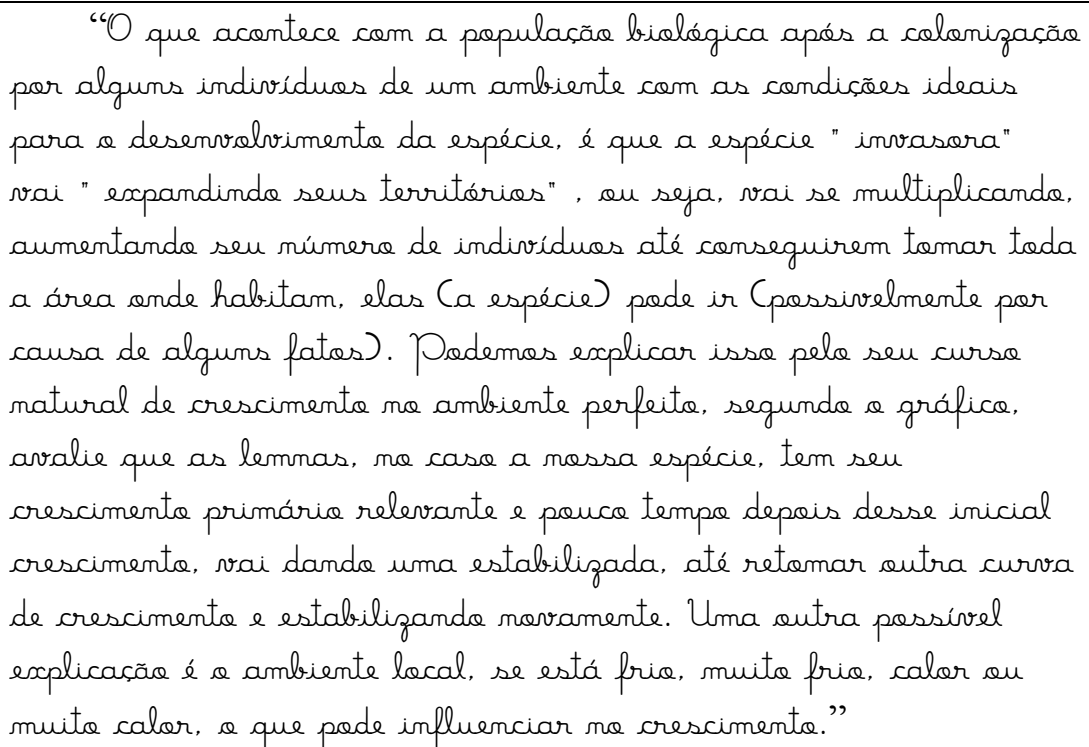 & & $\mathbf{X}$ & $\mathbf{X}$ & $\mathbf{X}$ & & & & & $\mathbf{X}$ & $\mathbf{X}$ & $Y$ & \\
\hline 11 & $\begin{array}{l}\text { Conclusão } 2 \\
1^{\circ} \text { parágrafo }\end{array}$ & $\begin{array}{l}\text { "Respondenda a pergunta inicial, a que acontece com a } \\
\text { populaçãa que é colonizada por individuas de um ambiente com } \\
\text { boas condisães, é a reproduçãa da espécie/a aumenta da espécie, } \\
\text { pois aquele ambiente oferece tuda a que ela precisa para ter um } \\
\text { bom desenvolvimenta." }\end{array}$ & & & & & & & & & $\mathbf{X}$ & $\mathbf{X}$ & & $\mathbf{X}$ \\
\hline 12 & $\begin{array}{l}\text { Conclusão } 2 \\
2^{\circ} \text { parágrafo }\end{array}$ & $\begin{array}{l}\text { "Coma mastra a gráfica, a cada dia que passa, aumenta um } \\
\text { tanta de individuas, nunca se estabiliza." }\end{array}$ & & & & & & & $\mathbf{X}$ & & & & & $\mathbf{X}$ \\
\hline
\end{tabular}


Thiago Marinho Del Corso

INDICADORES DE ALFABETIZAÇÃO CIENTÍFICA, ARGUMENTOS E EXPLICAÇÕES -

Análise de Relatórios no Contexto de uma Sequência de Ensino Investigativo

\section{O Relatório 17 - 2013}

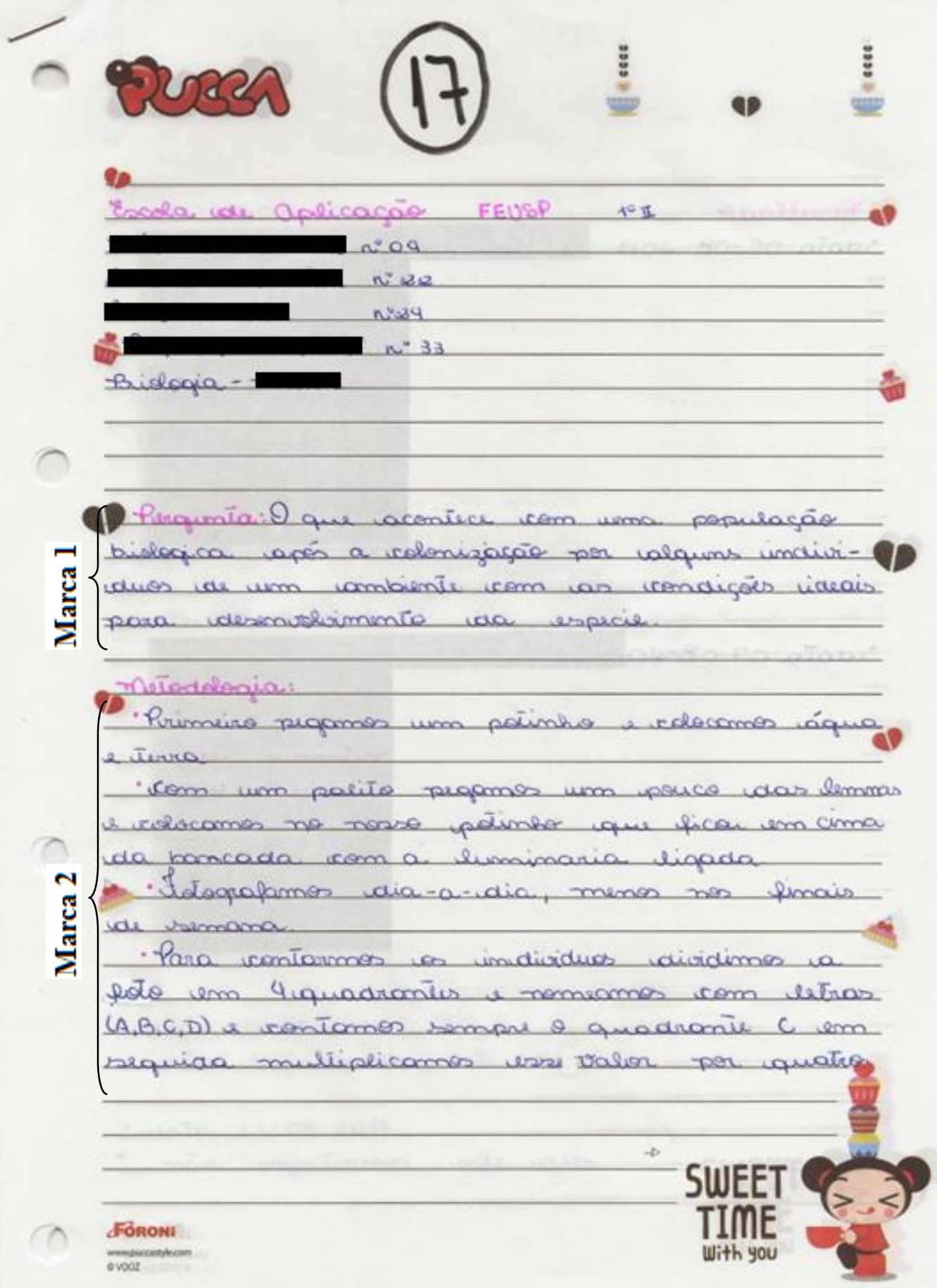


Thiago Marinho Del Corso

INDICADORES DE ALFABETIZAÇÃO CIENTÍFICA, ARGUMENTOS E EXPLICAÇÕES -

Análise de Relatórios no Contexto de uma Sequência de Ensino Investigativo

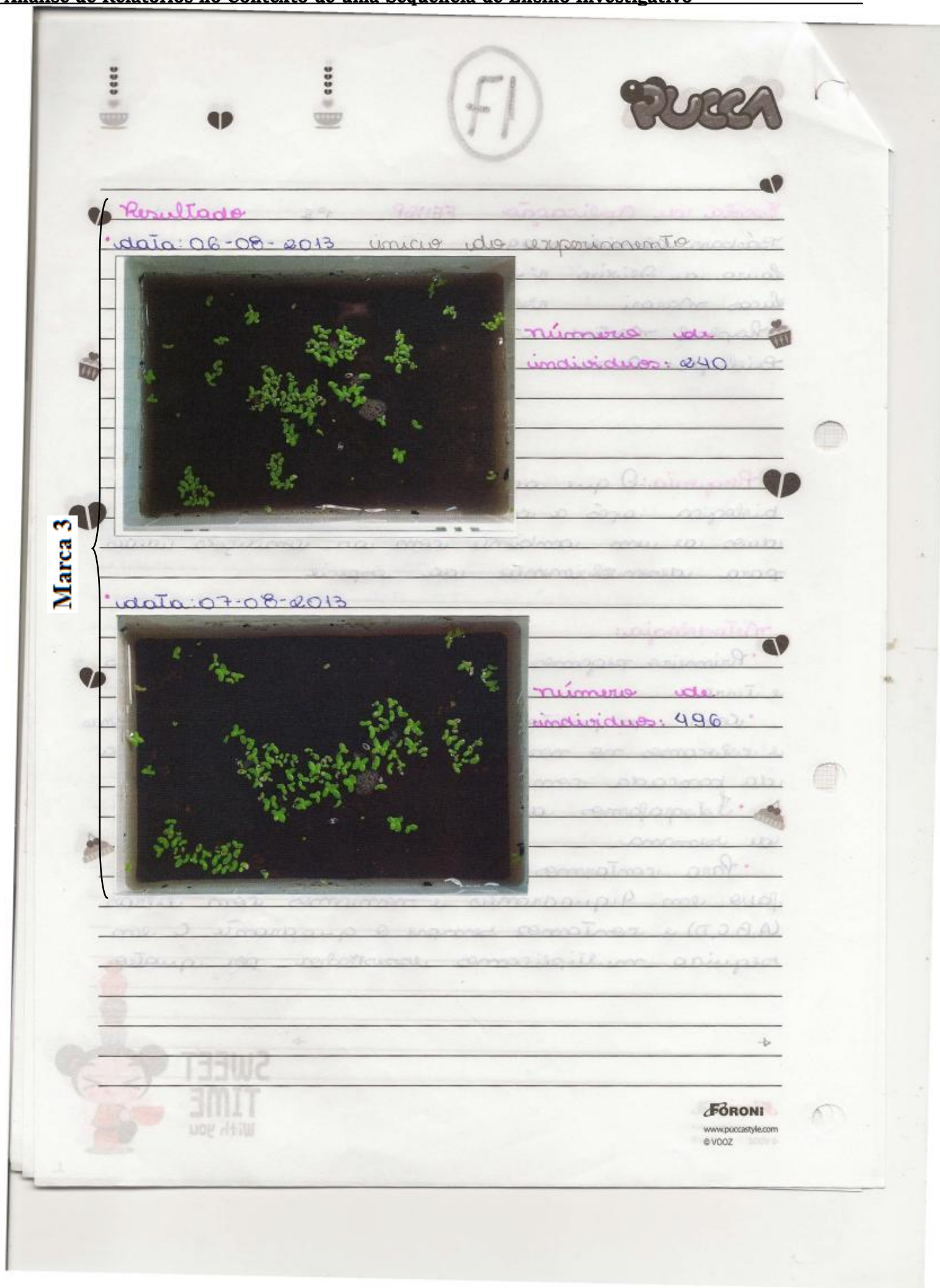


Thiago Marinho Del Corso

INDICADORES DE ALFABETIZAC̄ÃO CIENTÍFICA, ARGUMENTOS E EXPLICAÇÕES -

Análise de Relatórios no Contexto de uma Sequência de Ensino Investigativo

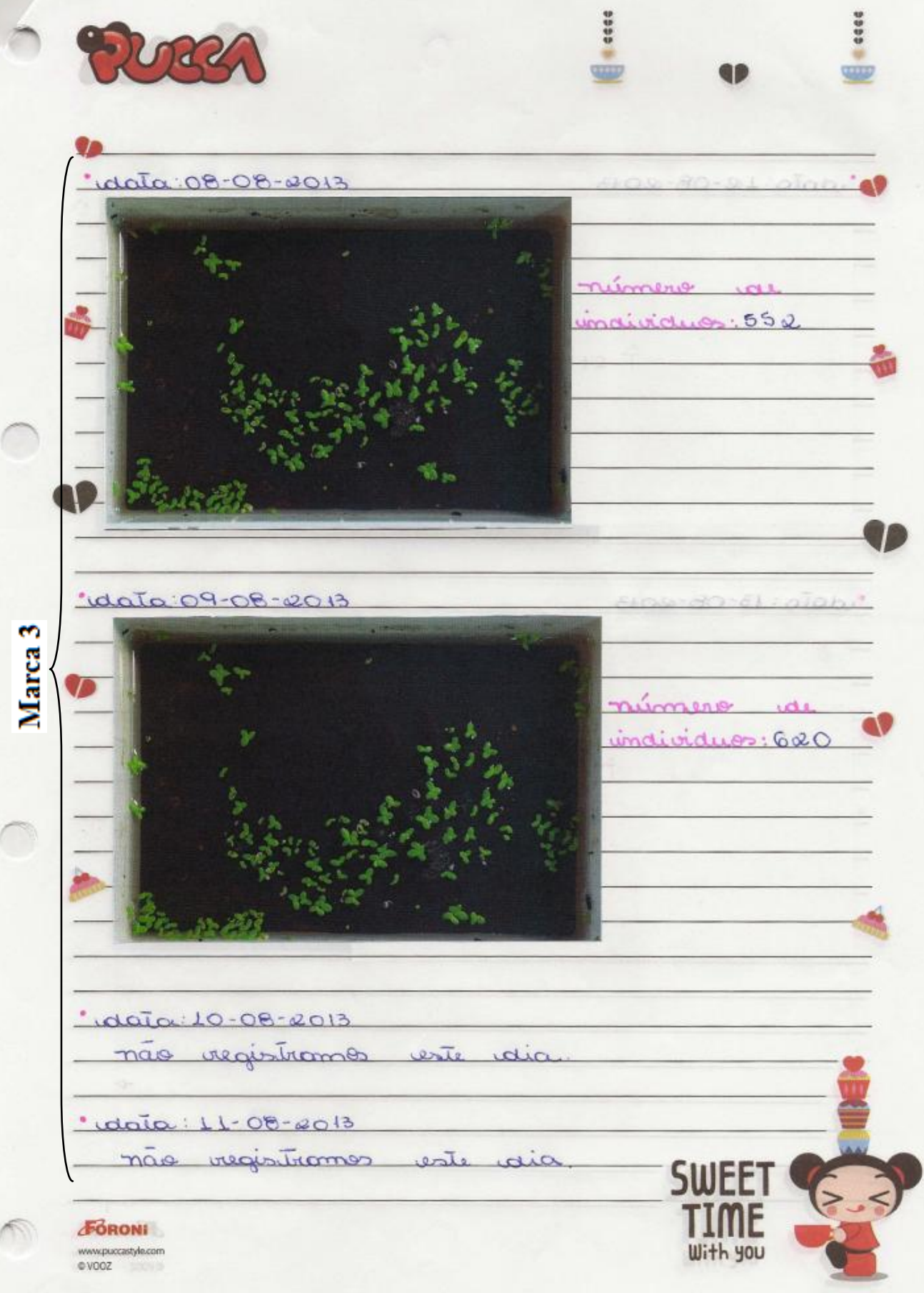


Thiago Marinho Del Corso

INDICADORES DE ALFABETIZAÇÃO CIENTÍFICA, ARGUMENTOS E EXPLICAÇÕES -

Análise de Relatórios no Contexto de uma Sequência de Ensino Investigativo

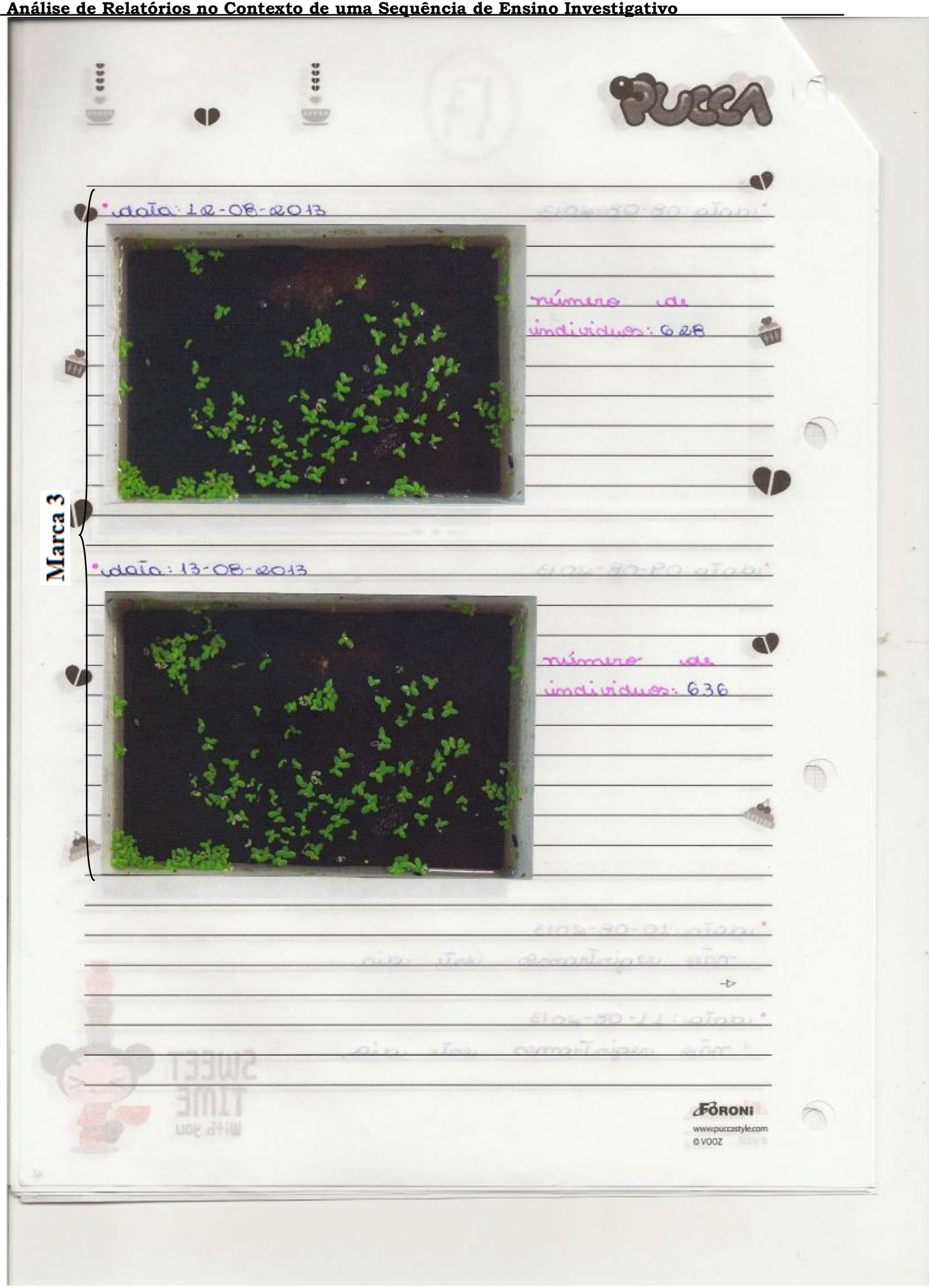


Thiago Marinho Del Corso

INDICADORES DE ALFABETIZAÇÃO CIENTÍFICA, ARGUMENTOS E EXPLICAÇÕES -

Análise de Relatórios no Contexto de uma Sequência de Ensino Investigativo
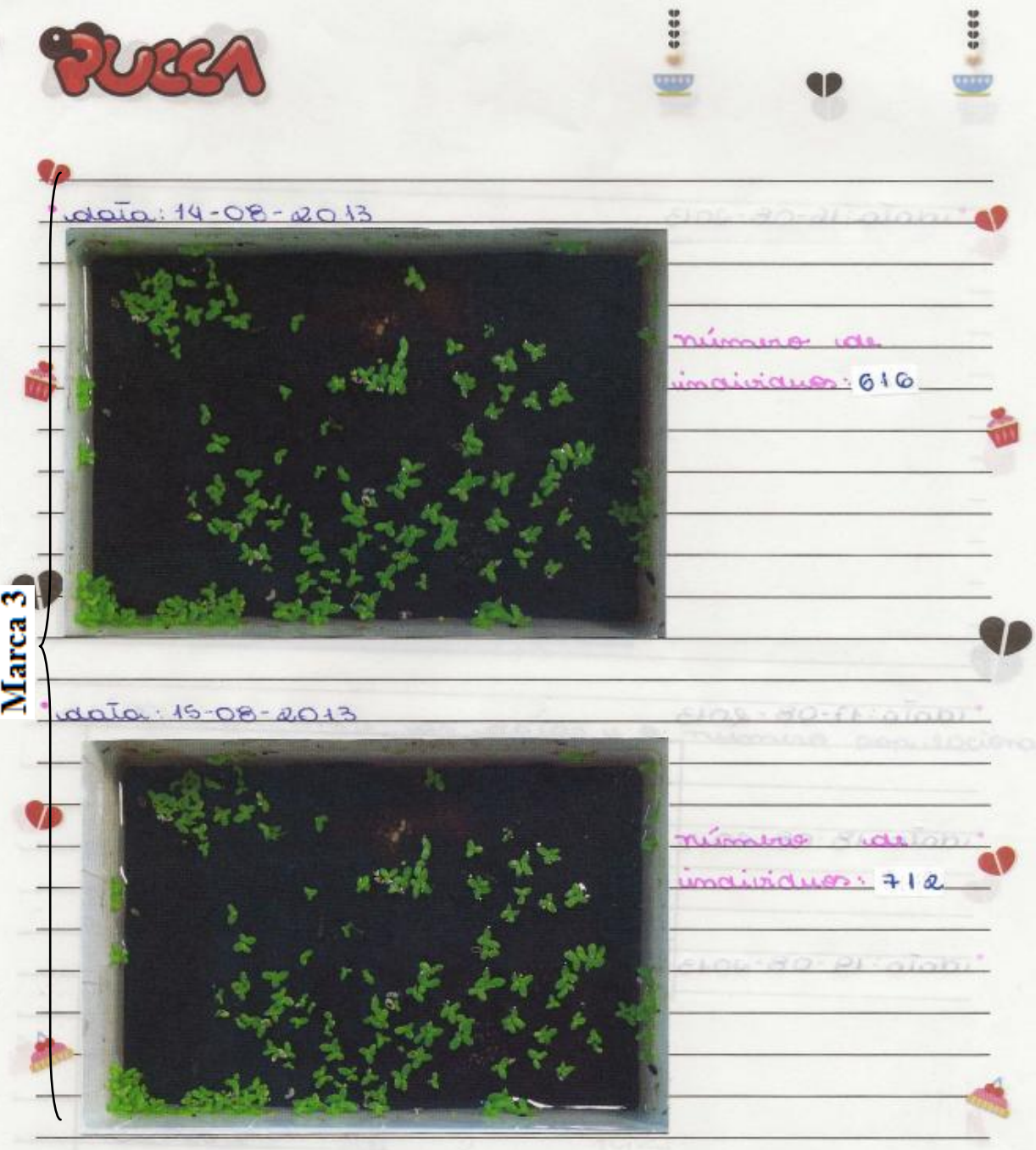
Thiago Marinho Del Corso

INDICADORES DE ALFABETIZAÇÃO CIENTÍFICA, ARGUMENTOS E EXPLICAÇÕES -

Análise de Relatórios no Contexto de uma Sequência de Ensino Investigativo

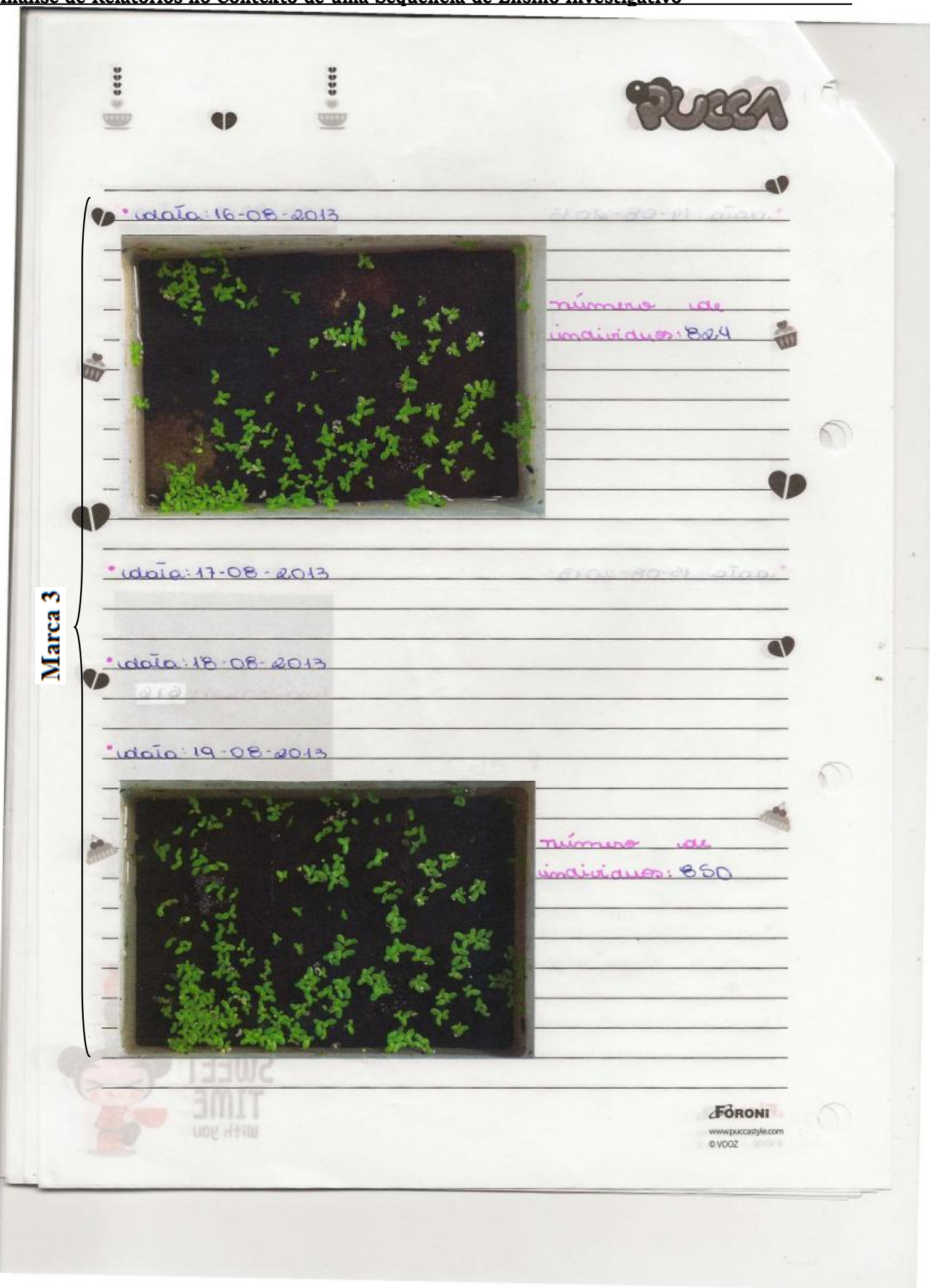


Thiago Marinho Del Corso

INDICADORES DE ALFABETIZAÇÃO CIENTÍFICA, ARGUMENTOS E EXPLICAÇÕES -

Análise de Relatórios no Contexto de uma Sequência de Ensino Investigativo
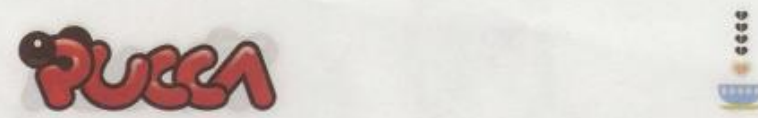

1
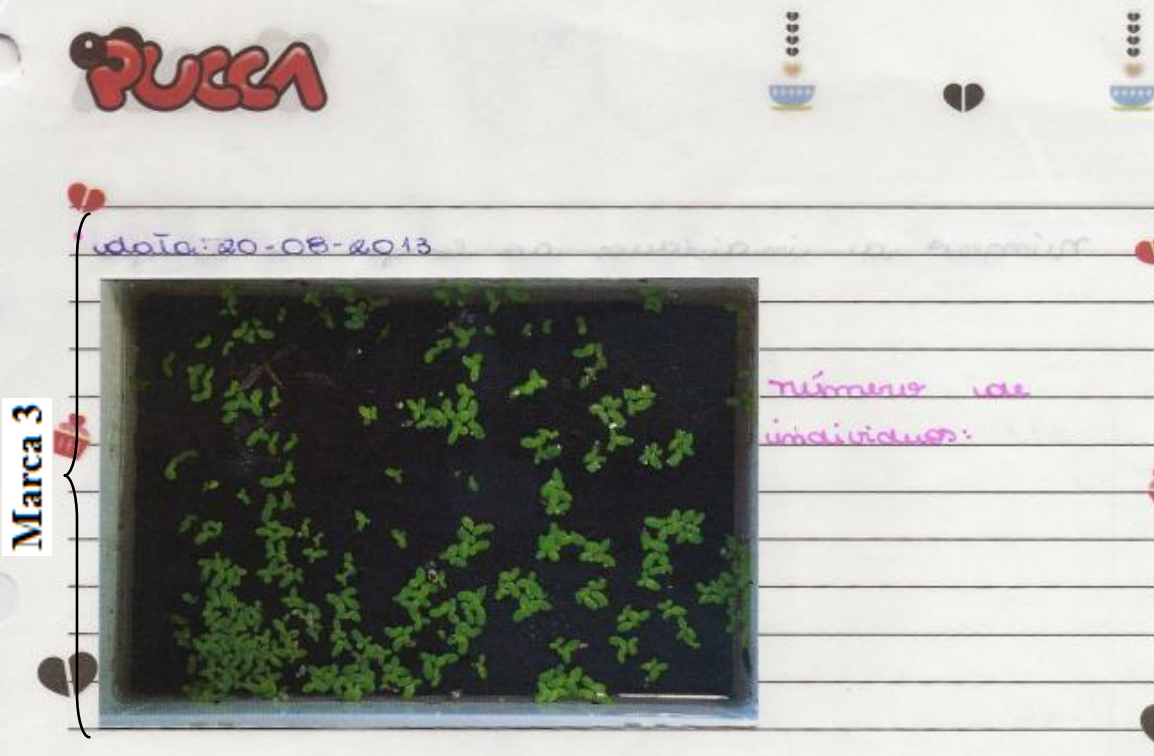

númene we

Ginclividues?

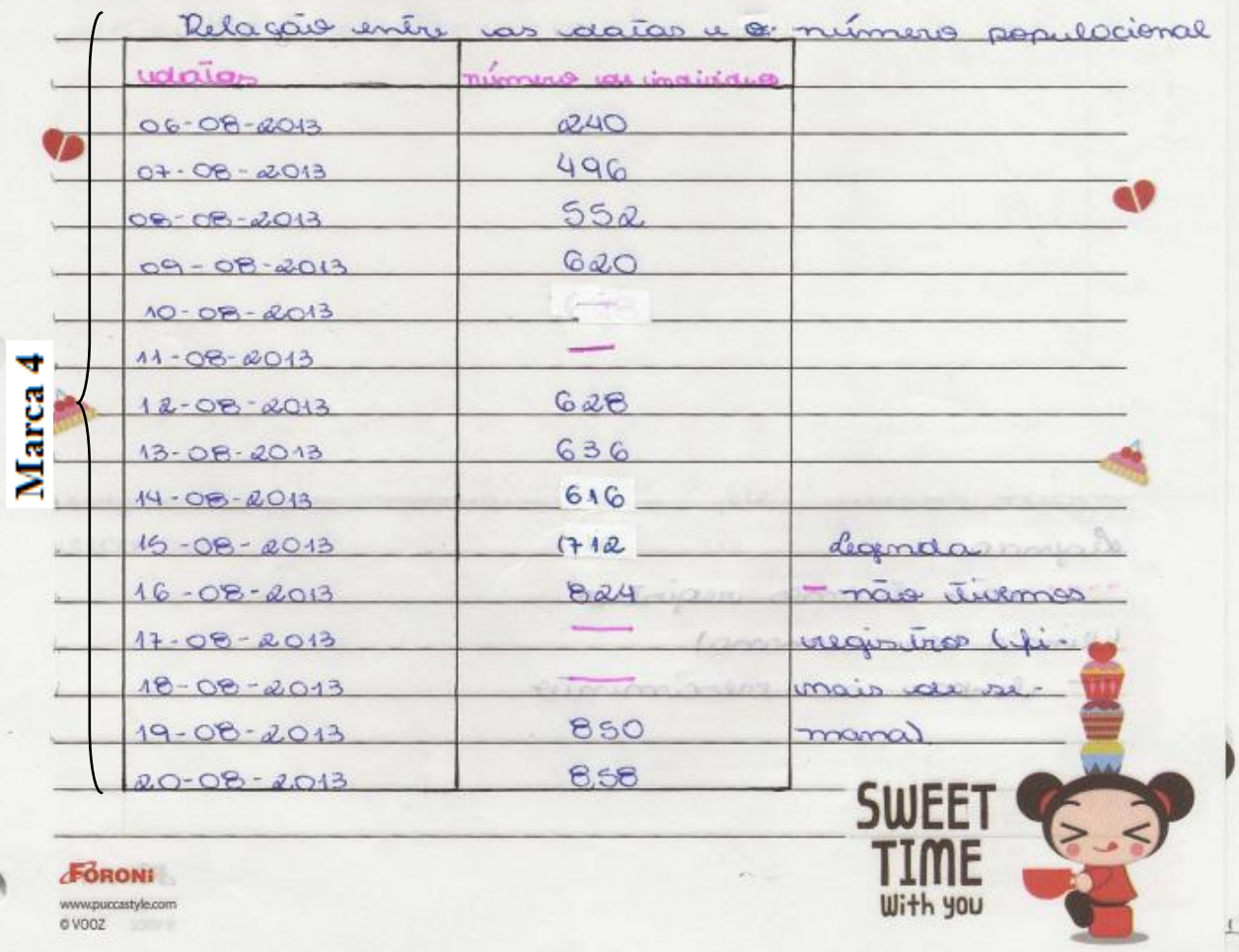


Thiago Marinho Del Corso

INDICADORES DE ALFABETIZAÇÃO CIENTÍFICA, ARGUMENTOS E EXPLICAÇÕES -

Análise de Relatórios no Contexto de uma Sequência de Ensino Investigativo

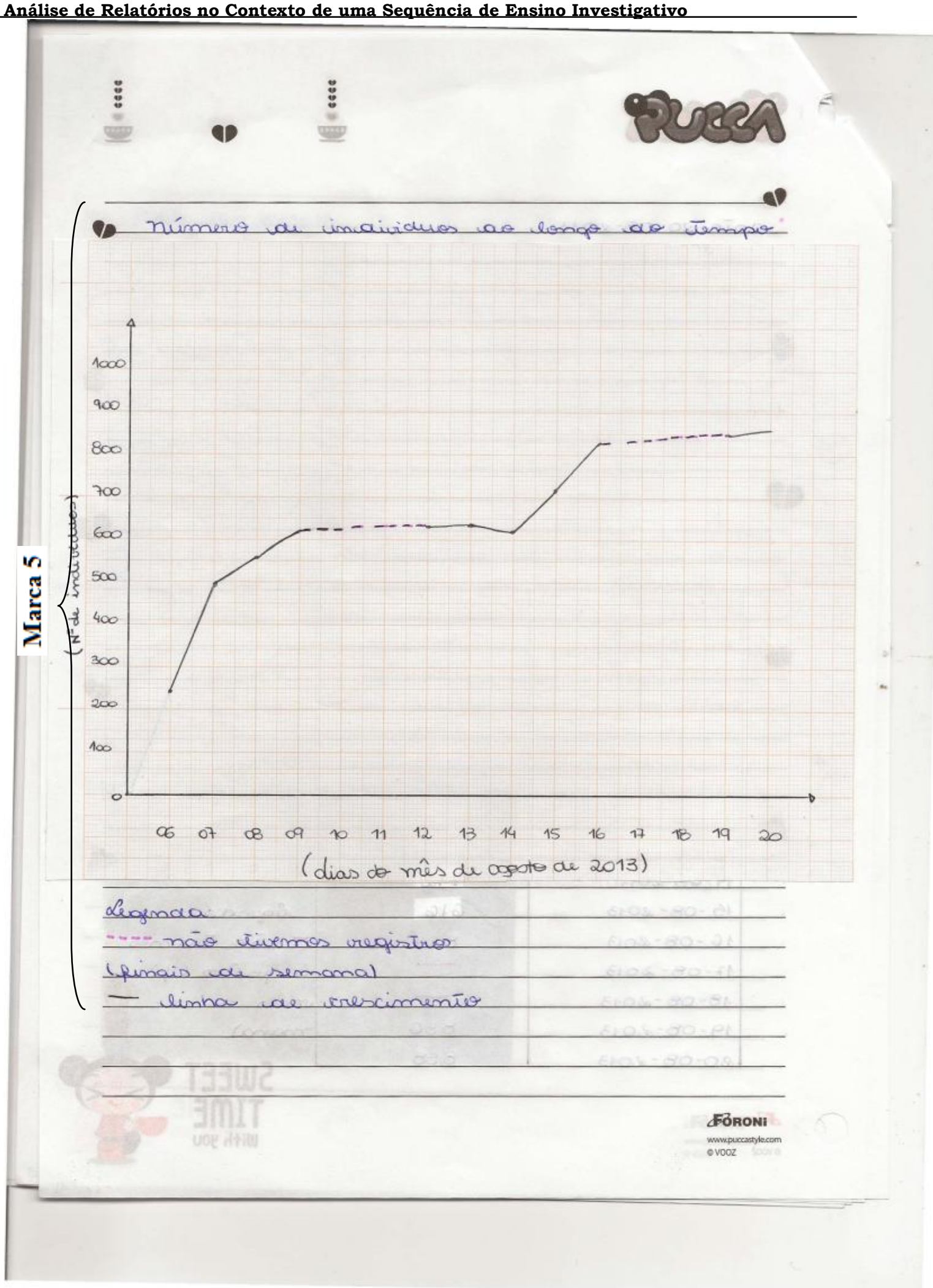




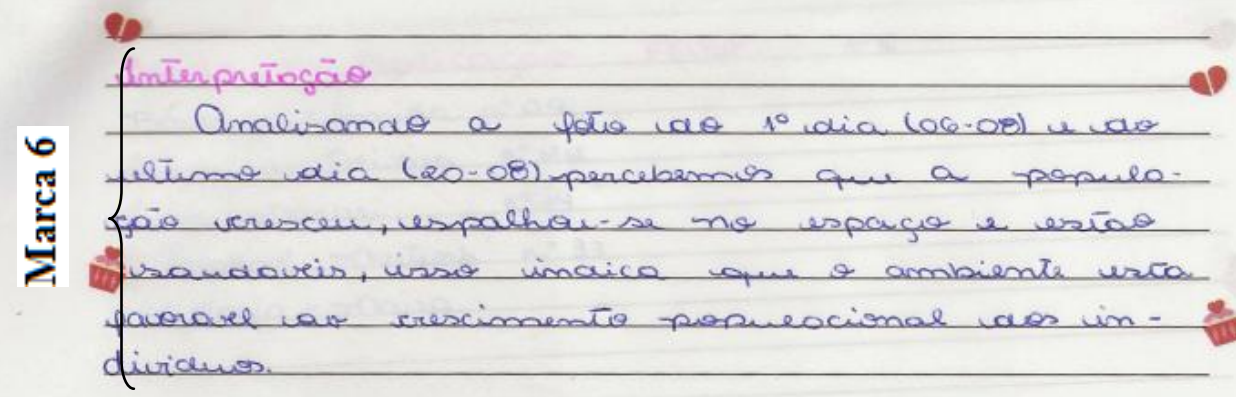

f Amalisando o grafico, dbosersamos qull ne

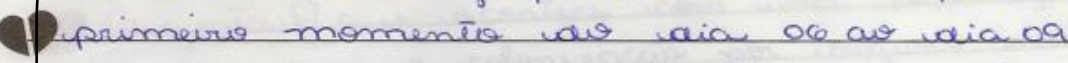
a ponsulogäo aumentou, poir timba concligües def erpago e de reproaucäar. No usequndi momento do dia 10 ao dia 12 nāo obtivenos dacus Uihais de usemano 1 , fá ne dia 12 ao 13 a populo- 
Thiago Marinho Del Corso

INDICADORES DE ALFABETIZAÇ̃̃O CIENTÍFICA, ARGUMENTOS E EXPLICAÇÕES -

Análise de Relatórios no Contexto de uma Sequência de Ensino Investigativo

Quadro 17

Identificação dos Indicadores de Alfabetização Científica no Relatório 17 de 2013 e conclusões individuais correspondentes

\begin{tabular}{|c|c|c|c|c|c|c|c|c|c|c|c|c|c|c|}
\hline 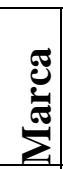 & $\begin{array}{l}\text { Subtítulo, } \\
\text { divisão ou } \\
\text { Item }\end{array}$ & Texto & $\mathbf{L M}$ & SI & OI & CI & $\mathbf{R L}$ & $\mathbf{R P}$ & $\mathbf{L H}$ & TH & $\mathbf{J}$ & $\mathbf{P}$ & & $\sum$ \\
\hline 1 & $\begin{array}{l}\text { Pergunta } \\
\text { (Pergunta) }\end{array}$ & $\begin{array}{l}\text { "O que acontece com uma papulaçãa bialógica após colonizaçãa par } \\
\text { alguns individuos de um ambiente com as condiçâes ideais para a } \\
\text { desenvolvimenta da espécie?" }\end{array}$ & Nãc & $\mathrm{o} \mathrm{av}$ & aliad & lo, te & xto & $\mathrm{da} \mathrm{pr}$ & rofes & ssora. & & & & \\
\hline 2 & $\begin{array}{l}\text { Metodologia } \\
\text { (Metodologia) }\end{array}$ & 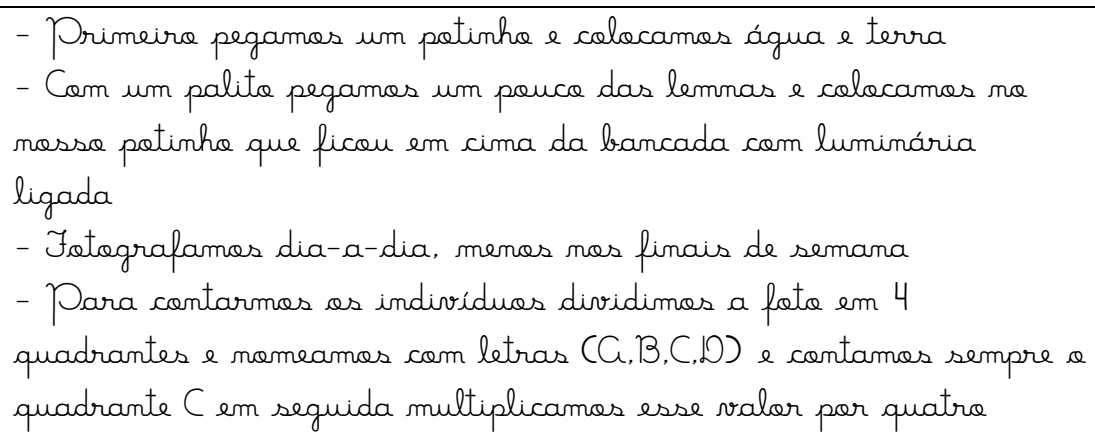 & $\mathbf{X}$ & & $\mathbf{X}$ & & & $\mathbf{X}$ & & & & & & \\
\hline 3 & $\begin{array}{l}\text { Resultados } \\
\text { (Resultados) } \\
\text { Fotos }\end{array}$ & 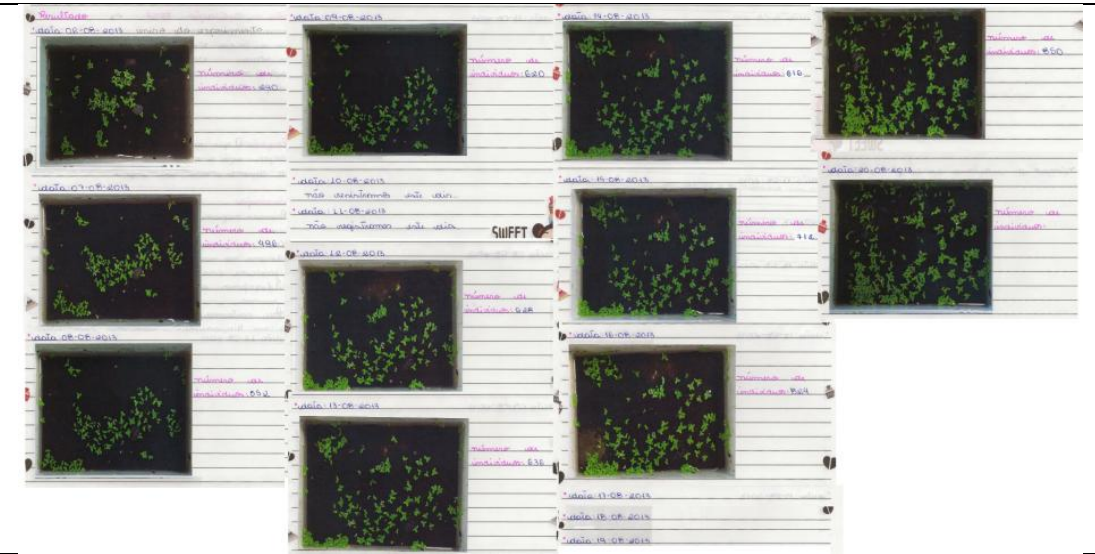 & & $\mathbf{X}$ & $\mathbf{X}$ & & & & & & & & & \\
\hline
\end{tabular}


Thiago Marinho Del Corso

INDICADORES DE ALFABETIZACÃO CIENTÍFICA, ARGUMENTOS E EXPLICACOÕES -

Análise de Relatórios no Contexto de uma Sequência de Ensino Investigativo

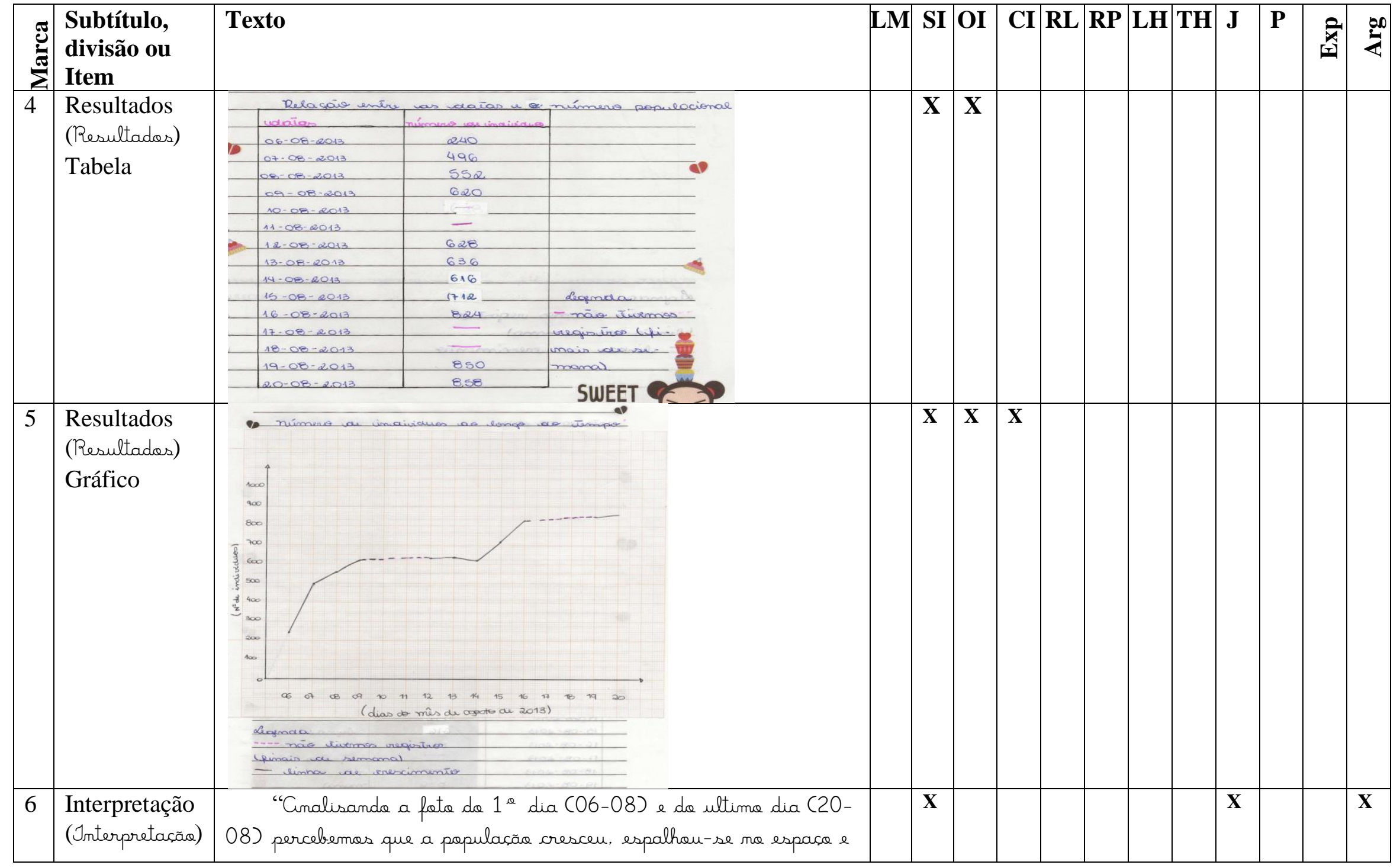


Thiago Marinho Del Corso

INDICADORES DE ALFABETIZAÇÃO CIENTÍFICA, ARGUMENTOS E EXPLICAÇÕES -

Análise de Relatórios no Contexto de uma Sequência de Ensino Investigativo

\begin{tabular}{|c|c|c|c|c|c|c|c|c|c|c|c|c|c|c|}
\hline & $1^{\circ}$ parágrafo & $\begin{array}{l}\text { estäa saudáveis, issa indica que a ambiente esta favorável ae } \\
\text { crescimenta populacional das individuas." }\end{array}$ & & & & & & & & & & & & \\
\hline 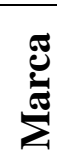 & $\begin{array}{l}\text { Subtítulo, } \\
\text { divisão ou } \\
\text { Item }\end{array}$ & Texto & $\mathbf{L M}$ & SI & OI & CI & RL & $\mathbf{R P}$ & $\mathbf{L H}$ & TH & $\mathbf{J}$ & $\mathbf{P}$ & $\underset{1}{2}$ & $\sum$ \\
\hline 7 & $\begin{array}{l}\text { Interpretação } \\
\text { (Interpretaçãa) } \\
2^{\circ} \text { parágrafo }\end{array}$ & 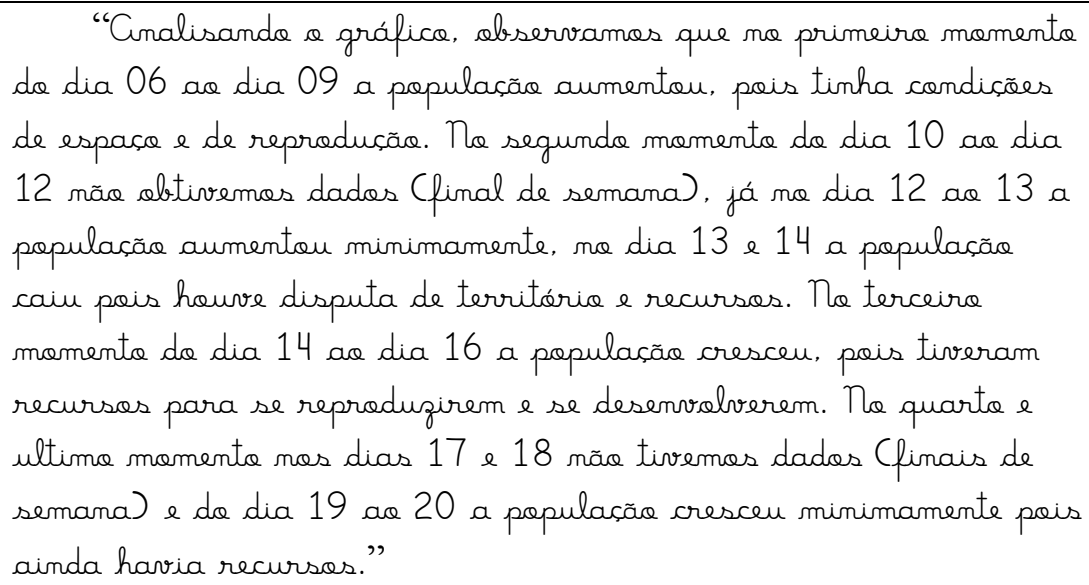 & & $\mathbf{X}$ & $\mathbf{X}$ & $\mathbf{X}$ & & & & & $\mathbf{X}$ & & & \\
\hline 8 & $\begin{array}{l}\text { Conclusão } \\
\text { individual } 1\end{array}$ & 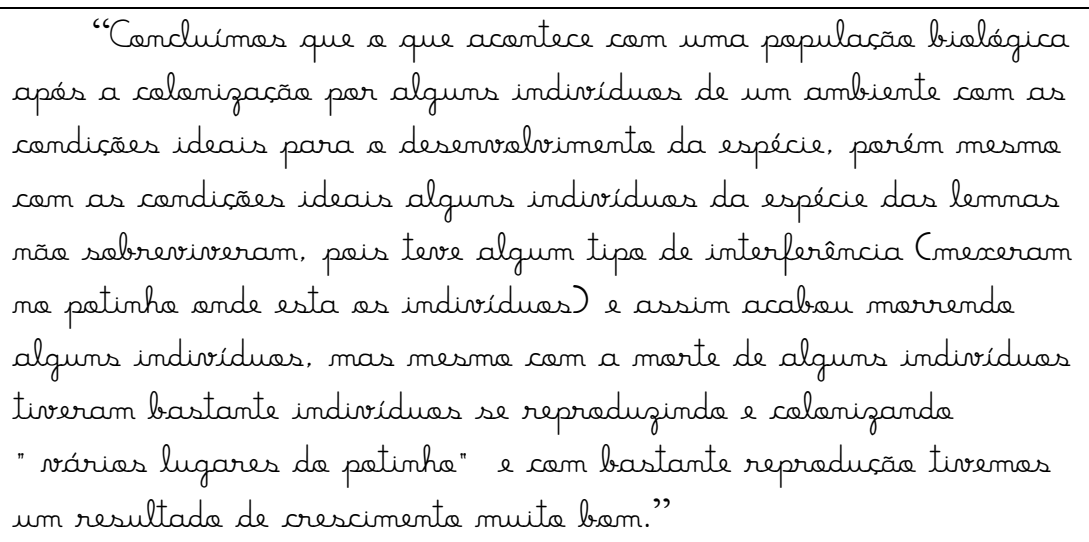 & & $\mathrm{X}$ & & $X$ & & & $\mathrm{X}$ & $\mathrm{X}$ & $X$ & & $X$ & \\
\hline
\end{tabular}


Thiago Marinho Del Corso

INDICADORES DE ALFABETIZAÇÃO CIENTÍFICA, ARGUMENTOS E EXPLICAÇÕES -

Análise de Relatórios no Contexto de uma Sequência de Ensino Investigativo

\begin{tabular}{|c|c|c|c|c|c|c|c|c|c|c|c|c|c|c|}
\hline 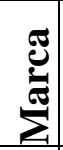 & $\begin{array}{l}\text { Subtítulo, } \\
\text { divisão ou } \\
\text { Item }\end{array}$ & Texto & $\mathbf{L M}$ & SI & OI & CI & RL & $\mathbf{R P}$ & $\mathbf{L H}$ & TH & $\mathbf{J}$ & $\mathbf{P}$ & $\underset{y}{a}$ & $\sum_{4}^{+\infty}$ \\
\hline 9 & $\begin{array}{l}\text { Conclusão } \\
\text { individual } 2 \\
1^{\circ} \text { parágrafo }\end{array}$ & 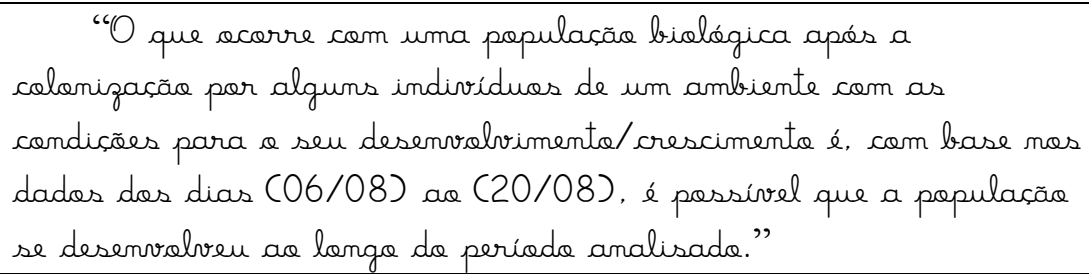 & & $\mathrm{X}$ & & & & & & & & & & $\mathrm{X}$ \\
\hline 10 & $\begin{array}{l}\text { Conclusão } \\
\text { individual } 2 \\
2^{\circ} \text { parágrafo }\end{array}$ & 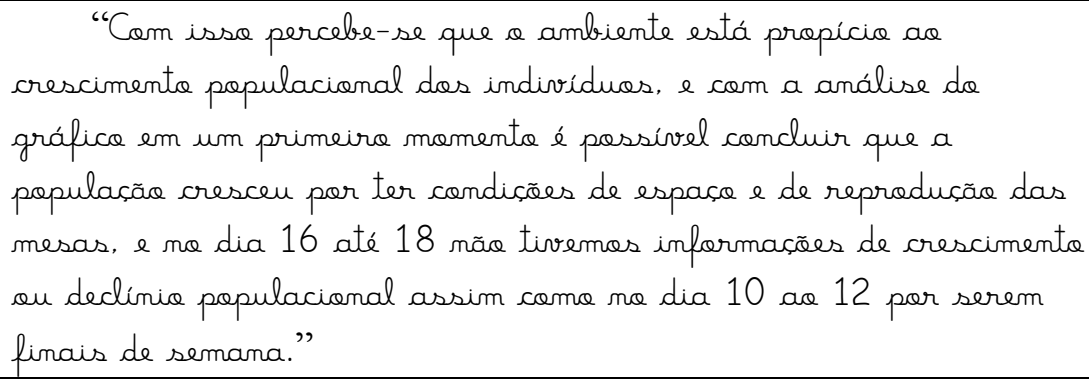 & & $\mathrm{X}$ & & & & & & & $\mathrm{X}$ & & & $X$ \\
\hline 11 & $\begin{array}{l}\text { Conclusão } \\
\text { individual } 2 \\
3^{\circ} \text { parágrafo }\end{array}$ & $\begin{array}{l}\text { "Senda assim, a que acarre com uma populaçãa bialágica em } \\
\text { um ambiente com plenas condiçäes de desenvolvimenta é um } \\
\text { crescimenta de alta escala com paucas chances de declinia." }\end{array}$ & & & & & & & & & & $X$ & & \\
\hline 12 & $\begin{array}{l}\text { Conclusão } \\
\text { individual } 3 \\
1^{\circ} \text { parágrafo }\end{array}$ & 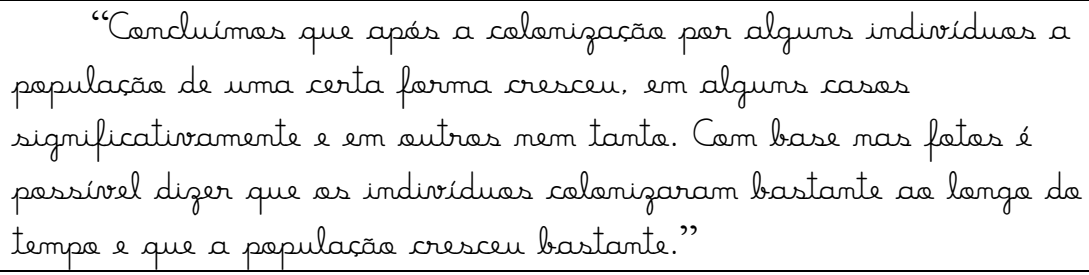 & & $\mathrm{X}$ & & $\mathrm{X}$ & & & & & & & & \\
\hline 13 & $\begin{array}{l}\text { Conclusão } \\
\text { individual } 3 \\
2^{\circ} \text { parágrafo }\end{array}$ & 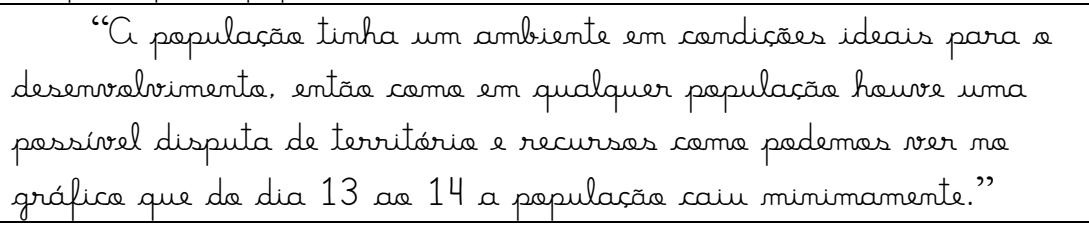 & & $\mathrm{X}$ & & $\mathrm{X}$ & & & & & $X$ & & & \\
\hline
\end{tabular}


Thiago Marinho Del Corso

INDICADORES DE ALFABETIZAÇÃO CIENTÍFICA, ARGUMENTOS E EXPLICAÇÕES -

Análise de Relatórios no Contexto de uma Sequência de Ensino Investigativo

\begin{tabular}{|c|c|c|c|c|c|c|c|c|c|c|c|c|c|c|}
\hline 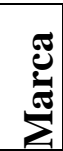 & $\begin{array}{l}\text { Subtítulo, } \\
\text { divisão ou } \\
\text { Item }\end{array}$ & Texto & $\mathbf{L M}$ & SI & OI & CI & RL & $\mathbf{R P}$ & $\mathbf{L H}$ & TH & $\mathbf{J}$ & $\mathbf{P}$ & & $\sum_{4}^{\infty}$ \\
\hline 14 & $\begin{array}{l}\text { Conclusão } \\
\text { individual } 3 \\
3^{\circ} \text { parágrafo }\end{array}$ & $\begin{array}{l}\text { "Entãa a papulaçãa com a colonizaçãa das individuas cresce, } \\
\text { se desenvolve e aumenta ar longa da tempa." }\end{array}$ & & & & & & & & & & $\mathrm{X}$ & & \\
\hline 15 & $\begin{array}{l}\text { Análise das } 3 \\
\text { marcas juntas } \\
\text { da conclusão } \\
\text { individual } 3\end{array}$ & 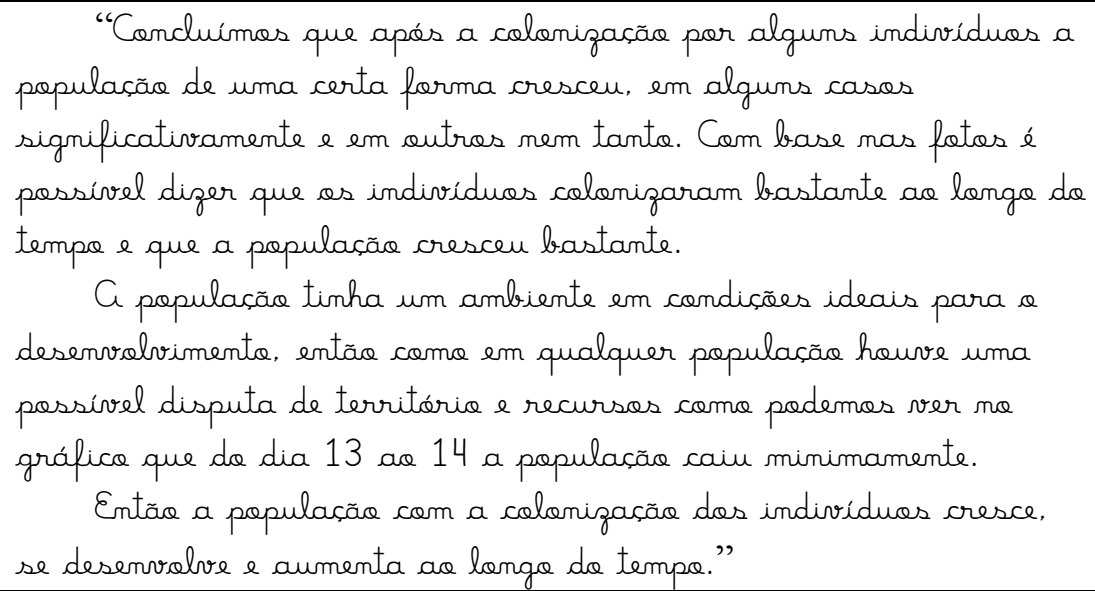 & & & & & & & & & & & & $X$ \\
\hline 16 & $\begin{array}{l}\text { Conclusão } \\
\text { individual } 4\end{array}$ & 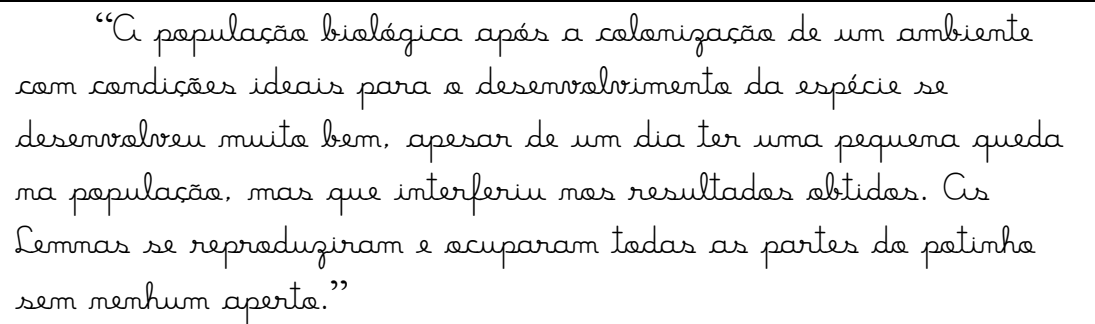 & & $X$ & & $\mathrm{X}$ & & & & & & & $\mathrm{X}$ & \\
\hline
\end{tabular}


Thiago Marinho Del Corso

INDICADORES DE ALFABETIZAÇÃO CIENTÍFICA, ARGUMENTOS E EXPLICAÇÕES -

Análise de Relatórios no Contexto de uma Sequência de Ensino Investigativo

\section{O Relatório 18 - 2013}

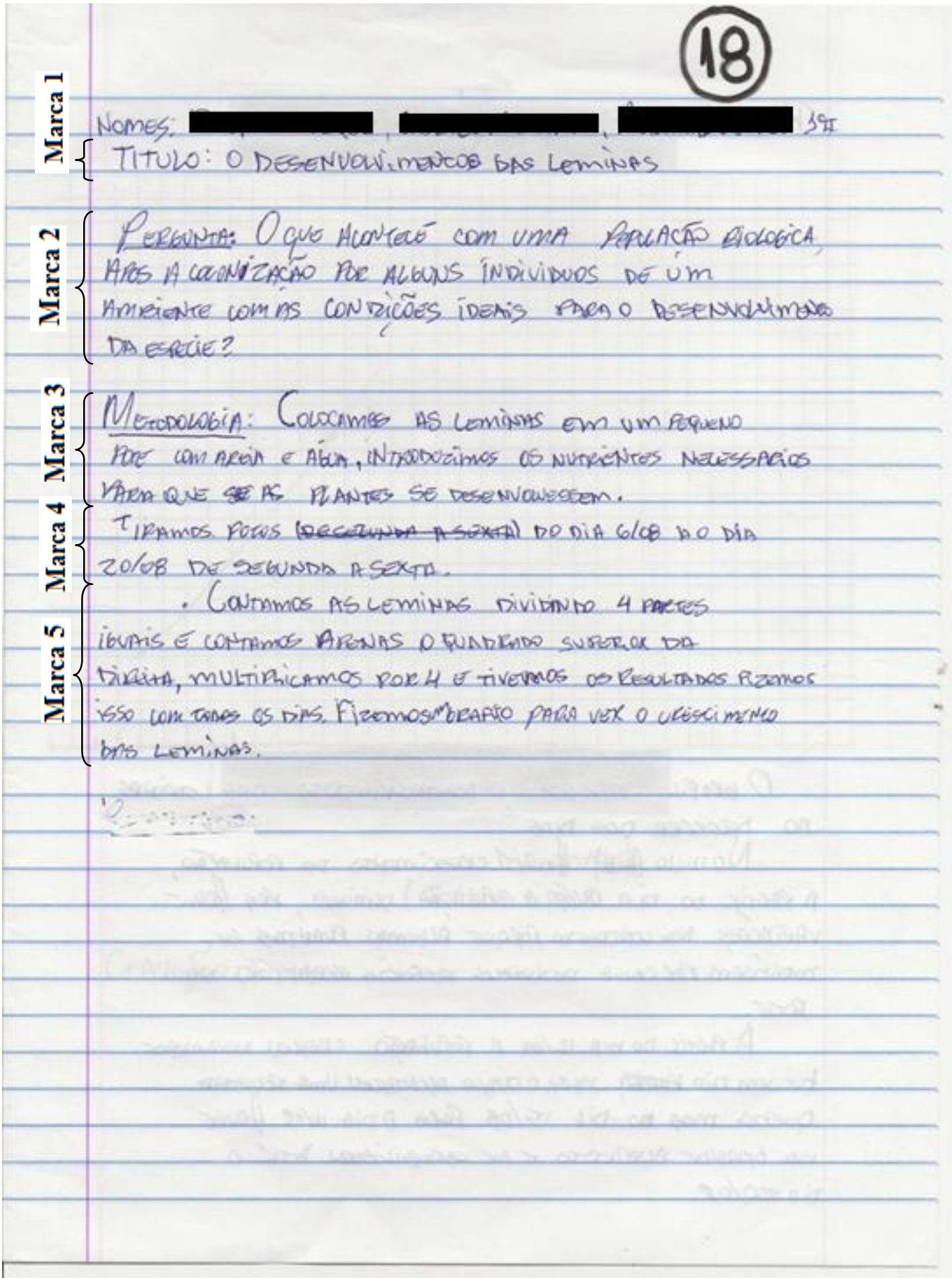


Thiago Marinho Del Corso

INDICADORES DE ALFABETIZAÇÃO CIENTÍFICA, ARGUMENTOS E EXPLICAÇÕES -

Análise de Relatórios no Contexto de uma Sequência de Ensino Investigativo

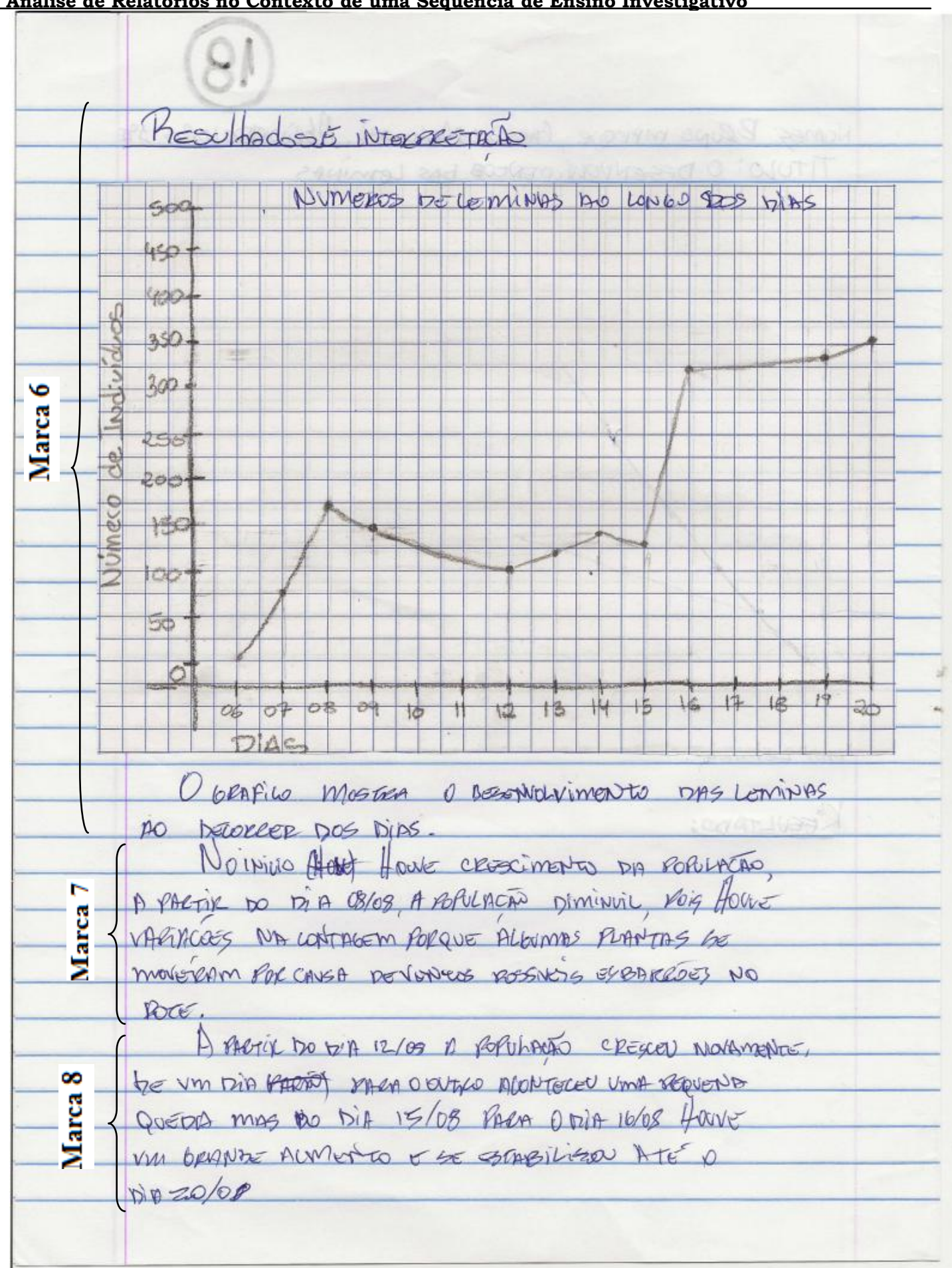


Thiago Marinho Del Corso

INDICADORES DE ALFABETIZAÇÃO CIENTÍFICA, ARGUMENTOS E EXPLICAÇÕES -

Análise de Relatórios no Contexto de uma Sequência de Ensino Investigativo

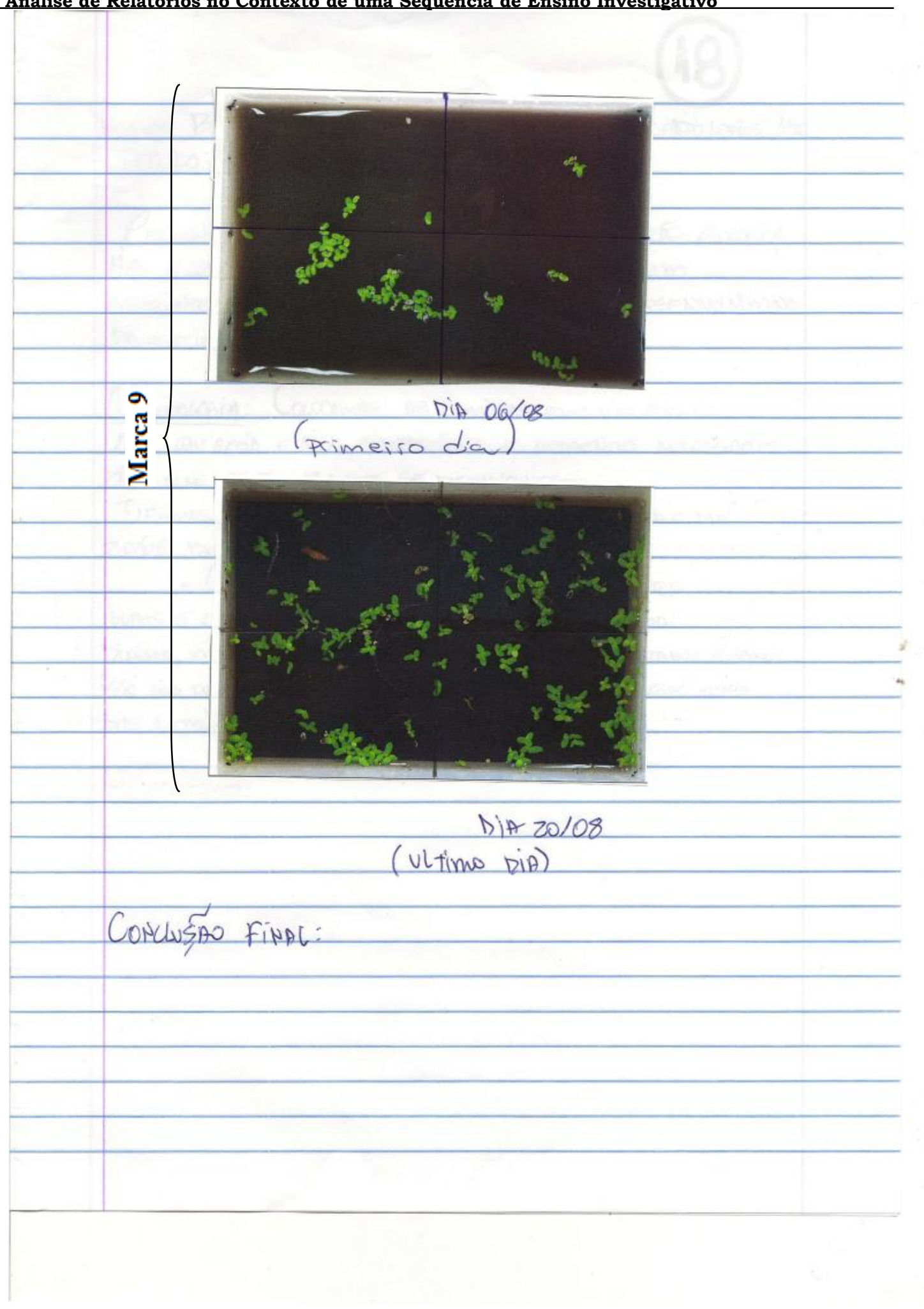


Thiago Marinho Del Corso

INDICADORES DE ALFABETIZAÇÃO CIENTÍFICA, ARGUMENTOS E EXPLICAÇÕES -

Análise de Relatórios no Contexto de uma Sequência de Ensino Investigativo

Quadro 18

Identificação dos Indicadores de Alfabetização Científica no Relatório 18 de 2013 e conclusões individuais correspondentes

\begin{tabular}{|c|c|c|c|c|c|c|c|c|c|c|c|c|c|c|}
\hline 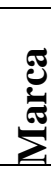 & $\begin{array}{l}\text { Subtítulo, } \\
\text { divisão ou } \\
\text { Item }\end{array}$ & Texto & $\mathbf{L M}$ & SI & $\mathbf{O I}$ & $\mathbf{C I}$ & $\mathbf{R L}$ & $\mathbf{R P}$ & $\mathbf{L H}$ & TH & $\mathbf{J}$ & $\mathbf{P}$ & 弐 & $\underset{Z}{20}$ \\
\hline 1 & Titulo & "O desenvalvimenta das Lemmas" & & & & & & & & & & & & \\
\hline 2 & Pergunta & $\begin{array}{l}\text { "O que acontece com uma papulaçãa bialógica após a calonizaçãa } \\
\text { par alguns individuas de um ambiente com as condiçães ideais } \\
\text { para desenvolvimenta da espécie?" }\end{array}$ & \multicolumn{12}{|c|}{ Não avaliado, texto da professora. } \\
\hline 3 & $\begin{array}{l}\text { Metodologia } \\
\text { (Metodologia) } \\
1^{\circ} \text { parágrafo }\end{array}$ & $\begin{array}{l}\text { "Colacamos as lemnas em um pequena pote com areia e água. } \\
\text { Introduzimas as nutrientes necessários para que as plantas se } \\
\text { desenvolvessem." }\end{array}$ & $\mathbf{X}$ & & $\mathbf{X}$ & & & & & & & & & \\
\hline 4 & $\begin{array}{l}\text { Metodologia } \\
\text { (Metodologia) } \\
2^{\circ} \text { parágrafo }\end{array}$ & "Firames fotos do dia 6/08 ae dia 20/08 de segunda a sexta." & & & $\mathbf{X}$ & & & & & & & & & \\
\hline 5 & $\begin{array}{l}\text { Metodologia } \\
\text { (metodalogia) } \\
3^{\circ} \text { parágrafo }\end{array}$ & $\begin{array}{l}\text { "Contamas as lemnas dividinda } 4 \text { partes iguais e contamas apenas } \\
\text { a quadrada superior da direita, multiplicamas por } 4 \text { e tivemas as } \\
\text { resultados. Fizemos issa com tados as dias. Figemas um gráfica } \\
\text { para ver a crescimenta das lemnas." }\end{array}$ & & & $\mathbf{X}$ & & & & & & & & & \\
\hline
\end{tabular}


Thiago Marinho Del Corso

INDICADORES DE ALFABETIZACCÁO CIENTÍFICA, ARGUMENTOS E EXPLICAÇÕES -

Análise de Relatórios no Contexto de uma Sequência de Ensino Investigativo

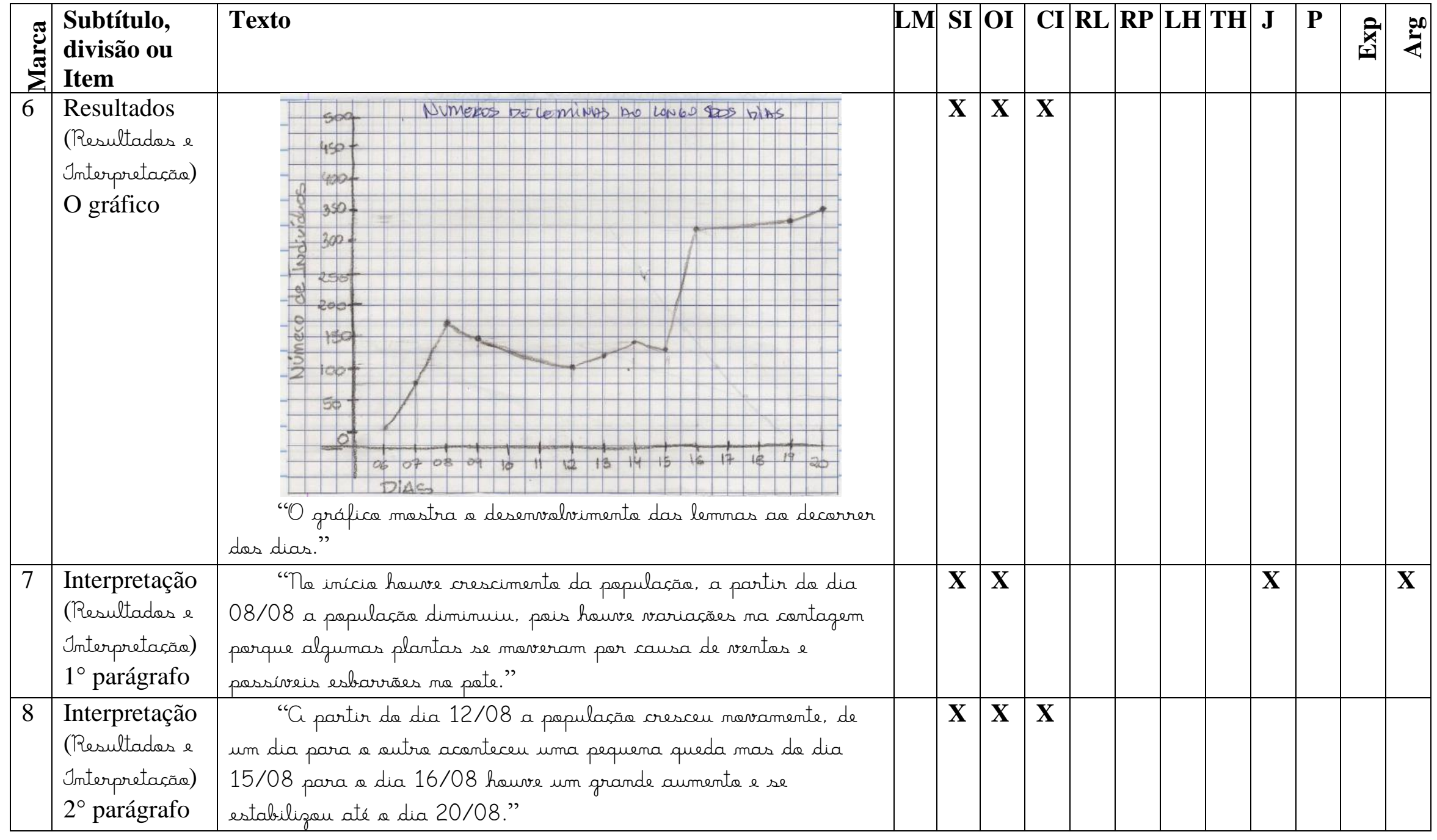


Thiago Marinho Del Corso

INDICADORES DE ALFABETIZAC̄̃o CIENTÍFICA, ARGUMENTOS E EXPLICAÇÕES -

Análise de Relatórios no Contexto de uma Sequência de Ensino Investigativo

\begin{tabular}{|c|c|c|c|c|c|c|c|c|c|c|c|c|c|c|}
\hline 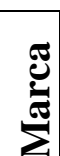 & $\begin{array}{l}\text { Subtítulo, } \\
\text { divisão ou } \\
\text { Item }\end{array}$ & Texto & $\mathbf{L M}$ & SI & OI & CI & $\mathbf{R L}$ & RP & LH & TH & $\mathbf{J}$ & $\mathbf{P}$ & 斑 & $\sum_{4}^{\infty}$ \\
\hline 9 & $\begin{array}{l}\text { Resultados } \\
\text { (Resultados e } \\
\text { Interpretaçãa) } \\
\text { Figuras }\end{array}$ & 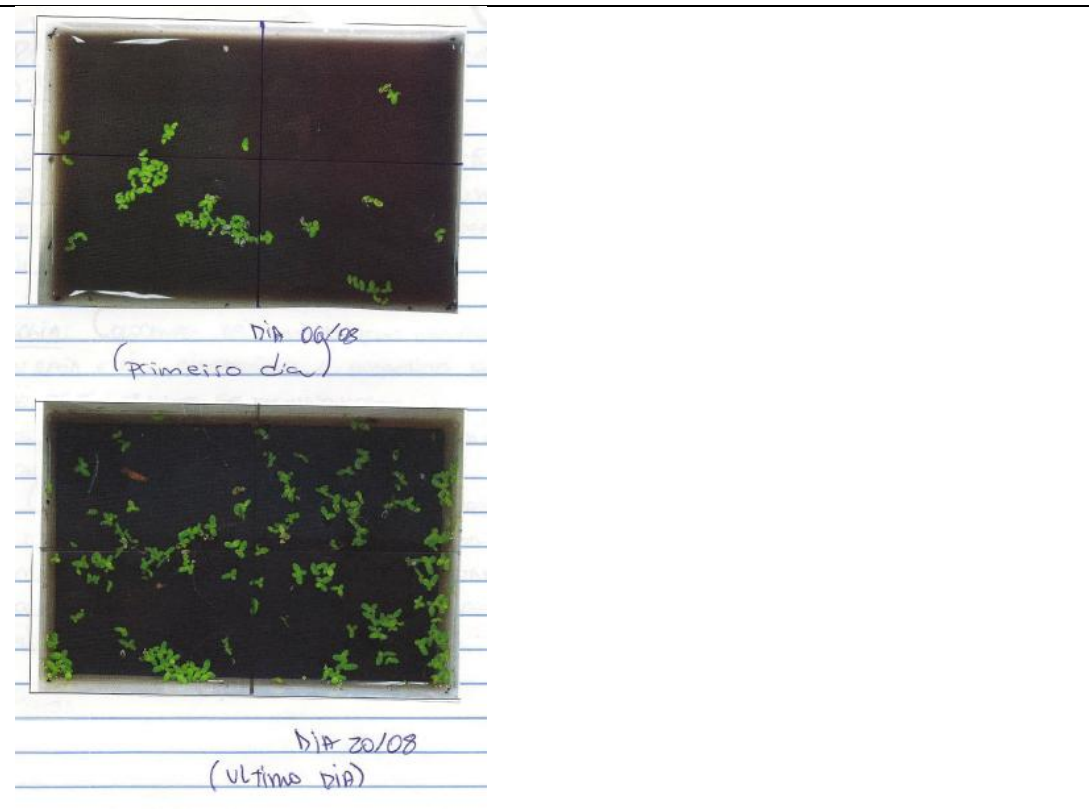 & & & & & & & & & & & & \\
\hline 10 & $\begin{array}{l}\text { Conclusão } \\
\text { individual } 1 \\
1^{\circ} \text { parágrafo }\end{array}$ & $\begin{array}{l}\text { "A populaçãa consegue se reproduzir e aumentar a númera de } \\
\text { individuas, acontecem muitas variacões durante a pesquisa, mas } \\
\text { conseguem aumentar sua populaçãa." }\end{array}$ & & $\mathbf{X}$ & & & & & & & & $\mathbf{X}$ & & \\
\hline 11 & $\begin{array}{l}\text { Conclusão } \\
\text { individual } 1 \\
2^{\circ} \text { parágrafo }\end{array}$ & 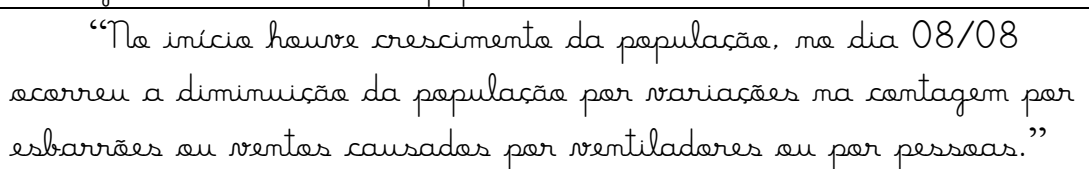 & & $\mathbf{X}$ & $\mathbf{X}$ & & & & & & $\mathbf{X}$ & & & $\mathbf{X}$ \\
\hline 12 & $\begin{array}{l}\text { Conclusão } \\
\text { individual } 1 \\
3^{\circ} \text { parágrafo }\end{array}$ & $\begin{array}{l}\text { "O dia } 12 / 08 \text { a papulaçãa voltau a crescer de um dia para a } \\
\text { autra houve queda mas no dia 15/08 para 16/08 ocorreu um } \\
\text { grande aumenta que se estabilizau até a dia 20/08." }\end{array}$ & & $\mathbf{X}$ & $\mathbf{X}$ & $\mathbf{X}$ & & & & & & & & \\
\hline
\end{tabular}


Thiago Marinho Del Corso

INDICADORES DE ALFABETIZAÇÃO CIENTÍFICA, ARGUMENTOS E EXPLICAÇÕES -

Análise de Relatórios no Contexto de uma Sequência de Ensino Investigativo

\begin{tabular}{|c|c|c|c|c|c|c|c|c|c|c|c|c|c|c|}
\hline 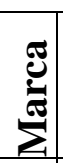 & $\begin{array}{l}\text { Subtítulo, } \\
\text { divisão ou } \\
\text { Item }\end{array}$ & Texto & $\mathbf{L M}$ & SI & OI & CI & $\mathbf{R L}$ & $\mathbf{R P}$ & $\mathbf{L H}$ & TH & $\mathbf{J}$ & $\mathbf{P}$ & 死 & $\sum^{00}$ \\
\hline 13 & $\begin{array}{l}\text { Conclusão } \\
\text { individual } 1 \\
4^{\circ} \text { parágrafo }\end{array}$ & $\begin{array}{l}\text { "Issa mastra que as plantas crescem bem com variaçäes nos } \\
\text { resultados por problemas de contagem, mas no final voltam a } \\
\text { crescer" }\end{array}$ & & $\mathbf{X}$ & $\mathbf{X}$ & $\mathbf{X}$ & & & & & $\mathbf{X}$ & $\mathbf{X}$ & & \\
\hline 14 & \begin{tabular}{|l} 
Conclusão \\
individual 2
\end{tabular} & 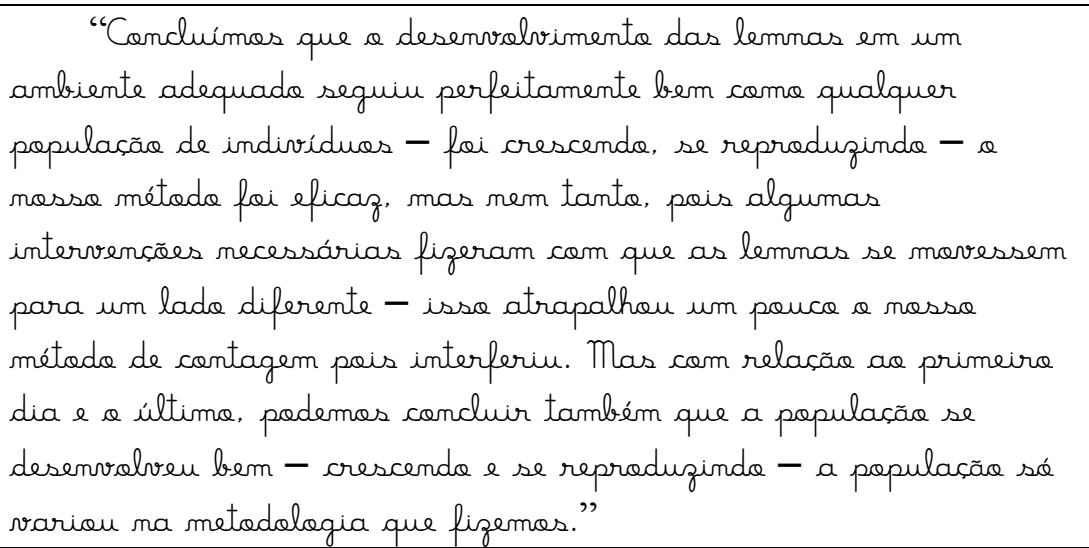 & & $\mathbf{X}$ & $\mathbf{X}$ & $\mathbf{X}$ & & & & & $\mathbf{X}$ & $\mathbf{X}$ & $\mathbf{X}$ & \\
\hline 15 & $\begin{array}{l}\text { Conclusão } \\
\text { individual } 3 \\
1^{\circ} \text { parágrafo }\end{array}$ & $\begin{array}{l}\text { "Olhanda a gráfica e fazenda as análises, pode-se concluir } \\
\text { que nas } 3 \text { primeiras dias as lemnas cresceram em um grande } \\
\text { númera. Hauve variacões, mas no fim a grupo populacional de } \\
\text { lemnas cresceu, chegamas a até } 350 \text { a } 400 \text { individuos } \\
\text { apraximadamente." }\end{array}$ & & $\mathbf{X}$ & $\mathbf{X}$ & $\mathbf{X}$ & & & & & & & & \\
\hline 16 & $\begin{array}{l}\text { Conclusão } \\
\text { individual } 3 \\
2^{\circ} \text { parágrafo }\end{array}$ & $\begin{array}{l}\text { "Entãa mesma com as variasães ocorreu a esperado de que as } \\
\text { individuas iriam crescer." }\end{array}$ & & & & & & & $\mathbf{X}$ & $\mathbf{X}$ & & & & \\
\hline
\end{tabular}


Análise de Relatórios no Contexto de uma Sequência de Ensino Investigativo

Quadro 19 - Identificação dos Indicadores de Alfabetização Científica no Relatório 18 de 2013 e conclusões individuais correspondentes

\begin{tabular}{|c|c|c|c|c|c|c|c|c|c|c|c|c|c|c|}
\hline 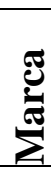 & $\begin{array}{l}\text { Subtítulo, } \\
\text { divisão ou } \\
\text { Item }\end{array}$ & Texto & $\mathbf{L M}$ & SI & OI & CI & $\mathbf{R L}$ & RP & $\mathbf{L H}$ & TH & $\mathbf{J}$ & $\mathbf{P}$ & $\underset{x}{a}$ & $\sum^{00}$ \\
\hline 1 & Titulo & "O desenvolvimenta das Lemnas" & & & & & & & & & & & & \\
\hline 2 & Pergunta & $\begin{array}{l}\text { "O que acontece com uma papulaçãa bialágica apás a colonizaçãa } \\
\text { por alguns individuas de um ambiente com as condiçäes ideais } \\
\text { para desenvolvimenta da espécie?" }\end{array}$ & Nã & $\mathrm{o}$ av & aliac & $\mathrm{o}, \mathrm{te}$ & exto & da $\mathrm{pr}$ & rofes & sora. & & & & \\
\hline 3 & $\begin{array}{l}\text { Metodologia } \\
\text { (Metodologia) } \\
1^{\circ} \text { parágrafo }\end{array}$ & $\begin{array}{l}\text { "Colocamos as lemnas em um pequence pote com areia e água. } \\
\text { Introduzimas as nutrientes necessários para que as plantas se } \\
\text { desenvolvessem." }\end{array}$ & $\mathbf{X}$ & & $\mathbf{X}$ & & & & & & & & & \\
\hline 4 & $\begin{array}{l}\text { Metodologia } \\
\text { (Metodologia) } \\
2^{\circ} \text { parágrafo }\end{array}$ & " Iiramas fotas de dia 6/08 ae dia 20/08 de segunda a sexta." & & & $\mathbf{X}$ & & & & & & & & & \\
\hline 5 & $\begin{array}{l}\text { Metodologia } \\
\text { (Metodologia) } \\
3^{\circ} \text { parágrafo }\end{array}$ & $\begin{array}{l}\text { "Contamos as lemnas dividinda } 4 \text { partes iguais e contamas } \\
\text { apenas a quadrada superior da direita, multiplicamas por } 4 \text { e } \\
\text { tivemas as resultados. Fizemas issa com todas as dias. Fizemas } \\
\text { um gráfica para ver a crescimenta das lemnas." }\end{array}$ & & & $\mathbf{X}$ & & & & & & & & & \\
\hline 6 & $\begin{array}{l}\text { Resultados } \\
\text { (Resultados e } \\
\text { Interpretaça) } \\
\text { O gráfico }\end{array}$ & 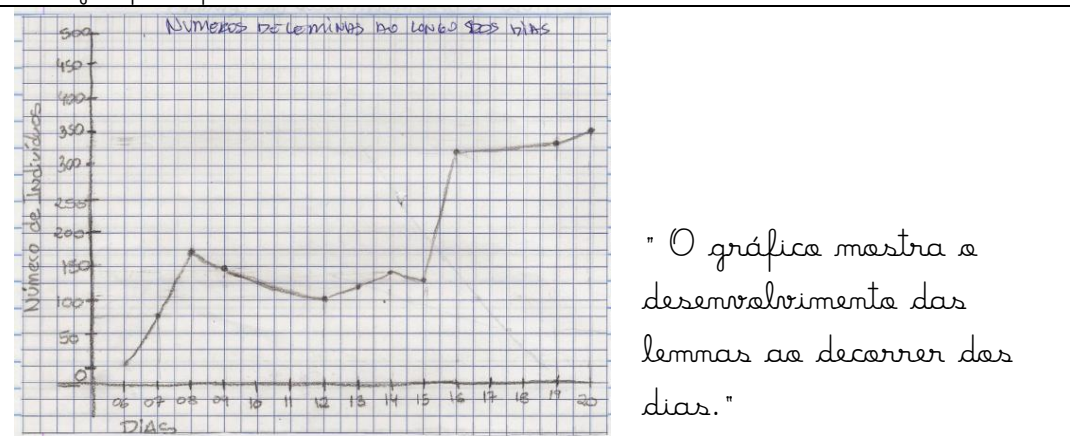 & & $\mathbf{X}$ & $\mathbf{X}$ & $\mathbf{X}$ & & & & & & & & \\
\hline
\end{tabular}

[Digite texto] 
Thiago Marinho Del Corso

INDICADORES DE ALFABETIZAÇ̃̃o CIENTÍFICA, ARGUMENTOS E EXPLICAÇÕES -

Análise de Relatórios no Contexto de uma Sequência de Ensino Investigativo

\begin{tabular}{|c|c|c|c|c|c|c|c|c|c|c|c|c|c|c|}
\hline 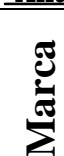 & $\begin{array}{l}\text { Subtítulo, } \\
\text { divisão ou } \\
\text { Item }\end{array}$ & (n) & $\mathbf{L M}$ & SI & OI & CI & $\mathbf{R L}$ & $\mathbf{R P}$ & $\mathbf{L H}$ & $\mathbf{T H}$ & $\mathbf{J}$ & $\mathbf{P}$ & 気 & $\frac{00}{4}$ \\
\hline 7 & $\begin{array}{l}\text { Interpretação } \\
\text { (Resultados e } \\
\text { Interpretaçãa) } \\
1^{\circ} \text { parágrafo }\end{array}$ & $\begin{array}{l}\text { " To inicia houve crescimenta da papulaçãa, a partir do dia } \\
08 / 08 \text { a populaçãa diminuiu, pois houve variaçäes na contagem } \\
\text { porque algumas plantas se moveram por causa de ventas e } \\
\text { possiveis esbarräes no pote." }\end{array}$ & & $\mathbf{X}$ & $\mathbf{X}$ & & & & & & $\mathbf{X}$ & & & $\mathbf{X}$ \\
\hline 8 & $\begin{array}{l}\text { Interpretação } \\
\text { (Resultados e } \\
\text { Interpretaçãa) } \\
2^{\circ} \text { parágrafo }\end{array}$ & $\begin{array}{l}\text { "A partir da dia } 12 / 08 \text { a populasãa cresceu movamente, de um } \\
\text { dia para a outro aconteceu uma pequena queda mas da dia 15/08 } \\
\text { para a dia 16/08 houve um grande aumenta e se estabilizau até a } \\
\text { dia 20/08." }\end{array}$ & & $\mathbf{X}$ & $\mathbf{X}$ & $\mathbf{X}$ & & & & & & & & \\
\hline 9 & $\begin{array}{l}\text { Resultados } \\
\text { (Resultados e } \\
\text { Interpretaçãa) } \\
\text { Figuras }\end{array}$ & 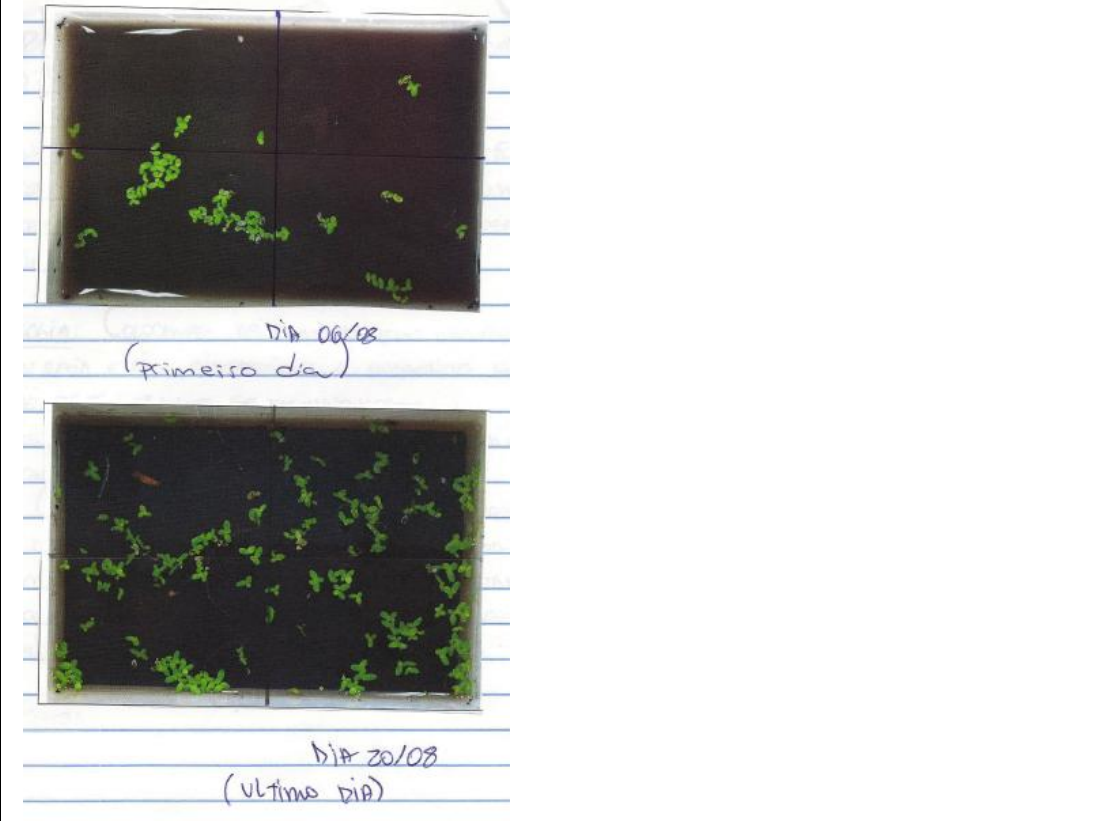 & & & & & & & & & & & & \\
\hline
\end{tabular}

[Digite texto] 
Thiago Marinho Del Corso

INDICADORES DE ALFABETIZAÇÃO CIENTÍFICA, ARGUMENTOS E EXPLICAÇÕES -

Análise de Relatórios no Contexto de uma Sequência de Ensino Investigativo

\begin{tabular}{|c|c|c|c|c|c|c|c|c|c|c|c|c|c|c|}
\hline 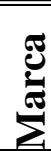 & $\begin{array}{l}\text { Subtítulo, } \\
\text { divisão ou } \\
\text { Item }\end{array}$ & Texto & $\mathbf{L M}$ & SI & OI & CI & RL & RP & LH & TH & $\mathbf{J}$ & $\mathbf{P}$ & 商 & $\sum_{4}^{00}$ \\
\hline 10 & $\begin{array}{l}\text { Conclusão } \\
\text { individual } 1 \\
1^{\circ} \text { parágrafo }\end{array}$ & $\begin{array}{l}\text { "A papulaşa consegue se repraduzir e aumentar a númera de } \\
\text { individuas, acontecem muitas variaçaes durante a pesquisa, mas } \\
\text { conseguem aumentar sua populaçãa." }\end{array}$ & & $\mathbf{X}$ & & & & & & & & $\mathbf{X}$ & & \\
\hline 11 & $\begin{array}{l}\text { Conclusão } \\
\text { individual } 1 \\
2^{\circ} \text { parágrafo }\end{array}$ & 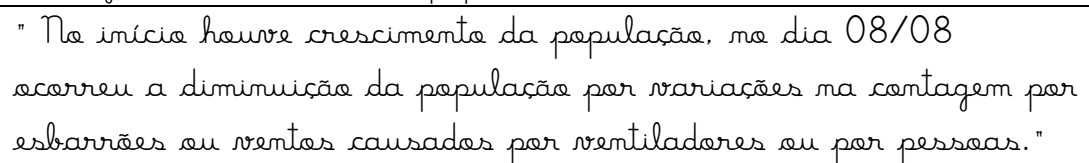 & & $\mathbf{X}$ & $\mathbf{X}$ & & & & & & $\mathbf{X}$ & & & $\mathbf{X}$ \\
\hline 12 & $\begin{array}{l}\text { Conclusão } \\
\text { individual } 1 \\
3^{\circ} \text { parágrafo }\end{array}$ & $\begin{array}{l}\text { "O dia } 12 / 08 \text { a papulaçãa valtau a crescer de um dia para a } \\
\text { outra houve queda mas me dia 15/08 para 16/08 ocorren um } \\
\text { grande aumenta que se estabilizan até a dia 20/08." }\end{array}$ & & $\mathbf{X}$ & $\mathbf{X}$ & $\mathbf{X}$ & & & & & & & & \\
\hline 13 & $\begin{array}{l}\text { Conclusão } \\
\text { individual } 1 \\
4^{\circ} \text { parágrafo }\end{array}$ & $\begin{array}{l}\text { "Issa mastra que as plantas crescem bem com variasães nos } \\
\text { resultados por problemas de contagem, mas ne final voltam a } \\
\text { crescer" }\end{array}$ & & $\mathbf{X}$ & $\mathbf{X}$ & $\mathbf{X}$ & & & & & $\mathbf{X}$ & $\mathbf{X}$ & & \\
\hline 14 & $\begin{array}{l}\text { Conclusão } \\
\text { individual } 2\end{array}$ & 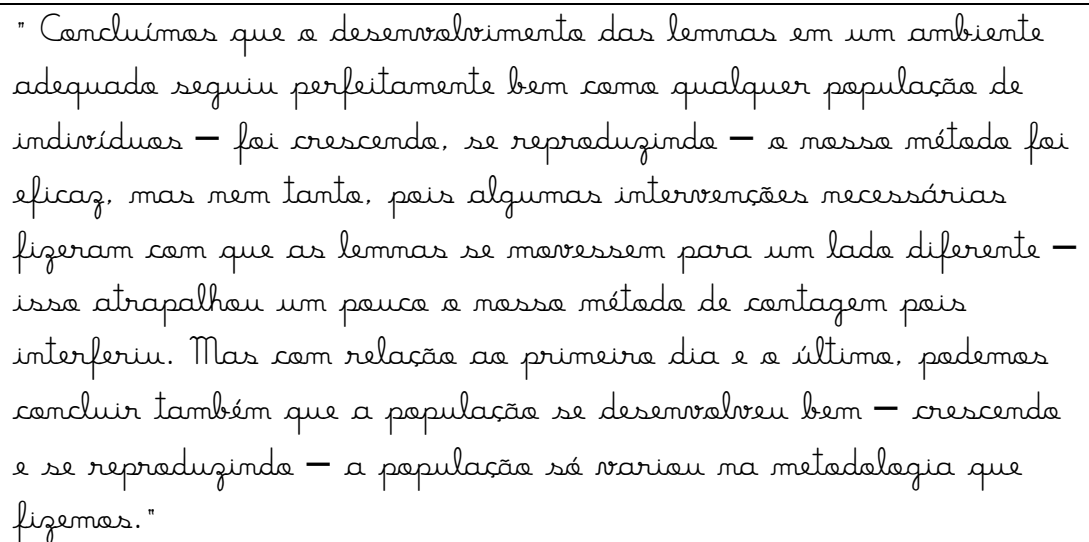 & & $\mathbf{X}$ & $\mathbf{X}$ & $\mathbf{X}$ & & & & & $\mathbf{X}$ & $\mathbf{X}$ & $\mathbf{X}$ & \\
\hline 15 & $\begin{array}{l}\text { Conclusão } \\
\text { individual } 3 \\
1^{\circ} \text { parágrafo }\end{array}$ & $\begin{array}{l}\text { "Olhanda a gráfica e fazenda as análises, pade-se concluir que } \\
\text { nas } 3 \text { primeiras dias as lemnas cresceram em um grande númera. } \\
\text { Hauve variacães, mas na fim a grupa papulacional de lemnas }\end{array}$ & & $\mathbf{X}$ & $\mathbf{X}$ & $\mathbf{X}$ & & & & & & & & \\
\hline
\end{tabular}

\section{[Digite texto]}


Thiago Marinho Del Corso

INDICADORES DE ALFABETIZAÇÃO CIENTÍFICA, ARGUMENTOS E EXPLICAÇÕES -

Análise de Relatórios no Contexto de uma Sequência de Ensino Investigativo

\begin{tabular}{|c|c|c|c|c|c|c|c|c|c|c|c|c|c|c|}
\hline & " & $\begin{array}{l}\text { cresceu, chegamas a até } 350 \text { a } 400 \text { individuas } \\
\text { apraximadamente." }\end{array}$ & & & & & & & & & & & & \\
\hline 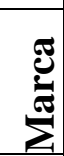 & $\begin{array}{l}\text { Subtítulo, } \\
\text { divisão ou } \\
\text { Item }\end{array}$ & Texto & $\mathbf{L M}$ & SI & OI & CI & $\mathbf{R L}$ & $\mathbf{R P}$ & $\mathbf{L H}$ & TH & $\mathbf{J}$ & $\mathbf{P}$ & 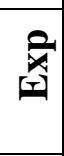 & $\sum_{i}^{\infty}$ \\
\hline 16 & $\begin{array}{l}\text { Conclusão } \\
\text { individual } 3 \\
2^{\circ} \text { parágrafo }\end{array}$ & $\begin{array}{l}\text { "Entãa mesma com as variaçäes acorreu a esperado de que as } \\
\text { individuos iriam crescer." }\end{array}$ & & & & & & & $\mathbf{X}$ & $\mathbf{X}$ & & & & \\
\hline
\end{tabular}


Thiago Marinho Del Corso

INDICADORES DE ALFABETIZAÇÃO CIENTÍFICA, ARGUMENTOS E EXPLICAÇÕES -

Análise de Relatórios no Contexto de uma Sequência de Ensino Investigativo

Relatórios 2012

\section{O Relatório 1 - 2012}

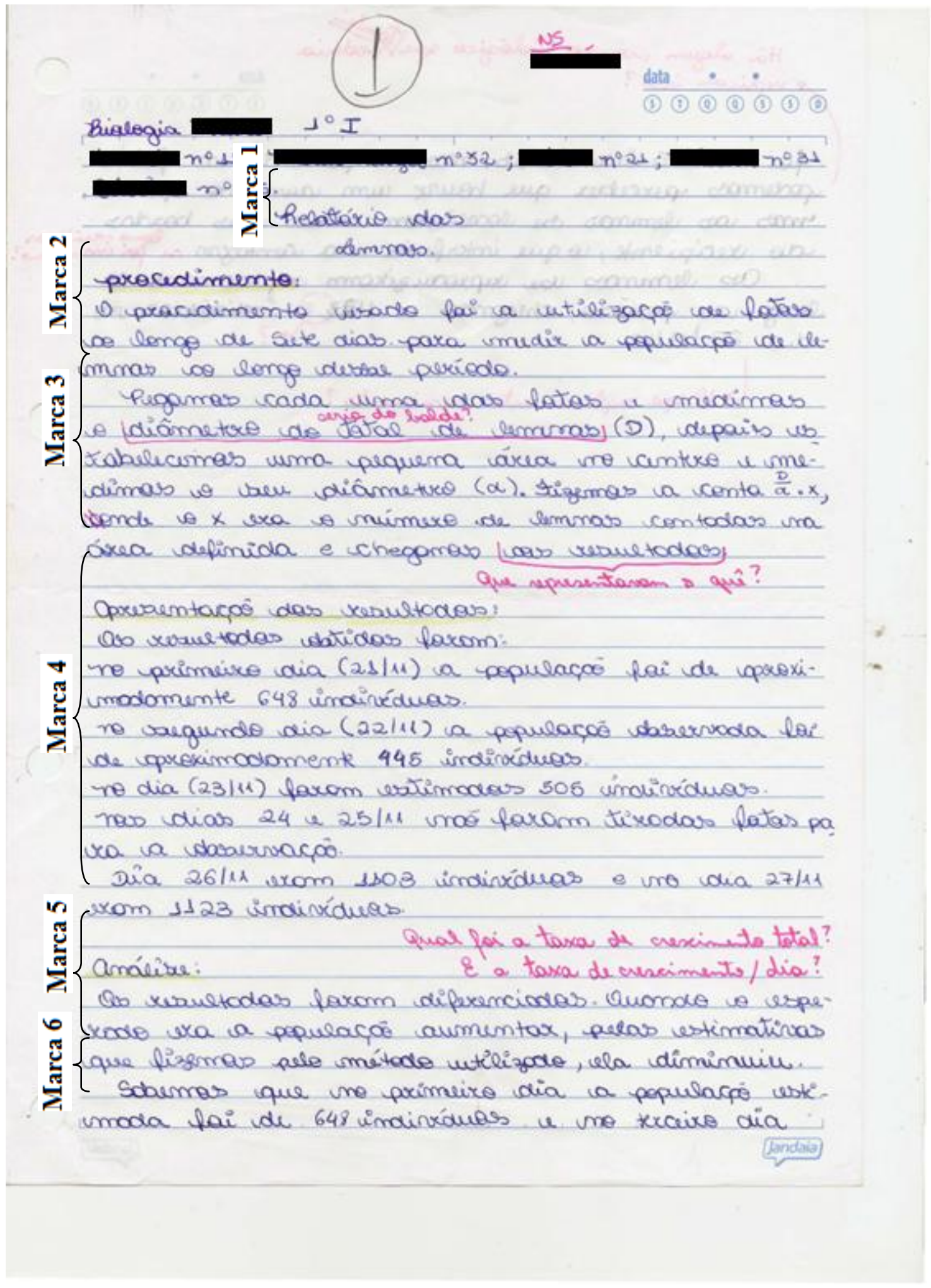

[Digite texto] 
Thiago Marinho Del Corso

INDICADORES DE ALFABETIZAÇÃO CIENTÍFICA, ARGUMENTOS E EXPLICAÇÕES -

Análise de Relatórios no Contexto de uma Sequência de Ensino Investigativo

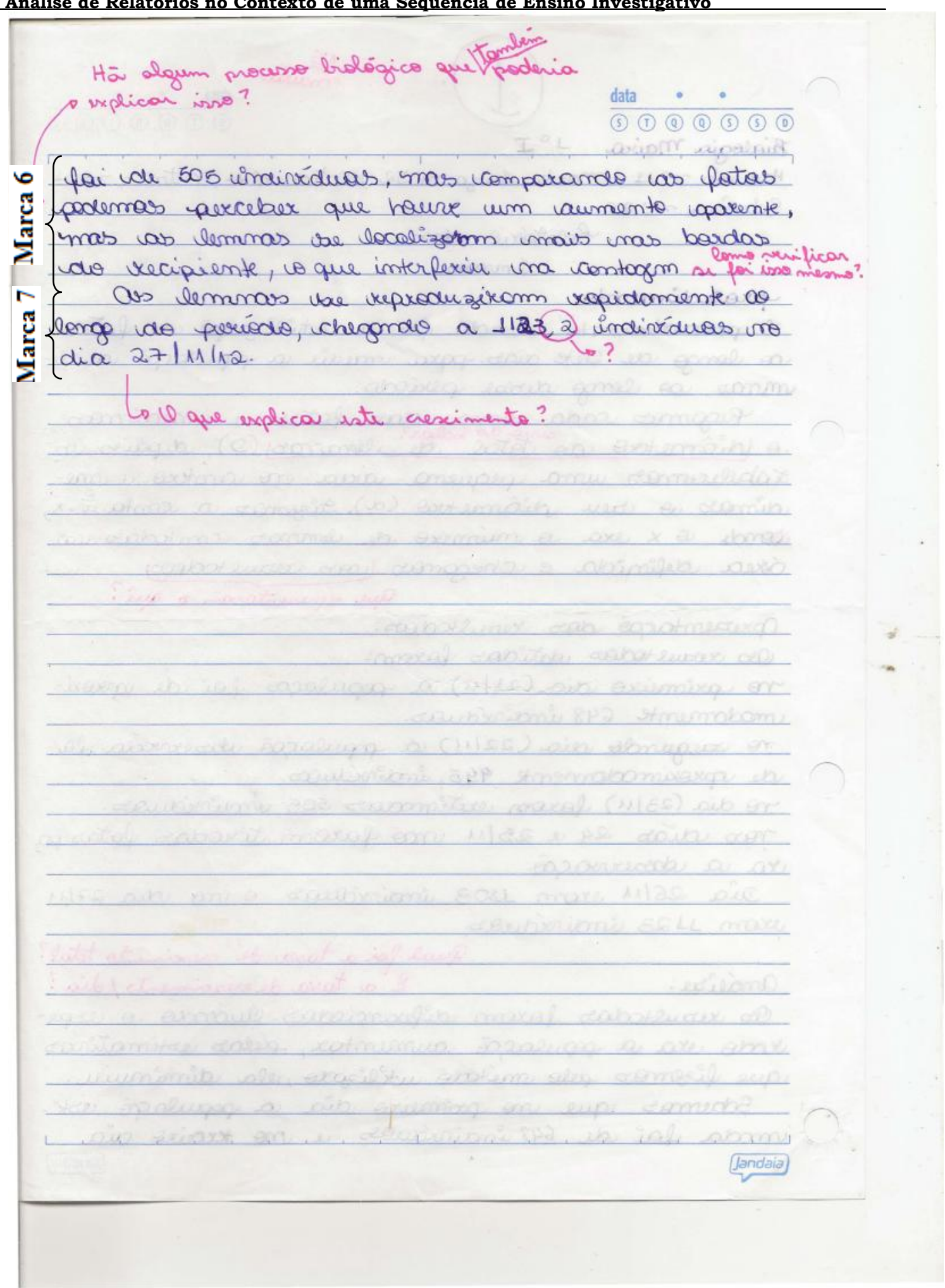

[Digite texto] 
Thiago Marinho Del Corso

INDICADORES DE ALFABETIZAÇÃO CIENTÍFICA, ARGUMENTOS E EXPLICAÇÕES -

Análise de Relatórios no Contexto de uma Sequência de Ensino Investigativo

Quadro 19

Identificação dos Indicadores de Alfabetização Científica no Relatório 1 - 2012

\begin{tabular}{|c|c|c|c|c|c|c|c|c|c|c|c|c|c|c|}
\hline 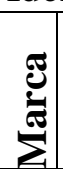 & $\begin{array}{l}\text { Subtítulo, } \\
\text { divisão ou } \\
\text { Item }\end{array}$ & Texto & $\mathbf{L M}$ & SI & $\mathbf{O I}$ & CI & RL & $\mathbf{R P}$ & $\mathbf{L H}$ & TH & $\mathbf{J}$ & I & & $\sum_{4}^{\infty}$ \\
\hline 1 & Titulo & "Relatóric das Lemnas" & & & & & & & & & & & & \\
\hline 2 & $\begin{array}{l}\text { Metodologia } \\
\text { (Procedimenta) } \\
1^{\circ} \text { parágrafo }\end{array}$ & $\begin{array}{l}\text { "O pracedimenta usada fai a utilizacãa de fatas ae longa de } \\
\text { sete dias para medir a papulaçãa de lemnas ae langa desse } \\
\text { períada." }\end{array}$ & & & $\mathbf{X}$ & & & & & & & & & \\
\hline 3 & $\begin{array}{l}\text { Metodologia } \\
\text { (Procedimenta) } \\
2^{\circ} \text { parágrafo }\end{array}$ & 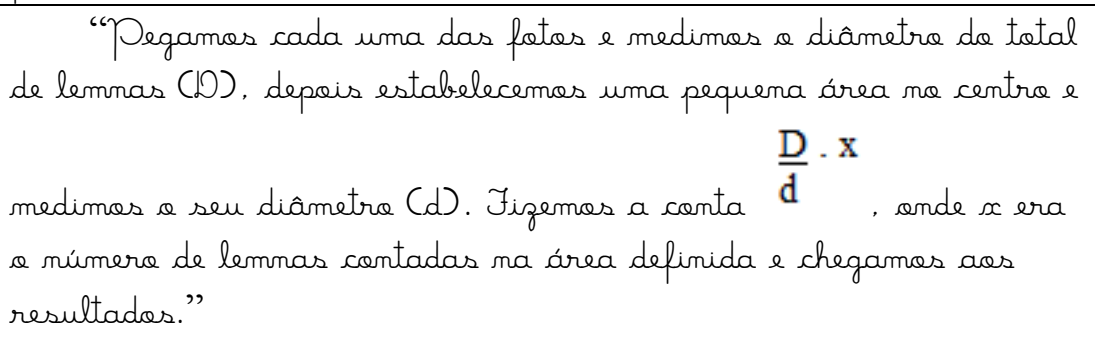 & & & $\mathbf{X}$ & & $\mathbf{X}$ & $\mathbf{X}$ & & & & & & \\
\hline 4 & $\begin{array}{l}\text { Resultados } \\
\text { (apresentaçãa das } \\
\text { resultadas) }\end{array}$ & 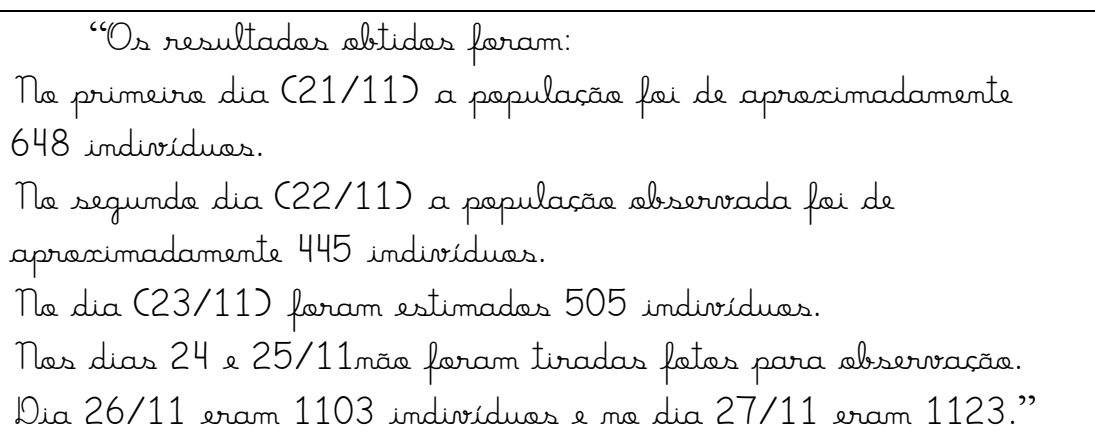 & & $\mathbf{X}$ & $\mathbf{X}$ & & & & & & & & & \\
\hline 5 & $\begin{array}{l}\text { Interpretação } \\
\text { (Análise) } 1^{\circ} \\
\text { parágrafo }\end{array}$ & $\begin{array}{l}\text { "Os resultadas foram diferenciados. (Duanda e esperada era a } \\
\text { populaça aumentar, pelas estimativas que fizemos pelo métado } \\
\text { utilizado, ela diminuiu." }\end{array}$ & & $\mathbf{X}$ & & & & & $\mathbf{X}$ & $\mathbf{X}$ & & & & \\
\hline
\end{tabular}

[Digite texto] 
Thiago Marinho Del Corso

INDICADORES DE ALFABETIZAÇÃo CIENTÍFICA, ARGUMENTOS E EXPLICAÇÕES -

Análise de Relatórios no Contexto de uma Sequência de Ensino Investigativo

\begin{tabular}{|c|c|c|c|c|c|c|c|c|c|c|c|c|c|c|}
\hline 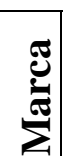 & $\begin{array}{l}\text { Subtítulo, } \\
\text { divisão ou } \\
\text { Item }\end{array}$ & Texto & $\mathbf{L M}$ & SI & OI & CI & $\mathbf{R L}$ & RP & LH & TH & $\mathbf{J}$ & $\mathbf{P}$ & 商 & $\underset{L}{200}$ \\
\hline 6 & $\begin{array}{l}\text { Interpretação } \\
\text { (Cinálise) } 2^{\circ} \\
\text { parágrafo }\end{array}$ & $\begin{array}{l}\text { "Sabemas que na primeira dia a papulaçãa estimada fai de } \\
648 \text { individuas e ma terceira dia fai de } 505 \text { individuas, mas } \\
\text { comparanda as fotas podemas perceber que hauve um aumenta } \\
\text { aparente, mas as lemnas se lacalizaram mais mas bordas do } \\
\text { recipiente, a que interferiu na contagem." }\end{array}$ & & $\mathbf{X}$ & & $\mathbf{X}$ & & & & & $\mathbf{X}$ & & & $\mathbf{X}$ \\
\hline 7 & $\begin{array}{l}\text { Interpretação } \\
\text { (Cinálise) } 3^{\circ} \\
\text { parágrafo }\end{array}$ & $\begin{array}{l}\text { "Cs lemnas se repraduziram rapidamente ae longa da } \\
\text { periada, cheganda a } 1123 \text { individuas ma dia 27/11/12." }\end{array}$ & & $\mathbf{X}$ & & $\mathbf{X}$ & & & & & & & & \\
\hline
\end{tabular}


Thiago Marinho Del Corso

INDICADORES DE ALFABETIZAÇÃO CIENTÍFICA, ARGUMENTOS E EXPLICAÇÕES -

Análise de Relatórios no Contexto de uma Sequência de Ensino Investigativo

O Relatório 2 - 2012
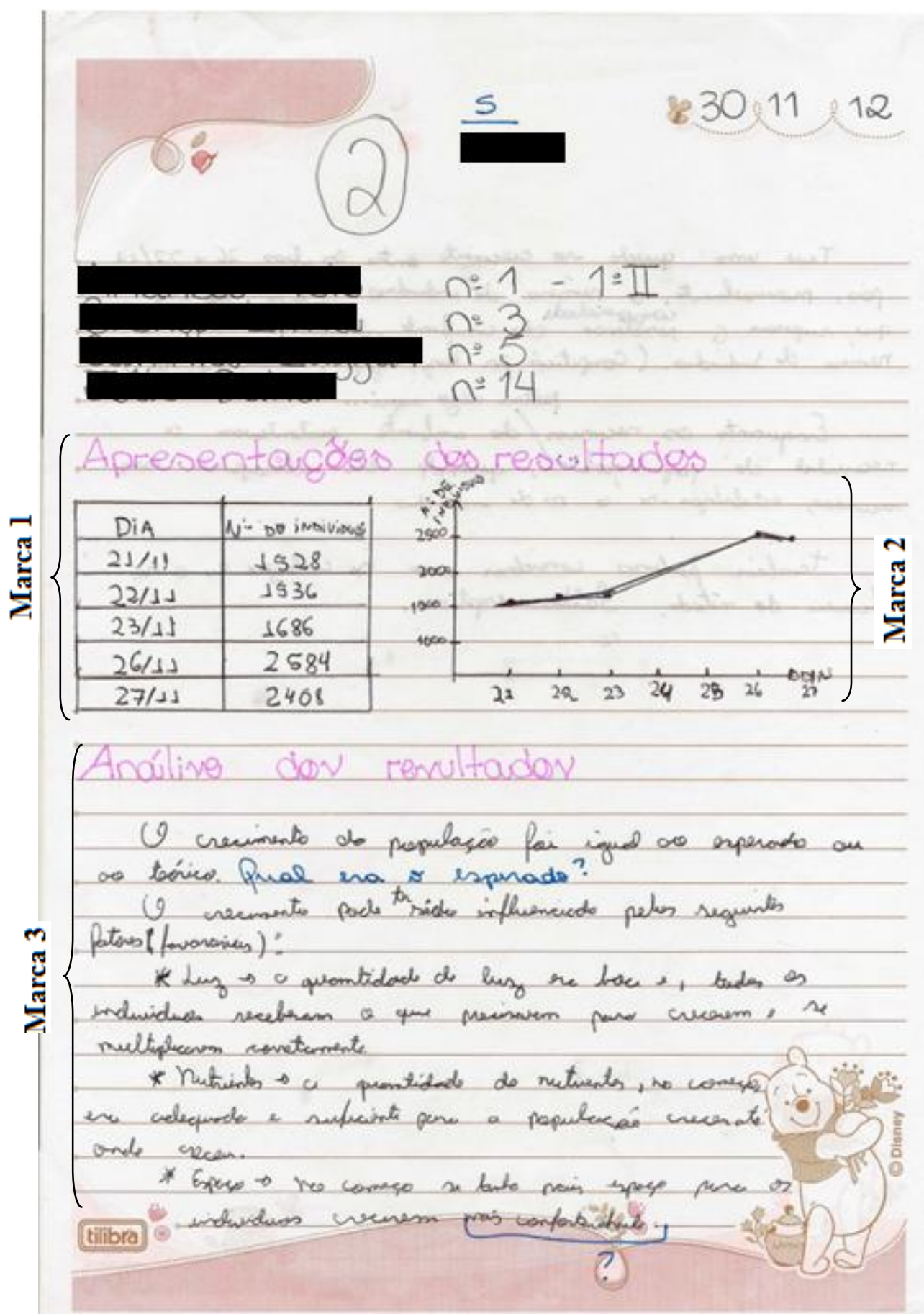

[Digite texto] 

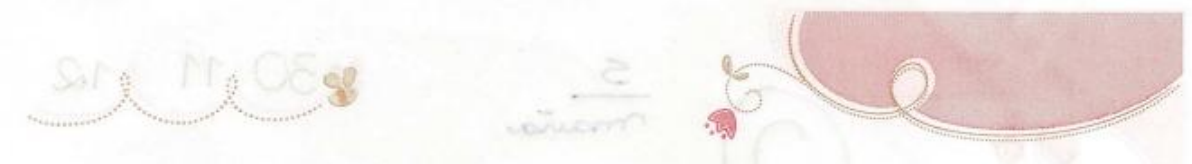

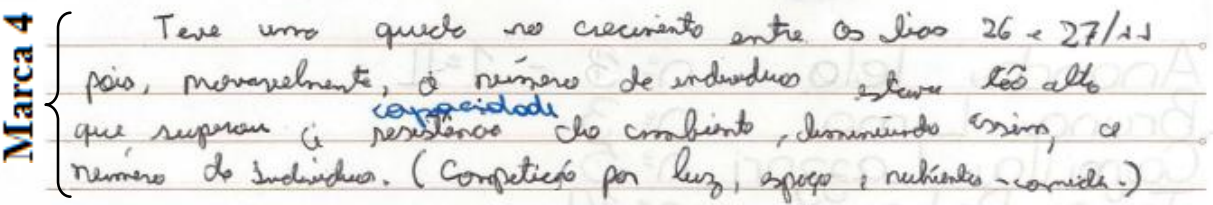
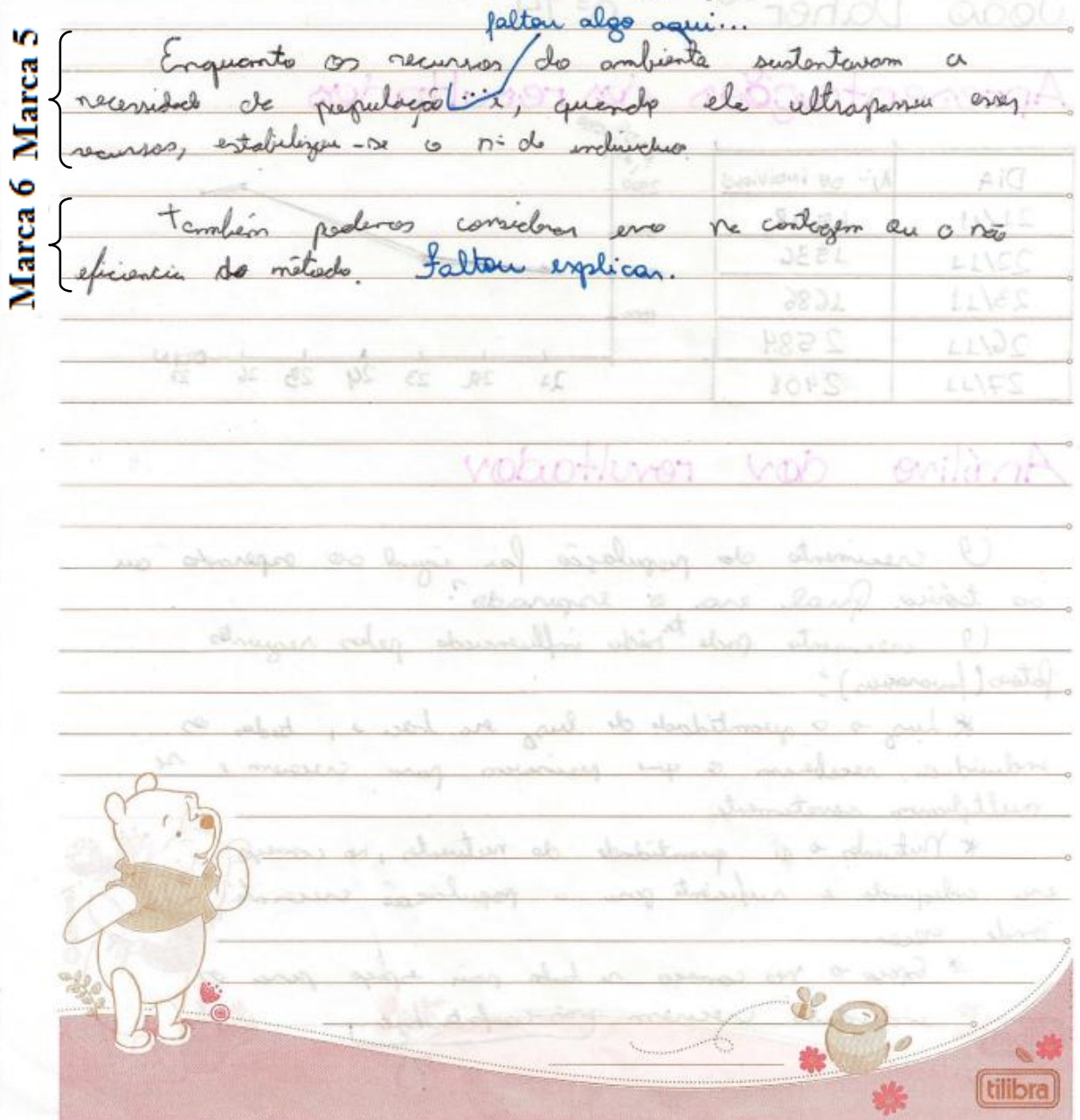

[Digite texto] 
Thiago Marinho Del Corso

INDICADORES DE ALFABETIZAÇ̃̃o CIENTÍFICA, ARGUMENTOS E EXPLICAÇÕES -

Análise de Relatórios no Contexto de uma Sequência de Ensino Investigativo

Quadro 20

Identificação dos Indicadores de Alfabetização Científica no Relatório 2 - 2012

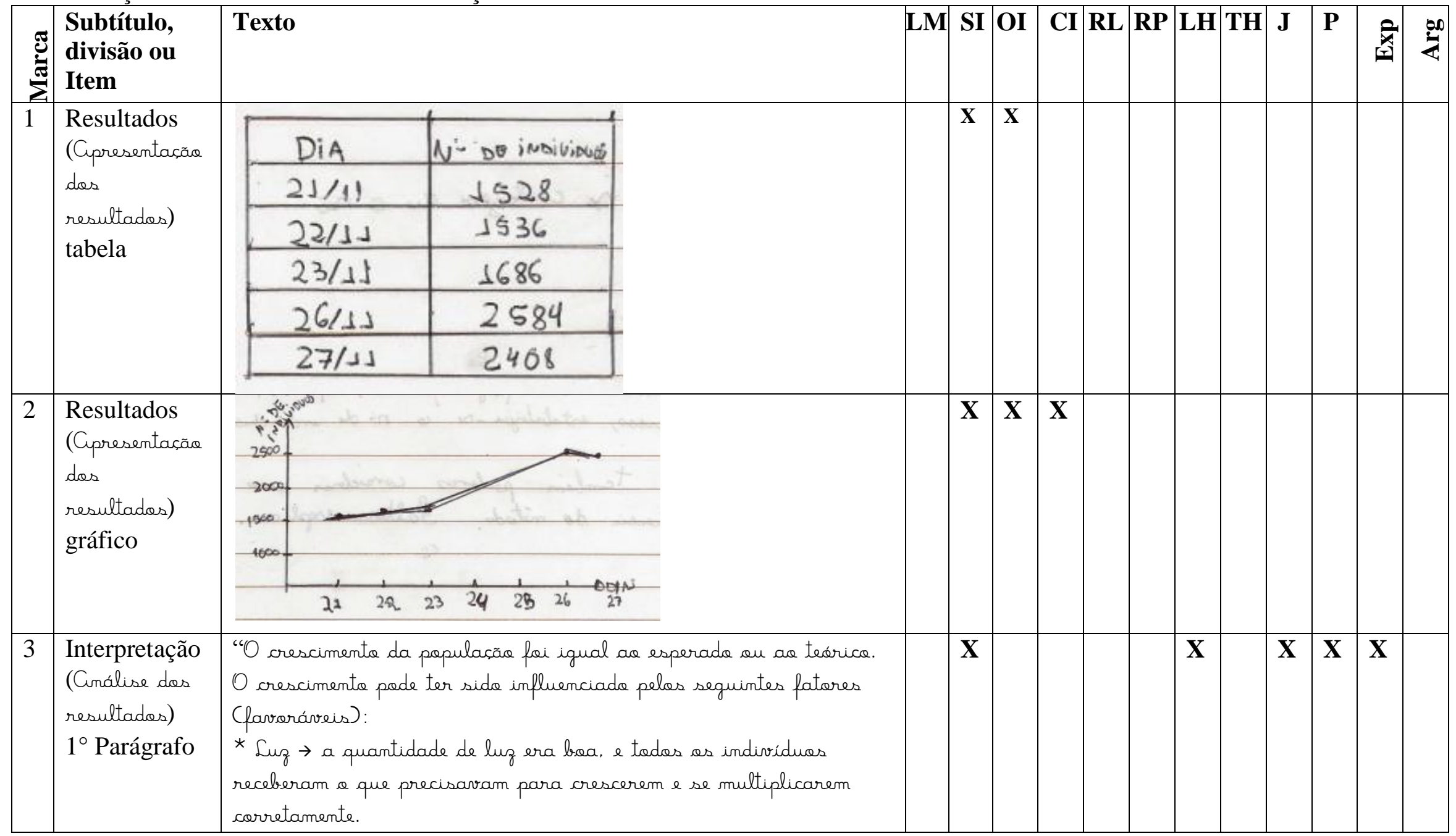

[Digite texto] 
Thiago Marinho Del Corso

INDICADORES DE ALFABETIZAÇÃO CIENTÍFICA, ARGUMENTOS E EXPLICAÇÕES -

Análise de Relatórios no Contexto de uma Sequência de Ensino Investigativo

\begin{tabular}{|c|c|c|c|c|c|c|c|c|c|c|c|c|c|c|}
\hline & & 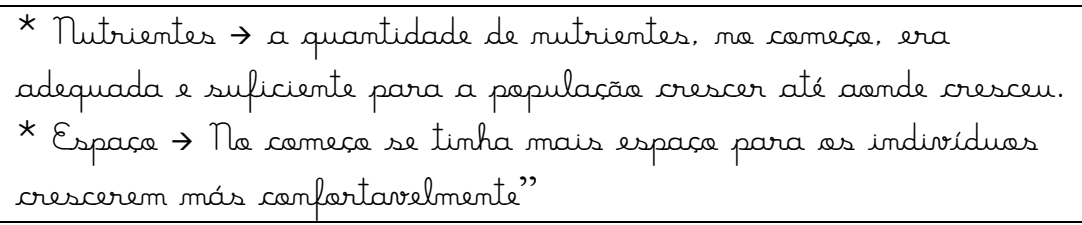 & & & & & & & & & & & & \\
\hline 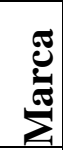 & \begin{tabular}{|l|} 
Subtítulo, \\
divisão ou \\
Item \\
\end{tabular} & Texto & $\mathbf{L M}$ & SI & OI & $\mathbf{C I}$ & $\mathbf{R L}$ & $\mathbf{R P}$ & $\mathbf{L H}$ & TH & $\mathbf{J}$ & $\mathbf{P}$ & $\underset{x}{a}$ & $\sum^{\infty}$ \\
\hline 4 & $\begin{array}{l}\text { Interpretação } \\
\text { (Cinálise dos } \\
\text { resultados) } \\
2^{\circ} \text { Parágrafo }\end{array}$ & 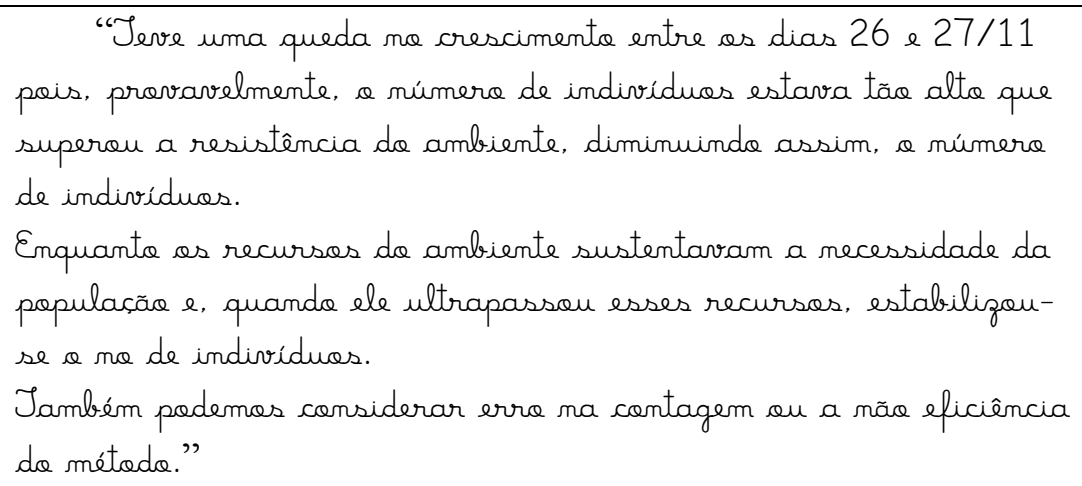 & & $\mathbf{X}$ & $\mathbf{X}$ & & $\mathbf{X}$ & & & & $\mathbf{X}$ & & & $\mathbf{X}$ \\
\hline
\end{tabular}


Thiago Marinho Del Corso

INDICADORES DE ALFABETIZAÇÃO CIENTÍFICA, ARGUMENTOS E EXPLICAÇÕES -

Análise de Relatórios no Contexto de uma Sequência de Ensino Investigativo

O Relatório 3 - 2012

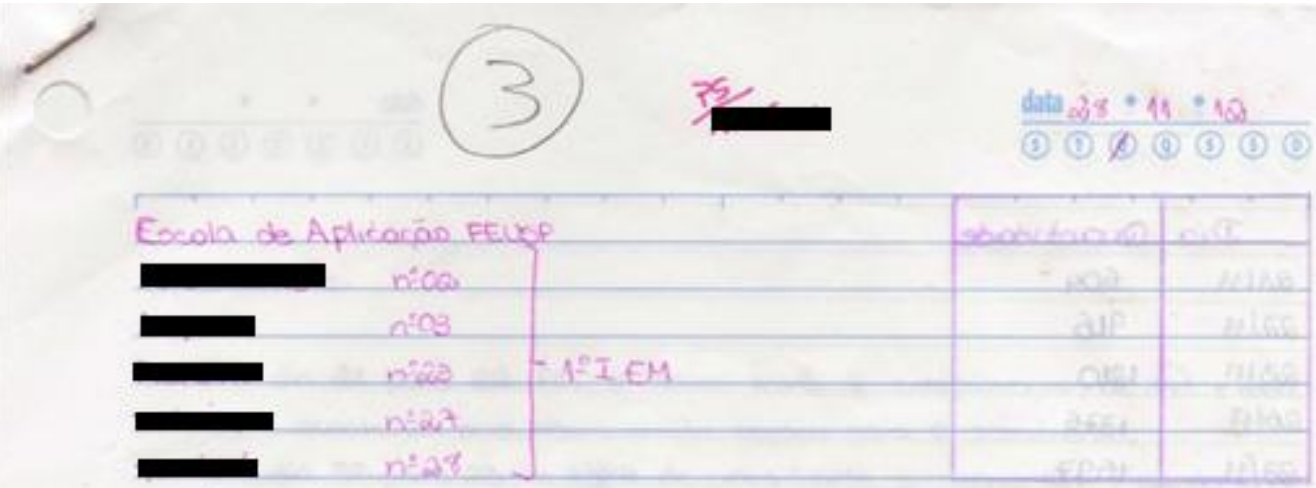

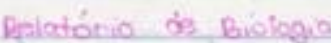

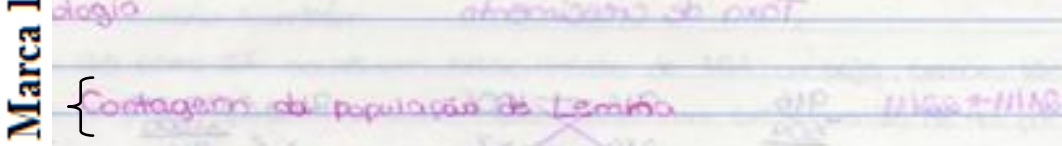

N Coram tiradas fotos do balde com Lemno do longo de ofete dros lectre.

Iु $\{$ dia 21 de novembro até o dia 27 de novembrol. Temos 5 fotos, 1 tirada

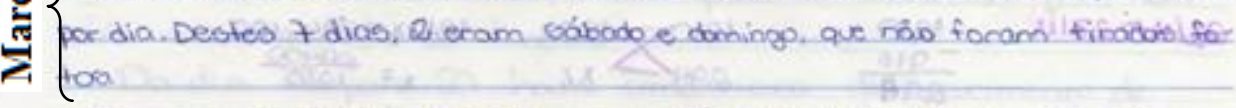

Pegamos cada fato e medimos o díanatro do balde com uma régua, fois o dicimetrs é a moior distáncio entre un ponto e outro numa ciroun $=$

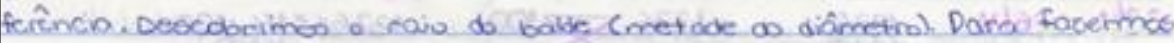

" a circunferêncio menor, dividimos o rajo do balde em dois a deoenka. J mos com un comproso.

党

Fiziemos a contagen de Lemnas dentro da ciccunfuŕncia menor e multipli. amas pelo valor da divisón entre o raio do balde e o rajo da circunfóéncia. menor, Obtendo un valor aproximads da quantidade total de vempos.

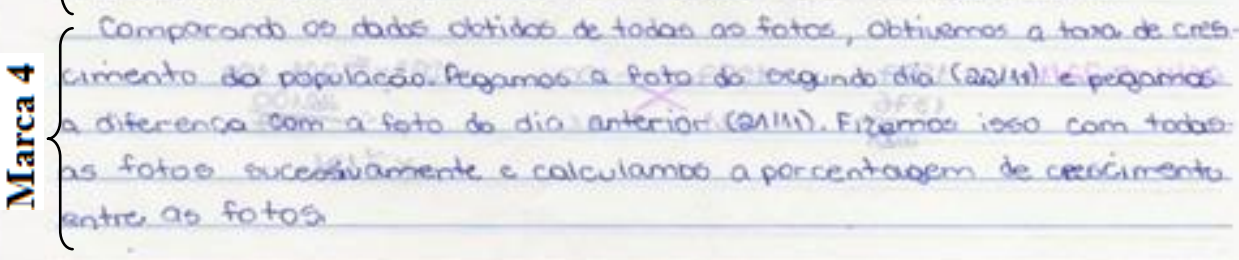


Thiago Marinho Del Corso

INDICADORES DE ALFABETIZAÇÃO CIENTÍFICA, ARGUMENTOS E EXPLICAÇÕES -

Análise de Relatórios no Contexto de uma Sequência de Ensino Investigativo
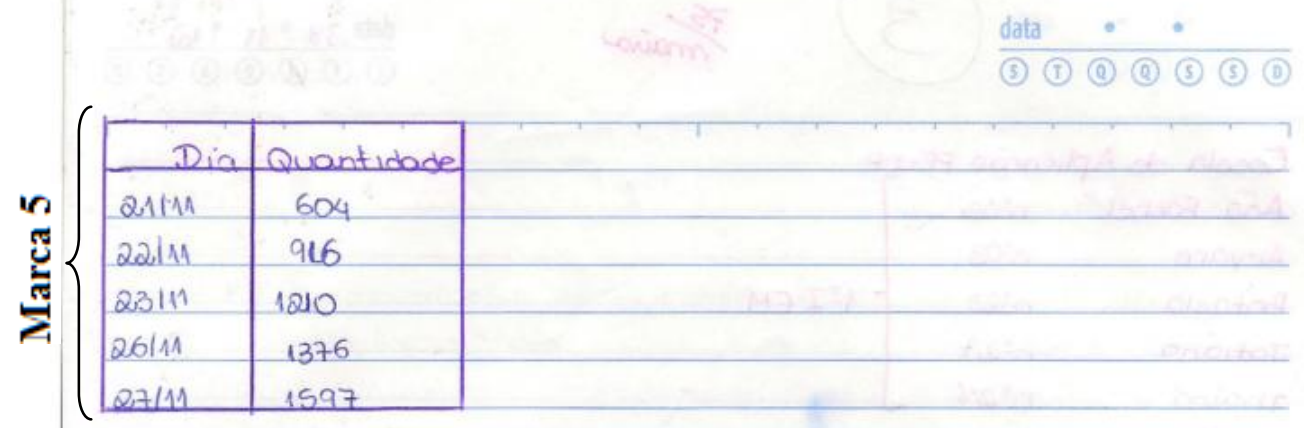

Taxa de crescimento

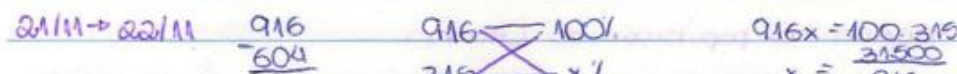

$\frac{604}{315} \quad 315 \leq x \%=\frac{31500}{916}$

$x \cong 34 \%$

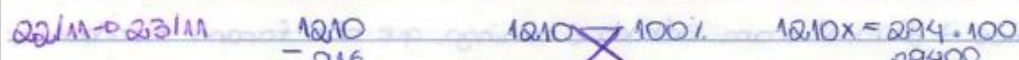

$\frac{-916}{294} \quad 2,94-x \% \quad x=\frac{29400}{1010}$

$x \cong 24 \%$

률

$23 / 4426 \tan \quad 1376 \quad 1376 \rightleftharpoons 100 \% \quad 1376 x=166 \cdot 10$

$-\frac{1210}{166} \quad 166 \geq x=\frac{16600}{1376}$

$x=12 \% \rightarrow 3 d$

$3 d=12$

$d=\frac{12}{3}$

$d \stackrel{N}{=} \%$

$26111 \rightarrow 27 / 11 \quad 1597 \quad 1597,1001 \quad 1597 x=221 \cdot 100$

$\frac{1376}{221} \quad 221 \geq x \% \quad x=\frac{22100}{1597}$

$x \cong 13 i$

[Digite texto] 
Do dia 22 para 23 , a taxa de crescimento diminuiu $10^{\circ} \mathrm{K}$, ficando em 24\% porém ainda foi alta. Podemos dizer que diminuiu poin gue o espal que tinha diminuiu também

(Do dia 23 para 26 houve um crescimento de 12i, ou seja, cresceu $12 \%$ a em 3 dias, por isso podemos dizer que houve um crescimento de $4 \%$ por y dia. Podemos ver que diminuiv muito a taxa de crescimento e a nosso. *3 hipótese para explicar essa diminuicäa é que o nível de nhortali1 dode reste período aumentoo, e isso pode ter acontecido (pois nás havia mais espago ou alimento

C Da dia 26 para 27 houve uma taxa de crescimento de - $13 \%$, ou seja, aumentou a taxa de crscimento, e podemos dizer J que ioso aconteces por que já que ms dias anteriores houve maior *ี mortdidode, aumentou o espaco para neproducáo e também os componentes ongavioos aumentaram, aumentondo o alimento das lemnab 
Thiago Marinho Del Corso

INDICADORES DE ALFABETIZAÇ̃̃O CIENTÍFICA, ARGUMENTOS E EXPLICAÇÕES -

Análise de Relatórios no Contexto de uma Sequência de Ensino Investigativo

Quadro 21

Identificação dos Indicadores de Alfabetização Científica no Relatório 3 - 2012

\begin{tabular}{|c|c|c|c|c|c|c|c|c|c|c|c|c|c|c|}
\hline 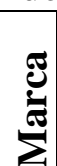 & $\begin{array}{l}\text { Subtítulo, } \\
\text { divisão ou } \\
\text { Item }\end{array}$ & Texto & $\mathbf{L M}$ & SI & OI & CI & RL & $\mathbf{R P}$ & $\mathbf{L H}$ & TH & $\mathbf{J}$ & $\mathbf{P}$ & 엇 & $\sum^{00}$ \\
\hline 1 & Titulo & "Contagem da Papulaşãa de Lemna" & & & & & & & & & & & & \\
\hline 2 & $\begin{array}{l}\text { Metodologia } \\
1^{\circ} \text { parágrafo }\end{array}$ & $\begin{array}{l}\text { "Foram tirados fotas da balde com Lemna ae longa de sete } \\
\text { dias (entre a dia } 21 \text { de novembra até a dia } 27 \text { de novembra). } \\
\text { Jemas } 5 \text { fotos, } 1 \text { tirada por dia. Destes } 7 \text { dias, } 2 \text { eram sábada e } \\
\text { dominge, que nãa foram tiradas fotas." }\end{array}$ & $\mathbf{X}$ & & $\mathbf{X}$ & & & & & & & & & \\
\hline 3 & $\begin{array}{l}\text { Metodologia } \\
2^{\circ} \text { e } 3^{\circ} \\
\text { parágrafo }\end{array}$ & 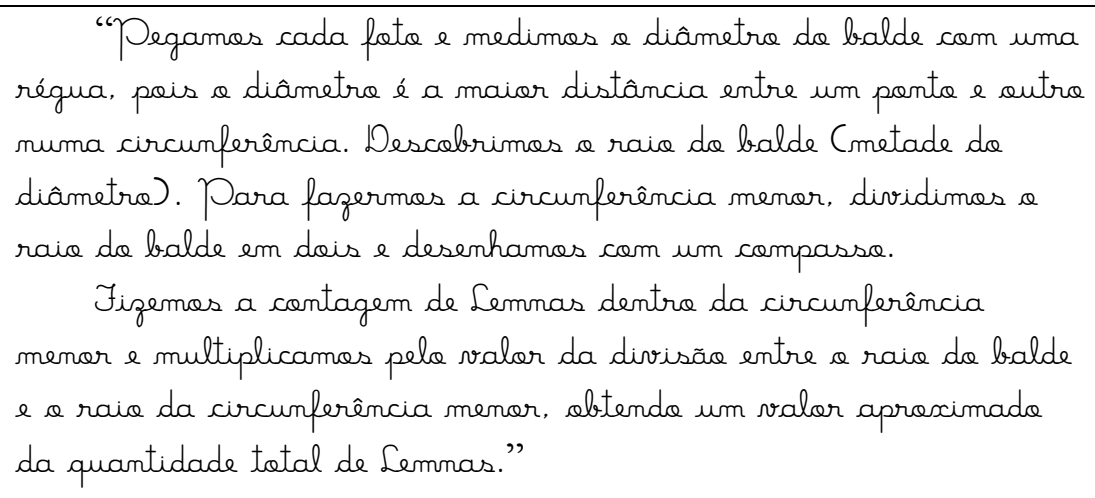 & & & $\mathbf{X}$ & & $\mathbf{X}$ & $\mathbf{X}$ & & & $\mathbf{X}$ & & & \\
\hline 4 & $\begin{array}{l}\text { Metodologia } \\
\text { (Metodologia) } \\
4^{\circ} \text { parágrafo }\end{array}$ & 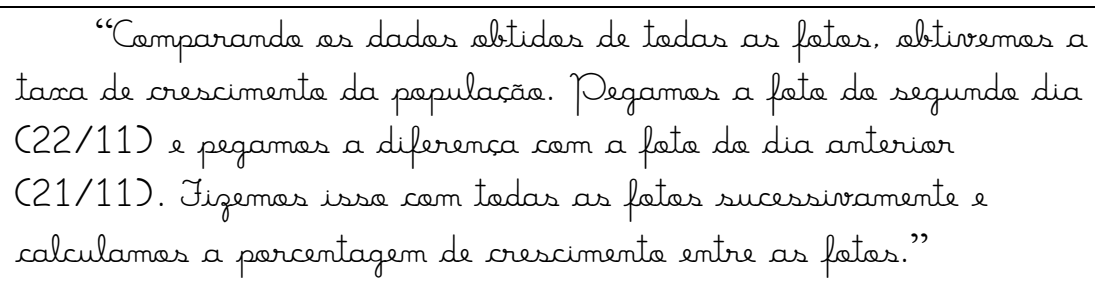 & & & $\mathbf{X}$ & & $\mathbf{X}$ & & & & & & & \\
\hline
\end{tabular}

[Digite texto] 
Thiago Marinho Del Corso

INDICADORES DE ALFABETIZAC̄̃o CIENTÍFICA, ARGUMENTOS E EXPLICAÇÕES -

Análise de Relatórios no Contexto de uma Sequência de Ensino Investigativo

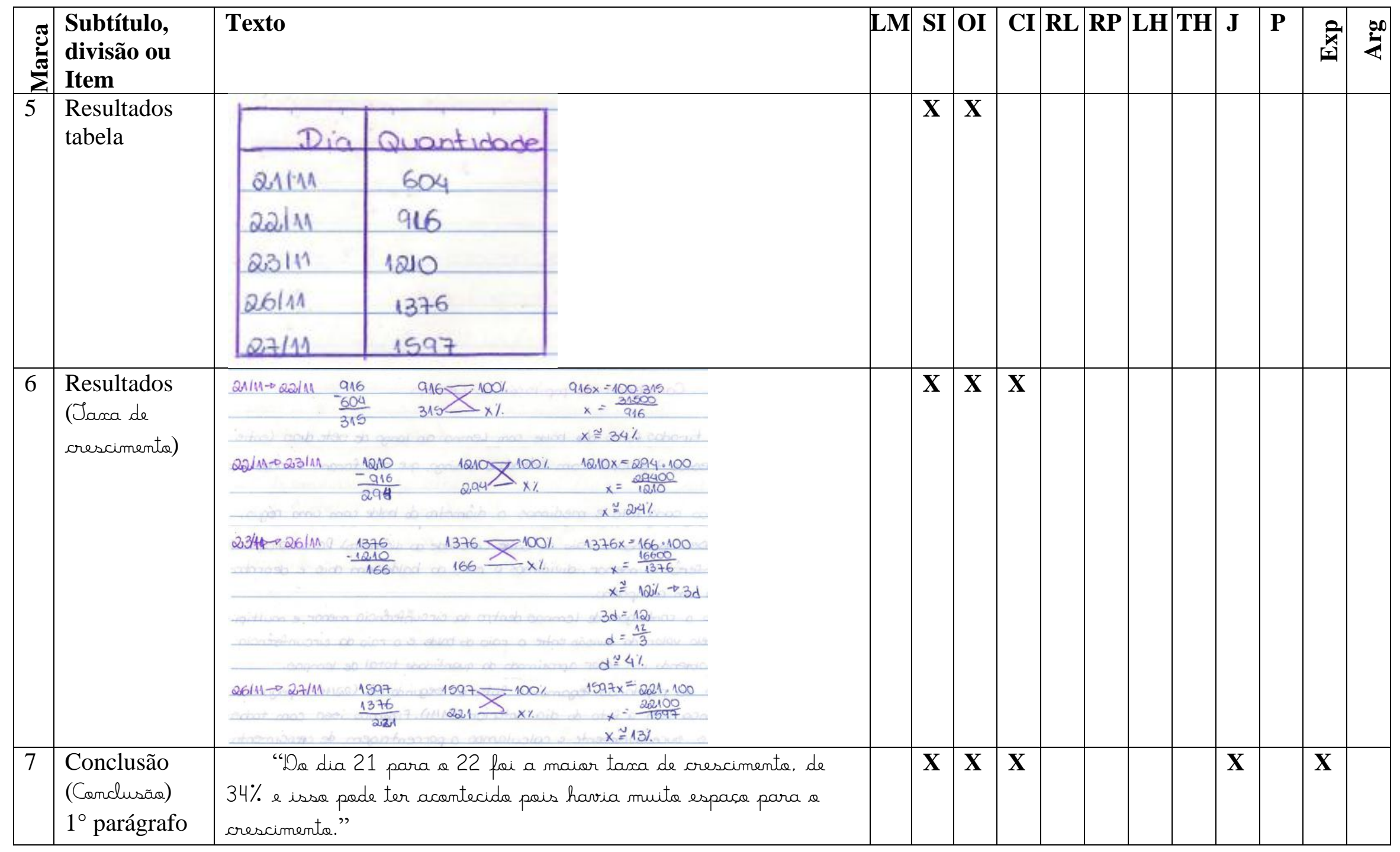

[Digite texto] 
Thiago Marinho Del Corso

INDICADORES DE ALFABETIZAÇÃO CIENTÍFICA, ARGUMENTOS E EXPLICAÇÕES -

Análise de Relatórios no Contexto de uma Sequência de Ensino Investigativo

\begin{tabular}{|c|c|c|c|c|c|c|c|c|c|c|c|c|c|c|}
\hline 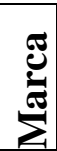 & $\begin{array}{l}\text { Subtítulo, } \\
\text { divisão ou } \\
\text { Item }\end{array}$ & Texto & $\mathbf{L M}$ & SI & OI & CI & $\mathbf{R L}$ & $\mathbf{R P}$ & $\mathbf{L H}$ & $\mathbf{T H}$ & $\mathbf{J}$ & $\mathbf{P}$ & 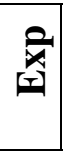 & $\sum^{200}$ \\
\hline 8 & $\begin{array}{l}\text { Conclusão } \\
\text { (Conclusãa) } \\
2^{\circ} \text { parágrafo }\end{array}$ & $\begin{array}{l}\text { "Do dia } 22 \text { para a 23, a taxa de crescimenta diminuiu 10\%, } \\
\text { ficanda em } 24 \% \text {, porem ainda muita alta. Pademas dizer que diminuiu } \\
\text { pois que a espa- que timha diminuiu também" }\end{array}$ & & $\mathbf{X}$ & $\mathbf{X}$ & $\mathbf{X}$ & & & & & $\mathbf{X}$ & & $\mathbf{X}$ & \\
\hline 9 & $\begin{array}{l}\text { Conclusão } \\
\text { (Conclusãa) } \\
3^{\circ} \text { parágrafo }\end{array}$ & 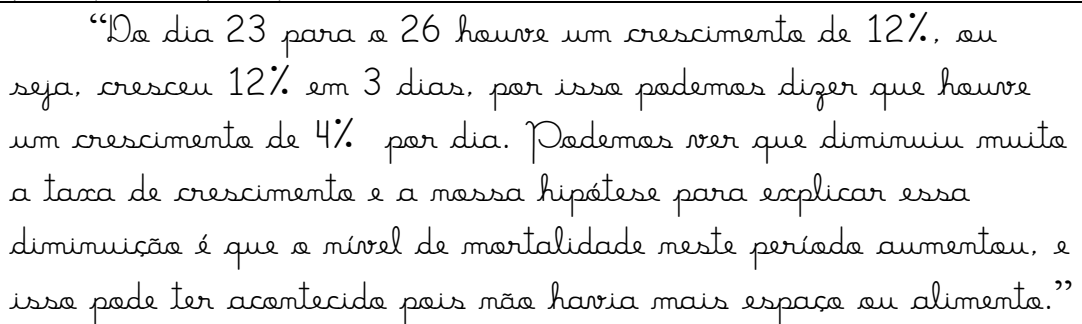 & & $\mathbf{X}$ & $\mathbf{X}$ & $\mathbf{X}$ & $\mathbf{X}$ & & $\mathbf{X}$ & & $\mathbf{X}$ & & & $\mathbf{X}$ \\
\hline 10 & $\begin{array}{l}\text { Conclusão } \\
\text { (Conclusãa) } \\
4^{\circ} \text { parágrafo }\end{array}$ & $\begin{array}{l}\text { "Do dia } 26 \text { para a } 27 \text { hauve uma taxa de crescimenta de } \\
\text { 13\%, au seja, aumentau a taxa de crescimenta, e podemas dizer } \\
\text { que issa aconteceu por que já que nos dias anteriores hauve } \\
\text { maior mortalidade, aumentau a espaça para reproduçãa e também } \\
\text { as componentes orgânicos aumentaram, aumentanda a alimenta } \\
\text { das Lemnas" }\end{array}$ & & $\mathbf{X}$ & $\mathbf{X}$ & $\mathbf{X}$ & $\mathbf{X}$ & & & & $\mathbf{X}$ & & $\mathbf{X}$ & \\
\hline
\end{tabular}


Thiago Marinho Del Corso

INDICADORES DE ALFABETIZAÇÃO CIENTÍFICA, ARGUMENTOS E EXPLICAÇÕES -

Análise de Relatórios no Contexto de uma Sequência de Ensino Investigativo

O Relatório 4 - 2012

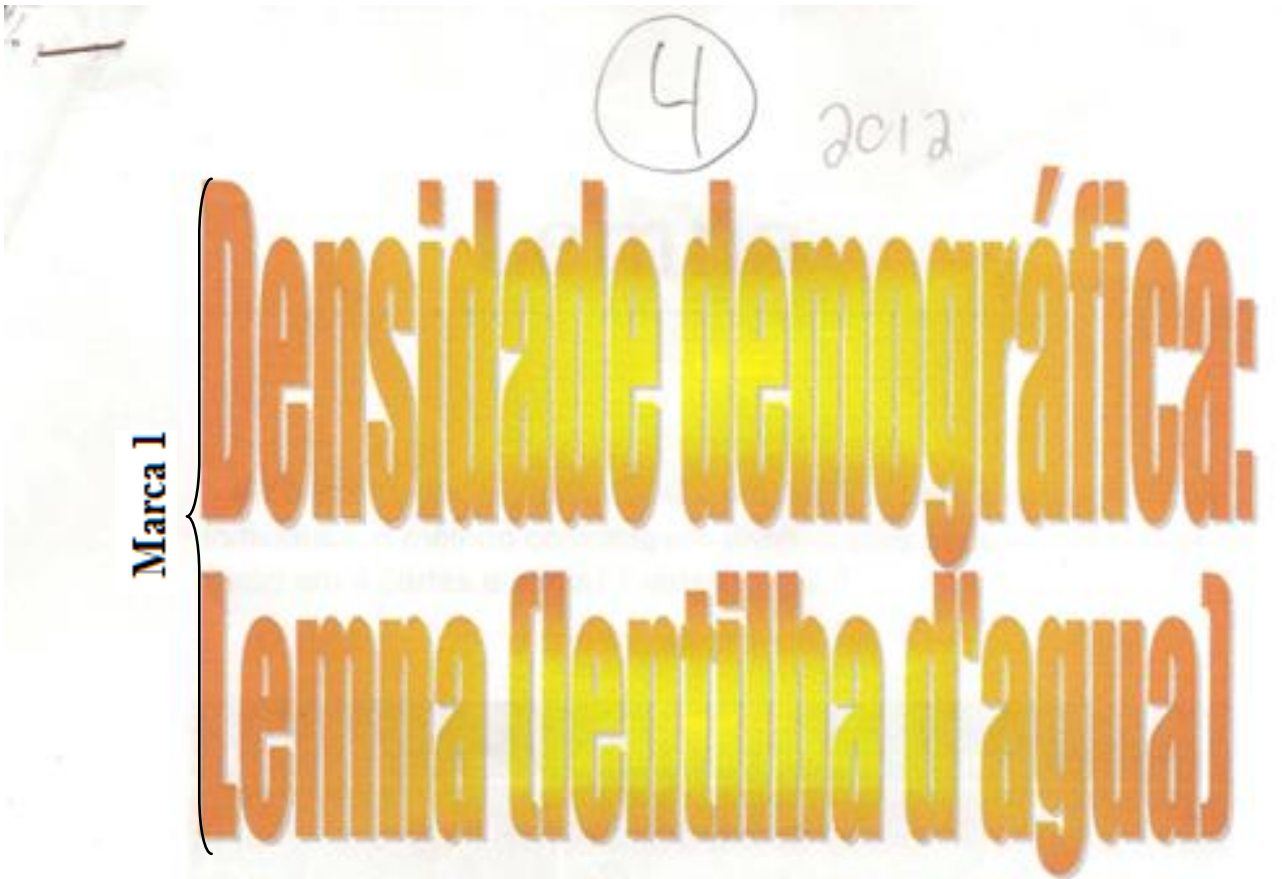

Escola de Aplicação FEUSP

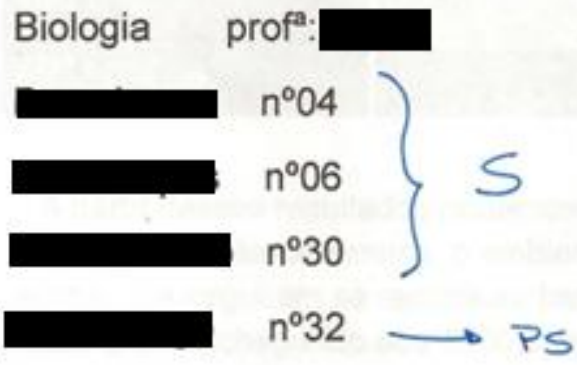

[Digite texto] 
Thiago Marinho Del Corso

INDICADORES DE ALFABETIZAÇÃO CIENTÍFICA, ARGUMENTOS E EXPLICAÇÕES -

\section{Lemna}

N $\int$ No primeiro dia, o grupo decidiu um método para a contagem dos

热 $\left\{\begin{array}{l}\text { indivíduos, o método consistia em dividir o pote onde os indivíduos } \\ \text { estão em } 4 \text { partes e contar } 1 \text { delas. } s=\text { ? }\end{array}\right.$

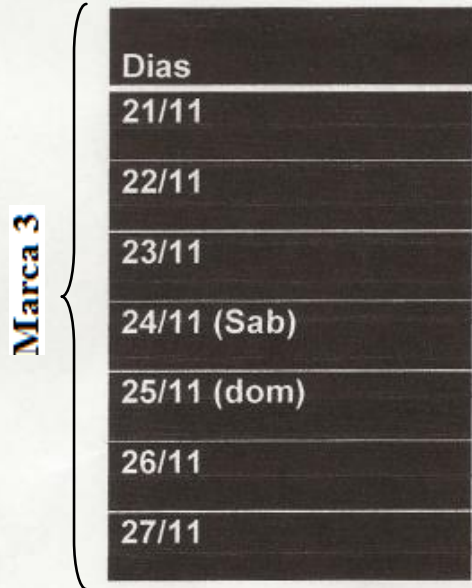

\section{Numero de individuos totais}

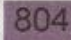

880

- A partir desses resultados podemos observar um crescimento

J dessa população de lemnas, o ambiente foi favorável e assim as

Iemnas conseguiram se reproduzir bem, tendo uma população

muito grande chegando aos 1800 indivíduos.

Marca $5\{$ Os indivíduos que estavam mais juntos foram contados como 1 só!

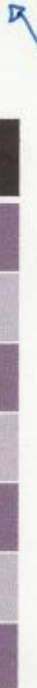

6 A população de Lemna se tiver um ambiente propicio para sua ขู ช్ reprodução, terá um crescimento rápido e grande. 

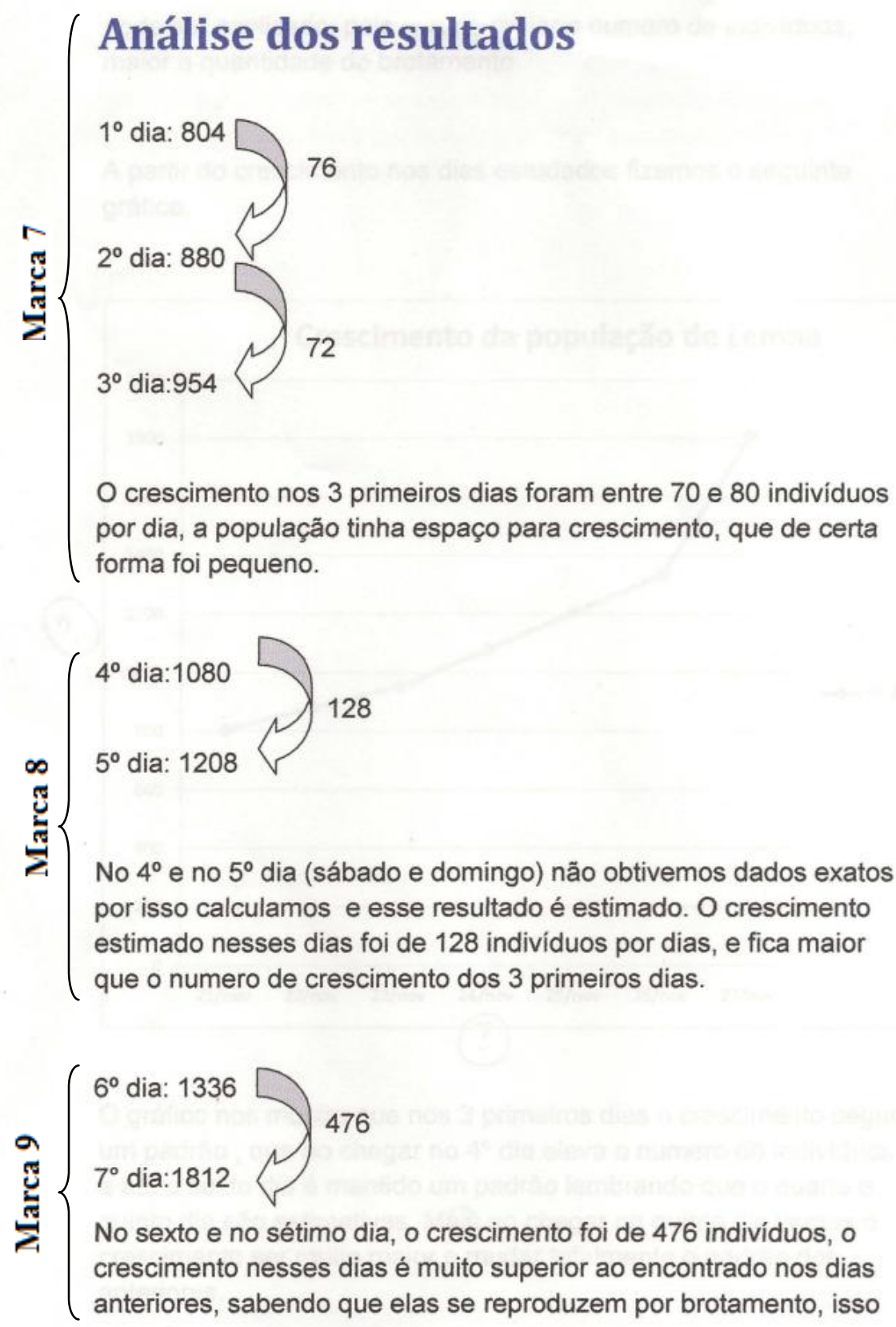
J $\{$ pode ser explicado, pois quanto maior o numero de indivíduos, 帘 maior a quantidade de brotamento.

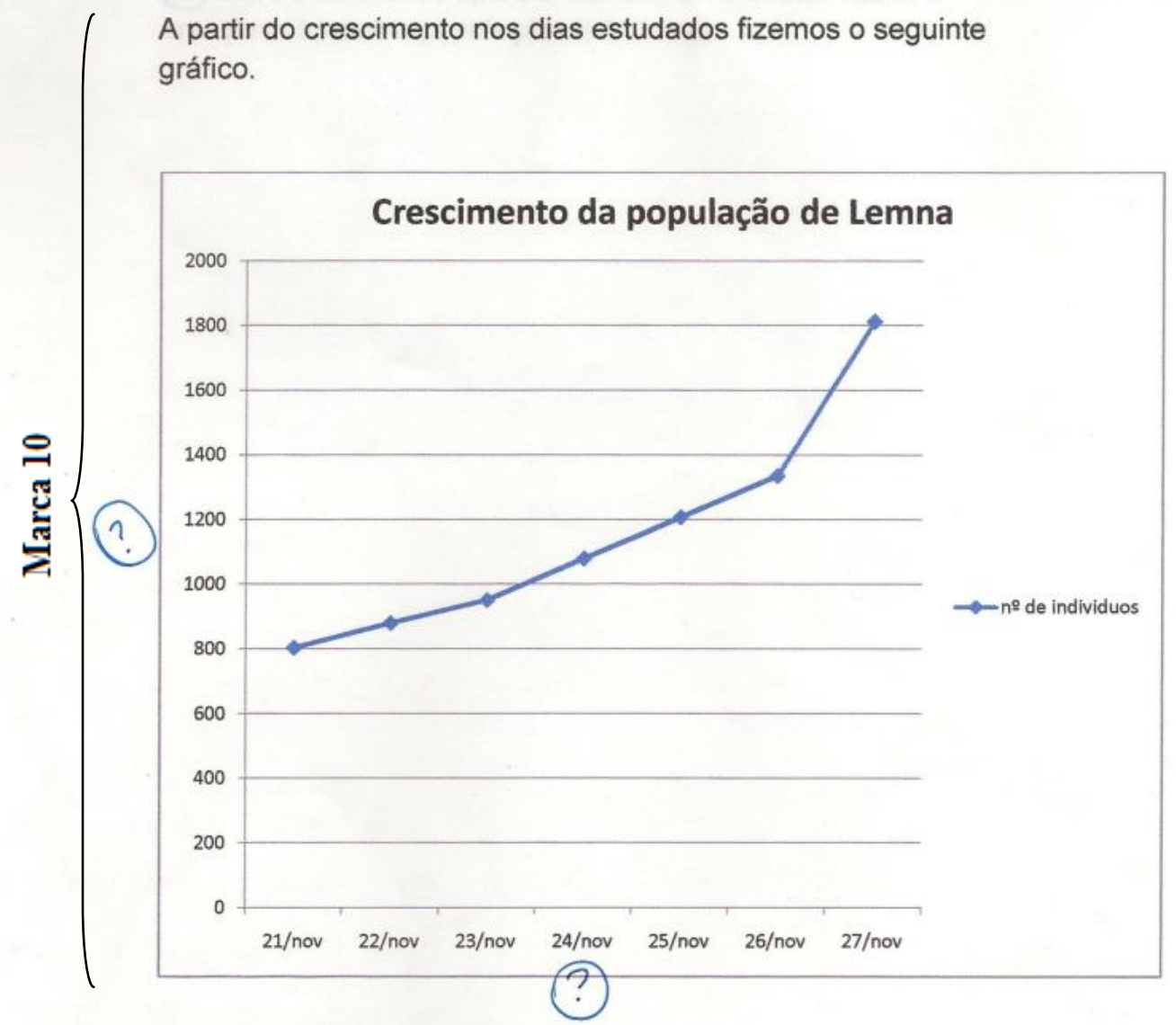

O gráfico nos mostra que nos 3 primeiros dias o crescimento segue
um padrão, que ao chegar no $4^{\circ}$ dia eleva o numero de indivíduos
e até o sexto dia é mantido um padrão lembrando que o quarto e
quinto dia são estimativas. Mais ao chegar no quinto dia vemos o
crescimento ser muito maior e mudar totalmente o padrão dos
anteriores.


INDICADORES DE ALFABETIZAÇÃO CIENTÍFICA, ARGUMENTOS E EXPLICAÇÕES Análise de Relatórios no Contexto de uma Sequência de Ensino Investigativo

I (O fato ocorrido pode ser justificado pelo fato das Lemnas se

I. reproduzirem por brotamento ( quando uma já está apta, ela da

grigem a outra e assim por diante), então quanto maior esse

Uunero de indivíduos aptos a dar origem a outros, maior o crescimento dessa população de Lemnas.

[Digite texto] 
Thiago Marinho Del Corso

INDICADORES DE ALFABETIZAÇÃO CIENTÍFICA, ARGUMENTOS E EXPLICAÇÕES -

Análise de Relatórios no Contexto de uma Sequência de Ensino Investigativo

Quadro 22

Identificação dos Indicadores de Alfabetização Científica no Relatório 4 - 2012

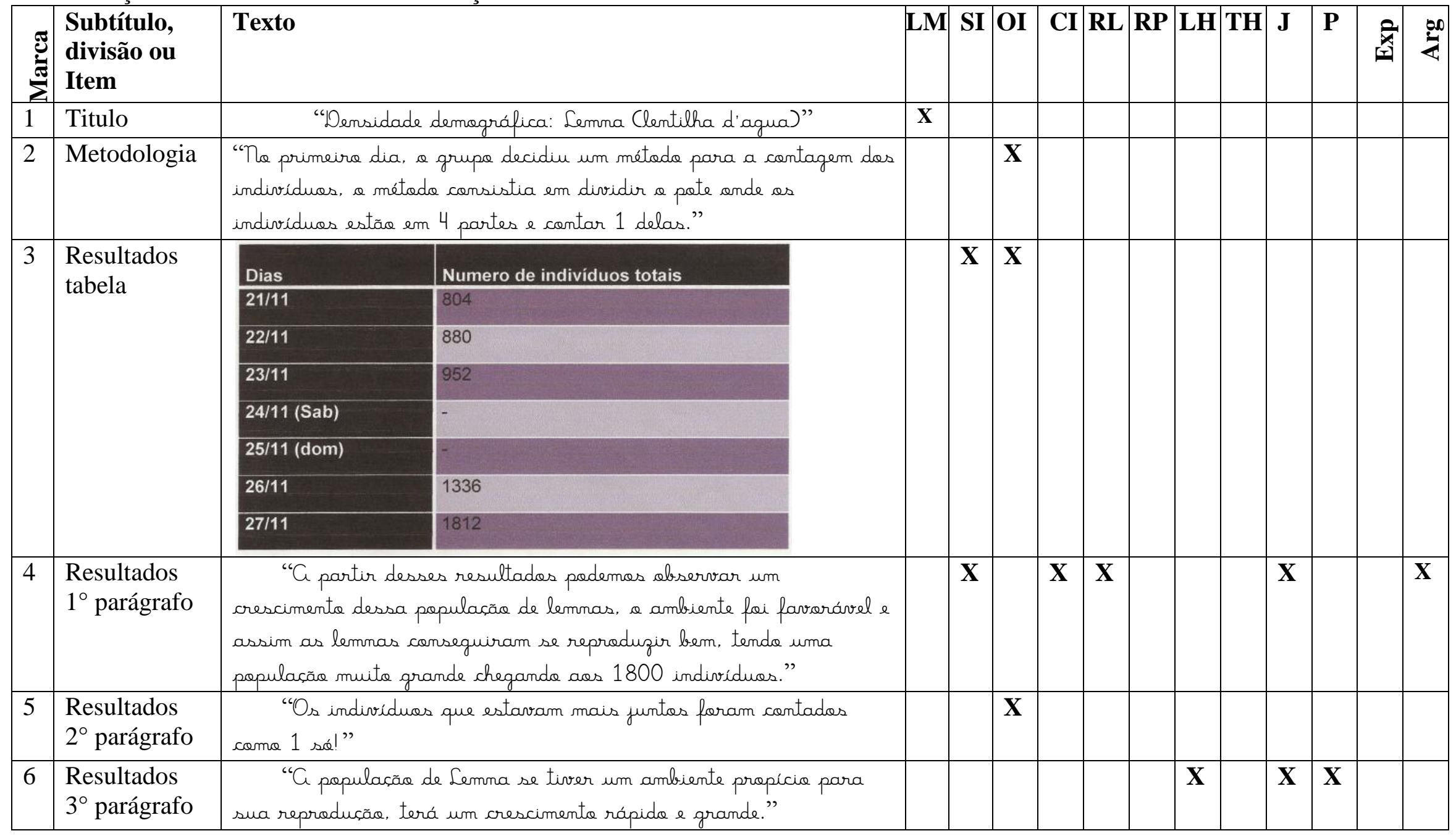

[Digite texto] 
Thiago Marinho Del Corso

INDICADORES DE ALFABETIZAÇÃO CIENTÍFICA, ARGUMENTOS E EXPLICAÇÕES -

Análise de Relatórios no Contexto de uma Sequência de Ensino Investigativo

\begin{tabular}{|c|c|c|c|c|c|c|c|c|c|c|c|c|c|c|}
\hline$\sum^{\mathbb{3}}$ & $\begin{array}{l}\text { Subtítulo, } \\
\text { divisão ou } \\
\text { Item }\end{array}$ & Texto & $\mathbf{L M}$ & SI & OI & CI & RL & $\mathbf{R P}$ & $\mathbf{L H}$ & $\mathbf{T H}$ & $\mathbf{J}$ & $\mathbf{P}$ & 8 & $\underset{Z}{20}$ \\
\hline 7 & $\begin{array}{l}\text { Interpretação } \\
\text { (Análise dos } \\
\text { resultados) } \\
1^{\circ} \text { parágrafo }\end{array}$ & 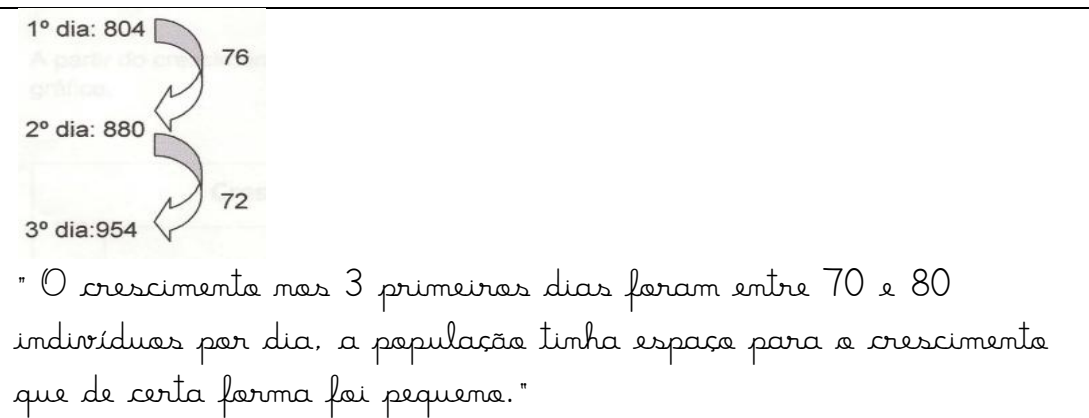 & & $\mathbf{X}$ & $\mathbf{X}$ & $\mathbf{X}$ & & & & & $\mathbf{X}$ & & $\mathbf{X}$ & \\
\hline 8 & $\begin{array}{l}\text { Interpretação } \\
\text { (Gnálise dos } \\
\text { resultados) } \\
2^{\circ} \text { parágrafo }\end{array}$ & $\begin{array}{l}\text { 40 dia:1080 } \\
\text { 50 dia: } 1208 \\
\text { " Ta } 4 \text { a e } 5 \text { a dia (sábada e dominga) nãa tivemas dadas exatas } \\
\text { por issa calculamas e esse resultada é estimada. (O crescimenta } \\
\text { estimada nesses dias fai de } 128 \text { individuas par dias, e fica maiar } \\
\text { que a númera de crescimenta das } 3 \text { primeiras dias" }\end{array}$ & & $\mathbf{X}$ & $\mathbf{X}$ & $\mathbf{X}$ & $\mathbf{X}$ & & & & & & & \\
\hline 9 & $\begin{array}{l}\text { Interpretação } \\
\text { (Cinálise dos } \\
\text { resultados) } \\
3^{\circ} \text { parágrafo }\end{array}$ & 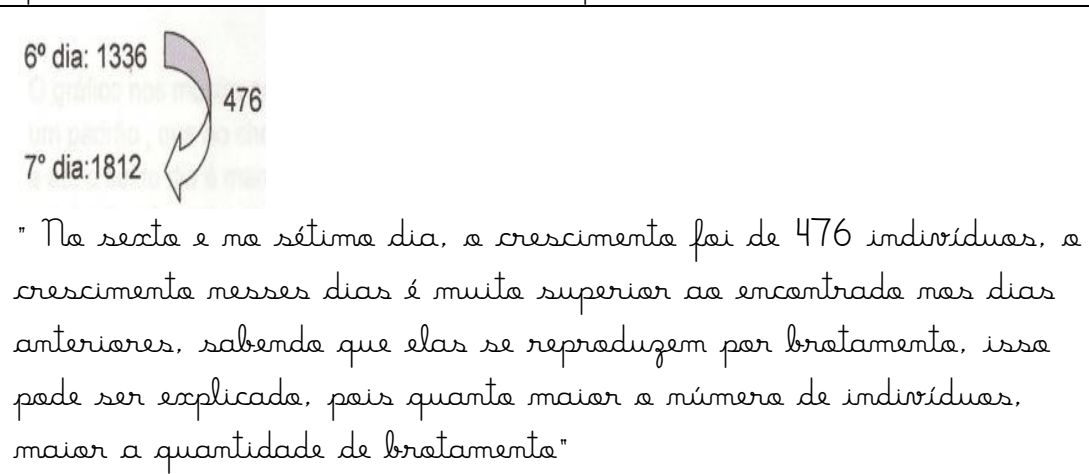 & & $\mathbf{X}$ & $\mathbf{X}$ & $\mathbf{X}$ & $\mathbf{X}$ & & & & $\mathbf{X}$ & & $\mathbf{X}$ & \\
\hline
\end{tabular}

[Digite texto] 
Thiago Marinho Del Corso

INDICADORES DE ALFABETIZAÇ̃̃o CIENTÍFICA, ARGUMENTOS E EXPLICAÇÕES -

Análise de Relatórios no Contexto de uma Sequência de Ensino Investigativo

\begin{tabular}{|c|c|c|c|c|c|c|c|c|c|c|c|c|c|c|c|}
\hline 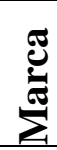 & $\begin{array}{l}\text { Subtítulo, } \\
\text { divisão ou } \\
\text { Item }\end{array}$ & \multicolumn{2}{|l|}{ Texto } & $\mathbf{L M}$ & SI & OI & CI & $\mathbf{R L}$ & $\mathbf{R P}$ & $\mathbf{L H}$ & TH & $\mathbf{J}$ & $\mathbf{P}$ & $\hat{x}$ & $\sum^{\infty}$ \\
\hline 10 & Gráfico & \multicolumn{2}{|c|}{$\begin{array}{l}\text { "A partir da crescimenta nos dias estudadas fizemas a seguinte } \\
\text { gráfica } \quad \text { crescimento da populasăo de temna }\end{array}$} & & $\mathbf{X}$ & $\mathbf{X}$ & $\mathbf{X}$ & & & & & & & & \\
\hline 11 & $\begin{array}{l}\text { Conclusão } \\
1^{\circ} \text { parágrafo }\end{array}$ & \multicolumn{2}{|c|}{$\begin{array}{l}\text { "O gráfica mas mastra que mas } 3 \text { primeiras dias a crescimenta } \\
\text { segue um padrãa, que ae chegar ma } 4 \text { a dia eleva a númera de } \\
\text { individuas a até a sexta dia é mantida um padrãa lembranda que } \\
\text { a quarta e quinta dia sãa estimativas. Mais aa chegar ma quinta } \\
\text { dia vemas a crescimenta ser muita maior e mudar tatalmente a } \\
\text { padrãa das anteriares. }\end{array}$} & & $\mathbf{X}$ & $\mathbf{X}$ & $\mathbf{X}$ & & & & & & & & \\
\hline 12 & $\begin{array}{l}\text { Conclusão } \\
2^{\circ} \text { parágrafo }\end{array}$ & \multicolumn{2}{|c|}{ 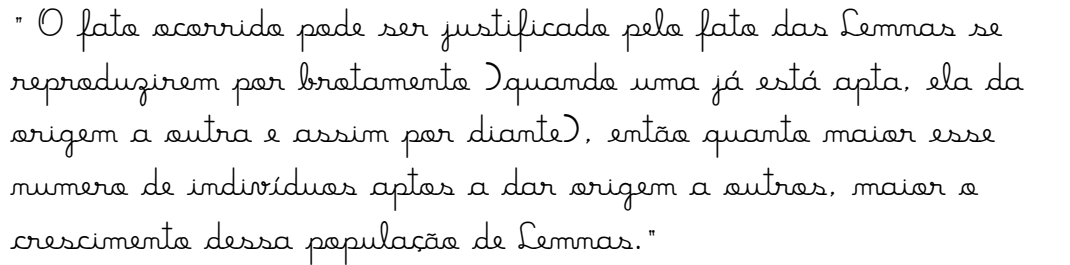 } & & & & & $\mathbf{X}$ & & & & $\mathbf{X}$ & & $\mathbf{X}$ & \\
\hline
\end{tabular}


Thiago Marinho Del Corso

INDICADORES DE ALFABETIZAÇÃO CIENTÍFICA, ARGUMENTOS E EXPLICAÇÕES -

Análise de Relatórios no Contexto de uma Sequência de Ensino Investigativo

O Relatório 5 - 2012

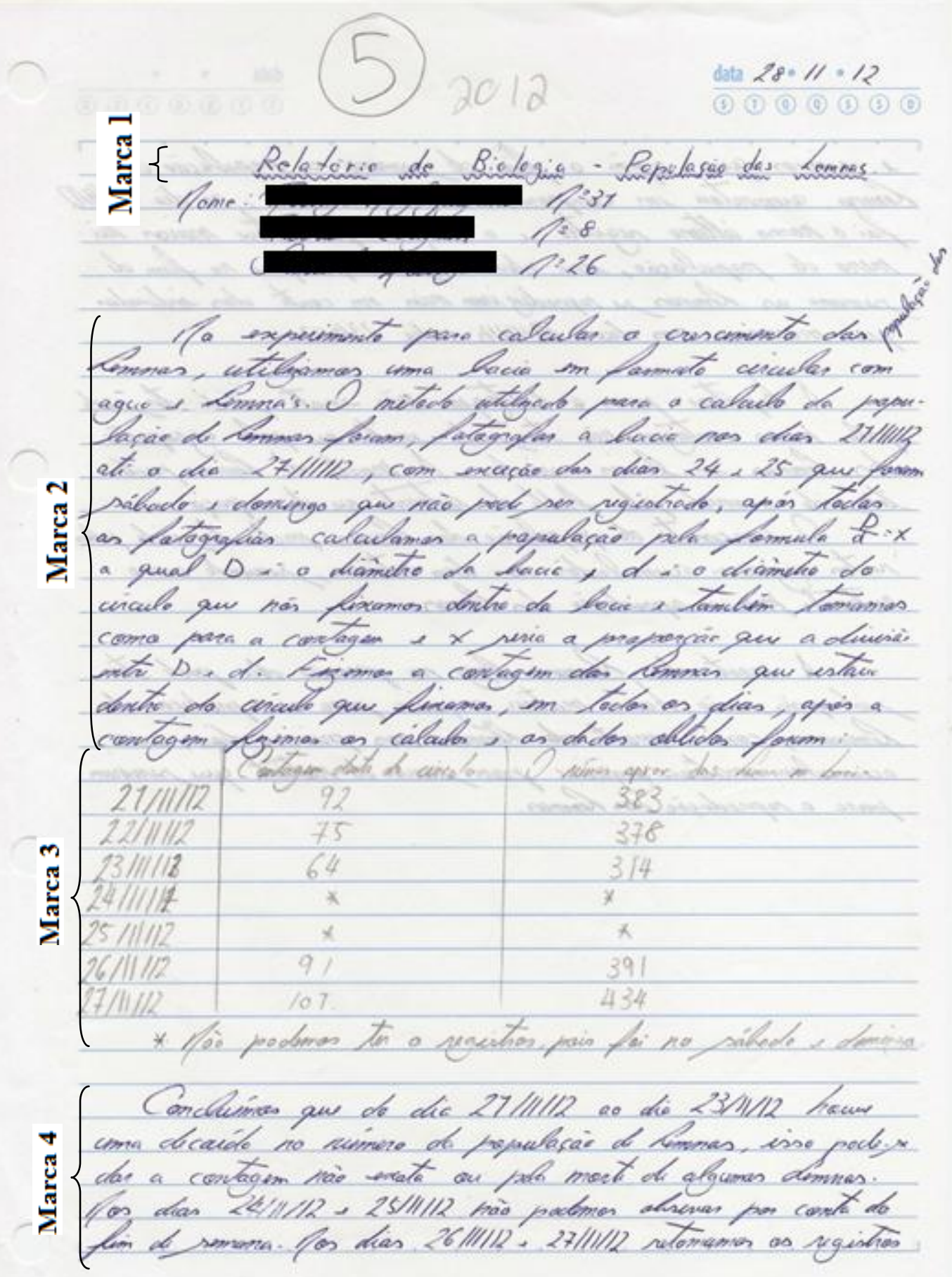

[Digite texto] 
Thiago Marinho Del Corso

INDICADORES DE ALFABETIZAÇÃO CIENTÍFICA, ARGUMENTOS E EXPLICAÇÕES Análise de Relatórios no Contexto de uma Sequência de Ensino Investigativo

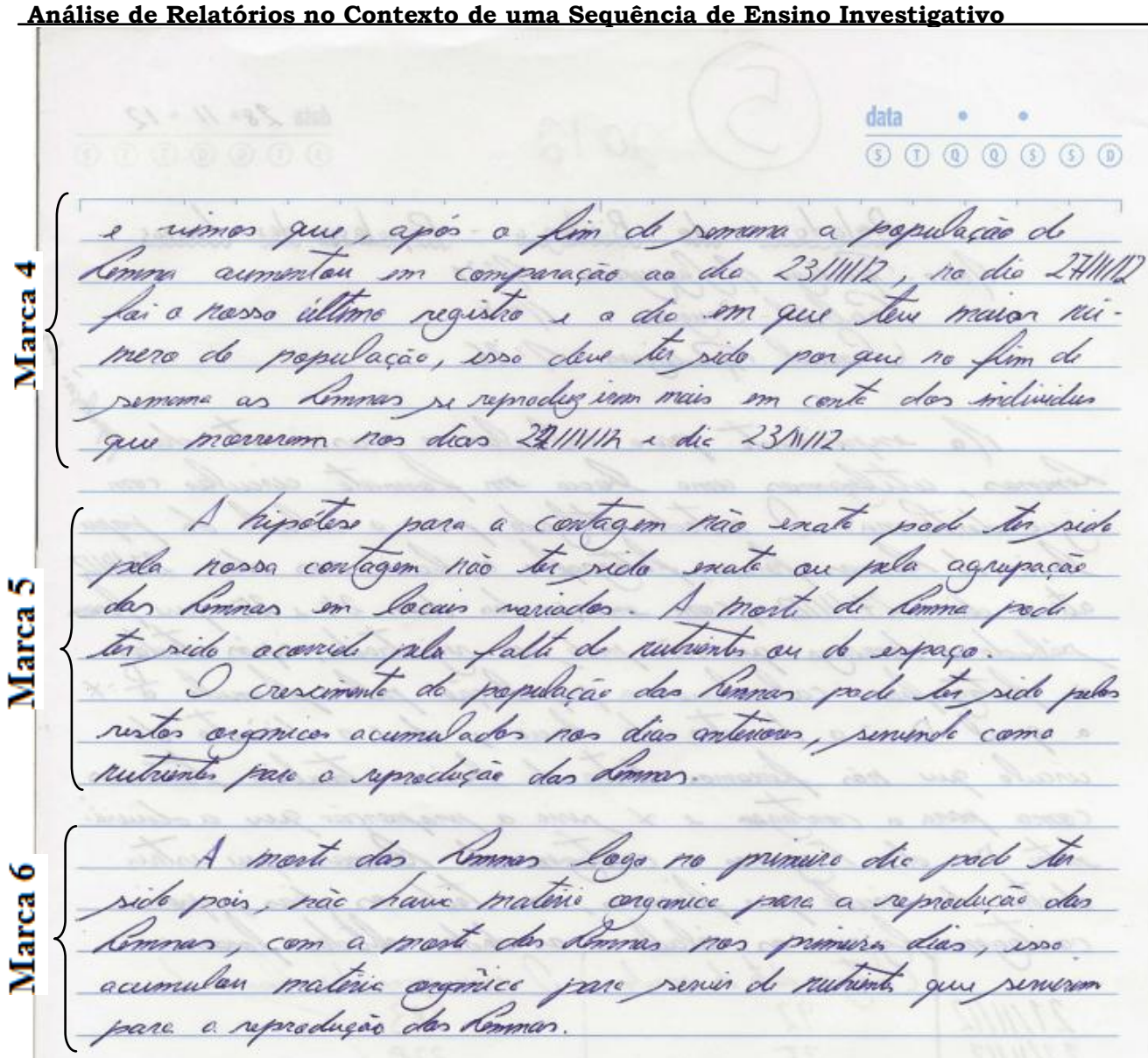

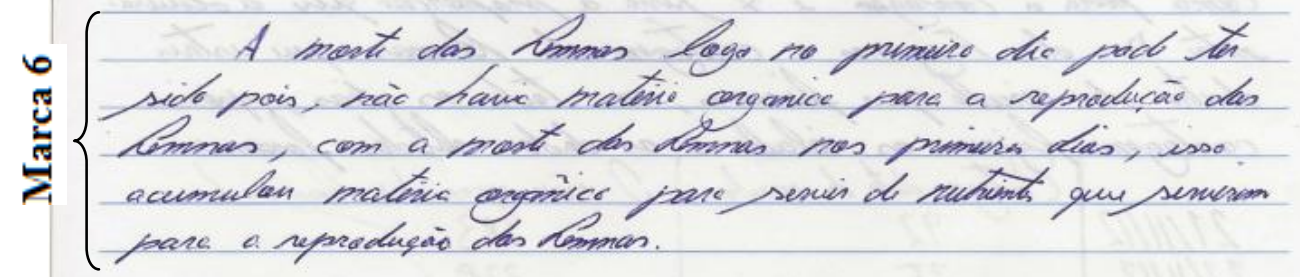
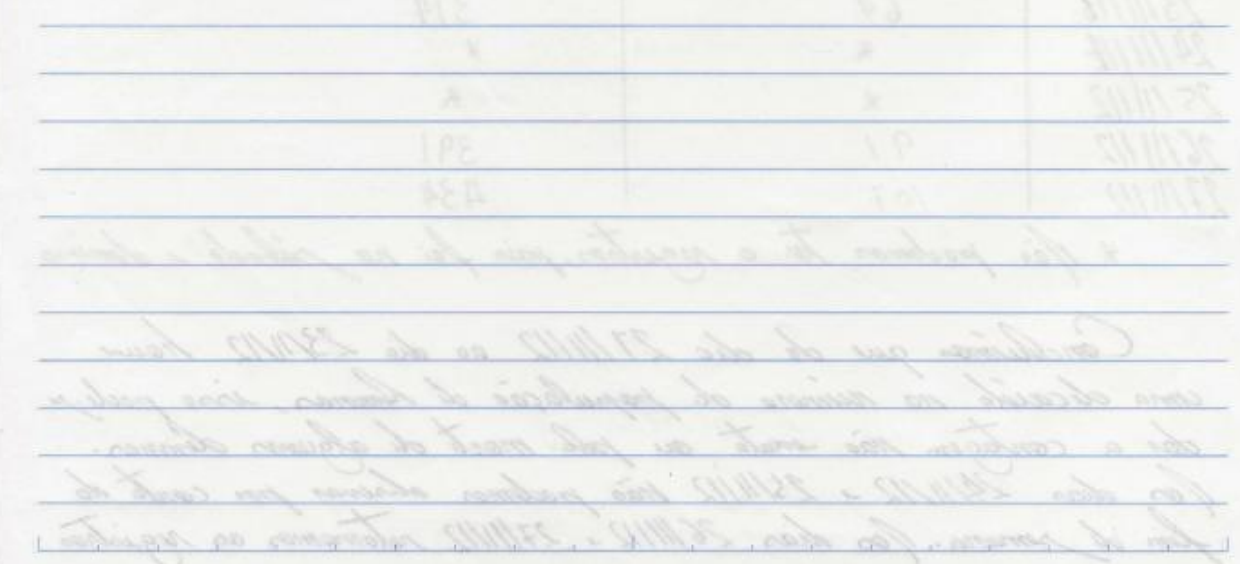
Thiago Marinho Del Corso

INDICADORES DE ALFABETIZAÇ̃̃O CIENTÍFICA, ARGUMENTOS E EXPLICAÇÕES -

Análise de Relatórios no Contexto de uma Sequência de Ensino Investigativo

Quadro 23

Identificação dos Indicadores de Alfabetização Científica no Relatório 5 - 2012

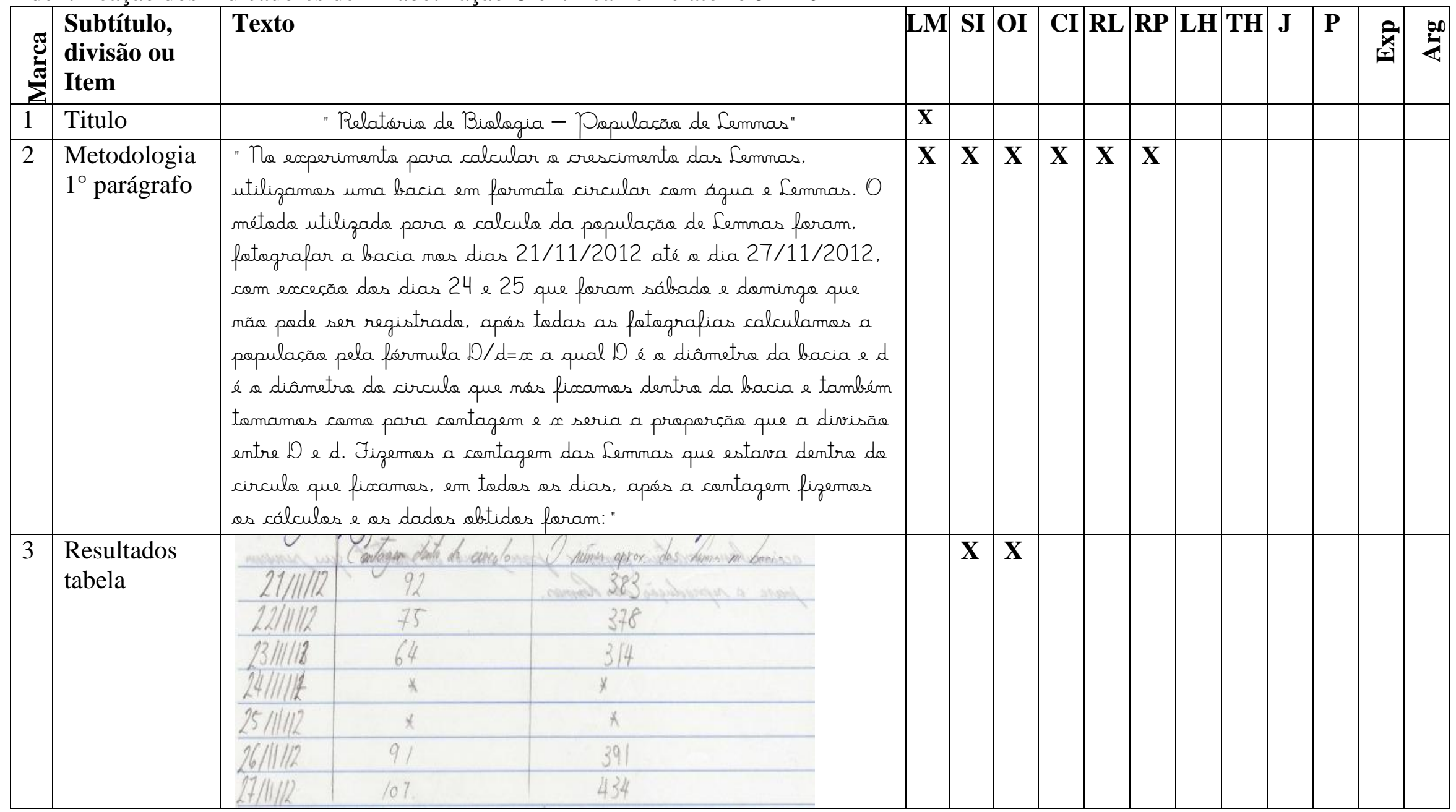


Thiago Marinho Del Corso

INDICADORES DE ALFABETIZAÇÃO CIENTÍFICA, ARGUMENTOS E EXPLICAÇÕES -

Análise de Relatórios no Contexto de uma Sequência de Ensino Investigativo

\begin{tabular}{|c|c|c|c|c|c|c|c|c|c|c|c|c|c|c|}
\hline 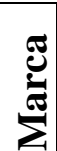 & $\begin{array}{l}\text { Subtítulo, } \\
\text { divisão ou } \\
\text { Item }\end{array}$ & Texto & $\mathbf{L M}$ & SI & OI & CI & RL & $\mathbf{R P}$ & $\mathbf{L H}$ & TH & $\mathbf{J}$ & $\mathbf{P}$ & 死 & $\sum_{4}^{+\infty}$ \\
\hline 4 & $\begin{array}{l}\text { Interpretação } \\
1^{\circ} \text { parágrafo }\end{array}$ & 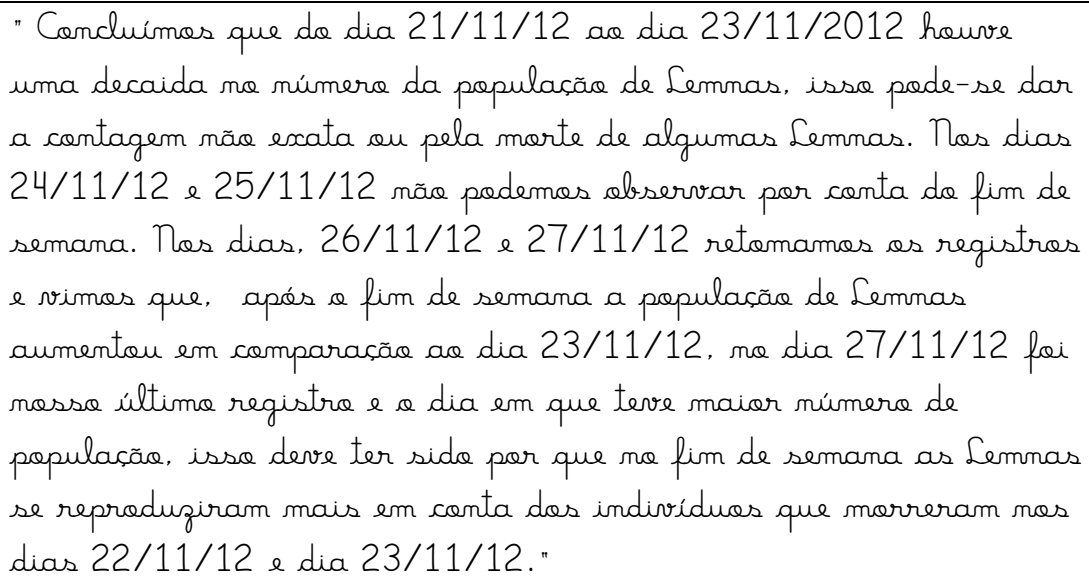 & & $\mathbf{X}$ & $\mathbf{X}$ & $\mathbf{X}$ & & & $\mathbf{X}$ & & $\mathbf{X}$ & & $\mathbf{X}$ & $\mathbf{X}$ \\
\hline 5 & $\begin{array}{l}\text { Interpretação } \\
2^{\circ} \text { parágrafo }\end{array}$ & $\begin{array}{l}\text { "A hipétese para a contagem nãa exata pode ter sida pela massa } \\
\text { contagem nãa ter sida exata ou pela agrupacãa das Lemnas em } \\
\text { lacais variadas. A morte de Lemna pode ter sida ocorrida pela } \\
\text { falta de nutrientes ou de espacso." }\end{array}$ & & & & & & & & & $\mathbf{X}$ & & & \\
\hline 6 & $\begin{array}{l}\text { Interpretação } \\
3^{\circ} \text { parágrafo }\end{array}$ & 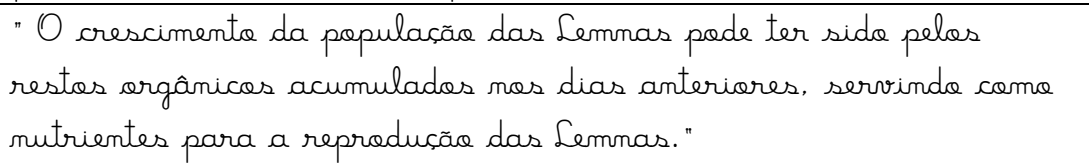 & & $\mathbf{X}$ & & & & & & & $\mathbf{X}$ & & & \\
\hline 7 & $\begin{array}{l}\text { Interpretação } \\
4^{\circ} \text { parágrafo }\end{array}$ & $\begin{array}{l}\text { "A moerte das Lemnas loga na primeira dia pode ter sida pois, nãa } \\
\text { havia matéria orgânica para a reproduçãa das Lemnas, com a } \\
\text { morte das Lemnas nos primeiras dias, issa acumulou matéria } \\
\text { orgânica para servir de nutrientes que serviram para a } \\
\text { reproduçãa das Lemnas." }\end{array}$ & & $\mathbf{X}$ & & & $\mathbf{X}$ & & & & $\mathbf{X}$ & & $\mathbf{X}$ & \\
\hline
\end{tabular}

[Digite texto] 
Thiago Marinho Del Corso

INDICADORES DE ALFABETIZAÇÃO CIENTÍFICA, ARGUMENTOS E EXPLICAÇÕES -

Análise de Relatórios no Contexto de uma Sequência de Ensino Investigativo

\section{O Relatório 6 - 2012}

Escola de Aplicaçăo - FE USP

Grupo: 101 - EM

$\mathbf{N}^{\circ} 07$
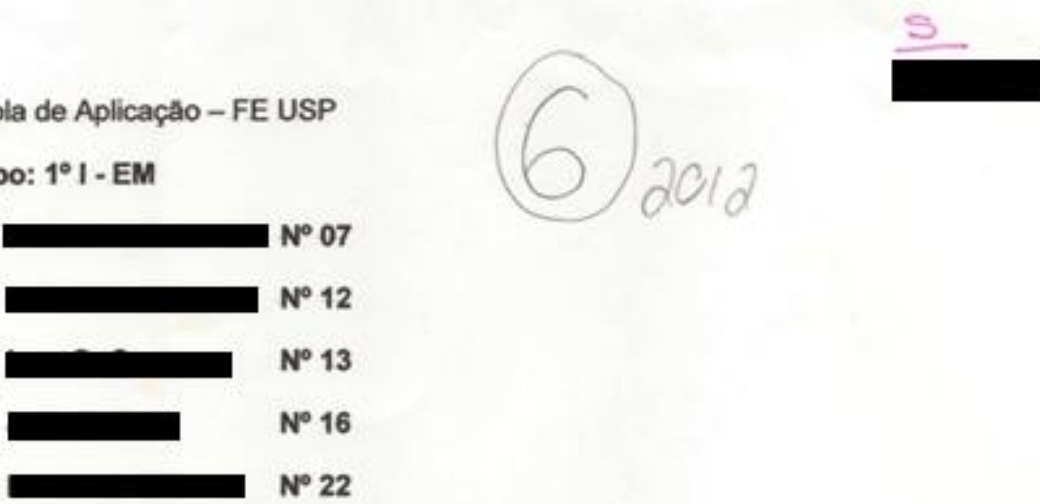

Prof." ${ }^{a}$ - Biologia

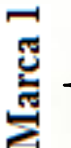

\section{$\{$ Verificando o crescimento da populacão de Lemnas}
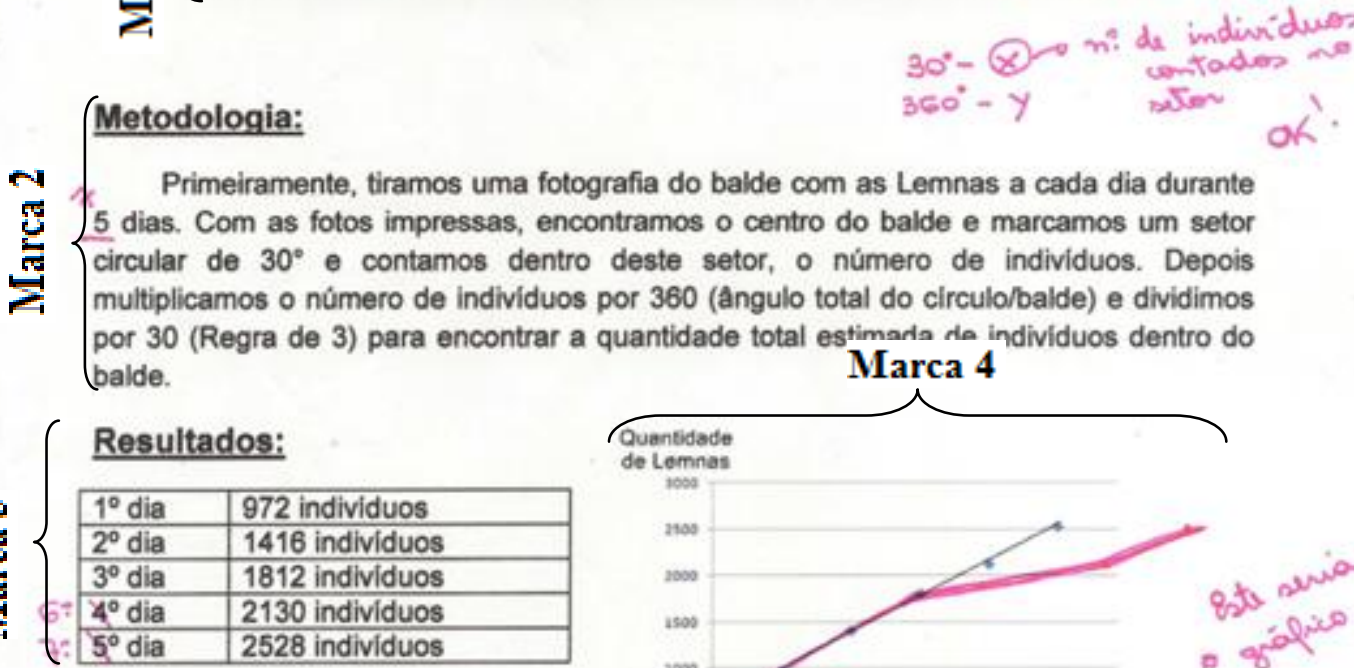

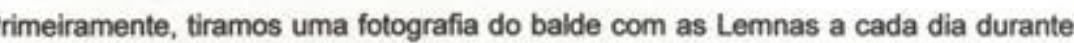

5 dias. Com as fotos impressas, encontramos o centro do balde e marcamos um setor os por 360 (ângulo total do circulo/balde) e dividimos por 30 (Regra de 3 ) para encontrar a quantidade total estimaria de individuos dentro do

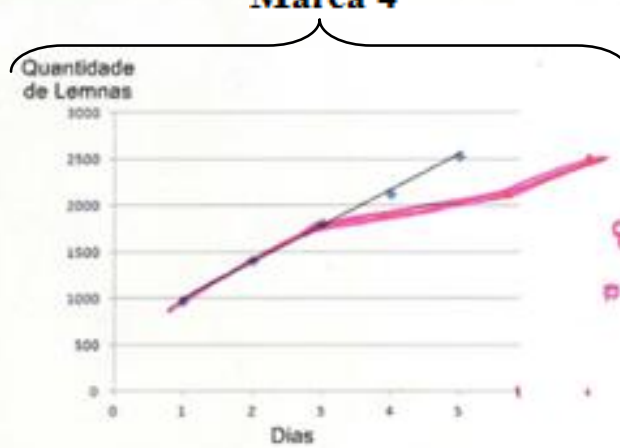

\footnotetext{
Análise dos Resultados:

Neste experimento podemos observar que houve um aumento gradual no decorrer \{os dias. Com a metodologia utilizada, conseguimos uma estimativa dos resultados e nossa hipótese para explicar esse fenômeno é que a grande quantidade de matéria orgânica (individuos de Lemnas mortas) e a quantidade de sol oferecido às Lemnas favoreceu o crescimento dessa populaçăo.
} 
Thiago Marinho Del Corso

INDICADORES DE ALFABETIZAÇ̃̃o CIENTÍFICA, ARGUMENTOS E EXPLICAÇÕES -

Análise de Relatórios no Contexto de uma Sequência de Ensino Investigativo

\section{Quadro 24}

Identificação dos Indicadores de Alfabetização Científica no Relatório 6 - 2012

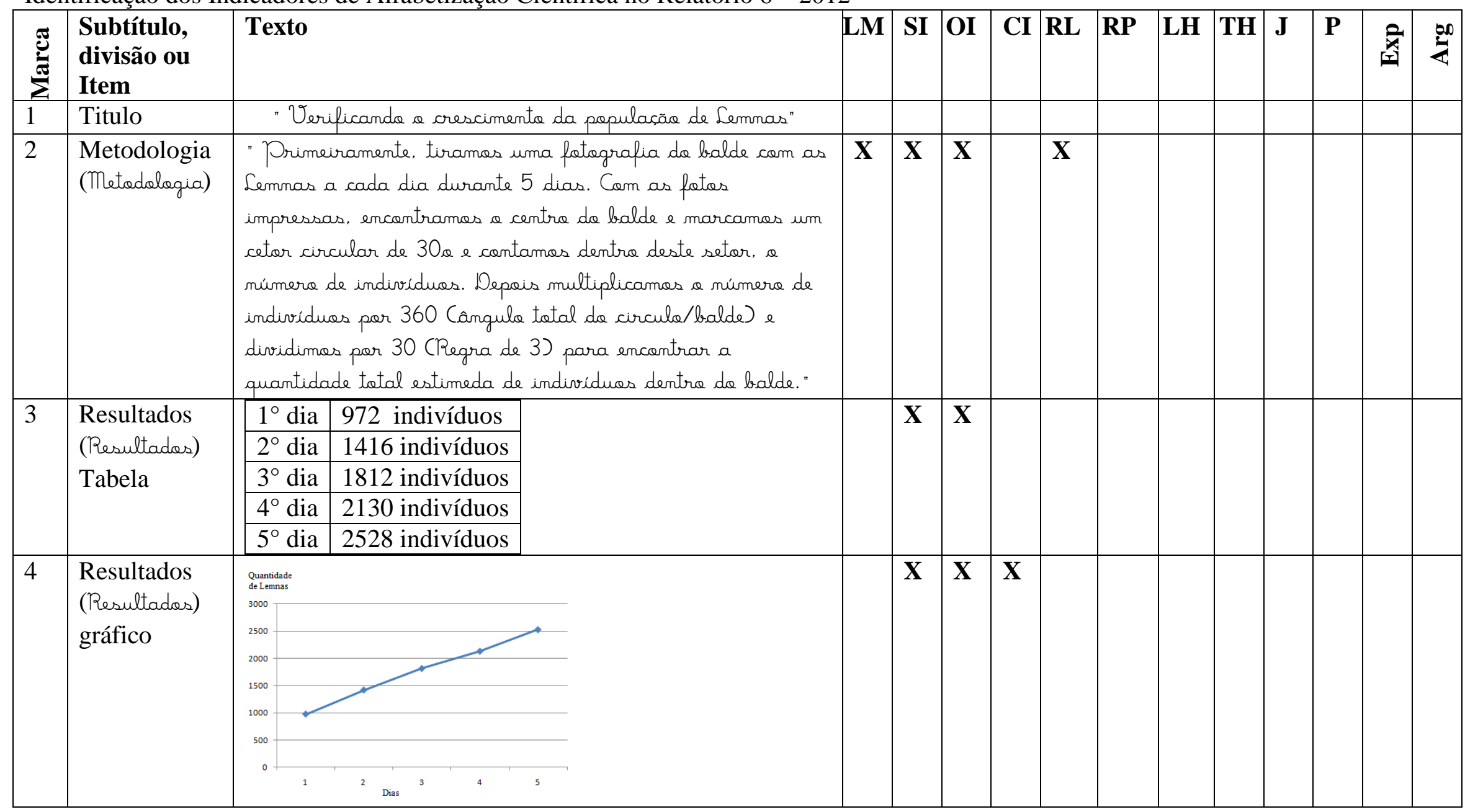

[Digite texto] 
Thiago Marinho Del Corso

INDICADORES DE ALFABETIZACÃO CIENTÍFICA, ARGUMENTOS E EXPLICAÇÕES -

Análise de Relatórios no Contexto de uma Sequência de Ensino Investigativo

\begin{tabular}{|c|c|c|c|c|c|c|c|c|c|c|c|c|c|c|}
\hline 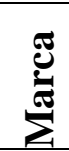 & $\begin{array}{l}\text { Subtítulo, } \\
\text { divisão ou } \\
\text { Item }\end{array}$ & Texto & LM & SI & OI & CI & RL & $\mathbf{R P}$ & LH & TH & $\mathbf{J}$ & $\mathbf{P}$ & 勾 & ${ }_{2}^{20}$ \\
\hline 5 & $\begin{array}{l}\text { Interpretação } \\
\text { (Cinálise dos } \\
\text { resultados) }\end{array}$ & 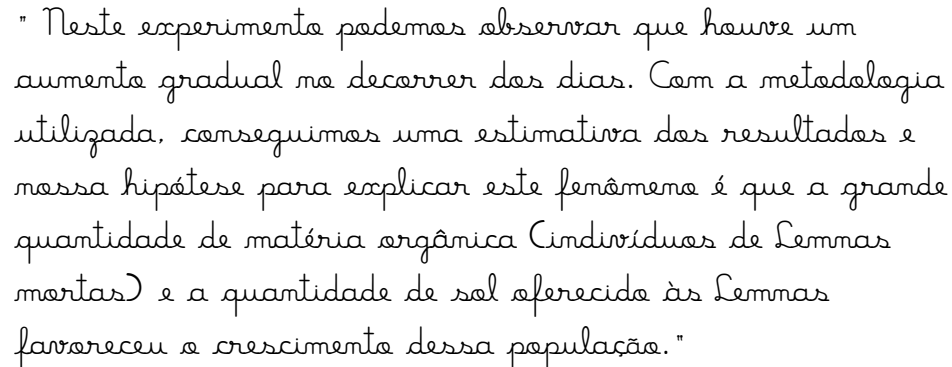 & & $\mathbf{X}$ & & $\mathbf{X}$ & & & $\mathbf{X}$ & & $\mathbf{X}$ & & $\mathbf{X}$ & \\
\hline
\end{tabular}


Thiago Marinho Del Corso

INDICADORES DE ALFABETIZAÇÃO CIENTÍFICA, ARGUMENTOS E EXPLICAÇÕES -

Análise de Relatórios no Contexto de uma Sequência de Ensino Investigativo

O Relatório 7 - 2012

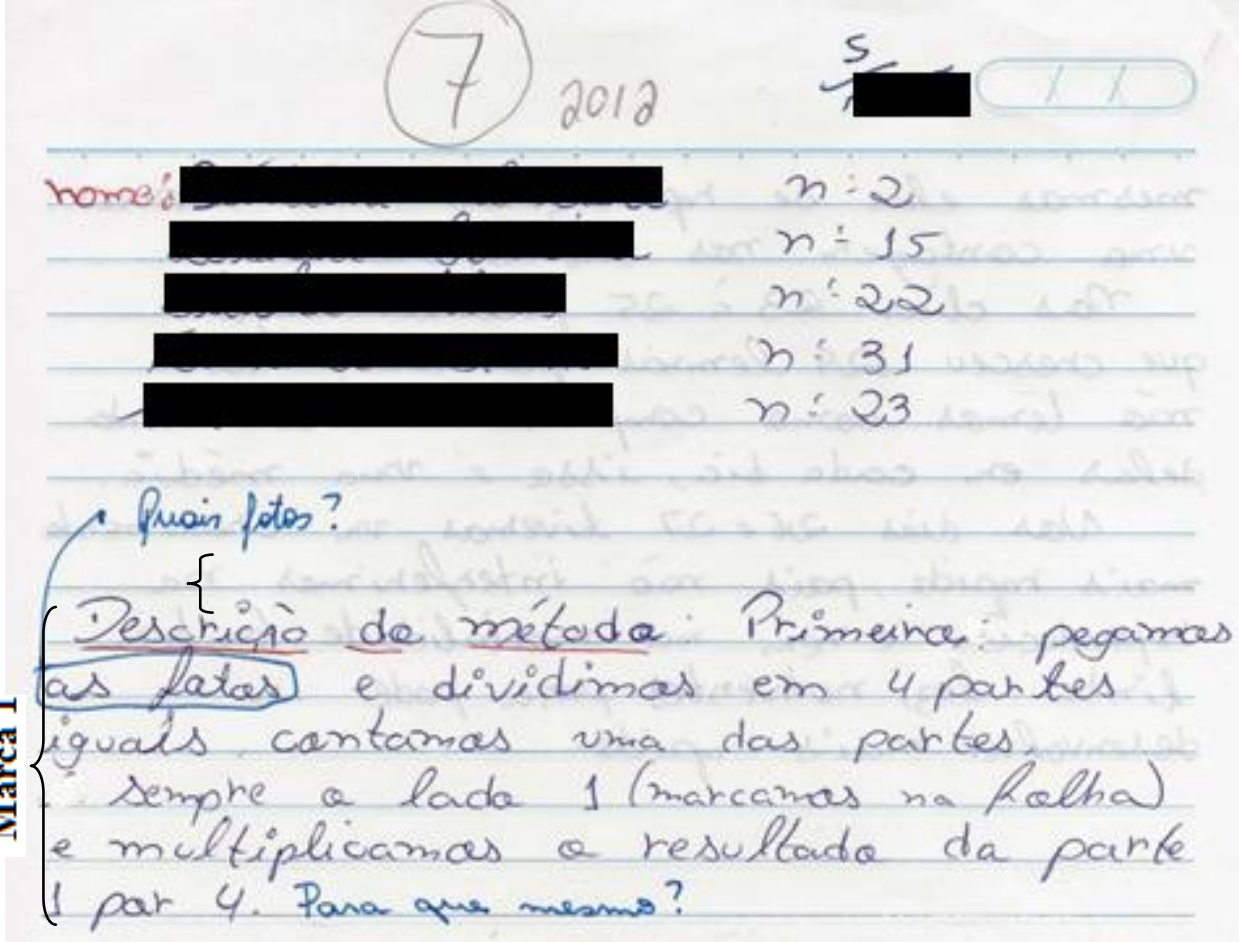

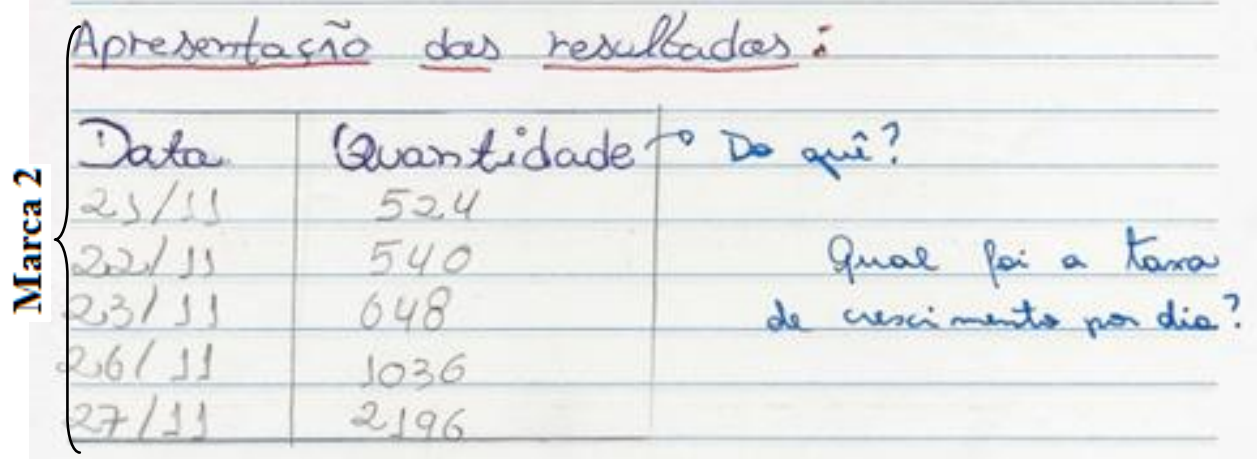

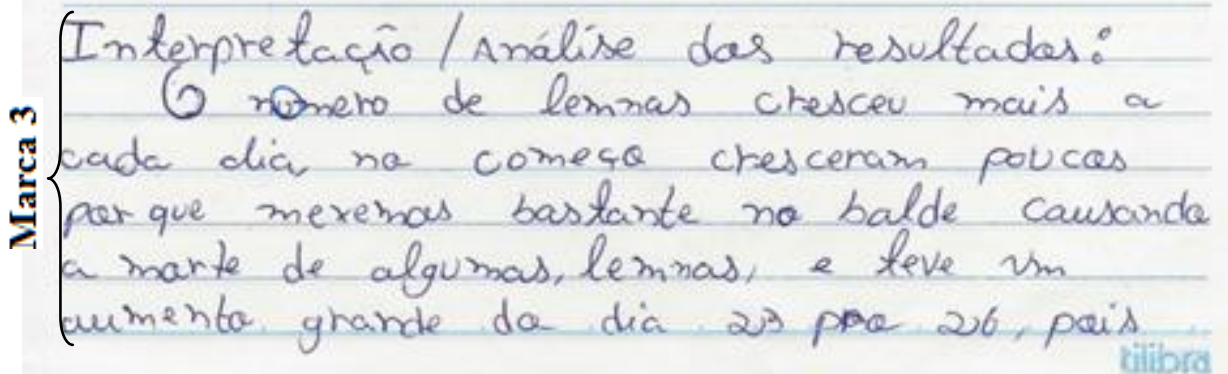


Thiago Marinho Del Corso

INDICADORES DE ALFABETIZAÇ̃̃o CIENTÍFICA, ARGUMENTOS E EXPLICAÇÕES -

Análise de Relatórios no Contexto de uma Sequência de Ensino Investigativo

Quadro 25

Identificação dos Indicadores de Alfabetização Científica no Relatório 7 - 2012

\begin{tabular}{|c|c|c|c|c|c|c|c|c|c|c|c|c|c|c|}
\hline 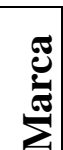 & $\begin{array}{l}\text { Subtítulo, } \\
\text { divisão ou } \\
\text { Item }\end{array}$ & Texto & $\mathbf{L M}$ & SI & OI & CI & RL & $\mathbf{R P}$ & LH & TH & $\mathbf{J}$ & $\mathbf{P}$ & a & $\sum^{00}$ \\
\hline 1 & $\begin{array}{l}\text { Metodologia } \\
\text { (Descriçãa da } \\
\text { métada) }\end{array}$ & $\begin{array}{l}\text { "Primeira pegamas fotas e dividimas em } 4 \text { partes iguais, } \\
\text { contamas uma das partes, sempre a lada } 1 \text { (marcamas na folha) e } \\
\text { multiplicamas a resultada da parte } 1 \text { por } 4 \text {." }\end{array}$ & $X$ & & $\mathrm{X}$ & & & $\mathrm{X}$ & & & & & & \\
\hline 2 & $\begin{array}{l}\text { Resultados } \\
\text { (Cupresentasãa } \\
\text { das } \\
\text { resultados) }\end{array}$ & \begin{tabular}{l|l|} 
Data & Quantidade \\
$21 / 11$ & 524 \\
$22 / 11$ & 540 \\
$23 / 11$ & 648 \\
$26 / 11$ & 1036 \\
$27 / 11$ & 2196 \\
\end{tabular} & & $\mathrm{X}$ & $X$ & & & & & & & & & \\
\hline 3 & $\begin{array}{l}\text { Interpretação } \\
\text { (Interpretaçãa } \\
\text { /Cinálise dos } \\
\text { resultados) } \\
1^{\circ} \text { parágrafo }\end{array}$ & $\begin{array}{l}\text { "O múmera de lemnas cresceu mais a cada dia na comesa } \\
\text { cresceram paucas par que mexemas bastante no balde causanda a } \\
\text { morte de algumas, lemnas, e teve um aumenta grande da dia } 23 \\
\text { pro 26, pois mesmas elas se reproduzinda nãa tivemas uma } \\
\text { contagem nos dias } 24 \text { e 25." }\end{array}$ & & $\mathrm{X}$ & $\mathrm{X}$ & $X$ & & & & & $\mathrm{X}$ & & $X$ & \\
\hline 4 & $\begin{array}{l}\text { Interpretação } \\
\text { (Interpretaçãe } \\
\text { /Cinálise dos } \\
\text { resultados) } \\
2^{\circ} \text { parágrafo }\end{array}$ & $\begin{array}{l}\text { " Nas dias } 23 \text { à } 25 \text { podemos diger que crescen } 129 \text { lemnas por } \\
\text { dia, mas nãa temas como comprovar a crescimenta delas em cada } \\
\text { dia, issa é uma média." }\end{array}$ & & $X$ & $\mathrm{X}$ & $X$ & & & $X$ & & & & & \\
\hline 5 & $\begin{array}{l}\text { Interpretação } \\
\text { (Interpretaçãa } \\
\text { /Cinálise dos } \\
\text { resultados) } \\
3^{\circ} \text { parágrafo }\end{array}$ & $\begin{array}{l}\text { " Mas dias } 26 \text { e } 27 \text { tivemas um crescimenta mais rápida, pais nãa } \\
\text { interferimas na reproduçãa, e nem na mortalidade, também tinha } \\
\text { luz, nutrientes para poder se desenvolver mais rápida." }\end{array}$ & & $X$ & $\mathrm{X}$ & $X$ & & & & & $\mathrm{X}$ & & $X$ & \\
\hline
\end{tabular}

[Digite texto] 
Thiago Marinho Del Corso

INDICADORES DE ALFABETIZAÇÃO CIENTÍFICA, ARGUMENTOS E EXPLICAÇÕES -

Análise de Relatórios no Contexto de uma Sequência de Ensino Investigativo

\section{O Relatório 8 - 2012}

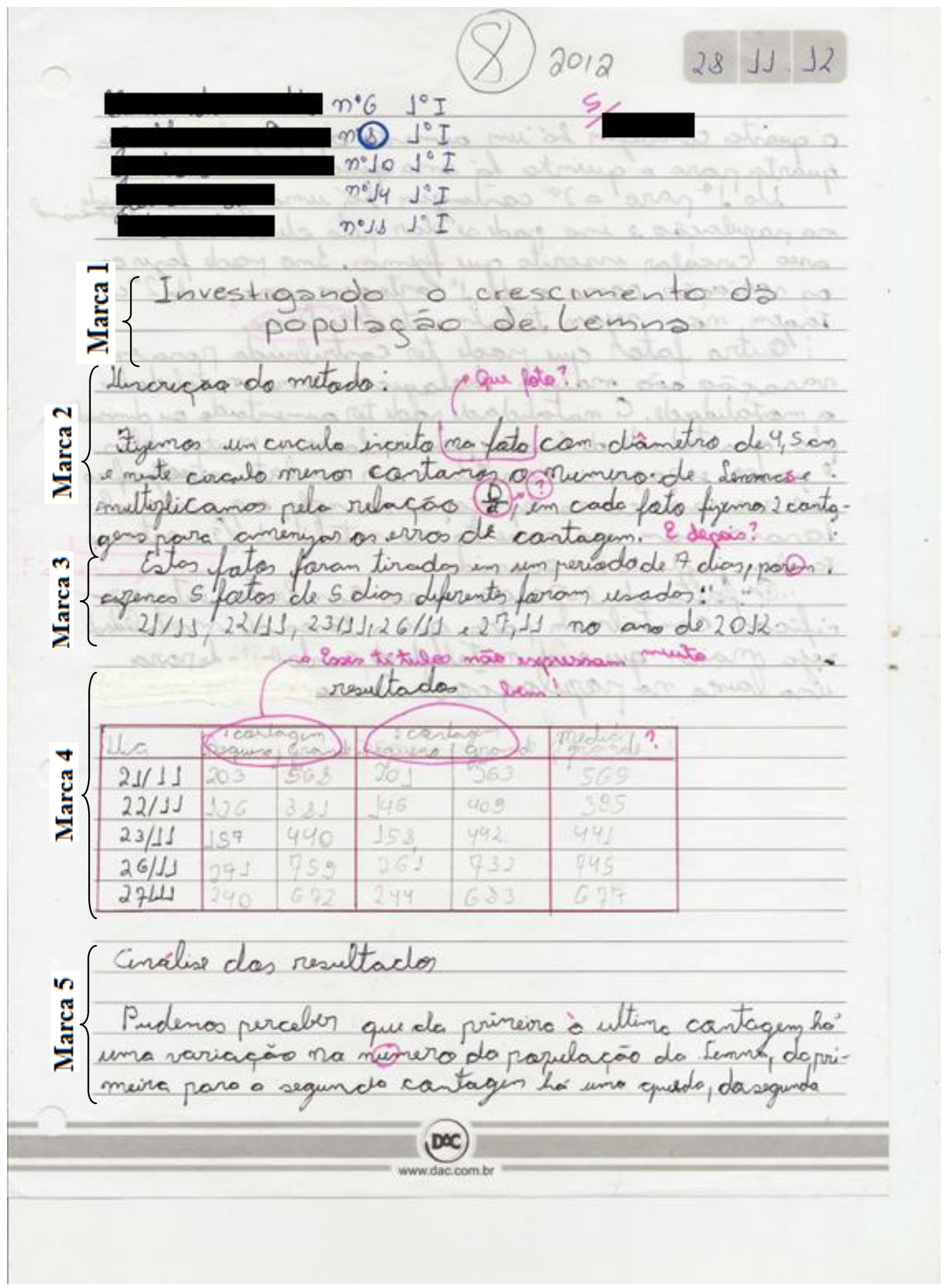

[Digite texto] 
Thiago Marinho Del Corso

INDICADORES DE ALFABETIZAÇÃO CIENTÍFICA, ARGUMENTOS E EXPLICAÇÕES -

Análise de Relatórios no Contexto de uma Sequência de Ensino Investigativo

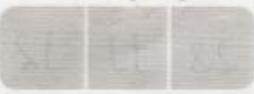

I $\{$ a quarta cantagem há um aumento da paculacião ida

quarta parc a quinta há uma quedo.
Lo jo pare a $2^{\circ}$ cantagem há uma

( Lo. pare a 2 canagem há uma grande quede.

- na rasulacia e ino pade se dar pele clessodade ñó

İ area Carcalar inscrite que fijemos. Ino prodo fajer cam

$\because$ as variacos como o de $1^{\circ}$ cantagem vara e de 2 con-

tagem, nó sejam tatalmente@ridicago.

Cutro fator eque pade ter contribuido para ena

- a mortalidado. A natalidad pode ter aumentado ou diminicla

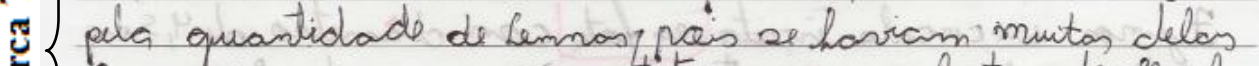

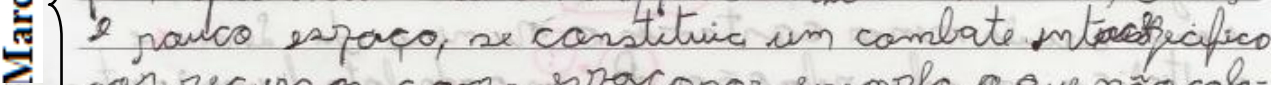
pan recursos como espacopor escenofo, o que não cala-

Larava cam um aumento no natalidado. O contrario

Fambem pagleria ter ocarrido

$\infty$ G falts de eszacas ans combates inbraese-

I Sificos cantribuem para que a tasca de mortalidad

seja maior que a de natalidade conbubuindopara

- uma bava na rapulacio de Lema

retuatlenar and salismi

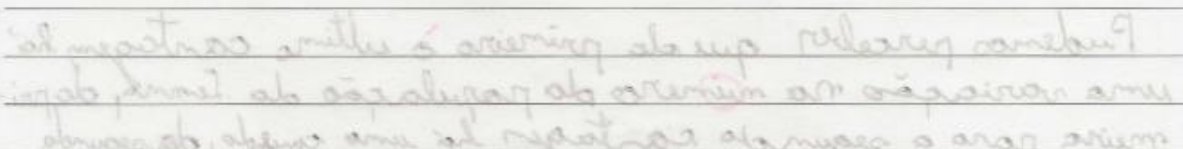

[Digite texto] 
Thiago Marinho Del Corso

INDICADORES DE ALFABETIZAÇ̃̃o CIENTÍFICA, ARGUMENTOS E EXPLICAÇÕES -

Análise de Relatórios no Contexto de uma Sequência de Ensino Investigativo

\section{Quadro 26}

Identificação dos Indicadores de Alfabetização Científica no Relatório 8 - 2012

\begin{tabular}{|c|c|c|c|c|c|c|c|c|c|c|c|c|c|c|c|c|c|c|c|}
\hline 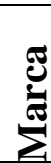 & $\begin{array}{l}\text { Subtítulo, } \\
\text { divisão ou } \\
\text { Item }\end{array}$ & \multicolumn{6}{|l|}{ Texto } & $\mathbf{L M}$ & SI & OI & CI & $\mathbf{R L}$ & $\mathbf{R P}$ & $\mathbf{L H}$ & TH & $\mathbf{J}$ & $\mathbf{P}$ & $\underset{x}{-1}$ & $\sum^{\infty}$ \\
\hline 1 & Titulo & \multicolumn{6}{|c|}{ "Investiganda a crescimenta da papulaçãa de Lemnas" } & & & & & & & & & & & & \\
\hline 2 & $\begin{array}{l}\text { Metodologia } \\
\text { (Descriçãa da } \\
\text { metada) } \\
1^{\circ} \text { parágrafo }\end{array}$ & \multicolumn{6}{|c|}{$\begin{array}{l}\text { "Fizemas um circula inscrita na fata com diâmetra de } 4,5 \mathrm{~cm} \text { e } \\
\text { neste circula menar contamas a númera de Lemnas. Multiplicamas } \\
\text { pela relascãa D/d, em cada fata fizemas } 2 \text { contagens para amenizar } \\
\text { as erras de contagem" }\end{array}$} & $\mathbf{X}$ & & $\mathbf{X}$ & & & $\mathbf{X}$ & & & & & & \\
\hline 3 & $\begin{array}{l}\text { Metodologia } \\
\text { (Descriçãa do } \\
\text { métada) } \\
2^{\circ} \text { parágrafo }\end{array}$ & \multicolumn{6}{|c|}{$\begin{array}{l}\text { "Estas fotas foram tiradas em um periada de } 7 \text { dias, porem } \\
\text { apenas } 5 \text { fotos de } 5 \text { dias diferentes foram usadas. } \\
\text { 21/11, 22/11, 23/11, 26/11 e 27/11 ne ane de 2012." }\end{array}$} & $\mathbf{X}$ & & $\mathbf{X}$ & & & & & & & & & \\
\hline 4 & $\begin{array}{l}\text { Resultados } \\
\text { (Resultados) }\end{array}$ & \multicolumn{6}{|c|}{ "Resultados" } & & $\mathbf{X}$ & $\mathbf{X}$ & & & & & & & & & \\
\hline 5 & $\begin{array}{l}\text { Interpretação } \\
\text { (Análise dos } \\
\text { resultados) } \\
1^{\circ} \text { parágrafo }\end{array}$ & \multicolumn{6}{|c|}{$\begin{array}{l}\text { "Pudemas perceber que da primeira à ultima contagem há uma } \\
\text { variaçãa na númera da populaçãa de Lemna, da primeira para a } \\
\text { segunda contagem há uma queda, da segunda para a quarta } \\
\text { contagem há um aumenta da populaçãa e da quarta para a quinta } \\
\text { há uma queda." }\end{array}$} & & $\mathbf{X}$ & $\mathbf{X}$ & & & & & & & & & \\
\hline 6 & $\begin{array}{l}\text { Interpretação } \\
\text { (Gnálise dos }\end{array}$ & \multicolumn{6}{|c|}{$\begin{array}{l}\text { " Da } 1^{\text {a }} \text { para a } 2^{\text {a }} \text { contagem há uma grande queda na populaçãa } \\
\text { e issa pode se dar pela densidade na área circular inscrita que }\end{array}$} & & $\mathbf{X}$ & $\mathbf{X}$ & $\mathbf{X}$ & & & & & $\mathbf{X}$ & & & $\mathbf{X}$ \\
\hline
\end{tabular}

[Digite texto] 
Thiago Marinho Del Corso

INDICADORES DE ALFABETIZAÇ̃̃o CIENTÍFICA, ARGUMENTOS E EXPLICAÇÕES -

Análise de Relatórios no Contexto de uma Sequência de Ensino Investigativo

\begin{tabular}{|c|c|c|c|c|c|c|c|c|c|c|c|c|c|c|}
\hline & $\begin{array}{l}\text { resultados) } \\
2^{\circ} \text { parágrafo }\end{array}$ & $\begin{array}{l}\text { fizemas. Issa pode fazer com as variaçäes coma a da primeira } \\
\text { contagem para a segunda contagem nãa sejam tatalmente } \\
\text { verídicas." }\end{array}$ & & & & & & & & & & & & \\
\hline 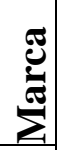 & $\begin{array}{l}\text { Subtítulo, } \\
\text { divisão ou } \\
\text { Item }\end{array}$ & Texto & $\mathbf{L M}$ & SI & OI & CI & RL & $\mathbf{R P}$ & $\mathbf{L H}$ & TH & $\mathbf{J}$ & $\mathbf{P}$ & a & 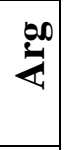 \\
\hline 7 & $\begin{array}{l}\text { Interpretação } \\
\text { (Análise dos } \\
\text { resultados) } \\
3^{\circ} \text { parágrafo }\end{array}$ & 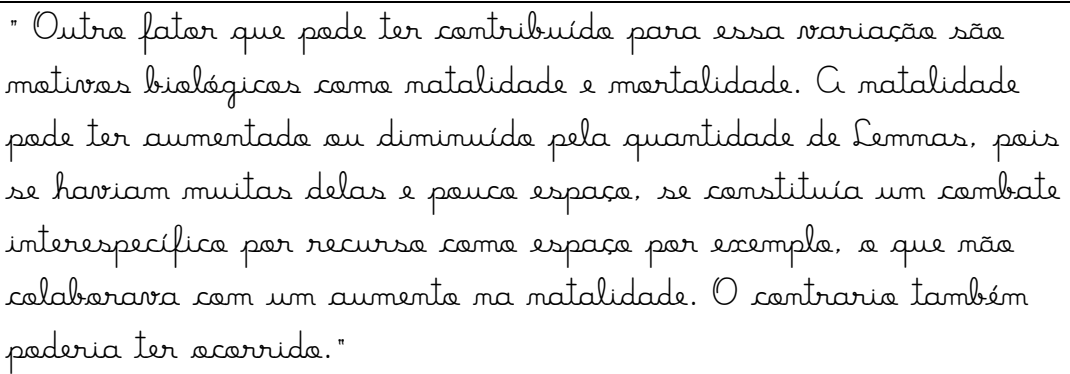 & & & & & $\mathbf{X}$ & & & & $\mathbf{X}$ & & & $\mathbf{X}$ \\
\hline 8 & $\begin{array}{l}\text { Interpretação } \\
\text { (Análise dos } \\
\text { resultados) } \\
3^{\circ} \text { parágrafo }\end{array}$ & $\begin{array}{l}\text { "A falta de espaca e esses combates intraespecificas contribuem } \\
\text { para que a taxa de mortalidade seja maior que a de natalidade, } \\
\text { contribuinda para a baixa na populaçãa de Lemna." }\end{array}$ & & $\mathbf{X}$ & & & & & & & $\mathbf{X}$ & & & $\mathbf{X}$ \\
\hline
\end{tabular}


Thiago Marinho Del Corso

INDICADORES DE ALFABETIZAÇÃO CIENTÍFICA, ARGUMENTOS E EXPLICAÇÕES -

Análise de Relatórios no Contexto de uma Sequência de Ensino Investigativo

\section{O Relatório 9 - 2012}

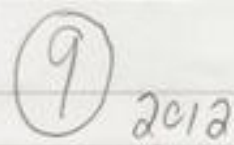

NS

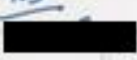

STlimat

Esala de Aplicacão fEúsp

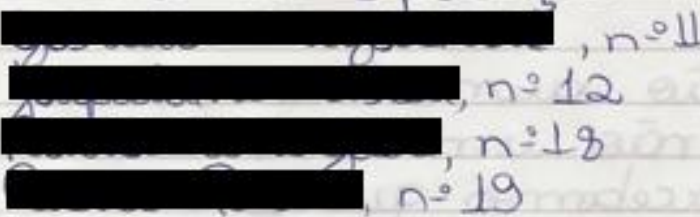

喜\{Relatório:

(descriģa do métoob

- Sicridimors o pote om 4 setores,

I certames quantos indivídues tinham

II em cada um e multiplicamos per 4.

En algums cases em que harrio

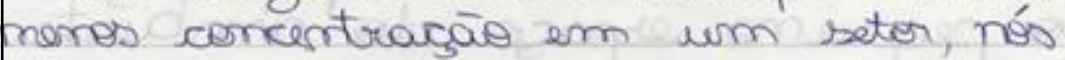

tirames la médioy e muetiplieames per 4

- apresentaf̧ão dos resultados

" De primeiro dia, e númexo de

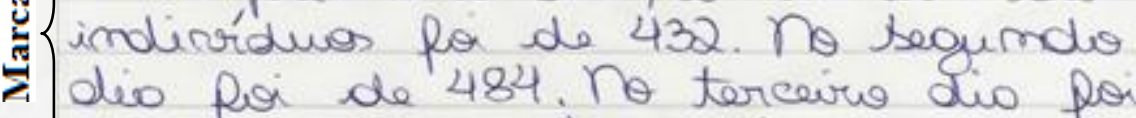

de 688 . No sexto dia poi de $\$ 16$.

¿ ne ú́lime dio floi de 1016. Qual foi a taxa de crescimento por dia? 


\section{- análise dos resultados}

A população aumentour todos is dias, rnas nồ um erescimento tão grande. Percebomos que no internolo de does dias houre um

- maior erescimento, mas se formos

I Avaliar os padriós certó tudo don-

tro do esperado $\rightarrow$ frual ra o pachāo esperado?

OBS: O erescimento pri quimentando, Po quï?

mas do sexcto pro sétimo dio di.

minuiu em pequemas proporgéses, levomos em consideraçâto a grande disputa por esparso derido ao gramde erescimmento do pepulargio \& $\theta$ pequemo espaço do ambiente.

Quair fatores, aleim da disputa por espaco, podem ter influenciado a cuescimento de populajeà por. dia? 
Thiago Marinho Del Corso

INDICADORES DE ALFABETIZAÇ̃̃o CIENTÍFICA, ARGUMENTOS E EXPLICAÇÕES -

Análise de Relatórios no Contexto de uma Sequência de Ensino Investigativo

\section{Quadro 27}

Identificação dos Indicadores de Alfabetização Científica no Relatório 9 - 2012

\begin{tabular}{|c|c|c|c|c|c|c|c|c|c|c|c|c|c|c|}
\hline 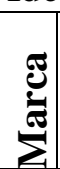 & $\begin{array}{l}\text { Subtítulo, } \\
\text { divisão ou } \\
\text { Item }\end{array}$ & Texto & $\mathbf{L M}$ & SI & OI & CI & $\mathbf{R L}$ & $\mathbf{R P}$ & $\mathbf{L H}$ & $\mathbf{T H}$ & $\mathbf{J}$ & $\mathbf{P}$ & 党 & $\sum^{\infty}$ \\
\hline 1 & Titulo & "Relatéria" & & & & & & & & & & & & \\
\hline 2 & $\begin{array}{l}\text { Metodologia } \\
\text { (descriçãa da } \\
\text { métada) }\end{array}$ & 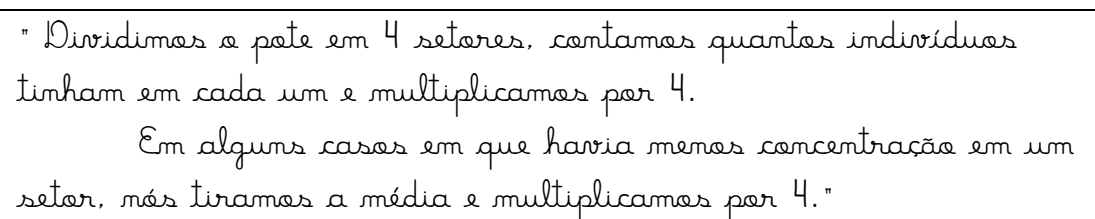 & & & $\mathbf{X}$ & $\mathbf{X}$ & & $\mathbf{X}$ & & & & & & \\
\hline 3 & $\begin{array}{l}\text { Resultados } \\
\text { (apresentaçãa } \\
\text { dos } \\
\text { resultados) }\end{array}$ & $\begin{array}{l}\text { " Ta primeira dia, a númera de individuas fai de 432. Ma segunda } \\
\text { dia fai de 484. Na terceira dia fai de 668. Ma sexta dia fai de } \\
\text { 916. E na ultima dia fai de 1016." }\end{array}$ & & $\mathbf{X}$ & $\mathbf{X}$ & & & & & & & & & \\
\hline 4 & $\begin{array}{l}\text { Interpretação } \\
\text { (análise das } \\
\text { resultados) }\end{array}$ & 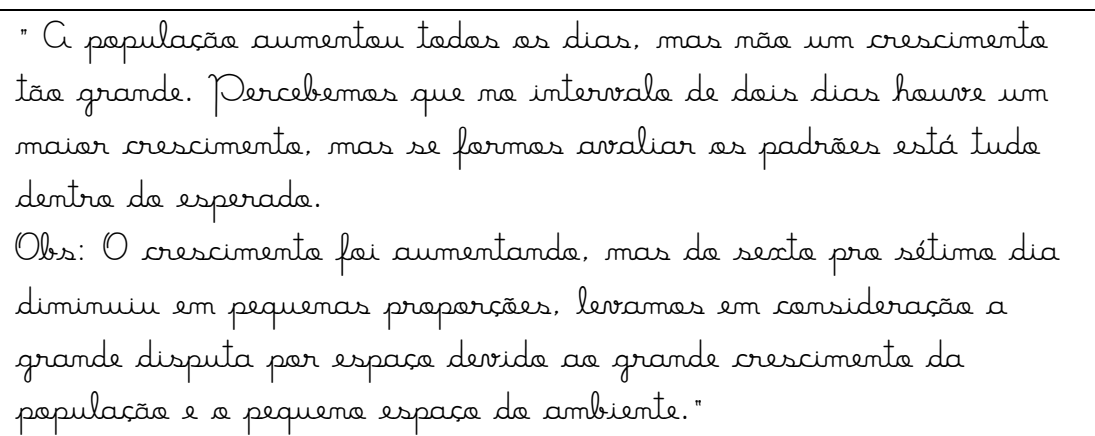 & & $\mathbf{X}$ & $\mathbf{X}$ & $\mathbf{X}$ & & & & & $\mathbf{X}$ & & $\mathbf{X}$ & \\
\hline
\end{tabular}




\section{O Relatório 10 - 2012}
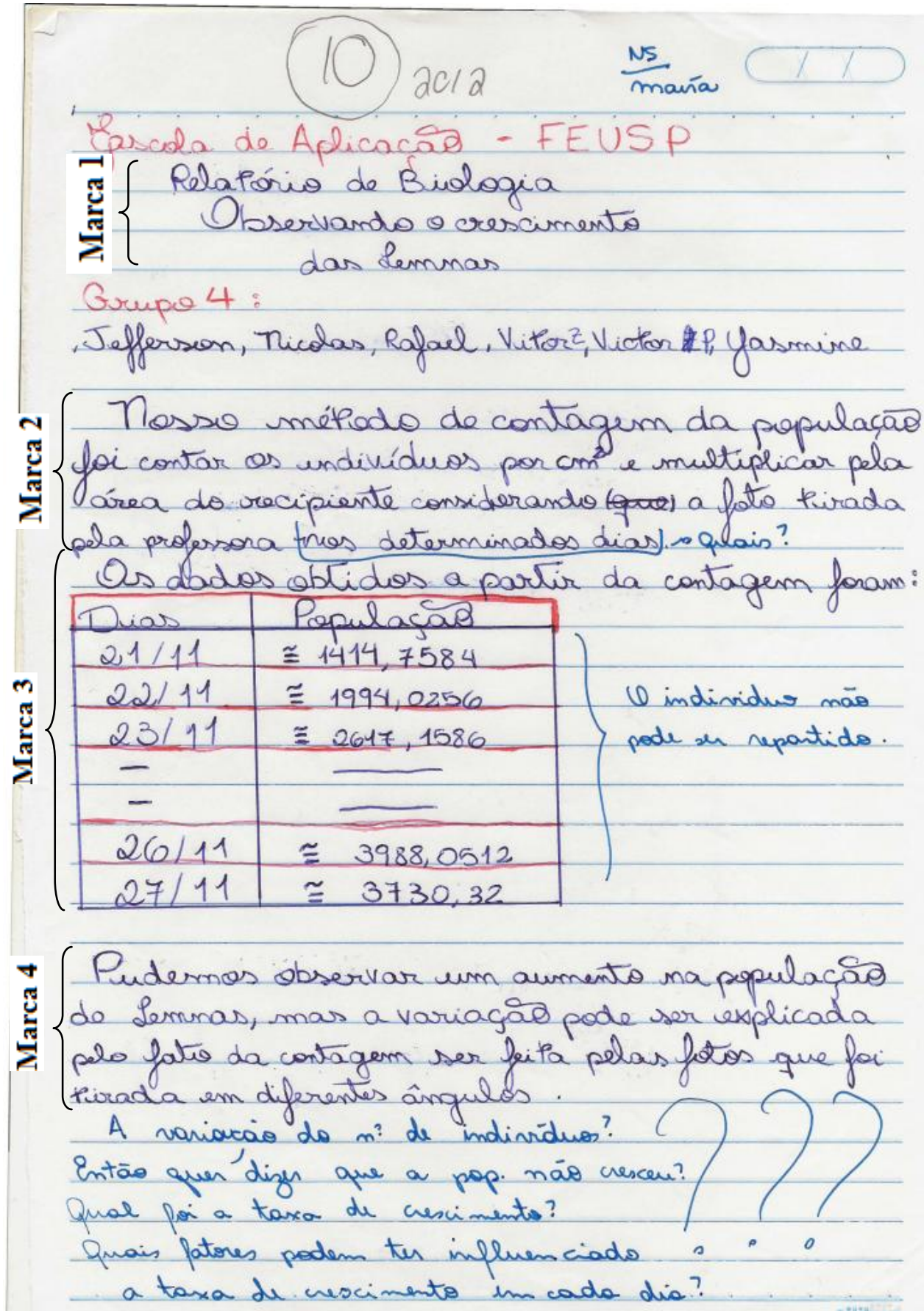
Thiago Marinho Del Corso

INDICADORES DE ALFABETIZAÇÃO CIENTÍFICA, ARGUMENTOS E EXPLICAÇÕES -

Análise de Relatórios no Contexto de uma Sequência de Ensino Investigativo

Quadro 28

Identificação dos Indicadores de Alfabetização Científica no Relatório 10 - 2012

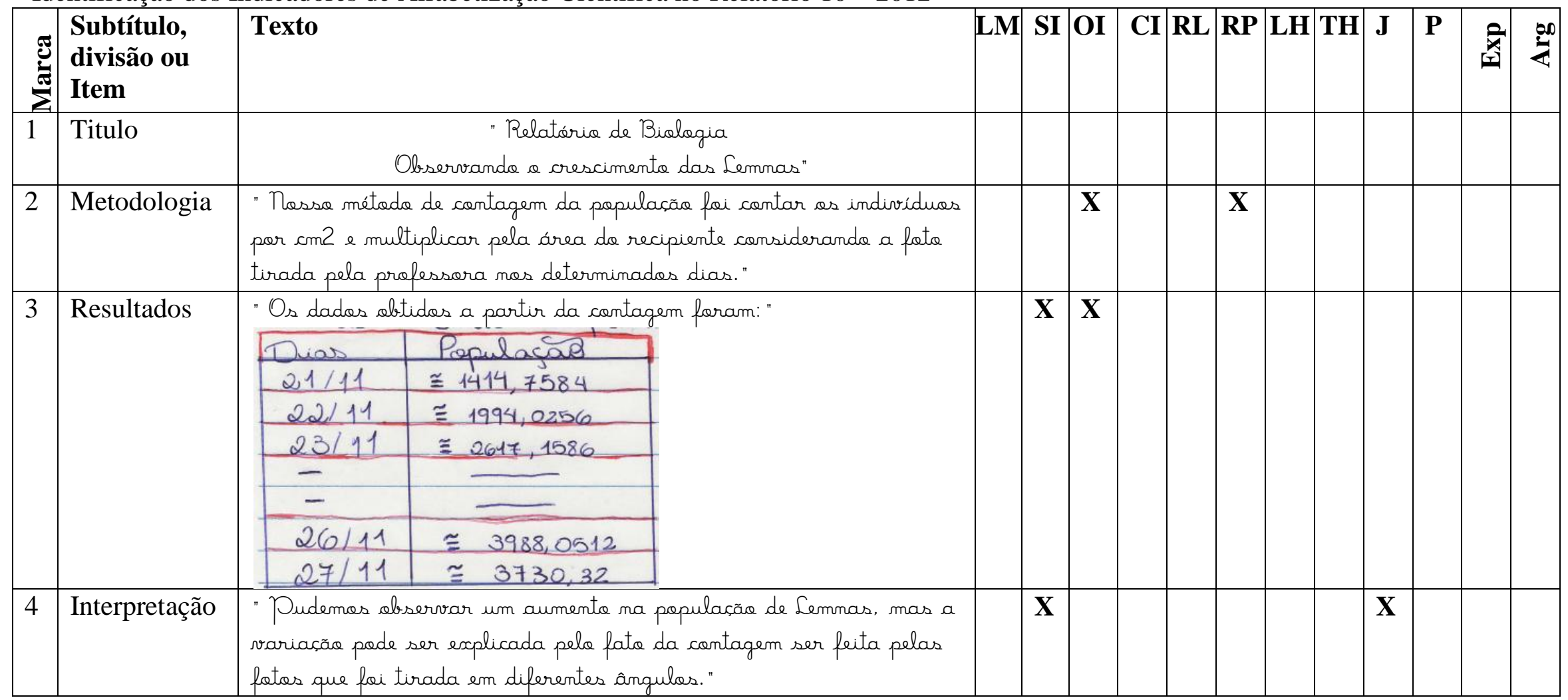

[Digite texto] 
Thiago Marinho Del Corso

INDICADORES DE ALFABETIZAÇÃO CIENTÍFICA, ARGUMENTOS E EXPLICAÇÕES -

Análise de Relatórios no Contexto de uma Sequência de Ensino Investigativo

\section{O Relatório 11 - 2012}

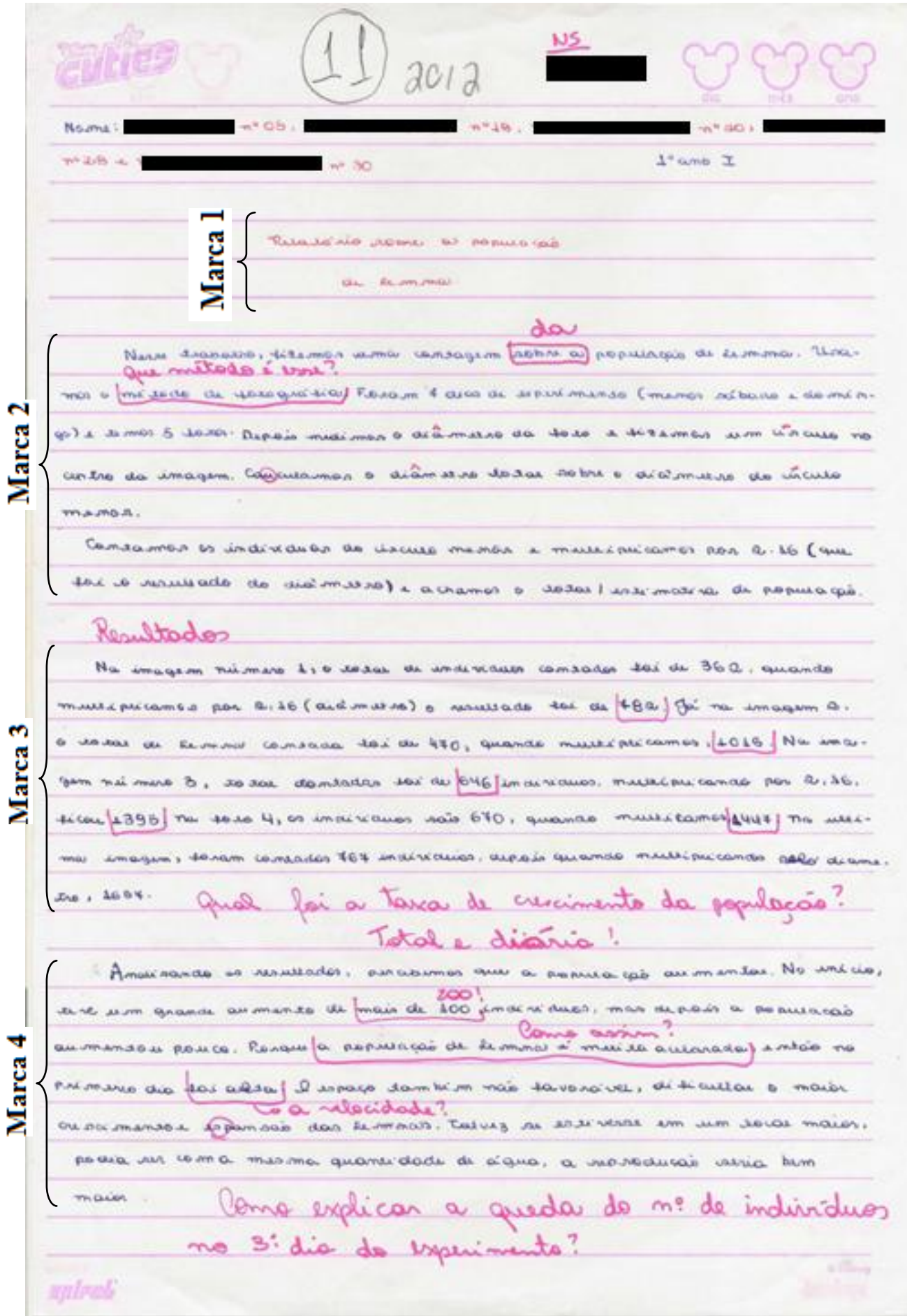

[Digite texto] 
Thiago Marinho Del Corso

INDICADORES DE ALFABETIZAÇÃO CIENTÍFICA, ARGUMENTOS E EXPLICAÇÕES -

Análise de Relatórios no Contexto de uma Sequência de Ensino Investigativo

Quadro 29

Identificação dos Indicadores de Alfabetização Científica no Relatório 11 - 2012

\begin{tabular}{|c|c|c|c|c|c|c|c|c|c|c|c|c|c|c|}
\hline లేّ & $\begin{array}{l}\text { Subtítulo, } \\
\text { divisão ou } \\
\text { Item }\end{array}$ & Texto & $\mathbf{L M}$ & SI & OI & CI & $\mathbf{R L}$ & $\mathbf{R P}$ & LH & TH & $\mathbf{J}$ & $\mathbf{P}$ & & $\sum_{4}^{\infty}$ \\
\hline 1 & Titulo & "Relatórice sobre a papulascãa de Lemna" & & & & & & & & & & & & \\
\hline 2 & Metodologia & 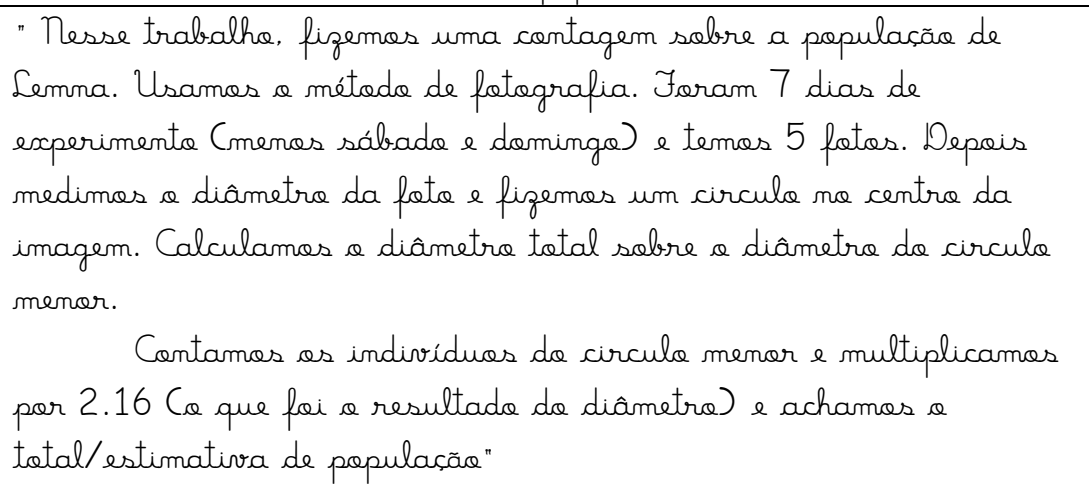 & & & $\mathbf{X}$ & & & $\mathbf{X}$ & & & & & & \\
\hline 3 & Resultados & 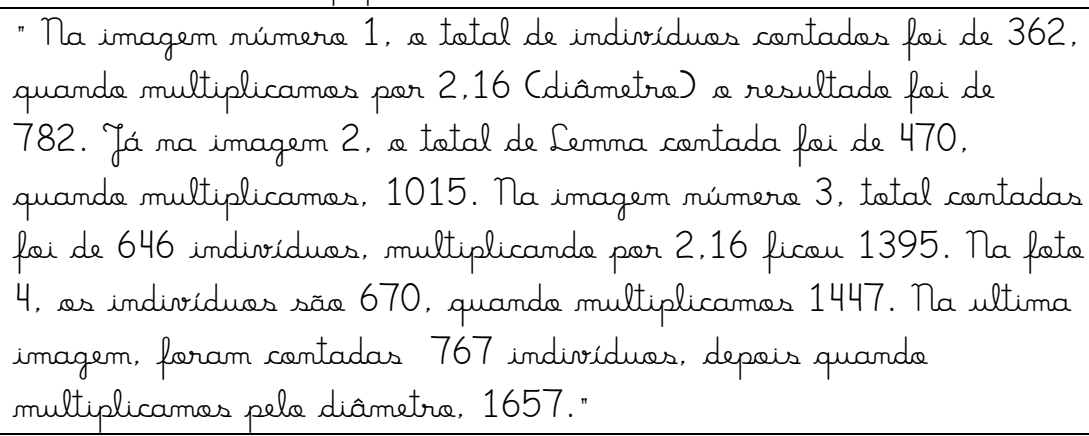 & & $\mathbf{X}$ & $\mathbf{X}$ & & & & & & & & & \\
\hline 4 & Resultados & 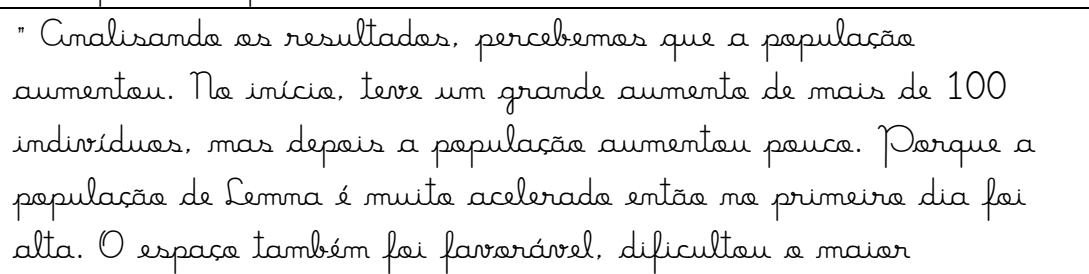 & & $\mathbf{X}$ & $\mathbf{X}$ & $\mathbf{X}$ & & & & & $\mathbf{X}$ & & & \\
\hline
\end{tabular}

[Digite texto] 
Thiago Marinho Del Corso

INDICADORES DE ALFABETIZAÇÃO CIENTÍFICA, ARGUMENTOS E EXPLICAÇÕES -

Análise de Relatórios no Contexto de uma Sequência de Ensino Investigativo
crescimenta e espançãa das Lemnas. Talvez se estivesse em um
lacal maiar, poderia ser com a mesma quantidade de água, a
repraduçãa seria bem maior." 


\section{ANEXOS}

\section{ANEXO 1: A SEQUÊNCIA DIDÁTICA ENSINO INVESTIGATIVA (SEI) O planejamento da sequência didática}

Sou professora da Escola de Aplicação da Faculdade de Educação da Universidade de São Paulo (EA-FEUSP) desde maio de 2005. Iniciei minha carreira como professora desta escola trabalhando com alunos do Ensino Fundamental II, dando aulas de Ciências. Em 2011 assumi a disciplina de Biologia para as três turmas do Ensino Médio.

Dentre tantos processos e eventos que nos intrigam nesta profissão, sempre me chamou a atenção a dificuldade dos alunos das diferentes faixas etárias e níveis de escolarização em representar os fenômenos através de inscrições e, especialmente, enxergar fenômenos traduzidos em inscrições.

Quando integrada ao GEPEB, participando de reuniões nas quais discutíamos sequências de ensino baseadas em investigação, me interessei em pesquisar como atividades investigativas poderiam auxiliar o domínio e apropriação das inscrições pelos alunos.

Foi com esta questão inicial em mente que planejei, para o $1^{0}$ ano do Ensino Médio, uma sequência didática sobre "Dinâmica populacional" na qual os alunos trabalhariam com inscrições fornecidas por mim e com inscrições produzidas por eles ao longo de uma investigação. Meu intuito era compreender como os alunos utilizavam cada uma das representações (fornecida ou produzida por eles) sobre o mesmo fenômeno biológico - crescimento populacional.

No $2^{\circ}$ semestre de 2012 apliquei a sequência planejada e apresentei a descrição das aulas e as produções dos alunos para o grupo de pesquisa, para que fossem feitos os ajustes necessários e pudéssemos validá-la, considerando sua capacidade de promover a alfabetização científica.

Deste momento em diante, a narrativa será feita na $1^{\text {a }}$ pessoa do plural, pois considero a sequência didática trabalhada em sala de aula em 2013, uma produção coletiva do GEPEB e, como pesquisadora, faço parte deste grupo. Quando a narrativa estiver na $1^{\text {a }}$ pessoa do singular é porque as ações se referem à professora Maíra que, além de aplicar a sequência, tal como planejada, precisou tomar decisões em razão dos eventos de sala de aula.

Apresentamos a seguir a descrição detalhada da sequência didática reformulada após o pré-teste e aplicada em sala de aula no $2^{\circ}$ semestre de 2013 como forma de obtenção dos dados para a pesquisa. Méheut e Psillos (2004) afirmam que, embora haja muitos trabalhos que analisam a aprendizagem dos alunos resultante da aplicação de diversas sequências de ensino, são poucos aqueles que discutem as decisões e suposições que concernem ao desenvolvimento destas sequências. Considerando isto, quando houver alterações em relação à sequência didática inicial, 
Thiago Marinho Del Corso

INDICADORES DE ALFABETIZAÇ̃̃o CIENTÍFICA, ARGUMENTOS E EXPLICAÇÕES -

Análise de Relatórios no Contexto de uma Sequência de Ensino Investigativo

desenvolvida no ano de 2012, e a aplicada para coleta de dados em 2013, estas serão destacadas, assim como os motivos que levaram a elas.

$\mathrm{Na}$ EA-FEUSP, as aulas de Biologia se distribuem em dois encontros semanais de 50 minutos cada. As atividades desenvolvidas ao longo da sequência didática não foram pensadas para um número fixo e pré-determinado de aulas, pois sabemos que o tempo de aula realmente utilizado para o desenvolvimento das atividades pode variar de acordo com os eventos do cotidiano escolar. Desta forma, as atividades serão descritas na forma como foram planejadas e, em seguida, apresentaremos uma tabela resumindo a atividade e o número de aulas utilizadas, respectivamente.

$\mathrm{Na}$ apresentação de cada atividade, procuramos estabelecer relações entre elas e os objetivos desta pesquisa. Todo material entregue aos alunos, formatado exatamente como foi utilizado em classe, pode ser encontrado no anexo.

a) Atividade I - Leitura e discussão de artigo científico sobre dinâmica populacional de elefantesmarinhos.

Conceitos específicos abordados: população, competição intraespecífica, densidade populacional, taxa de natalidade e mortalidade, imigração, emigração, potencial biótico, capacidade suporte.

A primeira atividade propoe a leitura do artigo científico Demography of Notthern Elephant Seals, 1911-1982 (Cooper \& Stewart, 1983) traduzido e adaptado.

A adaptação do original consistiu em adequação da linguagem, inserção de mapa com local do estudo, simplificação das análises estatísticas e omissão da conclusão para que os alunos analisassem a conclusão sem conhecer as justificativas dos autores.

O artigo apresenta os resultados de uma pesquisa demográfica com elefantes marinhos na Califórnia (EUA) e na Califórnia do Sul (MEX). Os autores apresentam o crescimento populacional de elefantes marinhos ao longo de duas décadas em diferentes ilhas e discutem os motivos que favoreceram um altíssimo crescimento populacional em algumas delas.

A leitura foi realizada em voz alta e de forma compartilhada. Ao longo da leitura, eu fazia intervenções entre alguns trechos para esclarecimentos de dúvidas ou para destacar algum processo ou conceito. Numa dessas intervenções, eu demonstrei para os alunos como o gráfico do artigo foi construído. Para isso, preparei uma tabela com valores brutos aproximados do tamanho

\footnotetext{
${ }^{1} \mathrm{O}$ artigo original encontra-se no anexo.
} 
Thiago Marinho Del Corso INDICADORES DE ALFABETIZAÇÃO CIENTÍFICA, ARGUMENTOS E EXPLICAÇÕES -

Análise de Relatórios no Contexto de uma Sequência de Ensino Investigativo

das populações e fazia a correspondência entre os pontos do gráfico e os valores da tabela. Neste momento também aproveitei para apontar quando deve ser usado uma tabela ou um gráfico para apresentar os dados de uma pesquisa.

$\mathrm{Na}$ mesma ficha em que o artigo foi entregue aos alunos havia um roteiro com questões de interpretação do artigo. A resolução do roteiro de interpretação foi realizada aos poucos, conforme a leitura e análise do artigo transcorriam.

b) atividade II - Produção de argumentos a partir de dados do artigo "Demografia de elefantes marinhos" e construção de gráfico de crescimento populacional

$\mathrm{Na}$ aula seguinte, reunidos em trios ou quartetos, os alunos fizeram uma avaliação na qual tinham dois problemas: construir argumentos com base em evidências e produzir um gráfico a partir de dados fornecidos numa tabela. Durante esta atividade, não fiz nenhuma intervenção relacionada à avaliação e orientei que as dúvidas fossem discutidas e resolvidas no próprio grupo de trabalho.

Em 2012, para desencadear a produção de argumentos, os alunos receberam o seguinte problema:

"Os autores concluem, com base nos dados dos gráficos, que a constante imigração de fêmeas das Ilhas Guadalupe e San Benito foi fundamental para o crescimento populacional em San Miguel e San Nicolas. Por que é possível concluir isso?"

De acordo com o modelo de Toulmin, esperávamos que os alunos formulassem um argumento para o qual a conclusão foi fornecida pelo enunciado, o dado deveria ser retirado do gráfico e a justificativa, no texto. Conforme figura abaixo:

DADO QUE o crescimento
populacional nas Ilhas Guadalupe
e San Benito foi baixo em relação
a todas as Ilhas da Califórnia e
muito alto nas IIhas San Miguel e
San Nicolas.

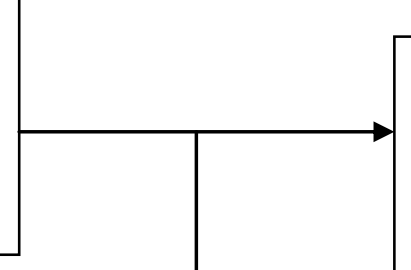

ENTÃO, a constante imigração de fêmeas das Ilhas Guadalupe e San Benito foi responsável pelo baixo crescimento nestas ilhas e foi fundamental para o alto crescimento populacional em San Miguel e San Nicolas.

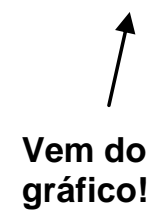

COMO a taxa de reprodução das fêmeas da espécie é baixa e não explica o alto crescimento populacional em San Miguel e San Nicolas.
Vem do

texto! 
Thiago Marinho Del Corso

INDICADORES DE ALFABETIZAÇ̃̃o CIENTÍFICA, ARGUMENTOS E EXPLICAÇÕES -

Análise de Relatórios no Contexto de uma Sequência de Ensino Investigativo

No entanto, a produção dos alunos revelou que o problema proposto não desencadeava a produção de argumentos, uma vez que grande parte das respostas apenas reforçava que o crescimento populacional em San Miguel e San Nicolas foi muito alto, não considerando o baixo crescimento em San Benito e Guadalupe, que poderia ser explicado devido à imigração.

Segundo Berland e Hammer (2012) quando os alunos estão realizando uma atividade desenhada com o objetivo de promover a argumentação, precisam entender que isto está sendo solicitado. Neste sentido, alteramos a instrução para:

"Considerando que a imigração foi fundamental para que o crescimento populacional nas ilhas San Miguel e San Nicolas fosse tão alto, duas cientistas estavam discutindo sobre a origem das fêmeas imigrantes. Daniela afirmava que as fêmeas que imigraram para San Miguel e San Nicolas vieram de Guadalupe e San Benito, enquanto Sílvia afirmava que vieram de Año Nuevo e Farallones. a) Quem está correta? b) Que dados vocês têm para afirmar isto? c) O que a cientista que está correta poderia fazer para convencer a outra sobre a origem das fêmeas imigrantes?"

Com esta nova instrução, pretendíamos deixar mais claro que a imigração não estava sendo questionada, mas sim o local de origem das fêmeas. Além disso, criamos um contexto de persuasão entre duas cientistas. Desta forma, esperávamos que os alunos, nos pequenos grupos, articulassem o conhecimento sobre crescimento populacional com os dados disponíveis no texto e no gráfico, na tentativa de persuadir os colegas de suas ideias.

Cada grupo de trabalho me entregou sua produção escrita como forma de avaliação na disciplina de biologia e também para que fossem fotocopiadas e, futuramente, utilizadas como dados para esta pesquisa.

Objetivo para a pesquisa: analisar como os alunos recorrem a dados que descrevem fenômenos não investigados empiricamente por eles para justificar argumentos explicativos ou persuasivos. No caso descrito, os dados disponíveis para os alunos eram: mapa, texto e gráfico.

Na mesma avaliação, para a construção de um gráfico de crescimento populacional, os alunos receberam a seguinte instrução:

"Construa um gráfico para representar o comportamento das populações da espécie 1 e da espécie 2 ao longo da década de 2000 a 2010. Considerando que ambas espécies se alimentam dos mesmos recursos e habitam o mesmo local, qual espécie apresenta vantagem competitiva? Justifique com dados do gráfico.".

\begin{tabular}{|c|c|c|}
\hline & \multicolumn{2}{|c|}{ № de indivíduos } \\
\hline & Espécie 1 & Espécie 2 \\
\hline 2000 & 5 & 5 \\
\hline
\end{tabular}

\begin{tabular}{|l|c|c|}
\hline 2001 & 7 & 15 \\
\hline 2002 & 10 & 30 \\
\hline 2003 & 20 & 60 \\
\hline
\end{tabular}


Thiago Marinho Del Corso

INDICADORES DE ALFABETIZAC̄̃O CIENTÍFICA, ARGUMENTOS E EXPLICACÕES -

Análise de Relatórios no Contexto de uma Sequência de Ensino Investigativo

\begin{tabular}{|c|c|c|}
\hline \hline 2004 & 40 & 120 \\
\hline 2005 & 80 & 150 \\
\hline 2006 & 160 & 160 \\
\hline 2007 & 180 & 170 \\
\hline
\end{tabular}

\begin{tabular}{|c|c|c|}
\hline 2008 & 190 & 160 \\
\hline 2009 & 195 & 140 \\
\hline 2010 & 195 & 140 \\
\hline
\end{tabular}

Esta atividade pretendia avaliar se os alunos conseguiam transpor os dados apresentados na forma de tabela para um gráfico. Ao fazer isto corretamente, os alunos ilustrariam as relações existentes entre as variáveis tempo, número de indivíduos e espécie de forma concisa e os dados necessários para justificar a conclusão solicitada no enunciado estariam disponíveis.

Objetivo para a pesquisa: analisar se a atividade I desta sequência (Leitura e discussão de texto científico sobre dinâmica populacional de elefantes-marinhos) forneceu repertório interpretativo da ferramenta gráfica, assim como do fenômeno biológico representado por ele (crescimento populacional).

c) Atividade III - Investigação sobre o crescimento populacional de Lemna sp.

$\mathrm{Na}$ primeira aula desta atividade eu apresentei aos alunos o objeto de estudo no qual eles baseariam a investigação sobre dinâmica populacional, uma população de Lemna sp. A apresentação foi feita oralmente, baseada na descrição abaixo e sem apoio de recursos audio visuais.

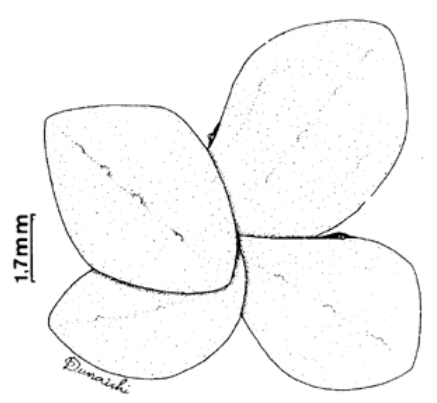

Disponível em:

http://delta-intkey.com/angio/images/lemna839.gif Acesso em: 06/03/2014

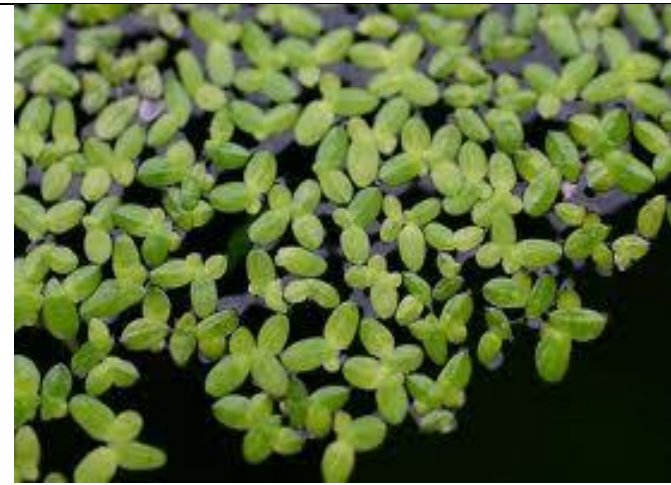

Disponível em:

http://www.peixefauna.com/t9580-lemna-minor Acesso em: 06/03/2014

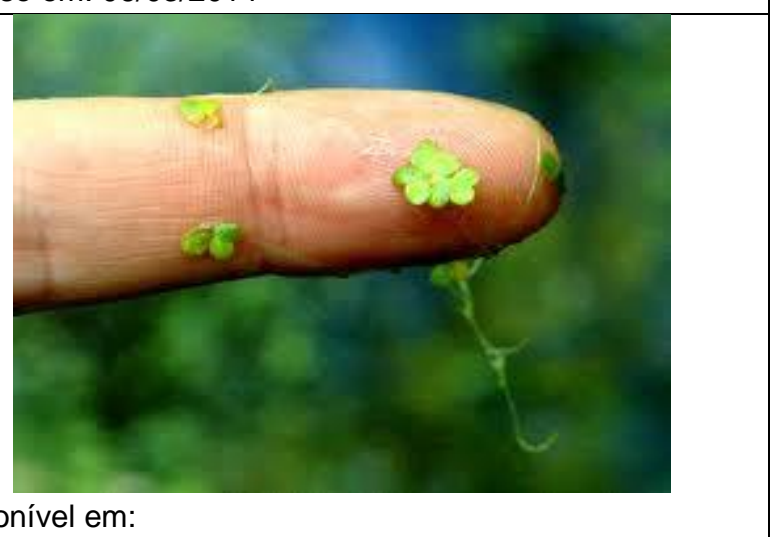

[Digite texto] 
Thiago Marinho Del Corso

INDICADORES DE ALFABETIZAÇÃO CIENTÍFICA, ARGUMENTOS E EXPLICAÇÕES -

Análise de Relatórios no Contexto de uma Sequência de Ensino Investigativo

Disponível em:

http://delta-intkey.com/angio/images/lemna839.gif

http://commons.wikimedia.org/wiki/File:Lemna minor.jpg

Acesso em: 06/03/2014

Lemna sp. pertence à família Lemnaceae Gray, as menores Angiospermas conhecidas. O nome comum no Brasil, quando utilizado ou conhecido, é "lentilha-d'água". É uma família pequena, com quatro gêneros e 36 espécies. A propagação, em geral, é vegetativa e, por isso e pelo reduzido tamanho das plantas, é uma família de difícil delimitação dos táxons, devendo sua identificação freqüentemente ser auxiliada por dados sobre sua distribuição geográfica. Apresenta distribuição subcosmopolita, com centro de dispersão tropical e subtropical na América do Sul. No Brasil, a família está representada pelos seus quatro gêneros: Spirodela, Lemna, Wolffiella e Wolffia. As espécies de Lemna são monóicas, aquáticas de água doce, flutuantes livres na superfície, ou levemente submersas, onde pequena parte da fronde é exposta ao ar, ou completamente submersa, vindo à tona no período da floração. São diminutas, sem diferenciação de caule e reduzidas a um pequeno corpo talóide, por isso chamado de fronde. Frondes simétricas ou assimétricas, arredondadas, verdes, com ou sem pigmentos castanhos ou avermelhados; com um nó, quase ao centro da linha mediana, de onde emergem raízes e nervuras (quando presentes), e novas frondes e flores. A propagação é na maioria das vezes por via vegetativa, através de 1 ou 2 cavidades vegetativas (ou reprodutivas), dando origem a frondes-filhas, e estas, por sua vez, a outras frondes-filhas, e assim sucessivamente. Podem apresentar uma forma latente em condições adversas, chamada de "turion". Cada fronde possui uma raíz, fasciculada, não funcional, sem pelos absorventes e protegida por coifa. (Potti e Cervi, 1999).

Após esta apresentação, os alunos foram informados que realizariam uma investigação a respeito da dinâmica populacional desta espécie de planta. Organizados nos mesmos grupos da atividade II, os alunos deveriam responder a seguinte questão de caráter científico:

"O que acontece com uma população biológica após a colonização por alguns indivíduos de um ambiente com as condições ideais para desenvolvimento da espécie?"

Para isso, cada grupo foi orientado a colocar água, um pouco de terra e alguns indivíduos de Lemna sp. num pequeno recipiente transparente. Os indivíduos selecionados foram considerados os colonizadores do novo ambiente (recipiente com água e terra). Em seguida, todos os recipientes foram dispostos sob uma luminária que fornecia luz constante (Figura 1) 


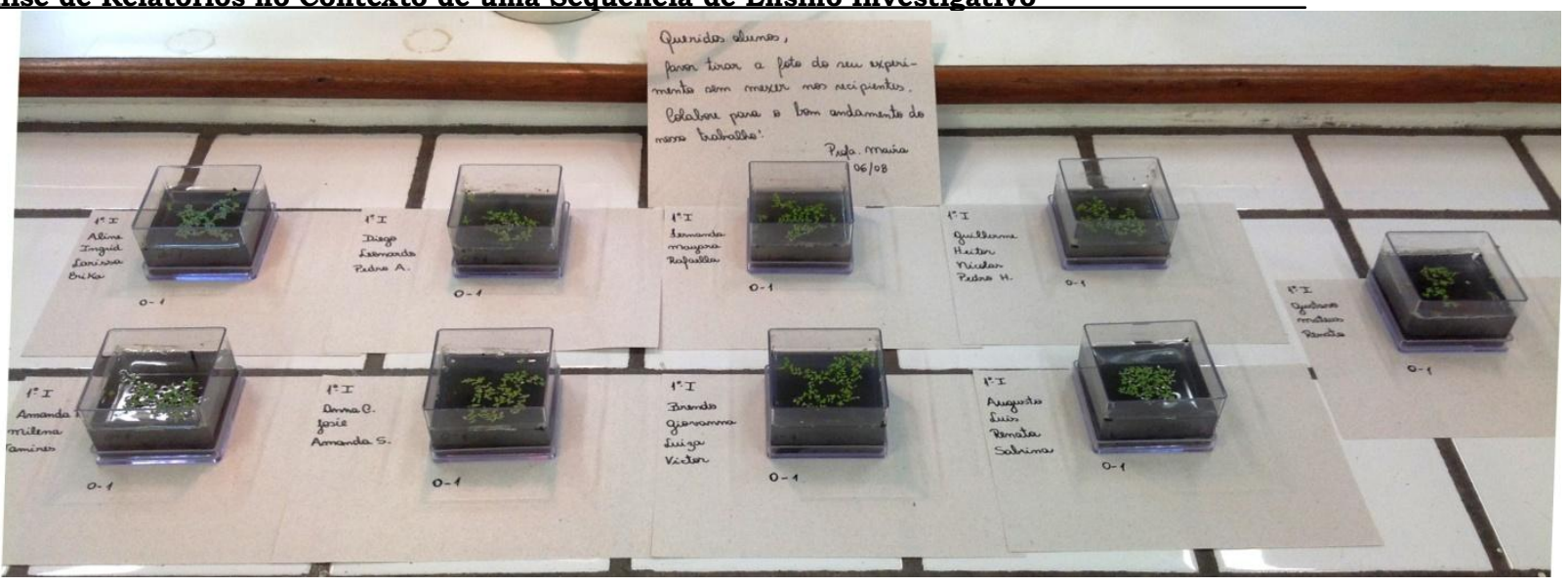

Figura 1 - Vista dos recipientes com populações de Lemnas sp. dispostos sob iluminação na bancada da sala de aula. Registro do $1^{\circ}$ dia de investigação.

Em 2012, o recipiente utilizado por cada grupo foi um balde transparente de 5L. Em uma semana de investigação, a população cresceu muito, o que exigiu dos alunos o desenvolvimento de estratégias de amostragem dos indivíduos para estimarem o tamanho populacional (Figura 2). Minha avaliação, como professora, foi que o formato do recipiente (circular) dificultou a amostragem correta da população, pois os alunos tiveram que fazer relações exponenciais entre a área amostrada e área total ocupada. Para fugir deste fator complicador da investigação, em 2013 optamos pelo recipiente retangular.
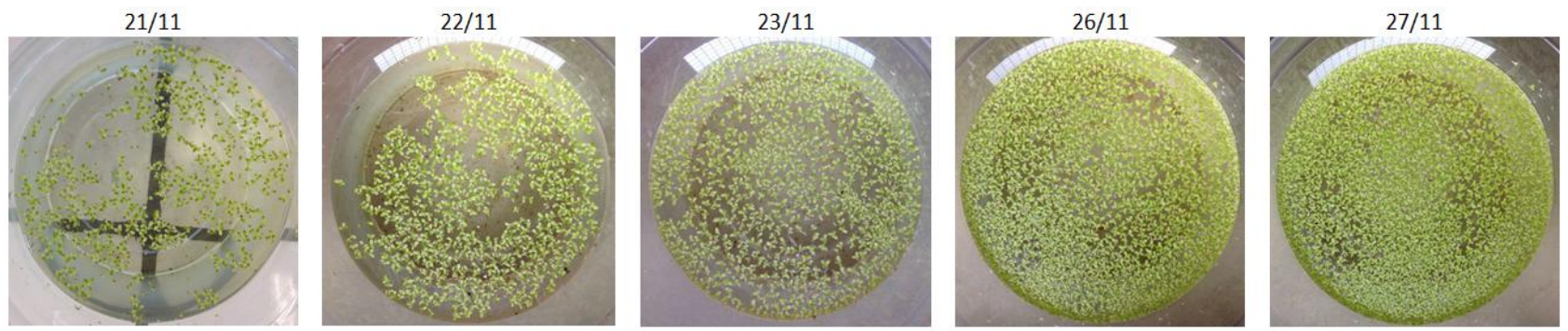

Figura 2 - Vista superior do recipiente utilizado pelos alunos para investigar o crescimento populacional de Lemnas sp. em 2013. As imagens em sequência temporal demonstram como, naquele momento, a taxa de reprodução vegetativa foi muito alta, o que exigiu estratégias de amostragem populacional.

Depois que cada grupo preparou sua própria população para investigação, os alunos puderam perceber a dificuldade de manipular os indivíduos de Lemna sp. Como são muito pequenos, se misturam com qualquer movimento da superfície da água e grudam facilmente nos objetos nos quais enconstam. A partir desta percepção dos alunos, mediei uma discussão sobre como fariam 
Thiago Marinho Del Corso

INDICADORES DE ALFABETIZAÇ̃̃o CIENTÍFICA, ARGUMENTOS E EXPLICAÇÕES -

Análise de Relatórios no Contexto de uma Sequência de Ensino Investigativo

para contar o número de indivíduos ao longo do tempo para poderem descrever a dinâmica populacional. Rapidamente alguns alunos propuseram o registro fotográfico dia a dia para que pudessem fazer a contagem sobre a imagem.

Decidido que este seria o procedimento de acompanhamento do tamanho populacional, orientei-os a fazerem o registro todos os dias no mesmo horário durante uma semana. Para evitar que, por ventura, algum grupo ficasse sem dados em algum dia do período de investigação, também fotografei cada recipiente diariamente.

O período de uma semana foi determinado a partir do crescimento observado em 2012, quando a capacidade suporte de um recipiente muito maior foi atingida em todos os grupos de trabalho em 6 dias. Porém, em 2013, a taxa de reprodução dos indivíduos foi muito menor e o período de observação foi estendido por mais uma semana. Possivelmente esta diferença na taxa de crescimento populacional foi decorrente da época do ano: em 2012 o experimento foi realizado em novembro, em dias com altas temperaturas, já em 2013, a sequência investigativa ocorreu em agosto, durante dias extremamente frios (abaixo dos $10^{\circ} \mathrm{C}$ ).

Findo o período de registro fotográfico, os aluno se reuniram em grupos para determinarem o tamanho populacional em cada dia e construírem inscrições para representar a dinâmica populacional observada. Por fim, ainda reunidos em grupos e durante as aulas, os alunos produziram um relatório para comunicar o processo de investigação.

Durante as aulas de produção escrita, orientei-os sobre os itens que deveriam constar no relatório e o que cada um deveria conter, a saber:

Pergunta: transcrição da pergunta que mobilizou o processo investigativo ( $O$ que acontece com uma população biológica após a colonização por alguns indivíduos de um ambiente com as condições ideais para desenvolvimento da espécie?).

Metodologia: descrição detalhada dos materiais e dos procedimentos realizados para coleta e produção de dados.

Resultados: descrição dos resultados encontrados na forma que o grupo achasse mais representativo daquilo que foi observado empiricamente (desenhos, fotos, tabelas, gráficos, símbolos, etc.)

Interpretação: explicação, baseada em conhecimento empírico ou teórico, de todos os resultados encontrados.

É importante ressaltar que esta não era a primeira vez que os alunos tiveram que produzir um relatório científico para comunicar os resultados de uma investigação. Em anos escolares [Digite texto] 
Thiago Marinho Del Corso

INDICADORES DE ALFABETIZAÇ̃̃o CIENTÍFICA, ARGUMENTOS E EXPLICAÇÕES -

Análise de Relatórios no Contexto de uma Sequência de Ensino Investigativo

anteriores e também no início do 1ํㅡㄹ os alunos receberam instruções de como produzir relatórios e também receberam relatórios que serviram de modelo daquilo que era esperado da produção deles.

Após a entrega, fiz uma cópia do relatório para cada aluno do grupo e ficamos com o material orgininal para pesquisa. No encontro seguinte, cada aluno, com sua cópia em mãos teve que produzir a conclusão, finalizando o relatório construído coletivamente de forma individual. O comando utilizado para esta última etapa foi colocado na lousa e constituia-se da seguinte instrução:

"Sabendo que a conclusão do relatório científico consiste na resposta à pergunta inicial, justificada com evidências (dados produzidos durante a investigação), conclua seu relatório."

Objetivo para a pesquisa: Estes relatórios serão utilizados para obtenção de informações sobre como se dá o processo de inscrição realizado pelos alunos (quantidade, tipos e número de transformações), além de informações sobre como os alunos recorrem a dados que descrevem fenômenos investigados empiricamente por eles para justificar argumentos explicativos ou persuasivos. No caso descrito, os dados disponíveis para os alunos eram exatamente as inscrições por eles produzidas.

Como já descrito, a coleta de dados durou 15 dias, período no qual as aulas de biologia foram destinadas para, além do registro fotográfico, outras atividades didáticas relacionadas ao tema dinâmica populacional. Estas atividades serão descritas a seguir, mas é importante esclarecer que não ocorrerão ao término da atividade de investigação e entrega dos relatórios, mas sim enquanto transcorria um tempo suficiente para os alunos observarem um crescimento populacional.

d) Atividade IV - Exercício de amostragem para estimar tamanho populacional.

Esta atividade foi criada com o objetivo didático de possibilitar aos alunos a aprendizagem de técnicas de amostragem utilizadas na biologia, para que pudessem utiliza-las na atividade III (descrita anteriormente). Ela foi realizada na aula seguinte àquela na qual cada grupo preparou sua população de Lemna sp..

Para relacionar as atividades anteriores com a investigação científica em andamento elaboramos um problema metodológico desencadeador da tarefa. Os alunos tiveram que responder duas questões relacionadas a amostragem populacional.

A primeira questão foi: "No artigo Demografia de Elefantes Marinhos do Norte, 1911-1982 (Cooper \& Stewart, 1983) vimos que a determinação do tamanho da população de elefantes marinhos foi 
Thiago Marinho Del Corso

INDICADORES DE ALFABETIZAÇÃO CIENTÍFICA, ARGUMENTOS E EXPLICAÇÕES -

Análise de Relatórios no Contexto de uma Sequência de Ensino Investigativo

realizada por um método de contagem de cada indivíduo. Quais as características da população estudada foram fundamentais para a escolha deste método de contagem?".

Com esta primeira questão, pretendíamos discutir que a escolha do método de contagem dos indivíduos adotado estava relacionada ao tipo de população estudada (pequena, restrita a uma ilha, com indivíduos grandes, sedentários e conspícuos).

Após conduzir a discussão para relacionar método de contagem populacional e característica dos indivíduos, forneci uma folha A4 preenchida dor círculos e quadrados e propus a segunda tarefa para ser finalizada em casa:

"A seguir, você vai encontrar uma área coberta por dois tipos de sinais: quadradinhos brancos e circunferências pretas. Considere que cada tipo de sinal representa uma espécie de capim. Estas populações, diferentemente da população de Elefantes Marinhos da Califórnia, são numerosas e a contagem de cada indivíduo não é o melhor método para quantificá-las. Os indivíduos de cada espécie estão espalhados de maneira bem uniforme, ou seja, não há regiões com uma concentração maior de indivíduos da mesma espécie, em comparação com outras regiões.

O desafio é propor um método para determinar o tamanho de cada população de capim sem contar um a um. Sabendo que a população de capim representada por quadradinhos brancos possui 1570 indivíduos e a população de capim representada por círculos pretos possui 630 indivíduos, descreva em detalhes o método que resultou em dados mais próximos dos valores reais.".

$\mathrm{Na}$ aula seguinte, solicitei que os alunos compartilhassem com a turma seu método de amostragem mais eficiente e discutimos as causas de cada método descrito ter sido mais ou menos preciso na estimativa do tamanho populacional de cada espécie.

e) Atividade VI - Aula teórica expositivo dialogada sobre dinâmica populacional.

Com o auxílio de um data show, apresentei alguns gráficos do número de indivíduos em função do tempo para retomar e/ou definir os seguintes conceitos relacionados ao tema dinâmica populacional: natalidade, imigração, mortalidade, emigração, potencial biótico, resistência do meio, capacidade de carga ou capacidade biótica máxima, curva padrão do crescimento populacional e suas respectivas fases (crescimento lento, crescimento exponencial e estabilização).

Durante minha exposição relacionei os conceitos com a investigação sobre dinâmica populacional de Lemna sp. em andamento e ressaltei que os conceitos discutidos nesta aula seriam importantes para a interpretação dos dados que eles coletariam.

f) Atividade VII - Lista de exercícios sobre dinâmica populacional. 
Thiago Marinho Del Corso

INDICADORES DE ALFABETIZAÇÃO CIENTÍFICA, ARGUMENTOS E EXPLICAÇÕES -

Análise de Relatórios no Contexto de uma Sequência de Ensino Investigativo

Os alunos receberam uma lista de exercícios selecionados de diversos vestibulares para

resolverem em casa. A correção foi feita de forma coletiva, na qual mediei as participações e fiz comentários sobre as respostas compartilhadas com a classe. 
Thiago Marinho Del Corso

INDICADORES DE ALFABETIZAÇ̃O CIENTÍFICA, ARGUMENTOS E EXPLICAÇÕES -

Análise de Relatórios no Contexto de uma Sequência de Ensino Investigativo

Tabela 1 - Principais atividades de cada aula da sequência didática investigada, seus objetivos de aprendizagem e dados produzidos para pesquisa.

\begin{tabular}{|c|c|c|c|}
\hline Aula & Principal atividade & Objetivos didáticos & Dados produzidos para pesquisa \\
\hline \multirow[t]{2}{*}{$01-03$} & \multirow[t]{2}{*}{$\begin{array}{l}\text { Leitura e interpretação do artigo Demography } \\
\text { of Notthern Elephant Seals, 1911-1982 } \\
\text { (Cooper \& Stewart, 1983). }\end{array}$} & $\begin{array}{l}\text { Definir conceitos de dinâmica populacional, } \\
\text { natalidade, mortalidade, emigração, imigração, } \\
\text { capacidade suporte. }\end{array}$ & \multirow[t]{2}{*}{$\begin{array}{l}\text { Gravação em áudio e vídeo das interações } \\
\text { entre professora e alunos. }\end{array}$} \\
\hline & & $\begin{array}{l}\text { Aumentar repertório interpretativo de gráficos } \\
\text { de crescimento populacional. }\end{array}$ & \\
\hline \multirow[t]{2}{*}{04} & $\begin{array}{l}\text { Produção de argumentos a partir de dados do } \\
\text { artigo "Demografia de elefantes marinhos". }\end{array}$ & $\begin{array}{l}\text { Argumentar com justificativas extraídas de } \\
\text { dados fornecidos aos alunos. }\end{array}$ & $\begin{array}{l}\text { Gravação em áudio e vídeo das interações } \\
\text { entre professora e alunos e entre alunos } \\
\text { trabalhando em grupos. }\end{array}$ \\
\hline & $\begin{array}{l}\text { Construção de gráfico de crescimento } \\
\text { populacional. }\end{array}$ & & $\begin{array}{l}\text { Argumentos escritos a partir de dados } \\
\text { fornecidos aos alunos. }\end{array}$ \\
\hline \multirow[t]{4}{*}{$05-14$} & \multirow[t]{4}{*}{$\begin{array}{l}\text { Investigação sobre o crescimento populacional } \\
\text { de Lemna sp. }\end{array}$} & $\begin{array}{l}\text { Produzir inscrições para materializar um } \\
\text { fenômeno biológico. }\end{array}$ & \multirow{2}{*}{$\begin{array}{l}\text { Gravação em áudio e vídeo das interações } \\
\text { entre professora e alunos e entre alunos } \\
\text { trabalhando em grupos. }\end{array}$} \\
\hline & & $\begin{array}{l}\text { Usar evidências empíricas para justificar } \\
\text { conclusões }\end{array}$ & \\
\hline & & $\begin{array}{l}\text { Argumentar com seus pares sobre quais } \\
\text { explicações adotar. }\end{array}$ & \multirow{2}{*}{$\begin{array}{l}\text { Relatórios científicos com os itens: pergunta, } \\
\text { metodologia, resultados, interpretação e } \\
\text { conclusão. }\end{array}$} \\
\hline & & $\begin{array}{l}\text { Comunicar resultados da investigação na } \\
\text { forma de relatório escrito. }\end{array}$ & \\
\hline $06-07$ & $\begin{array}{l}\text { Exercício de amostragem para estimar } \\
\text { tamanho populacional. }\end{array}$ & $\begin{array}{l}\text { Utilizar diferentes métodos de amostragem } \\
\text { populacional. }\end{array}$ & $\begin{array}{l}\text { Gravação em áudio e vídeo das interações } \\
\text { entre professora e alunos. }\end{array}$ \\
\hline 08 & $\begin{array}{l}\text { Aula teórica expositiva dialogada sobre } \\
\text { dinâmica populacional. }\end{array}$ & $\begin{array}{l}\text { Difinir os conceitos de natalidade, imigração, } \\
\text { mortalidade, emigração, potencial biótico, } \\
\text { resistência do meio, capacidade de carga ou } \\
\text { capacidade biótica máxima, curva padrão do } \\
\text { crescimento populacional e suas respectivas } \\
\text { fases (crescimento lento, crescimento } \\
\text { exponencial e estabilização). }\end{array}$ & $\begin{array}{l}\text { Gravação em áudio e vídeo das interações } \\
\text { entre professora e alunos. }\end{array}$ \\
\hline 09 & $\begin{array}{l}\text { Resolução de exercícios sobre dinâmica } \\
\text { populacional }\end{array}$ & $\begin{array}{l}\text { Revisar e sistematizar os conceitos referentes } \\
\text { ao tema dinâmica populacional }\end{array}$ & $\begin{array}{l}\text { Gravação em áudio e vídeo das interações } \\
\text { entre professora e alunos. }\end{array}$ \\
\hline
\end{tabular}

[Digite texto] 


\section{ANEXO 2: TERMO DE CONSENTIMENTO LIVRE E ESCLARECIDO}

\section{TERMO DE CONSENTIMENTO LIVRE E ESCLARECIDO}

\section{II. [Para pais e responsáveis]}

$\mathrm{Eu}$, $R G$ declaro saber da participação de meu/minha filho/a na pesquisa desenvolvida junto à Faculdade de Educação da Universidade de São Paulo pelo/a pesquisador/a

orientado/a por
, os/as quais podem ser contatados/as pelo e-mail ou telefone . O presente trabalho tem por objetivos: , e os instrumentos utilizados são:

Compreendo que tenho liberdade de retirar o meu consentimento em qualquer fase da pesquisa, sem penalização alguma. A qualquer momento, posso buscar maiores esclarecimentos, inclusive relativos à metodologia do trabalho. Os/as responsáveis pela pesquisa garantem o sigilo, assegurando a privacidade dos sujeitos quanto aos dados envolvidos na pesquisa. Declaro compreender que as informações obtidas só podem ser usadas para fins científicos, de acordo com a ética na pesquisa, e que essa participação não inclui nenhum tipo de pagamento.

Nome e Assinatura do responsável: 